\title{
ОЦЕНКА СОСТОЯНИЯ И УСТОЙЧИВОСТИ НАЗЕМНЫХ И ВОДНЫХ ГЕОСИСТЕМ
}

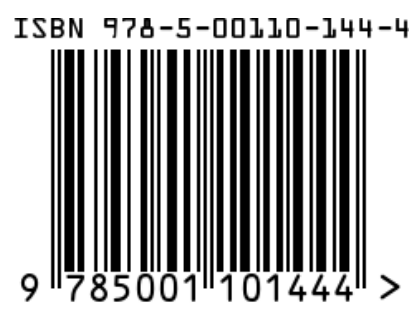

\section{Учебно-методическое пособие}

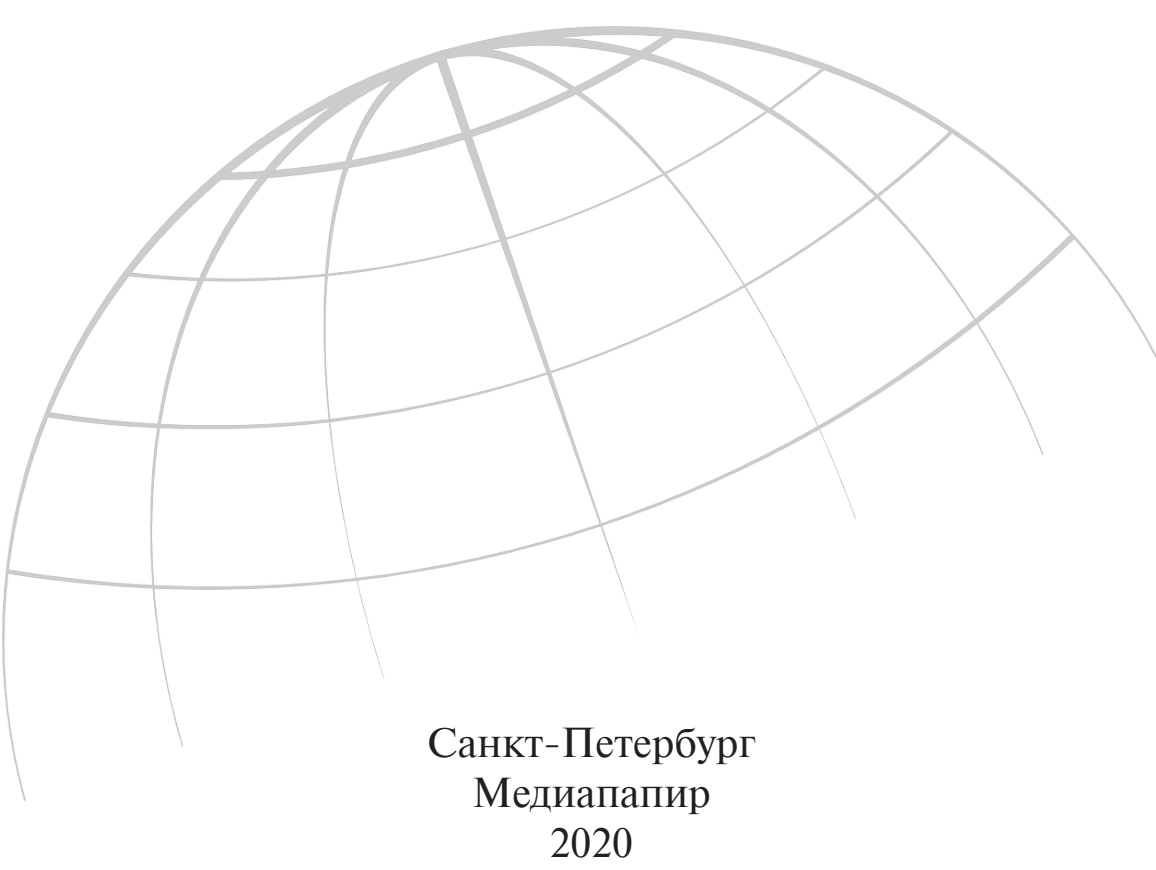




\section{Федеральное агентство по образованию Российской Федерации Санкт-Петербургский государственный университет \\ Институт наук о Земле}

\section{Оценка состояния и устойчивости наземных и водных геосистем}

\section{Учебно-методическое пособие}

для обучающихся в бакалавриате Института наук о Земле, осваивающих основную учебную программу «География» по дисциплине «Интегральная оценка наземных и водных ландшафтов»; для магистрантов Института наук о Земле, осваивающих основную учебную программу «География» по дисциплине «Моделирование природных систем»; для магистрантов Института наук о Земле, осваивающих основную учебную программу «Гидрометеорология» по дисциплинам «Экологическое нормирование и устойчивость водных объектов», «Интегральные оценки водных экосистем», «Моделирование круговорота веществ в водных экосистемах».

\section{Санкт-Петербург}


Рекомендовано к печати решением Учебно-методической комиссии Института наук о Земле СПбГУ от 20.03.2020 года

протокол №_06_05-03-4-1

Р е ц е н 3 е н т ы:

заведующий кафедрой прикладной и системной экологии Российского государственного гидрометеорологического университета (РГГМУ), кандидат географических наук, доцент

\section{Д.К. Алексеев}

профессор кафедры страноведения и международного туризма Санкт-

Петербургского государственного университета (СПбГУ), доктор географических наук, профессор

\section{Д.В. Севастьянов}

Автор-составитель - B.В. Дмитриев, профессор кафедры гидрологии суши Института наук о Земле СПбГУ, доктор географических наук, профессор.

\section{УДК 504.54}

ОЦЕНКА СОСТОЯНИЯ И УСТОЙЧИВОСТИ НАЗЕМНЫХ И ВОДНЫХ ГЕОСИСТЕМ. Учебно-методическое пособие для обучающихся в бакалавриате Института наук о Земле, осваивающих основную учебную программу «География» по дисциплине «Интегральная оценка наземных и водных ландшафтов»; для магистрантов Института наук о Земле, осваивающих основную учебную программу «География» по дисциплине «Моделирование природных систем»; для магистрантов Института наук о Земле, осваивающих основную учебную программу «Гидрометеорология» по дисциплинам «Экологическое нормирование и устойчивость водных объектов», «Интегральные оценки водных экосистем», «Моделирование круговорота веществ в водных экосистемах» - СПб.: Медиапапир, 2020. — 200 с.

Учебно-методическое пособие предназначено для обучающихся в бакалавриате и магистратуре, изучающих дисциплины естественно-географического, гидрометеорологического, геоэкологического профилей, в которых содержится акцент на теорию, методологию, методы оценки состояния и эмерджентных свойств (устойчивость, благополучие) естественных и антропогенно-трансформированных эко- и геосистем. Обсуждаются подходы и методы интегрального оценивания разномасштабных сложных систем в природе и обществе и их эмерджентных свойств в условиях обеспеченности натурными данными и в условиях недостатка мониторинговой информации о показателях и приоритетах оценивания. Рассматривается методология, методы, моделиклассификации, результаты оценки состояния, устойчивости, благополучия сложных систем в природе (наземные и водные эко- и геосистемы) и обществе (социо-экологоэкономические системы и их подсистемы, качество жизни населения). Рассмотрены этапы и опыт построения интегральных показателей состояния и устойчивости. В пособие включены примеры лекций и практических работ по курсам, модели интегральной оценки состояния и устойчивости водных объектов, наземных ландшафтов, социо-экологоэкономических систем и их свойств, разработанные на основе выполнения научных проектов и грантов последних лет. Пособие подготовлено при поддержке РФФИ, грант 19-05-00683. 


\section{Введение}

Впервые программа курса, в котором рассматривается проблема интегральной оценки состояния и устойчивости наземных и водных ландшафтов (наземных и водных геосистем) была разработана по просьбе зав.кафедрой, проф. К.В.Чистякова для кафедры Физической и эволюционной географии заведующим лабораторией «Моделирования и диагностики геосистем» НИИ Географии СПбГУ проф. В.В.Дмитриевым в 2004 году. Этот период развития кафедры был связан с ее переименованием в кафедру «Физической географии и ландшафтного планирования», было принято решение об открытии специализации 012535 «Ландшафтное планирование». В последствие на кафедре была открыта магистратура по программе «Ландшафтоведение и ландшафтное планирование». Разработанная программа курса в последующие годы неоднократно модернизировалась в части теории и практических заданий применительно к разным образовательным программам (бакалавриат, магистратура, аспирантура).

В разные годы курс «Интегральная оценка наземных и водных ландшафтов» читался бакалаврам (4 курс, 2 курс), магистрантам по профилю «Естественная география». В 2016 году основы интегрального оценивания по просьбе зав. кафедрой Егорова А.А. вошли в программу курсов «Моделирование природных систем», кафедры биогеографии и охраны природы, «Моделирование природных систем» - магистерский курс по профилю «Естественная география» (кафедры «Геоморфологии» и «Физической географии и ландшафтного планирования»).

В 2017 г. по просьбе зав. кафедрой Гидрологии суши Г.В. Пряхиной магистрантамгидрологам и климатологам впервые был прочитан курс «Интегральные оценки водных экосистем», в котором рассматривались основы теории, методологии, методы интегрального оценивания состояния и эмерджентных свойств водных объектов суши.

В 2016-2018 гг основы интегрального оценивания вошли в программы курсов «Математические модели в естествознании», «Моделирование природных систем», прочитанных проф. В.В. Дмитриевым бакалаврам 4 курса и аспирантам кафедры «Почвоведения и экологии почв» ИНЗ СПбГУ.

В 2019-2020 гг методы интегральной оценки экологического (геоэкологического) статуса, экологического благополучия, устойчивости наземных и водных эко- и геосистем вошли в программы по учебным дисциплинам «Интегральная оценка наземных и водных ландшафтов» (направление «География»), «Экологическое нормирование и устойчивость водных экосистем» (направление «Гидрометеорология»).

Учебное пособие включает в себя введение, некоторые ключевые лекции для обучающихся по курсам, в которых рассматривается проблема оценки состояния и эмерджентных свойств сложных систем в природе и обществе (эко-, гео-, социосистем) и примеры практических работ по методам интегральной оценки эмерджентных свойств (продукционный потенциал, устойчивость, уязвимость, экологическое благополучие и др.). На основе практических работ обучающиеся имеют возможность разработать собственные классификации (модели-классификации) для оценки интегративных свойств природных систем или их подсистем и подготовить статью в научном журнале по итогам оценочных исследований ключевых геосистем и прослушанного учебного курса.

Ряд практических работ легли в основу написания студентами курсовых работ, ВКР или кандидатских диссертаций по проблеме оценки интегративных свойств природных и общественных систем. Все работы имеют характерную особенность: они представляют собой некую базовую основу для дальнейшей работы. Привлечение для оценки дополнительных, новых, информативных критериев, проверка гипотез о задании приоритетов (весов) критериев дает исследователю возможность внести свой вклад в решение научной проблемы в условиях достаточного информационного обеспечения и 
недостатка информации о критериях и приоритетах оценивания простых и сложных свойств природных систем.

Автор выражает признательность сотрудникам Института наук о Земле СПбГУ (кафедры Гидрологии суши, Физической географии и ландшафтного планирования, Геоэкологии и природопользования), РГГМУ (кафедра Прикладной экологии, Прикладной и системной экологии); сотрудникам лаборатории «Моделирования и диагностики геосистем» НИИГ СПбГУ (1998-2015 гг) и ИНЗ СПбГУ, студентам соавторам научных публикаций, за совместную работу по созданию научных основ и моделей интегрального оценивания.

Автор признателен руководству Института наук о Земле СПбГУ (С.В.Аплонову, К.В.Чистякову) за поддержку и развитие данного направления в ИНо3, а также заведующим кафедрами института К.В. Чистякову, Г.В. Пряхиной, И.В. Федоровой, А.И. Жирову, Н.И. Каледину, Д.В. Севастьянову, М.И. Амосову, А.В. Русакову; проф. Ю.Н. Сергееву, проф. В.С. Вуглинскому, проф. В.А. Шелутко; доц. В.П.Кулешу, доц. В.Ю. Третьякову, н.с. А.Н. Огурцову; директору НИИГ СПбГУ, проф. А.И.Чистобаеву за совместные исследования в рамках научных проектов и совместные публикации.

Пособие предназначено для использования в рамках курсов: «Интегральная оценка наземных и водных ландшафтов» по направлению «География» для получения степени «бакалавр»; «Моделирование природных систем» по направлению «География» для получения степени «магистр»; «Экологическое нормирование и устойчивость водных объектов», «Экологическое нормирование и устойчивость водных экосистем», «Интегральные оценки водных экосистем» по направлению «Гидрометеорология» для получения степеней «магистр» и «бакалавр».

Автор благодарен рецензентам, сделавших ряд ценных замечаний и предложений по разделам пособия.

При написании учебно-методического пособия использовались опыт и результаты работы автора по грантам РФФИ за последние 5 лет: № 13-05-00648-a, 16-05-00715-а, 1805-60291-a; 18-05-00328-a, 19-05-00683-а. Публикация пособия выполнена при поддержке РФФИ, грант 19-05-00683-а. 
Раздел 1. Введение в курс «Интегральная оценка наземных и водных геосистем» и родственных курсов, содержащих основы теории, методологии и методы интегрального оценивания состояния и устойчивости сложных природных объектов и их свойств (организационно-методический раздел).

\section{Вводная лекция}

Раздел 2. Теоретико-методологические основы интегральной оценки экосистем, геосистем и их эмерджентных свойств.

Лекция №1. Особенности современного этапа исследования сложных систем в природе и обществе. Сложные системы в природе и обществе и их основные свойства. Понятия: элемент (компонент), структура, система. Фактор. Комплекс. Совокупность. Система. Простые и сложные системы, системообразующие связи. Свойства сложных систем. Простые и сложные системы, системообразующие связи. Свойства сложных систем. Эмергентность (эмержентность, эмерджентность) сложной системы. «Формулы», использующие родовое понятие «система» в географических и геоэкологических исследованиях.

Иерархии сложных систем в природе и обществе. Иерархия экосистем и геосистем. Иерархия экосистем. Иерархия в географии. Иерархия геосистем. Иерархия в биологии. Иерархия этническая. Фундаментальные и прикладные научные исследования. Оценка. Оценка состояния системы. Оценка и диагностика. Диагностика природного объекта. Прикладная экология.

Показатель, признак, критерий. Экологический критерий. Состояние природной системы и его оценка. Состояние природы. Состояние геосистемы. Режим. Опасные природные явления.

\section{Лекция №2}

Современные подходы и методы исследования геосистем и ландшафтов, сложных систем в природе и обществе.

От ОВОС к экологическому (системному) нормированию и экологическому сопровождению проектирования воздействий на природные экосистемы. ОВОС. Экологическое нормирование (ЭН). Основные определения. Экологическое сопровождение проектирования. Основные разделы темы «Экологическое сопровождения проектирования».

Определение системной экологии. Системный анализ. Системный подход. Модель. Экологическая модель. Имитационная модель. Портретная модель.

\section{Лекция №3.}

Информация 1, 2 и 3 рода о состоянии системы. Геоинформатика. Цифровизация и науки о Земле. Оценка. Оценка состояния системы. Оценка и диагностика. Диагностика природного объекта. Состояние природной системы и его оценка. Состояние природы. Состояние геосистемы. Режим. Вектор состояния системы. Пример описания состояния экосистемы (построения вектора системы) на основе аддитивных и неаддитивных параметров. Проблема. Ситуация. Обстановка. Экологическая проблема. Экологическая ситуация. Экологическая обстановка. Экологическая оценка. Примеры других подходов и определений экологической оценки (ЭО), встречающиеся в литературе. Стратегия экологической оценки. Эколого-географическая оценка. Триада Ю.П. Селиверстова. Ниша Хатчинсона. Трансформация ниши Хатчинсона. 
Экологическая и геоэкологическая оценка. Геоэкологическая регламентация. Геоэкологическое нормирование. Геоэкологический мониторинг. Основные задачи геоэкологического мониторинга. Уровни геоэкологического мониторинга. Экологический и геоэкологический статус природного объекта. Субъективизм в определении понятий экологическая оценка, эколого-географическая оценка. Качество среды. Оценка качества среды. Антропо-, био-, эко- и геоцентризм в оценке качества среды. Что подлежит изучению и оценке в естественных и антропогенно-трансформированных наземных и водных объектах (эко- и геосистемах). Свертки информации о состоянии системы. Методы свертки информации. Интегральные оценки в индексологии состояния природных экосистем и их эмерджентных свойств. Индикатор. Индекс.

\section{Лекция №4.}

Описательный и точный период развития науки. Схема основных стадий системного анализа применительно к исследованию состояния и устойчивости природных систем. Аксиология. Аксиометрия. Диагностический анализ (диагностика) состояния природных объектов. Характеристика состояния сложной системы. Индексы состояния. Классификационная схема индексов состояния сложной системы по литературным обобщениям (Дмитриев, 2009). Индексы-маркеры и индексы - условные параметры. Условные функционалы. Функции желательности. Пример использования логистической функции (1) для выделения стадий антропогенной трансформации экосистем. Примеры обобщенных $d$-функций. Обобщенные функции желательности.

\section{Лекция №5.}

История взглядов на соотношение детерминированного и случайного в моделях мира. Универсальная схема (модель) эволюционного процесса. Методологические позиции наук, изучающих сложные системы в природе и обществе и их свойства по О.А. Богатыревой (2006).

Объективное и субъективное понимание случайности при создании моделей.

Основные принципы теории сложных систем (системологии), о которых необходимо помнить при разработке моделей. Принцип интегративных уровней современный аналог принципа «бритвы Оккама». Принцип контринтуитивного поведения сложных систем (Дж. Форрестера, 1974, 1977, 1978). Принцип множественности моделей. Принцип осуществимости (Б.С. Флейшмана). Принцип несовместимости (Самарский, 1979, Заде, 1974). Системный подход и проблема целостности. Принципы системности (Ворощук, 1982).

\section{Лекция №6.}

Устойчивости и уязвимость природных объектов к изменению параметров естественного и антропогенного режимов. Основные понятия, связанные с устойчивостью экосистем. Два основных определения устойчивости. Адаптационная и регенерационная устойчивость. Определение устойчивости по И.Н. Росновскому (1993). Устойчивость экосистемы по И.И. Мазуру и О.И. Молдаванову (1989). Устойчивость природных систем по В.А. Светлосанову (1990). Устойчивость биосистем.Устойчивость геосистем и экосистем. Адаптационная устойчивость и принцип Ле-Шателье-Брауна. Устойчивость по Лагранжу, Ляпунову, Холлингу, Одуму, Свирежеву и Логофету. Устойчивость по В.Ф.Шуйскому (1997). Критерии оценки устойчивости. Индикаторный подход к оценке устойчивости. Обобщение современных подходов к оценке устойчивости геосистем. Примеры авторских подходов.

Раздел 3. Методические основы интегральной оценки экосистем, геосистем, ландшафтов и их эмерджентных свойств. 
Лекция №7. Методы балльного и балльно-индексного оценивания. Метод сводных показателей (composite indicators) (МСП). Метод рандомизированных сводных показателей (МРСП). АСПИД (анализ показателей при информационном дефиците) методология. APIS (AggregatedPreferenceIndicesSystem) - методология.

Раздел 4. Разработка и апробация моделей интегральной оценки экосистем, геосистем, наземных и водных ландшафтов и их эмерджентных свойств. Опыт интегрального оценивания.

Лекция 8. Некоторые результаты интегральной оценки состояния и устойчивости, эко-, гео- и социосистем.

\section{Практические работы.}

Практическая работа №1. Модели-классификации. Разработка концептуальных моделей стратегии развития наземных и водных экосистем. Оценка состояния экосистем на основе разработанных моделей.

Практическая работа №2. Интегральная оценка трофического статуса водоема на основе метода сводных показателей (МСП).

Практическая работа №3. Интегральная оценка качества природной среды на основе метода сводных показателей. Как построить интегральный показатель качества воды водоема.

Практическая работа №4. Оценка эмерджентных свойств наземных и водных геосистем и ландшафтов. Балльные и балльно-индексные оценки состояния и устойчивости водных объектов, почв, наземных геосистем. 1. Балльно-индексная оценка устойчивости водоемов к изменению параметров естественного и антропогенного режимов. 2. Балльно-индексная оценка устойчивости водотоков к изменению параметров естественного и антропогенного режимов.

Практическая работа №5. Балльная оценка устойчивости почвы и элементарного ландшафта к изменению параметров естественного и антропогенного режимов. Интегральная оценка устойчивости почв.

Практическая работа №6. Интегральная оценка эмерджентных свойств наземных геосистем. Индикаторный подход в оценке устойчивости ландшафта. Балльная и интегральная оценка устойчивости ландшафта по методу сводных показателей.

Практическая работа №7. Моделирование и оценка эмерджентных свойств наземных и водных геосистем и ландшафтов. Интегральная оценка экологического статуса и экологического благополучия водоема. 
Раздел 1. Введение в курс «Интегральная оценка наземных и водных геосистем» и родственных курсов, содержащих основы теории, методологии и методы интегрального оценивания состояния и устойчивости сложных природных объектов и их свойств (организационно-методический раздел).

В результате освоения курса «Интегральная оценка наземных и водных геосистем» и родственных курсов, содержащих основы теории, методологии и методы интегрального оценивания состояния и устойчивости сложных природных объектов и их свойств, обучающиеся должны ознакомиться с современными возможностями покомпонентного, косвенного, комплексного, многокритериального, интегрального оценивания состояния наземных и водных эко- и геосистем, получить представление об общих принципах построения интегральных показателей состояния, качества, продуктивности, устойчивости, экологического благополучия наземных и водных эко-, геосистем; методах получения интегральных оценок, практике анализа полученных результатов.

Цель изучения дисциплины состоит в подготовке обучающихся, имеющих представление о методах и средствах интегральной оценки состояния сложных систем (экосистем, геосистем, социосистем) и их неаддитивных (эмерджентных) свойств, умеющих оценить состояние сложной системы и ее эмерджентное свойство (устойчивость, целостность, благополучие) для применения полученных знаний в практике ландшафтоведения, природопользования, гидрометеорологии и др. и планирования воздействий на природные экосистемы, ландшафты, территории.

Целью учебных занятий по дисциплинам является обучение студентов физикогеографов, геоморфологов, биогеографов, гидрологов, климатологов, океанологов, почвоведов, и др. теоретико-методологическим основам и методам интегрального оценивания, практическим навыкам построения интегральных показателей состояния, устойчивости, благополучия природных систем.

Основные задачи изучения дисциплин связаны с:

- овладением теоретико-методологическими основами интегрального оценивания состояния и интегративных свойств сложных систем в природе и обществе;

- овладением методами балльно-индексного, многокритериального и интегрального оценивания геосистем и этапами построения интегральных показателей;

- овладением навыками отбора репрезентативных критериев для многоуровневой интегральной оценки состояния наземных и водных ландшафтов и их неаддитивных свойств;

- формированием обучающих классификаций для оценки отдельных свойств и состояния ландшафтов в целом;

- выполнением расчетов интегральных показателей и апробацией моделей интегрального оценивания на конкретных примерах, в которых рассматривались разные объекты исследования.

Требования к подготовленности обучающегося к освоению содержания учебных занятий. Обучающиеся должны предварительно изучить в пределах учебного плана: биологию, экологию, химию, физику, математику, пройти учебные и производственные практики. Обучающиеся также изучили или изучают в предусмотренные учебным планом предметы, в которых освещаются проблемы мониторинга, обработки и анализа данных мониторинговых наблюдений, оценки качества и токсического загрязнения среды, охраны природы, и готовы приступить к изучению моделей экосистем и геосистем. При разработке практических работ учитывается, что в теоретической части курса рассматриваются: теоретико-методологические основы оценки состояния экосистем, геосистем и ландшафтов, методы и средства индикаторного подхода, основы индексологии, выявление критических состояний и пределов воздействия на экосистемы и другие вопросы. 
Перечень результатов обучения. Курс дает возможность овладения навыками количественной оценки состояния сложных эмерджентных природных и антропогеннотрансформированных систем на основе изученных ранее методов покомпонентной оценки и анализа наземных и водных ландшафтов. Изучив курс, обучающийся приобретает навыки разработки способов районирования и зонирования территорий и акваторий на основе количественной интегральной оценки геосистем и их различных свойств. Профессионально подготовленный студент сможет также использовать для интегральной оценки неполную, неточную и нечисловую информацию о состоянии и свойствах геосистем.

В результате изучения дисциплины «Интегральная оценка наземных и водных геосистем» и родственных курсов, у обучающихся формируются следующие компетенции:

- Владеет теоретическими основами оценки состояния сложных систем (экосистем, геосистем, ландшафтов) и оценки их сложных (эмерджентных) свойств (устойчивости, благополучия и др.).

- Владеет практическими навыками построения интегральных показателей состояния, устойчивости, благополучия и интерпретации результатов интегральной оценки территории в условиях достаточного информационного обеспечения исследований и недостатка информации о критериях и приоритетах оценивания.

По итогам изучения курса преподавателем совместно с наиболее заинтересованной частью обучающихся может быть подготовлена публикация в научном журнале, в основу которой положен расчет интегральных показателей и апробация моделей интегрального оценивания на конкретных примерах. Примерами такого сотрудничества по итогам изучения курса явились публикации статей с участием студентов кафедр «Физической географии и ландшафтного планирования», «Гидрологии суши» ИНЗ СПбГУ и кафедры «Прикладной и системной экологии» РГГМУ в научных журналах: в 2014 г - «Развитие методологии интегральной оценки экологической целостности геосистем» в Международном журнале прикладных и фундаментальных исследований №8, 2014, с.7885; в 2016 г «Интегральная оценка устойчивости ландшафтов: модели, результаты, перспективы» в Международном журнале прикладных и фундаментальных исследований. - 2017. - № 9. - с. 110-114; ИД Академия Естествознания; в 2019 г. «Мониторинг и моделирование продукционно-деструкционных отношений в водных экосистемах» Успехи современного естествознания № 1 2019, с. 82-87; в 2020 г «Developmentof monitoring of water bodies ecological status by the example of small lakes in the North-western Ladoga region» в E3S Web Conf. Volume 163, 2020 IV Vinogradov Conference "Hydrology: from Learning to Worldview" in Memory of Outstanding Russian Hydrologist Yury Vinogradov. 2020. St. Petersburg, Russia E3S Web of Conferences 163, 03002 (2020). DOI: https://doi.org/10.1051/e3sconf/202016303002; «Интегральная оценка устойчивости наземных ландшафтов: от балльных оценок к композитным индексам на основе территориальных детерминант» Успехи современного естествознания 2020, №2, с.45-53. DOI: 10.17513/use.37330 и др.

В перечень активных и интерактивных форм учебных занятий включены: диалог преподавателя и обучающихся по типу "вопрос-ответ" в ходе занятий, обусловливающий получение выводов на основе рассмотренного материала (до 10 мин); проведение консультаций и опросов по темам, вынесенным на самостоятельное обучение; проведение консультации (коллоквиума, опроса) по завершению раздела программы; консультации по практическим работам и перед итоговой аттестацией, краткие выступления студентов по рассматриваемым вопросам (презентация выступления) до 10 мин.

Курс адаптирован для удаленного доступа в 2020 г.

Основные разделы курса имеют специфику в зависимости от профиля и года обучения, программы (бакалавриат, магистратура, аспирантура). В целом содержание курса укладывается в 4 основных раздела: 
1. Введение в курс «Интегральная оценка наземных и водных ландшафтов».

2. Теоретико-методологические основы интегральной оценки экосистем, геосистем, ландшафтов и их эмерджентных свойств.

3. Методические основы интегральной оценки экосистем, геосистем, наземных и водных ландшафтов и их эмерджентных свойств.

4. Разработка и апробация моделей интегральной оценки экосистем, геосистем, наземных и водных ландшафтов и их эмерджентных свойств. Опыт интегрального оценивания.

Методическое и информационное обеспечение занятий по курсу. Студентам, посещающим занятия, перед началом занятий выдаются учебно-практические материалы, в т.ч. конспекты лекций и практических работ по курсу, содержащие текст лекции (практической работы), рисунки, табличный материал, вопросы для проверки усвоения материала, список рекомендованной литературы.

Аттестация обучающихся проходит также на основе освоения пройденного материала. В качестве дополнительного вопроса на зачете преподаватель по его исходным данным для студента NN дает студенту задание рассчитать интегральный показатель его успеваемости после ответа на все вопросы зачета (экзамена).

\section{Критерии и показатели оценивания успешности освоения учебного курса, шкалы оценивания.}

Основные термины. Показателем (index, index figure, activity indicator, environmental indices) будем называть выраженную числом характеристику какого-либо параметра оценивания. Показатель включает в себя количественное значение и набор содержательных признаков (основных и дополнительных, разъясняющих). Показатели могут быть: средними, предельными, объемными, безразмерными, относительными, интегральными и т.п.

Признак (attribute, feature, mark) - неоднозначная, способная изменяться величина, характеризуемая в процессе оценивания. Признаки могут быть качественными и количественными, одномерными и многомерными, непрерывными и дискретными и др. Признаки могут использоваться как критерии классификаций, формирования шкал. В информационных системах на их основе строятся тематические классификаторы.

Критерий (criterion) - признак, на основании которого оценивается успешность овладения обучающимися содержания образовательной программы (учебного курса). Критерий оптимальности, оптимальный критерий (optimality criterion) - признак, по которому успешность овладения обучающимися содержания образовательной программы (учебного курса) может признаваться более высокой, чем по другим критериям в данных объективных условиях. Оценка остаточных знаний обучающихся по дисциплине осуществляется с учетом всех видов аудиторной и самостоятельной работы, текущей работы в аудитории и на основе результатов устного зачета.

\section{Работа на семинарах, практических занятиях, самостоятельная работа с использованием методических материалов.}

На первом этапе отбирается система критериев, использование которых дает возможность оценить качество полученных знаний. При этом нужно стремиться к тому, чтобы каждый из критериев был необходим, а все параметры вместе были достаточны для описания качества. При этом могут существовать характеристики, увеличение значений которых приводит к улучшению значения качества (первый тun), а также характеристики, увеличение значений которых приводит к его ухудшению (второй тиn). Кроме того, гипотетически возможно существование характеристик, критические значения которых разбивают оценочную шкалу на два интервала с противоположными свойствами влияния переменной на качество. 
Одновременно с введением признаков (критериев) оценивания вводятся классы качества. Рекомендуется провести (согласовать с коллегами) существующие классификации оценки качества знаний. Всегда легче опираться на существующие классификации, чем вводить свои, но иногда необходимо бывает формировать авторские классификации для техже целей. В связи с этим упомянем, например, существующую систему оценки качества знаний в Европейской системе трансфера кредитов (ECTS-Pkte). Система включает шесть классов качества, которые условно названы: 1- excellent (отлично); 2 - very good (очень хорошо); 3 - good (хорошо); 4 - satisfactory (удовлетворительно); 5 - sufficient (достаточно); 6-fail (недостаточно).

Адаптируем эту систему к российским традициям, введя классы: 1 - «отличноочень хорошо» (оценка 5); 2 - «хорошо» (оценка 4); 3 - «удовлетворительно-достаточно» (оценка 3); 4 - «недостаточно-неудовлетворительно» (оценка 2) (табл.1). В таблице 1 приведены 7 критериев, выбранных разработчиком учебного курса для оценки качества усвоения полученных знаний по предмету для оценки работы на семинарах, выполнения практических занятий, устного опроса и самостоятельной работы по учебнометодическим материалам. Эта система в 2020 г. впервые адаптирована нами также для условий удаленного доступа.

Таблица 1. Классификация оценки качества усвоения полученных знаний по учебному курсу для оценки работы на семинарах, выполнения практических заданий и самостоятельной работы с использованием учебно-методических материалов, работы в условиях удаленного доступа.

\begin{tabular}{|c|c|c|c|c|c|c|}
\hline \multirow[t]{2}{*}{ Перечень признаков } & \multicolumn{6}{|c|}{ Оценочные шкалы для признаков } \\
\hline & $\begin{array}{c}\text { I } \\
\text { Отлично } \\
\text {-очень } \\
\text { хорошо }\end{array}$ & $\begin{array}{c}\text { II } \\
\text { Хорошо }\end{array}$ & $\begin{array}{c}\text { III } \\
\text { Удовлетво } \\
\text {-рительно- } \\
\text { достаточно }\end{array}$ & $\begin{array}{l}\text { IV } \\
\text { Недоста- } \\
\text { точно- } \\
\text { неудовлетв } \\
\text { орительно }\end{array}$ & $\min$ & $\max$ \\
\hline $\begin{array}{l}\text { 1. Оценка за семинарские занятия в аудитории } \\
\text { и/или в режиме удаленного доступа. Оценка } \\
\text { результатов практической работы (удаленный } \\
\text { доступ). }\end{array}$ & $5,0-4,5$ & $4,5-3,5$ & $3,5-2,1$ & $2,1-0,0$ & 0 & 5 \\
\hline $\begin{array}{l}\text { 2. Оценка выполнения практической работы } \\
\text { (удаленный доступ): графический, табличный } \\
\text { материал, правильность расчетов, } \\
\text { инициативность, полнота, использование ПК, } \\
\text { оформление. }\end{array}$ & $5,0-4,0$ & $4,0-3,5$ & $3,5-2,1$ & $2,1-0,0$ & 0 & 5 \\
\hline $\begin{array}{l}\text { 3. Оценка полученных по итогам практ. работы } \\
\text { выводов (удаленный доступ) на основе } \\
\text { выполненных практических заданий } \\
\text { (формулировка выводов, полнота, правильность, } \\
\text { сравнение с имеющимися в литературе } \\
\text { аналогами). }\end{array}$ & $5,0-4,5$ & $4,5-3,5$ & $3,5-2,0$ & $2,0-0,0$ & 0 & 5 \\
\hline $\begin{array}{l}\text { 4. Ответы на вопросы преподавателя по } \\
\text { результатам практических работ, выводов, } \\
\text { графическому и табличному материалу, } \\
\text { дополнительные вопросы по теме практической } \\
\text { работы (удаленный доступ). }\end{array}$ & $10-8$ & $8-5$ & $5-3$ & $3-0$ & 0 & 10 \\
\hline $\begin{array}{l}\text { 5. Оценка за выполнение контрольных работ и } \\
\text { письменных опросов в конце занятий и в режиме } \\
\text { удаленного доступа. }\end{array}$ & $5,0-4,0$ & $4,0-3,0$ & $3,0-2,0$ & $2-0$ & 0 & 5 \\
\hline $\begin{array}{l}\text { 6. Оценка усвоения материала предыдущих } \\
\text { занятий при опросах на занятиях (по типу } \\
\text { «вопрос-ответ»), оценка самостоятельной } \\
\text { работы обучающегося в присутствии } \\
\text { преподавателя; оценка самостоятельной работы } \\
\text { с использованием методических материалов. }\end{array}$ & $5,0-4,5$ & $4,5-3,5$ & $3,5-2,0$ & $2,0-0,0$ & 0 & 5 \\
\hline $\begin{array}{l}\text { 7. Оценка преподавателем общего уровня } \\
\text { готовности и участия обучающегося в написании } \\
\text { научной публикации на основе выполнения }\end{array}$ & $10-8$ & $8-5$ & $5-3$ & $3-0$ & 0 & 10 \\
\hline
\end{tabular}


полевых исследований, практических работ и материалов, собранных по лит.источникам для выполнения расчетов. Оценка вклада в

написание статьи в режиме удаленного доступа.

Применительно к классификации отметим, что выбранные критерии характеризуют как качество полученных знаний, так и отношение обучающегося к учебному процессу; все шкалы имеют левую и правую границы внутри классов; не все шкалы являются непрерывными; возможны близкое к линейному или нелинейное изменение шкал. При этом можно использовать разные шкалы (5-балльную, 10-балльную, 100-балльную и т.д.). Шкалы имеют разные погрешности и точность задания характеристик. Отметим наличие в рассматриваемой классификации только одного типа параметров (прямая связь параметра с качеством усвоения знаний).

Введем левую и правую границы для всех исходных характеристик качества, хотя заметим, что данная процедура не является строго обязательной. Можно работать с показателями, отнесенными к серединам классов или с граничными значениями (между классами). При этом необходимо помнить, что в качестве правой границы параметров, характеризующих наилучшее качество (I класс) должны задаваться значения критериев, не противоречащие европейским стандартам, если таковые имеются.

На втором этапе с помощью несложных преобразований избавимся от размерности исходных характеристик так, чтобы наилучшим условиям по каждому критерию соответствовало значение равное 1, а наихудшим, равное 0. Такое преобразование (нормирование) выполним следующим образом. Для критериев введем правило перевода значений шкал в безразмерный вид: $\left(x_{i}-\min \right) /(\max -\min )$. Заметим, что обратная связь показателя с оцениваемым качеством потребует другой нормирующей функции: (max $\left.x_{i}\right) /(\max -\min )$. Значения $\min$ и $\max$ приведены в табл.2. В результате таблица 1 преобразуется в таблицу 2.

Таблица 2. Классификация качества усвоения полученных знаний по учебному курсу для оценки работы на семинарах, выполнения практических заданий и самостоятельной работы с использованием учебно-методических материалов, работы в условиях удаленного доступа (нормированные значения показателей)

\begin{tabular}{|c|c|c|c|c|c|c|}
\hline \multirow[t]{2}{*}{ Перечень признаков } & \multicolumn{6}{|c|}{ Оценочные шкалы для признаков } \\
\hline & $\begin{array}{l}\text { Отлично- } \\
\text { очень } \\
\text { хорошо }\end{array}$ & Хорошо & $\begin{array}{l}\text { Удовлетво } \\
\text {-рительно- } \\
\text { достаточно }\end{array}$ & $\begin{array}{l}\text { Недоста- } \\
\text { точно- } \\
\text { неудовлет- } \\
\text { воритель- } \\
\text { но }\end{array}$ & $\min$ & $\max$ \\
\hline $\begin{array}{l}\text { 1. Оценка за семинарские занятия в } \\
\text { аудитории и/или в режиме удаленного } \\
\text { доступа. Оценка результатов практической } \\
\text { работы (удаленный доступ). }\end{array}$ & $1,0-0,90$ & $0,90-0,70$ & $0,70-0,42$ & $0,42-0,00$ & 0 & 5 \\
\hline $\begin{array}{l}\text { 2. Оценка выполнения практической работы } \\
\text { (удаленный доступ): графический, табличный } \\
\text { материал, правильность расчетов, } \\
\text { инициативность, полнота, использование ПК, } \\
\text { оформление. }\end{array}$ & $1,0-0,80$ & $0,80-0,70$ & $0,70-0,42$ & $0,42-0,00$ & 0 & 5 \\
\hline $\begin{array}{l}\text { 3. Оценка полученных по итогам практ. } \\
\text { работы выводов (удаленный доступ) на } \\
\text { основе выполненных практических заданий } \\
\text { (формулировка выводов, полнота, } \\
\text { правильность, сравнение с имеющимися в } \\
\text { литературе аналогами). }\end{array}$ & $1,0-0,90$ & $0,90-0,70$ & $0,70-0,40$ & $0,40-0,00$ & 0 & 5 \\
\hline $\begin{array}{l}\text { 4. Ответы на вопросы преподавателя по } \\
\text { результатам практических работ, выводов, } \\
\text { графическому и табличному материалу, } \\
\text { дополнительные вопросы по теме } \\
\text { практической работы (удаленный доступ). }\end{array}$ & $1,0-0,80$ & $0,80-0,50$ & $0,50-0,30$ & $0,30-0,00$ & 0 & 10 \\
\hline
\end{tabular}




\begin{tabular}{|c|c|c|c|c|c|c|}
\hline $\begin{array}{l}\text { 5. Оценка за выполнение контрольных работ } \\
\text { и письменных опросов в конце занятий и в } \\
\text { режиме удаленного доступа. }\end{array}$ & $1,0-0,80$ & $0,80-0,60$ & $0,60-0,40$ & $0,40-0,00$ & 0 & 5 \\
\hline $\begin{array}{l}\text { 6. Оценка усвоения материала предыдущих } \\
\text { занятий при опросах на занятиях (по типу } \\
\text { «вопрос-ответ»), оценка самостоятельной } \\
\text { работы обучающегося в присутствии } \\
\text { преподавателя; оценка самостоятельной } \\
\text { работы с использованием методических } \\
\text { материалов. }\end{array}$ & $1,0-0,90$ & $0,90-0,70$ & $0,70-0,40$ & $0,40-0,00$ & 0 & 5 \\
\hline $\begin{array}{l}\text { 7. Оценка преподавателем общего уровня } \\
\text { готовности и участия обучающегося в } \\
\text { написании научной публикации на основе } \\
\text { выполнения полевых исследований, } \\
\text { практических работ и материалов, собранных } \\
\text { по лит.источникам для выполнения расчетов. } \\
\text { Оценка вклада в написание статьи в режиме } \\
\text { удаленного доступа. }\end{array}$ & $1,0-0,80$ & $0,80-0,50$ & $0,50-0,30$ & $0,30-0,00$ & 0 & 10 \\
\hline $\begin{array}{l}\text { Интегральный показатель успеваемости } \\
\text { (ИПУ1) }\end{array}$ & $1,000-0,843$ & $0,843-0,629$ & 0,629-0,377 & 0,377-0,000 & & \\
\hline
\end{tabular}

На третьем этапе выбирается вид интегрального показателя ИПУ1. Показатель строится таким образом, что зависит не только от результата нормирования, но и от значимости критериев, определяемой весовыми коэффициентами, сумма которых должна равняться 1,0. В качестве выражения для интегрального показателя будем использовать сумму нормированных значений равновесомых показателей. Вес каждого равен $1 / n$, где nчисло критериев оценивания. Проделав такое суммирование для левой и правой границ каждого класса получим оценочную шкалу интегрального показателя ИПУ1 (последняя строка в табл.2). Обоснование преподавателем и введение разных весов для критериев оценивания незначительно усложнит расчет ИПУ1.

На последнем этапе проводится расчет интегральных показателей качества (табл.3) для обучающихся. Как следует из таблицы, оценить качество усвоения знаний по учебному курсу студента NN при покомпонентной оценке представляется весьма сложным делом, поскольку оценка по отдельным критериям может иметь разброс в несколько классов. По правилам построения исходной классификации рассчитаем значение интегрального показателя качества ИПУ1 (табл.3). Отметим, что для равновесомых критериев расчет значительно упрощается, поскольку вес можно вынести за скобку и умножить на сумму $q_{i}$.

Таблица 3. Пример исходных данных и результат оценки качества усвоения полученных знаний по учебному курсу для практических занятий, контрольных работ и самостоятельной работы в присутствии преподавателя, работы в условиях удаленного доступа для студента NN.

\begin{tabular}{|l|c|l|l|}
\hline $\begin{array}{c}\text { Номер } \\
\text { критерия }\end{array}$ & $\begin{array}{c}\text { Численное значение } \\
\text { и класс качества по } \\
\text { оценкам } \\
\text { преподавателя (по } \\
\text { табл.1) }\end{array}$ & $\begin{array}{c}\text { Результат нормирования } \\
\text { по } \\
q_{i}=\left(x_{i}-\min \right) /(\max -\min )\end{array}$ & $\begin{array}{c}\text { Произведение результата } \\
\text { нормирования } q_{i} \text { на вес } \\
\text { критерия } w_{i}\end{array}$ \\
\hline 1 & $4,6(\mathrm{I})$ & $(4,6-0) / 5=0,92$ & $q_{1} w_{1}=0,92 * 0,143=0,132$ \\
\hline 2 & $3,5(\mathrm{II})$ & $(3,5-0) / 5=0,70$ & $q_{2} w_{2}=0,7 * 0,143=0,100$ \\
\hline 3 & $4,0(\mathrm{II})$ & $(4-0) / 5=0,80$ & $q_{3} w_{3}=0,8 * 0,143=0,114$ \\
\hline 4 & $5(\mathrm{III})$ & $(5-0) / 10=0,50$ & $q_{4} w_{4}=0,5 * 0,143=0,072$ \\
\hline 5 & 3,0 (II-III) & $(3-0) / 5=0,60$ & $q_{5} w_{5}=0,6 * 0,143=0,057$ \\
\hline 6 & 2 (III-IV) & $(2-0) / 5=0,40$ & $q_{6} w_{6}=0,4 * 0,143=0,086$ \\
\hline 7 & 3 (III-IV) & $(3-0) / 10=0,30$ & $q_{7} w_{7}=0,3 * 0,143=0,100$ \\
\hline
\end{tabular}




\begin{tabular}{|l|l|l|l|}
\hline & ИПУ $1=$ & $\sum_{i=1}^{7} q_{i} w_{i}=\mathbf{0 , 6 0}$ (II класс) \\
\hline
\end{tabular}

В итоге, по совокупности критериев оценивания успеваемость студента следует отнести к III классу (удовлетворительно - достаточно), так как диапазон изменения интегрального показателя у этого класса 0,629-0,377. Отметим близость оценки к границе между II и III классами. Такой результат получился, несмотря на то, что студент уверенно докладывал на семинаре, хорошо оформил практические работы и хорошо сформулировал выводы по ним. Однако, неуверенные ответы на вопросы преподавателя, низкие показатели за опросы на занятиях, неготовность или нежелание подготовить заявку на грант, научную статью по курсу на основе дополнительного материала или отказ от участия в студенческих олимпиадах, дали в итоге низкое значение ИПУ1.

Оценка устного ответа на зачете (экзамене) или письменного ответа в условиях удаленного доступа.

Следуя приведенной в выше методике получения интегральной оценки, разработаем классификацию оценки качества усвоения полученных знаний для зачета (экзамена) по учебному курсу.

Таблица 4. Классификация оценки качества усвоения полученных знаний для зачета/экзамена по учебному курсу

\begin{tabular}{|c|c|c|c|c|c|c|}
\hline \multirow{2}{*}{$\begin{array}{l}\text { Перечень признаков, выбранных преподавателем } \\
\text { для оценки успешности сдачи зачета по курсу }\end{array}$} & \multicolumn{6}{|c|}{ Оценочные шкалы для признаков } \\
\hline & $\begin{array}{c}\text { I } \\
\text { Отлично } \\
\text {-очень } \\
\text { хорошо }\end{array}$ & $\begin{array}{c}\text { II } \\
\text { Хорошо }\end{array}$ & $\begin{array}{c}\text { III } \\
\text { Удовлетво } \\
\text {-рительно- } \\
\text { достаточно }\end{array}$ & $\begin{array}{c}\text { IV } \\
\text { Недостато } \\
\text { чно- } \\
\text { неудовлетв } \\
\text { орительно }\end{array}$ & $\min$ & $\max$ \\
\hline $\begin{array}{l}\text { 1. Устный (письменный) ответ обучающегося на } \\
\text { вопросы билета. }\end{array}$ & $5,0-4,5$ & $4,5-3,5$ & $3,5-2,1$ & $2,1-0,0$ & 0 & 5 \\
\hline $\begin{array}{l}\text { 2. Полнота ответа, использование дополнительного } \\
\text { графического, табличного материала, рисунков, схем, } \\
\text { расчетов, демонстрация углубленного изучения } \\
\text { материала, публикаций. }\end{array}$ & $5,0-4,0$ & $4,0-3,0$ & $3,0-2,1$ & $2,1-0,0$ & 0 & 5 \\
\hline $\begin{array}{l}\text { 3. Ответы на тестовые вопросы преподавателя по } \\
\text { билету, правильность использования терминологии, } \\
\text { демонстрация имеющегося личного опыта, } \\
\text { подтверждающегося публикациями (подготовкой } \\
\text { статей) или участием в НИР грантах, конкурсах } \\
\text { (информацию подготовить и переслать вместе с } \\
\text { письменным ответом на вопросы билета). }\end{array}$ & $10-8$ & $8-5$ & $5-3$ & $3-0$ & 0 & 10 \\
\hline $\begin{array}{l}\text { 4. Оценка знакомства отвечающего с основной и } \\
\text { дополнительной литературой (российской и } \\
\text { зарубежной). }\end{array}$ & $5-4$ & $4-2$ & $2-1$ & $1-0$ & 0 & 5 \\
\hline $\begin{array}{l}\text { 5. Оценка самостоятельности подготовки к ответу (без } \\
\text { использования текста конспектов), разрешенной } \\
\text { литературы; учет времени, затраченного на } \\
\text { подготовку ответа и ответов на тестовые вопросы. }\end{array}$ & $5-4$ & $4-3$ & $3-2$ & $2-1$ & 0 & 5 \\
\hline $\begin{array}{l}\text { 6. Оценка преподавателем общего уровня готовности } \\
\text { обучающегося для решения проблем, рассмотренных } \\
\text { при изучении курса, участия в грантах по близкой } \\
\text { теме. }\end{array}$ & $10-8$ & $8-5$ & $5-3$ & $3-0$ & 0 & 10 \\
\hline
\end{tabular}

Таблица 5. Классификация оценки качества усвоения полученных знаний для зачета по учебному курсу (нормированные значения показателей)

\begin{tabular}{|c|c|c|c|c|c|c|}
\hline Перечень признаков & \multicolumn{5}{|c|}{ Оценочные шкалы для признаков } \\
\hline & $\begin{array}{c}\text { I } \\
\text { Отличн-- }\end{array}$ & $\begin{array}{c}\text { II } \\
\text { Хорошо }\end{array}$ & $\begin{array}{c}\text { ІІІ } \\
\text { Удвлетво- }\end{array}$ & Недостаточно & $\min$ & $\max$ \\
\hline
\end{tabular}




\begin{tabular}{|c|c|c|c|c|c|c|}
\hline & $\begin{array}{c}\text { очень } \\
\text { хорошо }\end{array}$ & & $\begin{array}{l}\text { рительно- } \\
\text { достаточно }\end{array}$ & $\begin{array}{l}\text { (неудовлетво- } \\
\text { рительно) }\end{array}$ & & \\
\hline $\begin{array}{l}\text { 1. Устный (письменный) ответ обучающегося на } \\
\text { вопросы билета. }\end{array}$ & $1,0-0,90$ & $0,90-0,70$ & $0,70-0,42$ & $0,42-0,0$ & 0 & 5 \\
\hline $\begin{array}{l}\text { 2. Полнота ответа, использование } \\
\text { дополнительного графического, табличного } \\
\text { материала, рисунков, схем, расчетов, } \\
\text { демонстрация углубленного изучения материала, } \\
\text { публикаций. }\end{array}$ & $1,0-0,80$ & $0,80-0,70$ & $0,70-0,42$ & $0,42-0,00$ & 0 & 5 \\
\hline $\begin{array}{l}\text { 3. Ответы на тестовые вопросы преподавателя } \\
\text { по билету, правильность использования } \\
\text { терминологии, демонстрация имеющегося } \\
\text { личного опыта, подтверждающегося } \\
\text { публикациями (подготовкой статей) или } \\
\text { участием в НИР грантах, конкурсах } \\
\text { (информацию можно подготовить и переслать } \\
\text { вместе с письменным ответом на вопросы } \\
\text { билета). }\end{array}$ & $1,0-0,80$ & $0,80-0,50$ & $0,50-0,30$ & $0,30-0,00$ & 0 & 10 \\
\hline $\begin{array}{l}\text { 4. Оценка знакомства отвечающего с основной и } \\
\text { дополнительной литературой (российской и } \\
\text { зарубежной). }\end{array}$ & $1,0-0,80$ & $0,80-0,40$ & $0,40-0,20$ & $0,20-0,00$ & 0 & 5 \\
\hline $\begin{array}{l}\text { 5. Оценка самостоятельности подготовки к } \\
\text { ответу (без использования текста конспектов), } \\
\text { разрешенной литературы; учет времени, } \\
\text { затраченного на подготовку ответа и ответов на } \\
\text { тестовые вопросы. }\end{array}$ & $1,0-0,8$ & $0,80-0,4$ & $0,4-0,2$ & $0,20-0,00$ & 0 & 5 \\
\hline $\begin{array}{l}\text { 6. Оценка преподавателем общего уровня } \\
\text { готовности обучающегося для решения проблем, } \\
\text { рассмотренных при изучении курса, участия в } \\
\text { грантах по близкой теме. }\end{array}$ & $1,0-0,80$ & $0,80-0,50$ & $0,5-0,30$ & $0,30-0,00$ & 0 & 10 \\
\hline $\begin{array}{l}\text { Интегральный показатель успеваемости } \\
\text { (ИПУ2) }\end{array}$ & $1,000-0,817$ & $\begin{array}{c}\mathbf{0 , 8 1 7}- \\
\mathbf{0 , 5 3 3}\end{array}$ & 0,533-0,307 & 0,307-0,000 & & \\
\hline
\end{tabular}

Таблица 6. Пример исходных данных и результат оценки качества усвоения полученных знаний на зачете/экзамене для студента NN.

\begin{tabular}{|c|c|c|c|}
\hline \begin{tabular}{c|} 
Номер \\
критерия
\end{tabular} & $\begin{array}{c}\text { Численное значение } \\
\text { и класс качества по } \\
\text { оценкам } \\
\text { преподавателя (по } \\
\text { табл.1) } \\
\end{array}$ & $\begin{array}{c}\text { Результат нормирования } \\
\text { по } \\
q_{i}=\left(x_{i}-\min \right) /(\max -\min )\end{array}$ & $\begin{array}{c}\text { Произведение результата } \\
\text { нормирования } q_{i} \text { на вес } \\
\text { критерия } w_{i}\end{array}$ \\
\hline 1 & $4,6(\mathrm{I})$ & $(4,6-0) / 5=0,92$ & $q_{1} w_{1}=0,92 * 0,167=0,011$ \\
\hline 2 & 4,0 (I-II) & $(4,0-0) / 5=0,80$ & $q_{2} w_{2}=0,8 * 0,167=0,043$ \\
\hline 3 & 7 (II) & $(7-0) / 10=0,70$ & $q_{3} w_{3}=0,7 * 0,167=0,029$ \\
\hline 4 & 3 (II) & $(3-0) / 5=0,60$ & $q_{4} w_{4}=0,6 * 0,167=0,072$ \\
\hline 5 & $5(\mathrm{I})$ & $(5-0) / 5=1,0$ & $q_{5} w_{5}=1,0 * 0,167=0,057$ \\
\hline \multirow[t]{2}{*}{6} & 8 (I-II) & $(8-0) / 10=0,80$ & $q 6 w 6=0,8 * 0,167=0,086$ \\
\hline & & ИПУ 2 = & $\sum_{i=1}^{6} q_{i} w_{i}=\mathbf{0 , 8 0}(\mathrm{II})$ \\
\hline
\end{tabular}

В итоге, по совокупности критериев оценивания за ответ на зачете/экзамене успеваемость студента следует отнести к II классу (хорошо), так как диапазон изменения интегрального показателя у этого класса 0,817-0,533 (табл.5). Отметим также, как и в случае с ИПУ1, близость результата к правой границе I класса. Такой итог был ожидаем, поскольку по всем критериям оценивания отмечалось попадание в I-II классы ИПУ2.

\section{Расчет итоговой оценки успеваемости обучающихся.}

1. Получение итоговой шкалы для промежуточной аттестации для равенства приоритетов (весов) ИПУ $1=0,5$ и ИПУ $2=0,5$ : 


\begin{tabular}{|l|c|c|c|c|}
\hline \multicolumn{1}{|c|}{\begin{tabular}{|}
\multicolumn{1}{|c|}{ Итоговая интегральная оценка } \\
промежуточной аттестации
\end{tabular}} & $\begin{array}{c}\text { I } \\
\text { Отлично- } \\
\text { очень } \\
\text { хорошо } \\
\text { Хорошо }\end{array}$ & $\begin{array}{c}\text { II } \\
\text { Удовлетво- } \\
\text { рительно- } \\
\text { достаточно }\end{array}$ & $\begin{array}{c}\text { IV } \\
\text { (недостаточн } \\
\text { о } \\
\text { о-рительно }\end{array}$ \\
\hline $\begin{array}{l}\text { Интегральный показатель успеваемости } \\
\text { (ИПУ1) }\end{array}$ & $\mathbf{1 , 0 0 0 - 0 , 8 4 3}$ & $\mathbf{0 , 8 4 3 - 0 , 6 2 9}$ & $\mathbf{0 , 6 2 9 - 0 , 3 7 7}$ & $\mathbf{0 , 3 7 7 - 0 , 0 0 0}$ \\
\hline $\begin{array}{l}\text { Интегральный показатель успеваемости } \\
\text { (ИПУ2) }\end{array}$ & $\mathbf{1 , 0 0 0 - 0 , 8 1 7}$ & $\mathbf{0 , 8 1 7 - 0 , 5 3 3}$ & $\mathbf{0 , 5 3 3 - 0 , 3 0 7}$ & $\mathbf{0 , 3 0 7 - 0 , 0 0 0}$ \\
\hline $\begin{array}{l}\text { Интегральный показатель успеваемости } \\
\text { (ИПУ) }\end{array}$ & $\mathbf{1 , 0 0 0 - 0 , 8 3 0}$ & $\mathbf{0 , 8 3 0 - 0 , 5 8 1}$ & $\mathbf{0 , 5 8 1 - 0 , 3 4 2}$ & $\mathbf{0 , 3 4 2 - 0 , 0 0 0}$ \\
\hline Ширина класса $(\boldsymbol{\Delta})$ & $\mathbf{0 , 1 7 0}$ & $\mathbf{0 , 2 4 9}$ & $\mathbf{0 , 2 3 9}$ & $\mathbf{0 , 3 4 2}$ \\
\hline
\end{tabular}

В этом случае оценка за курс: $0,6 * 0,5+0,8 * 0,5=0,700$ (II класс, «хорошо»), т.к. граница ИПУ для II класса: 0,805-0,625.

2. Получение итоговой шкалы для промежуточной аттестации для приоритетов ИПУ1 $=0,6$ и ИПУ $2=0,4$ :

\begin{tabular}{|l|c|c|c|c|}
\hline \multicolumn{1}{|c|}{$\begin{array}{c}\text { Итоговая интегральная оценка } \\
\text { промежуточной аттестации }\end{array}$} & $\begin{array}{c}\text { I } \\
\text { Отлично- } \\
\text { очень } \\
\text { хорошо }\end{array}$ & $\begin{array}{c}\text { II } \\
\text { Хорошо }\end{array}$ & $\begin{array}{c}\text { III } \\
\text { Удовлетво- } \\
\text { рительно- } \\
\text { достаточно }\end{array}$ & $\begin{array}{c}\text { IV } \\
\text { Недостаточно } \\
\text { (неудовлетво- } \\
\text { рительно) }\end{array}$ \\
\hline $\begin{array}{l}\text { Интегральный показатель успеваемости } \\
\text { (ИПУ1) }\end{array}$ & $\mathbf{1 , 0 0 0 - 0 , 8 4 3}$ & $\mathbf{0 , 8 4 3 - 0 , 6 2 9}$ & $\mathbf{0 , 6 2 9 - 0 , 3 7 7}$ & $\mathbf{0 , 3 7 7 - 0 , 0 0 0}$ \\
\hline $\begin{array}{l}\text { Интегральный показатель успеваемости } \\
\text { (ИПУ2) }\end{array}$ & $\mathbf{1 , 0 0 0 - 0 , 8 1 7}$ & $\mathbf{0 , 8 1 7 - 0 , 5 3 3}$ & $\mathbf{0 , 5 3 3 - 0 , 3 0 7}$ & $\mathbf{0 , 3 0 7 - 0 , 0 0 0}$ \\
\hline Интегральный показатель успеваемости (ИПУ) & $\mathbf{1 , 0 0 0 - 0 , 8 3 3}$ & $\mathbf{0 , 8 3 3 - 0 , 5 9 1}$ & $\mathbf{0 , 5 9 1 - 0 , 3 4 9}$ & $\mathbf{0 , 3 4 9 - 0 , 0 0 0}$ \\
\hline
\end{tabular}

В этом случае итоговая оценка за курс: 0,6*0,6+0,8*0,4=0,680 (II класс, «хорошо»), т.к. граница ИПУ для II класса: 0,833-0,591.

В итоге показано, что изменение весов (приоритетов) учета ИПУ1 и ИПУ2 при расчете итоговой оценки не привело к изменению оценки, относительно варианта с равновесомым учетом ИПУ1 и ИПУ2. Таким образом, для получения итоговой оценки будем использовать: ИПУ= 0,5*ИПУ $1+0,5 *$ ИПУ 2.

\section{Примеры вопросов для подготовки к зачету/экзамену по курсу «Интегральная оценка наземных и водных ландшафтов» (фрагмент).}

1. Сложные системы в природе и обществе и их основные свойства. Понятия: элемент (компонент), структура, система. Простые и сложные системы, системообразующие связи. Свойства сложных систем.

2. Интегральные свойства, неаддитивность, эмерджентность, целостность сложной системы.

3. Фактор. Комплекс. Совокупность. Система.

4. «Формулы», использующие родовое понятие «система» в географических и геоэкологических исследованиях.

5. Иерархия экосистем. Иерархия геосистем. Системологический принцип иерархической организации сложной системы.

6. Ценность. Оценка. Оценка состояния системы. Экологическая оценка. Эколого-географическая оценка. Геоэкологическая оценка.

7. Что такое аксиология и аксиометрия и зачем они нужны в оценочных исследованиях.

8. Геоэкологический мониторинг. Уровни геоэкологического мониторинга. 
9. Экологическая оценка. Стратегия экологической оценки. Экологическая оценка и оценка качества среды. Ниша Хатчинсона.

10. Два этапа оценочных исследований: 1 - диагностика и 2 - экологическое (системное) нормирование.

11. Показатель, признак, критерий, критерий оптимальности, экологический критерий.

12. Состояние природной системы и его оценка. Состояние природы. Состояние геосистемы. Режим. Вектор состояния системы.

13. Проблема. Ситуация. Обстановка. Экологическая проблема. Экологическая ситуация. Экологическая обстановка.

14. Качество среды. Оценка качества среды. Антропо-, био-, эко- и геоцентризм в оценке качества среды.

15. Что подлежит изучению и оценке в естественных и антропогеннотрансформированных наземных и водных объектах (эко- и геосистемах).

16. Описательный и точный период развития науки по академику А.А. Дородницину. Схема основных стадий системного анализа применительно к исследованию природной системы.

17. Единичные (прямые и косвенные) и комплексные оценки в географии и геоэкологии. Многокритериальная оценка. Интегральная оценка.

18. Основные этапы интегральных оценок.

19. Свертывания показателей о состоянии сложной системы. «Портрет экосистемы». Индикаторы и индексы состояния.

20. Классификационная схема индексов состояния экосистемы по литературным обобщениям. Индексы-маркеры и аналитические индексы.

21. Получение оценок состояния на основе метода сводных показателей (МСП).

22. Этапы получения интегральных оценок на основе построения интегральных показателей.

23. Устойчивость. Индексно-балльные оценки устойчивости и их развитие.

24. Устойчивость почв, устойчивость ландшафта (фации) на основе балльной оценки.

25. Устойчивость ландшафтов на основе балльной и интегральной оценки.

26. Устойчивость водоемов и водотоков на основе балльно-индексного подхода.

27. Экологическое благополучие и его оценка на основе интегрального подхода.

28. Концептуальная модель стратегии развития наземных экосистем. Разработка концептуальной модели стратегии развития водных экосистем.

\section{Примеры вопросов для подготовки к экзамену по курсу «Экологическое нормирование и устойчивость водных экосистем» (первый вопрос).}

1. Методы и средства ЭН. Индексы окружающей среды и их использование в экологическом нормировании.

2. Единичные (прямые и косвенные), комплексные, многокритериальные, интегральные оценки. Ваш опыт получения интегральных оценок на основе практик и публикаций.

3. Основные положения компилятивного подхода к экологическому нормированию.

4. Методы и средства ЭН. Экологические мишени. Биоиндикация и биотестирование.

5. Устойчивость к изменению параметров режимов: основное определение. Общая идея индексно-балльной оценки устойчивости водоемов и водотоков и её недостатки.

6. Устойчивость к изменению параметров режимов: основное определение. Общая идея применения метода сводных показателей (композитных индексов) для оценки устойчивости. Этапы интегральной оценки устойчивости. 
7. Методы и средства ЭН. Анализ зависимостей «доза-эффект» и пример введение классов антропогенной трансформации экосистем.

8. Понятие нормы. Норма и мера. Виды норм. Подходы к оценке нормы состояния водной экосистемы и нормы воздействия на неё.

9. Опасность. Риск. Основные определения. Экологический риск. Фактор риска и пример его определения.

10. Методы и средства ЭН. Нормирование воздействия на водную экосистему на основе системного моделирования.

\section{Вопросы для подготовки к экзамену по дисциплине «Экологическое нормирование и устойчивость водных экосистем» (второй вопрос).}

1. ПДК (определение). Недостатки системы ПДК.

2. Практика регламентации природопользования. Отечественный опыт. Современные предложения и акценты.

3. Практика регламентации природопользования. Зарубежный опыт. Европейская рамочная водная директива.

4. Авторские подходы к решению проблем экологического нормирования (на примере одного или нескольких авторов).

5. Принципы экологического нормирования О.Ф.Садыкова.

6. Ниша Хатчинсона. Построение и трансформация ниши Хатчинсона на основе лабораторного эксперимента.

7. Ущербы и их оценки. Экологический и экономический ущербы.

8. Экологический мониторинг для целей ЭН.

9. Европейская Рамочная Водная Директива (WFD). Содержание, планы и современное состояние.

10. Аксиология оценки экологического статуса и экологического благополучия. В чем разница в подходах.

11. Этапы интегральной оценки состояния водной экосистемы для целей ЭН.

\section{Вопросы для подготовки к экзамену по дисциплине «Экологическое нормирование и} устойчивость водных экосистем» (третий вопрос).

Примеры формулировок третьего вопроса:

1. Регламентация природо (водо) пользования в одной из зарубежных стран.

2. Экологическое нормирование (ЭН). Определения в широком и узком смысле. Отличие экологического нормирования от экологической оценки и экологической регламентации.

3. Основные определения, связанные с устойчивостью.

4. Адаптационная и регенерационная устойчивость в оценке устойчивости водных объектов.

5. Развитие ЭН в России (современное состояние).

6. Санитарно-гигиеническое нормирование и его отличие от ЭН.

7. Построение интегральных показателей состояния водной экосистемы в условиях неопределенности.

8. Рекреационный потенциал водоема. Ваше решение.

9. Неполная, неточная, нечисловая информация в интегральной оценке состояния водной экосистемы.

10. Основные изменения в законе «О плате за пользование водными объектами» за последние 20 лет. 
11. Предложите свой комментарий или пояснение для какого-либо одного (двух) положений компилятивного подхода к ЭН или обоснуйте своё (дополнительное) положение.

Примеры тестовых вопросов к первому или второму вопросам.

1. Что нормируется, состояние или воздействие?

2. Короткое определение ПДК.

3. Регламент и норматив. В чем разница.

4. Потенциальная устойчивость.

5. Как Вы понимаете термин «эмерджентность сложной системы»? В чем она проявляется.

6. Приведите определения «экологическое нормирование», «устойчивость сложных систем к изменению параметров режимов». Что объединяет эти определения.

7. Приведите пример использования индекса - «условного функционала» в паре с индексом качества среды. Что это дает исследователю.

8. Что, по Вашему мнению, произойдет с оценочной шкалой при использовании в нормирующих функциях «мини-макса» значений показателя степени $\lambda \neq 1$.

9. На основе каких параметров Вы определили экономическую целесообразность внедрения одной из двух разных систем очистки сточных вод на промышленном предприятии. Какой (какие) параметры оценки были взяты за основные.

10. Чем риск отличается от фактора риска.

11. Можно ли измерить устойчивость экосистемы в полевых условиях.

12. Может ли коэффициент очистки воды быть выше у одного способа очистки сточных вод, а эффективность очистки наоборот, ниже. Какой метод очистки сточных вод Вы в этом случае выберете.

13. Выполнены ли плановые показатели WFD в странах EC.

14. В некоторых современных публикациях политологов обсуждается необходимость перехода от устойчивого развития к стабильному. Прокомментируйте.

15. В некоторых отечественных и з/б публикациях рассматриваются термины «геотаксон», «патч». В чем их смысл.

16. Что такое «чистый портрет» и «антропогенно-трнсформированный портрет», определите понятия.

Раздел 2. Теоретико-методологические основы интегральной оценки экосистем, геосистем, ландшафтов и их эмерджентных свойств.

\section{Лекция №1}

Особенности современного этапа исследования сложных систем в природе и обществе. Сложные системы в природе и обществе и их основные свойства. Понятия: элемент (компонент), структура, система. Фактор. Комплекс. Совокупность. Система. Простые и сложные системы, системообразующие связи. Свойства сложных систем. Простые и сложные системы, системообразующие связи. Свойства сложных систем. Эмергентность (эмержентность, эмерджентность) сложной системы. «Формулы», использующие родовое понятие «система» в географических и геоэкологических исследованиях.

Иерархии сложных систем в природе и обществе. Иерархия экосистем и геосистем. Иерархия экосистем. Иерархия в географии. Иерархия геосистем. Иерархия в биологии. Иерархия этническая. Фундаментальные и прикладные научные исследования. Оценка. Оценка состояния системы. Оценка и диагностика. Диагностика природного объекта. Прикладная экология. Системный мониторинг.

Показатель, признак, критерий. Экологический критерий. Состояние природной системы и его оценка. Состояние природы. Состояние геосистемы. Режим. Опасные природные явления. 
Фундаментальные и прикладные научные исследования. Фундаментальные исследования - экспериментальная или теоретическая деятельность, направленная на получение новых знаний об основных закономерностях строения, функционирования и развития человека, общества, окружающей среды (определение РФФИ). В средствах массовой информации неоднократно отмечалось, что почти все приоритетные направления развития современной науки относятся к так называемой «прикладной» науке, фундаментальные же исследования объявлены приоритетом государства в целом. Комментируя подобные высказывания, уместно повторить известное выражение Л.Пастера о том, что «есть наука и ее приложения». Деление науки на «фундаментальную» и «прикладную» можно назвать традицией или жаргоном, принятым в обществе. Добавим к этому, что такой жаргон допустим, если признается, что в любом из направлений существует фундаментальная основа, результаты исследований, направленные на решение практических проблем и инновация.

Результаты исследований, направленные на решение практических проблем можно называть прикладными. Речь сегодня идет об адаптации классического фундаментального университетского образования в прикладное. Понятие инновация (нововведение) пришло на смену понятиям научно-технический прогресс, научно-технический проект. Инновация, это первое применение совершенно нового продукта, технологии, услуги. Нет применения - нет инновации, нет потребителя - нет инновации. Тематические планы, проекты и предложения, заявляемые сегодня в грантах должны предусматривать коммерческое освоение новых разработок. Таким образом, они становятся инновационными, а значит современными. Акцент сегодняшнего дня - создание условий для инновационной деятельности, создание инновационной системы, инновационных центров, фондов, парков и т.п.

Особенности современного этапа исследования сложных систем в природе и обществе. Покомпонентный анализ сложных систем и их свойств уже не может служить общеметодологической основой исследования сложных природных и общественных систем. Это обусловливает переход к методам многокритериального и интегрального оценивания и является подтверждением развития «цифровизации» в науках о Земле и экологии. Акцент исследований смещается на использование при анализе сложных систем в природе и обществе новых обобщений, характеризующих состояние сложной системы в целом и ее интегративные (эмерджентные) свойства. Речь идет о новых функциональных единицах систем (интегральных показателях подсистем и интегральных показателях последнего уровня свертки, характеризующего целостность системы. Эти показатели отражают интегративность систем, они должны являться основой их систематики, и позволяют сравнивать состояние систем в пространстве и времени или выявлять эффекты взаимосвязи и взаимодействия систем (подсистем), не аддитивные по отношению к внутрисистемным эффектам (Дмитриев и соавт., 2018).

Сложные системы в природе и обществе и их основные свойства. Основные понятия, использующиеся при изучении природных объектов как сложных систем. Система - множество элементов, находящихся в отношениях и связях друг с другом, которые образуют целостность, единство. Все определения системы подразделяются на 3 группы. В первой группе рассматривается как комплекс компонентов, процессов, явлений, так и связи между ними, существующие объективно, независимо от наблюдателя. Основная задача - выделить систему. Проф. кафедры геоморфологии СПбГУ А.Н. Ласточкин, выступая на одной из научных сессий ф-та географии и геоэкологии в 2010 г., сетовал на неумение географов выделять систему, порождающее зачастую, необоснованные «претензии географов на: а) экспертные геоэкологические оценки и прогнозы; б) познание динамики, функционирования своих объектов (геосистем или экосистем) и даже на управление ими». По мнению автора, «безосновательность того и другого заключена в игнорировании ими обязательного статического уровня, которое 
предусматривает их строгое определение, точное выделение и систематику этих объектов...». Любая система существует лишь в определенных границах изменений ее свойств, поэтому обычно задаются максимальные и минимальные значения ее переменных. Выделение границ важный и ответственный этап геосистемных исследований.

Во втором случае система рассматривается как инструмент, способ исследования процессов и явлений. Здесь система выступает как синоним модели. Вызов времени связан с умением оценивать и прогнозировать развитие эко-, гео-, урба-, этно-, социосистем. Сложность их оценивания возрастает в указанном ряду слева направо. В зависимости от целей исследования и степени представления в них геопространства для оценки состояния и особенностей функционирования сложных систем разрабатываются точечные, блочные (боксовые, резервуарные), непрерывные имитационные модели. На моделях рассматриваются результаты годового цикла развития наземных и водных экосистем и геосистем.

В третью группу входят определения, совмещающие первую и вторую группы.

По другому определению: Система есть множество связанных между собой компонентов той или иной природы, упорядоченное по отношениям, обладающим вполне определенными свойствами; это множество характеризуется единством, которое выражается в интегральных свойствах и функииях множества (определение акад. В.М.Глушкова, 1963).

На основе имеющихся в литературе обобщений выделим некоторые явные и неявные характеристики систем, заключенные в приведенном определении.

1. Любые системы состоят из исходных единиц — компонентов. В качестве компонентов системы (в широком смысле) могут рассматриваться объекты, свойства, связи, отношения, состояния, фазы функционирования, стадии развития. В рамках данной системы и на данном уровне абстракции (конкретизации) компоненты представляются как далее неделимые, целостные и различимые единицы, то есть исследователь абстрагируется от их внутреннего строения, но сохраняет сведения об их эмпирических свойствах.

Объекты, представляющие собой единицы, из которых состоит система, могут быть материальными или идеальными.

Свойства системы, отражают специфику объектов, могут стать компонентами системного анализа. Например, свойствами термодинамической системы могут быть температура, давление, объем, и др. Свойства могут быть как изменяющимися, так и неизменными при данных условиях существования системы. Свойства могут быть внутренними (собственными) и внешними. Собственные свойства зависят только от связей (взаимодействий) внутри системы, это свойства системы «самой по себе». Внешние свойства актуально существуют лишь тогда, когда имеются связи, взаимодействия с внешними объектами (системами).

Связи изучаемого объекта также могут быть компонентами при его системном анализе. Связи имеют вещественно-энергетический, субстанциальный характер. Аналогично свойствам, связи могут быть внутренними и внешними для данной системы. Так, если мы описываем механическое движение тела как динамическую систему, то по отношению к этому телу связи имеют внешний характер. Если же рассмотреть более крупную систему из нескольких взаимодействующих тел, то те же механические связи следует считать внутренними по отношению к этой системе.

Отношения отличаются от связей тем, что не имеют ярко выраженного вещественно-энергетического характера. Тем не менее, их учет важен для понимания той или иной системы. Например, пространственные отношения (выше, ниже, левее, правее), временные (раньше, позже), количественные (меньше, больше).

Состояния и фазы функционирования важны для анализа функциональных, действующих на протяжении длительного времени систем. Сам процесс 
функционирования (последовательность состояний во времени) познается путем выявления связей и отношений между различными состояниями.

Этапы, стадии, ступени, уровни развития выступают компонентами генетических систем. Если состояния и фазы функционирования относятся к поведению во времени системы, сохраняющей свою качественную определенность, то смена этапов развития связана с переходом системы в новое качество.

2. Между компонентами множества, образующего систему, существуют системообразующие связи и отношения, благодаря которым реализуется специфическое для системы единство. Система обладает общими функциями, интегральными свойствами и характеристиками, которыми не обладают ни составляющие ее элементы, взятые по отдельности, ни простая «арифметическая сумма» элементов. Иначе говоря, свойства системы в целом неаддитивны по отношению к свойствам ее элементов и подсистем. Существенным показателем внутренней целостности системы является ее автономность, или относительная самостоятельность поведения и существования. По степени автономности можно в известной степени судить об уровне и степени их относительной организованности и самоорганизованности.

3. Существенными характеристиками любых систем являются, присущие им организация и структура, с которыми тесно связано математическое описание систем.

4. Относительность понятий «компонент» («элемент») и «система» («структура») состоит в том, что любая система может, в свою очередь, выступать в качестве компонента или подсистемы для надсистемы. С другой стороны, компоненты, выступающие при анализе системы как нерасчлененные целые, при более детальном рассмотрении (микроанализе) сами по себе проявляют себя как системы. В любом случае (и именно это служит основой для расчленения системы на подсистемы) связи элементов внутри подсистемы сильнее, чем связи между подсистемами, и сильнее, чем связи между элементами, принадлежащими различным подсистемам. Существенно также то, что количество типов элементов (подсистем) ограничено, внутреннее разнообразие и сложность системы определяется, как правило, разнообразием межэлементных (межкомпонентных) связей, а не разнообразием типов элементов.

5. Для любых (и особенно высокоорганизованных) систем важно выяснить характер связи подсистем, иерархических уровней внутри системы; в системе сочетаются взаимосвязь ее подсистем по одним свойствам и отношениям и относительная независимость по другим свойствам и отношениям. В самоуправляемых системах это выражается, в частности, в сочетании централизации деятельности всех подсистем с помощью центральной управляющей инстанции с децентрализацией деятельности уровней и подсистем, обладающих относительной автономностью.

6. Сложная система - это результат эволюции более простой системы. Система не может быть изучена, если не изучен ее генезис.

Познание того или иного объекта как системы должно включать в себя следующие основные составляющие: a) определение структуры и организации системы; б) определение собственных (внутренних) интегральных свойств и функций системы; в) определение функций системы как реакций на выходах в ответ на воздействие других объектов на входы; г) определение генезиса системы, т.е. способов и механизмов ее образования, а для развивающихся систем - способов их дальнейшего развития.

Особенно важной характеристикой системы является ее структура. Унифицированное описание систем на структурном языке предполагает определенные упрощения и абстракции. Если при определении компонентов системы мы абстрагировались от их строения, рассматривая их как нерасчлененные единицы, то следующий шаг заключается в отвлечении от эмпирических свойств компонентов, от их природы (физической, биологической и пр.) при сохранении различий по качеству. Таким образом, при анализе структуры мы имеем дело с абстрактныли качественно различными единицами. 
Между компонентами системы, как было отмечено выше, существуют различные связи и отношения. Сами способы связи и виды отношений зависят как от природы компонентов, так и от условий существования системы. Для понятия структуры специфичен особый и в то же время универсальный тип отношений и связей отношения композищии элементов. Отношения порядка (упорядоченности) в системе существуют в двух видах: устойчивые и неустойчивые применительно к точно определенным условиям существования системы. Понятие структуры отображает устойчивую упорядоченность. Структура системы есть совокупность устойчивых связей и отношений, инвариантных по отнотению к вполне определенным изменениям, преобразованиям системы. Выбор этих преобразований зависит от границ и условий существования системы. Структуры объектов (систем) того или иного класса описываются в виде законов их строения, поведения и развития.

Кратко остановимся на взаимосвязи и взаимозависимости систем и составляющих их элементов. Здесь обнаруживаются следующие диалектические закономерности.

1. Относительная самостоятельность структуры, независимость ее от элементов. При удалении из системы одного или нескольких элементов структура может остаться неизменной, а система может сохранить свою качественную определенность (в частности, работоспособность). Удаленные элементы в некоторых случаях могут быть без ущерба заменены новыми. В этом проявляется преобладание внутренних структурных связей над внешними.

2. Зависимость структуры от элементов. Структура не существует как независимое от элементов организующее начало, а сама определяется составляющими ее элементами. Совокупность элементов не может сочетаться произвольным образом, следовательно, способ связи элементов (структура будущей системы) частично определяется свойствами элементов, взятых для ее построения.

3. Относительная самостоятельность элементов, независимость их от структуры. Вхождение элемента в структуру более высокого уровня мало сказывается на его внутренней структуре. Ядро атома не изменяется, если атом войдет в состав молекулы, а микросхеме «все равно», в составе какого устройства она функционирует.

4. Зависимость элементов от структуры. Элемент может выполнять присущие ему функции только в составе системы, только в координации с соседними элементами. В некоторых случаях даже сколько-нибудь длительное сохранение элементов своей качественной определенности невозможно за пределами системы.

Фактор. От нем Faktor от лат. factor -делающий, производящий причина, движущая сила какого-либо процесса, определяющая его характер или отдельные его части. По другому определению, фактор - движущая сила к.-либо процессов или условие, влияющее на них, существенное обстоятельство в каком-либо процессе, явлении. (Реймерс, 1990, с.541). Дискуссионными являются требование «делимость - неделимость» фактора, а также смысл недавно появившихся терминов «нано-фактор» или «нанофактор» и целесообразность их применения в научной литературе (Венецианов, 2010).

Комплекс. Совокупность. Система. Понятия «комплекс», «совокупность» близки понятию «система», но не тождественны ему. Их можно рассматривать как усеченные, неполные понятия по отношению к «системе». Комплекс включает части, не обязательно обладающие системными свойствами, но эти части сами могут быть системами, и элементы последних способны обладать такими свойствами по отношению к ним. Термином «совокупность» обозначается множество элементов, обладающих некоторыми общими свойствами, существенными для их характеристики и не обязательно находящихся в системных отношениях и связях друг с другом.

Простые и сложные системы, системообразующие связи. Свойства сложных систем. Сложная система - система, поведению которой присущ акт решения. Сложная система в отличие от простой имеет значительно большее число взаимосвязанных качеств. Она характеризуется с помощью простых (аддитивных) и сложных (неаддитивных) системных параметров. Сложные системы и их свойства нельзя изучать путем их простого «расчленения». Необходима методология системного подхода. Свойства сложной системы - см.рис.1. Известно много принципов структурнофункциональной организации сложных систем. Акад. Глушков и др. (1979) указывал на 
существование 22 принципов организации вещества, 10 принципов организации энергии, 9 принципов организации информации.

Основные черты сложных систем: большое число взаимосвязанных качеств сложность структуры; нелинейность связей; сложность поведения - выбор решения, стратегической цели; простые и сложные системные параметры. Примеры неаддитивных свойств сложных систем: устойчивость и ее варианты для экосистем (см. ниже), надежность, продолжительность жизни, живучесть, целостность, повторяемость, неидентичность, упорядоченность, эмергентность (эмержентность, эмерджентность). Последнее свойство очень важно для анализа сложных систем в природе и обществе. Свойства сложной системы - см. рис.1.

\section{Эмергентность (эмержентность, эмерджентность) сложной системы -} несводимость сложной системы к составляющим её компонентам («основным», «важным для человека», «слабым», «слабому звену» и т.п.). Таким образом, нельзя сводить характеристику сложной системы к характеристике её основных компонентов на основе единичных (покомпонентных), косвенных оценок.

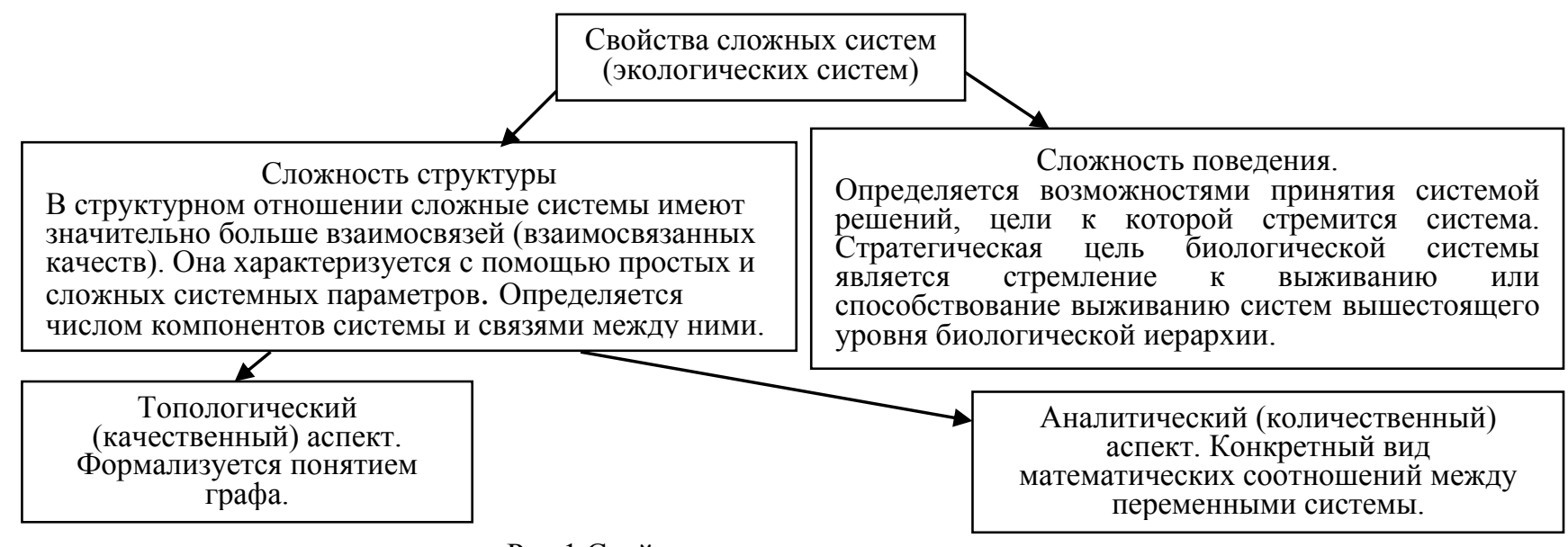

Рис.1 Свойства сложных систем.

Табл.7 «Формулы», использующие родовое понятие «система» в географических экологических и геоэкологических исследованиях (Дмитриев, 2000, 2010).

\begin{tabular}{|c|c|}
\hline Экосистема & $\begin{array}{l}\text { Биоценоз + биотоп. В биотопе иногда выделяют климатоп (совокупность климатических факторов на } \\
\text { данной территории), эдафотоп (биокосные составляющие почвы), гидротоп (гидрологические факторы } \\
\text { среды). Ниже все они обозначены как «физико-географическая среда». }\end{array}$ \\
\hline Водная экосистема & Водный биоценоз + водный биотоп. \\
\hline $\begin{array}{l}\text { Геосистема, } \\
\text { геоэкосистема }\end{array}$ & 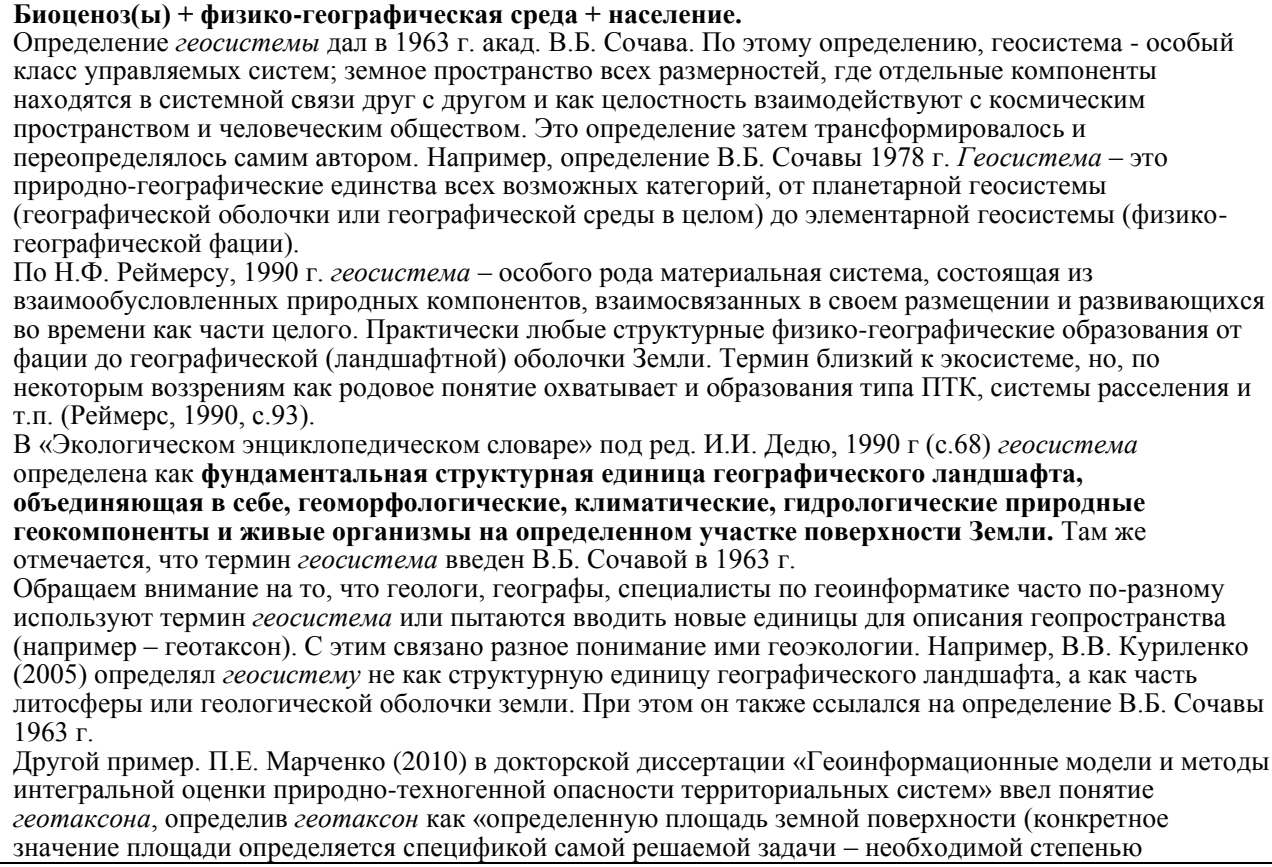 \\
\hline
\end{tabular}




\begin{tabular}{|c|c|}
\hline & $\begin{array}{l}\text { детализации анализируемой территории) с описанием ландшафтно-географической, техногенной и } \\
\text { других ситуаций, на которой задается перечень и характеристики опасных природных и техногенных } \\
\text { процессов (ОПТП) (в общем случае с учетом динамики по времени) и которой ставится во взаимно } \\
\text { однозначное соответствие определенное интегральное значение, характеризующее степень её } \\
\text { опасности». Найдите уязвимые места данного определения. Насколько и когда необходимы геотаксоны в } \\
\text { исследованиях. }\end{array}$ \\
\hline $\begin{array}{l}\text { Водная геосистема, } \\
\text { водная } \\
\text { геоэкосистема } \\
\text { См. также } \\
\text { гидросистема, } \\
\text { гидроэкосистема, } \\
\text { гидрологическая } \\
\text { геосистема, } \\
\text { речная система }\end{array}$ & 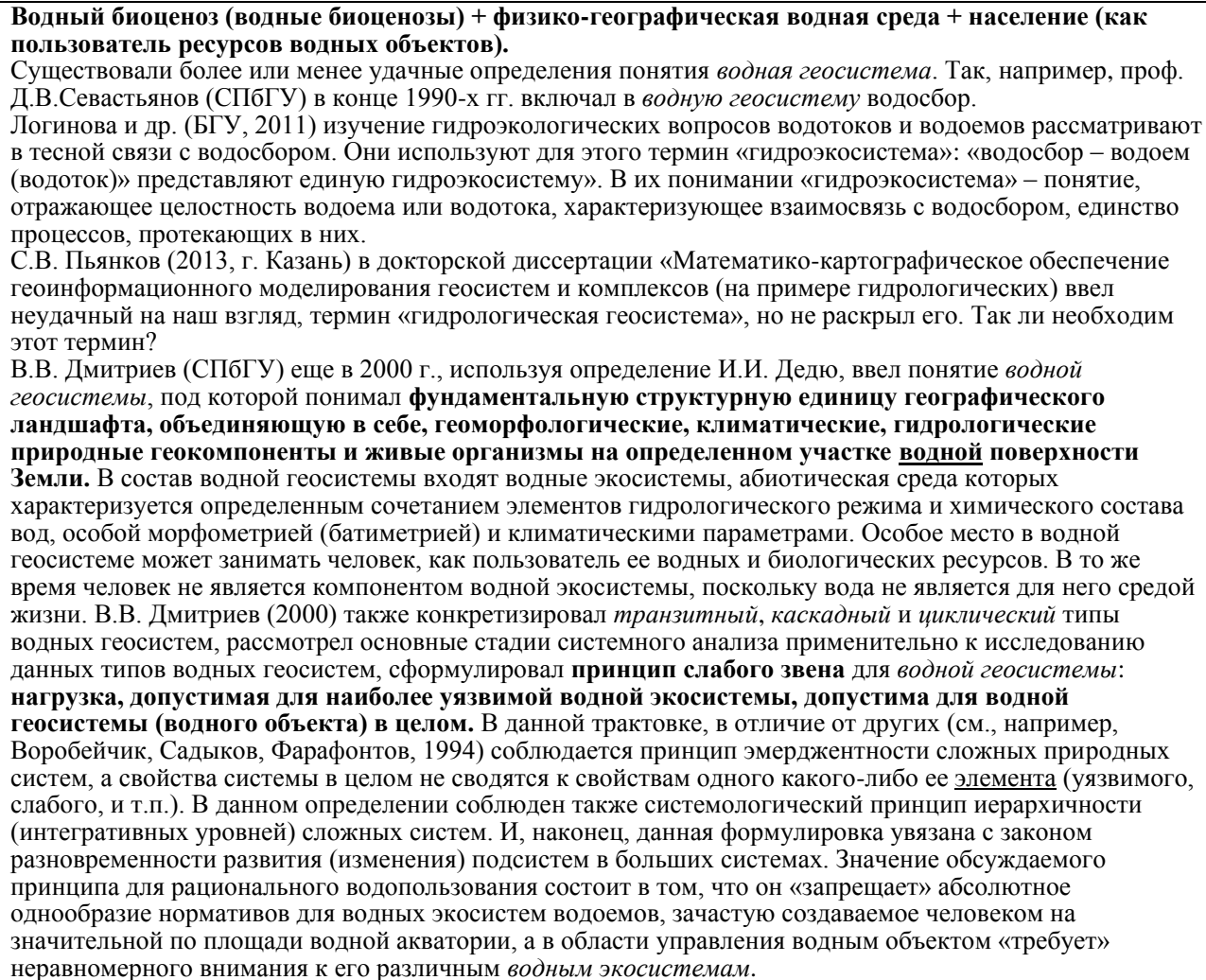 \\
\hline $\begin{array}{l}\text { Урбасистема, } \\
\text { урбосистема, } \\
\text { урбоэкосистема }\end{array}$ & $\begin{array}{l}\text { Антропогенно-трансформированные (биоценоз }(\text { ) }+ \text { физико-географическая среда) }+ \text { население }+ \\
\text { архитектурно-строительные объекты, или урбасистема = антропогенно-трансформированные } \\
\text { zеосистемь + архитектурно-строительные объекты. }\end{array}$ \\
\hline $\begin{array}{l}\text { «Земля», } \\
\text { агросистема, } \\
\text { агроэкосистема, } \\
\text { региональная } \\
\text { агроландшафтная } \\
\text { система. }\end{array}$ & $\begin{array}{l}\text { В существующих законах РФ понятие «почва» не отделено от понятия «земля» и не рассматривается как } \\
\text { отдельный объект. В некоторых документах почвы косвенно определены как «природная функция земли, } \\
\text { причём понятие «земля» в них понимается намного шире, чем понятие «почва». В соответствии с ГОСТ } \\
26640-85, \text { земля - это важнейшая часть окружающей природной среды, характеризующаяся } \\
\text { пространством, рельефом, климатом, почвенным покровом, растительностью, недрами, водами, } \\
\text { являющаяся главным средством производства в сельском и лесном хозяйстве, а также } \\
\text { пространственным базисом для размещения предприятий и организаций всех отраслей народного } \\
\text { хозяйства. } \\
\text { Существуют также термины агроэкосистема или региональная агроландшафтная система. Тогда под } \\
\text { землями (земельными ресурсами) можно понимать ландшафтные системы земледелия, региональные } \\
\text { агроландшафтные системы, агроландшафты, агроэкосистемы и т.п. В любом случае, имеет смысл } \\
\text { говорить об объектах исследования как о сложных антропогенно трансформированных агроэкосистемах. } \\
\text { Тогда об «изменении состояния земель», «оценке изменения состояния земель» логично говорить, } \\
\text { используя термины состояния и фазы функционирования агроэкосистем, если речь идет об их } \\
\text { изменении во времени с сохранением качественной определенности, если же характеристика системы } \\
\text { связана с её переходом в новое качество, то логично использовать термин смена этапов развития. }\end{array}$ \\
\hline $\begin{array}{l}\text { Этносистема, } \\
\text { Этноэкосистема }\end{array}$ & $\begin{array}{l}\text { Биоценоз(ы) + физико-географическая среда }+ \text { этнос }+ \text { экономика }+ \text { культура }+ \text { политика, или } \\
\text { этносистема (этноэкосистема) = геосистема (геоэкосистема) одного этноса }+ \text { экономика }+ \\
\text { культура одного этноса }+ \text { политика. Таким образом, понятия этносистема, этноэкосистема } \\
\text { парциальны по отношению к понятиям социосистема, социоэкосистема. Это их подсистемы. В } \\
\text { глобальном смысле это наверняка. В региональном отношении они в принципе могут совпадать, если } \\
\text { региональная социосистема является системой одного этноса. } \\
\text { В отличие от этноса, этническую систему или этносистему или этноэкосистему по Л.Н. Гумилеву - } \\
\text { реальную этническую целостность, мы можем определить, как «динамическую систему, включающую в } \\
\text { себя не только людей, но и элементы ландшафта, культурную традицию и взаимосвязи с соседями» } \\
\text { (сноска Л.Н. Гумилева: «это не биологическая и не только социальная система») (Гумилев, 2005, с.100). } \\
\text { У Н.Ф. Реймерса (1990, с.662): этноэкосистема - комплекс всех социально-экономических и } \\
\text { экологических факторов в совокупности с народом, на который эти факторы воздействуют, } \\
\text { составляющий динамическую систему: территориально ограниченный комплекс элементов среды, } \\
\text { окружающей человека, на который он оказывает влияние и который влияет на него. }\end{array}$ \\
\hline $\begin{array}{l}\text { Социосистема, } \\
\text { социоэкосистема }\end{array}$ & $\begin{array}{l}\text { Биоценоз(ы) + физико-географическая среда + население + экономика + культура + политика }+\ldots, \\
\text { или социосистема (социоэкосистема) = геосистема (геоэкосистема) + экономика + культура }+ \\
\text { политика }+ \text {. . . . В это определение могут быть также включены различные социальные детерминанты } \\
\text { (здоровье населения, общественное здоровье, подсистема «образование» и др.). } \\
\text { Социо(эко)системы представляют собой динамические саморазвивающиеся и саморегулирующиеся } \\
\text { системы «человеческое общество - природа» или «человеческое общество - окружающая среда», } \\
\text { динамическое равновесие в которых должно обеспечиваться общественным разумом. Различия в } \\
\text { региональных социоэкосистемах связаны с особенностями регионального развития экономики и } \\
\text { культуры, политики. Существенное отличие, например, европейской социоэкосистемы от российской } \\
\text { связано со становлением на региональном уровне человеческих культур и политик, пока еще не } \\
\text { сложившихся в единую европейскую (мировую) материальную и духовную культуру и политику. }\end{array}$ \\
\hline
\end{tabular}




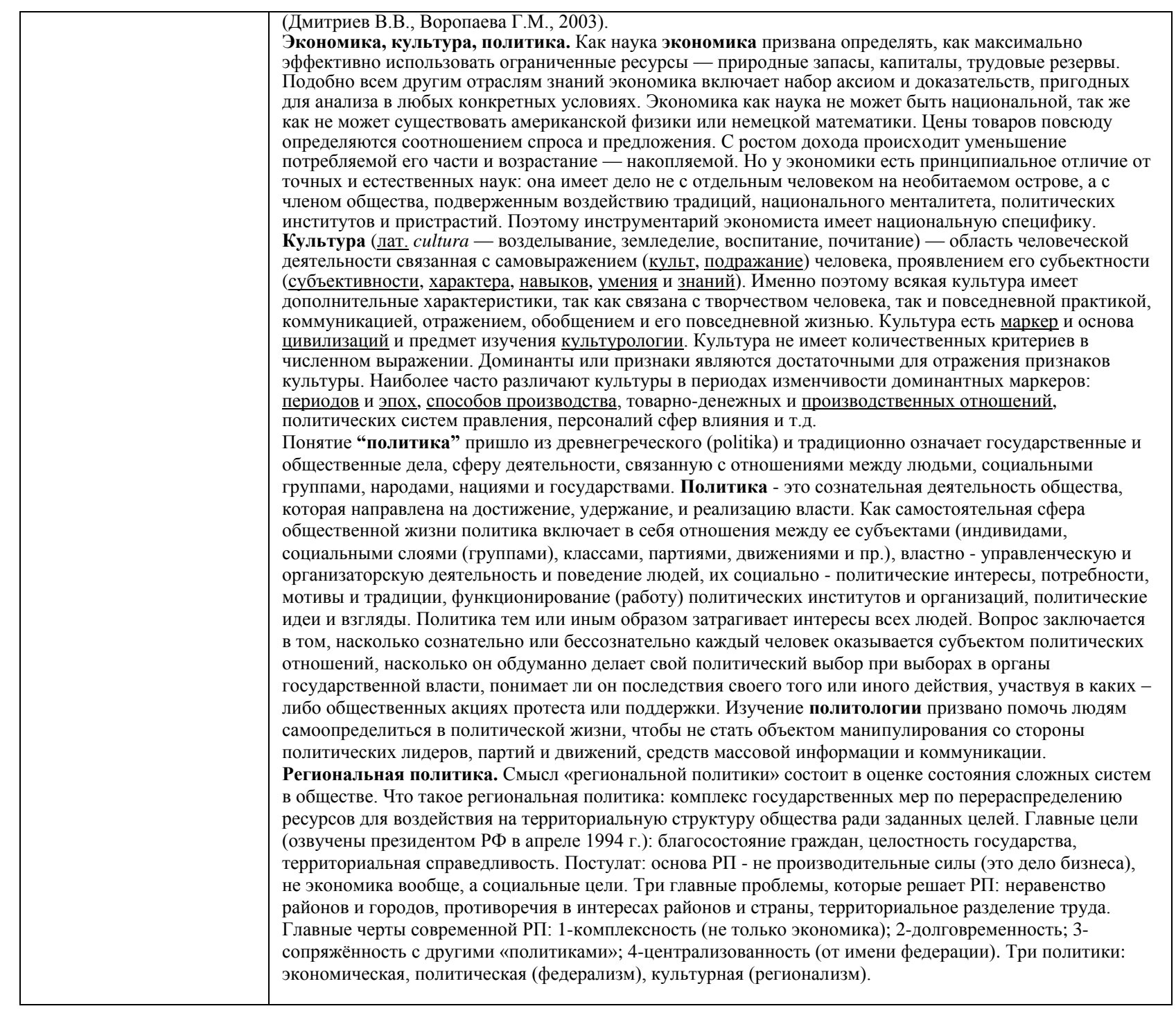

Иерархии сложных систем в природе и обществе. Иерархия экосистем и геосистем. Термин иерархия был введен примерно во 2-й половине 5 в. ПсевдоДионисием Ариопагитом в трактатах «О небесной иерархии» и «О церковной иерархии».

Иерархия: 1) принцип структурной организации сложных многоуровневых животных сообществ и растительных систем, состоящий в упорядочении взаимодействия между уровнями в порядке от высшего к низшему; 2) лестница естественного соподчинения от низшего к высшему, каждый элемент отличается от предыдущего, по меньшей мере, одним добавочным специфическим признаком или свойством. По Н.Ф. Реймерсу, 1990 - иерархия - расположение и функциональное соподчинение (вхождение в более крупную совокупность) элементов целого (его подсистем) в порядке от высшего к низшему (или наоборот - от низшего к высшему). Иерархия - одно из основных свойств природных систем и принципов управления. Она обусловливает эмерджентность и ряд других важных качеств природных образований.

Иерархия экосистем - структурное и функциональное соподчинение экосистем различного уровня организации в ряду: биогеоценоз - биогеоценотический комплекс ландшафт - биом (или ландшафтная провинция) - природный пояс - биогеографическая область - подсферы биосферы или экосистемы суши, океана, атмосферы, литосферы биосфера. Экосистемы каждого уровня организации имеют свой круговорот веществ.

Иерархия в географии - соподчинение геосистем (геохор), основанное на картографическом выявлении их «пространственной мозаики» (по В.Б. Сочаве).

Иерархия геосистем - рассмотрена В.Б. Сочавой как соподчинение геосистем, основанное на картографическом выявлении их «пространственной мозаики» (см. табл.8). 
Иерархия в биологии (биологический иерархический спектр): сообщество популяция - организм - орган - клетка - ген.

Иерархия этническая - естественное ранжирование этнических систем по их размерности и функциональному значению: этносфера - суперэтнос - этнос - субэтнос консорция - конвиксия - (клика - этнический индивидуум).

Таблица 8 Иерархия геосистем по В.Б. Сочаве

\begin{tabular}{|c|c|}
\hline $\begin{array}{c}\text { Порядок } \\
\text { размерности }\end{array}$ & Ряд геохор, их размеры по В.Б. Сочаве \\
\hline Планетарный & $\begin{array}{l}\text { Планетарная геосистема } \\
\text { Физико-географический пояс } \\
\text { Группа физико-географических областей } \\
\text { Субконтинент и составляющие его мегаположения } \\
\text { Физико-географическая область }\left(2 * 10^{6} \text { км }{ }^{2}\right) \\
\text { с широтной зональностью } / \text { с вертикальной зональностью }\end{array}$ \\
\hline Региональный & $\begin{array}{ll}\text { Природная зона } & \text { Группа провинций } \\
\text { Подзона } & \text { Провинция } \\
\text { Провинция }\left(6 * 10^{4} \mathrm{\kappa m}^{2}\right) & \end{array}$ \\
\hline Топологический & $\begin{array}{l}\text { Макрогеохора (округ, ландшафт) }\left(7^{*} 10^{3} \text { км}^{2}\right) \\
\text { Топогеохора (район) }\left(5^{*} 10^{2} \text { км²) }\right. \\
\text { Мезогеохора (местность, группа урочищ) }\left(9 \text { км² }^{2}\right) \\
\text { Микрогеохора (урочище) } \\
\text { Элементарный гетерогенный ареал, элементарная геохора }\end{array}$ \\
\hline
\end{tabular}

Табл.9 Современные иерархические уровни геосистем (ландшафтов)

\begin{tabular}{|l|l|}
\hline 1. Субтопический & $1-10^{2} \mathrm{~m}^{2}$ \\
\hline 2. Топический & $10^{2}-10^{4} \mathrm{M}^{2}$ \\
\hline 3. Хорический & $10^{4}-10^{6} \mathrm{M}^{2}$ \\
\hline 4. Региональный & $10^{7}-10^{12} \mathrm{~m}^{2}$ \\
\hline 5. Субглобальный & $10^{10}-10^{14} \mathrm{M}^{2}$ \\
\hline 6. Глобальный & $10^{14}-10^{16} \mathrm{M}^{2}$ \\
\hline
\end{tabular}

Показатель. Признак. Критерий. Экологический критерий. Показателем (index, index figure, activity indicator, environmental indices) будем называть выраженную числом характеристику какого-либо свойства природного объекта, процесса или решения. Показатель включает в себя количественное значение и набор содержательных признаков (основных и дополнительных, разъясняющих). Показатели могут быть: средними, предельными, объемными, безразмерными, относительными, интегральными и Т.П.

Признак (attribute, feature, mark) - неоднозначная, способная изменяться величина, характеризуемая в процессе исследования (можно говорить о признаке «цветность воды», но нельзя говорить о признаке «цветность воды $35^{0}$ по Pt-Со шкале»). Признаки могут быть качественными и количественными, одномерными и многомерными, непрерывными и дискретными и др. Признаки могут использоваться как критерии классификаций, формирования шкал. В информационно-экологических системах на их основе строятся классификаторы фактографических ИЭС.

Критерий (criterion) - признак, на основании которого проводятся:

- оценка состояния природного объекта или его свойств (например, качества вод, трофности, благополучия, функционирования водной экосистемы и др.);

- классификация объектов, явлений, свойств;

- сравнение альтернатив (возможных вариантов решения задачи). Задачи, которые состоят в выборе одной из существующих (известных) альтернатив, в исследовании операций называются задачами оценки. Задачи, которые состоят в разработке новых стратегий (существующие - недостаточны для достижения цели) называются задачами разработки.

- сравнение адекватности различных решений при моделировании. 
Критерий оптимальности (optimality criterion, оптимальный критерий) - частный случай признака, по которому функционирование системы признается наилучшим, из возможных (в данных объективных условиях) вариантов ее функционирования. Экологическим критерием будем называть признак, на основании которого проводится оценка, определение или классификация экологических систем, процессов и явлений.

Состояние системы. Состояние системы (state of system) - характеристика системы на определенный момент ее функционирования. К сожалению, в экологогеографической литературе пока еще не нашел широкого распространения термин «статус системы», которым можно было бы характеризовать состояние природной системы в определенный момент времени. По-видимому, единственным исключением является устоявшееся определение «трофический статус» и родственные ему понятия, которые служат для разделения природных водоемов и их отдельных участков по степени кормности (трофности), в зависимости от уровня их первичной продукции. В последние годы отмечается появление термина «статус системы» в литературе, при этом авторы не берут на себя смелость определить данный термин или сформулировать его авторское понимание. О состоянии как таковом принято говорить при характеристике физиологического состояния организмов (состояние покоя, активности и др.), термодинамического (равновесного, неравновесного, стабильного, нестабильного и т.д.) состояния природного объекта в целом или его свойства (постоянный уровень воды в реке) или при характеристике гомеостаза любой биосистемы (экосистемы).

Оценка. Оценка состояния системы. Термин оценка (estimation) чаще встречается в эконометрике, метрологии, квалиметрии и др. и по-разному определяется в каждой из них. Например, в метрологии оценка - это приближенное значение величины или параметра, найденного по экспериментальным данным. С помощью экономических оценок характеризуется и соизмеряется эффективность различных ресурсов. В квалиметрии реализуются методы количественной оценки качества продукции, широко применяются экспертные оценки, под которыми понимаются количественные или порядковые оценки процессов или явлений, неподдающихся непосредственному измерению.

Оиенки применяются для нахождения количественных значений свойств при анализе исследуемого объекта или процесса на основе экспериментальных данных, а также на этапе построения моделей при определении численных значений существенных параметров модели, которые численно определяются по экспериментальным данным и статистическими методами. В этом случае речь идет об оценке параметров моделей.

Основными производными от «оценки» являются «ценность» и «оценивать». Под ценностью-1 будем понимать положительную или отрицательную значимость объектов окружающего мира или их свойств для живых организмов, в том числе для человека и общества. В понятие цеенность-2 будем включать также критерии и способы определения значимости объектов. В этом случае при выборе критериев и способов выявления значимости речь может идти о принципах, идеалах, установках, целях, уровнях, нормах. По принятому определению ценность является антропоцентрической категорией и должна включать в себя объект и субъект оценивания.

Оценкой будем называть отношение субъекта к объекту оценивания, установление значимости для субъекта этого объекта в целом или отдельных его свойств на основе их соответствия определенным уровням или нормам. Таким образом, в основе определения значимости лежит представление о сложном (многопараметрическом) объекте, состояние которого описывается системой исходных характеристик. Примерами таких многопараметрических объектов могут служить природные образования различного масштаба, их компоненты; естественные и искусственные экологические системы и т.д. Оцениваемым свойством может оказаться качество среды, устойчивость экосистемы, трофический статус водоема, экологическое благополучие территории, ее пригодность для конкретных видов использования и т.д. При этом исходные характеристики, 
определяющие уровень оцениваемого свойства, могут быть весьма многочисленны (число их зачастую доходит до многих десятков наименований) и образовывать весьма сложные системы, структурированные множеством функциональных и корреляционных взаимосвязей.

Оценка и диагностика. Диагностика состояния природного объекта. Как будет показано далее, оценка включает в себя два этапа: 1 - диагностика (экологическая регламентация) и 2 - оценка воздействия (экологическое нормирование).

Формой и начальным этапом выражения отношения субъекта к объекту оценивания может служить диагностический анализ (диагностика) природного объекта. Диагностический анализ включает в себя рекогносцировочное выявление достоинств (положительная значимость) и недостатков (отрицательная значимость) объекта (действующей системы), его отдельных свойств, интервалов их естественного колебания, структуры и режимов функционирования на основе анализа параметров состояния и их критических значений (Дмитриев, 2000).

Установление значимости многопараметрических природных объектов и их свойств и получение количественных значений оцененных параметров сопряжено с использованием таких понятий, как показатель, признак, критерий, совокупность, комплекс, система и производных от них, например, комплексная оценка, многокритериальная оценка и др. (Дмитриев, 1994; Дмитриев и соавт.,1996, Дмитриев, Фрумин, 2004; Гальцова, Дмитриев, 2007).

Проблемы оценки состояния в этом случае находят выражение в анализе параметров состояния, определении интервалов их естественного колебания, выявлении пороговых и критических величин параметров состояния. Этот этап был назван «экологической регламентаџией» (Дмитриев, 2000). Экологическая регламентация есть определение нормы состояния экосистемы на основе анализа параметров состояния, интервалов их естественного колебания, выявления пороговых и критических величин параметров, при которых сохраняется nортрет экосистемbl. Таким образом, в соответствие с нашим подходом регламентируется - состояние природной системы, а нормируется, - воздействие на нее.

Норма состояния - состояние экосистемы, при котором сохраняется ее структура и видовое разнообразие, не меняется режим функционирования, процессы обмена веществом и энергией протекают с интенсивностями, амплитуда которых обусловлена естественно-исторической фазой развития природного объекта и он может существовать без заметных изменений реально неограниченное время.

Обобщение существующих подходов к проблеме экологического нормирования (второй этап оценки состояния) позволило определить второй ключевой термин норма воздействия на экосистему. Под экологическим (экосистемным, системным) нормированием понимается получение ответной реакции экосистемы в целом при внешнем воздействии на неё. При оценке воздействия определяются экологические нормативы допустимой антропогенной нагрузки на экосистемы на основе экологических регламентов.

Норма воздействия - дозволенное антропогенное воздействие, при котором обеспечивается сохранение: структуры и динамических качеств экосистем, устойчивости, видового разнообразия, естественного хода сукцессионных процессов, продуктивности; наиболее уязвимых звеньев трофических цепей. При таком понимании нормьl антропогенные воздействия на экосистему не вызывают изменения ее продуктивности (трофности), качества среды, а также ее устойчивости и благополучия в целом.

Норма воздействия - отклонение условий среды от типичных для классифицируемого состояния, не вызывающее выхода экосистемы за границы данного класса состояний, характеризующегося собственным набором критериев, и перехода ее в другой класс состояний или в критическую область (стрессовую зону) по совокупности факторов воздействия и развития в ней необратимых изменений. 
Таким образом, условия функционирования экосистем характеризуются "нормой состояния" на основе системы критериев, позволяющих выделить границы различных состояний экосистем, и "нормой воздействия "- отклонением условий среды от нормы, не вызывающим развития в ней необратимых изменений и не выводящим экосистему за пределы ее нормы и переход в другой класс состояний.

В силу эмерджентности природных систем свойства экосистем в целом не сводимы к экологическим регламентам (несмотря на это многие исследования ограничиваются только данным этапом оценочных исследований, более того, на этом этапе предлагаются «слабые» или наиболее уязвимые компоненты системы, как правило, - биоиндикаторы, что методологически также неверно). Соотнесение свойств природного объекта с нормой обусловило появление терминов «природоохранное нормирование», «экологическое нормирование», «экосистемное нормирование» и др. В фокусе нормировочной активности оказываются природные экосистемы. Нормы должны быть определены в расчете на их благополучие, целостность, регенерационные возможности, устойчивость.

При оченке воздействия определяются экологические нормативы допустимой антропогенной нагрузки на биогеоценозы на основе экологических регламентов. Поскольку свойства экосистем в целом не сводимы к экологическим регламентам, многие авторы видят решение проблемы получения нормативов в анализе свойств экосистемы как таковой, из которых важнейшим является устойчивость, и в поиске интегральных, обобщающих, комплексных показателей состояния ландшафтов. Такой поход позволяет при оиченке воздействия реализовать следующие этапы: оценка фактора воздействия $\rightarrow$ оценка свойства экосистемы (например, устойчивость) $\rightarrow$ оценка степени воздействия (измененности экосистемь).

Под оиенкой воздействия (экологическое или экосистемное нормирование) нами понимается количественная оценка ответной реакции экосистемы в целом на антропогенное воздействие на основе антропогенно трансформированного портрета экосистемы.

Прикладная экология. Системный мониторинг. Прикладная экология по Н.Ф. Реймерсу (1990) и по И.И. Дедю (1990) разрабатывает экологические нормы, формы управления экосистемами, определяет допустимые нагрузки на них и пределы устойчивости экосистем. Кроме этого, она изучает механизмы разрушения экосистем и разрабатывает подходы к рациональному природопользованию. Прикладная экология призвана на современном этапе ее развития разрабатывать научные методы решения экологических проблем, связанных с антропогенной трансформацией сложных систем в природе и обществе многих иерархических уровней. Различные разделы и «продукты» прикладной экологии широко представлены в научных публикациях в качестве иллюстраций практического решения экологических проблем и проблем охраны окружающей среды. В большинстве географо-экологических (эколого-географических) публикаций речь по существу идет о прикладном системном анализе в экологии, геоэкологии, урбоэкологии, социоэкологии. Теория прикладного системного анализа должна быть нацелена на теоретическое описание деятельности специалистов по системному анализу в решении практических задач данных областей знаний, и, в значительно меньшей степени - самих объектов данной деятельности (в нашем случае экосистем, геосистем, урбасистем, этносистем, социосистем).

В этом смысле термин прикладная экология в наши дни целесообразно трактовать шире, относя к объектам прикладных экологических исследований все виды сложных систем в природе и обществе. Так, отличие геоэкологии от социальной экологии обусловлено присутствием в последней специфического предмета исследования социальной сферы, испытывающей на себе последствия естественных и антропогенных трансформаций социоэкосистем. Так называемые геоэкологический и социоэкологический подходы, на основе которых реализуются эколого-географические исследования последних лет, исходят из наиболее общего понимания геоэкологии и 
социоэкологии как междисциплинарных направлений, всесторонне рассматривающих динамику антропогенно трансформированных геосистем и социосистем, а также взаимодействия человека (общества) и окружающей среды в локальном, региональном и глобальном масштабах. При этом, чаще упоминаются высокие уровни иерархии геосистем и социосистем.

В связи со сказанным, системная экология, системная геоэкология, системная социоэкология выделились из экологии, геоэкологии, социоэкологии и как формализованные (в большей или меньшей степени) целостные подходы стали самостоятельными разделами системного моделирования в науках о Земле и обществе благодаря современным математическим методам, развитию информатики и геоинформатики и т.д., а также формального упрощения и моделирования систем.

Прикладная составляющая исследований обусловливает необходимость решения практических задач по планированию региональной политики, использованию природных ресурсов и социальной сферы, их охраны, возобновления для реализации, как потребностей человечества, так и устойчивой коэволюции биосферы и общества.

Отметим, что во всех случаях речь идет об исследовании состояния природной и социальной (антропогенно-трансформированных) сред, обусловленного качественным отличием их от состояния, определяемого лишь естественными процессами. Переход от естественных к катастрофическим природным состояниям (или состояниям коллапса) характеризуется чаще всего необратимой утратой системой способности продуцировать органическое вещество или потерю ею таких свойств, которые отличают экосистемы от других комбинаций «жизнь - среда».

На рис.2 приводится схема экологического мониторинга, удовлетворяющая целям прикладных экологических исследований в природе и обществе.

Разработка научных методов решения экологических проблем сегодня опирается на достижения общей экологии, развития формальных математических методов, кибернетики, обработки данных на ПК, информатики и возможностей экологического (u геоэкологического) мониторинга природных и урбанизированных территорий (акваторий) разной степени антропогенной трансформации и должна включать в себя системы наблюдений, оценки и прогноза состояния природных и антропогеннотрансформированных экосистем (геосистем, урбасистем, социоэкосистем). При этом степень их нарушенности человеком может достигать значительных размеров.

В качестве характерных критериев применяются режимные, природозащитные, антропоэкологические и хозяйственные критерии.

Под диагностическим мониторингом понимается форма экологического мониторинга, позволяющая по выбранным показателям выявить основные тенденции в изменении биосферы.

Прогностический мониторинг - есть форма экологического мониторинга, позволяющая с помощью планируемого эксперимента предсказать (прогнозировать) биологические последствия на основании тенденций в изменении абиотической среды. Прогностический мониторинг опирается на научные методы решения экологических проблем и реализуется через систему экологических моделей разной степени сложности и разной степени отражения в них геопространства в зависимости от цели исследования. Разработка и размещение систем слежения - первый этап экологического мониторинга. Информация, поступающая от систем слежения, накапливается в базах данных (БД) и по требованию пользователя передается системам оценки.

Система оценки - составная часть (второй этап) экологического мониторинга, предназначенная для получения качественной и количественной оценки состояния, неаддитивных свойств и степени антропогенной трансформации экосистем.

Сбор и обработка данных; концептуальные и формализованные модели анализа, прогноза и оценки состояния экосистем, геосистем, социосистем с выходом на принятие природоохранного решения составляют потенциальный набор функций географической 
информационной системы (ГИС) состояния и качества среды. В настоящее время такие системы (зарубежные и отечественные) активно разрабатываются и внедряются в жизнь.

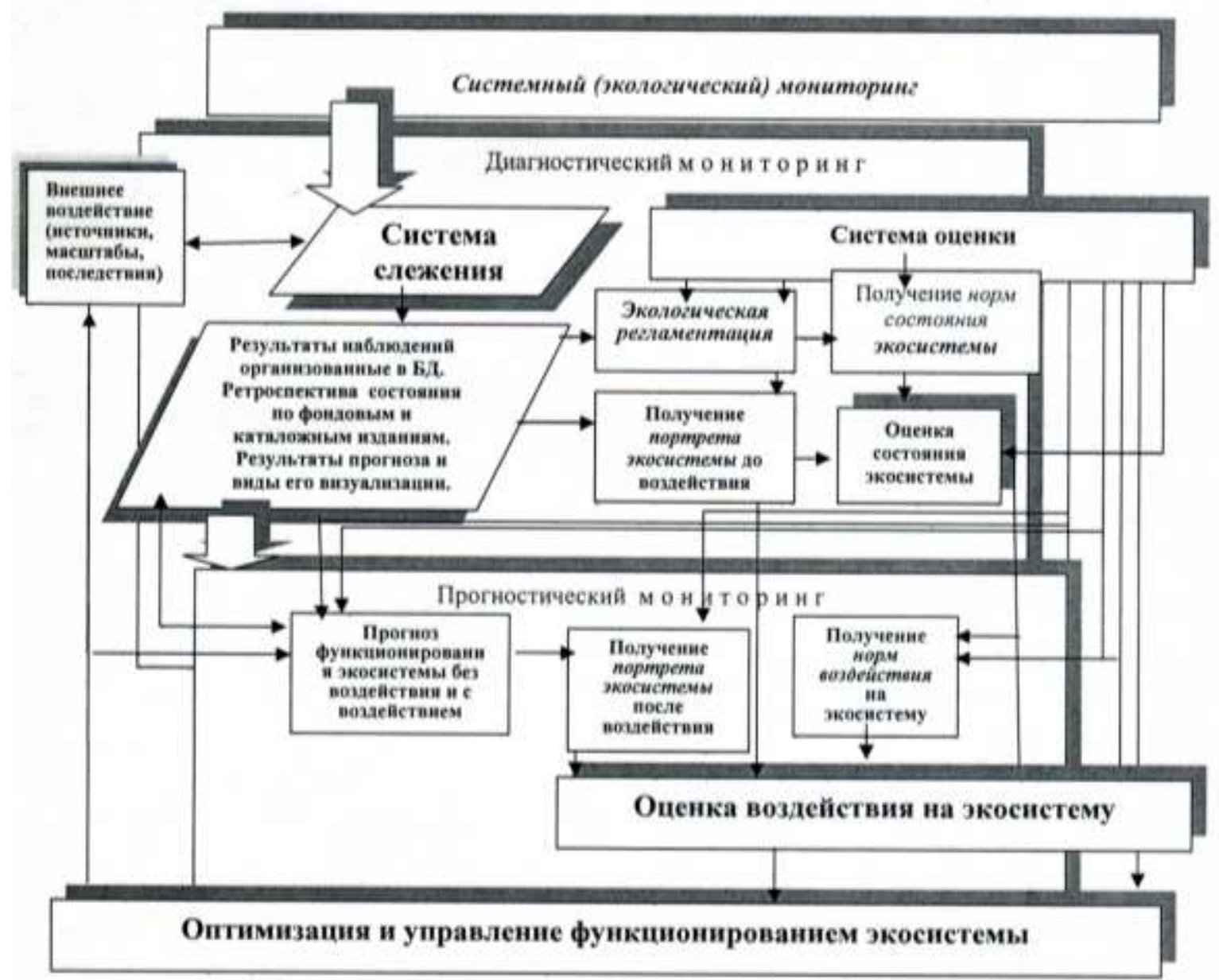

Рис.2 - Блок - схема системного мониторинга для целей прикладной экологии (Дмитриев, 2000; Дмитриев, Шелутко, 2015)

Состояние природы. Состояние геосистемы. Режим. Н.Ф. Реймерс (1990, с.487) ввел термин состояние природы (по степени нарушенности человеком) - качественное отличие ее от определяемого лишь естественными процессами. Г.А. Исаченко (1999) вводит понятие состояние геосистемы, под которым понимается пространственновременная однородность, выделяемая по критериям сохранения состава и соотношения системообразующих элементов и ведущих процессов системы. Это суждение близко к определению инварианта геосистемы, введенному В.Б. Сочавой в 1978 г., в основе которого лежит представление о совокупности присущих геосистеме свойств, которые сохраняются неизменными при преобразовании той или иной категории геосистем. С другой стороны, закономерные изменения состояния природного объекта во времени, обусловленные его физико-географическими свойствами, климатическими условиями и др. традиционно в географии называются режимом (гидрологический режим, гидрохимический режим и т.п.). Режимы проявляются в виде многолетних, сезонных, суточных колебаний элементов режимов.

Опасные природные явления. В последние годы широко обсуждаются термины, связанные со специфическими признаками, условиями, обстоятельствами, факторами, формирующими опасные природные явления (ОПЯ) и проявляющиеся в различных геосферах Земли. Так, например, при описании опасных гидрологических явлений (ОГЯ) 
используется термин «экстремальные природные условия», под которыми обычно подразумевают такие естественные ситуации, которые несут угрозу разрушений и гибели людей или создают неблагоприятные условия для их жизнедеятельности. К ним относятся как многие стихийные природные явления (цунами, землетрясения, и др.), так и территории (заполярье, пустыни, высокогорье), жизнедеятельность в которых сопряжена с рисками для здоровья населения (Чалов, Школьный, 2018). Экстремальность гидрологических, в том числе русловых процессов, согласно определению “экстремальности”, приведенному в словарях, - это крайнее, предельное состояние чеголибо, или “выходящее из рамок обычного, чрезвычайное" (Гуськова, Сотин, 2007). В точных науках за экстремальность принимается такое состояние системы, в котором она принимает пороговое значение (как максимальное, так и минимальное). Близкое к особенностям экстремальных процессов определение встречается в термодинамике: «экстремальный принцип» - это такое сочетание факторов, при котором своих наивысших возможных значений достигает энтропия, т.е. вероятность пребывания системы вне состояния равновесия. Н.И. Коронкевич с соавторами $(2010$, с.12) под экстремальной гидрологической ситуацией (ЭГС) или явлением понимают «такое количественное или качественное состояние водных объектов, элементов гидрологического режима территории, которое кардинально отличается от общего, общепринятого, среднего».

Вопросами, требующими дальнейшего изучения, являются: совершенствование классификаций, а зачастую - их создание, выявление соотношений между экстремальностью и специфичностью процессов, разработка и систематизация критериев и показателей, их характеризующих (их параметризация), методов и приемов прогнозирования и расчета, картографирование (составление карт на территории, крупные регионы или речные бассейны) и на их основе выявление географических закономерностей, условий развития и факторов, их определяющих, установление связей с другими гидрологическими явлениями, имеющими экстремальный или специфический характер. Представление о распространении и характеристиках экстремальных и специфических процессах, дадут возможность обосновать систему мониторинга ЭП, который должен быть составной частью мониторинга процессов геосистем России, которого в настоящее время не проводится. При решении этих вопросов нужно иметь в виду антропогенную составляющую и происходящие климатические изменения. Конечной целью этих исследований является обоснование и разработка мероприятий, позволяющих снизить ущерб, а, возможно, и предотвратить его.

\section{Вопросы для усвоения материала.}

1. Что такое «система», чем простая система отличается от сложной. Назовите простые и сложные свойства сложной системы.

2. Что такое оценка, экологическая оценка, эколого-географическая, геоэкологическая оценка.

3. Что подлежит изучению и оценке в естественных и антропогенно-трансформированных природных системах.

4. На что влияет профессия исследователя, занимающегося оценкой состояния сложной природной системы.

5. Из замечаний рецензента на диссертационную работу NN «Комплексная оценка экологогеографического положения приморских территорий (на примере Мурманской области)», представленную к защите по специальности 25.00.36 - геоэкология (Науки о Земле) на соискание ученой степени кандидата географических наук.

«Основные термины названия и содержания работы: «комплексная оценка» и «экологогеографическое положение», «проблема эколого-географического положения», «геоэкологические координаты». Традиционно во многих работах используется сочетание «комплексная экологогеографическая оценка». Автор использует в названии работы термин «комплексная оценка». Здесь стоит обратить внимание на то, что комплексные оценки не обязательно являются системными. Это перспективные, но наименее разработанные и унифицированные оценки. Они многочисленны и разнообразны, часто содержат оговорки и допущения, которые не позволяют с должной адекватностью воспринимать и далее использовать их в практической деятельности. Многообразие методов обусловлено различными уровнями исследования природных объектов, целями и задачами исследований, разнообразием 
позиций, с которых проводятся оценки, и аргументируется приоритетность критериев оценивания. Комплексная оценка природного объекта по большому количеству критериев, безусловно, важна, однако ее использование часто не предполагает свертку показателей, переход к функциям желательности и получение интегральных показателей состояния системы в целом или ее неаддитивных свойств. Между компонентами множества, образующего систему, существуют системообразующие связи и отношения, благодаря которым реализуется специфическое для системы единство. Система обладает общими функциями, интегральными свойствами и характеристиками, которыми не обладают ни составляющие ее элементы, взятые по отдельности, ни простая «арифметическая сумма» элементов. Иначе говоря, свойства системы в целом неаддитивны по отношению к свойствам ее элементов и подсистем. Это обусловливает необходимость применения методов оценки состояния систем в целом».

«Структура работы не оптимальная и уязвимая. Автор, претендуя на системный подход, должен учесть, что познание того или иного объекта как системы должно включать в себя следующие основные моменты: а) определение структуры и организации системы; б) определение собственных (внутренних) интегральных свойств и функций системы; в) определение функций системы как реакций на выходах в ответ на воздействие других объектов на входы; г) определение генезиса системы, т.е. способов и механизмов ее образования, а для развивающихся систем - способов их дальнейшего развития. В связи с этим выявляются методы исследования. По логике текста диссертации после второй главы «методологические подходы к проблеме...» должна следовать глава по методам исследований, в которой методический подход нахождения «геоэкологических координат», по-видимому, будет авторским вкладом в решение проблемы, но раздела по методам исследований в работе нет».

«У автора в «региональную геосистему» входят подсистемы: «природа, экономика, общество». Значение ГЭ при этом интерпретируются автором с позиций покомпонентного оценивания. Такая система в науке называется региональной социосистемой (или социоэкосистемой»). Разница принципиальная, поскольку «координаты» оказываются не «геоэкологическими», а «социоэкологическими». Область этих координат, называемая «устойчивым развитием» должна быть предварительно выявлена и охарактеризована с системных позиций». Согласны ли Вы с трактовкой NN или оппонента? Что представляет собой «региональная геосистема»?

6. В чем отличие «системной географии» от географии, «системной экологии» от экологии, геоэкологии. Чем должна была бы заниматься системная география, системная экология, системная геоэкология, системная социоэкология, если бы они были?

7. Что значит, оценить экологическое состояние; оценить состояние экосистемы. В чем разница между оценкой качества среды и оценкой экологического состояния?

8. Чем, по Вашему мнению, должна заниматься факториальная экология (геоэкология) и факториальная география (если бы такая была). Как Вы понимаете термин нанофактор? Надо ли, по вашему мнению учитывать влияние нанофакторов при моделировании?

9. Как Вы понимаете эмерджентность сложной системы? В чем она проявляется.

10. Что такое неаддитивные (сложные) свойства сложной системы. Приведите пример.

11. Нужна ли теория и практика нерационального использования природных ресурсов (природопользования), см., например, К.С. Лосев и др., 2008 г. Название проекта РФФИ: «Фундаментальные причины неустойчивого природопользования». Целью работы было проведение анализа способов природопользования первобытного человека и человека-агрария для выявления степени воздействия этих способов на окружающую среду с учетом особенностей возникшего в биосфере нового вида, обладающего способностью создавать и передавать информацию внегенетическим путем.

12. В чем Вы видите отличие геоэкологии от прикладной экологии.

13. Объясните разницу между фундаментальной наукой и прикладной.

14. Дайте определения мониторинга, как Вы понимаете диагностический и прогностический мониторинг.

\section{Литература}

Абакумов В.А. Руководство по гидробиологическому мониторингу пресноводных экосистем. СПб, 1992, $318 \mathrm{c}$ Александрова Л. В., Васильев В. Ю., Дмитриев В. В., Мякишева Н. В., Огуриов А. Н., Терехина Н. В., Третьяков $B$. Ю., Уфимиева М. Д. Многокритериальная оценка экологического состояния и устойчивости геосистем на основе метода сводных показателей. V. Интегральная оценка экологического состояния и качества среды урбанизированных территорий // Вестн. С.-Петерб. ун-та. Сер. 7. 2000. Вып. 4, № 31. С. 34-47.

Алимов А.Ф. Экология - наука биологическая // Экология,1990, №1, с.3-7.

Алимов А.Ф., Дмитриев В.В., Чистобаев А.И. и др. Интегральная оценка экологического состояния и качества среды городских территорий» / Под ред. А.К.Фролова, СПбНЦ РАН, СПб, 1999, 253 с.

Белозерский Г.Н., Дмитриев В.В. Становление геоэкологии как важный этап в развитии географии ХX столетия/ Известия РАН. Серия географическая, 2007, №2, с.19-28.

Белозерский Г.Н., Дмитриев В.В. Тенденции развития географии в ХХІ веке. Единая планетарная система./ Известия РАН. Серия географическая, 2007, №4, с.8-15.

1989.

Бигон М., Харпер Дж., Таунсенд К. Экология. Особи, популяции и сообщества: В 2-х т. Пер. с англ. М. Мир, 
Боблакова Л.М., Дмитриев В.В. Интегральная оценка качества жизни населения г. Санкт-Петербурга и г. Москвы / Научный журнал Российской Академии Естествознания "Международный журнал экспериментального образования", 2014, №3 Часть 1, с.91-95.

Веницианов E.B. Нанофакторы в процессах массопереноса в многофазных системах. Электронный научный журнал «Молекулярные технологии». 2010.

Веницианов E.B. Нано-факторы в формировании экологического состояния водных объектов. Проблемы безопасности в водохозяйственном комплексе России. Краснодар: ООО «Авангард плюс». 2010.- С. 29-40.

Воробейчик Е.Л., Садыков О.Ф., Фарафонтов М.Г. Экологическое нормирование техногенных загрязнений наземных экосистем. Екатеринбург, 1994.

Геоэкология и природопользование. Труды XII съезда Русского географического общества. Отв. редакторы д.г.н. В.В. Дмитриев, д.б.н. В.Н.Мовчан, Том 4., СПб, 2005, 400 с.

Гуськова А.П., Сотин Б.В. Популярный словарь русского языка: толково-энциклопедический. М.: Дрофа, 2007.

$869 \mathrm{c}$.

Дедю И.И. Экологический энциклопедический словарь. Кишинев, 1990, 406 с.

№ 3. C. 507-520.

Дмитриев В. В. Интегральные оценки состояния сложных систем в природе и обществе // Биосфера. 2010. Т. 2 ,

Дмитриев В. В. Определение интегрального показателя состояния природного объекта как сложной системы // Общество. Среда. Развитие. 2009. № 4 (12). С. 146-165.

Дмитриев В. В. Устойчивость природных объектов к изменению параметров естественного и антропогенного режимов // Дмитриев В. В., Фрумин Г. Т. Экологическое нормирование и устойчивость природных систем: учеб. пособие. СПб. : Изд-во «Наука», 2004. С. 241-278.

Дмитриев B. B. Экологическое нормирование состояния и антропогенных воздействий на природные экосистемы // Вестн. С.-Петерб. ун-та. Сер. 7. 1994. Вып. 2, № 14. С. 60-70. 2000. $419 \mathrm{c}$

Дмитриев В. В. Эколого-географическая оценка состояния внутренних водоемов. Дисс. д-ра геогр. наук. СПб. ,

Дмитриев B.B. Прикладная экология в системе высшего географического и гидрометеорологического образования / Вопросы прикладной экологии. Сборник научных трудов РГГМУ, СПб, РГГМУ, 2002, с.90-96.

Дмитриев В. В., Мякишева Н. В., Хованов Н. В. Многокритериальная оценка экологического состояния и устойчивости геосистем на основе метода сводных показателей. I. Качество природных вод // Вестн. С.-Петерб. ун-та. Сер. 7. 1996. Вып. 3, № 21. С. 40-52.

Дмитриев В. В., Мякишева Н. В., Третьяков В. Ю., Хованов Н. В. Многокритериальная оценка экологического состояния и устойчивости геосистем на основе метода сводных показателей. II. Трофический статус водных экосистем // Вестн. С.-Петерб. ун-та. Сер. 7. 1997. Вып. 1, № 23. С. 51-67.

Дмитриев B. В., Огурияов А. Н. Подходы к интегральной оценке и ГИС-картографированию устойчивости и экологического благополучия геосистем. II. Методы интегральной оценки устойчивости наземных и водных геосистем // Вестн. С.-Петерб. ун-та. Сер. 7. 2013. Вып. 3. С. 88-103.

Дмитриев B. В., Огурияов А. Н. Подходы к оценке и ГИС-картографированию устойчивости и экологического благополучия геосистем. І. Интегральная оценка устойчивости наземных и водных геосистем // Вестн. С.-Петерб. ун-та. Cер. 7. 2012. Вып. 3. С. 65-78.

Дмитриев В. В., Огуризов А. Н., Васильев В. Ю., Третьяков В. Ю. Многокритериальная оценка экологического состояния и устойчивости геосистем на основе метода сводных показателей. IV. Токсическое загрязнение воды и грунтов // Вестн. С.-Петерб. ун-та. Сер. 7. 1999. Вып. 1. С. 40-53.

Дмитриев B.B. Интегральная оценка качества жизни как показатель устойчивого развития населения региона / Устойчивое развитие и экологический менеджмент: учебное пособие. - СПб. : ВВМ; СПбГУ, 2009. - Ч 2. 18 стр.

Дмитриев B.B. Интегральная оценка экологического благополучия водного объекта: новый подход, результаты. Международная научно-практическая конференция «Обеспечение гидрометеорологической и экологической безопасности морской деятельности» 16-17 октября 2015, Астрахань, Россия.

Дмитриев B.B. Интегральная оценка экологического благополучия геосистем / Информационные технологии и системы: управление, экономика, транспорт, право: Сб. тр. Международной научно-практической конференции «Инфогео 2013» /Вып.2 (11), Под ред.д.т.н., проф. Истомина Е.П., д.т.н., проф. Марлей В.Е., д.э.н., проф. Скобелевой И.П., д.ю.н., проф. Соболь И.А. - СПб. : ООО «Андреевский издательский дом»- 2013 г., с.36-39.

Дмитриев В.В. Интегральные оценки состояния сложных систем в природе и обществе / Устойчивое развитие и экологический менеджмент: учебное пособие. Раздел 2.1. - СПб. : ВВМ; СПбГУ, 2009. - Ч 1., 17 стр.

Дмитриев В.В. Интегральные оценки состояния сложных систем в природе и обществе (статья). Междисциплинарный научный и прикладной журнал «Биосфера», 2010, т.2, №3, с.533-546.

Дмитриев В.В. Методические указания по дисциплине «СИСТЕМНАЯ ЭКОЛОГИЯ». Специальность 013600 геоэкология. Курс V. г. Санкт-Петербург, РГГМУ, 2002, 30 с.

Дмитриев В.В. Оценка экологического состояния природных объектов. Что такое экологическая оценка и как построить интегральный показатель состояния природной экосистемы. Экология. Безопасность. Жизнь. Экологический опыт гражданских, общественных инициатив. Выпуск 12. Гатчина, 2001 г, с.225-237.

Дмитриев B.B. Прикладная экология в системе высшего географического и гидрометеорологического образования/ Вопросы прикладной экологии. Сборник научных трудов РГГМУ, СПб, изд. РГГМУ, 2002, с.90-96.

Дмитриев B.B. Сложные системы в природе и обществе и оценка их состояния / Научно-теоретический журнал «Общество. Среда. Развитие». №4 (13), 2009, 19 стр.

Дмитриев В.B. Современное экологическое состояние водных объектов карельского Приладожья и его сравнение с ретроспективными данными / Научно-теоретический журнал Ученые записки Российского государственного гидрометеорологического университета №33. - СПб, : РГГМУ, 2014, с.102-118.

Дмитриев В.В. Экологическое нормирование состояния и антропогенных воздействий на природные экосистемы. Вестник С-Петерб. ун-та. Серия 7, 1994, вып 2. С.60-70.

Дмитриев В.В. Эколого-географическая оценка состояния внутренних водоемов. Дисс. на соиск. уч. степени докт. геогр. наук. СПб, 2000, 419 с.

Дмитриев В.В., Боблакова Л.М. Интегральная оценка качества жизни населения в регионах России / Информационные технологии и системы: управление, экономика, транспорт, право: Сб. тр. Международной научнопрактической конференции «Инфогео 2014»/Вып. 3 (14) / Под ред. д.т.н., проф. Истомина Е.П. - СПб: ООО «Андреевский издательский дом» - 2014 г., Informacionnye tehnologii i sistemy. Upravlenie, èkonomika, transport, pravo. ISSN 2306-5788, с.38-44. 
Дмитриев В.В., Огуриов А.Н. Подходы к интегральной оценке и ГИС -картографированию устойчивости и экологического благополучия геосистем. III. Интегральная оценка устойчивости почвы и наземных геосистем / Вестник СПбГУ. Сер. 7. 2014. Вып. 4, с.114-129.

Дмитриев В.В., Огуриов А.Н., Васильев В.Ю., Примак Е.А., Лобачева Ю.В., Скрыгина В.К. Оценка эмерджентных свойств сложных систем в природе и обществе на основе моделей интегрального оценивания / Сборник трудов VI международной конференции «Экологические и гидрометеорологические проблемы больших городов и промышленных зон, ЭКОГИДРОМЕТ - 2012». 2-4 июля 2012. Под редакцией: Л.Н.Карлина, В.Н. Воробьева, В.А. Шелутко, В.В.Дмитриева. - СПб.: изд. РГГМУ, 2013. - с.25-34.

Дмитриев В.В., Панов В.E., Пряхина Г.В. Методические указания по учебно-производственной практике «Экологическое состояние водных объектов»: Учебно-методическое пособие. - СПб. : ВВМ, 2010. — 104 с.

Дмитриев В.В., Фрумин Г.Т. Экологическое нормирование и оценка устойчивости природных систем. Учебное пособие, СПб, 2004, 300 с.

Дмитриев В.В., Хованов Н.В., Огуриов А.Н., Васильев В.Ю., Шелутко В.А., Проиенко Ю.А., Примак Е.А. Интегральная оценка экологического состояния и качества среды городских территорий, рек и морских акваторий (раздел монографии). Раздел V монографии «ЭКОЛОГИЯ И ГИДРОМЕТЕОРОЛОГИЯ БОЛЬШИХ ГОРОДОВ И ПРОМЫШЛЕННЫХ ЗОН [РОССИЯ-МЕКСИКА]». Том ІІ. Мониторинг окружающей среды. Под общей редакцией Карлина Л.Н. и Шелутко В.А. Редакторы: Скакальский Б.Г., Перевощикова М., Дмитриев В.В. и др. - СПб.: РГГМУ, 2010 - с.102-134. Дмитриев В.В., Шелутко В.А. МЕТОДОЛОГИЧЕСКИЕ АСПЕКТЫ РАЗВИТИЯ ПРИКЛАДНОЙ ЭКОЛОГИИ В СИСТЕМЕ НАУК О ЗЕМЛЕ. Научно-теоретический журнал Ученые записки Российского государственного гидрометеорологического университета, 2015, №39, стр.189-200.

Исаченко А.Г. Ландшафтоведение и физико-географическое районирование. М., 1991, 366 с.

Исаченко Г.А. Методы полевых ландшафтных исследований и ландшафтно-экологическое картографирование. СПб., 1999, $112 \mathrm{c}$

Коронкевич Н.И., Барабанова С.А., Бумакина А.С., Зайщева И.С. Общие представления об экстремальных гидрологических ситуациях // Экстремальные гидрологические ситуации. М.: Медиа-Пресс, 2010. С. 12-32.

Лопатников Л.И. Экономико-математический словарь. Под ред.акад. Н.П.Федоренко. М., Наука, 1987, 509c.

Многокритериальные географо-экологические оценки состояния и устойчивости природных и урбанизированных систем» / Под ред. В.В. Дмитриева и Н.В. Хованова. Деп. ВИНИТИ 01.09.2000, № деп.2342В00, 275 c.

Музалевский А.А. Экология. Учебное пособие. Изд. РГГМУ. Санкт-Петербург. 2008. 604 с.

Огуриов А.Н., Хованов Н.В. Многокритериальная оценка экологического состояния и устойчивости геосистем на основе метода сводных показателей. III. Оценка степени благоприятности природных условий макрорегионов северозапада РФ для жизни людей // Вестн. С.-Петерб. ун-та. Сер. 7. 1997. Вып. 2. С. 55-62.

Одум Ю. Основы экологии / Пер. с 3-го англ. изд. под ред. Н.П. Наумова. М., 1975, 740 с.

Примак $E$. A. Интегральная оценка устойчивости и экологического благополучия водных объектов: автореф. дис. канд. геогр. наук. 2009. 24 с.

Проблемы эколого-географической оценки состояния природной среды / Под ред. П.П. Арапова и Ю.П. Селиверстова. СПб., 1994.

Реймерс Н.Ф. Природопользование: Словарь-справочник. М., 1990, 638 с.

$144 \mathrm{c}$.

Словарь терминов и понятий, связанных с охраной живой природы / Н.Ф. Реймерс, А.В. Яблоков / М., 1982, природа, 1992, $127 \mathrm{c}$

Федорова И. В. Современное состояние и устойчивость к воздействию внутренних водоемов Антарктиды: автореф. дис. канд. геогр. наук. 2003. 19 с.

Хованов Н. В. Анализ и синтез показателей при информационном дефиците. СПб.: Изд-во СПбГУ, 1996. 196 с.

Чалов Р.С., Школьный Д.И. Экстремальные и специфические проявления русловых процессов: основные понятия, классификации, критерии оценки. Известия РАН. Серия географическая. 2018. №1, с.31-41.

\section{Лекция №2}

Современные подходы и методы исследования геосистем и ландшафтов, сложных систем в природе и обществе. Нормирование загрязнения окружающей среды.

От ОВОС к экологическому нормированию (системному нормированию) и экологическому сопровождению проектирования воздействий на природные экосистемы. ОВОС.

Экологическое нормирование (ЭН). Основные определения. Экологическое сопровождение проектирования. Основные разделы темы «Экологическое сопровождения проектирования».

Определение системной экологии. Модель. Экологическая модель. Имитационная модель. Портретная модель. Основные задачи математического моделирования экосистем. Проблемы, стоящие перед разработчиками моделей.

Современные подходы и методы исследования геосистем и ландшафтов, сложных систем в природе и обществе. Познание того или иного объекта как системы должно включать в себя следующие основные моменты: а) определение структуры и организации системы; б) определение собственных (внутренних) интегральных свойств и функций системы; в) определение функций системы как реакций на выходах в ответ на 
воздействие других объектов на входы; г) определение генезиса системы, т.е. способов и механизмов ее образования, а для развивающихся систем - способов их дальнейшего развития. В связи с этим по литературным обобщениям в практике исследований выявляются следующие методы исследования наземных и водных геосистем.

1. Ландшафтный подход - определяет комбинации и закономерности функционирования природных комплексов и систем, исходя из внутренних связей между различными компонентами; предусматривает оценку геосистем и ландшафтов по совокупности количественных и качественных данных, позволяющих оценить степень их устойчивости к хозяйственной деятельности и дать интегральную оценку их преобразования. Ландшафтный подход на определенном этапе исследований выступает в качестве общеметодологической базы или составной части в обосновании и реализации социальной, экономической, экологической, и других региональных «политик» и программ.

2. Геосистемный подход - является универсальным, так как обеспечивает анализ поведения систем различных рангов при неодинаковых антропогенных нагрузках и является приемлемым для оценок природных и антропогенно-трансформированных систем, территорий предприятий, городов, регионов независимо от их географического положения. Этот подход позволяет провести системный анализ многофакторных и функциональных составляющих в эколого-функциональном зонировании территорий различного иерархического уровня, предусматривающий группировку и последующую дифференциацию сочетаний различных функций ландшафтов, выделение наиболее значимых эко-, геосистем и ранжирование последних.

3. Геоэкологический подход - предполагает изучение природных комплексов в тесной связи с хозяйственной практикой с точки зрения жизнеобеспеченности человека, включая окружающую его природную и техногенную среду; направлен на сохранение и улучшение систем жизнеобеспечения человека и научную разработку мер по предотвращению деструкции природы, реализацию идеи «сотворчества человека и природы».

4. Геоситуационный подход - используется для формализации взаимодействия природных и социально-экономических составляющих с целью управления состоянием окружающей среды, предполагает выделение экологических проблем и их пространственно-временных сочетаний - экологических ситуаций. Использование этих понятий в работе свидетельствует о стремлении исполнителей представить в комплексе состояние окружающей среды как системы жизнеобеспечения человека. Экологические проблемы и ситуации являются понятиями информационными, отражающими степень экологического благополучия территории. Использование этого подхода для ключевых территорий и акваторий позволит отследить изменение их экологического состояния на протяжении последних лет, выделить наиболее острые экологические ситуации и приоритетные экологические проблемы.

5. Геоэкологический анализ - ведущий эффективный метод оценки экологического состояния территории, создания научных основ ее оздоровления и разработки оптимизационных мероприятий, направленные на снижение антропогенного и техногенного воздействия.

6. Информационно-картографический подход, ГИС, ГИС-технологии направлен на составление специализированных компьютерных карт. Основными среди них являются карты: ландшафтная, нарушенных территорий, экологического состояния территории, эколого-функционального зонирования, зонирования модельных и ключевых геосистем по величинам сводных показателей и др.

7. Аксиологический подход. Аксиология (греч. ахіа - ценность, logos - слово, учение) - занимается исследованием ценностей как смыслообразующих оснований человеческого бытия, задающих направленность и мотивированность человеческой жизни, деятельности и конкретных деяний и поступков. Основной вопрос, который 
изначально поставила аксиология, и который потом внутри нее неоднократно переформулировался, - это вопрос об условиях возможности оценок, имеющих "абсолютное значение", их критериях и соотносимости разных систем ценностей между собой. Основную задачу аксиологии можно видеть в анализе того, как возможна ценность в общей структуре бытия и как она соотносится с миром наличного бытия, как ценности, будучи обращены к человеку, реализуются в действительности. Последнее выводит аксиологию в разряд междисциплинарности и требует ее переформулирования в терминах многих наук, выступая основанием попыток построения отдельной научной дисциплины аксиометрии. В работе данный подход используется при формулировке понятий экологическое благополучие, экологическая ценность и др.

8. Аксиометрический подход используется при обосновании необходимых и достаточных параметров для получения интегральных оценок, формировании оценочных шкал и анализе результатов интегрального оценивания состояния сложных систем.

9. Системный анализ. Системный анализ заимствует у общей теории систем и системного подхода лишь самые общие исходные представления и предпосылки. Его методологический статус весьма необычен: с одной стороны, системный анализ располагает детализированными методами и процедурами, почерпнутыми из современной науки и созданными специально для него, что ставит его в ряд с другими прикладными направлениями современной методологии, с другой - в развитии системного анализа сегодня все еще отсутствует тенденция к оформлению его в строгую и законченную теорию. Об этом же свидетельствуют распространенные формулы системного анализа:

1. Системный анализ = научные методы + искусство их применения в определенной области знаний.

2. Системный анализ = перевод физических, химических, биологических представлений о системе в ряд математических зависимостей и операции над ними.

В системном анализе тесно переплетены элементы науки и практики. Поэтому далеко не всегда обоснование решений с помощью системного анализа связано с использованием строгих формализованных методов и процедур: допускаются и суждения, основанные на личном опыте и интуиции, необходимо лишь, чтобы это обстоятельство было ясно осознано.

10. Системный подход - направление методологии научного познания и социальной практики, в основе которого лежит исследование объекта как системы. К числу основных задач системного подхода относятся: 1 - разработка концептуальных (содержательных и формальных средств) представления исследуемых объектов как систем; 2 - построение обобщенных моделей систем и моделей разных классов и свойств систем, включая модели динамики систем, их целенаправленного поведения, их развития, иерархического строения, процессов управления в системах и т.д.; 3 - исследование методологических оснований различных системных теорий.

В процессе развития системных исследований в XX в. были определены задачи и функции разных форм теоретического анализа всего комплекса системных проблем. Системный подход в познании и осмыслении природы является наиболее мощным из освоенных людьми направлений методологии научного познания и социальной практики. Он способствует адекватной постановке проблем в конкретных науках, в том числе и в географии, и выработке эффективной стратегии их изучения. Методология системного подхода определяется тем, что он ориентирует исследование на раскрытие целостности объекта и обеспечивающих эту целостность механизмов, на выявление многообразных типов связей сложного объекта и сведение их в единую теоретическую картину.

Системный подход не существует в виде строгой методологической концепции. Он выполняет свои эвристические функции, оставаясь не очень жестко связанной совокупностью познавательных принципов, основной смысл которых состоит в соответствующей ориентации конкретных исследований объекта как системы. 
Эта ориентация осуществляется двояко. Во-первых, содержательные принципы системного подхода позволяют фиксировать недостаточность старых, традиционных приемов изучения среды для постановки и решения новых задач. Во-вторых, понятия и принципы системного подхода существенно помогают строить новые предметы изучения, задавая структурные и типологические характеристики этих предметов и способствуя, таким образом, формированию конструктивных исследовательских программ.

Согласно Н.Н. Моисееву при системном анализе все проблемы можно подразделить на три класса, одним из которых являются «неструктурированные», или качественно выраженные проблемы, содержащие лишь описание важнейших ресурсов, признаков и характеристик, количественные зависимости между которыми совершенно неизвестны (Моисеев, 1981).

11. Моделирование сложных систем. Системный подход не является строгой методологической концепцией, он выполняет эвристические функции, ориентируя конкретные исследования в двух основных направлениях. Во-первых, содержательные принципы системного подхода позволяют фиксировать недостаточность старых, традиционных методов исследования для постановки и решения новых задач. Во-вторых, понятия и принципы системного подхода помогают создавать новые программы изучения, ориентированные на раскрытие сущности функционирования сообществ, эко- и геосистем. В системном анализе тесно переплетены элементы науки и практики. Поэтому далеко не всегда обоснование решений с помощью системного анализа связано с использованием строгих формализованных методов и процедур: допускаются и суждения, основанные на личном опыте и интуиции, необходимо лишь, чтобы это обстоятельство было ясно осознано. Системные методы изучения окружающей среды развиваются на фоне роста внешних нагрузок на геосистемы, обусловленного деятельностью человека. Процессы «злокачественного увеличения первичной продукции» или утрата системой способности продуцировать органическое вещество, снижение качества сред стали приоритетными в гео- и гидроэкологической проблематике, их исследование предполагает использование моделирования для оценки состояния и прогноза развития эко- и геосистем.

12. Методология и метод анализа и синтеза показателей при информационном дефиците. Методологической базой исследований, позволяющей на интегральной основе количественно оценивать состояние геосистем в целом или их неаддитивные свойства с использованием нечисловой, неточной и неполной информации (ннн-информация) служит анализ и синтез показателей при информационном дефиците (АСПИД-методология). Инновационной стороной подхода является интеграция применения описанных подходов и методов для интегральной оценки и прогноза состояния природных и антропогеннотрансформированных геосистем и степени их экологического благополучия (здоровья). Использование ннн-информации в оценочных исследованиях обусловливает выполнение основных этапов построения интегральных показателей состояния геосистем и их свойств в условиях неопределенности на основе метода рандомизированных сводных показателей (МРСП), содержание которых будет раскрыто в лекциях и практической работе.

Апробация подхода для отдельных свойств и состояния изучаемого объекта (системы) обусловливает выполнение следующих этапов (в дальнейшем рассмотрим подробно):

1. выбрать необходимые и достаточные параметры, описывающие исследуемое свойство или состояние изучаемого объекта (системы);

2. определить набор классов, отражающих исследуемое свойство или состояние объекта при различных уровнях антропогенного воздействия;

3. найти для исходных параметров соответствующие классам градации или оценочные шкалы;

4. выбрать правило нормирования и нормировать исходные параметры исходной (обучающей) классификации; 
5. выбрать (обосновать) приоритеты оценивания (и их возможные изменения в перспективе) для всех уровней свертки показателей;

6. выбрать синтезирующую функцию (вид интегрального показателя);

7. ввести уровни свертки показателей для исходной (обучающей) классификации;

8. выполнить первый уровень обобщения информации;

9. выполнить последующие уровни обобщения информации;

10. для информации, собранной в полевых условиях для тех же параметров оценивания выполнить первый уровень обобщения информации по правилам построения исходной моделиклассификации;

11. выполнить последующие уровни обобщения информации;

12. выполнить районирование (зонирование) территории (акватории) по величине интегральных (сводных) показателей, отражающих состояние системы или степень ее антропогенной трансформации.

На основе данного подхода удается решить проблему определения нормь состояния сложной системы в условиях дефицита информации и неопределенности суждения о приоритетах оценивания исследуемых свойств.

13. В основу реализации теоретико-методологических положений современных НИР и грантов положено сочетание индуктивного и дедуктивного путей познания, аксиоматического метода исследований. Дедуктивный подход на первом этапе исследований проявляется во введении в методологию исследования аксиоматики, постулатов, гипотез, имеющих характер общих утверждений. На втором этапе эта система исходных положений и правил путем логической дедукции преобразуется в основополагающие утверждения теории - определения, условные «формулы», этапы построения интегральных показателей, выполнения интегральной оценки с позиций антропо- и биоцентризма и в предметно-методическую основу получения количественных оценок на основе разработанных информационных компьютерных систем.

Индуктивный подход реализуется в разработке и реализации многокритериальной и интегральной основы получения интегральных показателей состояния геосистем; модельном представлении характерных структурно-функциональных особенностей развития геосистем, разработке стратегий диагностики геосистем и оценки воздействия на них.

Нормирование загрязнения окружающей среды. В связи с разработкой ГОС ВПО - 3 планировалось включить в стандарт курс «Нормирование и снижение загрязнений окружающей среды» по направлению 022000 Экология и природопользование (бакалавриат). Основными разделами курса являются: Введение. Сущность, цели и задачи, история экологического нормирования в РФ. Экологическое нормирование как основа формирования устойчивой экономики; Направления, принципы, проблемы формирования экологических нормативов; Теоретические основы нормирования техногенных нагрузок. Экологический потенциал, ассимиляционная емкость и устойчивость природных систем; Правовые основы экологического нормирования и стандартизации. Виды экологических стандартов; Экологическое нормирование в сфере водопользования; Экологическое нормирование воздействий на атмосферу; Экологическое нормирование в сфере землепользования; Экологическое нормирование в сфере обращения с отходами; Экологическое нормирование в сфере использования объектов флоры и фауны; Экономические аспекты экологического нормирования; Экологическое нормирование и деятельность промышленных предприятий. Отраслевое экологическое нормирование. Экологический учет; Зарубежный опыт экологического нормирования.

ОВОС (оценка воздействия на окружающую среду). В работе СКОПЕ 5 содержится базовое определение: «оценка воздействия на окружающую среду» (ОВОС) это деятельность, направленная на выявление и прогнозирование ожидаемого влияния на среду обитания, на здоровье и благосостояние людей со стороны различных, 
мероприятий $и$ проектов, а также на последующую интерпретацию и передачу полученной информации.

Определены участники процесса ОВОС:

1. лица, принимающие решения,

2. инвесторы,

3. консультанты и советники,

4. исполнители (проектировщики),

5. эксперты,

6. - -общественность, в т.ч. в лице заинтересованных групп и организаций.

Определены основные этапы прочесса ОВОС:

1. определение целей намечаемой деятельности,

2. выработка политики ее реализации и составление программ,

3. определение воздействий и выделение сильнейших из них,

4. собственно оценка воздействий,

5. $\quad$ принятие решения по результатам ОВОС,

6. реализация и последующая проверка).

В качестве основных методов ОВОС тогда были рекомендованы:

- матрица Леопольда (100 наименований воздействий по горизонтальной оси, 88 «характеристик» и «условий» окружающей среды по вертикальной оси и, соответственно, 8800 ячеек для экспертной оценки по 10-балльной системе);

- совместный анализ карт, основанный на их наложении и балльной оценке воздействий в пределах выделяемых контуров;

- метод Баттеле, основанный на классификации факторов окружающей среды и оценке их относительной значимости, с последующей экспертной оценкой ожидаемых воздействий по методу Дельфи;

- имитационное моделирование (математические модели, описывающие возможные будущие сценарии развития природных и природно-социальных процессов и ситуаций).

Становление методологии и процедуры оценки воздействия на окружающую среду (OBОC), как и многое в природоохранной деятельности вообще, непосредственно связано с переходом к современному этапу природопользования и охраны окружающей среды. Его основное содержание составляют:

- принятие эффективных национальных природоохранных законов и создание для их реализации ведомств (министерств, комитетов, агентств), наделенных полномочиями по контролю всех компонентов окружающей среды;

- введение экономического механизма природопользования на основе принципа «загрязняющий платит» (эколого-экономическое регулирование);

- введение на государственном и межгосударственном уровнях экологических стандартов на выхлопы автомобилей, на содержание загрязняющих веществ в воздухе, воде, почвах, продуктах и т.д.;

- международное сотрудничество в решении глобальных проблем: парникового эффекта, охраны озонового слоя, кислотных дождей;

- предварительная экспертиза проектов хозяйственной и иной деятельности;

- организация подготовки и повышения квалификации кадров в области экологии и природопользования.

В качестве части своих усилий, направленных на совершенствование научных методов решения указанных выше проблем, СКОПЕ занимался научным обоснованием программ для разработки разных вариантов мер по управлению окружающей природной средой. Результаты этого были обобщены в выпуске СКОПЕ 5: «Оценка воздействия на окружающую среду: принципы и процедуры», опубликованном в 1975 г. и получившем широкое признание в качестве важного обобщающего документа. Начиная с 1975 г. оценку воздействия на окружающую среду стали производить во многих развитых странах; постепенно усовершенствовались методы ее проведения. В СКОПЕ 5 был обобщен 
немалый уже к тому времени опыт исследования экологических проблем, как в развитых, так и в развивающихся странах, разработаны термины и определения, относящиеся к процедуре ОВОС, выполнены классификации видов деятельности, компонентов и элементов окружающей среды (как природной, так и социальной), и предложены методы оценки их взаимодействия.

Экологическое нормирование: основные определения. Можно привести несколько более или менее удачных, на наш взгляд, определений понятия экологического нормирования (цит. по В.В.Дмитриеву, 1994; Дмитриев, Фрумин, 2004).

По первому из них экологическое нормирование есть научно обоснованное ограничение воздействия хозяйственной деятельности на ресурсы биосферы, обеспечивающее экологические потребности общества наряду с его социальноэкономическими интересами. Будем называть это определение - определением экологического нормирования в широком смысле (автор - акад. Яншин А.Л.) $)^{1)}$.

По второму определению (экологическое нормирование в узком смысле) экологическое нормирование есть нормирование любого антропогенного воздействия на экосистему, при котором можно оценить реакичю экосистемы в цеелом или какого-либо ее "критического звена" на воздействие (Дедю, 1990).

По третьему определению (Александрова, 1987, 1988, 1990) под экологическим нормированием понимается система действий по научному и методическому обоснованию разработки норм и собственно разработка и утверждение конкретных норм. При этом норма (вернее, нормативы) выступает как узаконенное правило, элемент управления проектированием, средство контроля за природопользованием, форма правовой гарантии экологической безопасности. Нормы должны создаваться для выполнения трех основных целей: 1) средосбережения и средообеспечения (т.е. сохранения среды, благоприятной для всего живого); 2) ресурсосбережения и ресурсовосстановления (при этом акцент делается на биологические ресурсы); 3 ) сохранения генофонда и условий его существования.

В четвертом определении конкретизируется понятие экологического норматива, под которым понимаются, с одной стороны, степень максимально допустимого вмешательства человека в экосистемы, обеспечивающая сохранение экосистем желательной структуры и динамических качеств, с другой, - обязательные рамки сохранения структуры и функций экосистемы конкретного иерархического уровня, а также всех экологических компонентов, учитываемых при хозяйственной деятельности (Реймерс, 1990).

В пятом определении экологическое нормирование - это специальная научноисследовательская и нормативно-правовая деятельность по обоснованию экологических критериев качества окружающей среды и разработке основанных на этих критериях нормативов допустимых антропогенных воздействий, природоохранных норм и правил применительно ко всем основным формам хозяйственной деятельности (Садыков, 1994).

В шестом определении под экологическим нормированием понимается процесс разработки регламентов антропогенного воздействия на окружающую среду, соблюдение которых гарантирует нормальное функционирование экосистем. В общем виде авторы видят задачу нормирования в установлении таких величин техногенных нагрузок, которые не вызывают в течение неопределенно длительного периода отклонений в нормальном функционировании экосистем, расположенных возле источника выбросов (Воробейчик, Садыков, Фарафонтов, 1994, с.127).

1) Алекса́ндр Леони́дович Я́ншин (28 марта 1911, Смоленск - 9 октября 1999, Москва) - советский и российский учёный-геолог, академик АН СССР (1958). Один из основателей Сибирского отделения АН СССР и Института геологии и геофизики СО АН СССР. Вице-президент АН СССР (1982-1988), крупный общественный и государственный деятель, президент Московского Общества Испытателей Природы (1967-1999), почётный директор Института литосферы окраинных и внутренних морей РАН, Герой Социалистического Труда, лауреат двух Государственных премий СССР, член многих зарубежных академий и научных обществ. 
В одних определениях экологическое нормирование понимается как система отношений общества с окружающей природной средой. В других определениях это система действий общества по научному и методическому обоснованию разработки регламентов и норм и собственно разработка и утверждение конкретных норм.

Первая международная конференция по экологическому нормированию (Пущино-на-Оке, 1992). Норма состояния и норма воздействия. Обобщение существующих подходов к проблеме экологического нормирования позволило в эти годы определить два ключевых термина: норма состояния экосистемы и норма воздействия на нее (Дмитриев, 1993; 1994). Эти понятия сформулированы нами для водной экосистемы, как составной части водной геосистемы.

Норма состояния - состояние экосистемы, при котором сохраняется ее структура и видовое разнообразие, не меняется режим функционирования, процессы обмена веществом и энергией протекают с интенсивностями, амплитуда которых обусловлена естественно-исторической фазой развития природного объекта и он может существовать без заметных изменений реально неограниченное время.

Норма воздействия - дозволенное антропогенное воздействие, при котором обеспечивается сохранение: структуры и динамических качеств экосистем, устойчивости, видового разнообразия, естественного хода сукцессионных процессов, продуктивности; наиболее уязвимых звеньев трофических цепей. При таком понимании нормы антропогенные воздействия на экосистему не вызывают изменения ее продуктивности (трофности), качества среды, а также ее устойчивости и благополучия в целом. Норма воздействия рассматривается нами как отклонение условий среды от типичных для классифицируемого состояния (трофности, сапробности и др.), не вызывающее выхода экосистемы за границы данного класса состояний, характеризующегося собственным набором критериев, и перехода ее в другой класс состояний или в критическую область (стрессовую зону) по совокупности факторов воздействия и развития в ней необратимых изменений (Дмитриев, 1993; 1994).

Таким образом, условия функционирования экосистем характеризуются "нормой состояния" на основе системы критериев, позволяющих выделить границы различных состояний экосистем, и "нормой воздействия "- отклонением условий среды от нормы, не вызывающим развития в ней необратимых изменений и не выводящим экосистему за пределы ее нормы и переход в другой класс состояний.

Этапы оценки воздействия. При оценке воздействия реализуются следующие этапы: оценка фактора воздействия $\rightarrow$ оценка аддитивных (масса, биомасса, мортмасса, концентрация и т.п.) и неаддитивных (устойчивость, благополучие) свойств экосистемы $\rightarrow$ оценка степени воздействия (изменения экосистемы).

Экологическое нормирование, основано не на оценке природопользователями качества наземных и водных природных объектов, а на оценке внутренних свойств и возможностей экосистем сохранять свое состояние или утрачивать его при внешнем воздействии на них (Дмитриев, 1994). Под оценкой воздействия нами понимается количественная (интегральная) оценка ответной реакции экосистемы в целом на антропогенное воздействие на основе получения антропогенно-трансформированного портрета экосистемы.

Экологическое сопровождение проектирования. Автор пособия «Экологическое сопровождение проектирования», 2011 проф. В.И. Стурман рассматривает процедуру ОВОС под углом зрения экологического сопровождения проектирования.

Общий контекст формирования методологии и процедуры экологического сопровождения проектирования был непосредственно связан с переходом к современному этапу природопользования и охраны окружающей среды, произошедшим в большинстве экономически развитых стран в конце 1960-х - начале 1970-х гг. Основное содержание современного этапа природопользования и охраны окружающей среды составляет:

- большая роль общественного мнения и общественных организаций 
природоохранной деятельности, постепенно трансформирующейся в экологическую политику - составную часть политики государств, партий и общественных движений;

- принятие эффективных национальных природоохранных законов и создание для их реализации ведомств (министерств, комитетов, агентств), наделенных полномочиями по контролю окружающей среды. Создававшиеся в этот период природоохранные ведомства отличались от более ранних природоохранных организаций государственным статусом, подконтрольностью всех компонентов среды, международной координацией и унификацией функций, широким использованием экономических рычагов;

введение экономического механизма природопользования на основе принципа «загрязняющий платит». Этот принцип означает, что природные ресурсы, используемые при получении определенной продукции, должны отражаться на ее стоимости, так же как, например, трудовые ресурсы;

- введение на государственном и межгосударственном уровнях экологических стандартов на выхлопы автомобилей,

- на содержание загрязняющих веществ в воздухе, воде, почвах, продуктах и т.д.;

- международное сотрудничество в решении глобальных проблем: парникового эффекта, охраны озонового слоя, кислотных дождей, что осуществляется путем заключения международных соглашений и контроля за их выполнением, включая санкции за невыполнение;

- предварительная экспертиза проектов хозяйственной и иной деятельности;

- организация подготовки и повышения квалификации кадров в области экологии и природопользования.

В результате указанных мер в развитых странах экологическая обстановка начала улучшаться, причем не в ущерб экономическому развитию и росту доходов населения. Однако всё это в значительной степени достигнуто за счет переноса грязных производств в страны «третьего мира» и «новые индустриальные страны», где нет эффективного природоохранного законодательства и контроля за его выполнением, т.е. где современный этап природопользования и охраны окружающей среды еще не наступил.

Руководство по оценке воздействия на окружающую среду (ОВОС) СКОПЕ 5. Одним из международных мероприятий, реализующих переход к современному этапу природопользования и охраны окружающей среды, стало создание в 1969 г. Научного комитета по проблемам окружающей среды (Scientific Committee on Problems of the Environment - SCOPE). Комитет был организован как межнациональный и междисциплинарный совет ученых, способный выступать в роли совещательного органа при правительствах или межправительственных организациях по проблемам окружающей среды, собирать воедино информацию об окружающей среде, поставляемую разными отраслями науки, чтобы выявить пробелы в наших знаниях и ликвидировать разобщенность результатов исследований.

В течение ряда лет исследования были направлены преимущественно на изучение следующих проблем: 1) биогеохимические циклы; 2) динамика и эволюция экосистем; 3) экологические аспекты структуры расселения людей; 4) экотоксикология; 5) моделирование природных систем; 6) мониторинг качества окружающей природной среды; 7) обмен информацией об окружающей природной среде, социальная оценка и реакция.

Основные разделы учебного курса «Экологическое сопровождения проектирования» (Стурман, 2011):

- история формирования методологии и современное состояние нормативной базы экологического сопровождения хозяйственной деятельности;

- свойства природной среды (литосферы, атмосферы, гидросферы, почв, живой природы), как условия хозяйственной деятельности;

- экологические требования к производственным объектам;

- инженерно-экологические изыскания: содержание и методы выполнения; 

выполнения;

- инженерно-гидрометеорологические

изыскания:

содержание

методы

- природоохранный раздел проектной документации.

Описательный и точный периоды в развитии наук по акад. А.А. Дородницыну (1982). Описательные и точные науки.

По А.А. Дородницыну развитие наук проходит следующие этапы: 1 - накопление информации об объектах, которые изучаются данной наукой. Одновременно или с небольшим опозданием начинается п.2.

2 - процесс упорядочивания - классификация объектов с целью облегчения анализа, выявления типологии.

3 - установление эмпирических качественных и количественных связей и соотношений между объектами.

Эти три этапа по акад. А.А. Дородницыну характеризуют описательный период развития науки, после которого начинается выделение определяющих связей и соотношений. С этого момента начинается математическое моделирование процессов на основе выделения существенных свойств (величин) исследуемого явления. Так появляются:

4 - установление величин.

5 - математическое моделирование.

6 - установление связей и соотношений (уже не на основе эмпирики, а на основе результатов моделирования). И т.о. реализуется переход от моделирования - к целям преобразования. Модель выступает в качестве инструмента преобразования экосистемы.

Стадии развития новых направлений в науке: восторженный прием новых идей, разносная критика и разочарование из-за неоправдавшихся надежд, спокойное развитие с получением основных достижений.

Основные признаки систем по акад. А.С. Саркисяну (1977):

1. По сложности: сверхпростые (нет связей между переменными); простые (только парные взаимосвязи); сложные (взаимосвязи между 3 и более переменными); сверхсложные (взаимосвязь между всеми переменными).

2. По масштабу: сублокальные (1-3 переменных); локальные (4-14 переменных); субглобальные (15-35 переменных); глобальные (36-100 переменных); суперглобальные (более 100 переменных).

3. По степени детерминированности различают: детерминированные, стохастические, смешанные системы. Чаще всего мы имеем дело с моделями смешанного типа. Они, как правило, формулируются как детерминированные.

Стохастичность в модели вводится принятием гипотез о случайности: - начальных условий; - внешних воздействий; - параметров моделей. Внутренняя и внешняя стохастичность. Стохастические экологические модели на сегодня составляют лишь $1 \%$ от всех существующих моделей.

4. По характеру развития системы во времени: дискретные, апериодические, циклические. Водные экосистемы: циклического, транзитного и каскадного типов (Дмитриев, 2000).

5. По степени информативной обеспеченности:

- наличие полной количественной информации о системе;

- наличие неполной количественной информации о системе;

- наличие качественной информации о ретроспективном состоянии системы;

- полное отсутствие информации (проект новой системы).

6. По возможности прогнозирования структуры и поведения различают системы типа «черного ящика», «белого ящика» и промежуточные.

Системная экология - раздел экологии, изучающий совокупность принципов, концепций, методов системного анализа применительно к экологии. С.э. как формализованный целостный подход стала самостоятельным разделом экологии в 
результате развития современных формальных математических методов, кибернетики, обработки данных на компьютере, информатики и т.д., а также формального упрощения сложных систем. Условная формула С.э.: Системная экология = системный анализ + экология.

Теория сложных систем. Системология. Теория сложных систем (системология) изучает общие свойства всех сложных систем, характерные свойства системных связей.

Цель общей теории систем - создание единой методологии исследования общесистемных признаков (характеристик) объектов (систем) различной природы.

Эмергентность (эмержентность, эмерджентность) сложной системы несводимость сложной системы к составляющим её компонентам («основным», «важным для человека», «слабым», «слабому звену» и т.п.). Таким образом, нельзя сводить характеристику сложной системы к характеристике её основных компонентов на основе единичных (покомпонентных), косвенных оценок.

Моделью будем называть опытную систему (материальную или знаковую), собственные свойства которой настолько близки к свойствам интересующего исследователя объекта, что при помощи экспериментов с этой опытной системой удается узнать нечто новое о самом объекте, причем это новое достаточно важно для исследователя (Штофф, 1966; Ивахненко, 1971). Математической моделью системы называются математические соотношения (уравнения, неравенства и пр.) или программы, описывающие некоторые характеристики этой системы. Следует отметить, что построение математической модели не есть просто применение математики в конкретном исследовании: построение математической модели предполагает наличие особой «идеологии».

Модель - реально существующий или виртуальный заменитель реальной системы (опытная система), адекватный по своим свойствам реальному прототипу, эксперименты с которым (заменителем) дают исследователю новую информацию о самой системе (реальной системе) - определение автора пособия.

Сравните: моде́ль (фр. modèle, от лат. modulus - «мера, аналог, образец») - это система, исследование которой служит средством для получения информации о другой системе, это упрощённое представление реальной системы (устройства и/или протекающих в них процессов, явлений) (определение из «Википедии» с исправлениями автора пособия).

Построение и исследование моделей, то есть моделирование, облегчает изучение имеющихся в реальной системе (устройстве, процессе, и т.п.) свойств и закономерностей. Применяют для нужд познания (созерцания, анализа и синтеза).

Моделирование является обязательной частью исследований и разработок, неотъемлемой частью нашей жизни, поскольку сложность любого материального объекта и окружающего его мира бесконечна вследствие неисчерпаемости материи и форм её взаимодействия, — как внутри себя, так и с внешней средой.

Одни и те же устройства, процессы, явления и т. д. (далее - «системы») могут иметь много разных видов моделей. Как следствие, существует много названий моделей, большинство из которых отражает решение некоторой конкретной задачи.

В последние годы в ряде публикаций всё чаще, молча, опускается требование адекватности реальному прототипу. Иногда об этом забывают, поскольку в публикации отсутствует доказательство адекватности (реже пишут о том, что для модели выполнена валидация). Но чаще (это относится к гуманитарной или общественной географии) делают вид, что будущее проектируется на основе конструктивно оформленного прогнозирования, то есть не столько предсказания будущего, сколько выстраивания цепочки логических умозаключений по поводу прогресса (продвижения к достижимым или, как правило, к недостижимым результатам и состояниям) и возникающих на его пути проблемах.

Экологическая модель - виртуальный, физический или математический заменитель реальной экосистемы, адекватный по своим свойствам этой экосистеме, с помощью которого можно получить новую информацию о самой экосистеме, её составе, структуре, свойствах. Экологическая модель должна на основе современных представлений описывать взаимосвязь между живыми системами и между живыми 
системами и окружающей их абиотической средой, скрытые от непосредственного наблюдения процессы обмена веществом в экосистеме.

Имитационная модель. Термин имитационное моделирование применяется при воспроизведении математическими методами временной динамики сложных динамических систем. По определению Н.Н.Моисеева и Г.С.Розенберга имитационная модель - математическая модель, построенная на пределе современных знаний о реальной системе и реализованная на ПК по блочному принципу. Другие исследователи (Горстко, 1977) выделяли имитацию разных рангов: нулевой ранг - подражание в области законов; первый ранг - подражание в области законов и поведения случайных величин; и собственно имитационные модели или второй ранг имитации - подражание в области поведения систем, а также законов и случайных величин, если они используются в модели.

Портретной моделью называют модель, в которой все коэффициенты определены по результатам экспериментов над некоторой конкретной экосистемой.

Акад. Н.Н. Моисеев (1979) считает основной целью имитационного моделирования определение границ гомеостазиса сложных систем. Кроме того, важными целями имитационного моделирования можно считать: увеличение фундаментальных знаний об экосистемах, проверку непротиворечивости и совместимости выдвигаемых гипотез о характере функционирования этих экосистем, выявление фундаментальных ограничений на это функционирование и ряд других целей, которые достигаются в процессе построения имитационной модели, ее проверки и экспериментирования с ней.

Для оценки состояния окружающей среды в региональном и локальном масштабах, а также для принятия решений, в настоящее время разработан и применяется ряд подходов и методик. Имитационное моделирование, конечно, является важным звеном при таких оценках, но на первом месте в последние годы стоят методы (модели) анализа и оценки рисков. В первую очередь речь идет о проблемах, связанных с анализом экологических рисков, их восприятием и управлением. Этой тематике посвящено в настоящее время огромное количество публикаций и многочисленные конференции. Сюда же примыкают методы оценки риска здоровью. Такие оценки являются естественной поведенческой реакцией человека и можно сказать, что на оценках риска здоровью базируется вся система информационной связи человека с окружающим его миром. Наиболее развитыми в настоящее время являются оценки радиационного риска. В этой области имеется больше всего информации о коэффициентах риска. К этому же направлению работ примыкают и исследования, связанные с анализом риска природных и техногенных катастроф. Оценка экологического риска является только одним из инструментов всего процесса управления экологическими рисками. Параллельно развиваются и методы оценки экологической пользы и методы анализа затрат и др.

Основные задачи математического моделирования экосистем. Обобщение исследований по данному направлению, выполненных за последние 30 лет по более 300 публикациям в России и за рубежом, показывает, что основной задачей математического моделирования экосистем является количественное описание внутренних связей и процессов, обусловливающих развитие этих сложных природных комплексов. В связи с этим в ряде работ и обобщений выделяются основные требования к моделям:

1. На моделях должны воспроизводиться круговороты основных химических элементов.

2. Модельный биоценоз должен быть представлен основными, дифференцированными по экологическим признакам, компонентами природных сообществ.

3. Модели должны учитывать возможные антропогенные поступления веществ. В состав компонентов моделей необходимо включить основные виды загрязняющих веществ.

4. Модели должны учитывать последние достижения эколого-токсикологического скрининга экосистем, эффекты синергизма, антагонизма, суммации.

5. При моделировании должны учитываться также: физико-динамические процессы, обусловливающие перенос компонентов в пространстве; обмен веществом и энергией через границы с отдельными экосистемами.

6. При параметризации интенсивностей обменных процессов должны использоваться многофакторные зависимости. 
7. На моделях должны воспроизводиться сценарии различных экологических ситуаций и количественно оцениваться последствия антропогенных воздействий на экосистемы.

8. По результатам моделирования необходимо выполнять интегральные оценки продуктивности, качества и токсического загрязнения природных объектов, оценивать их эмерджентные свойства (устойчивость, напряженность, благополучие).

9. Результаты моделирования необходимо использовать в целях экологического (экосистемного) нормирования и регламентации воздействий на экосистемы.

10. Результаты моделирования должны сочетаться с возможностями современных ГИС и ГИС-технологий для визуализации характерных особенностей развития экосистем и прогнозов их трансформаций при внешнем воздействии.

Проблемы, стоящие перед разработчиками моделей. Сравнение развития данного научного направления и стоящих перед разработчиками моделей проблем по нашим обобщениям для трех этапов: 1980-х, 1990-х гг и 2000-2010 гг позволяет выделить характерные моменты и проблемы развития системного моделирования:

1. Проблемы, стоящце перед разработчиками имитационных моделей в 1980-е 22:

- формулировка задач и выбор структуры моделей,

- выбор существенных переменных и их агрегирование,

- способ учета внешних воздействий,

- способы отражения пространственной структуры,

- способы моделирования транслокации и трансформации компонентов,

- выделение факторов, лимитирующих первичную продукцию;

- выбор способов описания метаболизма,

- проверка адекватности моделей.

2. Специфические проблемы, определяющце методологию имитационного моделирования в 1990-е г2:

- «проклятие размерности» (А.М. Молчанов);

- формулировка модели;

- параметрический учет явлений и процессов подсеточного масштаба (совместное моделирование всего ансамбля разномасштабных процессов невозможно, поэтому какието процессы должны учитываться параметрически);

- выбор методики численного интегрирования систем дифференциальных уравнений (решение краевых задач в многомерных пространственно-временных областях моделирования произвольной конфигурации. Аналитического решения нет. Численные методы нуждаются в апробации);

- информационный голод на начальном этапе моделирования, идентификации и верификации моделей;

- информационный «взрыв» при решении задачи (реализации модели);

- реализация имитационной модели на ПК (алгоритмы моделирования, информационное обслуживание и сервисные программы обработки и разноаспектной визуализации результатов моделирования);

- анализ чувствительности моделей к отдельным параметрам;

- оценка адекватности модели оригиналу.

моделирования в наши дни:

3. Специфические проблемы, определяющие методологию имитационного

- появление вычислительных комплексов и ППП для моделирования сложных систем;

ориентация на использование ГИС и ГИС-технологий в процессе моделирования и в анализе результатов моделирования;

- геоинформационное картографирование и другие виды геомоделирования, системный анализ многоуровневой и разнородной геоинформации;

- компьютерные геоизображения новых видов и типов, анимационные, мультимедийные, виртуальные и другие электронные продукты, развитие цифровизации в науках о Земле и обществе;

- взаимодействие геоинформатики, картографии и аэрокосмического зондирования;

- выход на управленческие решения в сферах планирования и проектирования, исследований в науках о Земле и смежных с ними социально-экономических науках, в 
развитии образования и культуры, сохранении экологического равновесия, предупреждения чрезвычайных ситуаций, обеспечении обороноспособности страны.

\section{Вопросы для проверки усвоения материала:}

1. Определите понятия: экологическое нормирование, устойчивость сложных систем к изменению параметров режимов. Что объединяет эти определения.

2. Чем оценка экологического состояния может отличаться от оценки качества. Есть ли разница между такими оценками. Можно ли оценивать состояние сложной системы на основе покомпонентных оценок. В чем слабость таких оценок.

3. Можно ли прогнозировать «устойчивое развитие» описательными методами (на основе покомпонентных аддитивных оценок)?

4. В некоторых, сравнительно недавно вышедших публикациях по оценке устойчивости водных экосистем к разливам нефти, идет речь о чувствительности экосистем (акваторий) к нефтяному загрязнению (см. рис.2 из статьи В.Б. Погребова и А.Ю. Пузаченко, 2003). В чем, на Ваш взгляд, разница между чувствительностью и уязвимостью (устойчивостью) экосистем. Можно ли считать их синонимами?

5. Какие мнения существуют по поводу того, что такое ЭО, ОВОС, Экологическое сопровождение проектирования, ЭН?

6. Почему не целесообразно выполнять экологическую оценку на основе одного какого-либо одного (слабого, основного и т.п.) компонента экосистемы. Обоснуйте ответ.

7. В чем отличие системной экологии от экологии, геоэкологии; системного анализа от системного подхода.

8. Что значит, оценить экологическое состояние; оценить состояние экосистемы.

9. Можно ли назвать моделью заменитель сложной системы, адекватность которого по отношению к реальному объекту не доказана.

10. В общении мы иногда употребляем слово «плеяда», понимая под ним совокупность, скопление каких-либо однородных событий, явлений, составляющих нечто единое, цельное. Можно ли на ваш взгляд использовать этот термин для характеристики сложной системы. Какими свойствами, в этом случае должны обладать события, явления, составляющих нечто единое, цельное.

11. Чем модель отличается от имитационной модели.

12. Можно ли заниматься планированием устойчивого развития без системной экологии (системного моделирования), на основе описательных методов.

13. Назовите физико-механические и химико-биологические процессы, протекающие в водной экосистеме.

14. К чему приводит учет нелинейности в формулировке удельной скорости процесса массообмена.

\section{Литература}

Александрова Л.В., Васильев В.Ю., Дмитриев В.В., Мякишева Н.В., Огуриов А.Н., Третьяков Н.В., Хованов Н.В. Многокритериальные географо-экологические оценки состояния и устойчивости природных и урбанизированных систем. Под ред. В.В. Дмитриева и Н.В. Хованова. Деп. ВИНИТИ 01.09.2000, № деп.2342В00, 275 с.

Алексеев Д.К., Гальциова В.В., Дмитриев В.В., Экологический мониторинг: современное состояние, подходы и методы. Часть І. Учебное пособие. Изд. РГГМУ, СПб, 2011. 302 с.

Алимов А.Ф. Экология - наука биологическая // Экология,1990, №1, с.3-7.

C.33-46.

Арманд А.Д. Механизмы устойчивости геосистем // Факторы и механизмы устойчивости геосистем. М., 1989.

Белозерский Г.Н. Введение в глобальную экологию, С.-Петербург: Изд. СПбГУ, 2002 г.

Белозерский Г.Н., Дмитриев В.В. Становление геоэкологии как важный этап в развитии географии ХХ столетия/ Известия РАН. Серия географическая, 2007, №2, с.19-28.

Белозерский Г.Н., Дмитриев В.В. Тенденции развития географии в ХХІ веке. Единая планетарная система./ Известия РАН. Серия географическая, 2007, №4, с.8-15.

Бигон М., Харпер Дж., Таунсенд К. Экология. Особи, популяции и сообщества: В 2-х т. Пер. с англ. М. Мир, 1989.

Бобров А.А. Эколого-экономическая устойчивость регионов России. М., 1999, 93 с.

Васильев В.Ю., Дмитриев В.В., Жиров А.И., Огуриов А.Н., Зеленков, В.М Мискевич, И.В., Машкин Ю.Л. Геоинформационный анализ и зонирование акватории Баренцева моря по степени экологического благополучия на участке проектирования нефтеналивного терминала в районе мыса Святой Нос (восточный) // ИнтерКарто - ИнтерГИС 15: устойчивое развитие территорий: теория ГИС и практический опыт: Материалы Международной конференции Том 2, Пермь, Гент 25 июня - 5 июля 2009, Пермь, ПГУ, 2009. С.303-310. $1933-39$;

Вернадский В. И., Очерки геохимии, 4 изд., М.- Свердловск, 1934; Ферсман А. Е., Геохимия, т. 1-4, Л.,

Вильямс В. Р., Собр. соч., т. 6, М., 1951

Виноградов А. П. Введение в геохимию океана, М., 1967

Виноградов А. П., Геохимия редких и рассеянных химических элементов в почвах, М., 1950

Воробейчик Е.Л., Садыков О.Ф., Фарафонтов М.Г. Экологическое нормирование техногенных загрязнений наземных экосистем. Екатеринбург: Изд. Наука, 1994. 280 с. 
Гальцова В.В., Дмитриев В.В. Практикум по водной экологии и мониторингу состояния водных экосистем. Изд. Наука - СПб., 2007, 364 с.

Геоэкология и природопользование. Труды ХІІ съезда Русского географического общества. Отв. редакторы д.г.н. В.В. Дмитриев, д.б.н. В.Н.Мовчан, Том 4., СПб, 2005, 400 с.

Глазовская М.А. Ландшафтно-геохимические системы и их устойчивость к техногенезу // Биогеохимические циклы в биосфере.- М.,1976.-356 с

Голубев Г.Н, Геоэкология, М., Изд. МГУ, 2000

Дедю И.И. Экологический энциклопедический словарь. Кишинев, 1990, 406 с.

Дмитриев В.В. Диагностика и моделирование водных экосистем. СПб, 1995, 215 с.

Дмитриев В.В. Интегральные оценки состояния сложных систем в природе и обществе, междисциплинарный // Научный и прикладной журнал «Биосфера», 2010. Т.2. №3. С.533-546

Дмитриев B.B. Методика диагностики состояния и устойчивости водных экосистем // Эколого-географический анализ состояния природной среды: проблема устойчивости геоэкосистем. СПб., изд-во РГО. 1995. С.41-67.

Дмитриев В.В. Методические указания по дисциплине «СИСТЕМНАЯ ЭКОЛОГИЯ». Специальность 013600 геоэкология. Курс V. г. Санкт-Петербург, РГГМУ, 2002, 30 с.

Дмитриев В.В. Определение интегрального показателя состояния природного объекта как сложной системы,// Научно-теоретический журнал «Общество. Среда. Развитие», 2009. №4 (12). С.146-165.

Дмитриев В.В. Прикладная экология в системе высшего географического и гидрометеорологического образования/ Вопросы прикладной экологии. Сборник научных трудов РГГМУ, СПб, изд. РГГМУ, 2002, с.90-96.

Дмитриев В.В. Устойчивость природных объектов к изменению параметров естественного и антропогенного режимов // Дмитриев В.В., Фрумин Г.Т. Экологическое нормирование и устойчивость природных систем. Учебное пособие, Изд. Наука, СПб, 2004. С.241-278.

Дмитриев В.В. Экологическое нормирование состояния и антропогенных воздействий на природные экосистемы // Вестник СПбГУ. Сер.7. Геология и география - 1994. - вып.2 (№14). С. 60-70.

Дмитриев В.В. Эколого-географическая оценка состояния внутренних водоемов. Автореф. докт. дисс., СПб, 2000.

Дмитриев В.В., Воропаева Г.М. Идеи устойчивого развития в программе обучения специалистов-экологов на кафедре экологической безопасности и устойчивого развития регионов / «Образование для устойчивого развития», Материалы Всероссийского совещания «Образование для устойчивого развития». Под ред. чл.-корр. РАН Н.С. Касимова и проф. В.С. Тикунова. Смоленск, 2003, с.60-72

Дмитриев В.В., Жиров А.И., Ласточкин А.Н. Прикладная экология. / Учебник для студентов высш. учеб. заведений. М.: Издательский центр «Академия», 2008. 608 с.; 2018 (2-е издание).

Дмитриев В.В., Кулеш В.П., Сергеев Ю.Н., Третьяков В.Ю. Моделирование экосистем. Часть 1. Методическое пособие. - СПб., 2006. - 16 с.

Дмитриев В.В., Огуриов А.Н., Афонин А.Н. Машкин Ю.Л. Оценка устойчивости растительного покрова в зоне активного техногенного воздействия с использованием ГИС-технологий // ИнтерКарто - ИнтерГИС 10: устойчивое развитие территорий: геоинформационное обеспечение и практический опыт: Материалы Международной конференции, Владивосток, Чанчунь (КНР), 12-19 июля 2004 г. Владивосток 2004. С.165-170

Дмитриев В.В., Огурцов А.Н., Васильев В.Ю. Использование геоинформационных технологий при экологическом зонировании городской территории // ИнтерКарто - ИнтерГИС 11: устойчивое развитие территорий: теория ГИС и практический опыт: Материалы Международной конференции - Ставрополь - Домбай - Будапешт (25 сентября - 3 октября 2005 года). - Ставрополь: Изд-во СГУ, 2005. С.308-312.

Дмитриев В.В., Третьяков В.Ю., Кулеш В.П., Васильев В.Ю., Огуриов А.Н., Бойцов А.В. Оценка устойчивости и чувствительности природных экосистем к антропогенному воздействию // Вестник С.-Петербургского университета. Серия Геология и география, 1995. Вып.2. №14. С.49-57

Дмитриев В.В., Третьяков В.Ю., Кулеш В.П., Огурцов А.Н., Васильев В.Ю., Бойцов А.В. Оценка устойчивости и чувствительности водных экосистем к антропогенному эвтрофированию // Известия Русского географического общества. СПб., изд. РГО, 1995. Т.127. Вып.2. С.16-26

Дмитриев В.В., Фрумин Г.Т. Экологическое нормирование и устойчивость природных систем: Учебное пособие./- СПб.: Изд. Наука, 2004, 293 с.

Дородницын А.А. Математика и описательные науки // Число и мысль, 1982, вып.5., М., «Знание», с.6-15.

Драбкова В.Г., Прыткова М.Я., Якушко О.Ф. Восстановление экосистем малых озер. СПб, 1994, 143 с.

Зуева H.B., Гальцова B.B., Дмитриев B.B., Степанова А.Б Использование структурных характеристик сообществ макрофитов как индикатора экологического состояния малых рек Ленинградской области // Вестн. С.-Петерб. ун-та. Сер.7. 2007. Вып.4. С.60 -71.

Исаченко А.Г. Ландшафтоведение и физико-географическое районирование./ А.Г.Исаченко. - М.: Издательство «Высшая школа», 1991. 160 с.

Исаченко Г.А. Методы полевых ландшафтных исследований и ландшафтно-экологическое картографирование: Курс лекций: [Для студентов геогр. и экол. спец.] / Г.А. Исаченко; С.-Петерб. гос. ун-т. - СПб.: Изд. СПбГУ, 1998.110 с.

Крассов О.И. Экологическое право: учебник / 2-е изд., - М.: Норма, 2008, 672 с.

Кудерский Л.А. Естественные и техногенные водные экосистемы: проблемы их устойчивости.// Региональная экология, 1996. №3-4. С.31-36.

Лодоло А., Гречищева Н.Ю., Мещеряков С.В., Рыбальский Н.Г., Снакин В.В., Барсов А.Р., Кулындыщев В.А. Технологии восстановления почв, загрязненных нефтью и нефтепродуктами. Справочник.. М.: РЭФИА, НИА-Природа, 2003. $258 \mathrm{c}$

Лопатников Л.И. Экономико-математический словарь. Под ред.акад. Н.П.Федоренко. М., Наука, 1987, 509с.

Мазур И.И., Молдаванов О.И., Шишов В.Н. Инженерная экология. Общий курс в двух томах. М., 1996.

Многокритериальные географо-экологические оценки состояния и устойчивости природных и урбанизированных систем. Под ред. В.В. Дмитриева и Н.В. Хованова. Деп. ВИНИТИ 01.09.2000. № деп.2342В00, 275 с. 
Моделирование экосистем. Часть 1. Методическое пособие. Дмитриев В.В., Кулеш В.П., Сергеев Ю.Н., Третьяков В.Ю. СПб., 2006,16 с.

Моисеев Н.Н. Математические задачи системного анализа. М: Наука, 1981.

Морозов Н.П. Концепция экологического нормирования при ведении хозяйственной деятельности //Экологическое нормирование: проблемы и методы. Тезисы научно-коорд. совещ. Пущино, 13-17 апреля 1992, М., 1992, c.94-96.

Новиков М.А. Эколого-рыбохозяйственный Атлас Баренцева моря, Изд. ПИНРО, 2003 (электронный вариант).

Огуриов А.Н., Разживин В.Ю., Пигольиина Г.Б., Хованов Н.В. Геоинформационный анализ и синтез показателей устойчивости почвенного покрова к загрязнению нефтяными углеводородами при информационном дефиците // ИнтерКарто - ИнтерГИС 13: устойчивое развитие территорий: теория ГИС и практический опыт: Материалы Международной конференции - Ханты-Мансийск - Йеллоунайф - 12-24 августа 2007 г. - Ханты-Мансийск: Изд-во Полиграфист, 2007. Т.1. С.189-196.

Одум Ю. Основы экологии / Пер. с 3-го англ. изд. под ред. Н.П. Наумова. М., 1975, 740 с.

Ожегов С.И. Толковый словарь русского языка /С.И.Ожегов. - М.: Изд. Сов. энциклопедия, 1970. - 973 с.

Печуркин И.С. Развитие и эволюция видов и звеньев системы и устойчивость круговорота веществ в замкнутых экосистемах. Красноярск, 1989, 25 с.

Погребов В.Б. и Пузаченко А.Ю. Интегральная чувствительность морских экосистем к нефтяному загрязнению // Материалы V научного семинара «Чтения памяти К.М. Дерюгина». - СПб, 2003. С.5-22.

Погребов В.Б. и Пузаченко А.Ю. Экологическая уязвимость Баренцева, Белого, Балтийского, Черного и Каспийского морей к операциям по добыче и транспортировке нефти: сравнительный анализ, 2003, 8 стр.

Примак Е.А., Дмитриев В.В. Интегральная оценка уязвимости и экологического благополучия водных объектов // Окружающая среда и устойчивое развитие регионов: новые методы и технологии исследований: Труды Всероссийской научной конференции с международным участием. Том 1: 19-22 мая 2009 г. / Под ред. проф. Ермолаева О.П. и проф. Сироткина В.В., Казань.: Изд-во «Бриг», 2009. С.63-67.

Примак E.А., Дмитриев В.В. Оценка уязвимости водоемов Европейского Севера к изменению параметров режимов // Экологические и гидрометеорологические проблемы больших городов и промышленных зон. Материалы Международной конференции. 25-27 октября 2006 г. СПб.; изд. РГГМУ, 2006. С.107-108

Примак Е.А., Дмитриев В.В. Разработка интегральных индексов для оценки устойчивости водоемов к изменению параметров естественного и антропогенного режимов // Географические и геоэкологические аспекты развития природы и общества. Сборник научных статей по материалам отчетных научно-практических конференций 2006-2007 гг. Под ред. Каледина Н.В., Дмитриева В.В., Алиева Т.А., СПб, Наука, 2008. С.234-241

Программа дисииплины «Системная экология» для высших учебных заведений. Специальность 013600Геоэкология. Автор В.В.Дмитриев. Отв. редактор В.А. Шелутко. Издательство РГГМУ, СПб, 2007, 13 с.

Пузаченко Ю.Г. Проблемы устойчивости и нормирования // Структурно-функциональная организация и устойчивость биологических систем. Днепропетровск, 1990. С.122-147.

Реймерс Н.Ф. Природопользование: Словарь-справочник. М., 1990, 638 с.

Розенберг Г.С. Модели в фитоценологии, М., «Наука», 1984, 265 с.

Росновский И.Н. Устойчивость почвы: техногенно-механические аспекты. Новосибирск, 1993, 170 с.

Светлосанов B.A. Устойчивость и стабильность природных экосистем // Итоги науки и техники. Серия «Теоретические и общие вопросы географии». М., 1990. С.56-74.

Свирежев Ю.М., Логофет Д.О. Устойчивость биологических сообществ, М., 1978, 190 с.

Сергеев Ю.Н. Моделирование экологических систем // Основы геоэкологии. СПб, 1994, с.297-349.

Словарь терминов и понятий, связанных с охраной живой природы / Н.Ф.Реймерс, А.В.Яблоков / М., 1982, 144

c.

Тульчинский Г.Л. Цифровая трансформация образования: вызовы высшей школе. Философские науки. 2017. № 6. C. 121-136.

129.

Федоров В.Д. Устойчивость экологических систем и ее измерение // Изв. АН СССР. Сер. биол. 1974. №3. с.115-

Хованов Н.В. Анализ и синтез показателей при информационном дефиците. / Н.В.Хованов. - СПб.: Издательство СПбГУ, 1996. 196 с.

Хованов Н.В. Математические модели риска и неопределенности. / Н.В. Хованов. - СПб.: Изд. СПбГУ, 1998.

$202 \mathrm{c}$.

Хованов Н.В. Стохастические модели теории шкал. / Н.В. Хованов. - Л.: Изд. СПбГУ, 1986. 196 с.

Хованов Н.В. Универсальность линейной свертки отдельных показателей / Н.В. Хованов // Методология и практика оценки качества продукции. - 1990. Вып.3. Л. С.70-74.

Хорошев А.В. ПОЛИМАСШТАБНАЯ ОРГАНИЗАЦИЯ ГЕОГРАФИЧЕСКОГО ЛАНДШАФТА, дисс. на соискание ученой степени доктора геогр. наук по специальности 25.00.23 Физическая география и биогеография, география почв и геохимия ландшафтов. Москва, МГУ, 2017, 370 с. $2006,36 \mathrm{c}$

Шилин М.Б. Геоэкологический мониторинг прибрежных природно-технических систем. Автореф. докт. дисс.,

Шуйский В.Ф. Закономерности лимитирования пресноводного макрозообентоса экологическими факторами// Автореф. дисс. на соиск. уч.ст. докт. биол.наук. СПб., 1997, 50 с.

Эколого-географическая оценка состояния природной среды / Под ред. П.П. Арапова и Ю.П. Селиверстова. СПб, 1994. $96 \mathrm{c}$

Afgan NH, Carvalho MG, Hovanov NV. Energy system assessment with sustainability indicators.// Energy Policy 2000. №28. pp.603-612

Afgan, N.H., Carvalho, M.G.,. Pilavachi P.A., Martins N. Evaluation of natural gas supply options for Southeast and

Central Europe: Part 2. Multi-criteria assessment // Energy Conversion and Management 2008. №49. pp.2345-2353

Borchert H., Zur Geochemie des Kohlenstoffs, "Geochimica et Cosmochimica acta", 1951, v. 2, № 1

Jovanovic M., Afgan N., Bakic V. An analytical method for the measurement of energy system sustainability in urban 
areas // Energy. Elsevier 2010. №35. pp.3909-3920

Jovanovic M., Turanjanin V., Bakic V., Pezo M., Vucicevic B. Sustainability estimation of energy system options that use gas and renewable resources for domestic hot water production // Energy. 2011. №36. pp. 2169-2175

Pilavachi PA, Roumpeas CP, Minett S, Afgan N. Multi-criteria evaluation for CHP systems. // Energy Conserv Manage 2006. №47. pp.3519-3529

Rankama K., Sanama Th. G., Geochemistry, Chi., 1950.

Shmelev S.E. Dynamic sustainability assessment: The case of Russia in the period of transition (1985-2008) // Ecological Economics. 2011. №70. pp.2039-2049.

Todorovica M. S., Kimb J. T. Buildings energy sustainability and health research via interdisciplinarity and harmony // Energy and Buildings. 2012. №47. pp.12-18

Zhou Zupeng, Hua Jiang, Liancheng Qin. Life cycle sustainability assessment of fuels. // Fuel 2007. №86. pp.256-263.

\section{Лекция №3}

Цифровизация и науки о Земле. Информация 1, 2 и 3 рода о состоянии системы. Геоинформатика. Оценка. Оценка состояния системы. Оценка и диагностика. Диагностика природного объекта. Состояние природной системы и его оценка. Состояние природы. Состояние геосистемы. Режим. Вектор состояния системы. Пример описания состояния экосистемы (построения вектора системы) на основе аддитивных и неаддитивных параметров. Проблема. Ситуация. Обстановка. Экологическая проблема. Экологическая ситуация. Экологическая обстановка. Экологическая оценка. Стратегия экологической оценки. Эколого-географическая оценка. Триада Ю.П. Селиверстова. Ниша Хатчинсона. Трансформация ниши Хатчинсона.

Экологическая и геоэкологическая оценка. Геоэкологическая регламентация. Геоэкологическое нормирование. Геоэкологический мониторинг. Основные задачи геоэкологического мониторинга. Уровни геоэкологического мониторинга. Экологический и геоэкологический статус природного объекта. Субъективизм в определении понятий экологическая оценка, эколого-географическая оценка. Качество среды. Оценка качества среды. Антропо-, био-, эко- и геоцентризм в оценке качества среды. Что подлежит изучению и оценке в естественных и антропогеннотрансформированных наземных и водных объектах (эко- и геосистемах). Свертки информации о состоянии системы. Методы свертки информации. Интегральные оценки в индексологии состояния природных экосистем и их эмерджентных свойств. Индикатор. Индекс.

Цифровизация и науки о Земле. На одном из научных семинаров в СПбГУ в конце 2017 г. д. филос. н., проф. Г.Л. Тульчинский предложил следующее определение термина «цифровизация»: «цифровизация = разработка и использование технологий, основанных на идеях дискретности, алгоритмичности, вычислимости, программируемости (то, что определяет облик современной цивилизации: компьютерные технологии, информационно-коммуникативные технологии, ...)». Чтобы продемонстрировать «обаяние» нового термина, по сути, носящего деятельностный, менеджерский характер, но с модным уклоном в сторону предметной области, автор предложил определение «социально-культурного инжиниринга» (СКИ): «СКИ = систематизация знаний, практик разработки, экспертизы и реализации проектов, связанных с преобразованием социальной реальности, социализацией личности». Отметим, что в России термины «инжиниринг», «инженерия», «инженерная деятельность», чаще всего, являются синонимами. Их связывают с организацией процессов создания пакета предпроектной и проектной документации, получения данных, отражающих результаты инженерных изысканий, и оформления документации, сопровождающей различные этапы и процедуры этой деятельности.

Следуя этому определению, для системы «природный объект - человек (общество)» можно предложить термины «геоэкологический инжиниринг» (ГЭИ), и др., например, ГЭИ = систематизация знаний, практик разработки, экспертизы и реализации 
проектов, связанных с преобразованием и управлением природными объектами. Или с акцентом на антропоцентризм: ГЭИ - систематизация знаний, практик разработки, экспертизы и реализации проектов, связанных с преобразованием и управлением природными объектами и отношениями в системе «природный объект - человек (общество)».

Для системы «природный объект - живые организмы» (биоцентризм, экоцентризм) возможен и «природно-экологический инжиниринг» (ПЭИ): систематизация знаний, практик разработки, экспертизы и реализации проектов, связанных с преобразованием и управлением природными объектами и их экосистемами. Характеризуя современный этап развития высшего образования в России, проф. Высшей школы экономики Г.Л. Тульчинский (2017) пишет: «Современные цифровые технологии радикально меняют экономику, образ жизни в целом. Рынок труда требует качественно иного содержания подготовки выпускников учебных заведений. Цифровизация затрагивает не только содержание образования, но и его организацию. Эти процессы имеют неоднозначные последствия для позиционирования, как университетов, так и преподавательского труда. Необходимые компетенции приобретаются часто за стенами учебных заведений, потому что образовательные программы часто не успевают за динамикой технологий. Рынок онлайн-образования вызывает вопрос о статусе университетского диплома. Преподаватель превращается из носителя транслируемых знаний и умений в навигатора, который помогает ориентироваться в базах знаний (и базах данных, ВВД). Все эти вопросы стоят особенно остро применительно к реформированию российской системы высшего образования. Необходимая оптимизация подменяется простым сокращением количества университетов, сокращением их финансовой поддержки. Оценка содержания научной деятельности подменяется формальными реквизитами наукометрии».

Информация 1, 2 и 3 рода о состоянии системы. Геоинформатика. Информация 1-го рода есть результат непосредственных измерений параметров системы, информация 2-го рода представлена на специфическом языке данной науки и рассчитана для потребления специалистами в данной области знания, информация 3-го рода преобразуется из информации 2-го рода и представляет собой рекомендации, методики, и др., написанные для не специалистов, например, для лиц, принимающих решения (т.н. ЛПРов). Характерная особенность современного этапа развития науки - преобладание информации 2-го и 3-го рода в конкретной области знания.

Геоинформатика - область науки и техники, отражающая и изучающая сложные системы (геосистемы), их взаимодействие и развитие посредством компьютерного моделирования на основе информационных систем и технологий, баз данных и баз знаний. В задачи геоинформатики входит изучение общих свойств геоинформации, закономерностей и методов ее получения, фиксации, накопления, обработки и использования, а также развитие теории, методологии и технологий создания геоинформационных систем (ГИС) с целью сбора, систематизации, хранения, анализа, преобразования, отображения и распространения пространственно-координированных данных. Значение научных и технических проблем данной специальности для хозяйствующего субъекта, управленца и населения страны состоит в обеспечении информацией, контроле и поддержке принятия управленческих решений в сферах планирования и проектирования, исследований в науках о Земле и смежных с ними социально-экономических науках, в развитии образования и культуры, сохранении экологического равновесия, предупреждения чрезвычайных ситуаций, обеспечении обороноспособности страны.

Оценка и диагностика. Диагностика природного объекта. В нашем представлении оценка состояния сложной природной системы включает в себя 2 этапа: (эко)диагностика (экологическая регламентация) и оценка воздействия (экологическое нормирование) (Дмитриев, 2000) Формой и начальным этапом выражения отношения субъекта к объекту оценивания может служить диагностический анализ (диагностика) 
природного объекта. Диагностический анализ включает в себя рекогносцировочное выявление достоинств (положительная значимость) и недостатков (отрицательная значимость) объекта (действующей системы), его отдельных свойств, интервалов их естественного колебания, структуры и режимов функционирования на основе анализа параметров состояния и их критических значений (Дмитриев, 2000).

Состояние природной системы и его оценка. Состояние природы. Состояние геосистемы. Режим. Состояние системы (state of system) - характеристика системы на определенный момент ее функционирования. К сожалению, еще совсем недавно в эколого-географической литературе не употреблялся термин «статус системы», которым можно было бы характеризовать состояние природной системы в определенный момент времени. Только в наши дни ставится вопрос об экологическом статусе природных объектов и методах его интегрального оценивания. По-видимому, единственным исключением являлось устоявшееся определение «трофический статус» и родственные ему понятия, которые служат для разделения природных водоемов и их отдельных участков по степени кормности (трофности), в зависимости от уровня их первичной продукции.

Г.А. Исаченко (1999) использует понятие состояние геосистемы, под которым понимается пространственно-временная однородность, выделяемая по критериям сохранения состава и соотношения системообразующих элементов и ведущих процессов системы. Это суждение близко к определению инварианта геосистемы, введенному акад. В.Б. Сочавой в 1978 г., в основе которого лежит представление о совокупности присущих геосистеме свойств, которые сохраняются неизменными при преобразовании той или иной категории геосистем. С другой стороны, закономерные изменения состояния природного объекта во времени, обусловленные его физико-географическими свойствами, климатическими условиями и др. традиционно в географии называются режимом (гидрологический режим, гидрохимический режим и т.п.). Режимы проявляются в виде многолетних, сезонных, суточных колебаний элементов режимов.

Вектор состояния системы. Сравнительно редко, главным образом в экологических и системных исследованиях используется понятие «вектора состояния системыл» - совокупность (список) упорядоченных переменных экосистемы, отражающих ее наиболее важные свойства, такие как продуктивность (урожай на корню), потоки энергии и др. Одна из ранних форм выражения вектора состояния системы приводится, например, И.И. Дедю (1990), в виде:

$\mathbf{V}=\begin{array}{lc}\mathrm{P} & 809 \\ \mathrm{H} & 37 \\ \mathrm{C} & 11 \\ \mathrm{TC} & 1.5,\end{array}$

где V - вектор экосистемы; Р - продуценты; Н - растительноядные; C - плотоядные; ТС верховные хищники. Цифры - соответственно количественные показатели в $\Gamma / \mathrm{M}^{2}$ сухой биомассы.

Пример описания состояния экосистемы (построения вектора системы) на основе аддитивных и неаддитивных параметров. Допустим, что для характеристики водной экосистемы циклического типа в соответствие с поставленной исследователем целью, важны следующие ее признаки: трофность, определяемая индексом трофности IT; качество воды, определяемое индексом сапробности $S$; устойчивость водной экосистемы $U$, определяемая по индексно-балльному методу; размер экосистемы, определяемый постоянным объемом $V$ или площадью $S 1$. Тогда состояние этой системы в момент времени $t_{1}$, можно будет описать неизменным параметром $V$ и значениями параметров $I T\left(t_{1}\right), S\left(t_{1}\right), U\left(t_{1}\right)$; в момент $t_{2}$ соответственно показателями $V, I T\left(t_{2}\right), S\left(t_{2}\right), U\left(t_{2}\right)$ и т.д. Таким образом, состояние природной системы всегда можно описать вектором (или кортежем, если учитываются также величины, не имеющие численных значений) состояния системы. Такой вектор В.В. Дмитриев (2000) предложил назвать «портретом» природной системы. 
В вектор состояния водной экосистемы Г.Т. Фрумин (1998) предложил включать параметры, характеризующие биоту, абиогенные факторы и антропогенные воздействия на экосистему.

Проблема. Ситуация. Обстановка. Экологическая проблема. Экологическая ситуация. Экологическая обстановка. Решение экологических проблем и характеристика экологических ситуаций зависят от того, как исполнители формулируют основные определения: проблема и ситуация. По Н.Ф. Реймерсу (1990) экологическая оценка - определение состояния среды жизни или степени воздействия на нее определенных факторов (с учетом динамики воздействия). В отличие от географов Н.Ф. Реймерс $(1990$, с.407) под экологической проблемой понимал любые явления, связанные с заметными воздействиями человека на природу, обратными влияниями природы на человека и его экономику, с жизненно и хозяйственно-значимыми процессами, обусловленными естественными причинами. Под экологически конфликтной ситуацией понималось локальное или региональное ухудшение состояния среды жизни (загрязнение вод, воздуха, деградация почв и т.п.), рассматриваемое как общественно неоправданное или опасное (Реймерс, 1990, с.479). Этот термин применяется по отношению к антропогенным, а не природным явлениям. Глобальная проблема - это природное, природно-антропогенное или чисто антропогенное (в т.ч. экономическое, социальное и др.) явление, затрагивающее мир в целом. К глобальным проблемам приближаются широко региональные проблемы, охватывающие крупные части биосферы (Реймерс, 1990, c.406).

Отметим, что использование географами и биологами указанных выше терминов связано с ухудшением среды обитания человека и обычно ассоциируется с экологическим неблагополучием или угрозой здоровью и самой жизни. А.Г. Исаченко, $(1994$, с.19) справедливо видит противоречивость употребления этих терминов в том, что «экологическая ситуация» в ряде работ отождествляется с природоохранной или экологической проблемой, но в других публикациях заключает в себе ряд природоохранных проблем, их сочетаний или устанавливается по сочетанию проблем.

Проблема - от греческого problema - задача. В широком смысле - сложный теоретический или практический вопрос, требующий изучения, разрешения. В науке проблема есть противоречивая ситуация, выступающая в виде противоположных позиций в объяснении каких-либо явлений, объектов, процессов и требующая адекватной теории для ее разрешения. Ситуация - сочетание условий (факторов) и обстоятельств, создающих определенную обстановку, положение. Таким образом, проблема в нашем понимании есть противоречивое сочетание и проявление факторов, условий и обстоятельств, характеризующих состояние системы в определенный момент времени или создающих определенную обстановку. В свою очередь, по-видимому, не логично писать, что ситуащия представляет собой сочетание проблем (Г.А. Исаченко, 1999, с.82), она определяется условиями, обстоятельствами, факторами, создающими определенную обстановку.

Г.Т. Фрумин (1998, с.10) предлагает определять термин «состояние экосистемы» на основе использования двух подходов: субъективного (с позиций человека) и объективного (с точки зрения объективно существующего состояния экосистемы) и отмечает, что последний путь «навряд ли может быть реализован». Первый подход привел автора к такому определению: состояние экосистемы - это характеристика этой экосистемы по совокупности ее количественных и качественных биогенных, абиогенных и антропогенных показателей применительно к видам ее использования.

А.Г. Исаченко (1994) под экологическим состоянием природной среды подразумевает состояние естественных «механизмов» жизнеобеспечения человека как живого существа всеми необходимыми первичными (не связанными с производством) средствами существования: воздухом, теплом, водой, источниками пищи, а также природными условиями трудовой деятельности, отдыха и культурного развития. Оценить 
экологическое состояние природной среды по А.Г. Исаченко, - значит оценить ее качество с гуманитарно-экологических позииий. Автор вводит понятие экологического потенциала, под которым понимаются условия обитания человека, в отличие от природно-ресурсного потенщиала, при котором оценивается ресурсно-производственная сфера его деятельности. Задачу эксперта-исследователя А.Г. Исаченко видит в создании оценочной экологической классификации геосистем. Эта классификация должна учитывать иерархию геосистем и, таким образом, их разномасштабность и временной уровень организации. Автором был обозначен подход к выбору критериев оценки экологического состояния геосистем в зависимости от уровня их иерархии. «Однако интегральную количественную меру всех возможных сочетаний экологических параметров по конкретным геосистемам практически найти невозможно», - утверждал автор и делал вывод: «поэтому интегральная экологическая оценка геосистем может быть только качественной». В наши дни уже разработаны подходы к количественной интегральной оценке сложных систем и их свойств. О них и пойдет речь далее.

Экологическая оценка. Стратегия экологической оценки. Объектами экологических исследований являются естественные и искусственные экосистемы разных уровней иерархии. Центральным вопросом экологии Ю.Одум (1975) считал ответ на вопрос: сколько организмов населяют данную местность, где и когда их можно встретить и почему? Строго говоря, исследование становится экологическим только после ответа на последний вопрос. Значимость природных объектов (и их свойств) с точки зрения экологии выявляется с антропоцентристских, биоцентристских или экоцентристских позиций.

Под экологической оценкой нами понимается параметрическое определение состояний природной среды, обеспечивающих существование живых организмов, характерных для этих состояний в условиях естественного или антропогенного режимов их развития. Для оценки экологического состояния можно предложить следующую стратегию. Вначале строится интегральный показатель на основе репрезентативных параметров, характеризующих абиотические условия среды и физико-химические свойства исследуемой природной системы. Затем строится сводный показатель состояния компонентов биоты для тех же классов на основе биологических параметров. Экологическая оценка сводится к сопоставлению первого и второго интегральных показателей. Если оба интегральных показателя указывают на один и тот же класс состояния (качества, трофности, устойчивости, благополучия, напряженности и др.), то можно сделать вывод о соответствии состояния среды состоянию биоты. Если же состояние среды позволяет отнести систему, например, к III классу качества, а состояние биоты - ко II-му, то можно определить тенденцию в изменении биоты в ближайшей перспективе. Если же состояние среды характеризуется II классом, а биоты - III, то можно предположить, что биота не является автохтонной, а, скорее всего, привнесена в систему извне.

Эколого-географическая оценка. Триада Ю.П. Селиверстова. Ю.П.Селиверстов (1994) ввел в географо-экологическую литературу понятие эколого-географической оценки (рис.1). Под такой оценкой автор понимал параметрическое определение состояния природной среды, обеспечивающее существование конкретных сообществ живых организмов, характерных для этих состояний и обусловленных природными условиями, в той или иной степени изменяющимися под воздействием антропогенных факторов (Селиверстов, 1994, с.9). Такая оценка, по мнению автора, носит фоновый характер и может отвечать на вопросы о степени соответствия существующей биоты и наблюдающейся природной среды. Автор вводит термин геоэкосистема для усиления внимания к живой составляющей геосистем и констатирует, что оценке подлежат только абиотические и биотические процессы и явления. Отмечается также, что в оценочных исследованиях существенно использование данных об устойчивости ландшафтов, их емкости, сопротивляемости к внешним воздействиям и т.п. Автор подчеркивает, что 
оценка не обязательно должна носить количественный характер, может выполняться балльная или стоимостная оценка.

Экологическая и геоэкологическая оценка. В работе «Разработка научных основ государственной экологической экспертизы и контроля», дается следующее определение геоэкологической оценки - это современные методы и методики геоэкологического картирования, моделирования, геоинформационные системы и технологии, базы данных (цит. по Е.А. Примак, 2009). Перечисленные авторами методы, несомненно, необходимы для проведения геоэкологической оценки, но не тождественны ей и не заменяют её.

А.Г. Осипов (2016) предлагает под геоэкологической оценкой понимать «многопараметрический анализ природно-ресурсного потенциала естественных и антропогенно-измененных ландшафтов с целью определения их возможности устойчиво выполнять задаваемые им социально-экономические функции без нарушения функций жизнеобеспечения (средо- и ресурсовоспроизводства)». На наш взгляд геоэкологическая оценка может выполняться для любых систем (не только устойчиво функционирующих), как с позиций антропоцентризма (для человека, общества), так и с позиций био-, эко- и геоцентризма или совмещения подходов.

Важным акцентом в этом определении является требование сохранения условий для самовоспроизводства экосистем (геосистем) так, чтобы меры по их защите не препятствовали бы экономическому росту. Это достигается постепенным снижением (в пределах допустимых нагрузок) предельных квот на воздействие для отдельных природои ресурсопользователей.

Нами (Дмитриев, Федорова, Бирюкова, 2016; Дмитриев, Амаро-Медина, Огурцов, Добрынина, 2018) было предложено следующее определение: «геоэкологическая оценка, это параметрическое определение состояния антропогенно-трансформированных геосистем, обеспечивающего существование конкретных сообществ живых организмов и человека (общества), с целью выделения антропогенной составляющей и последствий этих изменений на фоне природных процессов». Под критическим звеном нами понималась наиболее уязвимая подсистема. Это означало, что нагрузка допустимая на эту подсистему принималась в качестве допустимой нагрузки для геосистемы в целом. Таким образом, в соответствие с нашим подходом регламентируется - состояние природной системы, а нормируется воздействие на нее.

Экосистемные и геосистемные функции и услуги. В 1987 г R. Constanza и H. Daly (Costanza R., Daly H.E. Toward an Ecological economics. Ecological Modelling, 38. Elsevier Science Publishers B.V., Amsterdam. 1987. P. 1-7) обратили внимание на тот факт, что современная классическая и неоклассическая экономика плохо оценивает такие составляющие развития как природные ресурсы, имеют тенденцию игнорировать человеческое культурное и социальное поведение как объект прямого исследования и влияния на развитие, вклад немонетарных ценностей в развитие, дисконтирование, возможно существенно завышающее ценность настоящего относительно ценности в будущем, представления о том, что у вещей может быть некоторая ценность, независимая от текущего восприятия ее человеком. Они сформулировали представления об экологической экономике, подразумевая под этим синтез экономики и экологии в рамках единой науки с общими теоретико-методологическими основаниями. В том же году большой коллектив авторов в соответствие с концепцией экологической экономики ввел представление о натуральном капитале в сопоставлении его с банковским, промышленным и информационном капиталами, подразделив каждый из них на основной и оборотный, и дал старт широкому использованию понятия «экосистемные услуги». По их определению услуги экосистемы состоят из потоков вещества, энергии, и информации от естественных основных капиталов, которые объединяются с услугами производственного и человеческого капиталов, определяя человеческое благосостояние. Кроме того, они осуществили первую попытку выразить экосистемные услуги биосферы в монетарном измерении. 
Позже R. Costanza и др. (Costanza R., Daly H.E., Bartholomew J.A. Goals, Agenda and Police recommendations for ecological economics. Ecological Economics. www.uvm.edu/giee/publications/Costanza, Daly. Barth. 1991) определили, что «экологическая экономика - новая трансдисциплинарная область исследования, которая обращается к отношениям между экосистемами и экономическими системами в самом широком смысле. Эти отношения являются главными во многих из существующих проблем человечества и в строительстве жизнеспособного будущего, но не охвачены никакой существующей научной дисциплиной». Авторы особо отмечали, что экологическая экономика ориентирована на решение проблем устойчивого развития и определяют пути интеграции экологических и экономических теоретикометодологических оснований. Здесь же определены пять основных проблем: 1) устойчивость: поддержание нашей системы жизнеобеспечения; 2) оценка природных ресурсов и естественного капитала; 3) экологический бухгалтерский учет экономической системы; 4) эколого-экономическое моделирование в местном, региональном, и глобальном масштабах, 5) инновационные инструменты для экологического управления. Фактически именно эти работы создали теоретическую основу концепции устойчивого развития и экосистемных услуг, вошедшую в различные международные документы и получившую особо широкую популярность после выхода в свет фундаментального труда «Оценки экосистем на пороге тысячелетия, Экосистемы и благосостояние людей: рамки оценки. 2005» (Millennium Ecosystem Assessment. Ecosystems and Human Wellbeing: Synthesis. Island Press, Washington, DC, 2005), Assessing the Economic Value of Ecosystem Conservation (Stefano Pagiola, Konrad von Ritter, Joshua Bishop, Environment department paper № 101. The world bank environment department, In collaboration with The Nature Conservancy and IUCN - The World Conservation Union. October 2004). Очень близкие к экологической экономике идеи рассматривались и в рамках «естественного капитализма» (Natural capitalism). В рамках этой концепции утверждается, что "следующая промышленная революция" зависит от поддержки четырех центральных стратегий: сохранение ресурсов посредством более эффективных производственных процессов, повторного использования материалов как это происходит в естественных системах, переход от количества к качеству, увеличение капиталовложений в естественный капитал. Сходные положения формулируются и в «зеленой экономике».

Анализ обширной зарубежной литературы по проблеме показывает, что, несмотря на популярность темы, не существует ясного представления каковы пути выхода на траекторию устойчивого развития, существуют ли его пределы, возможна ли единая система измерения состояний четырех основных капиталов, обеспечивающих оценку соответствия реальных процессов критериям устойчивости и обеспечения через экосистемные услуги роста благосостояния в различных пространственно-временных масштабах. Вместе с тем, три базовых понятия, заложенных в экологической экономике капитал, пропускная способность и благосостояние - имеют все основания получить общее системное представление, связанное с фундаментальными законами функционирования и развития природы и общества, и тем, самым создать все основания для соизмеримости функций и процессов в природно-социально-экономической системе.

Наиболее узким местом экологической экономики является монетарное выражение стоимости экосистемных и, в первую очередь, поддерживающих услуг. По наиболее распространенным представлениям «поддерживающие услуги» - это услуги, необходимые для производства всех других экосистемных услуг. Они отличаются от обеспечивающих, регулирующих и культурных услуг тем, что их воздействие на людей, зачастую, является косвенным или осуществляется в течение очень длительного времени, в то время как изменения в других категориях услуг имеют относительно непосредственное и кратковременное влияние на людей». К ним относят: 
- Почвообразование. Поскольку, многие обеспечивающие услуги зависят от плодородия почв, скорость почвообразования оказывает влияние на благосостояние людей во многих отношениях.

- Фотосинтез. Фотосинтез продуцирует кислород, необходимый многим живым организмам.

- Первичная продукция. Ассимиляция и аккумуляция энергии и питательных веществ организмами.

- Круговорот питательных веществ. Около 20 питательных веществ, необходимых для жизни, включая азот и фосфор, циркулируют в экосистемах и сохраняются в различных концентрациях в различных частях экосистем.

- Круговорот воды. Вода циркулирует по экосистемам и является жизненно необходимой для живых организмов. Кроме того, судя по всеобщему интересу к изменению климата, теплообеспеченность, влагообеспеченность, влажность воздуха, безусловно, следует отнести к поддерживающим услугам.

С другой стороны, к поддерживающим услугам можно отнести рельеф и почвообразующую породу, которые, безусловно, определяют перераспределение тепла и влаги и условия минерального питания. Фундаментальной проблемой в рамках концепции экосистемных услуг является социально-экономическая оценка поддерживающих услуг, призванная прямо связывать основные физико-географические условия с социальноэкономической активностью. В более широкой постановке эта проблема связана с общей теорией организации ландшафта, в котором человеческая деятельность является эволюционно одним из ландшафтообразующих процессов.

Среди зарубежных работ в области оценки экосистемных (геосистемных) услуг в первую очередь стоит отметить масштабные международные исследования: Millennium Ecosystem Assessment (MA), The Economics of Ecosystems and Biodiversity (TEEB), разработки экологического департамента Всемирного Банка, Международного союза охраны природы, исследования европейской ассоциации Partnership for European environmental research (PEER) и их проект PRESS.

Millennium Ecosystem Assessment «Оценка экосистемных услуг на пороге тысячелетия» - фундаментальная работа, участие в которой приняли свыше 1300 экспертов из различных стран, фокусируется на взаимосвязи между экосистемами и благосостоянием человечества, что раскрывается через понятие «экосистемные услуги» (Ecosystems..., 2005; Millennium..., 2005; The UN Millennium..., 2006).

Важным аспектом исследования этой группы ученых является выражение экосистемных услуг в монетарном виде. В русском языке часто идет речь о ценностной оценке услуг естественных экосистем (природного капитала). До 1990-х гг природный капитал - это «совокупность природных ресурсов», которую можно измерить на основе рыночных цен на сырье и товары. После Конференции ООН в Рио-де-Жанейро (1992) это «совокупность природных активов, предоставляющих человечеству природные ресурсы и экологические услуги или услуги экосистем».

Услуги экосистем - выгоды, которые получают люди от экосистем. Они включают обеспечивающие услуги, такие как пища и вода; регулирующие услуги, такие как контроль наводнений и болезней; культурные услуги, такие как духовные, рекреационные и культурные выгоды, и поддерживающие услуги, такие как круговорот питательных веществ, которые поддерживают условия жизни на Земле. Их оценка должна обусловливать в итоге возможность параметрического выявления возможности бескризисного, сбалансированного (устойчивого) выполнения населением социальноэкономических функций без нарушения функций жизнеобеспечения (средо- и ресурсовоспроизводства) и экологические функции (а вообще-то, функций геосистем) или экосистемных услуг (УЭ). Термин «геосистема» является в этом случае более походящим понятием, чем экосистема и, соответственно, геосистемные функциии включают в себя экосистемные, что позволяет нам также говорить о «геосистемных услугах». Такой 
подход близок для ландшафтоведения, геоэкологии и, по-видимому, является более подходящим для анализа целостных природных систем. Заметим, однако, что в «геосистему» целесообразно включать и население, а также, что из-за отставания РФ в оценке экосистемных услуг (функций), потребуется некоторое время для перехода от традиционной для Европы «экосистемной» терминологии к «геосистемной».

Геоэкологическая регламентация - анализ параметров состояния антропогеннотрансформированной геосистемы, определение интервалов изменений элементов ее режимов (естественного и антропогенного), выявление пороговых и критических величин этих параметров.

Геоэкологическое нормирование. Геоэкологическое нормирование есть нормирование любого антропогенного воздействия на геосистему, при котором можно оценить реакцию геосистемы в целом или какого-либо ее "критического звена" на это воздействие. Под критическим звеном понимается наиболее уязвимая (слабая) экосистема. Это означает, что нагрузка допустимая на эту экосистему принимается в качестве допустимой нагрузки для геосистемы в целом.

Геоэкологический мониторинг - информационная система наблюдений, оценки и прогноза изменений в состоянии окружающей среды, созданная с целью выделения антропогенной составляющей этих изменений на фоне природных процессов. К основным задачам геоэкологического мониторинга относятся:

1 наблюдение за источниками антропогенного воздействия;

2 наблюдение за факторами антропогенного воздействия;

3 наблюдение за состоянием природной седы и происходящими в ней процессами под влиянием антропогенного воздействия;

4 оценка фактического состояния природной среды;

5 прогноз изменения состояния природной среды под влиянием факторов антропогенного воздействия и оценка прогнозируемого состояния природной среды.

\section{Уровни геоэкологического мониторинга:}

1 глобальный (биосферный);

2 национальный, осуществляемый в пределах государства;

3 региональный (геосистемный) - в пределах отдельных районов;

4 локальный, в обеспечение решения конкретной задачи, а также в пределах населенных пунктов, предприятий.

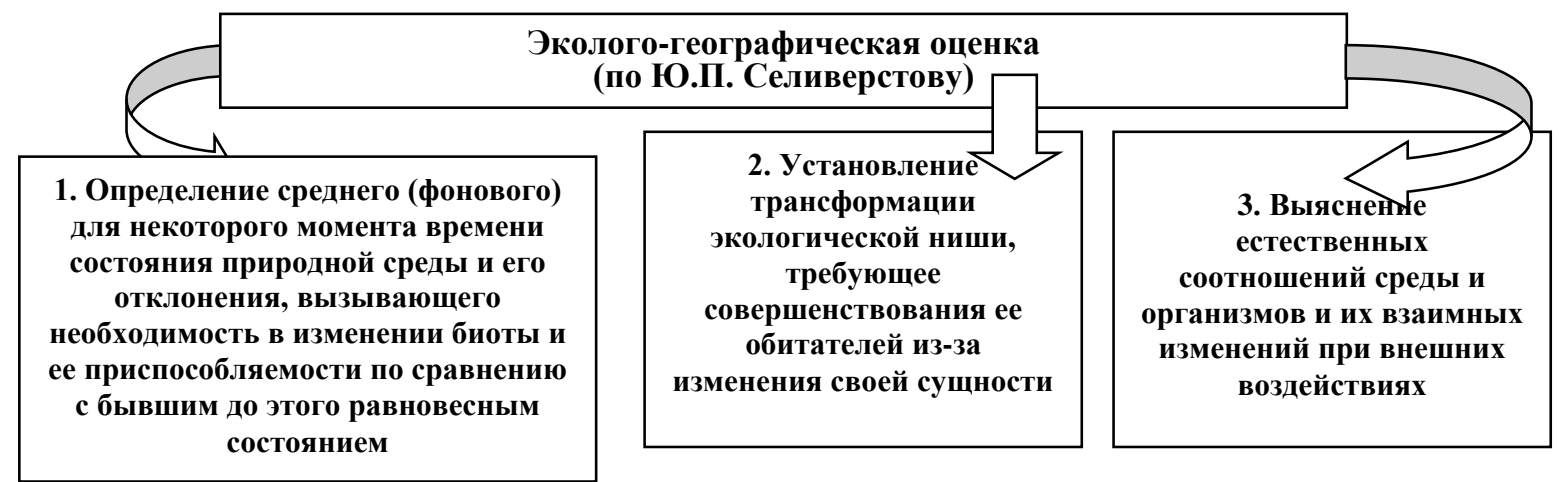

Рис. 3 «Эколого-географическая оценка» - триада Ю.П.Селиверстова (1994).

Понятия «экологическая оиенка», «эколого-географическая оиенка», «географоэкологическая оценка» и, позднее, «геоэкологическая оценка», неоднократно обсуждались многими специалистами (Дмитриев, 2000, 2017, 2018). В зависимости от целей, задач, масштаба, специфики исследования в понятие экологическая оценка состояния природной системы можно вложить разный смысл, например: 
- определение степени пригодности природных комплексов и их компонентов для жизни организмов;

- параметрическое определение состояний природной среды, обеспечивающих существование сообществ живых организмов, характерных для этих состояний в условиях естественного или антропогенного режимов их развития;

- получение на многокритериальной основе «портрета экосистемы» и соотнесение его с «портретом нормы» экосистемы;

- $\quad$ эколого-географическое нормирование состояния природной системы и внешнего воздействия на нее;

- субъект-объектная интегральная оценка состояния природного объекта с позиций устойчивого функционирования биоценозов, сохранения в них естественного хода сукцессионных процессов или с позиций степени пригодности (потенциальной полезности) его для человека (общества);

- оценка химического, биологического состава и физических свойств природного объекта, обусловливающих устойчивое функционирование в нем конкретных сообществ живых организмов, сохранение определенного типа экологической сукцессии, или оценка его пригодности для различных видов использования человеком;

- $\quad$ исследование параметров структуры и функционирования экосистем природного объекта в естественных и измененных условиях с целью их рационального использования, оптимальной эксплуатации для удовлетворения потребностей людей и жизни организмов.

Каждое из этих и других определений подчеркивает какую-либо, важную, с точки зрения субъекта (географа, биолога, эколога, математика), составляющую процесса получения «портрета» природной системы. Это само по себе достаточно важно, поскольку разные специалисты вносят свой субъективизм в получение оценки.

Экологический и геоэкологический статус природного объекта. Рассмотрим проблему оценки представления и оценки экологического статуса на примере водных объектов. Решение проблемы оценки экологического статуса в странах ЕС сопряжено с принятием, доработкой и адаптацией Европейской Рамочной Водной Директивой или Директивы Европейского парламента и Совета по установлению рамок действий Сообщества в области водной политики (Directive of the European Parliament and of the Council on setting the framework for Community action in the field of water policy). Основную цель «Директивы» в ЕС представляют, как достижение экологического благополучия или высокого экологического статуса для всех водных систем. Эта задача акцентируется в виде разработки интегрированного подхода к решению проблемы оценки современного и перспективного состояния водных объектов (речных бассейнов), выделения экорегионов в странах ЕС. Для РФ проблема не менее актуальна в связи с принятием Распоряжение Правительства РФ от 27.08.2009 N 1235-р (ред. от 17.04.2012) "Об утверждении "Водной стратегии Российской Федерации на период до 2020 года", разработкой "Стратегии научно-технологического развития Российской Федерации, утвержденной Указом Президента Российской Федерации от 1 декабря 2016 г. № 642"; систематизацией знаний, практик разработки, экспертизы и реализации проектов, связанных с преобразованием и управлением водными объектами в связи с развитием цифровизации в науках о Земле, природе, обществе.

Решение вопроса, с нашей точки зрения, связано с: 1 - обоснованием теоретикометодологических положений интегральной оценки экологического статуса и экологического благополучия водных объектов для оценки их современного и перспективного состояния; 2 - разработкой и апробацией моделей интегральной оценки трофического статуса (продукционного потенциала), качества и токсического загрязнения воды, устойчивости, экологического статуса и экологического благополучия водных объектов; 3 - разработкой математического аппарата и моделей интегральной оценки экологического (геоэкологического) статуса и экологического благополучия водных объектов; 4 - проверкой выдвигаемых гипотез: о достаточности интегральной оценки 
трофности, качества воды (и донных отложений), устойчивости водного объекта к изменениям параметров естественного и антропогенного режимов для формирования представлений об экологическом статусе водного объекта, о необходимости привлечения дополнительных параметров для интегральной оценки экологического благополучия водных объектов с учетом их типа и специфики; 5 - разработкой подходов к выявлению пределов устойчивости водных объектов к изменению параметров естественного режима (потенциальная устойчивость), антропогенному эвтрофированию, изменению качества воды; 6 - разработкой подходов к выявлению пределов устойчивости водных объектов к изменению экологического статуса при внешнем воздействии на водный объект; 7 разработкой моделей учета экологических функций водных объектов, исследование их изменений при антропогенной трансформации водных экосистем, а также при изменении экологического статуса; 8 - разработкой примеров и рекомендаций для разноаспектной ГИС-визуализации результатов оценочных исследований.

Оценить экологическое состояние природного объекта можно в определенный момент времени (экологическая ситуация) или за определенный временной интервал (экологическая обстановка). В нашем представлении, об оценке экологического статуса можно говорить на основе обобщения оценочных результатов за некоторый временной интервал (3-5 лет), в то время как оценивать экологическую ситуацию в водоеме можно на основе ежегодно проводимых мониторинговых исследований. Требует решения вопрос и об оценке геоэкологического статуса природной системы, его отличии от экологического статуса и подходах к его интегральной оценке.

Качество среды. Оценка качества среды. Антропо-, био-, эко- и геоцентризм в оценке качества среды. По международному стандарту №8402-86(94) «качество» есть совокупность характеристик, описывающих какой-либо объект. В новом международном стандарте ISO.9000 под качеством понимается степень соответствия объекта исследования (управления) требованиям, предъявляемым к нему. Качеством среды традиционно называют степень соответствия природных условий потребностям людей или других живых организмов. Качество окружающей среды - относительное понятие. Одно и то же состояние геосистемы может быть охарактеризовано как неодинаковое по качеству для различных видов ее использования человеком. Это же состояние геосистемы в разной степени пригодно для жизни различных групп организмов.

Под качеством водbl при антропоцентрическом подходе понимается сочетание химического и биологического состава и физических свойств воды, определяющее ее пригодность для конкретных видов использования человеком. При биоцентрическом подходе качество водbl - сочетание химического и биологического состава и физических свойств воды, определяющее ее пригодность для жизни организмов. При экоцентрическом подходе качество воды - сочетание химического и биологического состава и физических свойств воды, определяющее сохранение экосистемы в целом. При геоцентрическом подходе - качество воды - сочетание химического и биологического состава и физических свойств воды, определяющее сохранения водной геосистемьл в целом.

Что подлежит изучению и оценке в естественных и антропогеннотрансформированных наземных и водных объектах (эко- и геосистемах). См. рис.4.

Представление информации о состоянии системы. Методы свертывания информации. Ю.П. Селиверстов (1994) нацеливал исследователей географов и геоэкологов в своих исследованиях на получение навыков по «извлечению информации» из имеющегося материала натурных наблюдений. Не менее важно на наш взгляд уметь «свертывать информацию» для характеристики интегративных свойств системы в целом и получения вектора состояния системы или сводного (интегрального) показателя состояния системы на основе синтезирующих функций. 


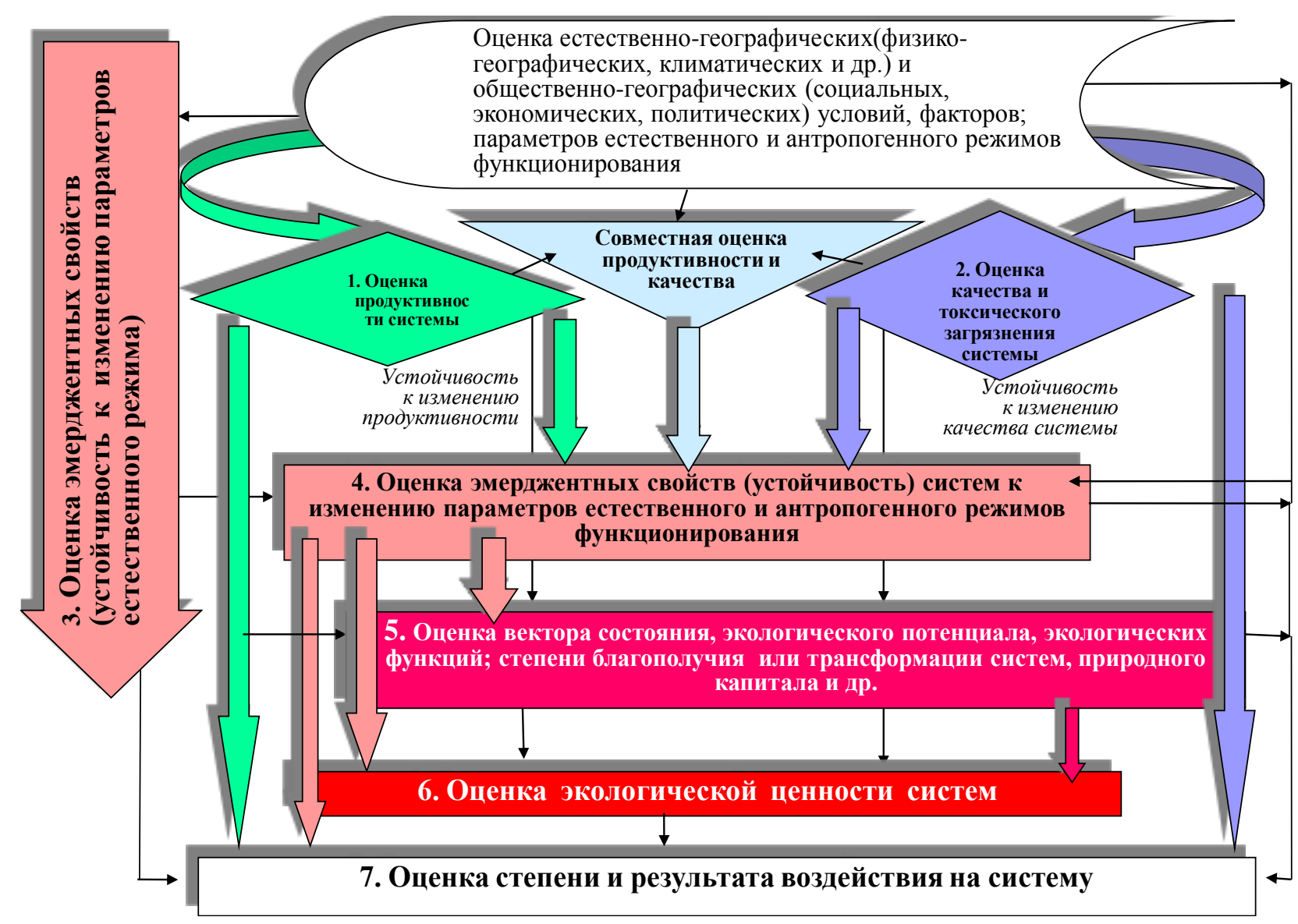

Рис. 4 Что подлежит изучению и оценке в естественных и антропогеннотрансформированных наземных и водных эко- и геосистемах.

Сложившаяся практика эколого-географических исследований показывает, что наиболее часто встречаются примеры применения в качестве синтезирующих функиий взвешенных средних арифметических, взвешенных средних геометрических и их комбинаций. Такие функции позволяют компенсировать малость одних параметров по сравнению с другими. Это также необходимо в случаях, когда значения только одного параметра уже достаточно для оценивания объекта. В этих случаях разумно выбрать в качестве синтезирующей функции первую из них. Если же малость, хотя бы одного параметра сильно сказывается на результатах оценки, т.е. необходимы достаточно хорошие значения по всем параметрам, то следует использовать вторую синтезирующую функцию. Показано (Джини, 1970; Воробейчик, Садыков, Фарафонтов, 1994), что среднее арифметическое и среднее геометрическое значения связаны между собой:

$$
\bar{X}_{\Gamma}=\bar{X}_{A}-\frac{1}{2} \frac{\sigma^{2}}{\bar{X}_{A}},
$$

где $\bar{X}_{\Gamma}$ - средняя геометрическая; $\bar{X}_{A}$ - средняя арифметическая, $\sigma^{2}$ - дисперсия. Авторы делают вывод о том, что т.н. «особая роль» среднего геометрического несостоятельна и не добавляет новой информации, но лишь усиливает «камуфляж наукообразия» в научные исследования.

Интегральная оценка как предмет исследования. Первым этапом оценки состояния водных эко и геосистем и их эмерджентных свойств является формирование представлений о предметах исследования: трофическом состоянии, качестве воды, степени антропогенной трансформации, устойчивости объекта к изменению параметров естественного и антропогенного режимов, экологическом благополучии (ЭБ), экологической ценности. Во всех случаях авторы должны определить свое отношение к 
объекту и предмету исследования, ввести необходимую аксиоматику. Выделение факторов, влияющих на оцениваемые свойства систем, или перечень необходимых и достаточных признаков, отражающих явления, процессы, химический и биологический состав компонентов, включаемых в интегральную оценку, выполняется на основе аксиологического подхода (общая теория ценностей, учение о природе ценностей), аксиометрии (экологической квалиметрии), и обусловлено возможностью получения натурной информации о требующихся показателях для количественной интегральной оценки. При обсуждении этого вопроса (рис.2) приходим к выводу о том, что на интегральной основе могут оцениваться также: вектор состояния системы, ее экологический потенциал, природный капитал, экологические функции; степень благополучия или трансформации системы, степень экологической напряженности, экологическая ценность, степень и результат воздействия на систему. На этой же основе в последние годы формируется методология оценки «мульти-опасных явлений» («multihazards», «мульти-ОЯ») и рисков («мульти-риски») при определении интегрального риска от совокупности ОЯ в целом, а также таких свойств геосистем, которые характеризуют количество энергии, требующейся для создания единицы биомассы на разных трофических уровнях (энмергия) или величины отклонения системы от равновесного состояния с окружающей средой, измеренного в единицах информации и/или энергии (эксергия).

Единичные (частные), косвенные, комплексные, многокритериальные и интегральные оценки. Единичные оценки представляют собой оценки по отдельным исходным характеристикам путем сопоставления с некоторыми уровнями и нормами. В качестве последних могут использоваться фоновые, предельно допустимые и т.п. концентрации компонентного состава или экспериментально установленные в токсикологических экспериментах эффективные, летальные, критические концентрации веществ. Это, как правило, покомпонентные (попарные), частные оценки, определяющие положительную или отрицательную значимость компонентов химического состава на свойства системы на покомпонентном уровне. Такие оценки реализуются также в экспериментах с биологическими или экологическими мишенями по принципу «доза эффект». В них отслеживаются критические концентрации (дозы), вызывающие триггерность (пусковой процесс, обеспечивающий резкий переход клетки, органа, целого организма или системы из одного функционального состояния в другое), или ингибирующие концентрации (эффективные, критические), определяющие резкое снижение скорости процесса массообмена, принятого в качестве экологической мишени.

Комплексные оценки, это перспективные, но наименее унифицированные оценки, они многочисленны и разнообразны, но часто содержат оговорки и допущения, которые не позволяют с должной адекватностью воспринимать и далее использовать их в практической деятельности. К этим оценкам мы будем относить также балльные и балльно-индексные оценки, которые в публикациях некоторые авторы называют интегральными. Комплексные оценки (в т.ч. на основе ГИС) в настоящее время представляют собой довольно разнородную систему методов оценки различной степени формализации. Авторы ограничиваются в них покомпонентным анализом состава, качества окружающей среды и других свойств с помощью традиционных аддитивных, количественных показателей или качественных (балльных) критериев. Для этого используются данные геопорталов областей, сайт Росстата (www.gks.ru), сайты регионов отраслевых и академических институтов, основу которых составляют тематические карты, отражающие экологические, социальные, экономические, политические и других аспекты развития регионов. Этот этап сопровождается разработкой методик количественной оценки состояния геосистем и их системных (интегративных, эмерджентных) свойств, характеризующихся возникновением новых функциональных единиц систем, в качестве которых рассматриваются показатели нескольких уровней обобщения информации и сводные показатели (в виде балльных оценок), характеризующие последний уровень обобщения. Такие сводные показатели, часто именуются индексами окружающей среды, 
они могут являться основой систематики сложных систем, позволяют сравнивать их состояние в пространстве и времени или выявлять эффекты взаимосвязи и взаимодействия, не аддитивные по отношению к локальным внутрисистемным эффектам, которые рассматриваются на покомпонентном уровне.

При классификации, а также оценке или ранжировании геосистем по неаддитивным признакам иногда на первый план выдвигается тезис о невозможности использовать какие-либо прямые показатели, относящиеся именно к этому их свойству, что вынуждает авторов искать косвенные признаки и показатели. Следует отметить, что и в этом случает авторы, уходя от «прямых показателей», вводят собственную балльную систему оценки, суммируют баллы и используют полученную сумму в качестве новой функциональной единицы систем. Результаты такой оценки закладываются в основу методики составления карт зонирования территорий. В других случаях, дискуссия об эмерджентных свойствах природных систем переводится плоскость анализа условий возникновения особых «эмерджентных пространственных эффектов». Вводится термин "эмерджентный эффект пространственной структуры" и делается попытка его исследования без обсуждения того, что исследованию подлежат «эмерджентные эффекты» систем (и подсистем), о которых пишут авторы и которые могут меняться в пространстве и во времени.

Многокритериальные оценки предполагают выполнение оценок по совокупности небольшого числа репрезентативных критериев (целевых индикаторов, индексов). Многокритериальная оценка предполагает необходимость проведения процедуры свертывания информации, что позволяет преодолеть "проклятие размерности". Как правило, свертывание информации, представляет собой целенаправленный процесс, базирующийся на четко сформулированных принципах выбора или конструирования наиболее информативных переменных - индексов состояния (воздействия). Введенный нами в географо-экологическую литературу термин «многокритериальная оиенка» (Дмитриев, 1994, 1995, 2000) отражает методологическую основу оценки состояния и воздействия на природные экосистемы, с помощью индексов состояния отдельных сред.

Использование в оценочных исследованиях многокритериального параметрического представления состояния сложных систем и их свойств часто приводит к проблеме возможной несравнимости получаемых оценок. Например, по одним индикаторам качество системы относят к одному классу, а по другим, - к другому (другим).

Интегральные оценки предполагают наличие этапа, связанного с объединением в одно целое полученных ранее многокритериальных оценок с учетом приоритетов (весов) их вклада в общую (сводную) оценку. Интегральные оценки, - это многоуровневые и многокритериальные оценки одновременно. Количество уровней и критериев оценивания обосновывается авторами. Например, для представления исторических и ожидаемых изменений в экосистеме разрабатывается система индикаторов, состоящая из трех групп: индикаторы состояния, индикаторы нагрузки, индикаторы тенденций. Индикаторы состояния связаны с определением условий среды и экологического статуса систем. Индикаторы нагрузки характеризуют виды хозяйственной деятельности. Индикаторы тенденций дают оценку динамике социально-экономических и экологических показателей в исследуемый период. На втором уровне, чаще всего, переходят к сводной оценке изменений или к «мульти-рискам» или к определению интегрального риска от совокупности видов нагрузки (к ним также относят ОЯ) или к сводной оценке эмерджентного свойства (устойчивость). В последнем случае необходимо обосновать переход от классов состояния к классам устойчивости или сразу ввести классы устойчивости. Уточнение оценок реализуется как за счет повышения точности и достоверности (при использовании аппарата «АСПИД-методологии»), так и с привлечением дополнительного количества параметров оценивания (уменьшении их количества) или пересмотра приоритетов оценивания на всех уровнях. В эколого- 
географических (геоэкологических) оценках значимость отдельных критериев традиционно оценивается при помощи сравнительных суждений типа «данный критерий более важен для общей оценки, чем другой критерий» или «данные критерии имеют одинаковую значимость для интегральной оценки» и т.п. Таким образом, значимость отдельных критериев, чаще всего измеряется по нечисловой (ординальной, порядковой) шкале или всем критериям навязывается равенство приоритетов оценивания. В других случаях исследователь задает интервалы возможного варьирования весовых коэффициентов. В связи с этим появляется необходимость работы с нечисловой (порядковой), неточной (интервальной) информацией, которая чаще всего бывает и неполной (не для всех весовых коэффициентов заданы нетривиальные равенства и неравенства, соответствующие интервальной и порядковой информации).

Нечисловая, неточная и неполная информация (т.н. «ннн»- информация) индуцирует целое множество допустимых наборов весовых коэффициентов при получении интегральных оценок. Для преодоления этого затруднения в современных подходах используется байесовская модель рандомизащии неопределенности. Идея этой модели восходит к работе Томаса Байеса (1702-1762) и состоит в переходе от неопределенного выбора весовых коэффициентов к случайному (рандомизированному) выбору их из множества всех допустимых наборов весовых коэффициентов. Таким образом, исследователь получает случайные весовые коэффициенты и случайные (рандомизированные) интегральные показатели.

Индикаторы и индексы состояния систем. Теоретически любая экосистема может быть описана бесконечным набором характеристик или параметров. Их число на современном этапе развития экологии достаточно велико. Для оценки состояния экосистем и ответной реакции системы в целом на воздействие рекомендуется отбирать «необходимые и достаточные» критерии оценивания. Практическая реализация этого приводит в наши дни к выполнению процедуры свертывания информации (точнее к свертке нормированных показателей, отражающих состав и свойства компонентов биоты и абиотической среды), направленной на преодоление «проклятия многомерности». Рекомендованы два пути решения рассматриваемой задачи.

Первый путь именуют «стихийным», он означает случайный отбор нескольких критериев из большого числа возможных. Это не свертывание, а произвольное усечение информации. Несоблюдение его осуществления таит в себе опасность существенных искажений реальности. Но здесь на первый план выходит принцип «регистрирую то, что могу», т.е. выбираются те критерии, которые исследователь в состоянии измерить или те, которые имеют оценочные шкалы. Подмечено, например, что обычно в качестве индикаторной группы специалист предлагает именно ту, по которой сам специализируется, хотя ее информативность остается неизвестной (Трофимов, 1990). Нет необходимости доказывать, что такая ситуация не может быть адекватна для экологического нормирования.

Второй путь свертывания информации - целенаправленный - подразумевает наличие специально организованной процедуры свертывания. Она может быть, как вербальной, так и формализованной. В любом случае, исходя из явно сформулированных критериев, осуществляется выбор или конструирование наиболее информативных переменных - индексов.

Форма переменных различна. Они могут быть натуральными параметрами (например, первичная продуктивность фитоценоза), условными (производными от натуральных, но сохраняющими содержательно интерпретируемую размерность), различными безразмерными коэффициентами (по своему смыслу функционалами от нескольких параметров, выражающимися в условных единицах). Но какова бы ни была форма представления индекса, он является результирующим показателем состояния и (или) функционирования экосистемы. Параметры состояния, лежащие в его основе, теряют свою индивидуальность. Другими словами, он заменяет собой все множество 
показателей, становится маркером экосистемы, трассером траекторий ее развития, выступает как бы видимой частью айсберга. Индексы состояния могут быть одномерными (одно число) и многомерными (набор чисел). В последнем случае важно, чтобы их мерность была не очень большой (существенно меньшей, чем мерность вектора состояния системы).

Индикатор. Индекс. «Методология индикаторов и индексов». Поскольку оценить на интегральной основе вектор состояния системы в целом по достаточно большому перечню критериев не просто, многие авторы рекомендуют для оценки состояния сложных природных или социально-эколого-экономических систем, их неаддитивныхх (эмерджентных) свойств использование индикаторов или индексов состояния и развития систем с учетом специфики природной среды, состояния экономики, социальной сферы и окружающей человека среды. Чаще всего здесь говорят об индексах или индикаторах устойчивого (сбалансированного) развития иерархически соподчиненных систем (региональных, глобальных).

Мощный толчок в нужном направлении определения, отбора и обоснования индикаторов дала известная Конференция по перспективам развития человеческой цивилизации, состоявшаяся в 1992 году в Рио де Жанейро. Сразу после Рио были созданы при ООН Комиссии и Комитеты, в обязанности которых вменялось, в том числе, разработка нового инструмента исследования взаимодействия человека и окружающей среды. Конференция оставила доработку и конкретизацию самой модели заинтересованным сторонам. Именно поэтому разработка работоспособных моделей и поиски нужных величин, необходимых для их описания, ведутся во многих странах мира. Весьма заметным, особенно в последнее десятилетие, стало направление, получившее название «Методология индикаторов и индексов».

К настоящему времени эта методология как инструмент исследования больших, сложных систем, получает, как за рубежом, так и в РФ, все более широкое распространение. Все чаще и чаще выходят в свет статьи, названия которых содержат слово «индикатор». В США издается специальный журнал «Экологические индикаторы». Вместе с таким интегральным показателем как риск, это направление как инструмент исследования сложных систем получило за рубежом название «Внешние технологии». В РФ эта терминология пока практически не применяется. Наибольшие успехи методология индикаторов и индексов демонстрирует в таких областях как «Экономика» и «Социальная сфера (социум)», военном деле, в политике. Однако в категории «ЭКОЛОГИЯ» достижения пока весьма скромны. Уже стало ясным, что удачно найденные индикаторы и индексы состояния и динамики антропогенных систем и окружающей среды (ОС), позволяют перейти к разработке системы моделей с целью создания унифицированного методического аппарата, позволяющего обработать и получить компактную, генерализованную информацию о состоянии, качестве и динамике исследуемой системы и компонентов ОС, доведенную до числовых значений и удобную для графической и картографической визуализации и последующей передачи в систему поддержки принятия решений для целей планирования и управления. На протяжении последних 30-ти лет термин индикатор все чаще и чаще используется в исследованиях проблем рационального природопользования, охраны окружающей среды и обеспечению экологической безопасности. Практически одновременно с этим в экологических исследованиях появился термин индекс.

Определение и свойства индикаторов и индексов. Конференция в Рио де Жанейро 1992 года, наряду с принятием ее Основного документа «Повестки дня на ХХІ век», разработала также ряд рекомендаций общего плана, где под индикатором рекомендуется понимать элемент информации, который: а) является характеристикой, используемой в интересах процесса оценки, планирования и управления; б) играет роль, выходящую за предель его непосредственного значения. 
Эти два положения могут рассматриваться как свойства, которыми индикаторы и индексы должны обладать, и их, конечно, необходимо принять во внимание. Однако эти два положения не дают определение термина индикатор. Подтверждением этому является тот факт, что на момент 2000 г. имелось, по крайней мере, 10 определений экологического индикатора. Добавим, что выбор характеристик, представляемых затем в качестве индикаторов должен отвечать дополнительно еще двум требованиям: 1) индикатор должен иметь более широкое значение, чем его непосредственный смысл; 2) индикатор должен также описывать отклонения от уровня, принимаемого за базовый на уровне фиксации явлений. (Федоров, Музалевский, 2013).

Формулирование подобных положений чрезвычайно полезно, однако, до настоящего времени продолжает оставаться открытым принципиально важный вопрос об определении понятий индикатора и индекса, которые стали бы общепринятыми. При этом следует также отметить, что проработка требуемых критериев, на основе которых введенные показатели (величины) объявляются индикаторами или индексами, далека от своего завершения, а введенные многими авторами показатели (величины), интерпретируемые ими как индикаторы и индексы, не удовлетворяют предъявляемым к ним требованиям, о которых будет сказано отдельно ниже. Разброс мнений по части вводимых терминов и их определений весьма велик, что затрудняет понимание между специалистами. Не предложена на сегодняшний день согласованная система единиц измерения индикаторов и индексов экодинамики и соответствующие оценочные шкалы. Выбор шкалы имеет принципиальное значение.

Более того, именно посредством оценочных шкал и через шкалы можно во многих практически значимых случаях проводить интегрирование и комплексирование индикаторов и индексов разной природы и разной размерности, например, байесовскими методами и преобразуя полученную информацию в показатели и форматы, приемлемые для систем принятия решений (Хованов, 1996, 1998).

Видя такую ситуацию, и понимая актуальность темы, Всемирный Банк, Комиссия по устойчивому развитию и Комиссия по глобальной экологии ООН еще во второй половине 1990-х годов, а затем и в начале XXI века сформулировали в этой области знаний некоторые общие положения, которые и сейчас широко применяются специалистами многих стран мира. При этом все дискуссии по данной проблеме были перенесены на так называемые «Методологические страницы», которые каждый желающий может посмотреть в Интернете.

В выделенной категории ЭКОЛОГИЯ под индикатором рекомендуется понимать эквивалент индуцируемого явления в модели: НАГРУЗКА - СОСТОЯНИЕ - ОТКЛИК. Индекс - это уровень, к которому надо стремиться.

Подведем итог. На сегодняшний день ряд авторов под индексом понимают математическую функцию, основанную на двух и более переменных, а под индикатором — функцию одной переменной. В другом варианте индикатор - это вектор состояния экосистемы, а индекс - количественное сравнение вектора с неким стандартом. Нам представляется возможным за термином «индекс» оставить расширительное толкование: индекс - это результат свертывания показателей о состоянии системы, процедура которого может осуществляться различными путями и приводит к различным видам индексов. Отметим, что некоторые ученые выступают против использования термина «свертка информации» в научной литературе.

В настоящее время существуют как сторонники индексов, так и их противники. Аргумент первых - индексы наглядны и легко интерпретируемы; с их помощью эффективно осуществляется коммуникация между специалистами и потребителями информации. Контраргумент вторых - возможность существенных искажений при свертывании показателей, что может вводить в заблуждение лиц, принимающих решения в области природопользования. 
Вопрос об индексах окружающей среды рассмотрен в серии обзоров. Авторы обзоров отмечают, что основная функция индексов - давать необходимую информацию для лиц, принимающих управляющие решения (т. е. индексы носят прикладной характер). Они указали на значительное сходство между индексами окружающей среды и известными индексами в других областях - экономическими (например, индексом цен, валовым национальным продуктом) и социальными (индекс качества жизни).

\section{Вопросы для усвоения материала}

1. Что такое оценка, экологическая оценка, эколого-географическая, геоэкологическая оценка.

2. Что подлежит изучению и оценке в естественных и антропогенно-трансформированных природных системах.

3. На что влияет профессия исследователя, занимающегося оценкой состояния сложной природной системы.

4. Что значит, оценить экологическое состояние; оценить состояние экосистемы. В чем разница между оценкой качества среды и оценкой экологического состояния?

5. Определите термин «экологический статус».

6. Определите термины «геоэкологическая оценка», «геоэкологический статус».

7. Чем, по Вашему мнению, должна заниматься факториальная экология (геоэкология) и факториальная география (если бы такая была).

8. Как Вы понимаете эмерджентность сложной системы? В чем она проявляется.

9. Ч Ч такое неаддитивные (сложные) свойства сложной системы. Приведите пример.

10. Чем бы Вы объяснили появление искажений при свертке показателей, как это происходит и как это может вводить в заблуждение лиц, принимающих решения в области природопользования.

11. В «Методологических страницах» выделена категория «ЭКОЛОГИЯ», в которой под индикатором рекомендуется понимать эквивалент индуцируемого явления в модели: «НАГРУЗКА СОСТОЯНИЕ - ОТКЛИК». Индекс - это уровень, к которому надо стремиться. Согласны ли Вы с предлагаемыми формулировками? Что Вы хотели бы исправить, изменить и почему?

\section{Литература}

Абакумов В.А. Руководство по гидробиологическому мониторингу пресноводных экосистем. СПб, 1992, 318 с Азгальдов Г.Г. Теория и практика оценки качества товаров (основы квалиметрии) / Москва, 1982. М. Экономика, 1982, - 256 c. https://elibrary.ru/item.asp?id=18446520

Александрова Л. В., Васильев В. Ю., Дмитриев В. В., Мякишева Н. В., Огуриов А. Н., Терехина Н. В., Третьяков B. Ю., Уфимцева М. Д. Многокритериальная оценка экологического состояния и устойчивости геосистем на основе метода сводных показателей. V. Интегральная оценка экологического состояния и качества среды урбанизированных территорий // Вестн. С.-Петерб. ун-та. Сер. 7. 2000. Вып. 4, № 31. С. 34-47.

Александрова Л.В., Васильев В.Ю., Дмитриев В.В., Мякишева Н.В., Огуриов А.Н., Третьяков Н.В., Хованов Н.В. Многокритериальные географо-экологические оценки состояния и устойчивости природных и урбанизированных систем. Под ред. В.В. Дмитриева и Н.В. Хованова. Деп. ВИНИТИ 01.09.2000, № деп.2342В00, 275 с.

Алимов А.Ф. Экология - наука биологическая // Экология, 1990, №1, с.3-7.

Алимов А.Ф., Дмитриев В.В., Чистобаев А.И. и др. Интегральная оценка экологического состояния и качества среды городских территорий» / Под ред. А.К.Фролова, СПбНЦ РАН, СПб, 1999, 253 с.

Белозерский Г.Н., Дмитриев В.В. Становление геоэкологии как важный этап в развитии географии ХX столетия/ Известия РАН. Серия географическая, 2007, №2, с.19-28.

Белозерский Г.Н., Дмитриев В.В. Тенденции развития географии в XXI веке. Единая планетарная система./ Известия РАН. Серия географическая, 2007, №4, с.8-15.

Бигон М., Харпер Дж., Таунсенд К. Экология. Особи, популяции и сообщества: В 2-х т. Пер. с англ. М. Мир, 1989.

Боблакова Л.М., Дмитриев В.В. Интегральная оценка качества жизни населения г.Санкт-петербурга и г.Москвы / Научный журнал Российской Академии Естествознания "Международный журнал экспериментального образования", 2014, №3 Часть 1, с.91-95.

Веницианов E.B. Нанофакторы в процессах массопереноса в многофазных системах. Электронный научный журнал «Молекулярные технологии». 2010.

Веницианов Е.В. Нано-факторы в формировании экологического состояния водных объектов. Проблемы безопасности в водохозяйственном комплексе России. Краснодар: ООО «Авангард плюс». 2010.- С. 29-40.

Воробейчик Е.Л., Садыков О.Ф., Фарафонтов М.Г. Экологическое нормирование техногенных загрязнений наземных экосистем (локальный уровень). Екатеринбург: Изд. УИФ «Наука», 1994 , 280 с.

Геоэкология и природопользование. Труды ХІІ съезда Русского географического общества. Отв. редакторы д.г.н. В.В. Дмитриев, д.б.н. В.Н.Мовчан, Том 4., СПб, 2005, 400 с.

Дедю И.И. Экологический энциклопедический словарь. Кишинев, 1990, 406 с.

Дмитриев В. В. Интегральные оценки состояния сложных систем в природе и обществе // Биосфера. 2010. Т. 2, № 3. C. $507-520$. 
Дмитриев В. В. Определение интегрального показателя состояния природного объекта как сложной системы // Общество. Среда. Развитие. 2009. № 4 (12). С. 146-165.

Дмитриев В. В. Устойчивость природных объектов к изменению параметров естественного и антропогенного режимов // Дмитриев В. В., Фрумин Г. Т. Экологическое нормирование и устойчивость природных систем: учеб. пособие. СПб.: Изд-во «Наука», 2004. С. 241-278.

Дмитриев B. В. Экологическое нормирование состояния и антропогенных воздействий на природные экосистемы // Вестн. С.-Петерб. ун-та. Сер. 7. 1994. Вып. 2, № 14. С. 60-70.

Дмитриев В. В. Эколого-географическая оценка состояния внутренних водоемов: автореф. дисд-ра геогр. наук. СПб., 2000. 419 с.

Дмитриев В. В., Мякишева Н. В., Третьяков В. Ю., Хованов Н. В. Многокритериальная оценка экологического состояния и устойчивости геосистем на основе метода сводных показателей. II. Трофический статус водных экосистем // Вестн. С.-Петерб. ун-та. Сер. 7. 1997. Вып. 1, № 23. С. 51-67.

Дмитриев В. В., Мякишева Н. В., Хованов Н. В. Многокритериальная оценка экологического состояния и устойчивости геосистем на основе метода сводных показателей. І. Качество природных вод // Вестн. С.-Петерб. ун-та. Сер. 7. 1996. Вып. 3, № 21. С. 40-52.

Дмитриев В. В., Огуриов А. Н. Подходы к интегральной оценке и ГИС-картографированию устойчивости и экологического благополучия геосистем. II. Методы интегральной оценки устойчивости наземных и водных геосистем // Вестн. С.-Петерб. ун-та. Сер. 7. 2013. Вып. 3. С. 88-103.

Дмитриев В. В., Огуриов А. Н. Подходы к оценке и ГИС-картографированию устойчивости и экологического благополучия геосистем. І. Интегральная оценка устойчивости наземных и водных геосистем // Вестн. С.-Петерб. ун-та. Cер. 7. 2012. Вып. 3. С. 65-78.

Дмитриев В. В., Огуриов А. Н., Васильев В. Ю., Третьяков В. Ю. Многокритериальная оценка экологического состояния и устойчивости геосистем на основе метода сводных показателей. IV. Токсическое загрязнение воды и грунтов // Вестн. С.-Петерб. ун-та. Сер. 7. 1999. Вып. 1. С. 40-53.

Дмитриев В.В. Интегральная оценка качества жизни как показатель устойчивого развития населения региона / Устойчивое развитие и экологический менеджмент: учебное пособие. - СПб.: ВВМ; СПбГУ, 2009. - Ч 2., 18 стр.

Дмитриев В.В. Интегральная оценка экологического благополучия водного объекта: новый подход, результаты. Международная научно-практическая конференция «Обеспечение гидрометеорологической и экологической безопасности морской деятельности» 16-17 октября 2015, Астрахань, Россия.

Дмитриев В.В. Интегральная оценка экологического благополучия геосистем / Информационные технологии и системы: управление, экономика, транспорт, право: Сб. тр. Международной научно-практической конференции «Инфогео 2013»/Вып.2 (11), Под ред.д.т.н., проф. Истомина Е.П., д.т.н., проф. Марлей В.Е., д.э.н., проф. Скобелевой И.П., д.ю.н., проф. Соболь И.А. - СПб.: ООО «Андреевский издательский дом» - 2013 г., с.36-39.

Дмитриев В.В. Интегральные оценки состояния сложных систем в природе и обществе / Устойчивое развитие и экологический менеджмент: учебное пособие. Раздел 2.1. - СПб.: ВВМ; СПбГУ, 2009. - Ч 1., 17 стр.

Дмитриев B.B. Интегральные оценки состояния сложных систем в природе и обществе (статья). Междисциплинарный научный и прикладной журнал «Биосфера», 2010, т.2, №3, с.533-546.

Дмитриев В.В. Оценка экологического состояния природных объектов. Что такое экологическая оценка и как построить интегральный показатель состояния природной экосистемы. Экология. Безопасность. Жизнь. Экологический опыт гражданских, общественных инициатив. Выпуск 12. Гатчина, 2001 г, с.225-237.

Дмитриев В.В. Прикладная экология в системе высшего географического и гидрометеорологического образования/ Вопросы прикладной экологии. Сборник научных трудов РГГМУ, СПб, изд. РГГМУ, 2002, с.90-96.

Дмитриев В.В. Сложные системы в природе и обществе и оценка их состояния / Научно-теоретический журнал «Общество. Среда. Развитие». №4 (13), 2009, 19 стр.

Дмитриев В.В. Современное экологическое состояние водных объектов карельского Приладожья и его сравнение $\mathrm{c}$ ретроспективными данными / Научно-теоретический журнал Ученые записки Российского государственного гидрометеорологического университета №33. - СПб,: РГГМУ, 2014, с.102-118.

Дмитриев В.В. Экологическое нормирование состояния и антропогенных воздействий на природные экосистемы. Вестник С-Петерб. ун-та. Серия 7, 1994, вып. 2. С.60-70.

Дмитриев В.В. Эколого-географическая оценка состояния внутренних водоемов. Дисс. на соиск. уч. степени докт. геогр. наук. СПб, 2000, 419 с.

Дмитриев В.В., Амаро Медина Д.Р., Огуриов А.Н., Добрынина А.С. Оценка экологического статуса системы «река-водосбор»: подходы, методика, результаты. Экология речных бассейнов: Труды 9-й Междунар. науч.-практ. конф. / Под общ. ред. проф. Т.А. Трифоновой; Владим. гос. ун-т. им. А.Г. и Н.Г. Столетовых, Владимир, 2018. С. 46-52.

Дмитриев В.В., Боблакова Л.М. Интегральная оценка качества жизни населения в регионах России / Информационные технологии и системы: управление, экономика, транспорт, право: Сб. тр. Международной научнопрактической конференции «Инфогео 2014» / Вып. 3 (14) / Под ред. д.т.н., проф. Истомина Е.П. - СПб: ООО «Андреевский издательский дом» - 2014 г., Informacionnye tehnologii i sistemy. Upravlenie, èkonomika, transport, pravo. ISSN 2306-5788, c.38-44.

Дмитриев В.В., Жиров А.И., Ласточкин А.Н. Прикладная экология. Учебник для студентов высш. учеб. заведений. М.: Издательский центр «Академия», 2008, 608 с.

Дмитриев В.В., Огуриов А.Н. Подходы к интегральной оценке и ГИС -картографированию устойчивости и экологического благополучия геосистем. III. Интегральная оценка устойчивости почвы и наземных геосистем / Вестник СПбГУ. Сер. 7. 2014. Вып. 4, с.114-129.

Дмитриев В.В., Огуриов А.Н., Васильев В.Ю., Примак Е.А., Лобачева Ю.В., Скрыгина В.К. Оценка эмерджентных свойств сложных систем в природе и обществе на основе моделей интегрального оценивания / Сборник трудов VI международной конференции «Экологические и гидрометеорологические проблемы больших городов и промышленных зон, ЭКОГИДРОМЕТ - 2012». 2-4 июля 2012. Под редакцией: Л.Н.Карлина, В.Н. Воробьева, В.А. Шелутко, В.В.Дмитриева. - СПб.: изд. РГГМУ, 2013. - с.25-34. 
Дмитриев В.В., Панов В.Е., Пряхина Г.В. Методические указания по учебно-производственной практике «Экологическое состояние водных объектов»: Учебно-методическое пособие. - СПб. : ВВМ, 2010. - $104 \mathrm{c.}$

Дмитриев В.В., Федорова И.В., Бирюкова А.С. Подходы к интегральной оценке и ГИС- картографированию устойчивости и экологического благополучия геосистем. Часть IV: Интегральная оценка экологического благополучия наземных и водных геосистем // Вестник СПбГУ. Сер. 7. 2016. Вып. 2. - С. 37-53.

Дмитриев В.В., Фрумин Г.Т. Экологическое нормирование и оценка устойчивости природных систем. Учебное пособие, СПб, 2004, 300 с.

Дмитриев В.В., Хованов Н.В., Огуриов А.Н., Васильев В.Ю., Шелутко В.А., Проченко Ю.А., Примак Е.А. Интегральная оценка экологического состояния и качества среды городских территорий, рек и морских акваторий (раздел монографии). Раздел V монографии «ЭКОЛОГИЯ И ГИДРОМЕТЕОРОЛОГИЯ БОЛЬШИХ ГОРОДОВ И ПРОМЫШЛЕННЫХ ЗОН [РОССИЯ-МЕКСИКА]». Том ІІ. Мониторинг окружающей среды. Под общей редакцией Карлина Л.Н. и Шелутко В.А. Редакторы: Скакальский Б.Г., Перевощикова М., Дмитриев В.В. и др. - СПб.: РГГМУ, 2010 - с.102-134.

Исаченко А.Г. Ландшафтоведение и физико-географическое районирование. М., 1991, 366 с.

Исаченко Г.А. Методы полевых ландшафтных исследований и ландшафтно-экологическое картографирование. СПб, 1999, 112 с.

Лобачева С.В., Дмитриев В.В. Сравнительная интегральная оценка качества жизни России и Канады. Журнал «Международный журнал прикладных и фундаментальных исследований», №9, часть 2, 2015, с.359-364.

Лопатников Л.И. Экономико-математический словарь. Под ред.акад. Н.П.Федоренко. М., Наука, 1987, 509 с.

Многокритериальные географо-экологические оценки состояния и устойчивости природных и урбанизированных систем» / Под ред. В.В.Дмитриева и Н.В. Хованова. Деп. ВИНИТИ 01.09.2000, № деп.2342В00, 275 с.

Огуриов А. Н., Хованов Н. В. Многокритериальная оценка экологического состояния и устойчивости геосистем на основе метода сводных показателей. III. Оценка степени благоприятности природных условий макрорегионов северозапада РФ для жизни людей // Вестн. С.-Петерб. ун-та. Сер. 7. 1997. Вып. 2. С. 55-62.

Одум Ю. Основы экологии / Пер. с 3-го англ. изд. под ред. Н.П. Наумова. М., 1975, 740 с.

Осипов А.Г. Интегральная оценка устойчивости ландшафтов при создании сельскохозяйственных угодий природно-аграрных систем // Вестник СПбГУ. Серия 7. Геология. География. 2016. Вып. 3. С. 140-162. DOI: 10.21638/11701/spbu07.2016.312

Осипова А.А., Дмитриев В.В. Интегральная оценка экологической обстановки в районах г.Санкт-Петербурга / Организационно-методическое обеспечение проведения Всероссийской студенческой олимпиады по экологии и природопользованию: учебно-методическое пособие / С.А.Куролап, В.И.Федотов, Л.М.Акимов, Т.И. Прожорина, М.А. Клевцова, Ю.А. Нестеров, О.В. Прохорова, М.В. Деревягина. - Воронеж, Издательство «Научная книга», 2013, - с.139143.

Примак E.A. «Интегральная оценка устойчивости и экологического благополучия водных объектов». Автореф. канд. дисс. по спец. 25.00.36 - Геоэкология, РГГМУ, СПб, 2009, 24 с.

Проблемы эколого-географической оценки состояния природной среды / Под ред. П.П. Арапова и Ю.П. Селиверстова. СПб., 1994.

Реймерс Н.Ф. Природопользование: Словарь-справочник. М., 1990, 638 с.

Словарь терминов и понятий, связанных с охраной живой природы / Н.Ф.Реймерс, А.В.Яблоков / М., 1982, 144

c.

Снакин В.В., Мельченко В.Е., Бутовский Р.О. и др. Оценка состояния и устойчивости геосистем. М. ВНИИ природа, 1992, $127 \mathrm{c}$.

Тульчинский Г.Л. Цифровая трансформация образования: вызовы высшей школе. Философские науки. Издательство: Издательский дом "Гуманитарий" (Москва). № 6 . 2017. С. 121-136.

Федоров М.П., Музалевский А.А. Индикаторы и индексы в моделировании природно-технических систем. Междисциплинарный научный и прикладной журнал «Биосфера», 2013, т. 5, № 3, с.311-326.

Федорова И. В. Современное состояние и устойчивость к воздействию внутренних водоемов Антарктиды: автореф. дис. канд. геогр. наук. 2003. 19 с.

Федорова И.В. Современное состояние и устойчивость к воздействию внутренних водоемов Антарктиды. Автореферат канд. дисс. по спец. 25.00.36 - Геоэкология; 25.00.27 - Гидрология суши, водные ресурсы, гидрохимия. 2003 г., СПбГУ, СПб, 19 с.

Хованов Н. В. Анализ и синтез показателей при информационном дефиците. СПб.: Изд-во СПбГУ, 1996. 196 с.

\section{Раздел 2. Теоретико-методологические основы интегральной оценки экосистем, геосистем, ландшафтов и их эмерджентных свойств.}

\section{Лекция №4}

Описательный и точный период развития науки. Схема основных стадий
системного анализа применительно к исследованию состояния и устойчивости
природных систем. Аксиология. Аксиометрия. Диагностический анализ (диагностика) состояния природных объектов. Характеристика состояния сложной системы. Индексы состояния. Классификационная схема индексов состояния сложной системы по литературным обобщениям (Дмитриев, 2009). Индексымаркеры и индексы - условные параметры. Условные функционалы. Функции желательности. Пример использования логистической функции (1) для выделения 
стадий антропогенной трансформации экосистем. Примеры обобщенных $\boldsymbol{d}$-функций. Обобщенные функции желательности.

Описательный и точный период развития науки. По академику А.А. Дородницину (1982) в развитии любой науки присутствуют описательный и точный периоды. Описательный период включает следующие этапы: 1 - накопление информации об объектах, которые изучаются данной наукой. Одновременно или с небольшим опозданием начинается этап 2 - процесс упорядочивания - классификация объектов с целью облегчения их анализа. Затем следует этап 3 - установление эмпирических качественных и количественных связей и соотношений между объектами. Эти три этапа по А.А. Дородницину характеризуют описательный период развития науки, после которого начинается выделение определяющих связей и соотношений. Другими словами, этот этап связан с выделением основных переменных (компонентов изучаемой системы) и процессов обмена веществом (энергией, информацией) между компонентами.

\begin{tabular}{|c|c|}
\hline $\begin{array}{l}\text { 1. Первичное } \\
\text { измерение } \\
\text { геокомпонентов } \\
\text { системы и ее } \\
\text { свойств }\end{array}$ & $\begin{array}{l}\text { Цель и задачи исследования природной системы. } \\
\text { Дефиниция геокомпонентов системы. } \\
\text { Перечень переменных (геокомпонентов), их разделение на основные и } \\
\text { дополнительные. } \\
\text { Основные сведения о переменных, их составе и свойствах. } \\
\text { Выбор БД (ГИС). }\end{array}$ \\
\hline $\begin{array}{l}\text { 2.Анализ данных } \\
\text { (измерений) }\end{array}$ & $\begin{array}{l}\text { Статистический анализ связей между переменными в природной системе. } \\
\text { Выявление важнейших взаимодействий внутри системы. } \\
\text { Классификации на основе натурных данных для системы. }\end{array}$ \\
\hline $\begin{array}{l}\text { 3.Моделирование } \\
\text { отдельных свойств } \\
\text { и связей в системе }\end{array}$ & $\begin{array}{l}\text { Простые модели отдельных свойств системы (модели парных или } \\
\text { множественных внутрисистемных и межсистемных связей). } \\
\text { Выявление на моделях влияния факторов среды на изменение интенсивностей } \\
\text { процессов обмена между компонентами системы (и средой). }\end{array}$ \\
\hline $\begin{array}{l}\text { 4.Имитация } \\
\text { поведения } \\
\text { отдельных } \\
\text { подсистем }\end{array}$ & $\begin{array}{l}\text { Синтез имитационных моделей отдельных частей системы, отдельных } \\
\text { подсистем. } \\
\text { Алгоритмическая реализация моделей на ПК. } \\
\text { Проверка моделей по критериям адекватности. } \\
\text { Экспериментирование с моделями на ПК. } \\
\text { Этот этап не является строго обязательным. Можно сразу переходить от этапа } 3 \\
\text { к этапу 5. }\end{array}$ \\
\hline $\begin{array}{l}\text { 5.Имитация } \\
\text { поведения системь } \\
\text { в целом }\end{array}$ & $\begin{array}{l}\text { Разработка стратегии моделирования системы в целом с учетом межсистемных } \\
\text { связей. } \\
\text { Синтез общей имитационной модели на основе моделей } 3 \text { и (или) } 4 . \\
\text { Алгоритмическая реализация модели на ПК. } \\
\text { Проверка модели по критериям адекватности. } \\
\text { Экспериментирование с моделью на ПК. }\end{array}$ \\
\hline $\begin{array}{l}\text { 6.Оптимизация } \\
\text { модели }\end{array}$ & $\begin{array}{l}\text { Поиск наилучшего (оптимального) варианта. } \\
\text { Управление поведением системы с помощью моделей. } \\
\text { Оценка воздействия на основе общей модели. } \\
\text { Получение экологических (эколого-географических) нормативов. }\end{array}$ \\
\hline
\end{tabular}

Рис.5. Схема основных стадий системного анализа применительно к исследованию природной системы.

С этого момента начинается математическое моделирование процессов, явлений, объектов, систем на основе выделения существенных переменных, свойств (величин) исследуемого явления. Так появляются следующие этапы: 4 - установление величин, 5 математическое моделирование, 6 - установление связей и соотношений (уже не на основе этапа 3 , а на основе результатов моделирования). В итоге реализуется переход от моделирования к целям преобразования. Модель выступает в качестве инструмента преобразования изучаемой системы. Схема основных стадий системного анализа применительно к исследованию природной системы представлена на рис.5.

Аксиология и аксиометрия. Первым этапом оценки состояния эко и геосистем и их эмерджентных свойств является формирование представлений о предметах исследования: биопродуктивности (продукционном потенциале), качестве среды, устойчивости системы к изменению параметров естественного и антропогенного 
режимов, экологическом благополучии (ЭБ), экологической ценности. Во всех случаях автор должен определить свое отношение к объекту и предмету исследования, ввести необходимую аксиоматику. Выделение факторов, влияющих на оцениваемые свойства систем, или перечня необходимых и достаточных признаков, отражающих явления, процессы, химический и биологический состав компонентов, включаемых в интегральную оценку, выполняется на основе аксиологического подхода (общая теория ценностей, учение о природе ценностей), аксиометрии (экологической квалиметрии), и обусловлено возможностью получения натурной информации о требующихся показателях для количественной интегральной оценки. При обсуждении этого вопроса приходим к выводу о том, что на интегральной основе могут оцениваться также: вектор состояния системы, ее экологический потенциал, природный капитал, экологические функции; степень благополучия или трансформации системы, степень экологической напряженности, экологическая ценность, степень и результат воздействия на систему. На этой же основе в последние годы формируется методология оценки «мульти-опасных явлений» («multihazards», «мульти-ОЯ») и рисков («мульти-риски») при определении интегрального риска от совокупности ОЯ в целом, а также такие свойства геосистем, которые характеризуют количество энергии, требующейся для создания единицы биомассы на разных трофических уровнях (энмергия) или величину отклонения системы от равновесного состояния с окружающей средой, измеренного в единицах информации и/или энергии (эксергия).

Диагностический анализ (диагностика) природного объекта. Как уже говорилось ранее, формой и начальным этапом выражения отношения субъекта к объекту оценивания может служить диагностический анализ (диагностика) природного объекта. Диагностика включает в себя рекогносцировочное выявление достоинств (положительная значимость) и недостатков (отрицательная значимость) объекта (системы), его отдельных свойств, интервалов их естественного колебания, структуры и режимов функционирования на основе анализа параметров состояния и их критических значений. Диагностический анализ (диагностика) природного объекта (его свойств) чаще всего сводится к установлению отличительных особенностей и элементов его режимов, продуктивности, токсического загрязнения, способности сохранять свои свойства и функционировать в условиях антропогенных воздействий и изменения качества среды в целом, применительно к запросам человека или с точки зрения оптимального существования организмов. В качестве критериев оценивания применяются режимные, природозащитные, антропоэкологические и хозяйственные критерии (Дмитриев, 2000). Так или иначе, все указанные задачи неотделимы от мониторинга окружающей человека природной и антропогенно-трансформированной среды, геоэкологических аспектов устойчивого (сбалансированного) глобального и регионального развития, разработки и совершенствования государственного нормирования и стандартов в природопользовании, в оценке состояния окружающей среды.

В экологических и системных исследованиях целесообразно использовать понятие «вектора состояния системыл), под которым понимается совокупность (список) упорядоченных переменных экосистемы, отражающих ее наиболее важные свойства. В перечень переменных включаются такие переменные как размер, параметры режимов, продуктивность, потоки энергии, характерные загрязнения и др. В вектор состояния экосистемы предлагается включать параметры, характеризующие биоту, абиогенные факторы и антропогенные воздействия на экосистему. В вектор состояния геосистемы можно включать все параметры, характеризующие рассматриваемое геопространство, не делая акцента на его биотических геокомпонентах. Таким образом, состояние природной системы всегда можно описать вектором состояния системы. Такой вектор был назван нами «портретом системы»» (Дмитриев, 2000). Тогда основной задачей оценочных экологических исследований будет нахождение портретов природных и природноантропогенных экологических систем. Понятно, что такие портреты условно можно именовать чистыми или антропогенно трансформированными на основе сопоставления 
их с фоновыми (нормальными) портретами. Для снижения субъективизма необходимо уметь выполнять интегральные оценки состояния геосистем и уметь строить векторы состояния на основе большого числа параметров оценивания с привлечением экспертной, а также неполной, неточной, нечисловой информации.

Таким образом, состояние сложной системы в любой момент времени оценивается вектором состояния или портретом системы. Знание начального состояния позволяет в соответствии с принятым решением, предсказать поведение системы в будущем. Конечное состояние системы может рассматриваться как цель принимаемого решения. Сравнение различных состояний сложных систем целесообразно проводить на основе интегральных оценок.

Поскольку оценить на интегральной основе вектор состояния системы в целом по достаточно большому перечню критериев не просто, многие авторы начали рекомендовать для оценки состояния сложных природных и социально-эколого-экономических систем, их аддитивных и неаддитивных свойств использование индикаторов или индексов состояния и развития систем с учетом специфики природной среды, состояния экономики, социальной сферы и окружающей человека среды. Чаще всего здесь говорят об индексах или индикаторах устойчивого (сбалансированного) развития иерархически соподчиненных систем (региональных, глобальных).

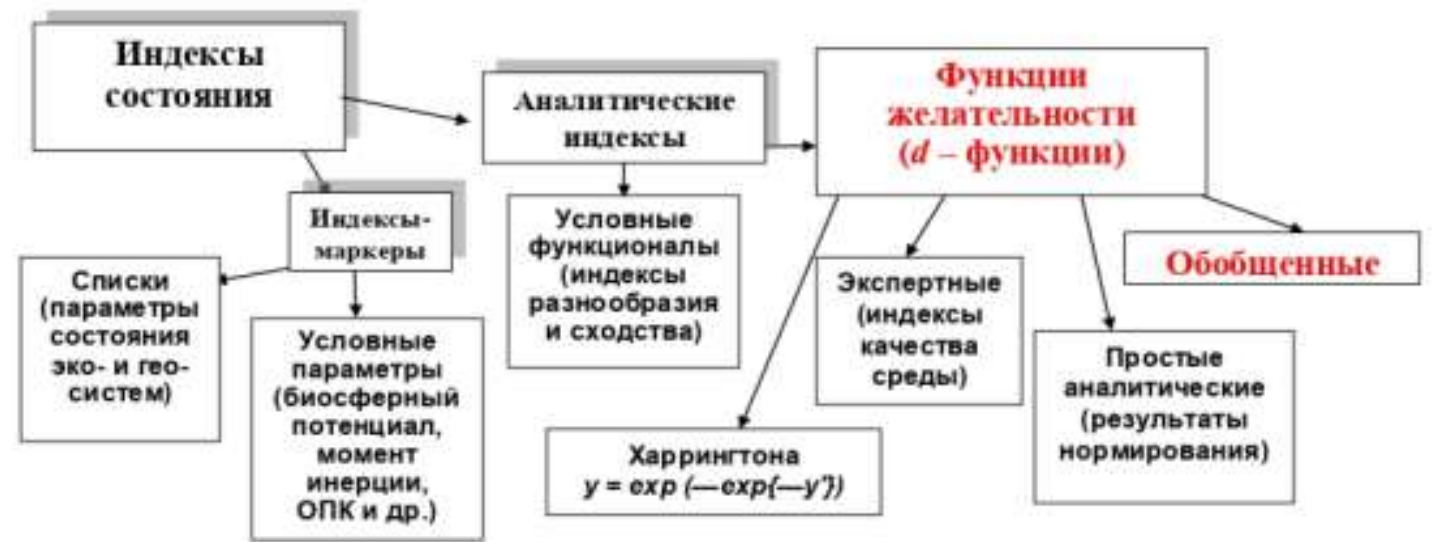

Рис 6 Классификационная схема индексов состояния сложной системы по литературным обобщениям (Воробейчик, Садыков, Фарафонтов, 1994; Дмитриев, 2009).

Вопрос об индексах окружающей среды рассмотрен в серии обзоров (Воробейчик, Садыков, Фарафонтов, 1994, Дмитриев, 2009, Музалевский, 2015). Авторы отмечали, что основная функция индексов - давать необходимую информацию для лиц, принимающих управляющие решения (т.е. индексы носят прикладной характер). Они указывали на значительное сходство между индексами окружающей среды и известными индексами в других областях - экономическими (например, индексом цен, валовым национальным продуктом) и социальными (индекс качества жизни). Рассмотрим подробнее различные виды индексов (по Воробейчик, Садыков, Фарафонтов, 1994, Дмитриев, 2009).

Индексы-маркеры и индексы - условные параметры. Индексы - маркеры, это натуральные параметры состояния эко- (гео-) систем. Каждая из приведенных в авторских перечнях (списках) переменных может толковаться и как одномерный индекс, и как составляющая многомерного. Кроме того, есть некоторое перекрывание между списками и индексами - условными параметрами, к анализу которых мы переходим.

В.В. Бугровским с соавторами (1984), был предложен критерий, названный «биосферныцй потенциал леса». Он представляет собой произведение биомассы леса на его продуктивность

$$
\Pi_{\sigma}=M(d M / d t)
$$


где Пб - биосферный потенциал; $M$ - биомасса, т/га; $d M / d t$ - скорость продуцирования биомассы, т/га в год. По мысли авторов, произведение биомассы на продуктивность лучше характеризует функционирование и устойчивость экосистем, чем каждый из показателей в отдельности (приводится пример молодой поросли с большой продуктивностью, но малой биомассой и перестойного леса с большой биомассой, но малой продуктивностью). Вводится даже специальная единица измерения - «щвария (в честь академика С. С. Шварца, предложившего считать максимум произведения биомассы на продуктивность одним из признаков «хорошего» (с точки зрения человека) биогеоценоза. Этот показатель далее был расширен для степных и любых других экосистем.

В качестве интегрального параметра состояния экосистемы, тесно связанного с ее устойчивостью, Ю.Г. Пузаченко (1990) предложил использовать момент инеричии:

$$
J=\sum m_{i} m_{j} r_{i j}^{2} / \sum m_{i},
$$

где $m_{i}, m_{j}$ - масса $i$ - й $\left(j-\right.$ й) части системы, $r_{i j}$ - расстояние между частями в многомерном пространстве. Основываясь на физических аналогиях, автор полагает, что чем $J$ больше, тем меньше амплитуда колебаний, подверженность случайным флуктуациям и действиям внешних сил. Однако переход с уровня аналогий на уровень практических приложений выявляет большую неопределенность в использовании данного показателя: что считать частью системы - вид или какую-либо экологическую группировку; что считать «массой»; как находить расстояние и т. д. Без решения этих вопросов оперирование рассматриваемым показателем, несмотря на его очень красивую интерпретацию, вряд ли прибавит что-либо новое по сравнению с использованием традиционных переменных, например числа видов или общей биомассы сообщества.

Другой условный индекс состояния - подстилочно-опадочный коэффициент (ОПК) П.А. Костычева, представляющий собой отношение массы подстилки к массе ежегодного опада. Распространены также связанные с ним показатели времени полуразложения и 95\%-го разложения. Подстилочно-опадочный коэффициент интерпретируется как время, необходимое для полного разложения опада, и изменяется в широких пределах (крайние значения для различных типов экосистем различаются более чем на три порядка). Есть и ОПК= подстилка / часть опада, формирующая подстилку. Этот коэффициент достигает максимума в заболоченных лесах (более 50), минимален он в влажных тропических лесах $(0,1)$. Чем меньше ОПК, тем устойчивее биогеоценоз.

В качестве интегрального показателя функционирования популяций предложено использовать чистую кратность прироста численности за год. По мысли авторов, этот показатель наиболее приемлем «...с точки зрения возможности экспериментального определения, учета интегрального влияния всех возможных факторов, объективности оценки состояния популяции». Снижение показателя ниже естественных флуктуаций рассматривается как граница перехода в ненормальное состояние.

А.С. Алексеевым с соавторами (1986) предложен метод расчета предельного времени жизни древостоя, которое может рассматриваться как интегральный показатель его состояния. Метод основан на анализе матрицы вероятностей переходов между категориями санитарного состояния. Однако для реализации процедуры расчета требуется знать распределение деревьев по категориям состояния, по крайней мере, в два момента времени. Это существенно сужает область применимости данного метода. Другое ограничение связано с допущением, что в древостое отсутствуют пополнение деревьев и их выбытие. Следовательно, метод может быть использован только для переходных состояний (быстрых процессов трансформации).

Рассмотренные условные параметры, обладают неоспоримым преимуществом интегральностью. Тем самым они в компактной форме характеризуют важнейшие процессы в экосистемах. Но они должны применяться с определенной долей 
осторожности, поскольку могут иметь большую статистическую ошибку, чем составляющие их показатели.

Условные функционалы. Аналитическими индексами - условныли функиионалами могут служить многочисленные показатели, широко представленные в арсенале количественной экологии. Это индексы разнообразия, выравненности, обилия, сходства, пространственной неоднородности и т. д. Их анализ не входит в наши задачи, тем более что есть подробные обзоры на эту тему. Мы ограничимся лишь несколькими замечаниями, касающимися использования индексов в работах биоиндикационного плана.

Чаще других находят применение индексы разнообразия и структуры сообществ, являющиеся функционалами (не обязательно в виде средних) относительных обилий видов либо других таксономических единиц. Наиболее популярны из них индекс Симпсона и информационная мера Шеннона, а также основанные на них меры выравненности коллекций. Индексы разнообразия используются даже в системе государственного контроля над состоянием окружающей среды в ряде стран, в том числе и у нас в стране.

Однако всем этим показателям вряд ли можно придавать столь большое значение, поскольку вопрос о достоверности различий индексов, рассчитанных для разных сообществ, практически всегда остается нерешенным. В дополнение к сказанному несколько слов о мере Шеннона (по Воробейчик, Садыков, Фарафонтов, 1994). После информационного бума 1950-60-х годов и последовавшего за ним информационного «вторжения» в экологию использование этого индекса стало очень модным. Если в работе, связанной с изучением сообществ, нет индекса Шеннона, это расценивается почти как признак дурного тона. К тому же неявно подразумевается, что данный критерий, измеряющий информацию в системе,- удобный, универсальный и незаменимый инструмент. Мы не ставим целью подробно анализировать его свойства. Отметим лишь, что мнение об особой роли индекса Шеннона как измерителя экосистемной информации в большинстве случаев является мифом. Элементарное разложение в ряд Тейлора дает следующий результат:

$$
-\sum p_{i} \ln p_{i}=\ln S-1 / 2 C V^{2}+1 / 6 S A s C V^{3} \text {, }
$$

где $p_{i}$ - доля $i$-го вида; $S$ - количество видов; $C V$ и $A s-$ коэффициенты вариации (в долях единицы) и асимметрии абсолютных значений численности видов. Поскольку третий член разложения уменьшается при увеличении $S$, им можно пренебречь. Итак, индекс Шеннона есть всего лишь функция от общего числа видов в сообществе и их выравненности по обилию.

Действительно, формула Шеннона в некотором смысле уникальна по своим свойствам: это единственная функция, которая удовлетворяет совокупности требований к измерителю информации. Но корректность ее использования целиком определяется корректностью ее содержательной интерпретации, а она возможна лишь в весьма узкой области (той, для которой, собственно, и была предложена мера Шеннона) - анализе передачи сообщений по линиям связи, теории кодов и т. д._В экологии применение формулы Шеннона не добавляет ничего нового по сравнению с традиционными показателями (числом видов и выравненностью), имеющими, однако, в отличие от нее четкую интерпретацию. Кроме теоретических возражений против использования индекса Шеннона в экологии есть и другие доводы. Так, показано, что величина индекса существенно зависит от дробности таксономических единиц, по которым он рассчитывается.

Наиболее слабое место индексов разнообразия и сходных с ними показателей неопределенность их интерпретации в терминах качества среды. В русле холистического направления в экологии им придавался смысл «экологического градусника». Однако «градусник» этот несколько странный, если не сказать ущербный. Он измеряет нечто 
совершенно отвлеченное, строго говоря, не имеющее прямого отношения к качеству среды. При этом оказывается, что «здоровой» экосистеме могут соответствовать разные «температуры» и в то же время одна «температура» может наличествовать у совершенно различных с точки зрения качества состояний. Примеры этого многочисленны. Думается, ни один врач не стал бы пользоваться подобным прибором для постановки диагноза больному.

Исходя из сказанного, многие исследователи считают, что индексы - условные функционалы сами по себе в большинстве случаев не адекватны целям экологического нормирования. Более того, в силу своей математической псевдоточности они только запутывают дело, а никак не способствуют эффективной коммуникации между поставщиками и потребителями информации о качестве состояний экосистем. Заметим, однако, что их использование в паре с индексами состояния (загрязнения) ОС дает интересную информацию исследователю. В этом случае устраняется «путаница» о которой говорится выше.

Функции желательности. Часть аналитических индексов базируется на так называемых функциях желательности, которые снимают отмеченную трудность в интерпретации значений. Эти функции (обычно обозначаются буквой $d$ от фp. desirable желательный) представляют собой способ перевода натуральных значений в единую безразмерную числовую шкалу с фиксированными границами. При этом полярные значения функции (например, 0 и 1, 0 и 100, 1 и 10 и т. д.) соответствуют градациям «плохо» - «хорошо», а промежуточные также могут быть интерпретированы в данных терминах (по принципу «чем ближе значение к верхней границе, тем лучше»). Необходимость введения функций желательности определяется различной размерностью переменных, входящих в индекс, что не позволяет усреднять их непосредственно. Перевод же в единую для всех числовую шкалу снимает это затруднение и дает возможность объединять в единый показатель самые различные параметры. Конкретные способы реализации функций желательности могут быть весьма разнообразны.

Экспертные функци желательности. В наиболее простом случае соответствие между натуральными показателями и числами в безразмерной шкале задается экспертным путем. В гидробиологии для оценки степени загрязнений водной, среды органикой существуют различные «системы сапробности». Первая из них (Колквитца - Марссона) была предложена еще в начале века. Сейчас известны многочисленные варианты и модификации систем сапробности (Пантле -Букка, Сладечека, Ватанабе и др.), индексы качества воды BMWP, ASTP и др. (Семенченко, Разлуцкий, 2010). Все они построены на основе наблюдений за очередностью исчезновения или появления, групп организмов при увеличении загрязнения, что позволяет ранжировать виды по их чувствительности. На аналогичных посылках базируются индексы в лихеноиндикации.

Вариантом сапробной системы является известный биотический индекс $Ф$. $B y \partial и в и с c a$, представляющий собой балльную оценку чистоты воды (самой чистой воде соответствует 10 баллов, самой грязной - 1 балл). Индекс основывается на наличии и числе видов индикаторных групп; само определение значений осуществляется с помощью таблицы. Распространены и другие варианты экспертных систем, аналогичные индексу Вудивисса.

В гидробиологии распространены также различные таксономические индексы отношения численности или биомассы некоторых индикаторных таксонов. Например, используются отношение биомассы насекомых к биомассе олигохет (индекс Кинга Болла), отношение численности олигохет к общей численности организмов бентоса (индекс Гуднайта-Уитлея), соотношения различных отрядов нематод и т. д. Иногда предлагаются не отношения, а более сложные функции. Примером может служить хирономидный индекс Балушкиной. Таковы же и общепринятые балльные оценки санитарного состояния деревьев, используемые в санитарном надзоре лесов, либо 
балльные шкалы, создаваемые для специальных целей, например, для диагностики техногенных нарушений древостоя. Аналогичную роль может выполнять класс бонитета насаждения. Во всех случаях определенному набору признаков ставится в соответствие балл, т. е. числовая шкала функции желательности, в данном случае - порядковая.

На основе полученных частных желательностей может создаваться усредненный показатель. Предлагается использовать в качестве показателя жизненности фитоценоза среднее арифметическое жизненности каждого вида (жизненность выражается в числах от 0 до 1, что достигается нормированием всех баллов на максимальное их количество).

Об экспертных функциях желательности необходимо отметить следующее. Хотя они измеряют состояние экосистем в «слабых» количественных шкалах, получаемые с их помощью результаты могут адекватно отражать действительность. Причина этого в том, что они базируются на опыте экспертов, генерализующем многие разнонаправленные процессы. При этом значительно точнее измеряются такие малоформализуемые «невещественные» и инструментально с трудом измеримые признаки, как «степень поражения», «пригодность местообитания» и т. д. Поэтому многие считают, что экспертные функции желательности могут быть эффективно использованы в экологическом нормировании.

Простые аналитические функции желательности. Одно из наиболее простых преобразований натуральных значений параметров в числовую шкалу $[0 ; 1]$ — функция желательности следующего вида:

$$
y_{i}{ }^{1}=y_{i} / \max \left[y_{i}\right] \text { или } y_{i}{ }^{l}=y_{i} / y_{\text {эталон }}
$$

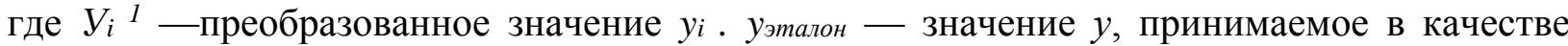
эталона (фона, контроля). При этом первая формула - частный случай второй, поскольку верхний лимит выборки в рассматриваемом контексте - это оценка эталонного значения. Функция желательности $y^{\prime}$ принимает значения от нуля (когда натуральное значение параметра равно нулю) до единицы (когда натуральное значение параметра равно эталонному или максимальному). Ввиду своей простоты идея такого рода преобразований уже многие годы витает в. воздухе. Результат этого - довольно частое «переоткрытие» данной функции желательности (при этом иногда с претензией на приоритет). И сейчас уже весьма затруднительно как указать истинного первооткрывателя, так и дать скольконибудь полный обзор использования данной функции.

Указанные выше формулы — частный случай следующего преобразования, являющегося расширением для ситуации, когда минимальные значения не равны нулю:

$$
y_{i}{ }^{l}=\left(y_{i}-\min \left[y_{i}\right]\right) /\left(\max \left[y_{i}\right]-\min \left[y_{i}\right]\right)
$$

Эта формула широко используется в математике и количественной экологии. Причина популярности данной функции, кроме всего прочего, - в удобной форме представления переменных, делающих их легко интерпретируемыми. Соотнесение величины с максимумом (или эталоном) входит в метод Бателя - одну из процедур оценки воздействия на окружающую среду.

Функция желательности Харрингтна. Это одна из наиболее популярных в математике функций желательности, которая задается следующей формулой:

$$
y=\exp \left(-\exp \left\{-y^{\prime}\right\}\right),
$$

где $y^{\prime}$ - кодированное значение признака. Эта функция находит применение в экологических работах, в том числе связанных с нормированием. Рассмотрим функцию Харрингтона более подробно. Данная функция была предложена для сопоставления физических параметров и психологических откликов и базируется на обширном экспериментальном материале. Из психологии известно, что оценка какого-либо раздражителя нелинейно связана с величиной этого раздражителя (закон Вебера Фехнера). Этот принцип реализуется в функции Харрингтона: в областях желательностей, близких к 0 и 1 , ее «чувствительность» меньше, чем в средней зоне. Функция обладает такими положительными свойствами, как непрерывность, монотонность и гладкость. 
В качестве аргумента в функции желательности используются кодированные значения, представляющие собой положительные или отрицательные целые числа. От количества интервалов, задаваемых кодами, зависит крутизна наклона функции. Обычно используют шесть интервалов в сторону возрастания и шесть в сторону убывания (для более крутой кривой), либо по три интервала (для более пологой).

Функция Харрингтона имеет несколько критических точек, что позволяет задавать границы градаций желательности не произвольным, а строгим образом. Точки перегиба имеют ординаты 0,$8 ; 0,63 ; 0,37 ; 0,2$. Они задают стандартные отметки на шкале желательности: «очень хорошо» $(1,00-0,80), \quad$ «хорошо» $(0,80-0,63)$, «удовлетворительно» $(0,63-0,37)$, «плохо» $(0,37-0,20)$, «очень плохо» $(0,20-0,00)$.

На этом «отсутствие произвола» при использовании функции Харрингтона заканчивается. Построение шкалы желательности, т.е. задание соответствия между кодированными откликами и натуральными значениями, осуществляется чисто субъективно. Как отмечается в литературе, «построение этой шкалы напоминает игру, а конкретные решения определяются соотношением азартности и осторожности исследователя» (Воробейчик и соавт., 1994).

Кроме функции Харрингона могут использоваться и другие, близкие к ней по смыслу и свойствам функции, например:

$$
P=a /\left(1+b \exp \left(-\left|c A+d A^{2}\right|\right)\right)
$$

Приведенное логистическое уравнение имеет аналитическое решение:

$$
X_{j}(t)=\frac{K_{j}}{1+\frac{K_{j}-X_{j 0}}{X_{j 0}} e^{-r_{j}^{m}\left(t+t^{2}\right)}},
$$

и определяется тремя независимыми параметрами $X_{j 0}, K_{j}, r^{m_{j}}$, где $X_{j 0}$ - начальное значение нарушенности $\left(X_{j}\right.$ при $\left.t=t_{0}\right), K_{j}$ - высота плато насыщения с максимумом $X_{j}(t)$ при $\mathrm{t} \rightarrow \infty, r^{m}$ - крутизна начального роста, почти экспонентная.

Пример использования логистической функции (1) для выделения стадий антропогенной трансформации экосистем. Введем стадии антропогенной трансформации экосистемы (рис.7): Н - «норма» - неизмененные и слабо измененные экосистемы; P - зона экологического риска, включает в себя экосистемы с заметным изменением продуктивности и устойчивости, тенденцией к дальнейшей спонтанной деградации экосистем, но еще с обратимыми нарушениями экосистем, предполагающими сокращение хозяйственного использования и планирование улучшения, деградация - в пределах 5-20\%; К - зона экологического кризиса, включает экосистемы с сильным снижением продуктивности, потерей устойчивости, трудно обратимыми нарушениями экосистем, предполагающими лишь выборочное их хозяйственное использование и планирование глубокого улучшения, деградация - в пределах 20-50\%; Б - зона экологического бедствия, включает экосистемы с полной потерей продуктивности, практически необратимыми нарушениями, полностью исключающими их из хозяйственного использования и требующими коренного улучшения (деградация превышает $50 \%$ ).

Обобщенные функции желательности. Рассмотрим две функции, использующиеся в качестве обобщенных функций желательности:

1. Вводится интерпретирующая (синтезирующая) функция $Q(q)=Q\left(q_{1}, \ldots, q_{m}\right)$, агрегирующая нормированные показатели $q_{1}, \ldots, q_{m}$ в единый интегральный (сводный) показатель $Q=Q(q)$, сопоставляя, $j$-му свойству (т.е. его многокритериальной оценке $\left.q^{(j)}=\left(q_{1}^{(j)}, \ldots, q_{m}^{(j)}\right)\right)$ некоторую числовую оценку $Q^{(j)}=Q\left(q^{(j)}\right)=Q\left(q_{1}^{(j)}, \ldots, q_{m}^{(j)}\right)$. На синтезирующую функцию, определяющую интегральный показатель, накладываются ограничения: $Q(0, \ldots, 0)=0, Q(1, \ldots, 1)=1,0 \leq Q \leq 1$. Простейшей синтезирующей функцией является линейная функция вида:

$$
Q=Q(q ; w)=Q\left(q_{1}, \ldots, q_{m} ; w_{1}, \ldots, w_{m}\right)=\sum_{i=1}^{m} q_{i} w_{i}
$$




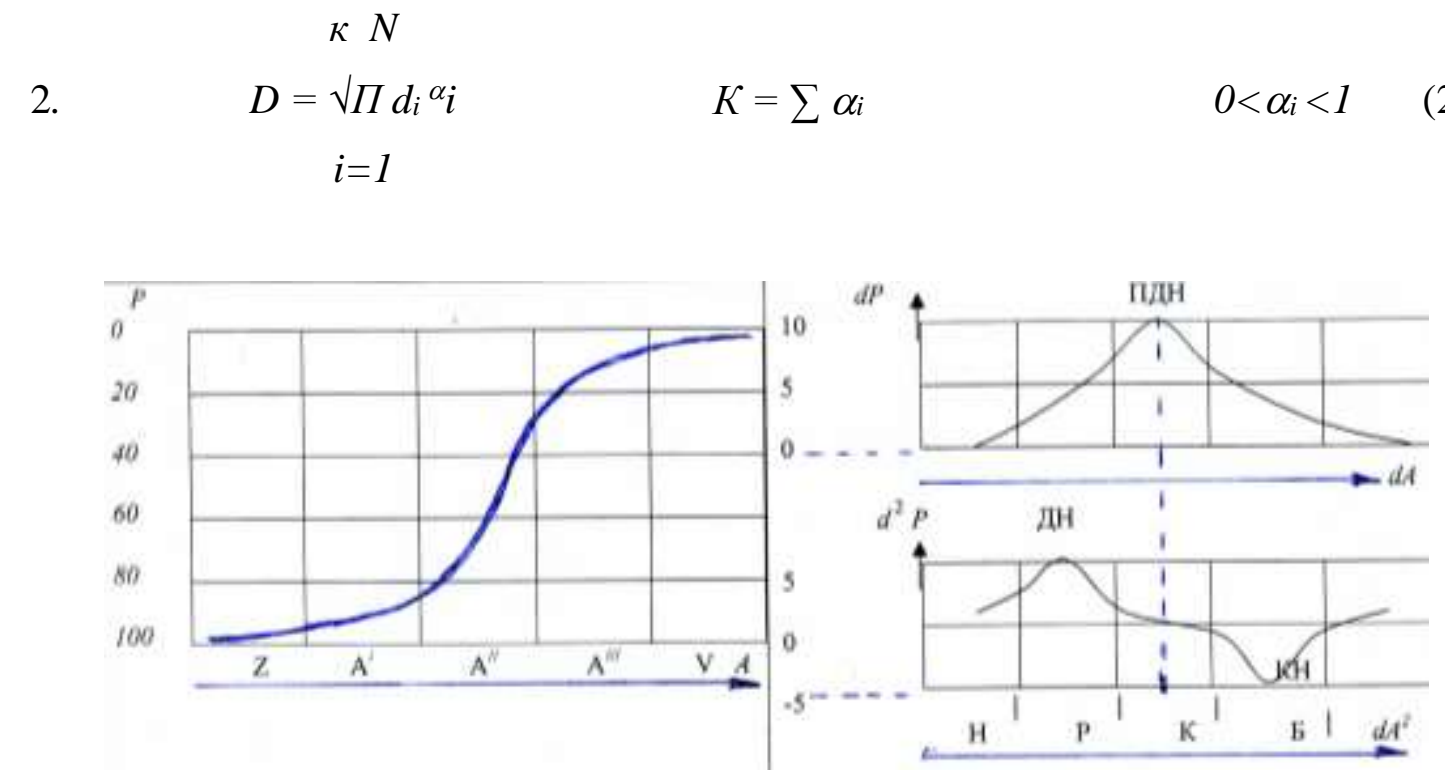

Рис.7. Вывод классов экологической напряженности: Н- норма, $\mathbf{P}$ - риск, $\mathbf{K}-$ кризис, $\mathbf{\mathbf { L }}-$ бедствие. Анализ зависимости $\mathrm{P}(\mathrm{A})$ : $\mathrm{P}$ - экологическая мишень, выбранная для характеристики стадий антропогенной трансформации экосистемы (\%); А - нагрузка на экосистему. Классы трансформации: Z - неизмененные, $\mathrm{A}^{\prime}$ - слабо, $\mathrm{A}^{\prime \prime}$ - средне, $\mathrm{A}^{\prime \prime \prime}$ сильно трансформированные, $\mathrm{V}$ - полностью трансформированные; $d A, d P$ - первая производная, $d A^{2}, d^{2} P-$ вторая производная.

В практических исследованиях также встречаются:

- индекс B.A. Абакумова (Руководство по гидробиологическому мониторингу пресноводных экосистем. СПб, 1992, 318 с.), рекомендуется для оценки загрязнения воды:

$$
I=\prod_{j=1}^{j=n} x_{j}^{(-1)^{k} a_{j}}
$$

где $n$ - число показателей; $x_{j}-j$-й показатель загрязнения; $a_{j}$ - показатель степени для $x_{j} ; k$ - показатель степени, определяющий характер вклада $j$-го показателя в загрязнение, т.е. $k=2 n$, если $x_{j}$ увеличивается с ростом загрязнения, $k=2 n-1$, если $x_{j}$ уменьшается с ростом загрязнения. Автор предлагает в пределах одного района использовать исходные значения характеристик, а для сравнения качества воды разных водоемов - нормировать каждый показатель в конкретной точке на величину среднего (фонового) его значения для всего водоема (Абакумов, 1992, с.142).

- индекс Т.И. Моисеенко с соавторами (Моисеенко, Родюшкин, Даувальтер, Кудрявцева, 1996). Вводятся два уровня свертки. На первом уровне вычисляются три индекса: токсический, физико-химический и индекс эвтрофирования:

$$
\mathrm{X}_{\text {ток }}=\sum\left(\frac{C_{i}}{\Pi Д K_{i}}\right) ; \quad \mathrm{X}_{\phi-\mathrm{x}}=\sum\left(\frac{C i}{C_{\text {фон } \max _{i}}}-1\right) ; \quad \mathrm{X}_{\text {эвт }}=\sum\left[\left(\frac{C i}{C_{\text {фон } \max _{i}}}-1\right) * 2\right]
$$

На втором этапе рассчитывается сумма этих индексов с разными весами:

$$
\mathrm{X}_{\mathrm{cyм}}=\mathrm{X}_{\phi-\mathrm{x}}+2 \mathrm{X}_{\text {эвт }}+3 \mathrm{X}_{\text {ток }}
$$




\section{Примеры обобщенных $d$-функций.}

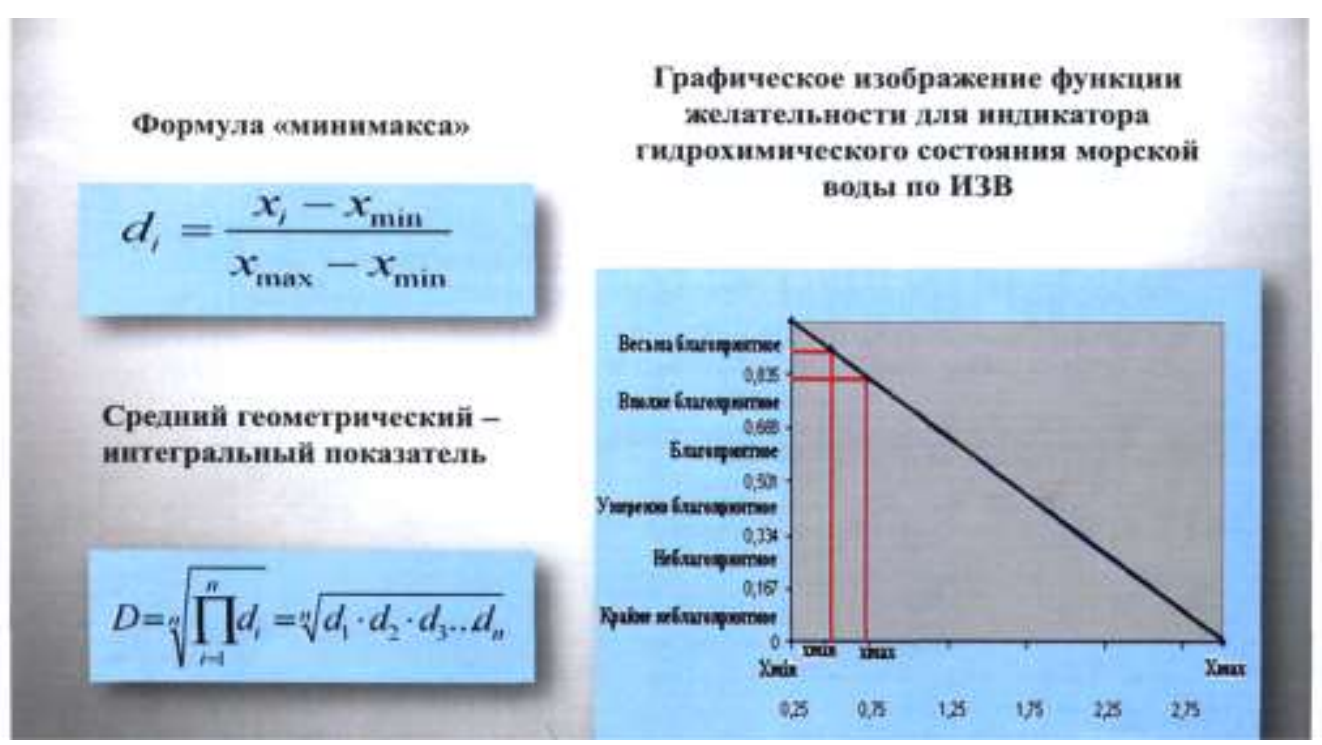

Рис.8 Пример использования варианта функции 2 из докторской диссертации Л.П. Ярмака «Методы и технологии экологической оценки и управления природно-техническими системами при проведении операций с нефтью (на примере прибрежной морской зоны Краснодарского края), СПб, РГГМУ, 2010.

Завершая рассмотрение индексов, приведем список их возможных формул, включающий как известные, так и оригинальные выражения:

$$
\begin{aligned}
& F_{1}=\sum_{i=1}^{k} \frac{x_{i j}}{\max _{i}\left[x_{i j}\right]}, F_{i}=\frac{1}{k} \sum_{i=1}^{k} \frac{x_{i j}}{\max _{i}\left[x_{i j}\right]} ; \\
& F_{2}=\sum_{i=1}^{k}\left[\frac{x_{i j}-\min \left[x_{i j}\right]}{\max _{i}\left[x_{i j}\right]-\min _{i}\left[x_{i j}\right]}\right], F_{2}^{\prime}=\frac{1}{k} \sum_{j=1}^{k}\left[\frac{x_{i j}-\min _{i}\left[x_{i j}\right]}{\max _{i}\left[x_{i j}\right]-\min _{i}\left[x_{i j}\right]}\right] \\
& F_{3}=\sum_{j=1}^{k} \frac{x_{i j}}{\min _{i}\left[x_{i j} \mid\right.}, F_{3}^{\prime}=\frac{1}{k} \sum_{j=1}^{k} \frac{x_{i j}}{\min _{i}\left|x_{i j}\right|}, F_{3}^{*}=\sum_{j=1}^{k} \frac{x_{i j}}{\min _{i}\left|x_{i j}\right|}-K ; \\
& F_{4}=\sum_{i=1}^{k} \frac{x_{i j}}{n \lambda K_{x_{j}}}, F_{4}^{\prime}=\frac{1}{k} \sum_{i=1}^{n} \frac{x_{i j}}{n \pi k_{x_{j}}} ; \\
& F_{\mathrm{s}}=\max _{1}\left[\frac{x_{i j}}{\min \left[x_{i j}\right]}\right] \\
& F_{\mathrm{a}}=\sum_{j=1}^{L} x_{i j} \\
& F_{2}=1-\left[\prod_{j=1}^{k}\left[1-\frac{x_{i j}-\min \left[x_{i j}\right]}{\left.\max _{i} \mid x_{i j}\right]-\min _{i}\left[x_{i j}\right]}\right]\right] \text {. }
\end{aligned}
$$

Вопросы для проверки усвоения материала:

1. Назовите основные стадии системного анализа применительно к исследованию природной системы.

2. Что такое аксиология и аксиометрия и зачем они нужны в оценочных исследованиях.

3. Расскажите о единичных, косвенных, комплексных, многокритериальных и интегральных оценках. 
4. К каким оценкам Вы отнесете балльные оценки.

5. Что такое «ннн»- информация.

6. Как можно использовать в количественных оценках качественную информацию.

7. Назовите основные этапы оценочных исследований.

8. Как правильно «свертка информации» или «свертывание информации».

9. Какие индексы состояния Вы знаете. Назовите их.

10. Назовите несколько известных Вам экспертных $d$-функций.

11. Расскажите о функции Харрингтона.

12. В функции Харрингтона имеется несколько критических точек, что позволяет задавать границы градаций желательности строгим образом. Есть ли смысл при задании границ между классами для линейной функции использовать те же граничные значения между классами.

13. Чем оценка экологического состояния может отличаться от оценки качества среды. Есть ли разница между такими оценками. Можно ли оценивать состояние сложной системы на основе покомпонентных оценок. В чем слабость таких оценок.

14. Можно ли прогнозировать «устойчивое развитие» описательными методами (на основе покомпонентных аддитивных оценок)?

15. Почему не целесообразно выполнять экологическую оценку на основе одного какого-либо одного (слабого, основного и т.п.) компонента экосистемы. Обоснуйте ответ.

16. В чем, по-Вашему, должно быть отличие между интегральным показателем «чувствительности» и интегральным показателем «устойчивости» растений к загрязнению атмосферы.

17. В некоторых, сравнительно недавно вышедших публикациях по оценке устойчивости водных экосистем к разливам нефти, идет речь о чувствительности экосистем (акваторий) к нефтяному загрязнению (см. рис. из статьи В.Б. Погребова и А.Ю. Пузаченко, 2003). В чем, на Ваш взгляд, разница между чувствительностью и уязвимостью (устойчивостью) экосистем. Можно ли считать их синонимами?

18. Что такое аксиология и аксиометрия и зачем они нужны в оценочных исследованиях.

19. Расскажите о единичных, косвенных, комплексных, многокритериальных и интегральных оценках.

20. К каким оценкам Вы отнесете балльные оценки.

\section{Литература}

Александрова Л.В., Васильев В.Ю., Дмитриев В.В. и др. Многокритериальные географо-экологические оценки состояния и устойчивости природных и урбанизированных систем. Под ред. В.В. Дмитриева и Н.В. Хованова. Деп. ВИНИТИ № 2342В00, 2000, 275 с.

Алимов А.Ф., Дмитриев В.В., Флоринская Т.М., и др. Интегральная оценка экологического состояния и качества среды городских территорий. Под ред. А.К.Фролова, СПб, 1999, $253 \mathrm{c}$.

Воробейчик Е.Л., Садыков О.Ф., Фарафонтов М.Г. Экологическое нормирование техногенных загрязнений наземных экосистем (локальный уровень). Екатеринбург: Изд. УИФ «Наука», 1994,280 с.

Гальцова В.В., Дмитриев В.В. Практикум по водной экологии и мониторингу состояния водных экосистем (учебное пособие). Изд. Наука - СПб., 2007. - 364 с.

Дмитриев В.В. Методика диагностики состояния и устойчивости водных экосистем //Эколого-географический анализ состояния природной среды: проблема устойчивости геоэкосистем. Под ред. П.П. Арапова и Ю.П. Селиверстова. СПб., Изд-во РГО, 1995. С.41-67.

Дмитриев В.В. Прикладная экология в системе высшего географического и гидрометеорологического образования / Вопросы прикладной экологии. Сборник научных трудов РГГМУ, СПб, Изд. РГГМУ, 2002, с.90-96.

Дмитриев В.В. Экологическая оценка, оценка качества среды, экологическое нормирование. Основные определения / В кн. Дмитриев В.В., Фрумин Г.Т. Экологическое нормирование и устойчивость природных систем. СПб., Изд. Наука, 2004, с.10-29.

Дмитриев В.В. Эколого-географическая оценка состояния внутренних водоемов. Автореферат докт. дисс. , СПб, 2000, $52 \mathrm{c}$.

Дородницын А.А. Математика и описательные науки // Число и мысль, 1982, вып.5., М., Изд. «Знание», с.6-15. Дородницын А.А. Математика и описательные науки // Число и мысль, 1982, вып.5., М., Изд. «Знание», с.6-15.

Исаченко А.Г. Ландшафтоведение и физико-географическое районирование. М., 1991, 366 с.

Колесов Д.Н., Михайлов М.В., Хованов Н.В. Оценка сложных финансово-экономических объектов с использованием системы поддержки принятия решений АСПИД-3W/ учебное пособие. ОЦЭиМ. СПб. 2004, 63 с.

Одум Ю. Основы экологии / Пер. с 3-го англ. изд. под ред. Н.П. Наумова. М., 1975, 740 с.

Розенберг Г.С. Модели в фитоценологии., М., «Наука», 1984, 265 с.

2011.

Стурман В.И. «Оценка воздействия на окружающую среду». Ижевск, Издательский дом «Удмуртский университет»,

Хованов Н.В. Анализ и синтез показателей при информационном дефиците. СПб,СПбГУ,1996, 195 с.

Harington, J. The Desirability Function. Industrial Quality Control, 1965, V. 21, № 10. P. 494-498.

Лекция №5
История взглядов на соотношение
детерминированного и случайного в моделях мира. Универсальная схема (модель) 
Методологические позиции наук, изучающих сложные системы в природе и обществе по О.А. Богатыревой (2006).

Объективное и субъективное понимание случайности при создании моделей.

Основные принципы теории сложных систем (системологии), о которых необходимо помнить при разработке моделей. Принцип интегративных уровней современный аналог принципа «бритвы Оккама». Принцип контринтуитивного поведения сложных систем (Дж. Форрестера, 1974, 1977, 1978). Принцип множественности моделей. Принцип осуществимости (Б.С. Флейшмана). Принцип несовместимости (Самарский, 1979, Заде, 1974). Системный подход и проблема целостности. Принципы системности (Ворощук, 1982).

История взглядов на соотношение детерминированного, случайного, холизма и элементаризма в моделях мира (по Дульнев, 1998, Дмитриев, 2008). По НьютоновоКартезианской модели мира ${ }^{1)}$ : материя существует в трехмерном (евклидовом) пространстве во времени; в мире наблюдается линейная причинно-следственная связь; материя, пространство и время независимы друг от друга; материальный мир имеет четко очерченные границы.

Таким образом, в классической механике процессы обратимы и там нет места случайности, все предопределено и все можно в принципе «вычислить».

Ученые XVIII - начала XIX в. были убеждены, что если задать законы движения (законы Ньютона), начальное положение тела в координатах $x_{o}, y_{o}$, zo и начальные скорости $V x o, V y o$, $V z o$, то поведение системы полностью определено и известно заранее, т.е. возможно рассчитать положение и скорости тел в любой момент времени в прошлом и будущем. Мир - часовой механизм, который был однажды заведен.

П.Лаплас (1749-1827) утверждал, что если бы существовал некий демон (теперь говорят «демон Лапласа»), способный определить начальные координаты и скорости, то, зная законы движения, можно было бы наперед рассчитать, что будет с движущимися молекулами.

Незнание субъективно, оно не отражает закона Природы, т.е. случайность в этой картине мира объективно не существует, за ней скрываются вполне детерминированные параметры системы. Их знает «демон Лапласа». Мы их не знаем.

Термодинамика ввела в научный обиход понятие вероятности. Однако еще ранее оно возникло в биологии. Для живого мира в XIX в. английский ученый Дарвин открыл основной закон его эволюции, который существенно отличался от закона эволюции косного мира. В органическом мире Дарвин подметил механизм эволюции естественный отбор.

Каждая популяция обладает наследственной изменчивостью, которая означает случайное отклонение от наиболее вероятного среднего значения какой-либо характеристики организма. Физический мир не несет памяти о своем эволюционном развитии; биологический мир несёт память об этом. В биологических системах наследственная изменчивость не затухает, как в физических, а наследует и закрепляет те

1) Картезианство - (от Картезий (лат. Cartesius) — латинизированного имени Декарта) направление в истории философии, идеи которого восходят к Декарту. Для картезианства характерны скептицизм, рационализм, критика предшествующей схоластической философской традиции. Помимо этого картезианство характеризуется последовательным дуализмом - предельно чётким разделением мира на две самостоятельные (независимые) субстанции - протяжённую (лат, res extensd) и мыслящую (лат, res cogitans), при этом проблема их взаимодействия в мыслящем существе оказалась в принципе неразрешимой. Для картезианства характерно также развитие рационалистического математического (геометрического) метода. Самодостоверность сознания (декартовское «мыслю, следовательно, существую»; «Cogito. ergo sum»), paвно как и теория врождённых идей, является исходным пунктом картезианской гносеологии. Картезианская физика, в противоположность ньютоновской, считала всё протяжённое телесным, отрицая пустое пространство, и описывала движение с помощью понятия «вихрь»; физика картезианства впоследствии нашла своё выражение в теории близкодействия. 
признаки, которые позволяют выжить. По Дарвину в мире происходит непрерывное рождение всё более сложно организованных живых форм, структур и систем. В косном мире эволюция ведёт для изолированной системы к состоянию равновесия, т.е. к затуханию разнообразия.

Биологическая теория говорит о повсеместном и непрерывном созидании Природы, а косный мир стремится к разрушению структур, выравниванию различий.

XIX век дал науке две великие теории эволюции для косного и животного мира. В косном мире развитие идет однонаправлено, в сторону роста энтропии, т.е. к выравниванию разнообразий форм, градиентов и т.д. В животном мире наоборот: развитие приводит к росту многообразия форм, т.е. к увеличению порядка и падению энтропии (системы замкнутые).

В середине XX в. Шредингер спрашивал: возможно существует два типа законов для живой и неживой материи? Этот вопрос оставался открытым до 1970-х гг, пока не возникло новое учение об эволюции, нашедшее свое выражение в синергетике.

Синергетика И. Пригожина - наука об универсальных законах эволюции в природе и обществе; о самоорганизации физических, биологических, социальных систем; о неустойчивых состояниях, предшествующих катастрофе; термодинамика открытых систем вдали от равновесия. Синергетика занимается исследованием «физических основ формирования структур». Классический, господствующий по сей день подход к управлению сложноорганизованными системами основывается на линейном представлении об их функционировании. Согласно этому представлению, результат внешнего управляющего воздействия есть однозначное и линейное, предсказуемое следствие приложенных усилий, что соответствует схеме: «управляющее воздействие желаемый результат».

В синергетике исследуются существенно неравновесные системы, т. е. системы, находящиеся вдали от состояний равновесия, существенно нелинейные процессы эволюции систем, такие процессы, когда при определенных условиях внутренние или внешние флуктуации могут привести систему к направленным изменениям, к возникновению различных новых относительно устойчивых структур, а не просто к прежнему состоянию равновесия. Если флуктуация недостаточно велика, то система вернется к прежней равновесной структуре, "скатится" на тот же самый аттрактор. Стало быть, процессы гомеостатического характера охватываются синергетикой как один из частных случаев в сфере ее исследования.

Синергетика делает еще один новый качественный шаг. Структуры-аттракторы, к которым идут процессы в открытых нелинейных средах, представляют собой, по сути, цели эволюции. А раз есть цели, то естественно встает вопрос и о ценности информации. Ценность связана со значением информации для достижения определенной цели. Без цели нет ценности: вопрос о ценности информации возникает лишь тогда, когда сформулировано представление о цели. Т.о., раз цели стали истолковываться как нечто объективное, как структуры-аттракторы эволюции, то возникает «объективность» и «ценности» информации.

Универсальная схема (модель) эволюционного процесса (см. рис.9).

AВ - начальный этап развития, медленное изменение свойств системы. Предсказуемость с точностью до случайных флуктуаций, не меняющих характера развития.

В - внешние воздействия достигают критического значения, или происходит кумуляция внутренних воздействий. Параметры системы начинают быстро изменяться. Состояние ранее стабильное теряет устойчивость и возникает возможность разных путей развития. В и В1 - точки бифуркации (точки ветвления решений, поле ветвящихся виртуальных путей эволюции).

Конус с штриховкой на рисунке - коридор траекторий, отличающихся отн. устойчивостью. Конус траекторий - аттрактор (цель). 
Из-за вероятностного характера бифуркационных процессов эволюция не может иметь обратного хода (необратимость эволюции и времени).

Таким образом, случайность - творческое, конструктивное начало, способное вывести систему на аттрактор, на одну из собственных структур среды, с учетом внутренней тенденции ее организации, движение с минимальным ростом энтропии.

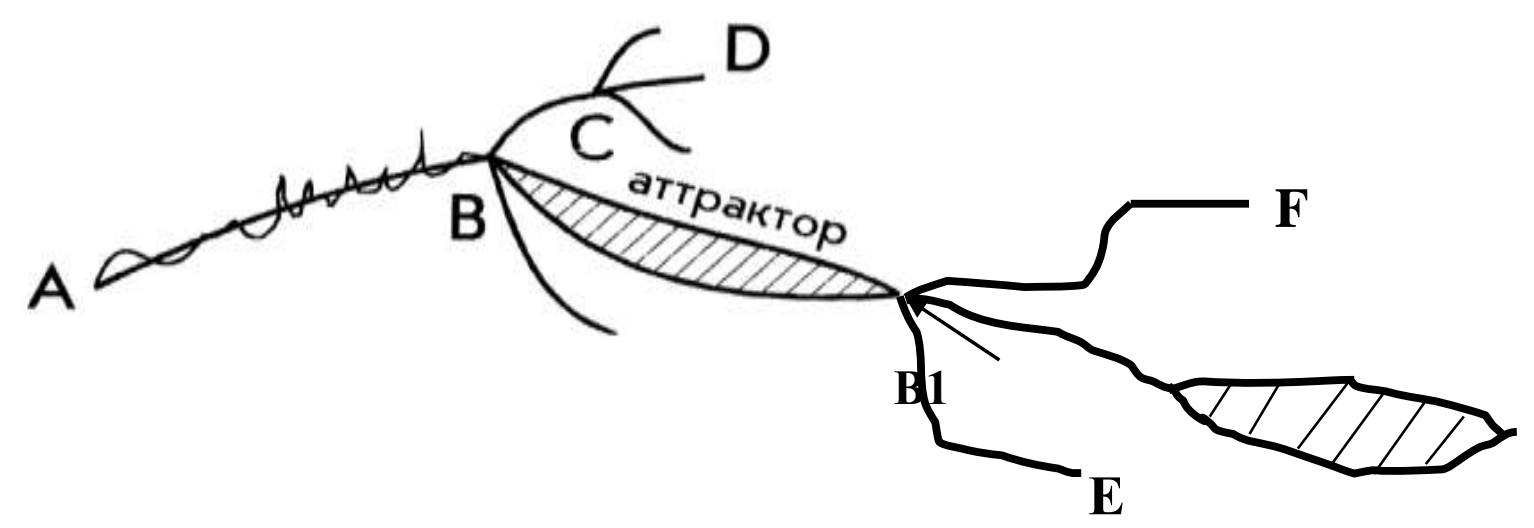

Рис. 9 Модель эволюционного процесса (Дульнев, 1998, Дмитриев, 2008)

А как обстоит сегодня дело в других науках, изучающих сложные системы в обществе, например, в социологии? В статье О.А.Богатыревой «Природа методологических трудностей синтеза социоэтологии и социологии человека и пути их разрешения» (Интернет-публикация, 2006) читаем: «Несомненно, что главной парадигмой современного рационалистического мышления должна стать идея единства определяющих особенностей всех процессов развития в косной природе, живом веществе и в обществе. Однако для практического применения одного декларирования единства оказывается недостаточно. В настоящее время антропоцентризм в целом потерял свои ведущие позиции на этом методологическом “поприще”. Осталось лишь потеснить его в частных вопросах и прийти к формулированию не только общесистемных закономерностей социальных трансформаций, но и наполнить их конкретным содержанием. Однако пока поиск причин эмерджентности человеческого социума даже в рамках системного подхода все еще многими специалистами сводится к постулированию неких особых "мифических" свойств элементов этого социума как системы. Иными словами, для применения системного подхода мало лишь декларации того, что социум представляет собой систему, необходимо еще создать и адекватную методологическую базу для его изучения».

Некоторые примеры-пояснения из схемы О.А. Богатыревой (рис.10).

Дарвинизм - триада Дарвина: изменчивость, наследственность, отбор.

Ортогенез - ортоэволюция - теория развития живой природы, утверждающая, что эволюция организмов происходит якобы в строго определенном направлении (подобно росту кристаллов в строго определенных плоскостях). Отрицает творческую роль естественного отбора в возникновении приспособлений у организмов, признавая идею изначальной целесообразности в природе. Изложена Т.Эймером (1888-97).

Концепции сукцессий. Экологическая сукцессия - это ценотическая серия, или автогенетическая смена стадий: пионерная стадия - промежуточные (сукцессионные) стадии - зрелое, коренное сообщество (климакс) (рис.10). От ранних стадий сукцессии к поздним меняется адаптивная стратегия: от r-отбора на ранних стадиях к К-отбору на поздних. 


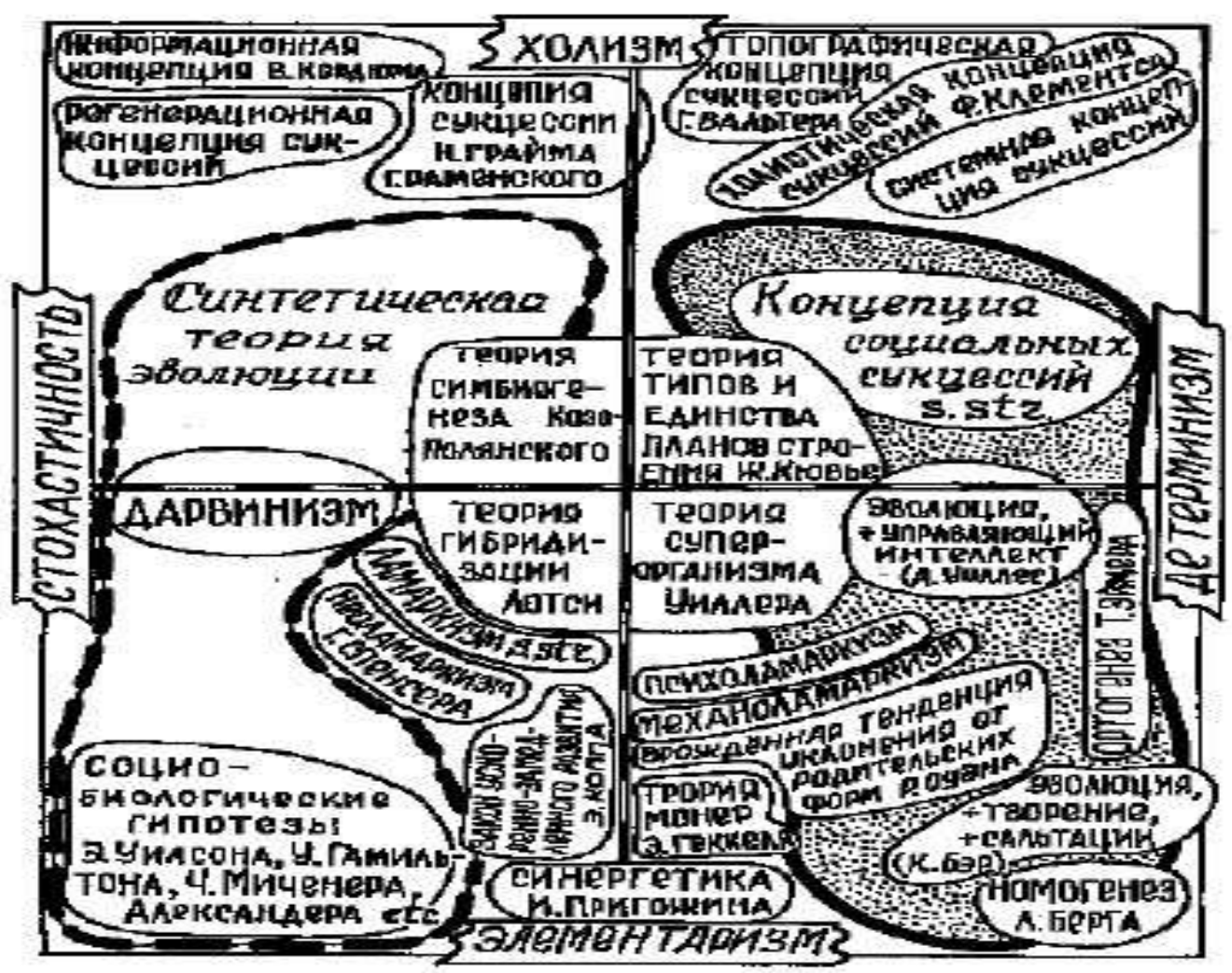

Рис. 10. Методологические позиции наук, изучающих сложные системы в природе и обществе. Схема из статьи О.А. Богатыревой (2006) «Природа методологических трудностей синтеза социоэтологии и социологии человека и пути их разрешения». Наш комментарий и дискуссия к схеме О.А. Богатыревой. Справедливо ли расположение осей под прямым углом друг к другу? Возможны ли случаи и примеры, где холизм ближе к детерминированности, а элементаризм ближе к стохастичности?

Ценотическая сукцессия подчиняется правилу сокращения производства энтропии в открытой системе. Пионерные и сукцессионные виды обладают более высокой продуктивностью (Р) относительно биомассы (В), чем климаксовые. В ходе сукцессии при общем увеличении биомассы отношение P/B сокращается. В этом же направлении сокращается и производство мортмассы, выводимой из биогенного круговорота веществ. Адаптивная стратегия изменяется в том же направлении, что и при эволюционной сукцессии. Разнообразие сообщества складывается из сукцессионных и климаксных компонентов. По мере вхождения климаксных видов в сукцессионные группировки разнообразие возрастает. Когда ценотические процессы протекают в условиях периодических колебаний природной среды, сукцессионные группировки не вытесняются полностью климаксовыми и разнообразие в такой системе максимальное.

Концепция социальных сукцессий. Термином сукцессия обозначают всякую последовательность, в том числе эволюционную. От эволюционной сукцессии экологическая сукцессия отличается территорией и масштабом времени. О.А. Богатыревой предложена системная теория развития социального образа жизни - концепция социальных сукцессий: последовательных смен устойчивых состояний сообществ и циклических смен этих состояний в зависимости от такой характеристики системы, как его относительная энтропия: соотношение хаотизирующих и упорядочивающих процессов в системе. Социальная экология опирается не только на достижения гуманитарных наук, но использует также фундаментальные концепции теории эволюции и экологии. Однако связь между ними нередко теряется из-за различных масштабов времени. В качестве связующего звена между эволюцией и экологическими процессами 
выступает сукцессия - последовательность стадий формирования экосистемы или биотического сообщества.

И далее: «Основные виды социальной активности большинства видов животных не могут быть описаны на основе стохастических принципов. Детерминированность, проявляющаяся подчас как “воля”, может иметь как внутренний, так и внешний источник. Остается вопрос, как же построить теоретическую базу науки, имеющей дело со сложными целеполагающими системами, да еще обладающими определенной свободой выбора действий? Представим себе поле логических возможностей всех методологических позиций обсуждаемой сферы науки и изобразим ситуацию для наглядности графически. Квадранты поля определяются двумя осями, на концах которых находятся крайние методологические взгляды исследователей: вертикальная ось соответствует противопоставлению холизма (универсализма) и элементаризма (атомизма), а горизонтальная - противопоставляет жесткому детерминизму и однозначности толкования - вероятностные процессы» (см. рис., поясняющий основные теоретические концепции, объясняющие механизмы возникновения и развития сообществ и рис с комментарием к нему).

По сути уже сегодня речь идет об умении оценивать и прогнозировать развитие социо(эко)систем под которыми мы понимаем физико-географическая среду + биоценозы + население + экономику + культуру + политику.

Объективное и субъективное понимание случайности при создании моделей. Часто в исследованиях сложных систем в природе и обществе вероятность используется не в объективном, а в субъективном её понимании. Не отвергая права на существование такого понимания (например, в гуманитарной сфере), в географических и экологических исследованиях речь должна идти об использовании вероятности в объективном смысле, которое предполагает выполнение двух условий: 1 - многократное повторение процессов при одном и том же комплексе факторов; 2 - статистические характеристики (математическое ожидание, среднее квадратическое отклонение, и др.) являются не случайными и не известными для исследователя, но не по причине незнания сведений о процессе, а по причине невозможности иметь дело с генеральной совокупностью данных.

Когда исследователи формулируют или используют модели, легко впасть в соблазн:

- считать модели стохастическими, если для одного или нескольких параметров модели с известным диапазоном их изменения (чаще всего получаемых методами первичной статистической обработки) рассчитываются сценарии по перебору параметров с некоторым шагом (или по выбору);

- реализованные на моделях сценарии не являются реализациями случайного процесса, но они могут стать таковыми, если мы будем многократно воспроизводить на ПК (разыгрывать) варианты обобщенной модели, в которых параметры частных моделей задаются в обозначенных границах случайным образом, например с помощью датчика случайных чисел и затем работать с реализациями модельных расчетов.

Таким образом, в детерминированную модель сознательно вносится стохастический неконтролируемый фактор.

Наш вывод. Если искать парадигму в соотношении детерминированности и случайности в моделях сложных систем, то её можно представить:

- в форме аддитивно наложенных детерминированной (Д) и стохастической (C) составляющих, при моделировании процессов в обобщенной модели, например, следующим образом:

Моделируемый процесс $=Д^{*} \boldsymbol{a}+\boldsymbol{C}^{*}(1-a), \quad$ где вес «а» изменяется от 0 до 1. или: 
- в форме аддитивно наложенных детерминированной (Д), стохастической (С), холистической $(\mathrm{X})$ (и других) составляющих в модельных описаниях объектов, процессов, явлений, например, по следующей схеме:

$$
\text { Моделируемый процесс }=\not \cdot d+C \cdot c+X \cdot b+\ldots,
$$

где весовые множители $d, c, b(u d p$.) изменяются от 0 до 1 , а их сумма равна 1.

Основной вывод. Парадигмальный переход в науках о Земле и обществе, в связи с вымеизложенным, будет связан с возможностями модельного описания современных сложных систем в природе и обществе, «исследованием взаимодействия между природными и общественными территориальными системами», поиском соотношения в них свободы выбора поведения, детерминированности и случайности, а также способности систем после оказанных на них воздействий выходить на одну из устойчивых собственных структур, с учетом внутренней тенденции ее организации. Таким образом, следуя акад. А.А. Дороднииьну, модели выступают в качестве инструмента преобразования сложных систем в природе и обществе и дают надежду на переход наук о Земле и обществе из описательного периода развития в точный.

Основные принципы теории сложных систем (системологии). Моделирование, в особенности математическое, является основным способом построения теории в системологии. При этом любая модель должна отвечать некоторым целям и задачам строящейся теории. Кроме того, при построении теории сложных систем необходимо иметь в виду и ряд специфических принципов, отличающих эти теории от теорий простых систем, построенных, например, в некоторых разделах физики и химии. К этим принципам, прежде всего, следует отнести: принцип иерархической организации сложных систем, принцип осуществимости моделей сложных систем, принцип множественности моделей, принцип несовместимости и принцип контринтуитивного поведения сложных систем.

\section{1. Принцип иерархической организации (или принцип интегративных уровней;}

Одум, 1975) Современный аналог кибернетического принципа «бритвы Оккама». Позволяет обозреть все многообразие окружающей природы и соподчинить друг другу как естественные, так и искусственные системы. Обобщая ряд исследований в этом направлении (Гупало, Литвак, 1974; Одум, 1975; Глушков и др., 1979; Флейшман, 1982 и др.), можно выделить несколько последовательно возникших иерархий, которые представлены на рис. 11. Кроме них можно вспомнить иерархию геосистем и иерархию экосистем (см.ниже).

Данная схема достаточно условна (например, такой объект, как почва, должен рассматриваться как объединение объектов иерархий А, Б и В, а промысловохозяйственные системы - как объединение объектов иерархий В, Г и Д). Несмотря на это, принцип иерархической организации оказывается весьма полезным при изучении сложных систем. Он широко используется при их моделировании в виде рекурентного принципа построения моделей (Флейшман, 1982), когда свойства систем некоторого уровня выводятся (объясняются) на основе постулируемых свойств и связей их элементов, то есть систем непосредственно нижестоящего уровня (в частности, свойства растительного сообщества должны выводиться из постулируемых свойств и связей слагающих его растительных популяций). Такой принцип построения моделей может рассматриваться как современный аналог кибернетического принципа «бритвы Оккама». 


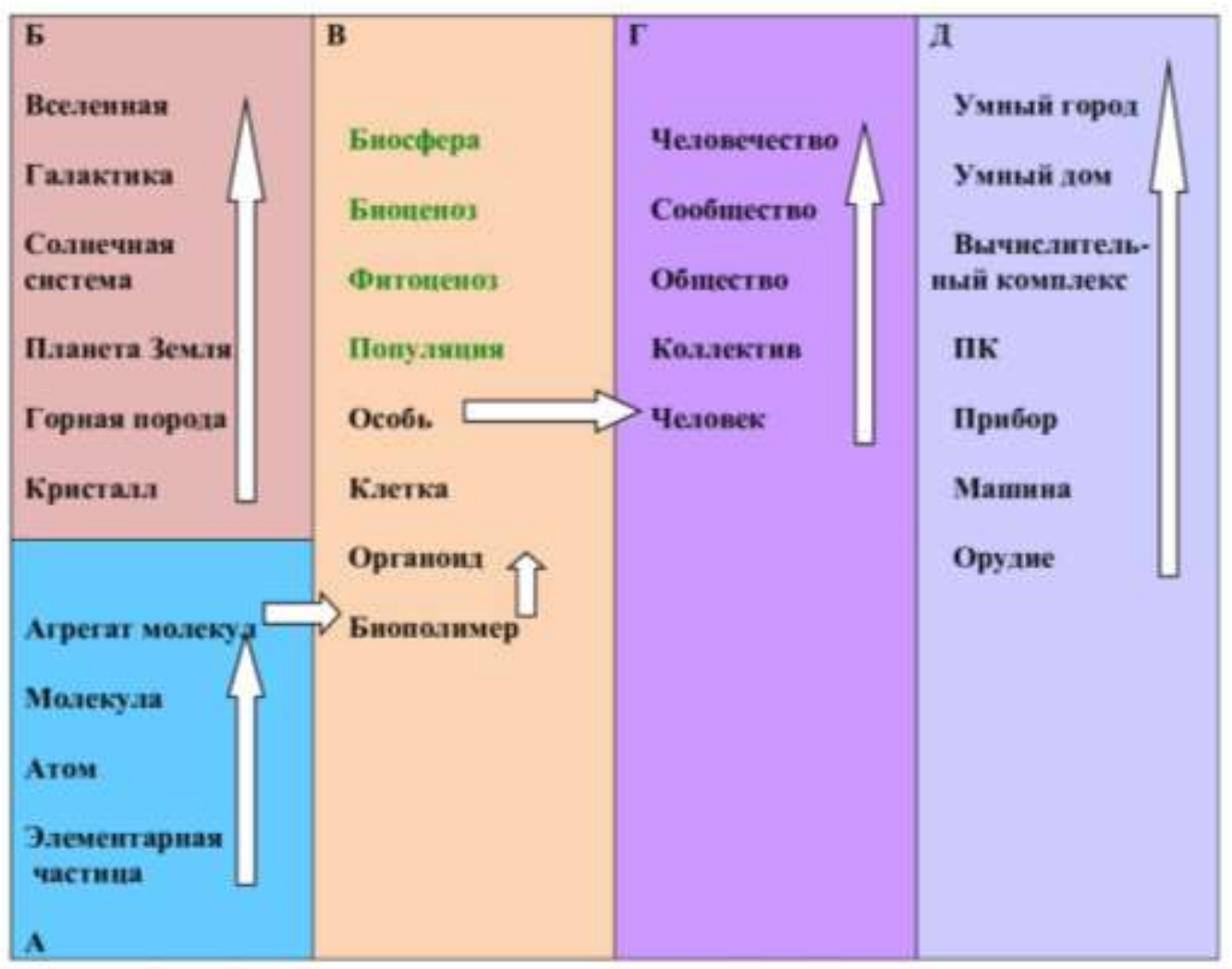

Рис.11 Иерархическое соподчинение систем разной природы: А - физическая иерархия; Б - геологическая иерархия; В - биологическая иерархия, Г - социальная иерархия; Д - техническая иерархия. Подсветкой текста отмечена часть биологической иерархии, исследуемая экологией и фитоценологией.

Принцип «бритвы Оккама», известный в науке так же, как «принцип бережливости», «принцип простоты» или «принцип лаконичности мышления» был сформулирован в XIV в. английским философом Уильямом Оккамом и в следующем виде: frustra fit plura, quod fieri potest pauciora - не следует делать посредством большего то, чего можно достичь посредством меньшего (Бирюков, Широков, 1968; Лем, 1968; Флейшман, 1982). Иногда переводят: «Не преумножайте сущности бытия». Этот же принцип проглядывается и в известном лозунге И. Ньютона: «Гипотез я не придумываю!».

Границы экосистем и экотоны. Граница экосистемы - переходная полоса, в пределах которой меняется соотношение (баланс) экологических компонентов (системообразующий фактор), а, следовательно, изменяются факторы среды и видовой состав биоты (Реймерс, 1990, с.105). Обычно бывает нечеткой в связи с тем, что это понятие отражает не столько морфологическую, сколько функционально-системную характеристику экосистемы.

По И.И. Дедю (1990, с.336) под экотоном понимается зона напряжения, переходная зона между двумя соседствующими климаксными сообществами, где происходит их взаимопроникновение. Может иметь значительную линейную протяженность, но всегда бывает уже территории соседних сообществ. Например, в состав водной геосистемы входят граничные экотоны: приводный, придонный, прибрежный, пойменный, отличающиеся специфичным составом биоты и абиотической среды. Выделение границ экосистем во многом еще не разработано. Но уже появились работы, в которых намечены пути решения данной проблемы (см. А.Н.Ласточкин «Общая теория геосистем», 2011). В этой монографии А.Н.Ласточкина намечены подходы и приведены 
методы геоморфологической структуризации земной поверхности, выделения границ и картографическое решение проблем их визуализации.

Понятие «экотон» («oikos» - дом, «tonus» - напряжение) впервые было введено в 1903 г. Б. Ливингстоном (Livingston, 1903). Автор термина подчеркивал особое «напряжение» жизни, то есть количественное развитие и повышение видового богатства в переходных зонах между сообществами в сравнении со смежными участками, а также частое экзогенное стрессовое воздействие абиогенных факторов на среду. Таким образом, экотоны - это переходные, граничные пространства между различными природными системами (экосистемами, ландмафтами), между природными и антропогенными системами, между различными средами (вода-суша) и между различными природными зонами. Распространенность экотонов в природе велика, а роль в биоценозах весьма существенна. Эти переходные пространства имеют специфическую структуру и служат местом формирования и сохранения видового и биологического разнообразия. Развитие понятия «экотон» шло от узкого значения применительно к конкретным растительным сообществам до категории «экотонная экосистема» (Залетаев, 1997; Папченков, 2003; Золотокрылин, 2003, 2007; Коломыц, 2005, 2008), однако, несмотря на огромный интерес к характеристикам и поведению экотонов (Розенберг, 2001, 2005; Кафанов, 2005, 2006; Миркин, 2005; Соловьева, Розенберг, 2006), на сегодняшний день отсутствует общепризнанный методологический и теоретический аппарат, описывающий и объясняющий динамику экотонов, как самостоятельных объектов изучения. Термин активно используется и продолжает развиваться в связи с исследованиями в геоботанике и фитоценологии, географии и зоогеографии, гидробиологии и гидроботанике, экологии и геоэкологии. Экотоны являются объектами изучения многих зарубежных ученых (Prach and Rauch, 1992; Janik, 1992; Fortin and Drapeau, 1995; Chen, 2002; Peters et al, 2006). Однако большая часть зарубежных и российских исследований представляет собой описание отдельных экотонов, их особенности и классификацию. Существуют исследования, в которых поведение экотонов описывается с помощью метода сигмовидных волн с элементами дисперсионного анализа (Hufkens et al, 2008, 2009), разрабатывались подходы к описанию экотона на основе использования нечетких множеств (Fortin, 1994; Jacquez et al, 2000; Fisher et al, 2006) для описания характеристик экотона (длины, ширины, формы). Для обнаружения границ экотонов авторами используются различные методы на основе вейвлет-анализа и двумерные методы обнаружения края с использованием фильтров и ядер (Hobbs et al, 1990; Csillag and Kabos, 2002). Для обнаружения и описания характеристик экотонов, анализа динамики поведения их границ, наряду с полевыми измерениями широко используются данные дистанционного зондирования (Nystrom et al, 2012; Heiskanen, 2006; Hill et al., 2007; Ranson et al., 2004; Weiss \& Walsh, 2009; Zhang et al., 2009). Наблюдения во многих природных зонах показывают, что процесс возникновения новых экотонов различного уровня сложности организации в настоящее время быстро прогрессирует. Этот процесс получил название «экотонизации биогеоценотического (экосистемного) и ландшафтного покровов» (Залетаев, 1997). Таким образом, в наши дни существует потребность в теоретической проработке имеющихся данных об экотонах и построение моделей динамики и поведения экотонов.

2. Принцип осуществимости позволяет отличить модели сложных систем от обычных математических моделей. Математические модели требуют только указания необходимых и достаточных условий существования решения (логическая непротиворечивость, т. е. ответ на вопрос: что есть на самом деле?) модели конструктивной математики - дополнительно к этому указания алгоритма нахождения этого решения (например, путем полного перебора всех возможных ситуаций, т. е. ответ на вопрос: как надо это сделать?). Системология рассматривает только те модели, для которых такой алгоритм осуществим, т. е. решение может быть найдено с заданной вероятностью за заданное время (преодоление сложности или ответ на вопрос: что мы 
можем сделать?). Иными словами, принцип осуществимости может быть сформулирован следующим образом: мы не надеемся на везение и у нас мало времени. Теория осуществимости развита в работах Б. С. Флейшмана $(1963,1971)$ как раздел теории потенциальной эффективности сложных систем. Этот принцип является наиболее формализованным в системологии.

3. Принцุип множественности моделей, гласящий, что для объяснения и предсказания структуры и (или) поведения сложной системы в пределах ошибок наблюдений возможно построение нескольких моделей (Налимов, 1971), формализован в меньшей степени. Множественность моделей проявляется даже в такой «строгой» области знания, как современная физика - в частности, известно несколько теорий квантовой физики, на разных принципах, объясняющих наблюдаемые явления. Один из крупнейших физиков-теоретиков Р. Фейнман (1968, с. 186) замечает, что «каждый приличный физиктеоретик знает шесть или семь теоретических обоснований одних и тех же физических фактов. Он знает, что они эквивалентны и что никто и никогда не сможет решить, оставаясь на этом же уровне, какая из этих теорий верна, но он помнит о них всех, надеясь, что это подскажет ему разные идеи для будущих догадок».

По укоренившейся традиции научного мышления понимание явления отождествляется с возможностью его количественного анализа.

4. Принцип несовместимости Л. Заде (1974) накладывает ограничения на эти возможности: чем глубже анализируется реальная сложная система, тем менее определенны наши суждения о ее поведении. Иными словами, сложность системы и точность, с которой еe можно анализировать, связаны обратной зависимостью. Несовместимость «простоты» модели и точности решения задачи проявляется и в следующем высказывании А. А. Самарского (1979, с. 28): «...исследователь постоянно находится между Сциллой усложненности и Харибдой недостоверности. С одной стороны, построенная им модель должна быть простой в математическом отношении, чтобы ее можно было исследовать имеющимися средствами. С другой стороны, в результате всех упрощений она не должна утратить и «рациональное зерно», существо проблемы».

5. Принцип контринтуитивного поведения сложной системы был сформулирован Дж. Форрестером (1974, 1977, 1978), который один из первых обратил внимание на то, что дать удовлетворительный прогноз о поведении сложной системы на достаточно большом промежутке времени, опираясь только на собственный опыт и интуицию, практически невозможно. Наша интуиция «воспитана» на общении с простыми системами, где связи элементов практически всегда удается проследить. Контринтуитивность поведения сложной системы состоит в том, что она реагирует на воздействия совсем иным образом, чем это нами интуитивно ожидалось. Этот принцип, как и принщип несовместимости, совсем не формализован (правда, Дж. Форрестер приводит большое число примеров его проявления и указывает пути преодоления связанных с ним трудностей).

\section{Системный подход и проблема целостности.}

Познать целое (целостную систему), значит раскрыть: компонентов);

- состав (количественные и качественные характеристики его частей,

- структуру (внутреннюю организацию);

- функции (как функции частей работают на общие функции);

- интегративные системные факторы (механизмы, обеспечивающие целостность системы, её совершенствование, развитие, взаимодействие, коммуникацию с внешней средой, связь с более общим целым);

- историю данного целого (начало, источник возникновения, становления, тенденции и перспективы развития, превращения в новую систему).

Принципы системности (Ворощук, 1982). 
Специалисты по теории принятия коллективных решений (Ворощук, 1982) также выдвигали ряд важных принципов, называя их принщипами системности, которые необходимо соблюдать при построении имитационных систем, например:

- требование непротиворечивости критериев исследования запрещает навязывать противоречивые условия развития процесса в системных исследованиях;

- вводимая совокупность модельных параметров должна быть одновременно установлена количественно, должна иметься возможность синхронного установления величин параметров в определенные моменты времени;

- введенные параметры должны иметь смысл на всем рассматриваемом пространстве и этот смысл должен оставаться неизменным в ходе всего процесса исследования;

- принцип консервативности (проверка законов сохранения вещества в модели)

и др.

\section{Вопросы для проверки усвоения материала:} экосистем.

1. Каким образом можно вводить случайность в детерминированные модели

2. Почему эволюция необратима во времени.

3. Какова может быть размерность компонентов биоценоза (биотопа) в экологической модели.

4. Назовите примеры сложных систем в природе и обществе.

5. Назовите основные иерархии сложных систем в природе (обществе) и определите их подсистемы.

6. Назовите основные принципы теории сложных систем (системологии). Зачем они нужны.

7. Перечислите основные стадии системного анализа в изучении сложных систем в природе и обществе.

8. Расскажите о принщипах системности, которые необходимо соблюдать при построении моделей.

9. Может ли быть эмерджентной структура сложной системы.

10. В общении мы иногда употребляем слово «плеяда», понимая под ним совокупность, скопление каких-либо однородных событий, явлений, составляющих нечто единое, цельное. Можно ли на ваш взгляд использовать этот термин для характеристики сложной системы. Какими свойствами, в этом случае должны обладать события, явления, составляющих нечто единое, цельное.

\section{Литература}

Айзатуллин Т.А., Шамардина И.П. Математическое моделирование экосистем континентальных водотоков и водоемов // Общая экология. Биоценология. Гидробиология. М., 1980. Т.5. (Итоги науки и техники ВИНИТИ АН СССР), c.154-228.

Бигон М., Харпер Дж., Таунсенд К. Экология. Особи, популяции и сообщества: В 2-х т. Пер. с англ. М. Мир, 1989.

Богатырева O.A. Природа методологических трудностей синтеза социоэтологии и социологии человека и пути их разрешения. Интернет-публикация, 2006

Воробейчик Е.Л., Садыков О.Ф., Фарафонтов М.Г. Экологическое нормирование техногенных загрязнений наземных экосистем. Екатеринбург, 1994, 280 с.

Дедю И.И. Экологический энциклопедический словарь. Кишинев, 1990, 406 с.

Дедю И.И. Экологический энциклопедический словарь. Кишинев, 1990, 406 с.

Дмитриев B.B. Баланс естественной и общественной географий и является ли этнос геосистемой. «Географические и геоэкологические аспекты развития природы и общества». Сборник научных статей по материалам отчетных научно-практических конференций 2006-2007 гг. Под ред. Каледина Н.В., Дмитриева В.В., Алиева Т.А., СПб, Наука, 2008, с.34-51.

Дмитриев В.В. Баланс естественной и общественной географий и является ли этнос геосистемой? Географические и геоэкологические аспекты развития природы и общества. Сборник научных статей по материалам отчетных научно-практических конференций 2006-2007 гг. Под ред. Каледина Н.В., Дмитриева В.В., Алиева Т.А., СПб, Наука, 2008, с. 34-51.

Дмитриев В.В. Диагностика и моделирование водных экосистем. СПб, 1995, 215 с. 
Дмитриев В.В. Моделирование круговорота вещества в водных экосистемах умеренных широт. Диссертация на соискание уч. степени канд. геогр. наук, Л., ЛГУ,1987, 286 с.

Дмитриев В.В. Эколого-географическая оценка состояния внутренних водоемов. Автореф. докт. дисс., СПб,

2000.

Дмитриев В.В., Воропаева Г.М. Идеи устойчивого развития в программе обучения специалистов-экологов на кафедре экологической безопасности и устойчивого развития регионов. В сборнике «Образование для устойчивого развития», Материалы Всероссийского совещания «Образование для устойчивого развития». Под ред. Н.С. Касимова и В.С. Тикунова. Смоленск, 2003, с.60-72.

Дмитриев В.В., Кулеш В.П., Сергеев Ю.Н., Третьяков В.Ю. Моделирование экосистем. Часть 1. Методическое пособие. - СПб., 2006. - 16 с.

Дмитриев В.В., Фрумин Г.Т. Экологическое нормирование и устойчивость природных систем. Учебное пособие. СПбГУ-РГГМУ, изд-во «Наука», СПб, 2004, 294 с.

Дородницын А.А. Математика и описательные науки // Число и мысль, 1982, вып.5., М., «Знание», с.6-15.

Дульнев Г.Н. Введение в синергетику. СПб, Изд. «Проспект», 1998, 256 с.

Красилов В.А. Нерешенные проблемы теории эволюции. - Владивосток, 1986.

Лопатников Л.И. Экономико-математический словарь. Под ред. акад. Н.П.Федоренко. М., Наука, 1987, 509c.

Марфенин Н.Н. «Устойчивое развитие человечества», М., МГУ, 624 с.

Миркин Б.М. Экологический гамлетизм. «Химия и жизнь», 1992, №2.

Одум Ю. Основы экологии / Пер. с 3-го англ. изд. под ред. Н.П. Наумова. М., 1975, 740 с.

Пригожин И. Перспективы исследования сложности.// Системные исследования: методологические проблемы. - M., 1986. - C. 45-57.

Реймерс Н.Ф. Природопользование: Словарь-справочник. М., 1990, 638 с.

Розенберг Г.С. Модели в фитоценологии., М., «Наука», 1984, 265 с.

http://economics.wideworld.ru

http://politics5.ru

http://ru.wikipedia.org

\section{Лекция №6}

Устойчивости и уязвимость природных объектов к изменению параметров естественного и антропогенного режимов. Основные понятия, связанные с устойчивостью экосистем. Два основных определения устойчивости. Адаптационная и регенерационная устойчивость. Определение устойчивости по И.Н. Росновскому (1993). Устойчивость экосистемы по И.И. Мазуру и О.И. Молдаванову (1989). Устойчивость природных систем по В.А. Светлосанову (1990). Устойчивость биосистем. Устойчивость геосистем и экосистем. Адаптационная устойчивость и принцип Ле-Шателье-Брауна. Устойчивость по Лагранжу, Ляпунову, Холлингу, Одуму, Свирежеву и Логофету. Устойчивость по В.Ф.Шуйскому (1997). Критерии оценки устойчивости. Индикаторный подход к оценке устойчивости. Обобщение современных подходов к оценке устойчивости геосистем. Примеры авторских подходов.

Научный интерес к проблеме оценки устойчивости и изменчивости природных экосистем и геосистем различных уровней иерархии, сформировался в конце 1960-х - начале 1970-х годов. С одной стороны, это объяснялось успехами, достигнутыми классической экологией и бурным развитием математической экологии, с другой стороны, необходимостью получения количественных оценок нагрузок на экосистемы, превышение которых приведет к "экологической катастрофе", т.е. разрушению экосистем. С решением этой проблемы неразрывно связана и проблема экологического нормирования, основным содержанием которой является поиск нормы состояния природной экосистемы, нормы воздействия на нее и ответной реакции экосистемы на внешнее воздействие.

Несмотря на новизну данной проблемы, она уже успела обрасти изрядным количеством терминов, большей частью заимствованных из техники, математики и общей теории систем. Стабильность, инертность, инериионность, инвариантность, равновесие, упругость, надежность, долговечность, пластичность, эластичность, саморегуляция, организованность, гомеостазис, - вот далеко не полный терминологический аппарат, которым оперируют исследователи, затрагивая проблему устойчивости. Понятие "устойчивости" в экологии и смежных науках является наиболее полисемантичным. Прежде всего, так называют несколько разных свойств биосистем 
надорганизменного уровня. Далее, в пределах каждой из этих категорий имеется множество более конкретных ее определений и, соответственно, способов оценки, выражающих собственные представления различных исследователей о ее наиболее приоритетных критериях. В связи с этим в экологической литературе используются термины, обозначающих не только различные, но, часто, одни и те же категории устойчивости: устойчивое равновесие, гомеостаз, способность сохранять гомеостаз, резистентность, упругость, резистентная устойчивость, упругая устойчивость, живучесть, персистентность, самоорганизуемость, устойчивость к воздействию, и т.д.; в англоязычной литературе - stability, perseverance, firmness, steadiness, elasticity, resilience, stationary, и др. Большинство этих терминов произвольно используется авторами в разных значениях, для выражения собственных представлений об устойчивости. Наиболее очевидно различие двух основных значений термина устойчивость: во-первых, устойчивость, как способность системы длительно существовать, сохраняя свои основные свойства, или в неизменной среде, или в среде, изменения которой не принимаются исследователем во внимание; во-вторых, устойчивость, как способность системы противостоять внешнему воздействию, сохраняя свои свойства.

Чаще всего в экологической литературе термин устойчивость используется в следующих значениях. Инертность системь - способность экосистемы сохранять при внешнем воздействии исходное состояние в течение некоторого времени; пластичность системь - способность экосистемы переходить из одного состояния равновесия в другое, сохраняя при этом внутренние связи; восстанавливаемость системь - способность экосистемы возвращаться в исходное состояние после временного внешнего воздействия. Первые два понятия трактуются как адаптацционная устойчивость, третье - как регенерационная.

Как отмечал И.Н. Росновский (1993), если убрать эмоциональные и словесные "накрутки", то все определения устойчивости природных систем сходятся в одном: устойчивость системы - это ее способность сохранять свои свойства и параметры режимов в условиях действующих внутренних и внешних возмущений. Такое определение совпадает с определением устойчивости в общей теории систем в кибернетике (Кафаров,1985; Ackoff, 1960; Bertalanfi, 1962). По И.И. Мазуру и О.И. Молдаванову (Мазур, Молдаванов, 1989) устойчивость - это свойство, внутренне присущее экосистеме, характеризующее способность: выдерживать изменения, создаваемые внешними воздействиями; оказывать сопротивление внешним (техногенным) воздействиям; обнаруживать способность к восстановлению или самовосстановлению экосистемы. В.А. Светлосанов (1990) ввел понятия простой, эластичной и упругой стабильности природных экосистем. Эластичной стабильностью он называет способность экосистемы вернуться в положение равновесия после кратковременного (не очень большого по амплитуде) возмущения, если период между возмущениями меньше времени релаксации системы. Чем меньше время возвращения системы после возмущения в устойчивое положение равновесия, тем эластичнее природная экосистема. В том случае, когда имеется лишь одно положение равновесия, в зависимости от того, насколько оно устойчиво к возмущениям, можно говорить о простой стабильности или нестабильности природных систем. Определения, связанные с устойчивостью водных экосистем обобщены в табл. 10.

Таблица 10. Основные понятия, связанные с устойчивостью экосистем (Дмитриев, 1995, 2000, 2004, 2007).

\begin{tabular}{|l|l|}
\hline \multicolumn{1}{|c|}{ Понятие } & \multicolumn{1}{|c|}{ Авторское определение понятия } \\
\hline $\begin{array}{l}\text { 1.Устойчивость } \\
\text { экосистемы к воздействию. }\end{array}$ & $\begin{array}{l}\text { Способность экосистемы сохранять квазипостоянными свои свойства и параметры } \\
\text { режимов в условиях действующих внутренних и внешних возмущений. }\end{array}$ \\
\hline 2. Уязвимость экосистемы. & $\begin{array}{l}\text { Утрата экосистемой (отсутствие у экосистемы) способности сохранять } \\
\text { квазипостоянными свои свойства и параметры режимов в условиях действующих } \\
\text { внутренних и внешних возмущений. }\end{array}$ \\
\hline 3.Изменчивость & Свойство экосистемы менять характеристики своего функционирования вследствие \\
\hline
\end{tabular}




\begin{tabular}{|c|c|}
\hline экосистемы. & изменений собственных параметров или при внешних возмущениях. \\
\hline $\begin{array}{l}\text { 4.Чувствительность } \\
\text { экосистемы }\end{array}$ & Способность экосистемы реагировать на незначительные по величине воздействия. \\
\hline 5.Период релаксации & $\begin{array}{l}\text { Время, необходимое } \text { для } \text { приведения экосистемы в } \text { вавновесное состояние } \\
\text { неравновесного после действия внутреннего или внешнего возмущающего фактора. }\end{array}$ \\
\hline $\begin{array}{l}\text { 6.Пределы устойчивости } \\
\text { (верхний и нижний) }\end{array}$ & $\begin{array}{l}\text { Количество возмущающего фактора в единицах его измерения, которое приводит } \\
\text { экосистему к необратимым изменениям. Применительно к такому фактору как } \\
\text { температура, Б.Небел (1993) ввел понятие диапазона устойчивости (интервал } \\
\text { температур от минимальной до максимальной, при которых еще возможен рост } \\
\text { организма). Точки, ограничивающие интервал, он называет пределами устойчивости. } \\
\text { Между зоной оптимума и пределами устойчивости, по его мнению, расположена } \\
\text { стрессовая зона в рамках диапазона устойчивости по данному фактору. }\end{array}$ \\
\hline 7. Инертность & $\begin{array}{l}\text { Способность экосистемы сохранять при внешнем воздействии исходное состояние в } \\
\text { течение некоторого времени. }\end{array}$ \\
\hline 8. Пластичность & $\begin{array}{l}\text { Способность экосистемы накапливать результаты внешних воздействий, не изменяя } \\
\text { при этом до определенного предела кардинально своих свойств и режима. }\end{array}$ \\
\hline 9. Эластичность & $\begin{array}{l}\text { Способность экосистемы вернуться в положение равновесия после кратковременного } \\
\text { (не очень большого по амплитуде) возмущения, если период между возмущениями } \\
\text { меньше времени релаксации системы. }\end{array}$ \\
\hline 10. Восстанавливаемость & $\begin{array}{l}\text { Способность экосистемы возвращаться в исходное состояние после временного } \\
\text { внешнего воздействия на нее. }\end{array}$ \\
\hline 11. Резисте́нтность & $\begin{array}{l}\text { От лат. resistentia- сопротивление, противодействие) - сопротивляемость } \\
\text { (устойчивость, невосприимчивость) организма к воздействию различных факторов - } \\
\text { инфекций, ядов, загрязнений, паразитов, и т.п. В частности, «неспецифической } \\
\text { резистентностью» называют средства врождённого иммунитета. Термин чаще } \\
\text { применяется в отношении микроорганизмов (возникновение механизмов } \\
\text { невосприимчивости к антимикробным лекарственным средствам, к антибиотикам); } \\
\text { или растений (к болезням). В отношении человека и животных чаще используется } \\
\text { термин иммунитет. Резистентность организма не является постоянной величиной, а } \\
\text { зависит от экологических условий, ослабевая при сильном переолаждении, } \\
\text { недостаточном питании, физическом переутомлении. У млекопитающих, впадающих в } \\
\text { спячку, во время её отмечена высокая сопротивляемость воздействию инфекций и } \\
\text { токсинов. }\end{array}$ \\
\hline 12. Упругость & $\begin{array}{lrrrrrr}\text { Свойство экосистемы полностью } & \text { возвращаться } & \text { в } & \text { исходное } & \text { состояние } & \text { после } \\
\text { прекращения внешнего воздействия. } & & & & & \end{array}$ \\
\hline $\begin{array}{l}\text { 13. Буферность } \\
\text { буферная емкость }\end{array}$ & $\begin{array}{l}\text { Способность экосистемы сохранять присущее ей состояние и в определенной мере } \\
\text { нейтрализовывать направленные на нее внешние воздействия. }\end{array}$ \\
\hline 14. Персистентность & 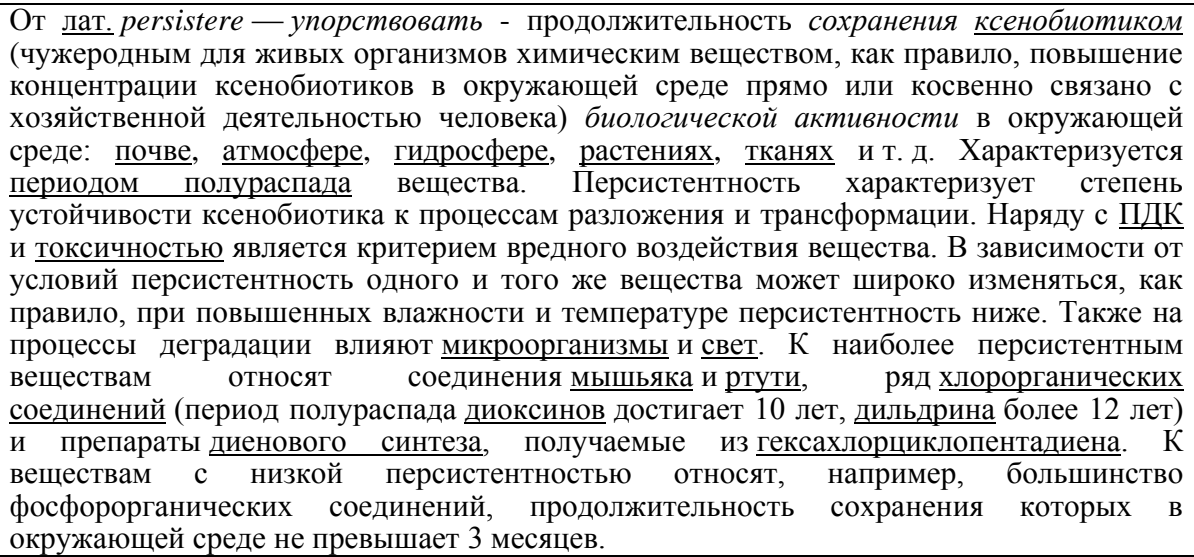 \\
\hline
\end{tabular}

Два основных определения устойчивости. Наиболее очевидно различие двух основных значений термина устойчивость: во-первых, устойчивость, как способность системы длительно существовать, сохраняя свои основные свойства, или в неизменной среде, или в среде, изменения которой не принимаются исследователем во внимание; вовторых, устойчивость, как способность системы противостоять внешнему воздействию, сохраняя свои свойства.

Адаптационная и регенерационная устойчивость. Чаще всего в экологической литературе термин устойчивость используется в следующих значениях. Инертность системь - способность экосистемы сохранять при внешнем воздействии исходное состояние в течение некоторого времени; пластичность системы - способность экосистемы переходить из одного состояния равновесия в другое, сохраняя при этом внутренние связи; восстанавливаемость системы - способность экосистемы возвращаться в исходное состояние после временного внешнего воздействия. Первые два понятия трактуются как адаптационная устойчивость, третье - как регенерационная. 
Определение устойчивости по И.Н. Росновскому. Как отмечал И.Н. Росновский (1993), если убрать эмоциональные и словесные "накрутки", то все определения устойчивости природных систем сходятся в одном: устойчивость системы - это ее способность сохранять свои свойства и параметры режимов в условиях действующих внутренних и внешних возмущений. Такое определение совпадает с определением устойчивости в общей теории систем в кибернетике (Кафаров, 1985; Ackoff, 1960; Bertalanfi, 1962). Оценка уязвимости или устойчивости к изменению свойств геосистемы не сводится только к учету одного какого-либо свойства (фактора). Она получается, как результат учета многих факторов, характеризующихся большим набором параметров оценивания, среди которых группы физико-географических факторов, климатических условий и характер антропогенного воздействия являются определяющими.

Устойчивость экосистемы по И.И. Мазуру и О.И. Молдаванову. Авторы (Мазур, Молдаванов, 1989) под устойчивостью экосистемы понимали свойство, внутренне присущее экосистеме, характеризующее способность: выдерживать изменения, создаваемые внешними воздействиями; оказывать сопротивление внешним (техногенным) воздействиям; обнаруживать способность $к$ восстановлению или самовосстановлению экосистемьл.

Устойчивость природных систем по В.А. Светлосанову. Автор (Светлосанов, 1990) ввел понятия простой, эластичной и упругой стабильности природных экосистем. Эластичной стабильностью он называет способность экосистемы вернуться в положение равновесия после кратковременного (не очень большого по амплитуде) возмущения, если период между возмущениями меньше времени релаксации системы. Чем меньше время возвращения системы после возмущения в устойчивое положение равновесия, тем эластичнее природная экосистема. В том случае, когда имеется лишь одно положение равновесия, в зависимости от того, насколько оно устойчиво к возмущениям, можно говорить о простой стабильности или нестабильности природных систем. Определения, связанные с устойчивостью водных экосистем обобщены нами в таблице 1 .

Устойчивость биосистем. Соответствующие свойства биосистем иногда называются, соответственно, их резистентностью и упругостью. Однако обычно под резистентностью и упругостью понимают формы устойчивости к внешнему воздействию, что более соответствует первоначальному смыслу обоих терминов. Иногда устойчивость отождествляется только с внутренней способностью самой биосистемы поддерживать постоянство своих свойств, сама эта возможность ставится в строгую зависимость от способности биосистемы регулировать ее, функционируя в автономном режиме. Постоянство свойств экосистем, прямо связывается с их гомеостазом, часто понимаемым с позиций крайнего органицизма, с их замкнутостью или эндогенной сбалансированностью в них потоков энергии, с их персистентностью, как способностью стабилизировать собственные характеристики и т.п. Понятие резистентной устойчивости $\kappa$ воздействию традиционно для исследований на организменном и суборганизменном уровне, из которых оно и было заимствовано экологами. При использовании этого понятия в дем- и синэкологических исследованиях не всегда делается поправка на то, что речь идет уже о биосистемах надорганизменного ранга, обладающих, в сравнении с организмами, значительно меньшей целостностью. В частности, такое понимание "устойчивости к воздействию", как синонима "резистентности" ("токсикорезистентности") или "толерантности" ("resistance to...", "tolerance to..."), прямо связанное с сохранением гомеостаза, широко используется (применительно к организму) в физиологии, токсикологии, фармакологии, медицине (Jayasankar, Muthu, 1983; Williams e.a., 1986; Лукьяненко, 1986; France, Stockes, 1987; Dhingra, Phokela, Mehrota, 1988; Власов, 1994; и др., цит. по Шуйский, 1997).

Устойчивость геосистем и экосистем. Теоретические и методические разработки по устойчивости геосистем охватывают два комплекса вопросов. Первый заключается в познании устойчивости и изменчивости геосистем как фундаментального свойства объ- 
ектов реального мира. Здесь исследуются основные понятия устойчивости геосистем и связанные с ней представления об инварианте системы. Инвариантными называют свойства геосистемы, которые сохраняются неизменными при преобразовании той или иной категории геосистем. Если в результате внешнего воздействия инвариант сохранен, то можно говорить о возвращении геосистемы по прошествии некоторого времени в первоначальное состояние. Если изменения привели к смене инварианта, то восстановление геосистемы маловероятно. В разных ситуациях инвариантными могут быть: состояние системы, структура, способ функционирования, траектория саморазвития. Выбор инварианта зависит от свойств системы и от задач исследования. При таком подходе устойчивой считают систему, которая любым способом сохраняет инвариант в течение времени, значительного относительно времени смены инварианта (переходного процесса), и механизмы устойчивости разделяют на четыре группы: сохраняющие (стабилизирующие) состояние системы, сохраняющие тип функционирования, сохраняющие структуру, сохраняющие направленность (траекторию) движения системы.

Второй комплекс вопросов охватывает исследование устойчивости геосистем разного ранга к антропогенным воздействиям разнообразного характера (Куприянова, 1989). Здесь разрабатываются подходы к определению запаса устойчивости экосистем, выяснению критериев и методов оценки устойчивости природных и природноантропогенных ландшафтов к нагрузкам от различных видов промышленного производства и сельского хозяйства. Обсуждению параметров устойчивости географических и эколого-экономических систем посвящена монография А.А.Быстрова (1999). Автор вводит понятие «морфологического куба параметров устойчивости», характеризующего 196 вариантов взаимосвязи элементов устойчивости. Современные ландшафты при этом рассматриваются как системы, сочетающие характерную для природы самоорганизацию и управление, характерное для социальных процессов.

Как отмечает А.Д.Арманд (1989), в процессе отбора наиболее жизнеспособными оказываются два крайних типа систем: с преобладанием сильных внутренних взаимодействий (сильные системы) и слабых внутренних связей (слабые системы). Отличительной чертой первых можно считать четкое разделение функций внутри целого, вторых - сходство свойств и функций, выполняемых в системе ее составными частями. Системы с сильнылм типом взаимодействия элементов легко и в широких пределах меняют состояния своих подсистем и характер их функционирования. Это позволяет им нейтрализовать изменения внешних условий и сохранять от разрушения структуру (Федоров, 1974). Системы со слабыми взаимодействиями реагируют на внешние перемены структурными перестройками. Такие системы отображаются при районировании территории в виде "однородных" районов (места обитания животных одного вида, совокупность водосборных бассейнов первого порядка и т.д.). Важной особенностью этих подсистем является их качественная однородность, не позволяющая им взаимодействовать по принципу дополнения.

Адаптационная устойчивость и принцип Ле-Шателье-Брауна. Для условноравновесных природных систем, в том числе и экологических, справедлив принцип ЛеШателье-Брауна: при внешнем воздействии, выводящем систему из состояния устойчивого равновесия, равновесие смещается в том направлении, при котором эффект внешнего воздействия ослабляется. Следствием из этого принципа является положение, при котором при прочих неизменных условиях более продуктивная экосистема будет более устойчива к эвтрофированию, а более сапробная (токсобная) экосистема будет более устойчива к снижению качества воды (Дмитриев, 1995). В этом смысле устойчивая экосистема не всегда должна ассоциироваться с экологическим благополучием, необходим анализ факторов, определяющих причину ее высокой устойчивости.

Многими исследователями признается, что более сложные, более разнообразные экосистемы являются и более устойчивыми. Так, в случае озерной экосистемы 
последовательность еe развития направлена на усложнение организации и усовершенствование метаболической эффективности, что обусловливает ее высокие защитные свойства (Драбкова, 1991).

Необходимо подчеркнуть, что наблюдаемая неизменность во времени свойств какой-либо экосистемы отнюдь не свидетельствует об ее устойчивости и, наоборот, экосистема с ярко выраженными колебаниями характеристик может быть устойчива к определенным внешним воздействиям.

Известно, что в природных экосистемах характеристики различных сообществ регулируются и удерживаются в некоторых константных диапазонах постоянными соотношениями притока доступной энергии и элиминации. Если изменить это соотношение, соответственно изменятся и свойства экосистемы, однако, пока их баланс сохраняется, можно говорить об устойчивости системы во времени. Человек постоянным воздействием на биосистемы, часто стабилизирует их, примерами таких систем могут служить агроценозы, удобряемые озера, объекты аквакультуры. В связи с этим А.Ф. Алимов $(1986,1994)$ предлагает вообще не разделять биосистемы на "стабильные" и " нестабильные".

Экосистемы, в которых наблюдаются существенные периодические колебания характеристик, например, экосистемы водоемов с поймами, обладают значительной устойчивостью благодаря импульсной стабилизащии (Одум, 1975). Вообще, любым экосистемам умеренной и полярной зон в отличие от экваториальных экосистем свойственна значительная внутригодовая динамика характеристик, при этом в климаксной экосистеме их внутригодовой ход повторяется каждый год практически без изменений. Как отмечал И.С. Печуркин (1989), малые колебания поддерживают систему и оберегают ее от больших катастроф. Пространственно-временные периодические флуктуации компонентов могут резко повысить глобальную устойчивость системы.

Устойчивость по Лагранжу, Ляпунову, Холлингу, Одуму, Свирежеву и Логофету. Если число видов в сообществе остается постоянным, т.е. ни один вид не вымирает, то в этом случае применительно к экосистеме говорят об устойчивости по Лагранжу. Самым жестким является требование глобальной устойчивости экосистемы, или устойчивости по Ляпунову. В этом случае должно существовать некоторое равновесное положение экосистемы в многомерном пространстве ее характеристик, причем из окрестностей точки равновесия экосистема не должна никогда выходить, несмотря на внешние возмущения. Естественно, что система, устойчивая по Ляпунову, тем более устойчива по Лагранжу.

При обсуждении способности экосистем сохранять основные свойства в условиях воздействия также выделяются понятия: "резистентная устойчивость к воздействию (резистентность)" и "упругая устойчивость к воздействию (упругость)" по Холлингу. С 1973 года, когда Холлинг высказал предположение, что природные экосистемы обладают двумя свойствами: стабильностью (stability) и упругостью (resilience), термин "stability" на русский язык переводился и как устойчивость и как стабильность. Под упругостью природных систем Холлинг понимал способность переходить под действием возмущений из одного устойчивого положения в другое, сохраняя при этом внутренние взаимосвязи. Под стабильностью им понималась способность природной экосистемы возврашаться $в$ прежнее состояние устойчивого равновесия после временного воздействия на нее. Чем быстрее возвращение и чем меньше флуктуаций (т.е. отклонений от среднего значения), тем более стабильна по Холлингу система. Автор отмечает, что чем однороднее окружающая среда (т.е., чем больше ее энтропия), тем более вероятно, что природная экосистема имеет слабую флуктуацию, низкую упругость и высокую стабильность (цит. по Шуйскому, 1997).

По определению Ю.Одума (1975), эти свойства соответствуют способности сопротивляться нарушениям, поддерживая неизменной свою структуру и функцию, и способности восстанавливаться после того, как структура и функции были нарушены. 
Подчеркивается, что эти два свойства экосистем принципиально различны, но иногда устойчивость системы трактуется именно как обобщенная характеристика обоих этих качеств, т.е. как способность сохранять непременно и резистентность и упругость. Но, возможно, нет необходимости ни противопоставлять резистентность упругости, ни вводить какой-либо единый двухпараметрический критерий устойчивости с учетом обеих ее форм. Ясно, что по мере увеличения воздействия на экосистему, по достижении порога реакции, в ней происходят сначала обратимые изменения (потеря резистентности), и лишь потом, при более сильном воздействии, необратимые (потеря упругости). Следовательно, сохранение резистентной устойчивости уже предполагает сохранение упругости, а потеря упругости означает, что предварительно уже была потеряна резистентность (Шуйский, 1997).

В оценке устойчивости принципиальным моментом является позиция исследователя на влияние воздействия на систему, приводящему к изменению качества среды и загрязнению. В практике оценивания на этот счет встречаются разные точки зрения.

В ранних работах по устойчивости геосистем начала 1990-х гг. (Снакин и др, Дмитриев, 1995 и др.) оценивалась возможность влияния качества среды на изменение устойчивости. При этом имелась в виду адаптационная устойчивость, и предполагалось, что при оказанном воздействии на систему наиболее загрязненные водоемы будут более устойчивыми к загрязнению, чем чистые. Или высокопродуктивные водоемы будут более устойчивы к антропогенному эвтрофированию. В этом случае обычно ссылались на принцип Ле-Шателье - Брауна: при внешнем воздействии, выводящем систему из состояния устойчивого равновесия, равновесие смещается в том направлении, при котором эффект внешнего воздействия ослабляется.

Позднее мы пришли к выводу, что в исследованиях необходимо оговаривать тип устойчивости или трактовать ее как обобщенную характеристику нескольких типов, то есть, как способность сохранять и резистентность и упругость (по Ю.Одуму) или адаптационную устойчивость и регенерационную в нашем понимании. Это, как правило, оговаривалось или происходило по умолчанию в публикациях по устойчивости природных систем.

Другие авторы считают, что принцип Ле-Шателье - Брауна в этом случае не применим, поскольку с увеличением загрязнения среды, при росте интенсивности загрязнения буферная способность среды снижается (чем больше загрязняющего вещества в ней содержится, тем меньше она может его «поглотить»). Вывод о том, что «чистые» системы изначально являются наиболее уязвимыми к загрязнению опровергается на том основании, что «чистые» системы, может быть, никогда и не будут загрязнены, в то время как загрязненные - уже загрязнены.

Здесь, как говорилось выше, на наш взгляд, происходит подмена понятий, поскольку буферностью системы называют способность экосистемы сохранять присущее ей состояние и нейтрализовывать направленные на нее внешние воздействия. Использование данного термина, как синонима устойчивости переводит обсуждение в русло оценки биохимического самоочищения системы и факторов ее определяющих (это 2-й тип устойчивости, называемый нами регенерационной устойчивостью, или «упругость» по Ю. Одуму). И тогда получаем, что у системы имеется предел биохимического самоочищения, обусловленный критической концентрацией загрязняющего вещества в среде, а фактически субстрата, который используют микроорганизмы, потребляющие данный субстрат. Эти критические концентрации, наряду с факторами среды, главным из которых является температура воды, вызывают снижение скорости самоочищения и, вероятно, увеличение смертности организмовдеструкторов. В итоге получаем, что более «грязная» система может потерять регенерационную устойчивость к загрязнению, перейти в другой класс состояния и достаточно долго сохранять его при том же внешнем воздействии. Таким образом, 
система становится упругой по Холлингу и устойчивой по первому типу (адаптационная устойчивость).

Здесь чаще, наряду с буферностью используется термин резистентность (от лат. resistentia - сопротивление, противодействие) - сопротивляемость организма к воздействию различных факторов, в том числе и загрязнений. Этот термин чаще применяется в отношении микроорганизмов или растений. Резистентность организма не является постоянной величиной, а зависит от экологических условий, ослабевая с изменением влияющих факторов при сильном переохлаждении, недостаточном питании, физическом переутомлении, загрязнении и др.

Об этом же еще в 1997 г. писал В.Ф.Шуйский, используя другую терминологию. Важный вывод, сделанный автором, состоял в том, что, по-видимому, нет необходимости ни противопоставлять резистентность упругости (в нашем понимании адаптационную устойчивость регенерационной), ни вводить какой-либо единый двухпараметрический критерий устойчивости с учетом обеих ее форм. По мере увеличения воздействия на экосистему, по достижении порога реакции, в ней происходят сначала обратимые изменения, и лишь потом, при более сильном воздействии, необратимые. Обратимые изменения автор трактовал, как потерю способности сопротивляться нарушениям (резистентность), а необратимые, как потерю способности восстанавливаться (упругость).

Можно придерживаться следующей трактовки. При росте воздействия на систему она постепенно утрачивает возможности биологического и биохимического самоочищения. Это означает, что время биологического самоочищения при неизменности остальных факторов постепенно увеличивается. Но это не означает, что физические, физико-химические и др. факторы не могут приводить к восстановлению свойств системы. Напомним, что биотические и абиотические составляющие экосистемы по механизмам устойчивости различаются между собой. Если устойчивость первых обусловлена способностью адаптаџии организмов к воздействию или ее отсутствием, как в результате внутренней резистентности биохимической организации, так и за счет способности к биохимическому разложению токсичных соединений и изменению удельных скоростей обменных процессов в экосистеме под влиянием воздействия, то устойчивость вторых достигается физико-механическими и химическими процессами переноса, разбавления, сорбции вещества в системе. И тогда $\rho$-сапробная система может не изменить своего класса качества и таксономического состава организмов при поступлении в нее определенного количества загрязняющего вещества, а $\chi$-сапробная система может при том же поступлении загрязняющего вещества и последующим за этим изменением состава биоты перейти в $\beta$-о-сапробный класс. При этом аргумент авторов о том, что «чистые» системы, может быть, никогда и не будут загрязнены, в то время как загрязненные - уже загрязнены, лишен смысла, так как a priori исследуется воздействие на любую систему, которое может вывести ее за пределы класса, в котором она пребывала (система не способна сохранить свои свойства и параметры режимов) или система после оказанного воздействия способна сохранить свой класс состояния. В последнем случае воздействие признается допустимым и задачей исследователя будет выявить допустимое воздействие (по совокупности факторов), которое не выведет систему за пределы класса, в котором она пребывала.

С увеличением времени самоочищения система не утрачивает способности к самовосстановлению (потеря стабильности по Холлингу или утрата упругости по Одуму), ей потребуется больше времени на восстановление своих свойств и параметров режимов. И решающим фактором здесь могут оказаться физические факторы среды (температура воды). Система, перейдет в другой, менее устойчивый класс по 2 типу (регенерационная) класс устойчивости. Увеличение фоновых характеристик состава изменит статус системы и приведет к переходу системы в новый класс качества воды, трофности. При этом эффект дальнейшего воздействия на систему уже не будет сопровождаться потерей ее устойчивости. Тем самым, система станет более устойчивой по первому типу 
(адаптационная), упругой по Холлингу. Таким образом, переход в более «уязвимый» класс устойчивости по 2 типу (регенерационная) может одновременно сопровождаться переходом в более «устойчивый» класс по 1 типу (адаптационная).

В связи с вышесказанным при оценке устойчивости мы предлагаем отслеживать только сам факт изменения класса качества воды (загрязнения), без указания в какую сторону эти изменения происходят (ухудшение качества и улучшение качества, повлекшее выход системы за пределы класса, в котором она находилась определенное время, например, 3 года, и сохранение системой нового класса также в течение 3 лет свидетельствует о потере системой способности сохранять свой первоначальный статус). Но при оценке экологического благополучия системы уже важным будет, в какую сторону произошли эти изменения в сторону ухудшения качества или улучшения.

Иногда устойчивость рассматривается авторами как синоним экологического благополучия. И здесь вполне уместно упоминание о 2-м типе устойчивости, подтверждающем способность системы к самоочищению. Нами в ранних публикациях было показано, что достижение экологического благополучия водной экосистемой, в качестве которого были выбраны, с учетом региональных особенностей, различные оттенки олиго-мезотрофии и олиго-мезосапробности, предшествует достижению наиболее продуктивного или, что более прозрачно, наиболее загрязненного состояния (Дмитриев, 2000). Благополучные (с наибольшим числом видов и высоким разнообразием биоты и абиотических условий среды) водные экосистемы, на наш взгляд, не являлись наиболее устойчивыми к антропогенному эвтрофированию и загрязнению, но они могли сохранять класс устойчивости при незначительном внешнем воздействии на них и самоочищаться достаточно быстро, особенно в летнее время. Достижение ими высокой устойчивости к внешнему и внутреннему воздействию обеспечивалось, как правило, физикогеографическими параметрами водоема, физико-механическими и химическими процессами переноса и трансформации вещества в нем. При этом основным физическим фактором самоочищения являлась температура воды, обусловливающая самоочищение водоема, например, за счет фильтрационной активности и времени осветления воды зоопланктоном летом за несколько суток, а зимой примерно за 2 месяца.

По еще одной точке зрения, высказывающейся, как правило, географами, исследованию подлежит только потенциальная устойчивость или анализируются косвенные показатели и факторы влияния загрязняющих веществ на потенциальную устойчивость, индикаторы, изменяющие потенциальную устойчивость системы в результате воздействия на нее. При этом авторы, за редким исключением (Осипов, 2016), по рассмотренным выше причинам, не вводят в свои модели оценки устойчивости в явном виде влияние воздействия на устойчивость системы (или влияние на устойчивость усиления антропогенного эвтрофирования в водоемах).

Ю.М. Свирежев и Д.О. Логофет (1978) выделяли устойчивость глобального биогеохимического иикла, числа видов в сообществе, численности видов в сообществе. Видовая структура водной экосистемы фактически не обладает сопротивляемостью, т.е. реагирует на любые воздействия. Однако видовая структура упруга: при возвращении характеристик среды к первоначальным, видовая структура также возвращается к первоначальному состоянию, разумеется, если не произошло полного уничтожения ни одного вида. Структура трофической сети, как правило, отличается малой сопротивляемостью и высокой упругостью. Гораздо более высокой сопротивляемостью обладает структура биогеохимического круговорота веществ и особенно высока ее упругость. Последнее определение близко к термодинамическому понятию стабильности, по которому система считается стабильной, если малы вероятности больших флуктуаций.

Устойчивость по В.Ф.Шуйскому. В работе В.Ф.Шуйского (1997) показано, что информативной мерой как резистентной, так и упругой устойчивости служит минимальное значение лимитирующего фактора, вызывающее их потерю, а мерой резистентности, наиболее адекватной ее изначальному определению, должно служить 
именно постоянство значений количественных характеристик во времени. По мнению автора, более эффективно использование количественных показателей, учитывающих не фиксированные значения количественных характеристик биосистем и не строгий ход их временных изменений, а степень их вариабельности за период наблюдений.

Обсуждая возможности оценки различных форм устойчивости с использованием их интегральных количественных характеристик, автор упоминает о моделировании устойчивости. Преимуществом модельного подхода, по мнению В.Ф.Шуйского, является снятие упомянутого нереалистичного критерия - ожидания постоянства рассматриваемых количественных характеристик биосистем и замена его более правдоподобным критерием - постоянством режима, в котором флуктуируют значения характеристик. Для моделирования и оценки устойчивости по интегральным количественным характеристикам биосистем часто используется понятие странного аттрактора, при этом учитывают, что система с детерминированной динамикой может обладать случайным поведением, и ограничивают исследования поиском и описанием самого аттрактора.

Автором показано, что наиболее обоснованной мерой устойчивости $\kappa$ воздействию на какую-либо биосистему является такой уровень воздействия, при котором вызываемые им изменения теряют обратимость. «Обратимость последствий воздействия, безусловно, лучше оценивать эмпирически, а не путем "принудительной" экстраполяции на биосистемы свойств неживых или гипотетических, модельных систем», - утверждает автор. Несмотря на это, модель устойчивости (Шуйский, 1997, с.117), названная автором «простой и универсальной формулой количественной оценки устойчивости», по своей сути является такой гипотетической моделью и лишь характеризует принадлежность биосистемы (бентоценоза) по совокупности факторов к области состояния (n-факторного гиперпространства), ограниченной критическими точками.

В качестве структурных характеристик устойчивости обычно приводятся видовое богатство и разнообразие, видовое своеобразие, сложность, степень иерархичности, которые часто считаются приоритетными при оценке устойчивости биосистем надорганизменного ранга. Поскольку высокое разнообразие сообществ реализуется преимущественно в относительно стабильных условиях среды, постольку находилось и подтверждение прямой зависимости устойчивости сообществ от их сложности и высокого разнообразия. Такие выводы еще недавно считались традиционными в экологии, при этом преувеличивалась системная организация сообществ и экосистем в целом. Позднее было рекомендовано учитывать количество реально действующих обратных связей в системах, реализованную долю потенциальных связей между экологическими компонентами и другие параметры. Сукцессионное усложнение сообществ - вынужденное, обусловленное, преимущественно, обострением межвидовой и внутривидовой конкуренции за ограниченные пространства и пищевые ресурсы. Поэтому устойчивость реальных экосистем и сообществ к внешнему дестабилизирующему воздействию на самом деле редко возрастает в связи с увеличением их видового разнообразия и количества межвидовых связей. Обычно же устойчивость к воздействию в обеих ее формах при росте видового разнообразия, наоборот, закономерно уменьшается, так как возрастает вероятность потери в результате этого воздействия наиболее уязвимых видов сообщества или межвидовых связей по мере увеличения их количества (Шуйский, 1997).

По поводу этих выводов автора мы отмечали (Дмитриев, Фрумин, 2004), что: 1сукцессионное развитие сообществ только до определенного предела связано с сукцессионным усложнением; устойчивость реальных экосистем нельзя оценивать по отношению к абстрактному внешнему дестабилизирующему воздействию. В той же мере, в какой биолог озабочен выделением типов устойчивости биосистем, при геоэкологической оценке необходимо учитьвать тип воздействия на экосистему $и$ устойчивость к воздействию данного типа. Таким образом, дополнительное поступление в водоем, например, биогенов, никак не скажется на изменении устойчивости водной 
геосистемы к изменению параметров гидрологического режима или устойчивости к изменению физико-географических (морфометрических) особенностей водоема. В то же время значительное поступление биогенов неизбежно изменит устойчивость к режиму продуцирования органического вещества в водоеме (антропогенному эвтрофированию).

2 - устойчивость к изменению видового разнообразия максимальна для наиболее разнообразных по видовому обилию экосистем. При снижении видового разнообразия в системе будет снижаться и устойчивость к его изменению. Устойчивость к воздействию необходимо оценивать по репрезентативному критерию оценки типа воздействия на экосистему, а не по изменению видового разнообразия в ней, как некоторого «универсального» критерия. В одних случаях этот параметр пригоден для оценки воздействия, в других - нет. Поскольку с загрязнением (эвтрофированием) водной экосистемы после достижения экологического благополучия видовое разнообразие в ней снижается, то снижается и устойчивость к его изменению, но возрастает адаптационная устойчивость к загрязнению (эвтрофированию) системы.

Критерии оценки устойчивости. Индикаторный подход к оценке устойчивости. Очевидно, что выбор критерия, по которому следует определять устойчивость природной экосистемы, диктуется предъявляемыми к экосистеме требованиями. Если нас интересуют лишь характеристики поступающих из экосистемы веществ (например, качество воды в вытекающей из водоема реке), то необходимо оценить устойчивость в экосистеме биогеохимического круговорота. При этом в случае неизменности характеристик круговорота веществ, изменения видового состава и трофической структуры сообщества не играют роли. Если речь идет о сохранении заповедной водной экосистемы в неизменном состоянии, то необходимо определить устойчивость экосистемы к сохранению числа видов организмов. Понятно, что данное требование бессмысленно распространять на фито-, зоопланктон и бактериальное сообщество из-за высокой способности этих организмов к распространению и короткого периода жизни отдельного организма. Требование сохранения в экосистеме всех видов применимо к достаточно крупным организмам, с жизненным циклом порядка года и более: макрофитам, рыбам, земноводным, моллюскам, олигохетам и другим. Если же важно не допустить снижения изъятия из экосистемы какого-либо ресурса (например, ценного вида рыб или животных), то устойчивость экосистемы должна быть оценена по устойчивости численностей составляющих сообщество видов. Естественно, что устойчивость численностей видов сообщества предполагает также устойчивость его трофической структуры.

Понятно, что устойчивость экосистемы по данной характеристике к какому-либо внешнему возмущению будет тем больше, чем большее возмущение она способна испытать без изменения этой характеристики. Для оценки степени воздействия внешнего фактора на состояние экосистемы необходимо через систему слежения гидроэкологического мониторинга получить конкретное значение репрезентативного параметра (параметров), отражающих системные свойства, до воздействия и после него. На основании этого разработана и опубликована система параметров, характеризующих устойчивость водных экосистем (Дмитриев, Третьяков, Кулеш и др., 1995; Дмитриев, Фрумин, 2004).

Изучая закономерности воздействия факторов среды на гидробионтов, весьма важно выбрать оптимальные критерии устойчивости сообществ, которые следует положить в основу метода ее количественной оценки. В настоящее время в рамках указанных выше различных понятий об устойчивости выделяют различные ее признаки. Что касается градаций и шкал устойчивости, то они слабо разработаны и не обобщены в отечественной и зарубежной литературе.

Наиболее часто используются количественные характеристики различных форм устойчивости, основанные на интегральных показателях обилия (традиционно - биомасса, численность организмов в сообществе или биоте в целом; реже - также энергетические 
показатели). Формально по такому принципу могут оцениваться все выделенные выше формы устойчивости. Но при этом устойчивость биосистемы, рассматриваемая безотносительно воздействия на нее, может быть оценена только по степени постоянства этих количественных характеристик. Ясно, что для оценки устойчивости к воздействию этого явно недостаточно. На этой основе нельзя получить экологически обоснованных нормативов, регулировать и прогнозировать воздействия. Резистентную устойчивость к воздействию логично оценивать по тому, насколько постоянны во времени ее рассматриваемые количественные показатели. Упругая устойчивость к воздействию вообще не может быть оценена степенью постоянства или вариабельности количественных характеристик биосистемы, т.к. здесь важна не степень их вызываемого изменения, а скорость и полнота восстановления их исходных значений. В связи с этим упругость биосистем надорганизменного ранга практически оценивается временем полного восстановления их количественных характеристик или обратной величиной скоростью восстановления (Хумитаки Секи, 1986; Дмитриев, 1995; Шуйский, 1997).

Для оценки степени воздействия внешнего фактора на параметр состояния экосистемы необходимо знать конкретное значение последнего до воздействия и после него. На основании этого можно оценить степень изменения параметра (показатель измененности параметра Јс в \% у В.В. Снакина и соавторов, 1992) по формуле

$$
\mathrm{Jc}=|\mathrm{dP}| / \mathrm{P}_{\mathrm{e}} * 100,
$$

где $\mathrm{P}_{\mathrm{e}}$ - естественное значение параметра до возмущения.

Развивая данный подход, можно, по аналогии с (2) предложить параметры, характеризующие устойчивость экосистем (Дмитриев, Третьяков, Кулеш и др., 1995):

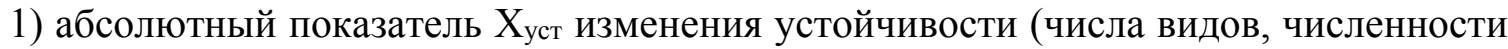
конкретного вида или параметра, отражающего круговорот веществ) при данном воздействии (\%):

$$
\mathbf{J}_{\text {хар.уст }}=\left|\mathrm{dX}_{\text {уст }}\right| / \mathrm{X}_{\text {уст }} * 100,
$$

2) абсолютная неизменность экосистемы $A_{c}$ по данной характеристике при известном воздействии:

$$
\mathrm{A}_{\mathrm{c}}=100-\mathbf{J}_{\text {хар.уст }}
$$

Например, число видов в экосистеме составляло 100, а после воздействия оно снизилось до $90, \mathrm{~J}$ числа видов $=10 \%, \mathrm{~A}_{\mathrm{c}}=90 \%$.

Более информативны, вероятно, относительные показатели, определяющие, как степень изменения параметра устойчивости соответствует степени изменения внешнего фактора. Пусть $\Phi$ - естественное значение фактора среды, возмущение которого привело к изменению характеристики устойчивости экосистемы $X$. Тогда

$$
\mathrm{y}_{\text {отн }}=(|\mathrm{d} X / X|):(|\mathrm{d} \Phi| / \Phi),
$$

где $\Phi$ - среднегодовое фоновое значение фактора внешней среды, $\mathrm{d} \Phi$ - его антропогенное изменение, также среднегодовое или максимальное. При У относительно устойчива, существенное изменение внешнего фактора приводит к незначительному изменению параметра устойчивости. При $\mathrm{y}_{\text {отн }}>1$ внешнее возмущение вызывает гораздо большее изменение.

Формула (5) не имеет смысла для не встречающихся в естественных условиях поллютантов. В этом случае, вероятно, следует применять следующий показатель:

$$
\mathrm{y}_{\text {отн }}=(|\mathrm{dX}| / \mathrm{X}):(|\mathrm{d} \Phi| / \Pi Д К),
$$

где ПДК принимается по наиболее опасному для экосистемы поллютанту. Для сравнения устойчивости экосистем различных водоемов небесполезным будет использование степени относительной неустойчивости экосистемы:

$$
\mathrm{C}_{\text {отн.неуст }}=(|\mathrm{dX}| / \mathrm{X}):(|\mathrm{d} \Phi| / \Phi)
$$

при $\Phi=a * \Phi$, где $a=$ const. 
Выражение (7) показывает, как изменение данного фактора воздействует на характеристику устойчивости экосистемы. Если принять $a=1$, то среднегодовая концентрация субстанции увеличивается в 2 раза (об уменьшении не говорим, так как это не типично для антропогенного загрязнения вод). Тогда

$$
\mathrm{C}_{\text {отн.неуст }}=|\mathrm{dX}| / \mathrm{X}
$$

при двукратном увеличении концентрации поллютанта. Для неизмененной системы $\mathrm{C}_{\text {отн.неуст }}=0$. Используя данные показатели, можно сравнивать различные водные системы по степени их устойчивости.

Обобщение современных подходов к оценке устойчивости геосистем. Анализ публикаций и результаты научных исследований позволили выделить и обобщить некоторые важные особенности.

Первая особенность - отрицание некоторыми авторами возможности количественной интегральной оценки устойчивости на том основании, что это свойство системы нельзя измерить, а можно оценить только косвенно, например, в баллах. При этом авторы отказываются работать с натурной информацией и оценочными шкалами, переводя, значения выбранных показателей в баллы и далее суммируют баллы для получения итоговой оценки. В процессе работы, как правило, не учитываются тип связи и весомость параметров. Эта идеология породила большое количество авторских балльных и балльно-индексных методик оценки устойчивости. В них рекомендуется по отдельности определять устойчивость ландшафта к каждому конкретному возмущающему фактору. Этот подход распространяется также на оценку устойчивости почвы, элементарного ландшафта, растительного покрова, как компонентов ландшафта. Зачастую, не учитывается прямая и обратная связь устойчивости с параметрами оценивания, нелинейность связи. При этом балльная оценка (как правило, баллы по отдельным факторам всё же суммируются) иногда именуется авторами «интегральной оценкой».

Вторая особенность - отсутствие во многих работах авторского понимания и определения устойчивости или абсолютизация только одного из возможных определений и неприятие других определений или оценочных средств. В результате часто выясняется, что автором оценивается не устойчивость системы, а, например, чувствительность организмов, населяющих эко- или геосистему к определенному типу воздействия на них (например, к нефтяному). При этом определяется площадь, занятая определенным видом (таксоном) на основе Д3З или на основе наземных наблюдений. Далее без обоснования принимается, что территория занятая наиболее чувствительным видом (таксоном) является наиболее уязвимой для воздействия (наименее устойчивой), предлагается полуэмпирическая формула расчета интегральной уязвимости (Погребов; Журавель, Чурсина, 2001; Зотов, Лазарева и др., 2006; Шаплыгина, 2010). При оценке не обсуждается таксис (возможность ухода организмов из загрязненной среды), факторы бактериальной деструкции загрязняющего вещества и т.п.

Случается, что, начиная исследование, автор ставит перед собой задачу разработать методику расчета, например, чувствительности разных районов акватории и береговой зоны к опасным природным явлениям. Затем, по мере знакомства с подходами других авторов, задача переформулируется, например, в виде: разработать подход, позволяющий согласованно оценивать уязвимость подверженных объектов, связанную с конкретными опасными и мульти-опасными явлениями. B paботах: Fischlin A., Midgley G.F., Price J.T., Leemans R., Gopal B., Turley C., Rounsevell M.D.A., Dube O.P., Tarazona J., Velichko A. (2007); Кулыгин (2018) авторы вводят "индекс уязвимости", который рассчитывают на основе переменных, характеризующих систему с точки зрения: 1подверженности воздействию, 2-чувствительности; 3-адаптивной способности. Идея не нова. Основная проблема, - ввести еще один уровень обобщения показателей для снятия неопределенности многокритериального оценивания, когда по одному индексу (у авторов - переменной) систему относят к одному классу уязвимости, а по другому индексу, - к другому классу. 
Tретья особенность состоит в том, что авторами оценивается не интегративное (эмерджентное, сложное) свойство системы в целом, а изменчивость компонентного состава системы (нарушение принципа эмерджентности сложной системы). Если изменчивость компонентов велика, делается вывод об уязвимости системы к воздействию или изменению параметров естественного режима (потенциальная устойчивость) (Кудерский, 1996). Как вариант, состояние системы в целом характеризуется на основе выявленной высокой корреляции одного из компонентов с исследуемым эмерджентным свойством. При этом выбранный компонент именуется «слабым звеном» экосистемы, а для обоснования подхода автор ссылается на принцип «бритвы Оккама». Методологически такой подход не является оправданным, поскольку «бритвы Оккама» или «принцип простоты» необходимо применять к само́й сложной системе или ее системному свойству, а не к компоненту системы. При этом «элементом» системы должен выступать не «компонент состава» или «фактор», а ее подсистема. К этим публикациям близки идеи покомпонентного оценивания состава и свойств геосистем на основе построения «синтетических карт устойчивости или уязвимости». При этом полученный «путем интегрирования нормированных данных» вектор состояния системы, авторы отожествляют с устойчивостью (уязвимостью) геосистем к воздействию.

Четвертая особенность раскрывается в анализе токсикологической уязвимости морских акваторий на основе построения вектора состояния системы по совокупности максимально большого перечня характеристик, имеющихся в базе данных автора, и этот вектор, либо a priori отожествляется с устойчивостью системы в целом, либо рассматривается как некая самостоятельная экологическая характеристика оцениваемой территории, не связанная с «устойчивостью» и «чувствительностью». [Новиков, 2006, 2007]. В основе оценки уязвимости по автору под уязвимостью экосистемьл понимается степень ее зависимости от внешних воздействий, которые могут привести к нарушению ее структуры и функционирования, т.е. к потере стабильности (пусть даже временной). Степень уязвимости различных акваторий по автору должна определять возможные потери биомассы гидробионтов и продуктивности биоценозов в случае загрязнения или отчуждения тех или иных акваторий при промышленной эксплуатации шельфа (разработка полезных ископаемых и т. п.). Синтетическая оценка уязвимости в этом подходе рассчитывается автором путем интегрирования нормированных данных всех цифровых тематических карт района, с учетом "весовых" характеристик последних. В работе отсутствует понимание необходимости введения многопараметрической модели интегральной классификации устойчивости. В принципе такой подход правомерен при условии, что автор обоснует и реализует переход от «интегрального показателя состояния системы» или «портрета экосистемы» по В.В. Дмитриеву (2000) к интегральному показателю ее устойчивости.

Пятая особенность современных исследований - присутствие в оценочных подходах одновременно нескольких видов устойчивости и их одновременное использование для получения итоговой оценки устойчивости (подробнее - см. Дмитриев, Огурцов, 2014). С одной стороны, оценка устойчивости к изменению параметров естественного (потенциальная устойчивость) и антропогенного режимов - необходимое условие оценки устойчивости природных систем. Такая оценка позволяет делать выводы о соотношении природных и антропогенных составляющих в интегральной оценке или, изменяя одну из них, выявлять, способна ли система (и до какого предела) сохранять тот класс устойчивости, который имела до воздействия. С другой стороны, встречаются подходы, в которых одновременно сочетаются два основных вида устойчивости (адаптационная и регенерационная), характеризующих разные механизмы ее формирования. Это проявляется в процессе формирования оценочных шкал или использования тех или иных нормирующих функций. При оценке устойчивости в первом случае (адаптационная устойчивость) важнейшим свойством природной системы является ее способность не менять свое состояние или плавно переходить в другой класс, сохраняя 
при этом свои свойства и связи (инертность, пластичность). В другом случае (регенерационная устойчивость) система способна многократно восстанавливать свои свойства и возвращаться в то состояние, которое она имела до внешнего воздействия и которое она временно утратила (восстанавливаемость). В итоге, в соответствии с методической платформой авторов, один и тот же параметр может иметь противоположные оценочные шкалы в первом и втором случаях. Это объясняется тем, что природа регенерационной устойчивости и фактора, ее характеризующего (например, скорость самоочищения) близки, а адаптационной устойчивости и того же параметра противоположны. Рассмотренные нами ранее примеры позволили выявить основные условия использования одних и тех же параметров в первом и втором типах устойчивости и целесообразность их совместного использования в одной модели-классификации (Дмитриев, Огурцов, 2014). В этом случае, по нашему мнению, важную роль играет системообразующий тип анализируемой геосистемы: 1 - циклический, 2 - транзитный, 3 каскадный (Дмитриев, 2000; Трушевский, Дмитриев, Осипов, 2018). Тогда логично оценивать адаптационную устойчивость для эко- и геосистем 1 типа, а регенерационную для 2 или для 2 и 3 типов систем. Этого на практике не происходит. В оценке устойчивости, как правило, присутствуют одновременно первый и второй типы, см., например, (Кесорецких, 2015) с различным соотношением параметров 1 и 2 типа и оценочных шкал.

B шестом примере рассмотрим более сложную для анализа авторскую интерпретацию уязвимости (устойчивости), основанную на учете основных механизмов формирования устойчивости. Оценивая уязвимость ландшафтов региона к химическим и механическим воздействиям, автор обосновал собственный набор из 8 критериев уязвимости (Кесорецких, 2015). Тип устойчивости (1-й тип - адаптационная, 2-й тип регенерационная) автором не обсуждается. Но при описании и характеристике определяющих механизмов сохранения устойчивости автор указывает на «миграционные каналы транспортировки вещества в пределах ландшафта», «миграции поллютантов через поверхностные водотоки», «формирование стока (миграции химических загрязнителей) и эрозионных процессов», «пути миграции и накопления поллютантов» и т.п. Таким образом, складывается впечатление, что автором формируется своеобразный «каркас потоков вещества» в ландшафте, обеспечивающий вынос загрязнений за пределы рассматриваемого региона. В результате формируется и поддерживается способность ландшафта сохранять свои свойства и параметры режимов в условиях действующих внутренних и внешних возмущений, а, точнее, способность ландшафта возвращаться в исходное состояние после временного внешнего воздействия на него. Ключевым термином такого подхода мог стать «транзит вещества» через составные части ландшафта (геосистемы). Если геосистема способна осуществлять транзит, значит, она способна восстанавливать свои свойства и параметры режимов в условиях внешних воздействий и является устойчивой по 2-му типу (регенерационная). Но тогда, близость к речной сети и сама речная сеть, большие уклоны земной поверхности, близость к водотоку, высокая густота речной сети должны свидетельствовать о повышении транзитной способности и низкой уязвимости (высокой устойчивости) по 2-му типу. На картах, приведенных автором (2015), эти зоны, наоборот отражают повышенную уязвимость ландшафта. Неясно, также, через какие признаки в оценке уязвимости (устойчивости) автором может быть явно учтено оказываемое воздействие (химическое, механическое). В этом случае система также может сохранить свой класс состояния или перейти в другой класс, если норма воздействия будет превышена, т.е. характеризоваться как устойчивая или уязвимая.

Седьмая особенность, состоит в медленном развитии аксиометрии устойчивости. Редко авторами предлагаются параметры или индексы устойчивости, для которых, разработаны оценочные шкалы. Но даже, если такие шкалы существуют, то они, при использовании часто заменяются балльными шкалами, что снижает их ценность как основы «экологической квалиметрии» или «экологической аксиометрии». 
К сожалению, развитие данного подхода часто сопровождается слепым копированием какого-либо одного-двух (модных) индексов и попыткой свести оценку устойчивости геосистемы к анализу изменения этих индексов. Так в одной из работ предлагается вводить универсальный (по автору - интегральный) индекс, характеризующий состояние и устойчивость экосистемы, в качестве которого рекомендуется индекс Шеннона, на том основании, что «наиболее сложные системы являются и наиболее устойчивыми». При этом устойчивость к определенному типу воздействия на экосистему сводится к оценке видового разнообразия в системе. Такой подход не учитывает совокупности большого числа физико-географических, климатических, гидрологических, гео- и гидрохимических, продукционных и других характеристик и факторов, определяющих в итоге устойчивость различных наземных и водных геосистем к определенному типу воздействия или сочетание изменений естественного и антропогенного режимов функционирования геосистемы. Увлечение индексологией в оценке устойчивости, как уже отмечалось, приводит авторов к простому и наиболее часто встречающемуся выводу о том, что наиболее сложные системы являются и наиболее устойчивыми. Анализ видового разнообразия в водных экосистемах СевероЗапада РФ, выполненный нами в ряде работ показал, что олиго-мезотрофные и олигомезосапробные экосистемы являются наиболее благополучными водными экосистемами, им и присущи высокие значения индекса Шеннона, но они же, часто достаточно уязвимы для внешнего воздействия и изменения свойств и параметров режимов в силу своих физико-географических, климатических, гидрологических и других особенностей.

В другой публикации (Дроздов, 2012), аналитическое выражение для оценки степени устойчивости абиотических компонентов экосистем внутренних морей к климатическим изменениям представляется в виде следующей, разработанной автором функции (9):

$$
\text { Stabl. } A=f\left(\alpha+\beta+\gamma+\delta+\lambda+\chi+\omega_{1}\right)
$$

где: $\alpha=V$ вм $Q$ пол. ( $V$ - объем водной массы моря, $Q-$ период полного водообмена); $\beta=V$ вм$/ V$ реч.ст $(V$ - объем водной массы моря, $V$ реч.ст. - объем суммарного речного стока в море); $\gamma=P / E$ ( $P$ - объем атмосферных осадков на поверхность моря); $\delta$ - индекс, отражающий площади мелководных заливов и среднюю глубину моря; $\lambda$ - индекс устойчивости поверхностных течений; $\chi$ - индекс сложности климатообразования с учетом географического положения моря и его бассейна; $\omega$ - обобщенный индекс антропогенного воздействия на абиотические параметры морской экосистемы (изъятие части стока впадающих рек на нужды сельского хозяйства и промышленности, строительство дамб и т.д.). Аналитическое выражение для оценки степени устойчивости биотических компонентов экосистем внутренних морей к климатическим изменениям представляется в работе в виде функции (10):

$$
\text { Stabl. } B .=f\left(\psi+v+\tau+\varphi+\omega_{2}\right),
$$

где: $\psi$ - общее количество видов планктонных организмов; $v$ - общее количество видов макрозообентоса; $\tau$ - общее количество видов рыб; $\varphi=E v / S t e n$ (соотношение между количеством видов эврибионтов и стенобионтов); $\omega_{2}-$ обобщенный индекс антропогенного воздействия на биотические параметры морской экосистемы (антропогенное токсическое загрязнение, влияние на концентрации биогенов и содержание растворенного кислорода, интенсивность промысла и т.д.). В целом авторский подход требует еще один уровень свертки и, скорее, напоминает оценку ассимиляционной емкости системы, чем ее устойчивости.

В 2015 г В.В.Дроздов предложил осуществлять с учетом степени и характера влияния внешних абиотических процессов и характеристик, задающих ритм и циклы 
изменчивости, а также биотических процессов и характеристик, отражающих адаптационные возможности организмов, направленные на обеспечение длительного существования различных популяций и восстановление биоценозов в меняющихся условиях среды. Автор обосновал 15 основных расчетных характеристик, обладающих высокой информативностью, применение которых целесообразно при реализации интегрального подхода к оценке устойчивости морских экосистем. В перечень характеристик были включены: 1-соотношение видов стенобионтов и эврибионтов в составе ихтиофауны; 2-соотношение видов стенобионтов и эврибионтов в составе макрозообентоса; 3-соотношение видов стенобионтов и эврибионтов в составе высшей водной растительности (макрофиты); 4-индекс Шеннона; 5-индекс выраженности экотона; 6-индекс восстановления (регенерации) фауны; 7-соотношение объема морской акватории и поступающего в нее речного стока в среднем за 30 лет; 8-амплитуда колебаний речного стока в акваторию в среднем за год, в среднем за 30 лет, \%; 9-объем речного стока в морскую акваторию за сезон с наибольшей водностью в среднем за 30 лет, в сравнении со средним годовым значением стока за данный период, \%; 10-глубина осенне-зимней конвекции, м; 11-высота приливов в среднем за год, см; 12-концентрация кислорода у дна в среднем за год в среднем за 30 лет; 13-количество дней в году с гипоксией в придонном слое в среднем за 30 лет; 14-амплитуда колебаний солености воды в среднем за год, в среднем за 30 лет на поверхности, \%; 15-амплитуда колебаний солености воды в среднем за год, в среднем за 30 лет у дна, \%. Автором были установлены количественные диапазоны изменчивости обоснованных характеристик и соответствующие им классы от 1 (весьма высокая) до 7 (весьма низкая). В зависимости от характера используемых данных и их доступного объема применительно к конкретной акватории, рекомендовано использовать три варианта интегрального индекса оценки устойчивости: AISE 1, основывающегося на учете 6 структурных биоценотических индикационных показателей; AISE 2, основывающегося на учете 9 структурных биоценотических индикационных показателей и динамических гидрологических индикационных показателей; AISE 3 основывающегося на учете 15 структурных биоценотических индикационных характеристик, динамических гидрологических и океанологических индикационных показателей. Были определены весовые коэффициенты факторов и индикационных показателей, использованных для оценки устойчивости. В 2016 г. автором был рассмотрен вариант балльной оценки устойчивости экосистем районов Балтийского, Белого, Черного и Азовского морей. Были опубликованы примеры расчета индексов AISE для районов морей. Было получено, что наибольшей информативностью в оценке устойчивости морских экосистем обладает индекс AISE 3, основанный на комплексном учете ведущих биотических и абиотических факторов и соответствующих им индикационных показателей. Используемый подход и характеристики планировалось использовать при оценке устойчивости не только внутренних, но и окраинных морей, акватории которых подвергаются существенному влиянию речного стока.

\section{Вопросы для проверки усвоения материала.}

1. Дайте основные определения, связанные с устойчивостью.

2. Объясните основные отличия между адаптационной и регенерационной устойчивостью.

3. Дайте определение потенциальной устойчивости.

4. Может ли устойчивость характеризовать «здоровье системы»?

5. Расскажите об индикаторном подходе к оценке устойчивости.

\section{Литература}

Александрова Л.В., Васильев В.Ю., Дмитриев В.В., Мякишева Н.В., Огуриов А.Н., Третьяков Н.В., Хованов Н.В. Многокритериальные географо-экологические оценки состояния и устойчивости природных и урбанизированных систем. Под ред. В.В. Дмитриева и Н.В. Хованова. Деп. ВИНИТИ 01.09.2000, № деп.2342В00, 275 с. 
Арманд А.Д. Механизмы устойчивости геосистем // Факторы и механизмы устойчивости геосистем. М., 1989, c.33-46.

Воробейчик Е.Л., Садыков О.Ф., Фарафонтов М.Г. Экологическое нормирование техногенных загрязнений наземных экосистем. Екатеринбург, 1994. $2007,364 \mathrm{c}$.

Гальцова В.В., Дмитриев В.В. Практикум по водной экологии и мониторингу состояния водных систем, СПб.,

Геоэкология и природопользование. Труды XII съезда Русского географического общества. Отв. редакторы д.г.н. В.В. Дмитриев, д.б.н. В.Н.Мовчан, Том 4., СПб, 2005, 400 с.

Глазовская М. А. Методологические основы оценки эколого-геохимической устойчивости почв к техногенным воздействиям. М.: Изд-во МГУ, 1997. 102 с.

Глазовская М.А. Ландшафтно-геохимические системы и их устойчивость к техногенезу // Биогеохимические циклы в биосфере - М.,1976,-356 с.

Глазовская М.А. Методологические основы оценки эколого-геохимической устойчивости почв к техногенным воздействиям. М., изд. МГУ, 1997, 102 с.

Дедю И.И. Экологический энциклопедический словарь. Кишинев,1990, 406 с.

Дмитриев В.В. «Определение интегрального показателя состояния природного объекта как сложной системы», научно-теоретический журнал «Общество. Среда. Развитие». №4 (12), 2009, с.146-165.

Дмитриев В.В. Диагностика и моделирование водных экосистем. СПб, 1995, 215 с.

Дмитриев B.B. Интегральные оценки состояния сложных систем в природе и обществе (статья). Междисциплинарный научный и прикладной журнал «Биосфера», 2010, т.2, №3.

Дмитриев В.В. Методика диагностики состояния и устойчивости водных экосистем // Эколого-географический анализ состояния природной среды: проблема устойчивости геоэкосистем. СПб., 1995. С.41-67.

Дмитриев В.В. Методические указания по дисциплине «СИСТЕМНАЯ ЭКОЛОГИЯ». Специальность 013600 геоэкология. Курс V. г. Санкт-Петербург, РГГМУ, 2002, 30 с.

Дмитриев В.В. Оценка экологического состояния водных объектов суши (часть II). Уязвимость водной экосистемы / Экология. Безопасность. Жизнь. Экологический опыт гражданских, общественных инициатив. Гатчина. 2000, c.284-296.

Дмитриев В.В. Оценка экологического состояния природных объектов. Что такое экологическая оценка и как построить интегральный показатель состояния природной экосистемы. Экология. Безопасность. Жизнь. Экологический опыт гражданских, общественных инициатив. Выпуск 12. Гатчина, 2001 г, с.225-237.

Дмитриев B.B. Прикладная экология в системе высшего географического и гидрометеорологического образования/ Вопросы прикладной экологии. Сборник научных трудов РГГМУ, СПб, изд. РГГМУ, 2002, с.90-96.

Дмитриев В.В. Устойчивость природных объектов к изменению параметров естественного и антропогенного режимов/ в кн. Дмитриев В.В., Фрумин Г.Т. Экологическое нормирование и устойчивость природных систем, СПб., 2004, c.241-278.

Дмитриев В.В. Экологическое нормирование состояния и антропогенных воздействий на природные экосистемы. Вестник С-Петерб. ун-та. Серия 7, 1994, вып 2. С.60-70.

Дмитриев В.В. Эколого-географическая оценка состояния внутренних водоемов. Дисс. на соиск. учен. степ. докт. географ. наук, СПб:, 2000. 416 с.

Дмитриев В.В., Жиров А.И., Ласточкин А.Н. Прикладная экология. Учебник для студентов высш. учеб. заведений. М.: Издательский центр «Академия», 2008, 608 с.

Дмитриев В.В., Огуриов А.Н. Подходы к интегральной оценке и ГИС-картографированию устойчивости и экологического благополучия геосистем. І. Интегральная оценка устойчивости наземных и водных геосистем. Вестник СПбГУ, сер.7 (геология, география), 2012, вып.3, с.65-78.

Дмитриев B.B., Огурцов А.Н. Подходы к интегральной оценке и ГИС-картографированию устойчивости и экологического благополучия геосистем. II. Методы интегральной оценки устойчивости наземных и водных геосистем. Вестник СПбГУ, сер.7 (геология, география), 2013, вып.3, с.88-103.

Дмитриев В.В., Огуриов А.Н. Подходы к интегральной оценке и ГИС-картографированию устойчивости и экологического благополучия геосистем. III. Интегральная оценка устойчивости почвы и наземных геосистем. Вестник СПбГУ. Сер. 7. 2014. Вып. 4, с.114-129.

Дмитриев В.В., Панов В.Е., Пряхина Г.В. Методические указания по учебно-производственной практике «Экологическое состояние водных объектов»: Учебно-методическое пособие. - СПб. : ВВМ, 2010. — 104 с.

Дмитриев В.В., Проченко Ю.А., Алексеева О.Н., Примак Е.А. Интегральная оценка качества воды и выявления водных экосистем с различной степенью антропогенной трансформации / Теория и практика эколого-географических исследований (Итоги научной работы Учебно-научного центра географии и геоэкологии в 2004 году) / Под ред. В.В.Дмитриева, А.И. Чистобаева, Т.А. Алиева, И.О. Шилова. СПб.: Изд.ТИН, 2005. с. 127-149.

Дмитриев В.В., Фрумин Г.Т. Экологическое нормирование и устойчивость природных систем., СПб., 2004, 294

c.

Дроздов В.В. Принципы оценки устойчивости экосистем Балтийского, Белого, Черного и Азовского морей к климатическим изменениям, "Ученые записки РГГМУ», изд. РГГМУ, 2012.

Исаченко А.Г. Ландшафтоведение и физико-географическое районирование. М., 1991, 366 с.

Исаченко Г.А. Методы полевых ландшафтных исследований и ландшафтно-экологическое картографирование. СПб.,1999,112 с.

Кудерский Л.А. Естественные и техногенные водные экосистемы: проблемы их устойчивости. Региональная экология, 1996, №3-4, с.31-36.

Новиков М.А. Эколого-рыбохозяйственный Атлас Баренцева моря, Изд. ПИНРО, 2003 (электронный вариант).

Одум Ю. Основы экологии / Пер. с 3-го англ. изд. под ред. Н.П. Наумова. М., 1975, 740 с.

Оценка состояния и устойчивости экосистем. Под ред. В.А. Красилова, М., Изд. ВНИИ Природы, 1992, 127 с.

Погребов В.Б. и Пузаченко А.Ю. Экологическая уязвимость Баренцева, Белого, Балтийского, Черного и Каспийского морей к операциям по добыче и транспортировке нефти: сравнительный анализ, 2003. 
Примак Е.А., Дмитриев В.В. Оценка устойчивости водоемов Европейского Севера к изменению параметров естественного и антропогенного режимов // Водные ресурсы Европейского Севера: итоги и перспективы исследований. Материалы юбилейной конференции, посвященной 15-летию ИВПС, Петрозаводск, 2006, с.408-417.

Примак Е.А., Дмитриев В.В. Оценка уязвимости водоемов Европейского Севера к изменению параметров режимов // Экологические и гидрометеорологические проблемы больших городов и промышленных зон. Сборник трудов международной конференции. 25-27 октября 2006 г. - СПб.: изд. РГГМУ, 2007. с.115-123.

Примак Е.А., Дмитриев В.В. Разработка интегральных индексов для оценки устойчивости водоемов к изменению параметров естественного и антропогенного режимов / Географические и геоэкологические аспекты развития природы и общества. Сборник научных статей по материалам отчетных научно-практических конференций 2006-2007 гг. Под ред. Каледина Н.В., Дмитриева В.В., Алиева Т.А., СПб, Изд. Наука, 2008, с.234-241.

Проблемы эколого-географической оценки состояния природной среды / Под ред. П.П.Арапова и Ю.П.Селиверстова. СПб., 1994.

Пузаченко Ю.Г. Проблемы устойчивости и нормирования // Структурно-функциональная организация и устойчивость биологических систем. Днепропетровск, 1990, с.122-147.

РД 52.24.620-200. РУКОВОДЯЩИЙ ДОКУМЕНТ. Методические указания. Охрана природы. Гидросфера. Организация и функционирование подсистемы мониторинга антропогенного эвтрофирования пресноводных экосистем. М., $2000,23 \mathrm{c}$.

Реймерс Н.Ф. Природопользование: Словарь-справочник. М., 1990, 638 с.

Росновский И.Н. Устойчивость почвы: техногенно-механические аспекты. Новосибирск, 1993, 170 с.

Светлосанов B.A. Устойчивость и стабильность природных экосистем // Итоги науки и техники. Серия «Теоретические и общие вопросы географии». М., 1990, с.56-74.

Свирежев Ю.М., Логофет Д.О. Устойчивость биологических сообществ, М., 1978, 190 с.

Словарь терминов и понятий, связанных с охраной живой природы / Н.Ф.Реймерс, А.В.Яблоков / М., 1982, 144

c.

Снакин В.В., Мельченко В.Е., Бутовский Р.О. и др. Оценка состояния и устойчивости геосистем. М. ВНИИ природа, 1992, 127 с. 2006,36 c.

Шилин М.Б. Геоэкологический мониторинг прибрежных природно-технических систем. Автореф. докт. дис., 2006,36 c.

Шилин М.Б. Геоэкологический мониторинг прибрежных природно-технических систем. Автореф. докт. дисс.,

Эколого-рыбохозяйственный Атлас Баренцева моря, Изд. ПИНРО, 2003.

Alexeeva O.N., Guzheva I.N., Dmitriev V.V. The development of approach to the water reservoir ecological prosperity assessment. 3rd Symposium «Quality and Management of Water Resources» Saint Petersburg, Russia, June 16-18, 2005. Book of proceedings. Scientific Editors V.V.Dmitriev, V.I.Sergeev Saint Petersburg, Изд. ГУП «Типография «Наука», 2005, с. 9-17.

Jovanovic M., Afgan N., Bakic V. An analytical method for the measurement of energy system sustainability in urban areas / Energy. Elsevier 2010 №35 pp3909-3920

Primak E. Elaboration of the integral index for the estimation of natural waters quality // Materials of $3^{\text {rd }}$ International Symposium «Quality and Management of Water Resources» St. Petersburg, Russia, June 16-18, 2005. Book of proceedings. St. Petersburg, 2005. p. 209-214.

Shmelev S.E. Dynamic sustainability assessment: The case of Russia in the period of transition (1985-2008) / Ecological Economics. 2011., №70, pp.2039-2049.

Todorovica M. S., Kimb J. T. Buildings energy sustainability and health research via interdisciplinarity and harmony / Energy and Buildings. Elsevier. 2012 №47. pp.12-18.

Раздел 3. Методические основы интегральной оценки экосистем, геосистем, ландшафтов и их эмерджентных свойств.

Лекция №7

Методы балльного и балльно-индексного оценивания. Метод сводных показателей (composite indicators) (МСП). Метод рандомизированных сводных показателей (МРСП). АСПИД (анализ показателей при информационном дефиците) - методология. APIS (Aggregated Preference Indices System) - методология.

Актуальность разработки методов интегральной оценки состояния сложных систем в природе и обществе, динамики их временного изменения, а также их естественных и общественных трансформаций не вызывает сомнений. Современными акцентами таких исследований являются: 1 - разработка подходов к оценке эмерджентных (сложных, неаддитивных, интегративных) свойств сложных систем, характеризующих систему в целом (современный или ретроспективный статус системы, ее благополучие, напряженность, степень трансформации системы, устойчивость, уязвимость системы, целостность и др.); 2 - разработка подходов к оценке воздействия на системы и их ответной реакции на воздействие. При решении этих проблем исследователь нацелен на прогнозирование состояния сложной системы (и ее подсистем) на основе моделей 
системной динамики и моделей интегрального оценивания, а также разработку подходов к системному нормированию воздействия на системы. Необходимость развития системного нормирования обусловлена тем, что воздействия на систему могут быть детерминированными или случайными и касаться изменений в одной, нескольких, или всех подсистемах одновременно (социальной, экологической, экономической) [1]. Такой подход на сегодняшний день не имеет альтернатив в решении проблемы устойчивого развития социо-эколого-экономических систем. Многочисленные попытки оценивать состояние сложных систем на покомпонентной основе не позволяют судить об изменении эмерджентных свойств, характеризующих систему в целом, а многокритериальные оценки, лежащие в основе индикаторного подхода и индикативного управления, могут привести к ситуации, когда по одному индикатору система попадает в один класс состояния (качества), а по другому индикатору, - в другой класс. Системы индикаторов, которые используются управленческими структурами в оценочных исследованиях сложных природных и общественных систем, качества жизни населения, которые часто называют индикаторами устойчивого развития, также, зачастую, порождают неопределенность в результатах оценивания временной динамики развития. Процесс управления такими системами, основанный на мониторинге факторных показателей, расчете индексов, их анализе с учетом влияния на целевой индикатор на основе различных авторских подходов, прогнозе возможных изменений выбранных показателей, часто не дает должного эффекта. В результате, например, по одному индикатору выявляется положительная динамика развития, а по другому (другим), - стагнация, снижение темпов или негативные системные эффекты. В связи с этим следует признать, что реализация конкретных целей деятельности органов государственной власти в сфере планирования устойчивого развития регионов не является высокоэффективной. С другой стороны, системологический принцип множественности моделей сложных систем подтверждает, что для оценки состояния и прогноза функционирования сложной системы возможно построение нескольких (разных) моделей.

Под оценкой состояния системы будем понимать характеристику системы в целом в определенный момент времени или за определенный интервал времени. Тогда в первом случае логично применить выражение «ситуация», а во втором - «обстановка» в определенный период развития системы. Остановимся еще на одном неотъемлемом признаке оценочных действий. В процессе оценивания выявляется положительная или отрицательная значимость оцениваемого объекта или его свойства на основе соотнесения с некоторым уровнем (нормой, регламентом, фоном, критическими значениями и др.). «Нормой» чаще всего назначается утвержденный регламент или допустимый интервал его изменения. В современных исследованиях «норма» часто подменяется некоторыми т.н. «собственными требованиями». При этом под «требованиями» понимается потребность или ожидание, которое является обязательным. Эти требования установлены или обычно задаются (предполагаются) субъектом, выполняющим оценку. Такой подход порождает некий «идеальный образ», близость к которому, должна свидетельствовать о некоторой (чаще высокой, положительной) значимости объекта или его свойства. Субъективная сторона такой оценки: качество есть степень удовлетворения потребителя, имеющего $a$ priori определенный взгляд или «ожидаемые» представления о результате оценивания. Для этого лицо, выполняющее оценку, должно узнать требования потребителя и выполнить оценку в соответствии с «идеальным образом», заданным «заказчиком». В этом смысле любая «оценка» субъективна, поскольку характеризует отношение некоторого субъекта к объекту оценивания, установление значимости именно для этого субъекта выбранного объекта в целом или отдельных его свойств на основе их соответствия введенным представлениям, уровням или нормам.

Балльные и балльно-индексные оценки. На наш взгляд относятся к комплексным оценкам. Обычно автор, применяющий такую оценку, работает с отдельными параметрами, характеризующими состояние системы, определяет разброс 
параметров (минимум и максимум), ставит в соответствие им определенное количество баллов в выбранной балльной шкале и последовательно суммирует баллы для оцениваемой системы или ее свойства. При этом, как правило, не учитывается вид связи параметра с оцениваемым свойством (прямая, обратная, линейная, нелинейная) и вес (приоритет) каждого параметра. Автор, как правило, отрицает возможность работы с натуральными значениями параметров на том основании, что оцениваемое системное свойство системы или состояние системы в целом нельзя измерить, а можно оценить только косвенно, например, в баллах. При этом, хотя автор и отказывается работать с натурной информацией и оценочными шкалами, переводя, значения выбранных показателей в баллы, он суммирует баллы для получения итоговой оценки. Далее проводит рейтингование и сравнивает таким способом состояние объектов и систем.

Возможна более сложная схема: индексы - разряды - баллы (Снакин и соавт., 1992). Баллам могут присваиваться приоритеты (веса), с которыми они участвуют в свертке. Также может выполняться нормирование баллов для перевода в безразмерный вид (Банчева, Алексеева, 2017). Косвенно весомость параметров может учитываться при переходе от индексов к разрядам и от них к баллам, когда, например, определенному количеству разрядов ставится в соответствие некоторое количество баллов. Эта идеология породила большое количество авторских балльных и балльно-индексных методик оценки устойчивости (Снакин и соавт, 1992; Федоров, 2008; Абалаков и соавт., 2014; Банчева, Алексеева, 2017). Наиболее распространенные, получившие широкую известность методики, также базируются на балльной и балльно-индексной системе оценки. Например, для комплексной оценки геохимической устойчивости почвенного покрова к загрязнению нефтяными углеводородами используется не менее 10 характеристик, отражающих процессы деструкции (биохимического окисления), аккумуляции, выноса и рассеивания нефтяных углеводородов. На идеях и принципах балльной системы оценки построены исследования сотрудников Института проблем освоения Севера СО PAH, ВНИИприроды, Московского государственного университета и др. За рубежом в рамках концепции "Nordicity" широкую известность получила балльная система оценки, предложенная канадским географом Л-Э. Амелиным (Louis-Edmond Hamelin, 2008; Totonova, 2016).

Остановимся на дискутируемом в последнее время положении, важном для дальнейших этапов работы, которое связано с проверкой адекватности полученных результатов интегрального оценивания (Дмитриев, Огурцов, 2017). При традиционном подходе - балльной и балльно-индексной оценке эмерджентного свойства природного объекта (например, устойчивости) исследователи, суммируя индексы и переходя к разрядам, а затем к баллам, в итоге получают класс (и подкласс) устойчивости. Отнесение к определенному классу устойчивости является завершающим этапом работы и позволяет выявлять более или менее устойчивые ландшафты или водные объекты и анализировать пространственно-временные изменения устойчивости водоемов и водотоков. Такой подход, по мнению авторов, является результатом косвенной оценки устойчивости, поскольку любое эмерджентное свойство в принципе не может быть измерено. При этом попытка перейти на другие методы инициирует вышеупомянутый вопрос о достоверности тех или иных полученных результатов. Поэтому авторы предпочитают не использовать термин «модель» или «модель-классификация» в отношении совокупности параметров и оценочных шкал для них по классам состояния (устойчивости), объединенных в единую (иногда многоуровневую) систему оценивания.

Здесь важно отметить, что цифровая форма выражения эмерджентного свойства через интегральный показатель, с одной стороны, не должна смущать исследователя, поскольку она не только помогает, как и в случае с балльной оценкой, отнести, например, интегральный показатель устойчивости (ИПУ), к определенному классу с указанием точности выполненных расчетов, с другой стороны, не противоречит исходному тезису «эмерджентность сложной системы нельзя измерить». Не имеет смысла сравнивать ИПУ 
двух объектов по самим величинам интегральных показателей, тем более, если для их построения использовался разный набор характеристик (например, разные моделиклассификации) или были по-разному заданы приоритеты (веса) отдельных показателей. Результатом оценки все равно остается отнесение объекта (системы) к определенному классу устойчивости. При этом необходимо предусмотреть оценку достоверности полученных результатов.

Методы многомерной статистической классификации параметров или признаков, характеризующих состояние сложных систем. Для целей диагностики экологического состояния и оценки качества природных сред можно предложить несколько подходов, основанных на использовании методов анализа и обобщения натурных данных. Обзор таких подходов приводится нами в монографии «Интегральная оценка экологического состояния и качества городской среды» (под ред. А.К.Фролова, СПб, 1999).

Один из таких подходов заключается в применении методов многомерной статистической классификации параметров или признаков, характеризующих состояние экосистем.

Методы классификации совокупности объектов или признаков разработаны в настоящее время достаточно хорошо (Айвазян, Бухштабер и др., 1989; Дюран, Оделл, 1977). Их принято делить на методы классификации при наличии обучающих выборок и методы классификации без обучения ("без учителя"). Под обучающими выборками обычно понимают некоторую совокупность объектов или признаков, классификация которых достоверно известна.

В первом случае предполагаются известными распределения векторов X внутри классов. Вектора задаются аналитически или с помощью перечисления всех возможных значений X. С использованием этой информации строится правило (алгоритм) классификации, с помощью которого совокупность объектов или признаков относят к одному из нескольких классов с известными (или полностью заданными) функциями распределения. К этому же типу принято относить и задачу, в которой распределения Х внутри классов определены лишь частично. В этом случае используется два вида информации: предположение о свойствах распределения векторов (гладкость, принадлежность к некоторому известному параметрическому классу) и обучающая выборка. Обычно предполагается, что функции распределения векторов X, либо их сочетания принадлежат известному параметрическому классу с неизвестными значениями параметров.

Цель классификации без обучения сводится к разбиению всей анализируемой совокупности объектов на сравнительно небольшое число (заранее известное или нет) однородных, в определенном смысле, групп или классов. Результат разбиения зависит от выбора меры близости (сходства) между объектами. Знание такого количественного критерия как функционал качества разбиения позволяет оценить, какому из них отдать предпочтение.

Выбор той или иной меры близости и того или иного функционала качества обычно осуществляется весьма произвольно и опирается скорее на эмпирические и профессионально-интуитивные соображения, чем на строгую формализованную систему. Пример использования методов классификации без обучения применительно к оценке качества природных и сточных вод содержится в работе [3].

Известно, что основные этапы создания статистической классификации включают следующие:

- описание пространства наблюдений, т.е. характеристика исходных данных;

- выбор системы Х признаков, с помощью которых осуществляется переход из пространства наблюдений в пространство признаков; 
- снижение мерности призначного пространства Х, выбор системы обобщенных независимых признаков, с помощью которых пространство X переводится в пространство обобщенных признаков Y;

- проведение классификации в пространстве Y;

- интерпретация результатов применительно к решаемой задаче.

Исследования временной изменчивости отдельных компонентов водных экосистем показали, что в настоящее время отсутствуют четкие представления о виде функций распределения даже для наиболее изученных гидрологических и гидрохимических параметров. Для некоторых гидрохимических, практически всех гидробиологических компонентов и показателей загрязненности вод вопрос о виде функций распределения не ставился вообще. Таким образом, при решении задачи диагностики экологического состояния и качества воды в рамках рассматриваемого подхода исследователь всегда находится в условиях отсутствия или дефицита информации о распределении векторов $\mathrm{X}$ внутри классов. Более того, анализ информационной базы натурных гидроэкологических данных свидетельствует об их существенной зашумленности. Поэтому представляется целесообразным применение метода построения сводных показателей (МСП), ориентированного на использовании нечисловой, неточной и неполной информации, что позволяет ему работать в условиях зашумленности данных. Опыт, приобретенный при обсуждении такого рода задач, позволяет с уверенностью утверждать, что в настоящее время может быть разработана единая методика построения сводных показателей экологического состояния, качества, экологического благополучия и устойчивости водоемов к внешнему воздействию с учетом значимости и приоритетности отдельных показателей и использовании как числовой, так и нечисловой информации об их сравнительном влиянии на общую оценку.

Предлагаемый подход к многокритериальной оценке состояния водной экосистемы можно рассматривать как своеобразное решение задачи многомерной статистической классификации параметров или признаков, его характеризующих, при наличии обучающих выборок в виде существующих классификаций состояния, качества, продуктивности, устойчивости и т.д. природных геосистем.

Метод сводных показателей (composite indicators) (МСП).

Метод сводных показателей (МСП), общая структура которого была разработана А.Н.Крыловым еще в 1908 г., хорошо зарекомендовал себя как инструмент построения интегральных показателей, синтезирующих информацию о различных свойствах природных экосистем.

Рассмотрим некоторые особенности оценочных исследований на основе МСП.

На первом этапе работ проводится анализ, структуризация информации и формирование матрицы исходных характеристик для ключевого объекта. Определяются оценочные шкалы измерений по каждой из характеристик и их экстремальные значения. На этом же этапе вводятся классы, уровни, левая и правая границы каждого параметра для каждого класса. Здесь же разрабатывается иерархическая схема построения интегральных показателей для всех уровней свертки. На наш взгляд, одновременное использование многокритериальности и нескольких уровней свертки наглядно иллюстрирует смысл интегральной оценки эмерджентного свойства сложной системы.

На втором этапе выполняется процедура нормирования исходных показателей оценочных шкал, формируется матрица нормированных значений показателей. В зависимости от характера поведения в качестве нормирующей функции используются возрастающая или убывающая функции.

Наш опыт показывает, что при нормировании на первом этапе, можно ограничиться линейной прямой или обратной зависимостью между выбранным параметром и оцениваемым свойством. Множество значений нормированных показателей представляет собой многокритериальную оценку оцениваемого свойства исследуемого ключевого объекта. В качестве модельной синтезирующей функиии нами обычно 
используется функция вида $Q=Q(q ; w)=\sum_{i=1}^{n} q_{i} w_{i}$, с помощью которой выполняется построение интегральных показателей (ИП) на отдельных уровнях и сводного показателя оцениваемого свойства на последнем уровне свертки. Величина ИП зависит от весовых коэффициентов $w=\left(w_{1}, \ldots, w_{n}\right)$, определяющих значимость нормированных показателей для интегральной оценки. Диапазон изменений ИП находится в интервале от 0 до 1.

Состояние системы характеризуется через ее способность сохранять свои свойства и параметры режимов при внешнем воздействии на систему или к внутренним, внутрисистемным изменениям (воздействие на одну из подсистем), характеризующим объект исследования. Для реализации подхода вводятся классы состояния (устойчивости) системы; блоки, уровни свертки показателей (первый -внутри блоков, второй - между блоками или по более сложной схеме). Определяются необходимые и достаточные критерии оценивания. Основой наших исследований является построение интегральных показателей состояния систем, на основе многоуровневых (2-3 уровня свертки показателей) и многокритериальных (3-5 блоков, содержащих 5-10 и более критериев оценивания). Такие исследования выполнялись нами на первом этапе работ на основе МСП. Их целью было получение рекогносцировочной информации об интегративных свойствах систем; выявление эффектов взаимосвязи и взаимодействия, не аддитивных по отношению к локальным внутрисистемным эффектам. На рис.12 приводится общая схема построения шкалы интегрального показателя для одного из блоков (подсистемы) в методе сводных показателей. Эта шкала используется на следующем уровне свертки для получения интегрального показателя второго уровня (сводного показателя).

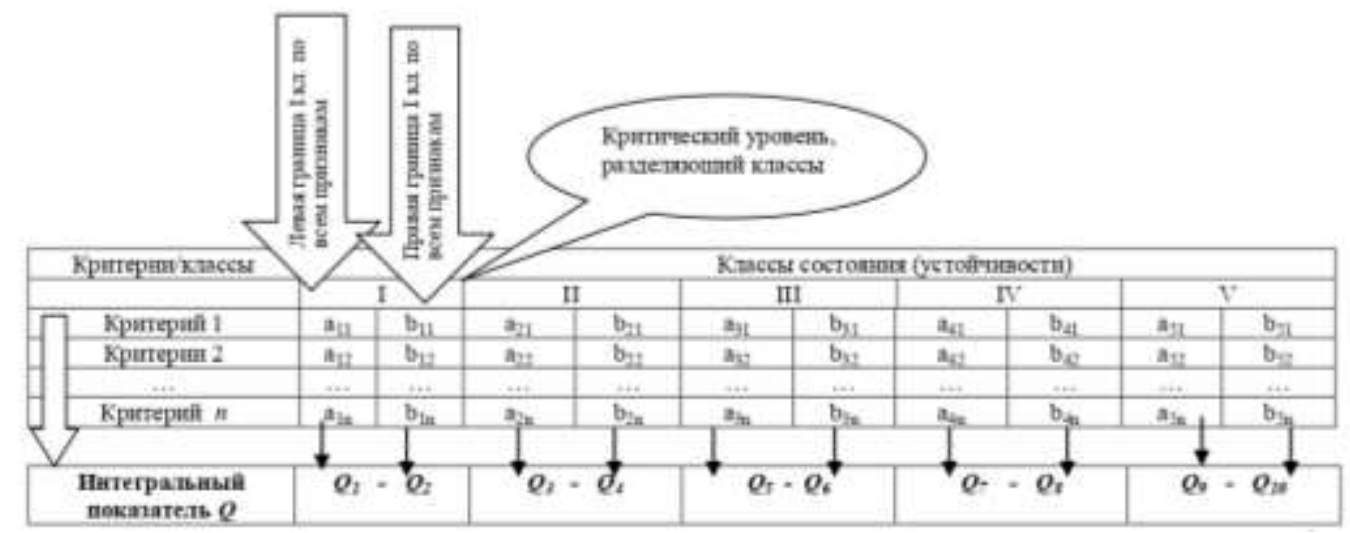

Рис. 12. Общая схема построения шкалы интегрального показателя для одного из блоков (подсистемы) в методе сводных показателей.

После построения оценочных шкал для всех блоков выполняется второй уровень свертки. При этом учитываются приоритеты (веса) отдельных блоков. В итоге исследователь работает с натуральными оценочными шкалами репрезентативных критериев оценивания этого свойства; вводит классы устойчивости, вводит или использует оценочные шкалы; может вводить несколько уровней свертки показателей, решает проблему нормирования исходных данных с учетом вида связи (прямая, обратная) и ее нелинейности, задает или моделирует веса (приоритеты) оценивания внутри групп и между ними и может изменять их при необходимости, учитывает количественную и качественную информацию о показателях и приоритетах оценивания, имитируя изменение приоритетов развития, обосновывает вид интегрального показателя.

Метод рандомизированных сводных показателей. В качестве методологической основы интегрального оценивания при решении широкого круга задач в рамках исследований и работ по проблеме интегральной оценки объектов окружающей среды нами используются идеи построения рандомизированных сводных показателей и 
принципы АСПИД-методологии (анализ и синтез показателей при информационном дефиците) (Хованов, 1996, 2009), на которых были построены модельные алгоритмы программы Geo-expert (Васильев, Огурцов, Хованов, 2004). Современным развитием «АСПИД» является «APIS» (Aggregated Preference Indices System) - агрегированная система индексов предпочтения на базе «АСПИД - методологии» (Hovanov et al. 2009).

Этапы и содержание оценки приведены на рис.2. Важным здесь является возможность моделировать веса на основе информации о приоритетах оценивания, поскольку в таких исследованиях значимость отдельных критериев традиционно оценивается при помощи сравнительных суждений типа «данный критерий более важен для общей оценки, чем другой критерий» или «данные критерии имеют одинаковую значимость для интегральной оценки» и т.п. Таким образом, значимость отдельных критериев, чаще всего измеряется по нечисловой (ординальной, порядковой) шкале или всем критериям навязывается равенство приоритетов оценивания. В других случаях исследователь задает интервалы возможного варьирования весовых коэффициентов. В связи с этим появляется необходимость работы с нечисловой (порядковой), неточной (интервальной) информацией, которая чаще всего бывает и неполной (не для всех весовых коэффициентов заданы нетривиальные равенства и неравенства, соответствующие интервальной и порядковой информации). Нечисловая, неточная и неполная информация (т.н. «ннн»- информация) индуцирует целое множество допустимых наборов весовых коэффициентов при получении интегральных оценок. Для преодоления этого затруднения в современных подходах используется байесовская модель рандомизации неопределенности. Идея этой модели восходит к работе Томаса Байеса (1702-1762) и состоит в переходе от неопределенного выбора весовых коэффициентов к случайному (рандомизированному) выбору их из множества всех допустимых наборов весовых коэффициентов. Таким образом, исследователь получает случайные весовые коэффициенты и случайные (рандомизированные) интегральные показатели (Хованов, 1996). Перспективным в этом направлении является не формальное усреднение, а использование методических приемов, базирующихся на теории моделирования дефицита информации при помощи стохастических процессов и полей (Хованов, 1996). Эта теория служит основой для построения обобщенных функций желательности состояния и устойчивости сложных систем с учетом неопределенности задания отдельных параметров и частных функций желательности и их влияния на интегральную оценку. Рис.12 поясняет сказанное.

В результате выполнения пятого этапа мы получили шкалу изменения сводного показателя по классам состояния (устойчивости) системы. После реализации данного этапа полезно проанализировать полученную шкалу изменения сводного показателя (на непрерывность и равномерность). Если в один класс состояния попадает $50 \%$ и более от всего интервала изменения величины сводного показателя, то, вероятнее всего, это вызвано поспешностью задания $X i_{\min }$ или, чаще, $X i_{\max }$. В этом случае следует вернуться на предыдущие этапы и, по возможности, устранить отмеченный недостаток.

На следующих этапах по собранным статистическим данным рассчитываются значения интегральных показателей для собранной информации по объектам исследования. В примерах, учитывающих неполную, неточную и нечисловую информацию, вводятся многоуровневые свертки информации о состоянии системы. Весовые коэффициенты задаются на основе моделей информационного дефицита. 
1. Отбор $m$ исходных критериев $X_{l}, \ldots, X_{m}$, которые образуют грушиы показателей, отражающих связь $\boldsymbol{X}_{t}, \ldots, \boldsymbol{X}_{\mathrm{m}}$ с одениваемым эмерджентным свойством водного объекта (ЭСВО). При необходимости вводятся иерархические системы многоуровневого обобщения информации. Определяются предельные значения $X_{\min } X_{\max }$, вид и монотонность связи неходиых параметров с ЭСВО.

2.Для кажаого параметра проводится нормирование показателей на основе нормируюших функиий (1) и (2). Вид функций предварительно обосновывается.

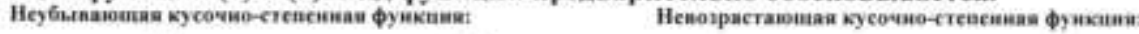

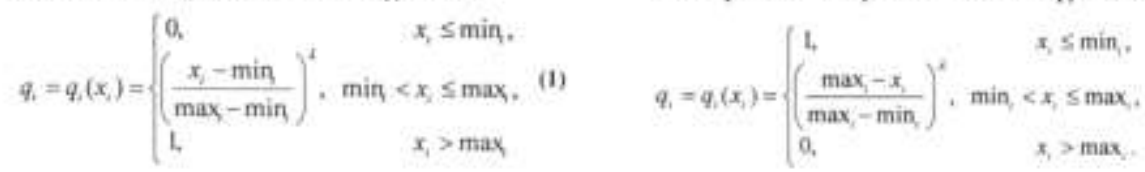

В результате нормирования получаются т.н. отоельные показатети $q_{i}, \ldots, q_{m}, \theta \leq q_{i} \leq 1$. Каждый $q_{i}$ являетея функиией исходной характеристики $q_{i}=q_{i}\left(x_{i}\right)$ и позволяет оценит. ЭСВО с точки зрения $i$-го критерия. Например, значение $q_{i}=l$ может свидетельствовать о величине ЭСВО-высокое, а $q_{i}=0$ - о величине ЭСВО -низкое по данному критерию (или наоборот).

3. Вводитея интерпретирующая (синтезирующая) функция $Q(q)=Q\left(q_{1}, \ldots, q_{-}\right)$, aгрегирующая нормированиые показатеан $q_{1}, \ldots, q_{n}$ в еднный интегральный (свооный) показатель $Q=Q(q)$, сопоставляя, $j$-му свойству (т.е. его оценке $\left.q^{(t)}=\left(q_{\mathrm{s}}^{(j)}, \ldots, q_{n}^{(4)}\right)\right)$ некоторую чнсловую оценку $Q^{(n)}=Q\left(q^{(n)}\right)=Q\left(q_{1}^{(j)}, \ldots, q_{n}^{(j)}\right)$. На синтезирующую функцию, определяющую интегральный (сводиый) показатель, накладываютея ограничения: $Q(0, \ldots, 0)=0, Q(1, \ldots, 1)=1,0 \leq Q \leq 1$. Простейшей, часто используемой в наших моделяхклассифнкациях синтезирующей функщией ивляетея линейная функиия вида: $Q=Q(q ; w)=Q\left(q_{1}, \ldots, q_{n} ; w_{1}, \ldots, w_{m}\right)=\sum^{m} q_{i} w_{1}$.

4. Задание весовых коэффициентов $w=\left(w_{1}, \ldots, w_{n}\right)$ - неотрицательные ивесам, дадаюшие значимость (важность) отаельных показателей дая оценки ЭСВО $\left(w_{1}+\ldots+w_{n}=1\right)$. Необходимо задать экепертиую информацию I о весах на основе ОI и II:

- ординальная (порядковая) - OI: $O I=\left\{w,>w_{1}, w_{*}=w_{2}, \ldots, r, s, u, v \in\{1, \ldots, m\}\right\}$

- ннтервальная- II: $I I=\left\{0 \leq a_{i} \leq w_{j} \leq b_{1} \leq 1, \quad i \in(1, \ldots, m\}\right\} . \mathbf{I}=\mathbf{O I}+\mathbf{I I}$.

5. Переход к средним значениям интегральных показателей и оценка точности:

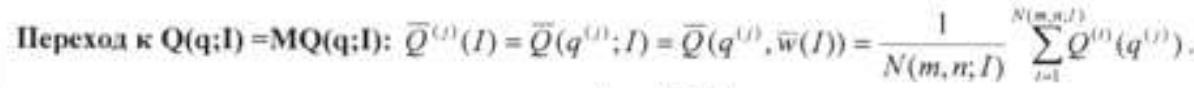
Оиенка точности Q(q;I): $\left[S^{(j)}(I)\right]^{2}=\frac{1}{N(m, n ; I)} \sum_{i=1}^{N(m, n)}\left[Q^{(n)}\left(q^{(n)}\right)-\bar{Q}^{(n)}(I)\right]^{2}$

Рис.13. Этапы и содержание интегральной оценки по МРСП.

Сравнение состояния экосистем на интегральной основе дает возможность количественно оценивать пространственно-временные особенности их динамики, степень их трансформации, тенденции их изменения, степень допустимого воздействия на них. В последнем случае, в качестве «предельно допустимого» значения сводного показателя при оценке можно рекомендовать значение, полученное на основе «свертки» предельнодопустимых значений исходных параметров или правое значение интервала сводного показателя для выбранного класса с лучшим качеством (первого или второго). Вторым подходом, использованным нами, является оценка способности системы сохранить свой класс состояния (устойчивости) при оказанном на нее воздействии. В этом случае в гипотетических сценариях с нагрузками на отдельные блоки или на всю систему в целом, выявляются пределы, при которых сохраняется класс состояния, в котором система пребывала до воздействия.

Применение МРСП позволяет сравнивать «несравнимые» объекты $x^{(r)}, x^{(s)} \in X$ («несравнимые» многокритериальные оценки $q^{(r)}, q^{(s)}$ ), так как числовые значения 
$Q^{(r)}=Q\left(q^{(r)}\right), \quad Q^{(s)}=Q\left(q^{(s)}\right) \quad$ сводного показателя $Q=Q(q) \quad$ оставляют всего три альтернативы для результата сравнения уровня оцениваемого свойства экосистем: (1) $Q^{(r)}>Q^{(s)}$ - уровень исследуемого свойства $x^{(r)}$ выше уровня $x^{(s)}$; (2) $Q^{(r)}<Q^{(s)}$ уровень $x^{(r)}$ ниже уровня $x^{(s)}$; (3) $Q^{(r)}=Q^{(s)}$ - экосистемы $x^{(r)}, x^{(s)}$ обладают одинаковым уровнем исследуемого свойства.

Простейшей синтезирующей функцией, удовлетворяющей условиям 1-3, является линейная функция

$$
Q=Q(q ; w)=Q\left(q_{1}, \ldots, q_{m} ; w_{1}, \ldots, w_{m}\right)=\sum_{i=1}^{m} q_{i} w_{i},
$$

представляющая собой взвешенное среднее арифметическое значений отдельных показателей и определяемая вектором параметров $w=\left(w_{1}, \ldots, w_{m}\right)$, неотрицательными компоненты которого являются весовые коэффициенты («веса»), задающие значимость (важность) отдельных показателей для сводной оценки уровня оцениваемого свойства экосистемы. Введение дополнительного условия для нормирования весов $\left(w_{1}+\ldots+w_{m}=1\right)$ позволяет говорить о значении параметра $w_{i}$ как об оценке относительной значимости отдельного показателя $q_{i}$.

Помимо простоты построения сводного показателя $Q$, осуществляемого при помощи синтезирующей функции (1), можно указать еще ряд достоинств этой аддитивной свертки отдельных показателей. Во-первых, аддитивная синтезирующая функция понятна исследователям, проводящим оценку качества многопараметрических объектов различной природы. Во-вторых, весовые коэффициенты, определяющие значимость отдельных показателей качества, легко интерпретируемы, а их влияние на величину сводного показателя нетрудно вычислить. В-третьих, аддитивная свертка отдельных показателей качества универсальна в том смысле, что любое наперед заданное ранжирование сложных объектов по уровню оцениваемого качества всегда можно представить как результат оценки качества при помощи некоторой линейной синтезирующей функции от определенной многокритериальной оценки. Учитывая эти и другие аргументы, в наших публикациях, начиная с начала 1990-х гг., чаще всего используется именно аддитивная свертка отдельных показателей различных свойств природных объектов, осуществляемая при помощи синтезирующей функции вида (Дмитриев, 1995; Дмитриев, Мякишева, Хованов, 1996; Дмитриев, Мякишева, Третьяков, Хованов, 1997; Дмитриев, Огурцов, Третьяков, Васильев, 1999 и др., Дмитриев, Огурцов, 2012, 2013, 2014, 2017).

Простейший вариант построения сводного (интегрального, обобщенного и т.п.) показателя, синтезирующего отдельные (локальные, дифференциальные, частные и т.п.) показатели, характеризующие качество (продуктивность, устойчивость, благополучие и т.п.) водных экосистем, можно представить, предполагая заданными объекты и их оцениваемое свойство, в виде последовательности следующих этапов (рис.2).

1. Формируется матрица $\left(x_{i}^{(j)}\right), i=1, \ldots, m, j=1, \ldots, k$, значений $m$ исходных критериев для $k$ исследуемых объектов. Здесь $x_{i}^{(j)}$ есть значение $i$-ого исходного критерия для $j$-го объекта.

2. Задаются нормирующие кусочно-линейные функции вида (1) и (2), определяющие матрицу $\left(q_{i}^{(j)}\right), i=1, \ldots, m, j=1, \ldots, k$, значений $m$ отдельных показателей для $k$ исследуемых объектов. Здесь $q_{i}^{(j)}$ есть значение $i$-го отдельного (нормированного) показателя исследуемого свойства для $j$-го водного объекта.

В качестве $d$-функции выберем линейную свертку нормированных равновесных значений критериев. Для нормирования будем использовать неубывающую кусочностепенную функцию вида 


$$
q_{i}=q_{i}\left(x_{i}\right)=\left\{\begin{array}{lr}
0, & x_{i} \leq \min _{i}, \\
\left(\frac{x_{i}-\min _{i}}{\max _{i}-\min _{i}}\right)^{\lambda}, & \min _{i}<x_{i} \leq \max _{i}, \\
1, & x_{i}>\max _{i}
\end{array}\right.
$$

Такая функция может быть использована в случае, когда увеличение значения $i$ ой исходной характеристики не влечет снижения уровня качества (трофности, устойчивости и др.), оцениваемого с точки зрения $i$-го критерия. При этом всем параметрам со значениями $x_{i}$, не превосходящими некоторого фиксированного уровня $\min _{i}$, приписывается минимальное значение $i$-го отдельного (нормированного) показателя, а параметрам со значениями $x_{i}$, превосходящими фиксированный уровень $\max _{i}$ - максимальное значение этого отдельного показателя. Исследователь должен дополнительно выбрать показатель степени $\lambda$, определяющий характер и степень выпуклости нормирующей функции $q_{i}\left(x_{i}\right)$ : при $\lambda>1$ соответствующая нормирующая функция выпукла вниз, а при $\lambda<1$ - вверх.

Если при увеличении значения $i$-ой исходной характеристики уровень качества (трофности, устойчивости и др.), оцениваемый по $i$-му критерию, не возрастает, то может быть применена невозрастающая кусочно-степенная функция вида

$$
q_{i}=q_{i}\left(x_{i}\right)=\left\{\begin{array}{lr}
1, & x_{i} \leq \min _{i}, \\
\left(\frac{\max _{i}-x_{i}}{\max _{i}-\min _{i}}\right)^{\lambda}, & \min _{i}<x_{i} \leq \max _{i}, \\
0, & x_{i}>\max _{i} .
\end{array}\right.
$$

Особенно просто построение нормирующих кусочно-линейных функций, получающихся при подстановке в формулы (1), (2) значения параметра $\lambda=1$. Далее, на первых этапах работы мы будем использовать именно такие простейшие нормирующие функции, учитывая, что выбор линейной нормировки всегда может быть оправдан на первом этапе исследования. В качестве $\min _{i}$ будем использовать левое граничное значение критерия для первого класса, а в качестве maxi $_{i}$ - правое граничное значение для последнего класса (у некоторых параметров - наоборот).

3. Определяются весовые коэффициенты $w_{1}, \ldots, w_{m}$, удовлетворяющие условиям $w_{i} \geq 0, \quad w_{1}+\ldots+w_{m}=1, \quad$ и определяющие сравнительную значимость отдельных показателей для определения сводного показателя исследуемого свойства. Знание весовых коэффициентов позволяет построить для каждого из исследуемых объектов $x^{(j)}$, $j=1, \ldots, k$, искомый сводный показатель качества $Q^{(j)}=Q\left(q^{(j)} ; w\right)$.

Опыт исследований показывает, что наиболее ответственным и тонким местом этого метода является этап определения значений весовых коэффициентов $w_{1}, \ldots, w_{m}$. Дело в том, что исследователь не имеет, как правило, достаточно информации для однозначного задания числовых значений весов. Такой дефищит информации можно описать, указав множество всех возможных значений для вектора весовых коэффициентов $w=\left(w_{1}, \ldots, w_{m}\right)$.

Будем полагать, что весовые коэффициенты задаются с некоторой конечной точностью, определяемой шагом отсчета $h=1 / n$, где $n$ - натуральное число $(n>1)$. Тогда множество всех возможных «весовых векторов» представляет собой конечное число элементов $N(m, n)$, определяемое формулой (Хованов, 1996):

$$
N(m, n)=\left(\begin{array}{c}
n+m-1 \\
n
\end{array}\right)=\left(\begin{array}{c}
n+m-1 \\
m-1
\end{array}\right)=\frac{(n+m-1) !}{n !(m-1) !} .
$$


Следует заметить, что число всех возможных весовых векторов очень быстро растет при увеличении числа $m$ используемых критериев и показателя дискретности $n$, достигая внушительных значений уже при сравнительно небольших значениях параметров $m, n: N(5,10)=1001, N(10,40)=2054455634$ и т.д. (Хованов, 1996).

Опыт также показывает, что, зачастую, исследователь может описать свои представления о значимости отдельных критериев оценивания в виде сравнительных суждений типа «значимость показателя $q_{r}$ выше (ниже) значимости показателя $q_{s}$ ", «показатели $q_{r}, q_{s}$ имеют одинаковую значимость», «значимость показателя $q_{i}$ не ниже (не выше) фиксированного значения $a_{i}\left(b_{i}\right)$ из отрезка [0,1]» и т.п. Эти утверждения позволяют сказать, что весовые коэффициенты измеряются не по абсолютной числовой шкале, но по некоторым ординальнымм (порядковым) и/или интервальным шкалам.

Ординальная (нечисловая) информация может быть описана при помощи системы

$$
O I=\left\{w_{r}>w_{s}, w_{u}=w_{v}, \ldots r, s, u, v \in\{1, \ldots, m\}\right\}
$$

равенств и неравенств для соответствующих весовых коэффициентов. Аналогично интервальная (неточная) информация задается системой неравенств

$$
I I=\left\{0 \leq a_{i} \leq w_{i} \leq b_{i} \leq 1, \quad i \in(1, \ldots, m\}\right\} .
$$

Информация, описываемая объединенной системой $I=O I \cup I I$ равенств и неравенств для весовых коэффициентов, определяет некоторое подмножество

$$
W(m, n ; I)=\left\{w^{(t)}=\left(w_{1}^{(t)}, \ldots, w_{m}^{(t)}\right) ; t=1, \ldots, N(m, n ; I)\right\}
$$

множества всех возможных дискретных весовых векторов $W(m, n)$, состоящее из тех и только из тех векторов весовых коэффициентов $w=\left(w_{1}, \ldots, w_{m}\right)$, компоненты которых удовлетворяют всем неравенствам системы $I$, и имеющее число элементов $N(m, n ; I)<N(m, n)$. Поскольку в общем случае не все весовые коэффициенты $w, \ldots, w_{m}$ входят в одно из равенств или неравенств системы $I$, постольку далее мы будем говорить о множестве $W(m, n ; I)$ как о множестве допустимых весовых векторов, определяемом нечисловой, неточной и неполной информацией I (Хованов, 1996).

Теперь в качестве оценки $\bar{w}_{i}(I) \quad i$-го весового коэффициента, учитывающей дополнительную информацию $I$, естественно взять среднее

$$
\bar{w}_{i}(I)=\frac{1}{N(m, n ; I)} \sum_{t=1}^{N(m, n ; I)} w_{i}^{(t)}
$$

всех допустимых значений $w_{i}^{(1)}, \ldots, w_{i}^{(N(m, n ; I))}$ этого весового коэффициента. Вектор числовых оценок $\bar{w}(I)=\left(\bar{w}_{1}(I), \ldots, \bar{w}_{m}(I)\right)$ можно трактовать как числовой образ нечисловой, неточной и неполной информации I (Хованов, 1996).

Точность полученной оценки $\bar{w}_{i}(I) \quad i$-го весового коэффициента можно измерить величиной $s_{i}(I)$, определяемой средним

$$
s_{i}^{2}(I)=\frac{1}{N(m, n ; I)} \sum_{i=1}^{N(m, n ; i)}\left[w_{i}^{(t)}-\bar{w}_{i}(I)\right]^{2}
$$

всех $N(m, n ; I)$ возможных квадратов отклонений от этой оценки.

Достоверность того, что весовой коэффициент $r$-го отдельного показателя превосходит по величине весовой коэффициент $s$-го отдельного показателя, можно оценить при помощи доли

$$
p(r, s ; I)=\frac{N\left\{t: w_{r}^{(t)}>w_{s}^{(t)}\right\}}{N(m, n ; I)}
$$

всех допустимых значений $w_{r}^{(t)}, w_{s}^{(t)}, t=1, \ldots, N(m, n ; I)$, для которых выполняется соответствующее неравенство (Хованов, 1996). 
Вектор числовых оценок $\bar{w}(I)=\left(\bar{w}_{1}(I), \ldots, \bar{w}_{m}(I)\right)$ трактуется как числовой образ нечисловой, неточной и неполной информации $I$.

Таким образом, значимость отдельных критериев измеряется по нечисловой (ординальной, порядковой) шкале или всем критериям навязывается равенство приоритетов оценивания. В других случаях мы можем задать интервалы возможного варьирования весовых коэффициентов. В связи с этим появляется необходимость работы с нечисловой (порядковой), неточной (интервальной) информацией, которая чаще всего бывает и неполной (не для всех весовых коэффициентов заданы нетривиальные равенства и неравенства, соответствующие интервальной и порядковой информации). Нечисловая, неточная и неполная информация (т.н. «ннн»- информация) индуцирует целое множество допустимых наборов весовых коэффициентов, что затрудняет непосредственное применение традиционного МСП. Для преодоления этого затруднения мы воспользовались байесовской моделью рандомизащии неопределенности (Хованов, 1986; 1996; 1998). Идея этой модели восходит к работе Томаса Байеса и состоит в переходе от неопределенного выбора весовых коэффициентов к случайному (рандомизированному) выбору их из множества всех допустимых наборов весовых коэффициентов. Таким образом, исследователь получает случайные весовые коэффициенты.

Логично теперь не ограничиться только средними значениями этих весовых коэффициентов и рассчитать по ним интегральные показатели, а пойти дальше, не осредняя их, а подставив каждую из комбинаций весовых множителей в формулу расчета интегрального показателя, получить множество из значений для всех комбинаций весов и перейти к средним значениям интегральных показателей. Таким образом мы получим случайные (рандомизированные) интегральные (сводные) показатели. Задачи оценки свойств экосистемы, определения нормы ее состояния, а также нормы воздействия на нее в этом случае сводятся к задачам сравнения соответствующих рандомизированных интегральных показателей, а МСП превращается в метод рандомизированных сводных показателей (МРСП).

Далее, поскольку вектор весовых коэффициентов определен с точностью до множества $W(m, n ; I)$, постольку и сводный показатель свойства $j$-го объекта, имеющего многокритериальную оценку свойства $q^{(j)}=\left(q_{1}^{(j)}, \ldots, q_{m}^{(j)}\right)$, определен с точностью до множества всех своих допустимых значений $Q^{(t)}\left(q^{(j)}\right)=Q\left(q^{(j)} ; w^{(t)}\right), t=1, \ldots, N(m, n ; I)$, где

$$
Q^{(t)}\left(q^{(j)}\right)=Q\left(q^{(j)} ; w^{(t)}\right)=\frac{1}{m} \sum_{i=1}^{m} q_{i}^{(j)} w_{i}^{(t)}
$$

В этом случае естественно взять в качестве оценки $\bar{Q}^{(j)}(I)=\bar{Q}\left(q^{(j)} ; I\right)$ сводного показателя свойства $j$-го объекта среднее

$$
\bar{Q}^{(j)}(I)=\bar{Q}\left(q^{(j)} ; I\right)=\bar{Q}\left(q^{(j)}, \bar{w}(I)\right)=\frac{1}{N(m, n ; I)} \sum_{i=1}^{N(m, n ; I)} Q^{(t)}\left(q^{(j)}\right)
$$

всех $N(m, n ; I)$ допустимых значений сводного показателя оцениваемого свойства этого объекта.

Точность полученной сводной оцеенки $\bar{Q}^{(j)}(I)$ качества $j$-го объекта можно измерить величиной $S^{(j)}(I)$, определяемой по среднему

$$
\left[S^{(j)}(I)\right]^{2}=\frac{1}{N(m, n ; I)} \sum_{t=1}^{N(m, n ; I)}\left[Q^{(t)}\left(q^{(j)}\right)-\bar{Q}^{(j)}(I)\right]^{2}
$$

квадратов отклонений допустимых значений сводного показателя $j$-го объекта от соответствующей сводной оценки.

Достоверность того, что сводный показатель качества $j$-го объекта превосходит по величине сводный показатель качества $l$-го объекта может быть оценена долей 


$$
P(j, l ; I)=\frac{N\left\{t: Q^{(t)}\left(q^{(j)}\right)>Q^{(t)}\left(q^{(l)}\right)\right\}}{N(m, n ; I)}
$$

всех допустимых значений $Q^{(t)}\left(q^{(j)}\right), Q^{(t)}\left(q^{(l)}\right), t=1, \ldots, N(m, n ; I)$, для которых выполнено соответствующее неравенство (Хованов, 1996).

Полученные сводные оценки $\bar{Q}^{(j)}(I), j=1, \ldots, k$, вместе с вычисленными для них показателями точности $S^{(j)}(I), \quad j=1, . ., k, \quad$ и показателями достоверности (надежсности) попарного доминирования $P(j, l ; I), \quad j, l=1, \ldots, k$, решают задачу применения МСП в условиях неопределенности, вызываемой дефицитом информации о точных числовых значениях весовых коэффициентов и связанной с необходимостью использовать нечисловую, неточную и неполную информацию о сравнительной значимости отдельных показателей качества для определения сводного показателя (Хованов, 1996).

Этот метод был адаптирован для оценивания состояния водных объектов и их эмерджентных свойств, характеризуемых большим числом признаков, для классификации различных свойств водоемов с использованием нечисловой, неточной и неполной информации об их принадлежности к определенным классам. На основе данного подхода удается решить проблему определения нормы состояния водной экосистемы в условиях дефицита информации и неопределенности суждения о приоритетах оценивания исследуемых свойств.

По результатам исследований нами были опубликованы монографии: «Интегральная оценка экологического состояния и качества городской среды» (под ред. А.К.Фролова, 1999); Александрова Л.В., Васильев В.Ю., Дмитриев В.В., Мякишева Н.В., Огурцов А.Н., Третьяков В.Ю., Хованов Н.В. «Многокритериальные географоэкологические оценки состояния и устойчивости природных и урбанизированных систем» (под ред. В.В. Дмитриева и Н.В. Хованова, 2000, Депонировано ВИНИТИ 01.09.2000. № деп.2342В00, 275 с.); В.В.Дмитриев, Н.В.Хованов, А.Н.Огурцов, В.Ю.Васильев, В.А. Шелутко, Ю.А.Проценко, Е.А.Примак «Интегральная оценка экологического состояния и качества среды городских территорий, рек и морских акваторий». Раздел $\mathrm{V}$ монографии «ЭКОЛОГИЯ И ГИДРОМЕТЕОРОЛОГИЯ БОЛЬШИХ ГОРОДОВ И ПРОМЫШЛЕННЫХ ЗОН [РОССИЯ-МЕКСИКА]». Том II. Мониторинг окружающей среды. Под общей редакцией Карлина Л.Н. и Шелутко В.А. Редакторы: Скакальский Б.Г., Перевощикова М., Дмитриев В.В. и др. - СПб.: РГГМУ, 2010 - с.102-134.; Dmitriev, V. V., Ogurtsov, A. N., Hovanov, N. V., Osipov, G. K., Kulesh, V. P., Sergeyev, Y. N., \& Fedorova, I. V. (2020). Integral Assessment of Condition and Sustainability of Socio-Ecological-Economic Systems. Landscape Modelling and Decision Support, 49-78. doi:10.1007/978-3-030-37421-1_4; Dmitriev, V. V., Terleev, V. V., Nikonorov, A. O., Ogurtsov, A. N., Osipov, A. G., Sergeyev, Y. N., Kulesh, V. P., Fedorova, I. V. (2020). Global Evaluation of the Status and Sustainability of Terrestrial Landscapes and Water Bodies. Landscape Modellingand Decision Support, 231-253. doi:10.1007/978-3-03037421-1_12 и др. (см. список литературы)

\section{Вопросы для проверки усвоения лекции:}

Продолжите предложение:

1. Роль эксперта предельно велика на каждом этапе построения сводных показателей в условиях неопределенности: 1 - при выборе исходных характеристик $x_{1}, \ldots, x_{m}$, когда исследователь должен зафиксировать список ...; 2- при получении отдельных показателей $q_{1}, \ldots, q_{m}$, когда необходимо задать правило ...; 3 - при расчете сводного показателя $Q=Q(q ; w)$, характеризующего качество объекта в целом, когда эксперт должен расставить ... .

\section{Литература}

Азгальдов Г.Г., Азгальдова Л.А. Количественная оценка качества. М.,1971. 176с. Азгальдов Г.Г., Райхман Э.П. О квалиметрии. М., 1973. 172 с. 
Айвазян С.А., Бухштабер В.М. и др. Классификация и снижение размерности. Под ред. С.А.Айвазяна, М., 1989.

Алексеев Д.К., Дмитриев В.В., Михтеева Е.Ю., Амаро-Медина Д.Р., Свердлова О.А. Интегральная оценка трофического статуса и качества воды акватории Невской губы. В сборнике:День Балтийского моря 2018. СанктПетербург, 22-23 марта 2018 г. Издательство ООО «Свое издательство», 2018.4 С. $48-51$. https://elibrary.ru/item.asp?id=35612738

Алексеев Д.К., Дмитриев В.В., Михтеева Е.Ю., Амаро-Медина Д.Р., Свердлова О.А. AN INTEGRATED ASSESSMENT OF THE TROPIC STATUS AND THE WATER QUALITY OF THE NEVA BAY. В сборнике: День Балтийского моря 2018. Санкт-Петербург, 22-23 марта 2018 г. Издательство ООО «Свое издательство», 2018. С. $52-$ 54.https://elibrary.ru/item.asp?id=35615713

Алефельд Г., Херибергер Ю. Введение в интервальные вычисления. М., 1987. 356 с.

Амаро Медина Д.Р., Дмитриев В.В. Подходы к интегральной оценке и ГИС-картографированию устойчивости и экологического благополучия геосистем. Интегральная оценка экологического благополучия речных систем. Журнал «Вестник СПбГУ» серия 7. 2019.

Андрианов Ю.М., Субетто А.И. Квалиметрия в приборостроении и машиностроении. Л., 1990. 216 с.

Богданчук В.З., Егоров Б.М., Катулев А.Н. Агрегирование векторных критериев. Л., 1990. 127 с.

Вилкас Э. Теория полезности и принятие решений // Мат. методы в соц. науках. Вильнюс, 1971. С.13-60.

Гермейер Ю.Б. Введение в теорию исследования операций. М., 1971. 383 с.

Гидрометеорология и гидрохимия морей СССР. Том III. Балтийское море. Вып. 1. Гидрометеорологические условия. Под ред. Ф.С. Терзиева, В.А.Рожкова, А.И.Смирновой. СПб., 1992.

Гидрометеорология и гидрохимия морей. Том III. Балтийское море. Вып. 2. Гидрохимические условия и океанологические основы формирования биологической продуктивности. Под ред. Ф.С.Терзиева, В.А.Рожкова, Е.Я. Римша, И.С.Шпаер. СПб., 1994.

Гличев А.В., Рабинович Г.О., Примаков М.И. Прикладные вопросы квалиметрии. М., 1983. 136 с.

Дмитриев В.В., Амаро Медина Д.Р., Огуриов А.Н., Добрынина А.С. Оценка экологического статуса системы «река-водосбор»: подходы, методика, результаты. Экология речных бассейнов: Труды 9-й Междунар. науч.-практ. конф. / Под общ. ред. проф. Т.А. Трифоновой; Владим. гос. ун-т. им. А.Г. и Н.Г. Столетовых, Владимир, 2018. C. 46-52.ISBN 978-5-93767-292-6 https://elibrary.ru/item.asp?id=35609968

Дмитриев В.В., Мякишева Н.В., Третьяков, В.Ю., Хованов Н.В., (1997), Многокритериальная оценка экологического состояния и устойчивости геосистем на основе метода сводных показателей . II.Трофический статус водных экосистем, Вестн. СПбГУ, Сер. 7: Геология, география, Вып. 1(N 7), С.51-67.

Дмитриев В.В., Мякишева Н.В., Хованов Н.В., (1996), Многокритериальная оценка экологического состояния и устойчивости геосистем на основе метода сводных показателей, І. Вестн. СПбГУ. Сер. 7: Геология. География, Вып. 3 (N 21), C. 40-52.

Дмитриев В.В., Пряхина Г.В., Огуриов А.Н., Примак Е.А., Амаро Медина Д.Р. Оценка эмерджентных свойств водных объектов: трофический статус, устойчивость, экологическое благополучие. В сборнике: Третьи Виноградовские чтения. Грани гидрологии. Сборник докладов международной научной конференции памяти выдающегося русского гидролога Юрия Борисовича Виноградова. Санкт-Петербург, 28-30 марта 2018 г. Под редакцией О.М. Макарьевой. Издательство «Наукоемкие технологии», Санкт-Петербург, 2018. С. 347-354. https://elibrary.ru/item.asp?id=35342482

Дмитриев В.В., Огурцов А.Н., Русаков А.В., Машкин Ю.Л., Петров И.М. Особенности пространственной структуры загрязнения тяжелыми металлами почвенного покрова на участке проектирования второй очереди полигона ТБО Великого Новгорода. Материаль Международной конференции «ИнтерКарто/ИнтерГИС». 2018; 24(1): 382393.http://doi.org/10.24057/2414-9179-2018-1-24-382-393.

Доес Р. Устойчивая привлекательность неправильных линейных моделей принятия решений // Нормативные и дескриптивные модели принятия решений. М., 1981. С.305-309.

Дружинин Н.И., Шишкин А.И. Математическое моделирование и прогнозирование загрязнения поверхностных вод суши. Л., 1989.

Дюран Б., Оделл П. Кластерный анализ. /Пер. с англ. ; Под ред. . М., 1977.

Жиров А. И., Дмитриев В. В., Ласточкин А. Н. Прикладная экология. В 2 т. Том 1 : учебник для академического бакалавриата / А. И. Жиров, В. В. Дмитриев, А. Н. Ласточкин ; под ред. А. И. Жирова. - 2-е изд., перераб. и доп. - М. : Издательство Юрайт, 2018. - 355 с. — (Серия: Бакалавр. Академический курс). — ISBN 978-5-534-06915-0.

Жиров А. И., Дмитриев В. В., Ласточкин А. Н. Прикладная экология. В 2 т. Том 2 : учебник для академического бакалавриата. Том 2 : учебник для академического бакалавриата / А. И. Жиров, В. В. Дмитриев, А. Н. Ласточкин ; под ред. А. И. Жирова. - 2-е изд., перераб. и доп. - М. : Издательство Юрайт, 2018. - 311 с. — (Серия: Бакалавр. Академическийкурс). - ISBN 978-5-534-06916-7.

Интегральная оценка экологического состояния и качества среды городских территорий. Под ред. А.К.Фролова, СПб, 1999, 253c. 9. Многокритериальные географо-экологические оценки состояния и устойчивости природных и урбанизированных систем. Под ред.В.В.Дмитриева и Н.В.Хованова. Деп. ВИНИТИ 01.09.2000 № деп.2342В00, 275 с.

Колесникова О.Н., Корников В.В., Рожков Н.Н. Стохастические процессы с равновероятными монотонными реализациями, моделирующие дефицит информации // Вестн. Ленингр. ун-та. 1987, №1. С.21-26.

Корников В.В., Хованов Н.В., Юдаева М.С. Многокритериальная классификация в условиях дефицита числовой информации // Труды Карельского научного центра Российской академии наук. №5. Серия «Математическое моделирование и информационные технологии». Выпуск 3. Петрозаводск: КарНЦ РАН, 2012. С. 38-43.

Ларичев О.И. Принятие решений как научное направление // Системн. исследов. Ежегодник-1982. М., 1982. C.227-243.

Меньшиков Г.Г. Практические начала интервальных вычислений. Л., 1991. 92 с.

Огуриов А.Н., Дмитриев В.В. Интегральная оценка и геоинформационный анализ социальных детерминант здоровья населения крайнего севера европейской части Российской Федерации. Материаль Международной конференции «ИнтерКарто/ИнтерГИС». 2019. 
Огуриов А.Н., Дмитриев В.В., Разживин В.Ю. Устойчивость почвенного покрова острова Сахалин к

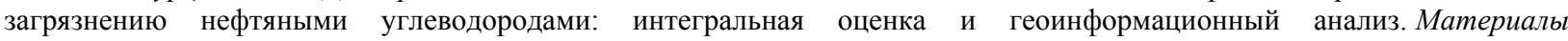
Международной конференции «ИнтерКарто/ИнтерГИС». 2018; 24(1): 437-449.http://doi.org/10.24057/2414-9179-2018-124-437-449.

Орлов А.И. Прикладная теория измерений // Прикл. многомерн. стат. Анализ. Ь., 1978. С.68-138.

Осипов А.Г., Дмитриев В.B. Метод геоэкологической оценки природно-аграрного потенциала земель природных ландшафтов. Экология речных бассейнов: Труды 9-й Междунар. науч.-практ. конф. / Под общ. ред. проф. T.А. Трифоновой; Владим. гос. ун-т. им. А.Г. и Н.Г. Столетовых, Владимир, 2018. С. 226-231.ISBN 978-5-93767-2926https://elibrary.ru/item.asp?id=35610008

Пфанцагль И. Теория измерений. М,. 1976. 248 с.

Трухаев Р.И. Модели принятия решений в условиях неопределенности. М., 1981. 257 с.

Трухаев Р.И., Гориков И.С. Факторный анализ в организационных системах. М., 1985.185 с.

Трушевский В.Л., Дмитриев В.В., Осипов А.Г. Оценка устойчивости водных объектов суши: подходы и результаты.Экология речных бассейнов: Труды 9-й Междунар. науч.-практ. конф. / Под общ. ред. проф. Т.А. Трифоновой; Владим. гос. ун-т. им. А.Г. и Н.Г. Столетовых, Владимир, 2018. C. 104-110.ISBN 978-5-93767-292-6 https://elibrary.ru/item.asp?id=35609984

Хованов К.Н., Хованов Н.В. Анализ и Синтез Показателей при Информационном Дефиците (АСПИД-3W). Свидетельство РосАПО об официальной регистрации программы для ЭВМ № 960087 от 22.03 .1996 г. Правообладатель: ЗАО «Академия».

Хованов Н.В. Анализ и синтез показателей при информационном дефиците. СПб., 1996. 196 с.

Хованов Н.В. АСПИД - система квалиметрических методов оценивания в условиях дефицита информации качества сложных технических объектов //Методология и практика оценки качества продукции. Л., 1988.

Хованов Н.В. Математические основы теории шкал измерения качества. Л., 1982. 185 с.

Хованов Н.В. Стохастические модели теории квалиметрических шкал. Л., 1986.

Хованов Н.В. Универсальность линейной свертки отдельных показателей // Методол. и практика оценки качества продукции. Вып.3. Л., 1990. С.70-74.

Хованов Н.В., (1996), Анализ и Синтез Показателей при Информационном Дефиците, 195 с.

Хоменюк В.В. Элементы теории многоцелевой оптимизации. М., 1983. 124 с.

Чиркова T.B. Физиологические основы устойчивости растений СПб. 2002.

Bayes T. An essay towards solving a problem in the doctrine of chances // Biometrika. 1958. Vol. 45. P. 296-315.

Vasily V. Dmitriev Глава V/4: Интегральная оценка состояния региональных социо-эколого-экономических систем, качества жизни населения, устойчивости социосистем. Chapter V/4: Integral Assessment of the State of Regional Socio-Ecological and Economic Systems, the Quality of Life of the Population, the Stability of Socio-Systems / Новые методы и результаты исследований ландшафтов в Европе, Центральной Азиии, Сибири (в пяти томах). Том 5. Планирование, управление и реабилитация ландшафтов /под редакцией академика РАН В.Г.Сычева, Л. Мюллера. - М.: изд-во ФГБНУ «ВНИИ агрохимии», 2018. - c.23-28. DOI 10.25680/1415.2018.75.85.350 http://www.vniia-pr.ru/monografii/tom5.htm

Dawes R., Carrigan B. Linear models in decision making // Psychol.Bull. 1974. Vol.81. P.95-106.

Dombi J. Basic concepts for a theory of evaluation: the aggregative operator // Eur.J.Oper.Res. 1982. Vol.10, N3. P.282-293.

Hovanov N.V., Kornikov V.V., Tokin I.B. The Mathematical Methods System of Decision Making for developmental Strategy under Uncertainty // Global Environmental Change. Perspectives of remote Sensing and Geographic Information System. New Delhi - Calcutta 1995.

Hovanov N., Hovanov K., Yudaeva M. 2009. Multicriteria estimation of probabilities on basis of expert non-numeric, non-exact and non-complete knowledge. European Journal of Operational Research. 195(3) pp 857-863

Hovanov, N.V. 2008. Decision Support System APIS for MEAD. Advanced User Guide. Decision Support System.

Wittmuss A. Scalarizing multiobjective optimization problems // Math.Res. !985. Vol.27. P.255-258.

http://iaap.narod.ru/stkDiks.htm

Раздел 4. Разработка и апробация моделей интегральной оценки экосистем, геосистем, наземных и водных ландшафтов и их эмерджентных свойств. Опыт интегрального оценивания.

\author{
Лекция № 8 \\ Некоторые результаты интегральной оценки состояния и устойчивости, эко-, \\ гео- и социосистем. \\ Объектами исследования выбраны наземные ландшафты, морские и озерные \\ системы, системы «водоток-водосбор», социо-эколого-экономические системы. \\ Предметами исследования являются теоретико-методологические аспекты и методы \\ построения интегральных показателей состояния (интегральный показатель \\ продуктивности, интегральный показатель качества среды и др.), интегральных \\ показателей устойчивости, интегральных показателей благополучия (здоровья) наземных, \\ озерных и речных систем, социо-эколого-экономических систем и качество жизни \\ населения. Акцент в исследованиях сделан на разработку многокритериальных и \\ многоуровневых классификаций для исследования эмерджентных свойств сложных
}


систем в природе и обществе и построение интегральных показателей на основе метода сводных показателей (MCП), ASPID и APIS методов и моделей.

Интегральная оценка трофического статуса водоемов. Интегральная оценка продукционных свойств водоемов для озер северо-западного Приладожья (оз.Суури) в 2018 г. была выполнена на основе покомпонентного оценивания и по методу сводных показателей (МСП). Покомпонентный анализ, выполненный по 10 параметрам оценивания показал, что по 3-м параметрам трофический статус озера соответствует классу олиготрофии и по 3-м параметрам - мезотрофии и по 3-м параметрам озеро относится к классу «эвтрофное». По совокупности критериев оценивания при интегральной оценке озеро Суури следует отнести к середине мезотрофного класса.

Интегральная оценка трофического статуса оз.Суури в 2017 г (Трушевский, Дмитриев, Осипов, 2018; Дмитриев, 2017) показала, что данный водоем при покомпонентном оценивании имел следующее соотношение признаков олиго:мезо:эвтрофии $=4: 3: 2$. По величине интегрального показателя $($ ИПТ $=0,28)$ водоем попадал в левую границу мезотрофного класса при ширине интервала класса 0,20-0,46.

В 2016 г. по величине интегрального показателя трофности (ИПТ), рассчитанного для 2014-2016 гг. трофический статус озера по средней величине интегрального показателя был отнесен к середине класса мезотрофных вод (ИПТ $=0,29)$ при ширине интервала класса от 0,14 до 0,34. В 2010-2013гг. по величинам ИПТ от 0,26 до 31 , рассчитанных по 4 параметрам трофический статус озера был определен как мезотрофный при ширине интервала класса 0,14-0,34.

Интегральная оценка трофического статуса морских арктических акваторий выполнялась для 2005-2012 гг. ИПТ района шельфа моря Лаптевых рассчитывались по 6 параметрам для периода 2005-2006 гг. По величине ИПТ=0,16 акватория отнесена к классу олиготрофных водоемов (ширина интервала для класса 0,00-0,27). Интегральная оценка трофического статуса для трех районов Карского моря, выполненная по 5 параметрам для 2007-2012 гг также позволила отнести исследованные районы к олиготрофному классу.

Интегральная оценка трофности Северного, Центрального, Южного районов Невской губы восточной части Финского залива выполнена по материалам натурных наблюдений 2000-2010 гг по 4 параметрам. На основе данных Росгидромета были рассчитаны среднегодовые значения показателей трофности для Северного (по 7 станциям.), Центрального (по 8 станциям), Южного (по 7 станциям) районов.

Выявлены характерные особенности изменения интегральных показателей трофности в районах. Для Северного района ИПТ изменялись от 0,36 (2000) до 0,38 (2010), таким образом, выявлена тенденция незначительного роста ИПТ за 10 лет $(6,5 \%)$ в пределах класса мезотрофных вод (границы класса - от 0,19 до 0,60). Все значения ИПТ относятся к середине класса. Для Центрального района ИПТ изменялись от 0,36 (2000) до 0,40 (2010). Также выявлена тенденция незначительного роста ИПТ за период 2000-2005 год и незначительного снижения ИПТ к 2010 году. Полученные значения также находятся в пределах класса мезотрофных вод. Для Южного района ИПТ изменялись от 0,45 (2000) до 0,46 (2010). Выявлена тенденция незначительного роста ИПТ за период 2000-2005 год и снижения ИПТ к 2010 году, все значения ИПТ находятся в пределах класса мезотрофных вод.

Интегральная оценка устойчивости водоемов к изменению параметров естественного и антропогенного режимов.

Пример 1. Различные методы и модели апробированы для водных объектов севера и северо-запада РФ по наблюдениям 2003-2004 гг (Дмитриев, Примак, 2009). Рассматривалась адаптационная устойчивость к изменению параметров режимов. Рассчитаны различные интегральные показатели устойчивости для 13 озер. В расчетах высокая адаптационная устойчивость характеризовалась значениями интегральных 
показателей (ИПУ) близкими к 1,0, низкая - близостью к 0,0. Для характеристики устойчивости к изменению параметров естественного режима (Уе) (потенциальная устойчивость) использовались данные по группе физико-географических характеристик: морфометрии, климату, гидрологическому режиму. Для характеристики устойчивости к изменению антропогенного режима использовались данные по изменению трофического статуса водоемов (антропогенному эвтрофированию) (Уэ) или по изменению качества воды (Ук). На втором уровне свертки оценивался совместный эффект Уе+Уэ или Уе+Ук. Самыми уязвимыми к изменению параметров естественного (6 параметров) и антропогенного (4 параметра) режимов при разном задании приоритетов оценивания оказались относительно крупные и наиболее чистые водоемы: Топозеро и Пяозеро IV класс устойчивости. Наиболее устойчивыми из рассмотренных озер оказались оз. Ильмень и Чудско-Псковское озеро, III класс устойчивости. Озера европейского севера по совокупности критериев охарактеризованы как «средне устойчивые» (III класс) и «устойчивые ниже среднего» (IV класс). Интегральная оценка устойчивости отдельных районов (6 районов) Ладожского озера к изменению параметров естественного и антропогенного режимов показала, что ни один район, ни озеро в целом не обладают максимальной устойчивостью к изменению параметров естественного и антропогенного режимов. Наиболее уязвимым оказался северный прибрежный район озера (IV класс). Самым устойчивым - южный прибрежный район (III класс). Озеро в целом оценивается как «средне устойчивое» III класс (левая граница). Сделан вывод о том, что при данном подходе высокая устойчивость водоема (района) a priori не обусловливает его экологического благополучия или высокого качества абиотической среды и биоресурсов. Высокая адаптационная устойчивость в целом может быть обусловлена различными группами параметров естественного режима (например, значительными размерами водоема) и антропогенного режима, характеризующего качество воды или степень антропогенного эвтрофирования водоема. Исследование адаптационной устойчивости целесообразно для длительных периодов развития водоемов, характеризующихся постепенной утратой своих свойств и изменением параметров режимов, и постепенным переходом в другие классы состояния и устойчивости. При построении ИПУ водотоков использовались модели-классификации второго типа оценки устойчивости (регенерационная).

Пример 2. Оценка устойчивости озер карельского Приладожья. Для оценки устойчивости использовался балльно-индексный подход и метод сводных показателей (МСП). Оценка потенциальной устойчивости оз. Суури в 2018 г. была выполнена на основе балльно-индексного подхода (I класс - максимальная устойчивость, V класс минимальная устойчивость). Устойчивость к изменению параметров естественного режима (потенциальная устойчивость) была оценена суммой баллов 22 (III-IV класс). Устойчивость к изменению параметров естественного режима и трофности оценена суммой баллов 27 (IV класс). Устойчивость к изменению параметров естественного режима и качества воды также оценена суммой баллов 27 (IV класс). Показано, что водоем и его экосистема не являются устойчивыми к изменениям естественного и антропогенного режимов функционирования.

На примере анализа наблюдений 2015 - 2017 гг. показано, что увеличение уровня воды в озере в 2016 г. обусловило снижение первичной продукции в водоемах и повышение уязвимости озер к изменению параметров естественного режима и эвтрофированию. Анализ ИПУ позволил выявить, что увеличение уровня воды в озере понизило его устойчивость к изменению параметров естественного режима и качества воды (Дмитриев, Огурцов, 2017).

Пример 3. По исходным литературным данным построена модель-классификация интегральной оценки устойчивости для озер-охладителей АЭС и озер-аналогов, не подверженных влиянию АЭС (21 критерий оценивания) (Лубенцова, Верещагина, Дмитриев, 2017). Значению интегрального показателя устойчивости (ИПУ), близкому к 
1,0 соответствовало максимальное значение устойчивости, значению ИПУ, близкому к 0,0 - минимальное значение. Расчеты выполнялись для моделей: «М1» - потенциальная устойчивость $\left(И П У_{1}\right)$, «М2» - устойчивость к изменению естественного режима и качества воды $\left(И П У_{1}+\right.$ ИПУ 2$)$, «М3» - устойчивость к изменению естественного режима и антропогенного эвтрофирования (ИПУ $1+$ ИПУ $\left._{3}\right)$. В результате было получено, что озераохладители ключевого района по «М1» относятся к III классу устойчивости («средняя») с значениями 0,438 и 0,453 соответственно (интервал изменения ИПУ для III класса 0,645 0,355). Водоемы-аналоги отнесены к IV классу устойчивости со значениями 0,240 и 0,245 соответственно (интервал ИПУ для IV класса 0,355 - 0,161). Анализ устойчивости по ИПУ показал, что водоемы-охладители АЭС по «М1» более устойчивы к изменению параметров естественного режима, чем их аналоги.

По «М2» водоем-охладитель отнесен к левой границе III класса устойчивости $(0,500)$, другой водоем отнесен к середине III класса $(0,453)$, водоемы-аналоги - к середине IV класса со значениями 0,240 и 0,245 соответственно. По «М3» водоем-охладитель отнесен к границе III - IV классов со значениями 0,271, другой водоем отнесен к правой границе III класса $(0,283)$. Водоемы-аналоги отнесены к правой границе III класса $(0,306)$ и к правой границе IV класса $(0,151)$.

В целом водоемы, подверженные влиянию АЭС в большей степени уязвимы к изменению естественного режима и эвтрофированию, чем к изменению естественного режима и качества воды. Для водоемов-аналогов, не подверженных влиянию АЭС наоборот водоемы более уязвимы к изменению естественного режима и качества воды, чем к изменению естественного режима и эвтрофированию.

Интегральная оценка экологического статуса (ЭС) и экологического благополучия (ЭБ) водоемов, водотоков, систем «водоток-водосбор».

Пример 4. Интегральная оценка экологического благополучия морских акваторий. Для интегральной оценки экологического благополучия (ЭБ) ключевого района акватории Баренцева моря нами учитывались: 1-биомасса бентоса, г $^{2}$; 2-видовое разнообразие бентоса по индексу Шеннона $(\mathrm{H})$; 3-степень экологического стресса, испытываемого бентосом по индексу (DE); 4-качество воды по ИЗВ; 5-загрязнение донных отложений по индексу загрязнения Zc; 6-степень геоморфологического риска (балльная оценка). Оценка ЭБ выполнялась для ключевого района Баренцева моря на участке проектирования нефтеналивного терминала в районе мыса Святой Нос (Восточный) для двух вариантов приоритетов (весов): А - равенство приоритетов и В - неравенство приоритетов: w2 $\geq$ w1 = w3 $\geq$ w5 $>$ w4 = w6. (Дмитриев, Федорова, Бирюкова, 2016).

Пример 5. Вводятся понятия «экологический статус» (ЭС) водоема (водного объекта) и экологическое благополучие водного объекта (ЭБ) с позиций био(эко)центризма и антропоцентризма. В био-(эко)центристском определении акцентируется использование водного объекта для жизни организмов-гидробионтов или для сохранения экосистемы в целом, в антропоцентристском подходе - способность системы выполнять социально-экономические функции без нарушения функций жизнеобеспечения (средо- и ресурсовоспроизводства). При рассмотрении ЭС учитывались: трофический статус водоема или способность продуцировать органическое вещество первичными продуцентами, качество воды с позиций био-(эко)центризма, устойчивость системы. Таким образом, допускалось, что одно эмерджентное свойство может определять другое или влиять на него. В последнее время, в основном в переводной литературе или у неспециалистов участилось определение ЭС на основе термина «экологическое качество воды». Встречается даже термин «хорошее экологическое качество» (буквальный перевод с английского). Остается сожалеть, что в такой форме в РФ акцентируется биоцентризм (экоцентризм) в оценке качества воды и состоянии экосистем (Семенченко, Разлуцкий, 2010). Акцент на методы биологического контроля качества воды, принятый в Европе использующийся в данных исследованиях, активно развивается в последние годы и в РФ, 
их одновременное использование с методами гидрохимического анализа качества дает более надежные результаты.

Разработаны модели-классификации интегральной оценки ЭБ речной системы. Оценка выполнялась для: 1-гипотетических сценариев, учитывающих масштаб водотока с позиций равновесомости задания параметров, уровней и неравновесного задания весов (приоритетов); 2- ключевых водотоков на основе разработанных моделей-классификаций. В группу характеристик, определяющих потенциальную устойчивость, включены параметры, учитывающие физико-географические признаки, характер маловодной фазы, гидрологический режим, размер и водность водотока. Для учета влияния антропогенной составляющей на устойчивость включим в перечень характеристик признак «изменение качества воды». При этом рекомендуем авторам оценивать качество воды самостоятельно, по величине гидрохимических и гидробиологических индексов качества воды или на многокритериальной основе, используя оценочные шкалы индексов или сводного показателя качества воды для включения в модель-классификацию устойчивости.

Модель 1 включала три варианта оценки ЭБ водотока (72, 50 и 28 параметров), относящихся к 5 блокам. Модель 2 включала в себя подсистему реки (7 блоков, 30 параметров) и подсистему водосбора (5 блоков, 33 параметра). На примере равновесного задания приоритетов оценивания рассмотрены гипотетические сценарии задания масштаба речной системы и масштаба воздействия на нее: для водотока и для водосбора. Показана возможность использования разработанной классификации для оценки ЭБ разномасштабных объектов и величины воздействия. Учет неравновесомости для второго уровня свертки: на 1-м уровне свертки показателей использовалось равновесомое задание характеристик внутри блоков. На 2-м уровне свертки реализованы 3 варианта задания приоритетов (весов): равновесное задание (1) антропоцентризм (2) биоцентризм (3).

Для ключевого объекта (река Мста) по значениям сводных показателей, полученным в результате равновесного задания параметров (1), ЭБ реки попадает в левую границу II класса - «ЭБ выше среднего» (значение сводного показателя 0,24), а ЭБ водосбора попадает в правую границу I класса - «Максимальное ЭБ» $(0,20)$. В варианте «2» - ЭБ реки попадает в левую границу II класса $(0,23)$, ЭБ водосбора - в правую границу I класса $(0,18)$. В варианте «3» - ЭБ реки и ЭБ водосбора попадают в середину II класса $(0,25)$ и $(0,33)$ соответственно.

При разработке основ технологии оценки влияния антропогенной нагрузки на изменение ЭБ реализован сценарий гипотетического увеличения антропогенной нагрузки на водоток и водосбор по 2 группам параметров для каждой подсистемы (водоток: 2 из 7 групп; водосбор 2 из 5 групп). При 2-х кратном увеличении антропогенной нагрузки на исходные параметры, значение сводного показателя ЭБ реки Мста переходит от левой границы II класса $(0,25)$ к его правой границе $(0,32)$. Это свидетельствует о снижении ЭБ практически на один класс. Класс ЭБ водосбора, при той же нагрузке остается неизменным, и значение сводного показателя изменяется незначительно (Дмитриев, Амаро Медина, Огурцов, Добрынина, 2018).

Интегральная оценка устойчивости наземных ландшафтов. Подробно методика описана в (Дмитриев, Огурцов, Морозова, Пилюгина, Свердлова, Сиротина, Федорова, Черепанов, Шакуров, 2017, Дмитриев В.В., Огурцов А.Н., Седова С.А., Алексеева А.А., Байжанова К.К., Грига С.А., Кислина А.Е., 2020).

Пример 6. В качестве первого ключевого района была выбрана территория Вишерского заповедника в Пермском крае с рекогносцировочным изменением и характерным значением параметров оценивания устойчивости. Рекогносцировочное изменение параметров в данном примере было задано границами классов (от минимума до максимума в пределах класса). В результате расчетов получен диапазон изменения интегрального показателя устойчивости на основе использования рекогносцировочных данных по каждому параметру и характерное значение интегрального показателя устойчивости ландшафта (ИПУЛ), по которому ландшафты района были отнесены к III 
классу устойчивости (правая граница). Исследование показало, что добавление в модель или изъятие из нее одного параметра при их равновесомом учете практически не сказывается на итоговом результате. Так, например, изъятие из модели девятого параметра - индекса биологической эффективности климата (ТК) дало характерное значение ИПУЛ, равное 0,531 , что дает разницу с рассмотренным выше результатом в пределах 4 \% при ширине интервала оценочной шкалы ИПУЛ, построенной для 8 параметров, для III класса 0,391-0,586. В то же время, придание в 2 раза большего веса этому параметру по сравнению с другими, дает характерное значение ИПУЛ, равное 0,630, что свидетельствует о приближении ИПУЛ вплотную к граничному значению между III и IV классами $(0,654$ - правая граница III класса для оценочной шкалы с учетом неравновесомости задания приоритетов).

Расчет ИПУЛ был выполнен для ландшафтов Прибайкалья на территории Иркутской области. Получен диапазон изменения интегрального показателя устойчивости 0,486-0,677, что позволило отнести ландшафты к III-IV классам устойчивости.

Третий район был выбран на территории республики Бурятия. Диапазон изменения интегрального показателя устойчивости ландшафтов составил 0,494-0,703, что позволило отнести их также к III-V классам устойчивости.

Четвертый ключевой район - территория национального парка «Шушенский бор» в Шушенском районе Красноярского края. Диапазон изменения интегрального показателя устойчивости ландшафтов составил 0,459-0,575, характерное значение ИПУЛ составило 0,567 (правая граница III класса).

Следующими шагами в работе с моделями-классификациями устойчивости будет сбор данных и уточнение исходных показателей, а также выявление параметров, наиболее подверженных естественным и антропогенным изменениям. Необходимо также введение в модель параметров, отражающих влияние антропогенного воздействия на систему и исследование устойчивости ландшафтов к изменению естественного и антропогенного режимов их функционирования. В этом случае оцениваемая «потенциальная устойчивость» является первым шагом оценочных исследований. Далее выделяется группа параметров для оценки устойчивости ландшафта к изменению антропогенного режима, указывается его специфика. В результате предстоит обосновать набор необходимых и достаточных параметров, приоритетов оценивания устойчивости к изменению антропогенного режима и ввести еще один уровень свертки показателей для отражения совместного эффекта «потенциальной устойчивости» и антропогенных воздействий на ландшафт.

Пример 7. Рассмотрены оценочные классификации устойчивости (моделиклассификации интегральной оценки устойчивости) для оценки потенциальной устойчивости наземного ландшафта к изменению параметров естественного режима (потенциальная устойчивость) на основе разработанного индекса потенциальной устойчивости ландшафта. На первом этапе вводятся параметры оценивания и классы устойчивости (I-минимальная, II-ниже средней, III-средняя, IV-выше средней, Vмаксимальная). Для каждого класса задаются левая и правая границы изменения параметров. На втором этапе выполняется нормирование показателей по всем шкалам с учетом вида связи параметра с устойчивостью (прямая, обратная) и степени линейности (нелинейности) связи. На третьем этапе решается проблема выбора весов (приоритетов) оценивания. На четвертом этапе вводится вид интегрального показателя (сумма нормированных значений характеристик, взятых со своим весом). Рассчитывается оценочная шкала интегрального показателя по совокупности всех характеристик. На завершающем этапе рассматривается апробация подхода на примере расчета интегральных показателей потенциальной устойчивости для нескольких разных ландшафтов. Выявляется роль количества исходных параметров и их весомости в расчетах интегральных показателей устойчивости. Выполняется оценка устойчивости для 5 ландшафтов территории России, на примере Новгородской области (Приильменская 
низменность), Республики Башкортостан, Уфимского плато, Лемболовской возвышенности Ленинградской области, арктических ландшафтов Земли Франца-Иосифа. Арктические ландшафты по величине интегрального показателя устойчивости являются самыми неустойчивыми (II класс, устойчивость ниже средней), остальные ландшафты отнесены к III-IV классам (среднеустойчивые - устойчивость выше средней) с учетом близости к левой, правой границе класса или его середине.

Интегральная оценка устойчивости социосистемы при гипотетическом изменении качества среды в северных регионах России.

Пример 8. Выполнено обобщение результатов интегральной оценки качества жизни населения северных регионов России в предположении снижения качества среды (КС) в северных регионах РФ на $30 \%, 50 \%$ и в 2 раза.

В целом ухудшение ситуации на $30 \%$ по экологическому блоку (блок качества среды) повлекло за собой изменения только в одном регионе из 9; на 50\% - в 3 регионах из 9 изменило класс качества среды с III (средний) на IV (ниже среднего); ухудшение ситуации в 2 раза в 6 регионах из исследуемых 9 повлекло переход социосистемы региона в более низкий класс. Такие регионы как Республика Саха (Якутия), Ненецкий и Чукотский автономный округ оказались самыми устойчивыми к изменениям. А самым уязвимым регионом при ухудшении состояния оказался Ханты-Мансийский автономный округ-Югра. Заметно, что после 30\% ухудшения ситуации на сводную оценку сильнее влияют экономические факторы (Dmitriev, 2017).

Оценка состояния социо-эколого-экономической системы региона и ее устойчивости к гипотетическому изменению состояния подсистем на примере Тверской области.

Пример 9. В качестве модельного объекта для анализа устойчивости СЭЭС принята Тверская область РФ. Результаты оценки качества жизни населения выполним для 2003 и 2013 г.г. Учитывался линейный характер связи параметров с оцениваемым состоянием системы (качеством жизни) при равной весомости параметров оценивания внутри трех подсистем (экологической, экономической, социальной) и между ними. Выполнена оценка изменения системы при 30\% и 2-кратном ухудшением ситуации внутри блоков и между блоками на фоне 2013 г.

В экологическую подсистему включены 8 параметров оценивания: 1- выбросы загрязняющих веществ в атмосферный воздух, отходящих от стационарных источников (тыс. тонн); 2- улавливание загрязняющих атмосферу веществ, отходящих от стационарных источников (тыс. тонн); 3- использование свежей воды (миллионов кубических метров); 4- объем оборотной и последовательно используемой воды (миллионов кубических метров); 5- лесовосстановление (тысяч гектаров); 6- внесение удобрений на один гектар посева сельскохозяйственных культур в сельскохозяйственных организациях (тонны); 7- сброс загрязненных сточных вод в поверхностные водные объекты (миллионов кубических метров); 8- образование отходов производства и потребления (тысяч тонн).

В экономическую подсистему включены 5 параметров оценивания: 1- численность населения (оценка на конец года; тыс. человек); 2- численность безработных (тыс. человек); 3- среднедушевые денежные доходы населения в месяц (рублей); 4- численность населения с денежными доходами ниже величины прожиточного минимума (в \% от общей численности населения); 5- число предприятий и организаций (шт.).

В социальную подсистему включены 5 параметров оценивания: 1- ожидаемая продолжительность жизни при рождении (число лет, все население); 2- число зарегистрированных преступлений на 100000 чел. населения; 3- число посещений музеев на 1000 чел. населения; 4- число больничных коек всего, тыс.; 5- число дошкольных образовательных организаций.

Все показатели выбраны из данных интернет-сайта Росстата (сборники «Регионы России») для 2003 и 2013 гг. Основной задачей исследований было выполнение свертки 
показателей на первом и втором уровнях и выявление ситуаций, при которых СЭЭС не сможет сохранить свои свойства и параметры режимов при заданном гипотетическом воздействии на нее в отдельных подсистемах и в системе в целом. Состояние системы и качество жизни населения региона оценивалось для 5 классов (I - высокое; II - выше среднего; III - среднее; IV - ниже среднего; V - низкое), в которых она находилась в 2013 $\Gamma$.

Анализ результатов позволил получить основные выводы, приведенные ниже. Поясним, что в данном примере близость интегрального показателя к 0,0 свидетельствует о высоком качестве жизни населения, близость к 1,0 - о низком. Интегральный показатель последнего уровня свертки назван в тексте сводным показателем.

Качество жизни населения региона на втором уровне свертки в 2003 г характеризовалось значением сводного показателя 0,64 (IV класс середина); в 2013 г 0,57 (граница III-IV классов). На изменение качества жизни населения, как следует из расчетов, сильнее всего повлияла экономика (интегральный показатель по подсистеме уменьшился на 18\%). Вклад социальной подсистемы составил 6,7\%, экологической 8,9\%. В целом, с 2003 по 2013 г. также выявлено улучшение социальных и экологических условий.

Оценка устойчивости СЭЭС показала, что гипотетическое $30 \%$ изменение ситуации в одной из подсистем в сторону ухудшения качества жизни относительно 2013 года приводит к увеличению интегрального показателя по экологической подсистеме на $7,3 \%$, по социальной подсистеме - на $18,6 \%$, по экономической подсистеме - на $6,8 \%$. По величине интегрального показателя при $30 \%$ изменении ситуации по всем подсистемам одновременно отмечается 10,5\% увеличение сводного показателя. Это увеличение обусловливает снижение качества жизни населения примерно на половину класса.

Двукратное изменение ситуации в одной из подсистем в сторону ухудшения качества жизни относительно 2013 года приводит к увеличению интегрального показателя по экологической подсистеме на $17 \%$, по социальной подсистеме - на $34 \%$, по экономической подсистеме - на 20\%. По величине сводного показателя при 2-кратном изменении ситуации по всем подсистемам одновременно отмечается $24 \%$ увеличение сводного показателя. Это увеличение обусловливает снижение качества жизни примерно на один класс.

Сравнительная оценка качества жизни населения Ленинградской области, Приморского края, Краснодарского края, Калининградской области, Алтайского края, Сахалинской области и выявление динамики их развития с 2003 до 2015 гг.

Пример 10. В данном примере нас интересовала тенденция изменения качества жизни населения от самого западного региона РФ до самого восточного, темпы и динамика показателей отдельных подсистем и регионов в целом. Расчеты интегральных показателей качества жизни выполнялись для тех же 18 показателей и 5 классов, с равновесными приоритетами, как и в примере 8. Приведем основные черты изменения ИПКЖ в регионах:

1 - во всех регионах ИПКЖ имеет положительную тенденцию изменения от 2003 к 2013 гг. Наибольший рост сводного показателя качества жизни отмечен в Калининградской обл. (16,7\%). Наименьший - в Приморском крае $(7,8 \%)$. В остальных регионах: Сахалинская обл. (15,2\%), Ленинградская обл. (14,3\%), Краснодарский край $(13,7 \%)$, Алтайский край $(10,3 \%)$.

2 - во всех регионах улучшение качества жизни происходит за счет роста интегрального показателя экономической подсистемы (от 18,6\% в Калининградской обл. до 26,5\% в Сахалинской обл.,). При продвижении с запада на восток интегральный показатель экономического блока, как правило, растет.

3 - минимальные изменения отмечены для интегрального показателя экологической подсистемы (качества среды): от тенденции к ухудшению в 2 регионах (Ленинградская обл. и Приморский край) на 2,6 и 2,2\% соответственно или нулевому 
изменению (Калининградская обл. и Алтайский край) до улучшения экологической ситуации в регионе на 2\% (Сахалинская обл.) и 11,8\% (Краснодарский край).

4 - изменения в социальной подсистеме во всех регионах, кроме Приморского края имеют тенденцию к улучшению от $3,8 \%$ (Краснодарский край) до $24,7 \%$ в Калининградской области. В Приморском крае за этот период отмечено ухудшение социальных условий на $2,2 \%$.

5 - оценка устойчивости СЭЭС указанных регионов показала, что 2 региона (Калининградская обл. и Ленинградская обл.) за это время перешли из IV в III класс, точнее из середины IV класса в правую границу III класса. Остальные регионы сохранили свой класс: Сахалинская обл., Алтайский край и Приморский край - IV класс, а Краснодарский край - III класс при росте качества жизни населения. Однако темпы роста не привели к переходу СЭЭС в другой класс с лучшим качеством жизни. Эти темпы оценены нами величиной 8-10 \% (Алтайский и Приморский край) до 15\% (Сахалинская обл.). Для всех рассмотренных регионов, кроме Краснодарского края, основным фактором улучшения качества жизни в ближайшие годы станет улучшение качества среды, а для Краснодарского края - улучшение социальных условий. Только в Приморском крае за 12 лет отмечено снижение качества в двух подсистемах: социальной и экологической. Это и привело к тому, что при приросте качества экономического блока на 24,6\% в этом регионе отмечен самый низкий прирост ИПКЖ населения по трем блокам из всех рассмотренных регионов $(7,8 \%)$.

Оценка состояния социо-эколого-экономических систем северных регионов РФ и их устойчивости к гипотетическому изменению состояния подсистем.

Пример 11. В экологическую, экономическую, социальную подсистемы включены те же параметры оценивания, что и в примерах, рассмотренных выше. Ранее нами был отмечен основной недостаток экспериментов с гипотетическим изменением ситуаций в регионах, рассмотренный в примере 8 . Он состоял в том, что в реальных условиях одновременное изменение нагрузки на $30 \%, 50 \%$, в 2 раза и т.п. внутри одного из блоков или во всех подсистемах одновременно, маловероятно. Каждый параметр, выбранный в качестве репрезентативного критерия, имеет, как правило, свои темпы и направленность изменений. Ситуация осложняется тем, что в разных регионах могут отмечаться разные темпы и направленность таких изменений. Поэтому было необходимо изучить временное изменение каждого из 18 критериев и получить тренды этих изменений для регионов. Эти результаты описаны в (Dmitriev, Kaledin, 2016) на примере Республики Коми за 2003-2013 гг.

Анализ трендов изменения отдельных характеристик, как и ожидалось, показал, что темпы и направленность изменений разные. Этот вывод использовался в экспериментах с северными регионами. В результате, было выявлено, что в 8 регионах присутствует тенденция на улучшение качества жизни населения: Мурманская область, Республика Коми, Ханты-Мансийский автономный округ Югра, Республика Саха (Якутия) - улучшение качества жизни населения на 7-10\%. В Архангельской области, Ненецком автономном округе, Чукотском автономном округе, Ямало-Ненецком автономном округе - улучшение качества жизни населения на 10-12\%. Неизменным осталось качество жизни в Таймырском Долгано-Ненецком автономном округе в период с 2003 по 2005 гг.

Сравнение качества жизни арктических регионов РФ с регионами Центральной части Российской Федерации (Тверская область за 2003 и 2013 гг и другие регионы) показало, что по величине сводного показателя качество жизни населения в Тверской области с 2003 г. $(0,64)$ до 2013 г. $(0,57)$ улучшилось на $11 \%$. Это указывает на близкие темпы изменения качества жизни в сравниваемых регионах. В целом, отмеченный вывод об улучшении качества жизни в регионах по процентному изменению величин сводных показателей может не выявить изменений, если оценивать их только по попаданию в определенный класс качества. В итоге изменение класса качества жизни выявлено только 
в 2 регионах, изменение на пол класса - в 3 регионах, изменение на 0,5-1 класс - в 4 регионах.

\section{Оценка личного, общественного здоровья и качества жизни населения северных регионов РФ.}

Пример 12. В данном примере нас интересовало личное и общественное здоровье, факторы, формирующие общественное здоровье, связь общественного здоровья с качеством жизни населения региона и оценка качества жизни населения с учетом и без учета личного здоровья. В связи с этим были реализованы две серии оценочных исследований на примере 5 субъектов Российской Федерации (Мурманская обл., Республика Карелия, Архангельская обл., Ненецкий АО, Республика Коми). В этом примере во всех случаях возрастание значений интегральных показателей от 0 до 1 свидетельствовало об увеличении благоприятности социо-эколого-экономических условий для общественного здоровья. Для этого были реализованы 6 вариантов оценочных расчетов и разработана шкала для классов с учетом задания приоритетов групп (второй уровень свертки). Данная классификация опирается на алгоритм естественных границ Дженкса (Jenks' Natural Breaks algorithm). Полученные границы: I - «наиболее благоприятное» влияние социальных детерминант 1-0,77; II - влияние выше среднего или «благоприятное» 0,77-0,57; III- среднее влияние или «относительно благоприятное» 0,570,48; IV- влияние ниже среднего или «неблагоприятное» 0,48-0,34; V - низкое или «наименее благоприятное» или «наиболее неблагоприятное» влияние 0,34-0,00. В серии экспериментов была выполнена интегральная оценка факторов, определяющих общественное здоровье за 2016 год для территорий пяти субъектов Российской Федерации. В качестве оценочных критериев социальных детерминант из материалов Росстата были выбраны 36 характеристик. Все характеристики были структурированы по пяти смысловым группам с условными названиями: 1 - факторы, отражающие уровень доходов населения, его платежеспособность в оплате услуг, питания, ЖКХ и т.п.; 2 факторы, отражающие уровень обеспечения региона врачами, медицинскими услугами, медучреждениями и т.п.; 3 - факторы, отражающие состояние системы образования (дошкольного, школьного, высшего) и уровень образования населения в регионе; 4 факторы, отражающие уровень преступности в регионе, состояние жилищного фонда, экологические проблемы региона; 5 - факторы, отражающие уровень социальной зрелости населения при создании семьи, участии в социальных сетях, пользовании интернет-услугами, участии в выборах и т.п.

На первом этапе рассчитывались интегральные показатели по всем оценочным группам при равенстве приоритетов в группах. Показано, что в этом случае наиболее благоприятные условия по всем факторам общественного здоровья в целом складываются в Мурманской и Архангельской областях. В этих субъектах РФ отмечаются более высокие оценки по двум группам (группа 2 и 4) критериев. В республике Коми наиболее благоприятные условия складываются по третьей группе критериев. Менее благоприятная ситуация отмечается на территории Ненецкого национального округа. Здесь интегральные показатели по всем группам критериев достаточно низкие и не превышают значения 0,5. Территория НАО характеризуется самым низким значением интегрального критерия по 4й группе факторов $(0,313 \pm 0,092)$ из всех групповых оценок. Немного лучше обстоят дела в республике Коми, где отмечаются менее низкие оценочные значения по 1-й группе критериев $(0,334 \pm 0,076)$. В республике Карелия оценки интегральных показателей групп не превышают 0,4 -0,6. В целом же по всем группам критериев значения интегральных показателей не превышают 0,7 .

В другом примере, на основе анализа информации о заболеваемости населения выполнена интегральная оценка личного здоровья в 9 регионах: Мурманская область, Республика Коми, Ханты-Мансийский автономный округ Югра, Республика Саха (Якутия), Архангельской области, Ненецком автономном округе, Чукотском автономном округе, Ямало-Ненецком автономном округе, Тверская область (см.п.3) за 2005-2015 гг. 
Для интегральной оценки было введено 2 группы критериев: 1 - заболеваемость взрослого населения; 2 - заболеваемость детского населения. Состав первой группы: 1 - всего заболевших; 2 - болезни органов дыхания; 3 - болезни системы кровообращения; 4 болезни костно-мышечной системы и соединительной ткани. Состав второй группы: 1 всего заболевших; 2 - болезни органов дыхания; 3 - болезни органов пищеварения; 4 болезни глаза и его придаточного аппарата. В первом расчетном сценарии использовалось представление о равномерном, прямолинейном изменении параметров по классам заболеваемости (здоровья) населения. Близость интегрального показателя к 0,0 свидетельствовала о минимальной заболеваемости (максимальном уровне здоровья) населения - I класс, близость к 1,0 - о максимальной заболеваемости (минимальном уровне здоровья) населения - V класс. В итоге получилось, что с 2005 по 2015 гг. уровень здоровья населения регионов в отдельные годы изменялся в целом от I до V классов. По регионам: Мурманская область II-II, Республика Коми II-III, Ханты-Мансийский автономный округ Югра I-I, Республика Саха (Якутия) I-II, Архангельская область II-III, Ненецкий автономный округ IV-V-IV, Чукотском автономном округе II-III-II, ЯмалоНенецком автономном округе II-III-II, Тверская область I-II. Большая часть рассматриваемых регионов относится ко II-III классам. Выделяется Ненецкий АО, который попадает в IV-V классы и Ханты-Мансийский AO, относящийся к I классу. Для большинства регионов (за исключением республики Саха) наиболее благоприятные значения показателя отмечены в 2005 году. Эксперименты по изменению весов (приоритетов) оценивания показали, что неравновесомость, учитывающая ранжирование приоритетов по видам болезней, не внесла существенных изменений в результаты интегральной оценки.

В последнем примере исследовался системный эффект учета блока заболеваемости в оценке качества жизни населения регионов наряду с блоками: экономика, экология (качество среды), социальный блок. Для этого использовались результаты п.3 и п.4. Варианты расчетов учитывали разные возможности выполнения второго уровня свертки (между блоками): по типу «1»- интегральная оценка по 4 блокам с равными весами для каждого блока $(0,25)$; по типу «2» - интегральная оценка для 3 -х блоков +1 блок (здоровье населения) с равными весами $(0,5$ и 0,5$)$.

Было получено, что в целом, интегральная оценка качества жизни в период с 2005 по 2015 г. по типу «1» по регионам дала следующие результаты: Мурманская область IIIIII, Республика Коми III-IV - IV, Ханты-Мансийский автономный округ Югра III-III, Республика Саха (Якутия) III-III, Архангельская область III-III, Ненецкий автономный округе IV-IV, Чукотский автономный округ III-III, Ямало-Ненецкий автономный округ IIIIV - III.

Свертка показателей по типу «2» дала следующие результаты: Мурманская область III-III, Республика Коми III - III-IV, Ханты-Мансийский автономный округ Югра II-II, Республика Саха (Якутия) II-III, Архангельская область III-III, Ненецком автономный округ IV-IV, Чукотский автономный округ III-III, Ямало-Ненецком автономный округ III III. Сравнение результатов «1» и «2» позволило выявить незначительные различия в сводной оценке по регионам. Важным выводом является необходимость учета блока заболеваемости населения и его оценочного приоритета при интегральной оценке качества жизни населения.

\section{Вопросы для проверки усвоения материала:}

1. Спланируйте свое исследование интегральной оценки устойчивости наземного (водного) ландшафта. Расскажите об этапах оценивания.

2. Спланируйте свое исследование интегральной оценки устойчивости социоэколого-экономической системы и качества жизни населения региона. Расскажите об этапах (и результатах) оценивания. 


\section{Литература}

Александрова Л.В., Васильев В.Ю., Дмитриев В.В. и др. Многокритериальные географо-экологические оценки состояния и устойчивости природных и урбанизированных систем. Под ред. В. В. Дмитриева и Н. В. Хованова. Деп. ВИНИТИ № 2342В00, 2000, 275 с.

Алексеев Д.К., Гальцова В.В., Дмитриев В.В. Экологический мониторинг: современное состояние, подходы и методы. Часть I. Экологический мониторинг атмосферного воздуха и поверхностных вод суши. Учебное пособие. Изд. РГГМУ, СПб, 2011, 302 с.

Алексеев Д.К., Дмитриев В.В. МОДЕЛИРОВАНИЕ И ПРОГНОЗИРОВАНИЕ ИЗМЕНЧИВОСТИ ВОДНЫХ ЭКОСИСТЕМ НА ОСНОВЕ СОЧЕТАНИЯ ДЕТЕРМИНИРОВАННЫХ МОДЕЛЕЙ И МОДЕЛЕЙ ИНТЕГРАЛЬНОГО ОЦЕНИВАНИЯ. ФУНДАМЕНТАЛЬНЫЕ ПРОБЛЕМЫ ЭКОЛОГИИ РОССИИ / ТезисЫ дОКЛадов Всероссийской научной конференции, г. Иркутск - пос. Листвянка (оз. Байкал), 25 июня - 01 июля 2017 г. - Иркутск: Издательство Института географии им. В. Б. Сочавы СО РАН, 2017. - c.4. ISBN 978-5-94797-291-7. https://elibrary.ru/item.asp?id=30543920

Боблакова Л.М., Дмитриев В.В. Интегральная оценка качества жизни населения г. Санкт-Петербурга и г. Москвы / Научный журнал Российской Академии Естествознания "Международный журнал экспериментального образования", 2014, №3 Часть 1, с.91-95.

Васильев В.Ю. Дмитриев В.В., Огурцов А.Н., Жиров А.И., Зеленков В.М., Мискевич И.В., Машкин Ю.Л. Геоинформационный анализ и зонирование акватории Баренцева моря по степени экологического благополучия на участке проектирования нефтеналивного терминала в районе мыса Святой нос (Восточный. ИнтерКарто/Интер ГИС 15: Устойчивое развитие территорий: теория ГИС и практический опыт. Материалы Международной конференции, Пермь, Гент 29 июня-5 июля 2009 г., с.403-410.

Дмитриев В. В., Огурцов А. Н., Лобачева С. В., Чистилина В. С. Интегральная оценка качества среды и качества жизни населения городов, регионов и федеральных округов РФ: анализ проблемы и результаты. фундаментальные проблемы экологии России / Тезисы докладов Всероссийской научной конференции, г. Иркутск - пос. Листвянка (оз. Байкал), 25 июня - 01 июля 2017 г. - Иркутск: Издательство Института географии им. В. Б. Сочавы СО РАН, 2017. - c.78. ISBN 978-594797-291-7 https://elibrary.ru/item.asp?id=29362565

Версия: Dmitriev V.V. Integral assessment of environmental quality and the quality of life of the population of the Arctic regions of Russia in the period from 2003 to 2015. International Scientific Jornal MATHEMATICAL MODELING 2/2017. YEAR I, ISSN 2/2017. Publisher: Scientific Technical Union of Mechanical Engineering «INDUSTRY 4.0», Sofia, Bulgaria, pp.100-104. http://mathmodel.eu/

Гальцова В.В., Дмитриев В.В. Практикум по водной экологии и мониторингу состояния водных систем: учеб. пос. - СПб.: Наука, 2007. - 364 с.

Дмитриев В.В. Здоровье водного объекта: аксиология, аксиометрия, оценка (статья в сборнике трудов межд. конференции). Озера Евразии: проблемы и пути их решения. Материалы 1-й Международной конференции (11-15 сентября 2017 г.). Петрозаводск: Карельский научный центр РАН, $2017 . \quad$ c.47-54. http://resources.krc.karelia.ru/water/doc/laev2017/ozera evrazii ivps 2017 small.pdf

Дмитриев В.В. Интегральная оценка устойчивости социо-эколого-экономической системы. Труды Объединенного научного совета по гуманитарным проблемам и историко-культурному наследию. 2016. Т. 2015. С. 150162. https://elibrary.ru/item.asp?id=30058336

Дмитриев В.В. Оценка воздействия на водный объект на основе АСПИД-моделей экологического благополучия (статья в сборнике научных трудов международного Форума). Сборник материалов XVIII Международного экологического Форума «День Балтийского моря» 22-23 марта 2017 г. Изд. «ООО Свое издательство», г. Санкт-Петербург, 2017, c.336-350. https://elibrary.ru/item.asp?id=29997289; https://elibrary.ru/item.asp?id=30798701

Дмитриев В.В., Амаро Медина Д.Р., Огурцов А.Н., Добрынина А.С. Оценка экологического статуса системы «река-водосбор»: подходы, методика, результаты. Экология речных бассейнов: Труды 9-й Междунар. науч.- практ. конф. / Под общ. ред. проф. Т.А. Трифоновой; Владим. гос. ун-т. им. А.Г. и Н.Г. Столетовых, Владимир, 2018. С. 46-52. https://elibrary.ru/item.asp?id=35609968

Дмитриев В.В., Боблакова Л.М. Интегральная оценка качества жизни населения в регионах России / Информационные технологии и системы: управление, экономика, транспорт, право: Сб. тр. Международной научнопрактической конференции «Инфогео 2014» / Вып. 3 (14) / Под ред. д.т.н., проф. Истомина Е.П. - СПб: ООО «Андреевский издательский дом» - 2014 г., Informacionnye tehnologii i sistemy. Upravlenie, èkonomika, transport, pravo. c.38-44.

Дмитриев В.В., Зуева Н.В., Лубенцова А.С., Валатин Д.И., Васякина А.В., Непомнящая А.В., Никонов И.А., Осташов А.А., Подшивалова Д.О., Прокопеня А.Д., Соколова Д.П., Черненко Ю.И. Экологическое состояние водных объектов карельского Приладожья: традиционный взгляд и современные акценты. Ученые записки РГГМУ, вып. 47, 2017, с. 126-144.

Дмитриев В.В., Зуева Н.В., Лубенцова А.С., Валатин Д.И., Васякина А.В., Непомнящая А.В., Никонов И.А., Осташов А.А., Подшивалова Д.О., Прокопеня А.Д., Соколова Д.П., Черненко Ю.И. Экологическое состояние водных объектов карельского Приладожья. Традиционный взгляд и современные акценты. Ученые записки РГГМУ, 2017, №47, c.126-144. https://elibrary.ru/item.asp?id=30058485

Дмитриев В.В., Зуева Н.В., Огурцов А.Н., Примак Е.А., Федорова И.В. Интегральные оценки в индексологии состояния водных экосистем и их эмерджентных свойств. Современные проблемы водохранилищ и их водосборов. Труды Международной научно-практической конференции (29 мая - 1 июня 2017 г., г. Пермь). Том 2. Качество воды. Геоэкология. Пермь, 2017, c.201-207. https://elibrary.ru/item.asp?id=30533776

Дмитриев В.В., Лобачева С.В., Чистилина В.С. ОЦЕНКА СОСТОЯНИЯ СОЦИО-ЭКОЛОГОЭКОНОМИЧЕСКИХ СИСТЕМ РЕГИОНОВ РОССИИ: РЕГИОНЫ АЗР. МатериалЫ Международной научнопрактической конференции «СОВРЕМЕННАЯ ЭКОЛОГИЯ: ОБРАЗОВАНИЕ, НАУКА, ПРАКТИКА», 4-6 окТября 2017, г. Воронеж, c.297-301. http://www.geogr.vsu.ru/Novosti/2017/12.pdf 
Дмитриев В.В., Огурцов А.Н. УСТОЙЧИВОСТЬ СЛОЖНЫХ СИСТЕМ В ПРИРОДЕ И ОБЩЕСТВЕ: МЕТОДОЛОГИЯ, ОЦЕНКА, РЕЗУЛЬТАТЫ. Ученые записки РГГМУ, 2017, №48, c.72-84. https://elibrary.ru/item.asp?id=30744920

Дмитриев В.В., Огурцов А.Н., Васильев В.Ю. Интегральная оценка экологического состояния водных объектов, трофности и качества воды, экологической напряженности рек, озер и морских акваторий. Географические и экологические аспекты гидрологии. Труды научной сессии, посвященной 90-летию кафедры гидрологии суши факультета географии и геоэкологии СПбГУ - С.Петербург, 26-27 марта 2008 г. / Под научной редакцией В.С. Вуглинского - СПб, АртЭкспресс, 2010. - с.143-153.

Дмитриев В.В., Огурцов А.Н., Васильев В.Ю., Примак Е.А., Лобачева Ю.В., Скрыгина В.К. Оценка эмерджентных свойств сложных систем в природе и обществе на основе моделей интегрального оценивания / Сборник трудов VI международной конференции «Экологические и гидрометеорологические проблемы больших городов и промышленных зон, ЭКОГИДРОМЕТ - 2012». 2-4 июля 2012. Под редакцией: Л.Н.Карлина, В.Н. Воробьева, В.А. Шелутко, В.В.Дмитриева. - СПб.: изд. РГГМУ, 2013. - с.18-27.

Дмитриев В.В., Огурцов А.Н., Морозова А.С., Пилюгина А.А., Свердлова О.А., Сиротина П.М., Федорова М.Е., Черепанов С.В., Шакуров В.А. ИНТЕГРАЛЬНАЯ ОЦЕНКА УСТОЙЧИВОСТИ ЛАНДШАФТОВ: МОДЕЛИ, РЕЗУЛЬТАТЫ, ПЕРСПЕКТИВЫ. Международный журнал прикладных и фундаментальных исследований. - 2017. - № 9. - C. 110-114; URL: https://applied-research.ru/ru/article/view?id=11837 (дата обращения: 26.09.2017). ИД Академия Естествознания. г.Пенза. https://elibrary.ru/item.asp?id=30056223

Дмитриев В.В., ОГУрцов А.Н., Разживин В.Ю. ИНТЕГРАЛЬНАЯ ОЦЕНКА И ГЕОПРОСТРАНСТВЕННЫЙ АНАЛИЗ АККУМУЛЯЦИИ НЕФТЯНЫХ УГЛЕВОДОРОДОВ В ПОЧВЕННОМ ПОКРОВЕ ОСТРОВА САХАЛИН. Международная конференция ИнтерКарто-ИнтерГИС - 23 «Геоинформационное обеспечение устойчивого развития территорий Азиатско-Тихоокеанского региона в условиях глобальных климатических изменений». Материалы Международной конференции «ИнтерКарто/ ИнтерГИС»; 3(23): 143-154. DOI:10.24057/2414-9179-2017-3-23-143-154. https://elibrary.ru/item.asp?id=30079887

Дмитриев В.В., Панов В.Е., Пряхина Г.В. Методические указания по учебно-производственной практике «Экологическое состояние водных объектов»: Учебно-метод. пособие. - СПб.: ВВМ, 2010. - 116 с.

Дмитриев В.В., Пряхина Г.В., Огурцов А.Н., Примак Е.А., Амаро Медина Д.Р. Оценка эмерджентных свойств водных объектов: трофический статус, устойчивость, экологическое благополучие. В сборнике: Третьи Виноградовские чтения. Грани гидрологии. Сборник докладов международной научной конференции памяти выдающегося русского гидролога Юрия Борисовича Виноградова. Санкт-Петербург, 28-30 марта 2018 г. Под редакцией О.М. Макарьевой. Издательство «Наукоемкие технологии», Санкт-Петербург, 2018. С. 347-354. https://elibrary.ru/item.asp?id=35342482

Дмитриев В.В., Федорова И.В., Бирюкова А.С. Подходы к интегральной оценке и ГИС - картографированию устойчивости и экологического благополучия геосистем Часть IV. Интегральная оценка экологического благополучия наземных и водных геосистем. Вестник СПбГУ. Сер. 7. 2016. Вып. 2. С.37-53.

Дмитриев В.В., Чистилина В.С., Кравченко В.А. Разработка и апробация моделей интегральной оценки социоэколого-экономических систем и качества жизни населения в регионах России. Информационные технологии и системы: управление, экономика, транспорт, право: Сб. тр. Международной научно-практической конференции «Инфогео 2015» / Вып. 4(15) / Под ред. д.т.н., проф. Истомина Е.П. - СПб: ООО «Андреевский издательский дом» - 2015 г., Informacionnye tehnologii i sistemy. Upravlenie, èkonomika, transport, pravo. c.86-94.

Добрынина А.С., Дмитриев В.В. Разработка и апробация моделей интегральной оценки экологического благополучия речных систем. Современные проблемы водохранилищ и их водосборов. Труды Международной научнопрактической конференции (29 мая - 1 июня 2017 г., г. Пермь). Том 2. Качество воды. Геоэкология. Пермь, 2017, с.208213. https://elibrary.ru/item.asp?id=30533777

Лубенцова А. С., Верещагина Е. А., Дмитриев В. В. Оценка состояния водных экосистем, испытывающих влияние предприятий атомной энергетики, на примере Калининской АЭС. Экология водоемов - охладителей энергетических станций : сб. материалов Всерос. науч.-практ. конф. с международным участием / Забайкал. гос. ун-т; [отв. ред. Г. Ц. Цыбекмитова]. - Чита: ЗабГУ, 2017. c.185-193. https://elibrary.ru/item.asp?id=30666075

Огурцов А.Н., Дмитриев В.В. ГЕОИНФОРМАЦИОННЫЙ АНАЛИЗ ИНДЕКСА БИОЛОГИЧЕСКОЙ ЭФФЕКТИВНОСТИ КЛИМАТА КАК КРИТЕРИЯ ОЦЕНКИ ПОТЕНЦИАЛЬНОЙ УСТОЙЧИВОСТИ ЛАНДШАФТА. Международная конференция ИнтерКарто-ИнтерГИС - 23 «Геоинформационное обеспечение устойчивого развития территорий Азиатско-Тихоокеанского региона в условиях глобальных климатических изменений». Материалы Международной конференции «ИнтерКарто/ИнтерГИС». 2017;1(23):191-204. DOI:10.24057/2414-9179-2017-1-23-191204. https://elibrary.ru/item.asp?id=30075506

Осипов А.Г., Дмитриев В.В., Масленников С.А., Пластинин С.В., Плюснин В.М. Картографическое моделирование трасс трубопроводов в арктической зоне Сибири. Ж. География и природные ресурсы 2017, №1. С.16-24 https://elibrary.ru/item.asp?id=28921851

Версия: CARTOGRAPHIC MODELING OF PIPELINE ROUTES IN THE ARCTIC ZONE OF SIBERIA Osipov A.G., Maslennikov S.A., Dmitriev V.V., Plastinin L.A., Plyusnin V.M. Geography and Natural Resources. 2017. T. 38. № 1. C. 12-19. https://elibrary.ru/item.asp?id=29500189

Осипов Г.К., Дмитриев В.В. Бассейново-ландшафтный подход к территориальному планированию. Журнал «Информация и космос 2017, №3, c.112-118 https://elibrary.ru/item.asp?id=30016817

Осипова А.А., Дмитриев В.В. Интегральные оценки качества жизни населения и качества городской среды г. Санкт-Петербурга / Научный журнал Российской Академии Естествознания "Международный журнал экспериментального образования", 2014, №3 Часть 1, с.96-102.

Поважный В.В., Золотарева А.Е., Поважный А.В. Разработка автономного флуориметра для определения прижизненной флуоресценции хлорофилла-а на основе цифрового фотоаппарата с передачей данных по каналу сотовой связи. «Экология. Экономика. Информатика». В 3 томах. Ростов-на-Дону, 2015. С. 189-195.

Прохоров Б.Б., Тикунов В.С. Общественное здоровье в регионах России // География и природные ресурсы. 2005. № 2. C. 26-33.

Семенова 3.А., Чистобаев А.И. Медицинская география и здоровье населения. Монография. - СПб.: СПБ НЦ 
РАН, СПбГУ. - Издательство «Европейский Дом», 2015. - 252 с. 2010,329 c.

Семенченко В.П., Разлуцкий В.И. «Экологическое качество поверхностных вод», Минск, «Беларуская навука»,

Dmitriev V. V., Fedorova I. V., Birykova A. S. Approaches to assessment and GIS mapping of sustainability and environmental well-being of geosystems. Part IV. Integrated assessment of ecological wellbeing of terrestrial and aquatic ecosystems. Vestnik of Saint-Petersburg University. Series 7. Geology. Geography, 2016, issue 2, pp. 37-53. doi: 10.21638/11701/spbu07.2016.204

Dmitriev V.V., Osipov G.K. Integral assessment of stability o social-ecological-economic system against changes in its functioning conditions. In Conference Proceedings of 17th International multidisciplinary Scientifics Geoconference SGEM. 2017. 17(52) pp 565-572. doi: 10.5593/sgem2017/52.

Dmitriev V. V., Kaledin N. V. Russian Northwest: An integral Assessment of the Conditions of Regional Social, Environmental and Economic Systems and Quality of Life, Baltijskij region, Vol. 8, no. 2, p. 125—140. doi: 10.5922/2074-98482016-2-7.

V.V. Dmitriev INTEGRAL ASSESSMENT OF ENVIRONMENTAL QUALITY AND THE QUALITY OF LIFE OF THE POPULATION OF THE ARCTIC REGIONS OF RUSSIA IN THE PERIOD FROM 2003 TO 2015. INTERNATIONAL SCIENTIFIC CONFERENCE MATHEMATICAL MODELING PROCEEDINGS TEMATIC FIELDS. 13 - 16 DECEMBER, 2017, BOROVETS, BULGARIA. PUBLISHER: SCIENTIFIC TECHNICAL UNION OF MECHANICAL ENGINEERING "INDUSTRY-4.0", pp.147-151. www.mathmodel.eu. ISSN 2535-0978 (Print). ISSN 2603-3003 (Online). https://elibrary.ru/item.asp?id=30761057

V.V. Dmitriev, G.K. Osipov INTEGRAL ASSESSMENT OF STABILITY OF SOCIAL-ECOLOGICAL-ECONOMIC SYSTEM AGAINST CHANGES IN ITS FUNCTIONING CONDITIONS. 17th International multidisciplinary Scientifc Geocoferrence SGEM 2017. Conference Proceedings. Volum 17. Ecology, Economics, Education and Legislation. ISSUE 52. Ecology and Environmental protection. 29 June - 5 July, 2017. Albena, Bulgaria, 565-572 pp. DOI: 10.5593/sgem2017/52. https://elibrary.ru/item.asp?id=30624151

Дмитриев В.В., Огурцов А.Н., Седова С.А., Алексеева А.А., Байжанова К.К., Грига С.А., Кислина А.Е. Интегральная оценка устойчивости наземных ландшафтов: от балльных оценок к композитным индексам на основе территориальных детерминант. Успехи современного естествознания 2020, №2, с.45-53.

https://www.elibrary.ru/download/elibrary_42492365_57353494.pdf

Dmitriev, V. V., Ogurtsov, A. N., Hovanov, N. V., Osipov, G. K., Kulesh, V. P., Sergeyev, Y. N., \&Fedorova, I. V. (2020). Integral Assessment of Condition and Sustainability of Socio-Ecological-Economic Systems. Landscape Modelling and Decision Support, 49-78. doi:10.1007/978-3-030-37421-1_4

Dmitriev, V. V., Terleev, V. V., Nikonorov, A. O., Ogurtsov, A. N., Osipov, A. G., Sergeyev, Y. N., Kulesh, V. P., Fedorova, I. V. (2020). Global Evaluation of the Status and Sustainability of Terrestrial Landscapes and Water Bodies. Landscape Modelling and Decision Support, 231-253. doi:10.1007/978-3-030-37421-1_12

\section{Примеры практических работ. Практическая работа №1}

\section{Модели-классификации. Разработка концептуальных моделей стратегии развития наземных и водных экосистем. Оценка состояния экосистем на основе разработанных моделей.}

Ю.Одум (1975) при разработке концептуальной модели стратегии развития наземных экосистем рассмотрел тенденции, которые следует ожидать в их развитии, сгруппировав основные критерии оценивания в 6 групп (табл.1). Он рассмотрел характерные значения этих критериев для 2-х стадий (классов) развития экосистем (1 молодые, развивающиеся и 2 - зрелые, климаксные, финитные стадии). Добавим к ним несколько критериев Н.Ф. Реймерса (1990), а также авторские критерии, появившиеся в литературе в последние годы. Рассмотрим изменение параметров в наземных экосистемах в соответствии с взглядами Ю. Одума и др.

Таблица 1. Концептуальная модель стратегии развития наземных экосистем (Ю.Одум, 1975; Реймерс, 1990; Йоргенсен, 1992,1994; Дмитриев, 2000).

\begin{tabular}{|c|c|c|}
\hline Группы и названия признаков экосистемы & 1 - развивающиеся стадии & 2 - зрелые стадии \\
\hline 1. Энергетика сообщества & & \\
\hline $\begin{array}{l}\text { 1*. Отношение деструкции к валовой первичной } \\
\text { продукции }\end{array}$ & $>1<1$ & $=1$ \\
\hline $\begin{array}{l}2 * \text { Отношение продукции к биомассе (валовой } \\
\text { продукции к урожаю на корню) }\end{array}$ & Высокое & Низкое \\
\hline 3. Биомасса, поддерживаемая единицей потока энергии & Низкая & Высокая \\
\hline 4. Урожай (чистая продукция сообщества) & Высокий & Низкий \\
\hline
\end{tabular}




\begin{tabular}{|c|c|c|}
\hline 5*. Пищевые цепи & $\begin{array}{c}\text { Линейные, } \\
\text { преимущественно } \\
\text { пастбищные }\end{array}$ & $\begin{array}{l}\text { Ветвящиеся (пищевые } \\
\text { сети), преимущественно } \\
\text { детритные }\end{array}$ \\
\hline \multicolumn{3}{|l|}{ 2. Структура сообщества } \\
\hline 6. Общее органическое вещество & Мало & Много \\
\hline 7. Неорганические биогенные вещества & Экстрабиотические & Интрабиотические \\
\hline 8*. Видовое разнообразие & Мало & Велико \\
\hline 9. Биохимическое разнообразие & Мало & Велико \\
\hline 10*. Ярусность и пространственная гетерогенность & Слабо выражены & Хорошо выражены \\
\hline \multicolumn{3}{|l|}{ 3. Жизненный цикл } \\
\hline 11. Специализация по нишам & Широкая & Узкая \\
\hline 12*. Размеры организмов & Небольшие & Крупные \\
\hline 13*. Жизненные циклы & Короткие и простые & Длинные и сложные \\
\hline \multicolumn{3}{|l|}{ 4. Круговороты биогенных веществ } \\
\hline 14*. Круговороты минеральных веществ & Открытые & Замкнутые \\
\hline $\begin{array}{l}15^{*} . \text { Скорость обмена биогенных веществ между } \\
\text { организмами и средой }\end{array}$ & Высокая & Низкая \\
\hline 16*. Роль детрита в регенерации биогенов & Незначительная & Значительная \\
\hline \multicolumn{3}{|l|}{ 5. Давление отбора } \\
\hline $17 *$. Характер роста & $R-$ отбор & $K$ - отбор \\
\hline 18. Продукция & Количество & Качество \\
\hline \multicolumn{3}{|l|}{ 6. Всеобщий гомеостаз } \\
\hline 19. Внутренний симбиоз & Не развит & Развит \\
\hline 20. Сохранение биогенных веществ & С потерями & Полное \\
\hline $\begin{array}{l}21 \text { *. Стабильность (устойчивость к внешним } \\
\text { возмущениям) }\end{array}$ & Низкая & Высокая \\
\hline $22 *$. Энтропия & Высокая & Низкая \\
\hline 23*. Информация & Мало & Много \\
\hline 24. Доступность & Достаточно высокая & Сравнительно низкая \\
\hline 25. Живучесть & Достаточно низкая & Сукцессионно высокая \\
\hline 26. Замкнутость, обособленность & Низкая & Повышенная \\
\hline 27. Надежность & Низкая, непостоянная & $\begin{array}{c}\text { Повышенная, более } \\
\text { постоянная } \\
\end{array}$ \\
\hline 28. Гомеостаз & Практически отсутствует & Высокий \\
\hline $\begin{array}{l}\text { 29. Эксергия системы (величина отклонения от } \\
\text { равновесного состояния в ед. информации или } \\
\text { энергии). }\end{array}$ & Не исследовалась & Не исследовалась \\
\hline 30. Экологическое благополучие (здоровье системы). & Не исследовалось & Не исследовалось \\
\hline
\end{tabular}

Задание по работе. Познакомьтесь с концептуальной моделью стратегии развития наземных экосистем (табл.1). Используя приведенную модель, предложите концептуальную модель стратегии развития водной экосистемы. Оцените по модели экологическое состояние у/о-олиготрофн.; олиго-мезотрофн.; эв-гипертрофных водных экосистем.

Указание. Для выполнения работы выбрать не менее 10 признаков, входящих в табл.1 (дополнительно можно использовать признаки из текста конспекта), в первую очередь - из числа отмеченных $(*)$ и обосновать их характерное значение в водных экосистемах разной продуктивности, для трех классов трофности: «у/о - олиготр.», «олиго - мезотрофных» и «эвтр. - гиперэвтрофных» (можно в терминах «высокое»-«низкое»). Введенные в табл. 2 классы продуктивности ориентированы на трофическую классификацию природных водоемов, под которой принято понимать разделение водоемов или их отдельных участков по степени кормности (трофности), в зависимости от уровня их первичной продукции. Части сложных слов ...mpофия или ...mpофный (от греч. trophe - пища, питание) означают: питание, вскармливание, рост. Можно также добавить собственные признаки, воспользовавшись справочной информацией по водным экосистемам для выполнения работы, приведенные в тексте конспекта или в лит.источниках (см. ниже). Результаты работы представить в виде таблицы (табл.2).

Всегда ли выводы, полученные Ю. Одумом для наземных экосистем, справедливы для водных экосистем? Укажите полученные Вами отличия. Отметьте, каким образом, на Ваш взгляд будут изменяться выбранные Вами параметры при усилении антропогенного воздействия на водную экосистему? 
Таблица 2. Концептуальная модель стратегии развития водных экосистем

\begin{tabular}{|l|c|c|c|}
\hline \multicolumn{1}{|c|}{$\begin{array}{l}\text { Названия признаков } \\
\text { водной экосистемы }\end{array}$} & $\begin{array}{c}\text { У/о- олиготрофные } \\
\text { водоемы }\end{array}$ & $\begin{array}{c}\text { Олиго- } \\
\text { мезотрофные } \\
\text { водоемы }\end{array}$ & $\begin{array}{c}\text { Эвтрофные - } \\
\text { гиперэвтрофные } \\
\text { водоемы }\end{array}$ \\
\hline 1. & & & \\
\hline 2. & & & \\
\hline 3. & & & \\
\hline 4. & & & Низкая \\
\hline 5. & Низкая & Высокая & Не высокое \\
\hline 6. & Не высокое & Высокое & \\
\hline 7. & & & \\
\hline 8. & & & \\
\hline 9. Эксергия & & & \\
\hline $\begin{array}{l}10 . \text { Экологическое } \\
\text { благополучие водоема на } \\
\text { основе интегральной } \\
\text { оценки. }\end{array}$ & \multicolumn{2}{|l}{}
\end{tabular}

Справочная информация по водным экосистемам для выполнения работы. Первая трофическая классификация водоемов была предложена в начале XX-го века известными лимнологами А. Тинеманном и Э. Науманном. Критериями оценки были выбраны: форма озерной котловины, концентрация биогенных элементов в воде, величины продукции и деструкции, а также содержание растворенного кислорода в придонных слоях воды.

Согласно ныне применяемому в России определению эвтрофированием называется повышение биологической продуктивности водных объектов в результате накопления в воде биогенных элементов под действием антропогенных или естественных (природных) факторов (Реймерс, 1990). Обобщение различных признаков эвтрофирования позволило В.В. Дмитриеву (1995, с.7) предложить определение, в котором под эвтрофированием понимается естественный процесс «старения» водоемов, вызванный поступлением в воду биогенных элементов и органических веществ, характеризующийся увеличением продуктивности водных экосистем, сопровождающчийся изменением видового состава компонентов биоченоза и скоростей обменных процессов, протекающих в экосистемах.

Наблюдающееся в промышленно развитых регионах усиление антропогенного воздействия на водные экосистемы неминуемо сопровождается изменением и нарушением эволюционно сложившихся биоценозов, уменьшением видового разнообразия, в результате чего снижается способность экосистемы к самоочищению и неизбежно наступает ее постепенная деградация. В табл.4 на примере США приводится перечень проблем, вызванных изменением состава и свойств природных вод по информации 1990-2000 гг. Из таблицы 3 следует, что у 88\% штатов в эти годы уже были отмечены проблемы в изменении состава и свойств водных объектов.

Таблица 3. Территориальное распределение проблемных районов с зарегистрированным ухудшением качества природных вод по регионам США.

\begin{tabular}{|c|c|c|c|c|c|c|c|c|}
\hline \multirow[t]{2}{*}{ Проблема } & \multicolumn{8}{|c|}{ Регион *) } \\
\hline & $\mathrm{I}$ & II & III & IV & V & VI & VII & Всего \\
\hline Наличие вредных веществ & $6 / 13$ & $6 / 9$ & $5 / 6$ & $4 / 8$ & $4 / 4$ & $2 / 6$ & $3 / 6$ & $30 / 52$ \\
\hline Изменение физических свойств & $7 / 13$ & $3 / 9$ & $3 / 6$ & $8 / 8$ & $3 / 4$ & $6 / 6$ & $5 / 6$ & $35 / 52$ \\
\hline Загрязнение биогенами & $11 / 13$ & $6 / 9$ & $6 / 6$ & $8 / 8$ & $2 / 4$ & $6 / 6$ & $4 / 6$ & $43 / 52$ \\
\hline Повышение $\mathrm{S} \%$, изменение $\mathrm{pH}$ & $3 / 13$ & $6 / 9$ & $2 / 6$ & $6 / 8$ & $4 / 4$ & $4 / 6$ & $2 / 6$ & $27 / 52$ \\
\hline Снижение содержания $\mathrm{O}_{2}$ & $11 / 13$ & $9 / 9$ & $6 / 6$ & $6 / 8$ & $4 / 4$ & $6 / 6$ & $4 / 6$ & $46 / 52$ \\
\hline Угроза здоровью населения & $11 / 13$ & $8 / 9$ & $5 / 6$ & $8 / 8$ & $3 / 4$ & $5 / 6$ & $5 / 6$ & $45 / 52$ \\
\hline
\end{tabular}

*) Примечание: I - Среднеатлантические штаты и Северо-Восток; II - Юг; III - Великие озера; IV - Центр; V - ЮгоЗапад; VI - Запад; VII - Острова.

Естественное эвтрофирование водоемов выражается в переходе от малопродуктивного состояния его экосистемы к высокопродуктивному и развивается 
чрезвычайно медленно (для озер - тысячелетиями). Обычно эвтрофирование начинается с увеличения притока биогенов в водоем. Так, за первые 40 лет XX века антропогенный приток фосфора в воду возрос в 2 раза, за последующие 40 лет - более чем в 4 раза (Алекин и др., 1985). Повышение в среде содержания растворенных форм минерального фосфора играет решающую роль при эвтрофировании, азот же и другие элементы в меньшей степени ускоряют этот процесс (Гусаков, 1987). В качестве «граничных» концентраций для разделения водоемов по трофности предлагаются значения 0,01 мг Р/л (олиго- и мезотрофные) и 0,02 мг Р/л (мезо- и эвтрофные). Критическое содержание фосфора, при котором нарушается сбалансированность экосистем мелководных водоемов, составляет около 0,1 мг/л, а для водных объектов с максимальной глубиной более 9-10 м оно устанавливается в диапазоне 0,3-0,4 мг/л. Для сохранения водоема в олиготрофном состоянии средняя концентрация общего фосфора не должна превышать 0,05 мг/л в замыкающем створе всех его основных притоков (Гусаков, 1987). Предотвращение перехода водоема к эвтрофному состоянию обеспечивает среднее содержание фосзфора не более 0,1 мг/л. Концентрация общего фосфора в стоках городов, предприятий, сельскохозяйственных комплексов в водоем также не должна выходить за пределы 0,1 мг/л. Эти оценки были получены на основании анализа данных по объемной фосфорной нагрузке (отношение суммы поступлений фосфора за год к объему водоема) и коэффициентов условного водообмена для 50 внутренних водоемов умеренной климатической зоны.

Антропогенное эвтрофирование, по мнению Г.Г. Винберга (Винберг, Бауэр, 1971), нельзя отождествлять с загрязнением до тех пор, пока суммарное содержание азота и фосфора не превысит концентрацию углерода в водоеме. Если такого превышения не отмечается, то можно говорить о естественном старении или ускорении эвтрофирования водоема. Дополнительное поступление в водоем биогенов за счет антропогенной составляющей стока вызывает постепенное увеличение продукции и биомассы начальных звеньев трофической цепи. Рост концентрации взвеси (сестона) в этом случае приводит к снижению прозрачности воды и является сдерживающим фактором для повышения продуктивности, эффект самозатенения незначительно ограничивает интенсивность первичного биосинтеза в тонком верхнем слое воды.

В летне-осеннее время (а иногда и зимой подо льдом) при эвтрофировании наблюдается падение содержания в воде кислорода от металимниона к гиполимниону и часто регистрируется дефицит кислорода с образованием заморных зон. В водоемах возникают новые ассоциации перифитона, отмечается постепенное (из года в год) увеличение летней вспышки цветения планктонных водорослей с преобладанием в них доли синезеленых. Все это сопровождается усиленным образованием детрита, заилением грунтов и влечет за собой изменение состава бентоса и рыбного населения (Антропогенное эвтрофирование Ладожского озера, 1982; Решетников и др., 1982; Дмитриев, 1987, 1995, 2000; Андроникова, 1989; Израэль, Цыбань, 1989; Петрова, 1990; Осипов, 1995).

Общая тенденция трансформации структуры сообществ сводится к замене крупных и длинноцикловых форм мелкими, рано созревающими и короткоцикловыми. Так, рыбное население водоема изменяется в последовательности: лососевые $\rightarrow$ сиговые $\rightarrow$ корюшковые $\rightarrow$ окуневые $\rightarrow$ карповые.

В фитопланктонном сообществе уменьшаются размеры организмов и видовой состав, возрастает доля синезеленых, снижается доля диатомовых в период летней вегетации. Большую роль при этом играют погодные условия. В теплое безветренное лето «цветение» синезеленых может быть бурным и повсеместным; в ветреное лето их доля в суммарной биомассе может не превышать несколько процентов, что объясняется ухудшением условий для образования крупных колоний этих водорослей в экосистемах с повышенной мутностью воды и значительной скоростью течения.

Обобщение материалов по формированию фитопланктона в водоемах, расположенных в разных ландшафтных зонах и различающихся размерами, гидрологией и геоморфологическими признаками (Кузьмин, 1979; Кожова, 1985), позволило выделить 3 4 фазы в антропогенной сукцессии альгофлоры: коренная ломка старых фитоценозов; увеличение разнообразия видов при приобретении фитопланктоном озерно-прудовых черт и незначительном росте его численности; расширение разнообразия и выпадение прудовых видов с резким приумножением численности при доминировании в летний 
период синезеленых и пирофитовых; образование озерно-речного монодоминантного фитопланктона с повышением биомассы озерных диатомовых. При этом усиление проточности водоема снижает развитие синезеленых водорослей (Жданова и др., 1980).

Уменьшение размеров пищевых частиц, в том числе и фитопланктона, обусловливает преобладание тонких фильтраторов в зоопланктонном сообществе. Из-за пресса хищников снижается численность крупных форм зоопланктона, а мелкие становятся более обильными; эта замена крупных доминантных форм мелкими может служить показателем того, что водоем интенсивно эвтрофируется (Андроникова, 1989). По мере эвтрофирования водоема сукцессия в зоопланктонном сообществе реализуется в последовательности: Bosmina $\rightarrow$ Daphnia $\rightarrow$ Chydorus $\rightarrow$ Ceriodaphnia.

Анализ данных по 53 водоемам для 83 вегетационных периодов позволил определить значения структурных и функциональных показателей зоопланктеров в водоемах разного типа (Андроникова, 1989). Оказалось, что средняя индивидуальная масса организмов в эвтрофных водоемах в 3,3 раза ниже, чем в олиготрофных. Отношение средней биомассы зоопланктона к средней биомассе фитопланктона в эвтрофных водоемах составляет $<0,5$, в то время как в олиготрофных оно $>4$. Отношение средней летней биомассы зоопланктона к зимней для олиготрофных водоемов $<4$, а для эвтрофных $>112$. Преобладающими таксономическими группами зоопланктона в эвтрофных водоемах являются Cladocera и Rotatoria, в олиготрофных - Copepoda.

Изменение продукционных способностей водоемов вследствие эвтрофирования приводит к перестройке пищевых цепей. Водоемы и водотоки из сигово-ряпушковых превращаются в корюшко-карповые. Нарушение естественного воспроизводства рыб обусловливает увеличение гибели икры при осенне-зимней инкубации, поэтому преимущество в развитии получают щуковые, окуневые и карповые, отличающиеся ранневесенним нерестом и коротким периодом инкубации икры в мелководных, хорошо аэрируемых водоемах. $\mathrm{B}$ результате ценные промысловые рыбы вытесняются малоценными видами с быстрым воспроизводством и высокими темпами прироста биомассы.

Сукцессионные изменения при эвтрофировании обусловливают, кроме того, увеличение зараженности водоемов паразитами, представляющими опасность для животных и человека. Паразитарными болезнями на Земле в 1990-2000 гг страдали более 500 млн. человек. У нас в стране количество больных составляло в начале 1990-х гг. 45 млн. В период интенсивного эвтрофирования водоемов особое место среди паразитов занимают личинки трематод, снижается число паразитов со сложным циклом развития и увеличивается число видов, имеющих эврибионтных и массовых хозяев. В водоемах возрастает инвазированность рыб паразитами, цикл которых начинается в зоопланктоне и заканчивается в рыбоядных птицах. Около водоемов, в которых происходит интенсивное эвтрофирование, вызванное антропогенными причинами, наблюдаются скопления пернатых, также подверженных паразитозам. Отмечено, например, что в таких местах увеличилось количество врановых (вороны, галки), которые вместе с другими птицами участвуют в распространении лигулеза или гельминтозной болезни рыб (Дмитриев, 1995, 2000).

В целом в водоемах по мере развития эвтрофикации увеличиваются продукция, биомасса и P/В-коэффициенты почти во всех звеньях трофической цепи. Качественный состав сообщества на ранних стадиях антропогенной сукцессии может не меняться, но на этом этапе повышается численность организмов, изменяются плодовитость, цикличность и другие параметры популяций, как правило, снижается качество воды. Таким образом, развитие экосистемы при антропогенном эвтрофировании и направленность экологической сукцессии в ней определяются:

- изменением физической среды обитания живых организмов, обусловленным обогащением ее биогенами и органикой, а зачастую, увеличением общего загрязнения и закисления воды;

-упорядоченным процессом развития сообщества, связанным с изменением функциональных показателей компонентов биоценоза и видовой структуры;

- стремлением экосистемы к стабилизации в новых условиях функционирования со стратегией получения максимальной биомассы на единицу поступающего извне потока энергии и вещества (Дмитриев, 1995, 2000). 
Дополнительная информация для выполнения работы. В.И. Вернадский и законы существования биосферы. Положения Вернадского о биосфере. В.И.Вернадский сформулировал основные философские принципы глобальной экологии и создал учение о биосфере. Свое видение биосферы и законы ее существования до того момента, когда развитие общества, еще не привело к ее антропогенной трансформации, было изложено им в книге «Биосфера» в 1926 г. (переиздана в 1967) и 5 февраля 1928 г. на заседании Ленинградского общества естествоиспытателей в виде следующих исторических тезисов (цит. по В.Б.Сапунову «Неизвестные страницы биографии В.И. Вернадского (истоки ноосферной философии) // Региональная экология. №3-4 (19), 2002):

Первое положение состоит в том, что биологический вид должен иметь не только биологическое, но и геохимическое определение. Биогеохимия в основном опирается на чисто количественные показатели - средний вес отдельных организмов и их совокупностей, средний элементарный химический состав и отвечающую ему среднюю геохимическую энергию, то есть на способность жизни к перемещению, иначе на миграцию химических элементов в среде обитания. Количество атомов и объем организма - видовой признак. Такое определение вида не отрицает, а дополняет традиционное биологическое. Понятие геохимика «живое однородное вещество» и биолога «вид» тождественны, но выражены по-разному.

Второе положение - об относительной стабильности биосферы. Биосфера в основных чертах неизменна в течение всего геологического времени, по крайней мере, полтора миллиарда лет. Такое ее состояние выражается во множестве отвечающих ей явлений, в том числе и биогеохимических. Это не отрицает эволюции и замены одних видов другими. Но биогеохимические проявления жизни остаются неизменными. Стабильны количество видов, распределение их по размерам, по экологическим нишам, по глобальным биогеохимическим функциям.

Отсюда следует третье положение теории. Геохимическая неизменность биосферы сочетается с непрерывным эволюционным изменением форм жизни. Изменяемость и предельная устойчивость - две стороны существования биосферы.

Четвертое положение заключается в том, что эффект жизни имеет интегральную характеристику - биогенную миграцию химических элементов биосферы. При этом:

1) - биогенная миграция химических элементов в биосфере стремится к максимальному своему проявлению;

2) эволюция видов, приводящая к созданию форм жизни, устойчивых в биосфере, должна идти в направлении, увеличивающем проявление биогенной миграции атомов в биосфере.

Энмергия, эксергия. В таблице 4 приведены некоторые новые критерии, рекомендованные для использования в оценке состояния водных экосистем. С.Э. Йоргенсен, [Jargensen, 2006] предложил использовать эко-эксэргию и структурную эксэргию в качестве целостных индикаторов состояния водных экосистем, что и происходило в последовавшие годы (Зилов, 2006, 2010).

Таблица 4. Энмергия, эксергия и их применение в водной экологии.

\begin{tabular}{|c|c|}
\hline $\begin{array}{l}\text { Энмергия } \\
\text { (количество энергии, } \\
\text { требующейся для } \\
\text { создания единицы } \\
\text { биомассы на разных } \\
\text { трофических уровнях) }\end{array}$ & 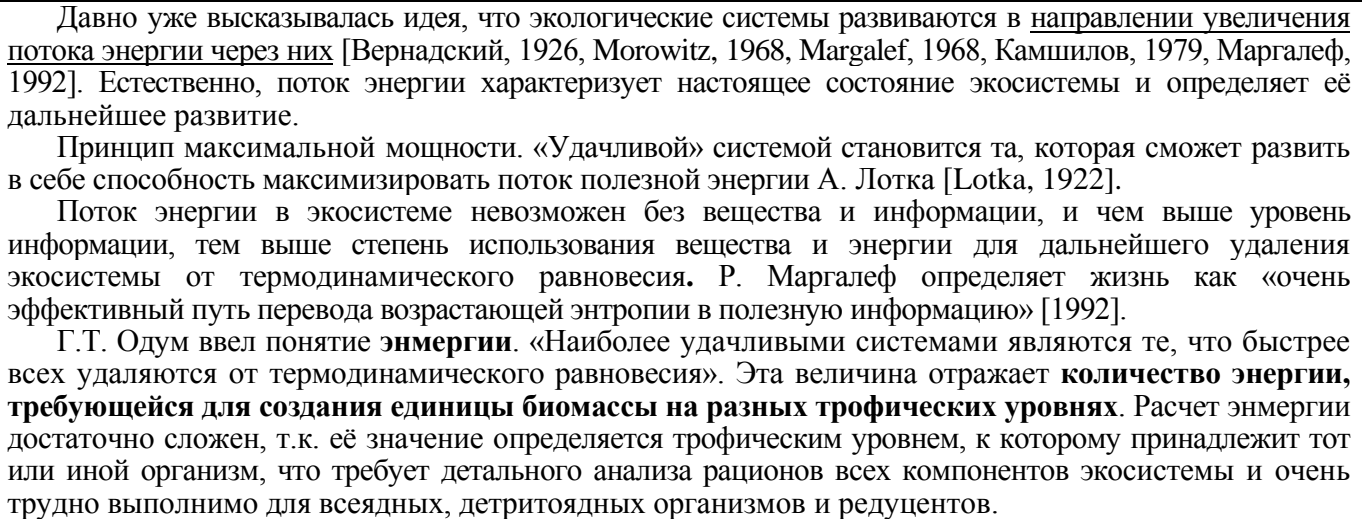 \\
\hline $\begin{array}{l}\text { Эксергия, эксэргия. } \\
\text { (Работоспособность } \\
\text { системы. Мера }\end{array}$ & $\begin{array}{l}\text { От греч. } e k \text {, ex - приставка, означающая высокую степень, и ergon- работа) - максимальная } \\
\text { работа, которую может совершить термодинамическая система при переходе из данного } \\
\text { состояния в состояние равновесия с окружающей средой. }\end{array}$ \\
\hline
\end{tabular}




\begin{tabular}{|c|c|}
\hline $\begin{array}{l}\text { здоровой экосистемы. } \\
\text { Величина отклонения } \\
\text { системы от } \\
\text { равновесного } \\
\text { состояния. Она } \\
\text { указывает на } \\
\text { количество работы, } \\
\text { затраченной на } \\
\text { создание данной } \\
\text { системы из первичных } \\
\text { компонентов и } \\
\text { использованной при } \\
\text { этом информации). }\end{array}$ & 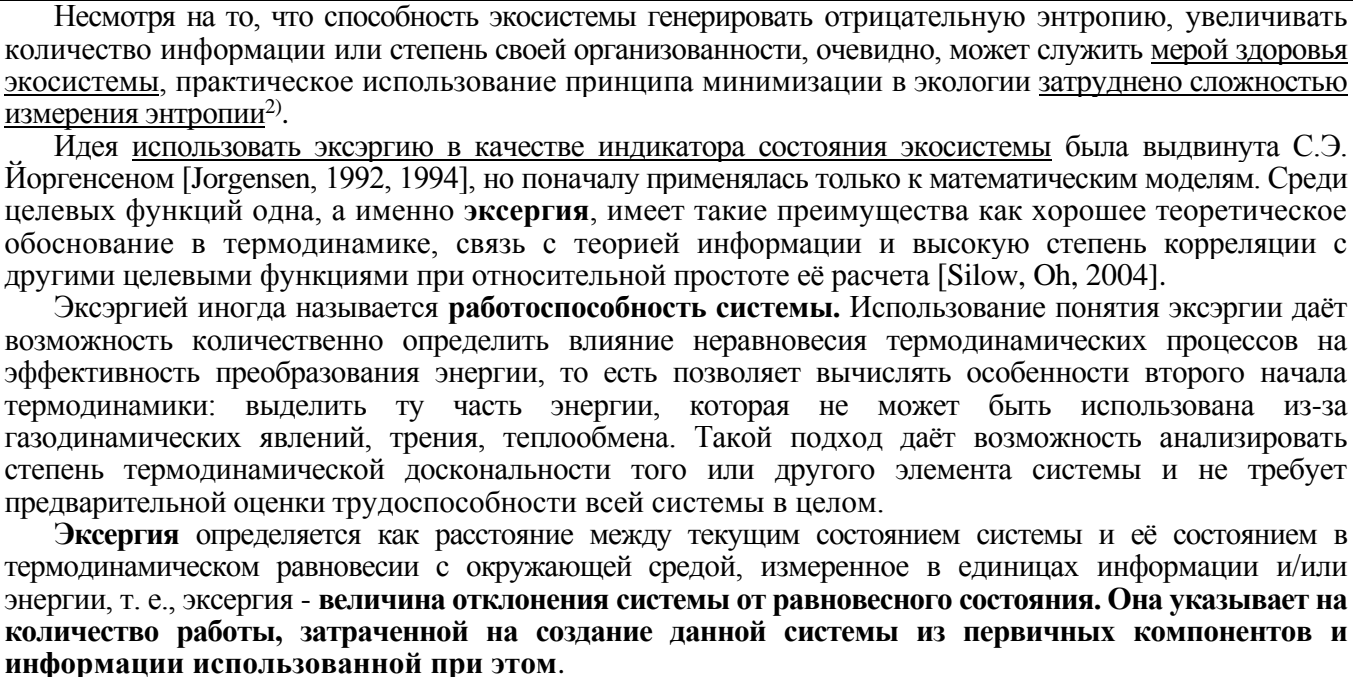 \\
\hline $\begin{array}{l}\text { Структурная } \\
\text { эксергия. }\end{array}$ & $\begin{array}{l}\text { Эксергия, отнесенная к общей биомассе (структурная эксергия), отражает способность } \\
\text { экосистемы усваивать поток энергии извне, служа одновременно индикатором степени развития } \\
\text { экосистемы, её сложности и уровня эволюционного развития организмов, из которых она состоит. }\end{array}$ \\
\hline
\end{tabular}

2) В 1994 г В.В.Дмитриев предложил для оценки энергосодержания (энтропии) водной экосистемы использовать коэффициент Тийдора. (см. Дмитриев В.В. Экологическое нормирование состояния и антропогенных воздействий на природные экосистемы//Вест.С.-Петербург. ун-та. Серия 7. 1994, вып 2. С.60-70). Этот коэффициент (ЕН) представляет собой произведение: $\mathrm{E}_{\mathrm{H}}=\alpha\left[\mathrm{t}^{0}\right]\left[\mathrm{CO}_{2}\right]$ [OB]. В 2004 г была опубликована оценочная шкала этого индекса для классов трофности водоемов: <600 (олиго); 600-1200 (мезо); 1200-2000 (эв); >5000 (гипер) (Дмитриев, 2004 в учебном пособии Дмитриев В.В., Фрумин Г.Т. «Экологическое нормирование и устойчивость природных систем», с.260). Обратите внимание на то, что индекс Тийдора растет по мере эвтрофирования, а энтропия имеет точку перегиба.

Эксергия указывает на количество работы, затраченной на создание данной системы из первичных компонентов (в случае экосистемы - из молекул исходных веществ), и информации использованной при этом, например:

Наиболее сложным является оценка соответствующего пересчетного фактора $f i$. Его значение определяется степенью сложности данного организма (сложной системы), зависящей от его эволюционного развития, и рассчитываемое на основе сведений о количестве информативных генов, числе, типах клеток для данного организма и_т.п. В настоящее время эти значения фактора определены для многих организмов и опубликованы [Xu, 1997, Marques et al., 1997, Silow, 1999, Fonseca et al., 2000, 2002, Jorgensen et al., 2005, Jorgensen, 2006, Ludovisi, 2006, Susani et al., 2006, Silow, Mokry, 2010].

Идея использовать эксэргию в качестве индикатора состояния экосистемы была выдвинута С.Э. Йоргенсеном [Jorgensen, 1992, 1994], но поначалу применялась только к математическим моделям. Первые работы, описывавшие приложение эксэргии в качестве индикаторов состояния природных экосистем были опубликованы в 1997 [Xu, 1997, Marques et al., 1997]. В 1998 эксергия была впервые использована Е.А. Зиловым для анализа результатов полевых и лабораторных экологических экспериментов [Silow1998]. При этом были показаны существенные отличия в динамике экоэксэргии и структурной эксэргии, способность структурной эксэргии указывать на обратимость/необратимость изменений в экосистемах. Эта работа была продолжена Ф.Л. Шу с коллегами [Xu et al., 1999a], проанализировавшими структурные, функциональные и экосистемные изменения экосистем в ответ на стрессовые воздействия, предложившими ряд индикаторов состояния экосистем и успешно приложившими их для оценки состояния озерной экосистемы [Xu et al., 1999b]. За этими работами последовал целый ряд других исследований по всему миру. С.Э. Йоргенсен, подводя итог работам в этой области [Jargensen, 2006], предложил использовать эко-эксэргию и структурную эксэргию в качестве целостных индикаторов состояния водных экосистем, что и происходило успешно в последовавшие годы (см. обзор; [Silow, Mokry, 2010]). 


$\begin{array}{ll}\text { Кафедральныи собор } & \text { многоклеточныи организм } \\ \uparrow & \uparrow \\ Д о м & \text { Эукариот } \\ \uparrow & \uparrow \\ \text { Кирпичи, сложенные в ку6 } & \text { Прокариот } \\ \uparrow & \uparrow \\ \text { Кирпичи } & \text { Вирус } \\ \uparrow & \uparrow \\ \text { Глина } & \text { Биомакромолекулы } \\ \uparrow & \uparrow \\ \text { Молекулы глины } & \text { «ервичның бульон” }\end{array}$

Эксергия в экологических исследованиях рассчитывается по формулам:

$$
E x=\sum_{i=1}^{N} c_{i} f_{i}, \quad E x_{S i r}=\left(\sum_{i=1}^{N} c_{i} f_{i}\right)\left(\sum_{i=1}^{N} c_{i}\right)^{-1},
$$

где $E x$ - эко-эксэргия, $E x_{S i r}-$ структурная эксэргия, $N$ - число компонентов, $c_{i}-$ концентрация компонента $i, f_{i}$-пересчетный коэффициент для компонента $i$.

Использование эксэргии оказалось плодотворным и в теоретической экологии для анализа приложения термодинамических законов к экологическим системам. Совместное использование эксэргии и трех принципов термодинамики к экосистемам привело в конце XX столетия к формулировке четвертого (экологического) закона термодинамики. Этот закон утверждает, что экосистема стремится к максимизации своей эко-эксэргии, удалению от равновесия с окружающей средой. Это может осуществляться как за счет роста биомассы, так и за счет усложнения организмов [Jorgensen, 1992, 1994, 2002, 2006, Patten et al., 1997, al., 1999, Jorgensen et al., 1999, 2000, Jorgensen, Svirezhev, 2002].

Исследование долговременной динамики энмергии, эко-эксэргии и структурной эксэргии для природных объектов позволит ответить на вопрос - имеет ли место в них максимизация экоэксергии, структурной эксергии и/или энмергии, либо их динамика определяется внешними факторами (такими как глобальное изменение климата, антропогенное воздействие и проч.).

\section{Вопросы для проверки усвоения материала:}

1. В чем особенность подхода Ю.Одума к оценке состояния наземной экосистемы.

2. В чем разница между загрязнением и антропогенным эвтрофированием.

3. С какого момента можно говорить не об антропогенном эвтрофировании, а о загрязнении водной экосистемы.

4. Назовите основные признаки антропогенного эвтрофирования.

5. Назовите основные тенденции изменения состава среды и биоты при переходе водоема от у/о-о к эв- и гипер(эв)трофному состоянию.

6. Можно ли утверждать, что табл.1 является вербальной моделью (информационная модель в мысленной или разговорной форме); знаковой моделью (информационная модель, выраженная специальными знаками, т. е. средствами любого формального языка. Знаковые модели окружают нас повсюду, это рисунки, тексты, графики и схемы).

\section{Литература}

Абакумов В.А. Руководство по гидробиологическому мониторингу пресноводных экосистем. СПб, 1992,318 с.

Алекин О.А., Драбкова В.Г., Коплан-Дикс И.С. Проблема эвтрофирования континентальных вод // Антропогенное эвтрофирование природных вод. Черноголовка, 1985, с.25-34.

Бойщов А.В., Васильев В.Ю., Горбовская А.Д., Дмитриев В.В. и др. Гидрохимический режим озера Ильмень / Экосистема озера Ильмень и его поймы, СПб, 1997, с.41-71.

Бульон В.В. Первичная продукция планктона внутренних водоемов // Тр. Зоол. ин-та АН СССР. 1983, т.98, 149 c.

Васильев В.Ю., Дмитриев В.В., Мякишева Н.В. и др. Диагностика состояния водных экосистем южного побережья Финского залива от г. Ломоносова до м. Кургальского / География и современность. Межвуз. сборник научных тр. Вып.7, СПбГУ, 1995 с.35-50.

Винберг Г.Г. Первичная продукция водоемов. Минск., 1960,329 с.

Гутельмахер Б.Л., Петрова Н.А. Продукционная характеристика планктонных водорослей // Антропогенное эвтрофирование Ладожского озера. Л., 1982, с.131-138.

Дедю И.И. Экологический энциклопедический словарь. Кишинев, 1990, 406 с.

Дмитриев В.B. Влияние изменений температуры среды и светового режима на функционирование водной экосистемы // Расчетные гидрологические характеристики: Междувед. сб. науч. трудов Ленингр. гидромет ин-та / Под ред. А.М.Владимирова. Л., 1991. Вып.110, с.94-98. 
Дмитриев В.В. Диагностика и моделирование водных экосистем. СПб, 1995, 215 с.

Дмитриев В.В. Оценка экологического состояния водных объектов суши// Экология. Безопасность. Жизнь, Гатчина, 1999, вып.8, с.200-217.

Дмитриев В.В. Экологическое нормирование состояния и антропогенных воздействий на природные экосистемы /В.В. Дмитриев// Вестник СПбГУ. Сер.7. Геология и география - 1994. - вып.2 (№14). - С. 60-70.

Дмитриев В.В., Васильев В.Ю., Горбовская А.Д., Огуриов А.Н и др. Диагностика состояния водоемов, наземной растительности и почвенного покрова геосистем карельского Приладожья. І. Диагностика состояния водных объектов // Известия Русского географического общества, 1996, Т.128, вып.1, 45-55.

Дмитриев В.В., Васильев В.Ю., Горбовская А.Д., Огуриов А.Н и др. Диагностика состояния водоемов, наземной растительности и почвенного покрова геосистем карельского Приладожья. II. Диагностика состояния почвенного и растительного покрова, устойчивость геосистем к антропогенному воздействию // Известия Русского географического общества,1996, Т.128, вып.2., с.49-54.

Дмитриев В.В., Кулеш В.П., Сергеев Ю.Н., Третьяков В.Ю. Моделирование экосистем. Часть 1. Методическое пособие. - СПб., 2006. - 16 с.

Дмитриев В.В., Мякишева Н.В., Третьяков В.Ю., Хованов Н.В. Многокритериальная оценка экологического состояния и устойчивости геосистем на основе метода сводных показателей. II.Трофический статус водных экосистем.//Вестник СПбГУ, сер.7., вып.1 (N23), 1997. С.51-67.

Дмитриев В.В., Пряхина Г.В., Огуриов А.Н., Примак Е.А., Амаро Медина Д.Р. Оценка эмерджентных свойств водных объектов: трофический статус, устойчивость, экологическое благополучие / Материалы международной научной конференции «Третьи Виноградовские чтения». СПб, СПбГУ, 2018.

Зилов Е.А. Возможность использования целевых функций для оценки «здоровья» водных экологических систем: эксэргия. // Сиб. экол. журнал 2006. №3, с.269-284.

Зилов Е.A. Эксергия и её использование в водной экологии / Проблемы экологии: чтения памяти проф. М.М. Кожова: тез. докладов международ. научн. конф. и межд. школы для молодых ученых (Иркутск, 20-25 сентября 2010 г). - Иркутск: Изд-во Иркут. гос. ун-та, 2010, с.19-22.

Израэль Ю.А., Цыбань А.В. Антропогенная экология океана. Л.,1989, 528 с.

Ладожское озеро. Критерии состояния экосистемы. / Под ред. Н.А. Петровой, А.Ю. Тержевика, СПб, 1992, 328

c.

Дмитриев В.В., Кулеш В.П., Сергеев Ю.Н., Третьяков В.Ю. Моделирование экосистем. Часть 1. Методическое пособие. СПб., 2006,16 с.

Одум Ю. Основы экологии / Пер. с 3-го англ. изд. под ред. Н.П. Наумова. М., 1975, 740 с.

Осипов Г.К. Комплексная оценка и управление потоками биогенных веществ в природно-аграрных системах (в связи с антропогенным эвтрофированием водоемов). Дисс. на соск. уч. ст. доктора геогр. наук. 1994, СПб, 491 с.

Остапеня А.П. Трансформация энергии пищи некоторыми видами планктонных ракообразных (Cladocera) // Журн. общ. биол. 1968. Т.29, вып.3, с.172-176.

Оценка состояния и устойчивости экосистем. Под ред. В.А. Красилова и соавт. М., 1992, 127 с.

Реймерс Н.Ф. Природопользование: Словарь-справочник. М., 1990, 638 с.

Толковый словарь современной фитоценологии / Б.М.Миркин, Г.С. Розенберг. М.,1983, 178 с.

Хендерсон-Селлерс Б., Маркленд Х.Р. Умирающие озера. Причины и контроль антропогенного эвтрофирования. / Пер. под ред.К.Я.Кондратьева.1990, 279 с.

Экосистема озера Ильмень и его поймы / Ю.Н.Сергеев, В.П.Кулеш, В.В.Дмитриев и др.; Под ред. Ю.Н.Сергеева, СПб.,1997, 276 с.

\section{Практическая работа №2}

\section{Интегральная оценка трофического статуса водоема на основе метода сводных показателей (МСП).}

Первая трофическая классификация водоемов была предложена в начале XX-го века известными лимнологами А. Тинеманном и Э. Науманном. Критериями оценки были выбраны: форма озерной котловины, концентрация биогенных элементов в воде, величины продукции и деструкции, а также содержание растворенного кислорода в придонных слоях воды.

Согласно ныне применяемому в России определению эвтрофированием называется повышение биологической продуктивности водных объектов в результате накопления в воде биогенных элементов под действием антропогенных или естественных (природных) факторов (Реймерс, 1990). Обобщение различных признаков эвтрофирования позволило В.В. Дмитриеву (1995, с.7) предложить определение, в котором под эвтрофированием понимается естественный процесс «старения» водоемов, вызванный поступлением в воду биогенных элементов и органических веществ, характеризуюшийся увеличением продуктивности водных экосистем, сопровождаюшийся изменением видового состава компонентов биоченоза и скоростей обменных процессов, протекаюших в экосистемах. 
Наблюдающееся в промышленно развитых регионах усиление антропогенного воздействия на водные экосистемы неминуемо сопровождается изменением и нарушением эволюционно сложившихся биоценозов, уменьшением видового разнообразия, в результате чего снижается способность экосистемы к самоочищению и неизбежно наступает ее постепенная деградация. В табл.1 на примере США приводятся данные об актуальности проблемы антропогенного эвтрофирования для отдельных штатов.

Из таблицы следует, что у 83-88\% штатов в эти годы уже были отмечено развитее антропогенного эвтрофирования водоемов.

Таблица 1. Территориальное распределение проблемных районов по регионам США.

\begin{tabular}{|l|c|c|c|c|c|c|c|c|}
\hline \multicolumn{1}{|c|}{ Проблема } & \multicolumn{9}{c|}{ Регион $^{*}$ Р } \\
\hline \multicolumn{1}{|c|}{ Районы } & I & II & III & IV & V & VI & VII & Всего \\
\hline $\begin{array}{l}\text { Загрязнение } \\
\text { биогенами }\end{array}$ & $11 / 13$ & $6 / 9$ & $6 / 6$ & $8 / 8$ & $2 / 4$ & $6 / 6$ & $4 / 6$ & $43 / 52$ \\
\hline $\begin{array}{l}\text { Снижение } \\
\text { содержания } \mathrm{O}_{2}\end{array}$ & $11 / 13$ & $9 / 9$ & $6 / 6$ & $6 / 8$ & $4 / 4$ & $6 / 6$ & $4 / 6$ & $46 / 52$ \\
\hline
\end{tabular}

*) Примечание: I - Среднеатлантические штаты и Северо-Восток; II - Юг; III - Великие озера; IV - Центр; V - Юго-Запад; VI - Запад; VII - Острова.

Для целей диагностики трофического состояния водоемов можно предложить несколько подходов, основанных на использовании методов анализа и обобщения натурных данных. Обзор таких подходов приводится нами в монографии «Интегральная оценка экологического состояния и качества городской среды» (под ред. А.К.Фролова), СПб, 1999.

Один из таких подходов заключается в применении методов многомерной статистической классификации параметров или признаков, характеризующих состояние экосистем.

Методы оценки трофности и трофического статуса водоемов. Методы классификации совокупности объектов или признаков разработаны в настоящее время достаточно хорошо [Айвазян С.А., Бухштабер В.М. и др. Классификация и снижение размерности. Под ред. С.А.Айвазяна, М., 1989; Дюран Б., Оделл П. Кластерный анализ. /Пер. с англ. М., 1977]. Их принято делить на методы классификации при наличии обучающих выборок и методы классификации без обучения ("без учителя"). Под обучающими выборками обычно понимают некоторую совокупность объектов или признаков, классификация которых достоверно известна.

В первом случае предполагаются известными распределения векторов X внутри классов. Векторы задаются аналитически или с помощью перечисления всех возможных значений X. С использованием этой информации строится правило (алгоритм) классификации, с помощью которого совокупность объектов или признаков относят к одному из нескольких классов с известными (или полностью заданными) функциями распределения. К этому же типу принято относить и задачу, в которой распределения X внутри классов определены лишь частично. В этом случае используется два вида информации: предположение о свойствах распределения векторов (гладкость, принадлежность к некоторому известному параметрическому классу) и обучающая выборка. Обычно предполагается, что функции распределения векторов $\mathrm{X}$, либо их сочетания принадлежат известному параметрическому классу с неизвестными значениями параметров.

Цель классификации без обучения сводится к разбиению всей анализируемой совокупности объектов на сравнительно небольшое число (заранее известное или нет) однородных, в определенном смысле, групп или классов. Результат разбиения зависит от выбора меры близости (сходства) между объектами. Знание такого количественного критерия как функционал качества разбиения позволяет оценить, какому из них отдать предпочтение. 
Выбор той или иной меры близости и того или иного функционала качества обычно осуществляется весьма произвольно и опирается скорее на эмпирические и профессионально-интуитивные соображения, чем на строгую формализованную систему. Пример использования методов классификации без обучения применительно к оценке качества природных и сточных вод содержится в работе [Дружинин, Шишкин, 1989].

Известно, что основные этапы создания статистической классификации включают следующие:

- описание пространства наблюдений, т.е. характеристика исходных данных;

- выбор системы X признаков, с помощью которых осуществляется переход из пространства наблюдений в пространство признаков;

- снижение мерности призначного пространства X, выбор системы обобщенных независимых признаков, с помощью которых пространство X переводится в пространство обобщенных признаков Y;

- проведение классификации в пространстве Y;

- интерпретация результатов применительно к решаемой задаче.

На примере исследований временной изменчивости отдельных компонентов водных экосистем Балтийского моря [Гидрометеорология и гидрохимия морей СССР. Том III. Балтийское море. Вып. 1. Гидрометеорологические условия. Под ред. Ф.С. Терзиева, В.А. Рожкова, А.И. Смирновой. СПб., 1992; Гидрометеорология и гидрохимия морей. Том III. Балтийское море. Вып. 2. Гидрохимические условия и океанологические основы формирования биологической продуктивности. Под ред. Ф.С. Терзиева, В.А. Рожкова, Е.Я. Римша, И.С. Шпаер. СПб., 1994] было показано, что в настоящее время отсутствуют четкие представления о виде функций распределения даже для наиболее изученных гидрологических и гидрохимических параметров водных экосистем. Для некоторых гидрохимических, практически всех гидробиологических компонентов и показателей загрязненности вод вопрос о виде функций распределения не ставился вообще. Таким образом, при решении задачи диагностики трофического состояния в рамках рассматриваемого подхода исследователь всегда находится в условиях отсутствия или дефицита информации о распределении векторов $\mathrm{X}$ внутри классов. Более того, анализ информационной базы натурных гидроэкологических данных свидетельствует об их существенной зашумленности. Поэтому представляется целесообразным применение метода построения сводных показателей (МСП). ориентированного на использовании нечисловой, неточной и неполной информации, что позволяет ему Опыт, приобретенный при обсуждении такого рода задач, позволяет с уверенностью утверждать, что в настоящее время может быть разработана единая методика построения сводных показателей трофического состояния, качества, экологического благополучия и устойчивости водоемов к внешнему воздействию с учетом значимости и приоритетности отдельных показателей и использовании как числовой, так и нечисловой информации об их сравнительном влиянии на общую оценку.

Предлагаемый подход к многокритериальной оценке трофического статуса водоемов можно рассматривать как своеобразное решение задачи многомерной статистической классификации параметров или признаков, его характеризующих, при наличии обучающих выборок в виде существующих классификаций трофности природных вод.

Метод сводных показателей. Метод сводных показателей, как и любой другой, требует формулирования ясных источников своего происхождения. Они, в этом случае, могут являться дополнительным подтверждением правильности выбора методологии.

Исторически первым исследователем, применившим метод сводного показателя для оценивания военных проектов, был полковник российского флота А.Н.Крылов. Для получения сводной оценки А.Н. Крылов считал необходимым решить следующие вопросы: 1 - какие качества влияют на оценку сравнительного достоинства; 2 - каким числом каждое качество оценивается; 3 - какой способ группировки этих чисел 
принимается; 4 - какие относительные множители приписываются тем качествам, которым отдается предпочтение. И теперь, ответы на эти вопросы определяют основные этапы построения сводных показателей. Они предполагают: 1 - формирование вектора исходных характеристик, каждая из которых необходима, а все они вместе достаточны для полного оценивания исследуемого объекта; 2 - формирование вектора отдельных (нормированных) показателей, оценивающих различные аспекты исследуемого объекта; 3 - выбор вида синтезирующей функции, сопоставляющей вектору отдельных показателей сводную оценку, характеризующую исследуемый объект в целом; 4 - определение значения вектора параметров, обычно интерпретируемых как весовые коэффициенты.

Все эти вопросы относятся к области квалиметрии, которую можно считать первым основанием метода. Саму квалиметрию можно определить как область науки об измерении и управлении качеством продукции и услуг. В настоящее время в рамках квалиметрии разработан широкий спектр математических моделей синтеза обобщенных оценок качества, позволяющих оценивать все многообразие социально-экономических благ (Азгальдов, 1982).

Вторым основанием метода сводных показателей является теория функций полезности. К настоящему времени накоплено множество математических моделей, позволяющих строить функции, оценивающие полезность в целом различных наборов хозяйственных благ. Сводные оценки при этом могут иметь как числовой ("кардинальная полезность"), так и нечисловой ("ординальная полезность") характер.

Третьим основанием описываемого метода является теория экономических индексов (можно вспомнить также экспертные $d$-функции или индексы качества среды, оценивающих единым числом многопараметрические объекты и явления. Следует отметить, что именно в рамках теории построения индексов начался систематический сравнительный анализ синтезирующих функций различного вида.

Вышеупомянутые основания метода естественным образом дифференцируют сам процесс оценки на три этапа: 1) задание отдельных показателей, 2) выбор синтезирующей функции, 3) определение весовых коэффициентов. Для их осуществления уже в наши дни (Хованов, 1996) разработаны и используются следующие три принципа:

1. Принцип линеризации, позволяющий переходить от частично упорядоченного по предпочтительности множества векторов отдельных показателей объектов к линейно упорядоченному множеству сводных оценок этих объектов.

2. Принцип арифметизации, позволяющий получать числовые оценки для исходной нечисловой информации, лежащей в основе построения показателей и определения весовых коэффициентов.

3. Принцип рандомизации, позволяющий моделировать дефицит, обычно существующий на всех этапах синтеза сводных оценок сложных многопараметрических объектов.

Эти три принципа составляют теоретическую основу методов многокритериального и интегрального оценивания в наши дни.

Трофический статус водоема. Трофический статус водоема - это интегральная характеристика, отражающая способность водоема продуцировать органическое вещество, его продукционные способности, которая определяется различными взаимосвязанными физико-химическими и биологическими процессами. Определение трофического статуса включает использование комплексов признаков, которые, как правило, дополняют друг друга. Уровень биологической продуктивности озер всегда связан с определенными лимнологическими характеристиками того или иного трофического типа, а также с характером водосбора, особенностями гидрографической сети и др., объединенными в единую систему.

Выделяют 4 основных типа водоемов: олиготрофные, мезотрофные, эвтрофные, дистрофные. 
Олиготрофный водоем - содержит незначительное количество биогенных веществ, имеет высокую прозрачность, низкую цветность, большую глубину. Фитопланктонные водоросли развиты слабо. Содержание кислорода немного отклоняется от его нормального насыщения. В водоеме преобладают пастбищные трофические цепи, разнообразие микроорганизмов невелико.

Мезотрофный тип - промежуточный тип между олиготрофным и эвтрофным. Это водоёмы со средним уровнем первичной продукции. Развитие фитопланктона в таких водоемах достаточно высокое, состав гидробионтов отличается большим разнообразием. Мезотрофные водоемы, как правило, возникают из олиготрофных и превращаются в эвтрофные.

Эвтрофный водоем - в связи с большей минерализацией и повышенным содержанием биогенных элементов фитопланктон развивается достаточно интенсивно. Прозрачность здесь уже ниже, чем в олиготрофном водоеме. В приповерхностных слоях часто наблюдается избыток кислорода, а в придонной зоне - его значительный недостаток. Присутствующие в водоеме детритофаги и редуценты становятся единственными организмами в условиях дефицита кислорода и обилия мертвого органического вещества.

Дистрофный водоем - характеризуется низкой минерализацией и незначительным количеством биогенных веществ. Фитопланктон в таких водоемах практически не развивается. Растворенное органическое вещество составляет 90-98\%, однако лишь 2-10 $\%$ из всей его массы представлено в форме живых организмов и детрита.

Первичная продукция является основным критерием оценки трофического состояния водоемов. Кроме того, в качестве критериев трофности применяют такие коррелятивные показатели, как концентрация хлорофилла в воде, прозрачность воды, биомасса фитопланктона, биомасса зоопланктона, отношение прозрачности к глубине, концентрации общего азота и фосфора и др.

В таблице 2 приведены некоторые критерии оценки трофности по литературным обобщениям (Дмитриев, 1995, 2000, 2004), которые были использованы для оценки трофности оз. Суури (район п.Кузнечное в северо-западном Приладожье) в 2017 г. Оценка трофического статуса выполнялась на основе покомпонентной оценки (8 параметров) и интегрального оценивания.

Задания по работе.

1. Выполнить покомпонентную оценку трофности оз.Суури. Подвести итог: анализ покомпонентной оценки (табл.4) показал, что озеро попадает в 3 класса трофности. По ... параметрам трофический статус озера соответствует ... классу, по ... параметрам ... классу, по ... параметрам ... классу.

2. На основе табл.3 разработать модель классификацию оценки трофности озера по МСП с учетом равновесомости параметров. Заполнить табл. 5. Учесть выбор нормирующих функций и вид интегрального показателя.

В качестве $d$-функции использовать линейную свертку нормированных равновесных (неравновесных) значений критериев.

$$
Q=Q(q ; w)=Q\left(q_{1}, \ldots, q_{m} ; w_{1}, \ldots, w_{m}\right)=\sum_{i=1}^{m} q_{i} w_{i}
$$

Для нормирования использовать неубывающую кусочно-степенную функцию вида:

$$
q_{i}=q_{i}\left(x_{i}\right)=\left\{\begin{array}{lr}
0, & x_{i} \leq \min _{i}, \\
\left(\frac{x_{i}-\min _{i}}{\max _{i}-\min _{i}}\right)^{\lambda}, & \min _{i}<x_{i} \leq \max _{i}, \\
1, & x_{i}>\max _{i}
\end{array}\right.
$$

Такая функция может быть использована в случае, когда увеличение значения $i$-ой исходной характеристики не влечет снижения уровня трофии, оцениваемого с точки 
зрения $i$-го критерия. При этом всем параметрам со значениями $x_{i}$, не превосходящими некоторого фиксированного уровня $\min _{i}$, приписывается минимальное значение $i$-го отдельного показателя , а параметрам со значениями $x_{i}$, превосходящими фиксированный уровень $\max _{i}$ - максимальное значение этого отдельного показателя. Исследователь должен дополнительно выбрать показатель степени $\lambda$, определяющий характер и степень выпуклости нормирующей функции $q_{i}\left(x_{i}\right)$ : при $\lambda>1$ соответствующая нормирующая функция выпукла вниз, а при $\lambda<1$ - вверх.

Если при увеличении значения $i$-ой исходной характеристики уровень трофии, оцениваемый по $i$-му критерию, не возрастает, то может быть применена невозрастающая кусочно-степенная функция вида

$$
q_{i}=q_{i}\left(x_{i}\right)=\left\{\begin{array}{lr}
1, & x_{i} \leq \min _{i}, \\
\left(\frac{\max _{i}-x_{i}}{\max _{i}-\min _{i}}\right)^{\lambda}, & \min _{i}<x_{i} \leq \max _{i}, \\
0, & x_{i}>\max _{i} .
\end{array}\right.
$$

Особенно просто построение нормирующих кусочно-линейных функций, получающихся при подстановке в формулы (1), (2) значения параметра $\lambda=1$. Далее мы будем использовать именно такие простейшие нормирующие функции, учитывая, что выбор линейной нормировки всегда может быть оправдан на первом этапе исследования. В качестве $\min _{i}$ можно использовать левое граничное значение критерия для первого класса, а в качестве тах прозрачности воды - наоборот).

Важным моментом, который необходимо учитывать при нормировании, является соотнесение значений отдельного показателя (результата нормирования) 0,0 и 1,0 с классами трофности, поскольку это зависит от предпочтений автора. Можно в качестве левой границы первого класса для нормированного значения принять 0,0 или 1,0. Это может отразиться на выборе нормирующих функций (прямая или обратная) при построении оценочной шкалы и выполнения расчетов.

3. Изменить приоритеты оценивания, присвоив больший вес признакам 1 и 2. Изменились ли результаты оценки.

Таблица 2. Критерии, использованные для оценки трофности оз. Суури в 2017 г.

\begin{tabular}{|c|c|c|c|c|c|c|}
\hline & & \multicolumn{4}{|c|}{ Тип трофии } & \multirow[b]{2}{*}{ Источник } \\
\hline № & Критерий & Олиготрофия & Мезотрофия & Эвтрофия & Гипертрофия & \\
\hline 1 & $\begin{array}{l}\text { Продукция фитопланктона, } \\
\text { мГС/л сут }\end{array}$ & $0,005-0,05$ & $0,05-0,5$ & $0,5-5$ & $>5$ & Гутельмахер, 1986 \\
\hline 2 & $\begin{array}{l}\text { Скорость фотосинтеза, } \\
\text { мгО/л сут }\end{array}$ & $0,7-1,0$ & $1,0-2,4$ & $>2,4$ & - & Цветкова и др.,1988 \\
\hline \multirow[t]{6}{*}{3} & \multirow{6}{*}{$\begin{array}{l}\text { Прозрачность воды по } \\
\text { белому диску, } \mathrm{H}_{\mathrm{sd}}, \mathrm{m}\end{array}$} & $>4$ & $2-3$ & $>5,5$ & - & Gantrbland, 1931 \\
\hline & & $11-6$ & $6-2$ & $<2$ & - & Thunmark, 1937 \\
\hline & & $>5$ & $5-3$ & $<3$ & - & Aberg, Roch, 1942 \\
\hline & & $>4$ & $4-1$ & $<1$ & - & Китаев, 1970 \\
\hline & & $>6$ & $6-3$ & $<3$ & - & Henderson-Selers, 1984 \\
\hline & & 9,9 & $4,2-2,4$ & $<1$ & - & Vollenweider, 1980 \\
\hline 4 & $\begin{array}{l}\text { Отношение прозрачности } \\
\mathrm{H}_{\text {sd }} \text { к глубине Н водоема }\end{array}$ & $1,01-2,0$ & $0,51-1,0$ & $0,5-0,25$ & - & Китаев, 1973 \\
\hline 5 & pH летом & $6,9-7,2$ & $7,2-8$ & $8-9,5$ & - & Тот же \\
\hline 6 & $\begin{array}{l}\text { Разность суточной } \\
\text { продукции и деструкции, Ф- } \\
\text { Д, мГО/л сут }\end{array}$ & $-0,1-0,1$ & $0,1-2,1$ & $>2,1$ & - & Тот же \\
\hline 7 & БПК 5, мГО/л & $2,3-3,3$ & $3,3-5,5$ & $>5,5$ & - & Тот же \\
\hline 8 & $\begin{array}{l}\text { Концентрация } \\
\text { растворенного кислорода в }\end{array}$ & $95-105$ & $50-155$ & $<50$ & - & Тот же \\
\hline
\end{tabular}




\begin{tabular}{|l|l|l|l|l|l|l|}
\hline \% насыщения & & & & & \\
\hline
\end{tabular}

Таблица 3. Критерии, использованные для оценки трофности оз. Суури в 2017 г. с учетом введения интервалов для шкал табл.2 внутри классов

\begin{tabular}{|c|c|c|c|c|c|}
\hline & & \multicolumn{4}{|c|}{ Тип трофии } \\
\hline № & Критерий & Олиготрофия & Мезотрофия & Эвтрофия & Гипертрофия \\
\hline 1 & $\begin{array}{l}\text { Продукция фитопланктона, мгС/л } \\
\text { сут }\end{array}$ & $0,005-0,05$ & $0,05-0,5$ & $0,5-5$ & $5-50$ \\
\hline 2 & Скорость фотосинтеза, мгО/л сут & $0,7-1,0$ & $1,0-2,4$ & $2,4-4,8$ & $4,8-7,2$ \\
\hline 3 & $\begin{array}{l}\text { Прозрачность воды по белому } \\
\text { диску, } \mathrm{H}_{\mathrm{sd}}, \text { м }\end{array}$ & $10-6$ & $6-3$ & $3-1$ & $1-0$ \\
\hline 4 & $\begin{array}{l}\text { Отношение прозрачности } \mathrm{H}_{\mathrm{sd}} \text { к } \\
\text { глубине Н водоема }\end{array}$ & $2,0-1,0$ & $1,0-0,5$ & $0,5-0,25$ & $0,25-0,1$ \\
\hline 5 & pH летом & $6,9-7,2$ & $7,2-8$ & $8-9,5$ & $9,5-10,0$ \\
\hline 6 & $\begin{array}{l}\text { Разность суточной продукции и } \\
\text { деструкции, Ф-Д, мГО/л сут }\end{array}$ & $-0,1-0,1$ & $0,1-2,1$ & $2,1-3,1$ & $3,1-4,1$ \\
\hline 7 & БПК $5, \mathrm{M \Gamma O} / л$ & $2,3-3,3$ & $3,3-5,5$ & $5,5-7,7$ & $7,7-10,0$ \\
\hline 8 & $\begin{array}{l}\text { Насыщение воды кислородом в } \\
\%\end{array}$ & $150-100$ & $100-50$ & $50-25$ & $25-0$ \\
\hline
\end{tabular}

Таблица 4. Покомпонентная оценка трофности

\begin{tabular}{|l|c|c|}
\hline \multicolumn{1}{|c|}{ Критерий } & Значение & Тип трофности \\
\hline Продукция фитопланктона, мгС/л сут & 0,31 & \\
\hline Скорость фотосинтеза, мгО/л сут & 0,83 & \\
\hline Прозрачность воды по белому диску, $\mathrm{H}_{\mathrm{sd}}, \mathrm{m}$ & 1,68 & \\
\hline Отношение прозрачности $\mathrm{H}_{\text {sd }}$ к глубине Н водоема & 0,53 & \\
\hline$p H$ летом & 7,03 & \\
\hline $\begin{array}{l}\text { Разность суточной продукции и деструкции, Ф-Д, мгО/л } \\
\text { сут }\end{array}$ & $-0,90$ & \\
\hline БПК5, мгО/л & 2,5 & \\
\hline Насыщение воды кислородом в \% & 69,8 & \\
\hline
\end{tabular}

Таблица 5. Вид исходной классификации после выполнения процедуры нормирования и построения оценочной шкалы интегрального показателя.

\begin{tabular}{|c|c|c|c|c|c|c|c|}
\hline № & Критерий & \multicolumn{4}{|c|}{ Тип трофии } & $\min$ & $\max$ \\
\hline & & $\begin{array}{l}\text { Олиго- } \\
\text { трофия }\end{array}$ & $\begin{array}{l}\text { Мезо- } \\
\text { трофия }\end{array}$ & $\begin{array}{c}\text { Эв- } \\
\text { трофия }\end{array}$ & $\begin{array}{l}\text { Гипер- } \\
\text { трофия }\end{array}$ & & \\
\hline 1 & $\begin{array}{l}\text { Продукция } \\
\text { фитопланктона, } \\
\text { мгС/л сут }\end{array}$ & & & & & 0,005 & 50 \\
\hline 2 & $\begin{array}{l}\text { Скорость фотосинтеза, } \\
\text { мГО/л сут }\end{array}$ & & & & & 0,7 & 7,2 \\
\hline 3 & $\begin{array}{l}\text { Прозрачность воды по } \\
\text { белому диску, } \mathrm{H}_{\mathrm{sd}}, \mathrm{M}\end{array}$ & & & & & 0 & 10 \\
\hline 4 & $\begin{array}{l}\text { Отношение } \\
\text { прозрачности } \mathrm{H}_{\mathrm{sd}} \kappa \\
\text { глубине Н водоема }\end{array}$ & & & & & 0,1 & 2,0 \\
\hline 5 & pН летом & & & & & 6,9 & 10,0 \\
\hline 6 & $\begin{array}{l}\text { Разность суточной } \\
\text { продукции и } \\
\text { деструкции, } \\
\text { Ф-Д, мГО/л сут }\end{array}$ & & & & & 0 & 4,1 \\
\hline 7 & БПК & & & & & 2,3 & 10,0 \\
\hline 8 & $\begin{array}{l}\text { Насыщение воды } \\
\text { кислородом в \% }\end{array}$ & & & & & 0 & 150 \\
\hline & $\begin{array}{l}\text { Интегральный } \\
\text { показатель трофности } \\
\text { (ИПТ) }\end{array}$ & & & & & - & - \\
\hline
\end{tabular}

Таблица 6 Исходные данные для интегральной оценки трофности оз.Суури (2017 г.).

\begin{tabular}{l|l|l|l} 
№ & Критерий & Значение & Нормированное значение
\end{tabular}




\begin{tabular}{|c|c|c|c|}
\hline 1 & $\begin{array}{l}\text { Продукция фитопланктона, } \\
\text { мГС/л сут }\end{array}$ & 0,31 & 0,006 \\
\hline 2 & Скорость фотосинтеза, мГО/л сут & 0,83 & 0,02 \\
\hline 3 & Прозрачность воды по белому диску, $\mathrm{H}_{\mathrm{sd}}$, м & 1,68 & 0,83 \\
\hline 4 & $\begin{array}{l}\text { Отношение прозрачности } \mathrm{H}_{\text {sd }} \text { к глубине } \mathrm{H} \\
\text { водоема }\end{array}$ & 0,53 & 0,77 \\
\hline 5 & $p H$ воды летом & 7,03 & 0,04 \\
\hline 6 & $\begin{array}{l}\text { Разность суточной продукции и деструкции, } \\
\text { Ф-Д, мгО/л сут }\end{array}$ & $-0,90$ & 0,00 \\
\hline 7 & БПК 5, мгО/л & 2,5 & 0,03 \\
\hline 8 & Насыщение воды кислородом в \% & 69,8 & 0,53 \\
\hline
\end{tabular}

Для более уверенного заключения о трофическом статусе озера рекомендуется повторно оценить его по материалам натурных наблюдений других лет, например, 2018 года (таблица 7).

Таблица 7. Критерии для оценки трофности оз. Суури в 2018 г.

\begin{tabular}{|c|c|c|c|c|c|}
\hline \multirow[t]{2}{*}{ № } & \multirow[t]{2}{*}{ Критерий } & \multicolumn{4}{|c|}{ Тип трофии } \\
\hline & & $\begin{array}{l}\text { Олиго- } \\
\text { трофия }\end{array}$ & $\begin{array}{c}\text { Мезо- } \\
\text { трофия }\end{array}$ & $\begin{array}{c}\text { Эв- } \\
\text { трофия }\end{array}$ & $\begin{array}{l}\text { Гипер- } \\
\text { трофия }\end{array}$ \\
\hline 1 & $\begin{array}{l}\text { Продукция } \\
\text { фитопланктона, } \\
\text { мГС/л сут }\end{array}$ & $0-0,001$ & $0,001-0,01$ & $0,01-0,10$ & $0,10-1,00$ \\
\hline 2 & $\begin{array}{l}\text { Скорость } \\
\text { фотосинтеза, мгО/л } \\
\text { сут }\end{array}$ & $0-0,05$ & $0,05-0,26$ & $0,26-0,63$ & $0,63-1,00$ \\
\hline 3 & $\begin{array}{l}\text { Прозрачность воды } \\
\text { по белому диску, } \mathrm{H}_{\mathrm{sd}} \text {, } \\
\text { м }\end{array}$ & $0-0,40$ & $0,40-0,70$ & $0,70-0,90$ & $0,90-1,00$ \\
\hline 4 & $\begin{array}{l}\text { Отношение } \\
\text { прозрачности } \mathrm{H}_{\mathrm{sd}} \text { к } \\
\text { глубине Н водоема }\end{array}$ & $0-0,53$ & $0,53-0,79$ & $0,79-0,92$ & $0,92-1,00$ \\
\hline 5 & $p H$ летом & $0-0,10$ & $0,10-0,35$ & $0,35-0,84$ & $0,84-1,00$ \\
\hline 6 & $\begin{array}{l}\text { Разность суточной } \\
\text { продукции и } \\
\text { деструкции, } \\
\text { Ф-Д, мГО/л сут }\end{array}$ & $0-0,02$ & $0,02-0,51$ & $0,51-0,76$ & $0,76-1,00$ \\
\hline 7 & $\mathrm{БПК}_{5}, \mathrm{M \Gamma O} /$ /л & $0-0,13$ & $0,13-0,42$ & $0,42-0,70$ & $0,70-1,00$ \\
\hline 8 & $\begin{array}{l}\text { Насыщение воды } \\
\text { кислородом в \% }\end{array}$ & $0-0,33$ & $0,33-0,67$ & $0,67-0,83$ & $0,83-1,00$ \\
\hline 9 & $\begin{array}{l}\text { Максимальная } \\
\text { концентрация } \\
\text { хлорофилла «а», } \mathrm{Cl} \\
\text { «а», мкг/л } \\
\end{array}$ & $0-0,06$ & $0,06-0,19$ & $0,19-0,57$ & $0,57-1$ \\
\hline 10 & $\begin{array}{l}\text { Концентрация } \\
\text { хлорофилла «а», } \mathrm{Cl} \\
\text { «а», мкг/л }\end{array}$ & $0-0,005$ & $0,005-0,05$ & $0,05-0,5$ & $0,5-1,0$ \\
\hline 11 & $\begin{array}{l}\text { Биомасса } \\
\text { фитопланктона, мг/л }\end{array}$ & $0-0,002$ & $0,002-0,02$ & $0,02-0,2$ & $0,2-1$ \\
\hline 12 & $\begin{array}{l}\text { Отношение биомассы } \\
\text { зоопланктона к } \\
\text { биомассе } \\
\text { фитопланктона }\end{array}$ & $0-0,6$ & $0,6-0,9$ & $0,9-0,95$ & $0,95-1$ \\
\hline & $\begin{array}{l}\text { Интегральный } \\
\text { показатель } \\
\text { трофности (ИПТ) }\end{array}$ & & & & \\
\hline
\end{tabular}

\section{Вопросы для проверки усвоения материала:}

1. Назовите основной (ые) критерии для оценки трофического статуса водной экосистемы.

2. Может ли меняться продуктивность экосистемы внутри года, учитывается ли это в оценке трофического статуса.

3. Важно ли на Ваш взгляд установить изменчивость первичной продукции внутри года. 
4. Достаточно ли на Ваш взгляд установить продкционные возможности системы в период кратковременной работы на водоеме для оценки трофического статуса.

5. Чем антропогенное эвтрофирование отличается от загрязнения воды в водоеме.

\title{
Литература
}

Азгальдов Г.Г. Теория и практика оценки качества товаров (основы квалиметрии) / Москва, 1982.

Азгальдов Г.Г., Азгальдова Л.А. Количественная оценка качества. М.,1971. 176с.

Азгальдов Г.Г., Райхман Э.П. О квалиметрии. М., 1973. 172 с.

Айвазян С.А., Бухштабер В.М. и др. Классификация и снижение размерности. Под ред. С.А.Айвазяна, М., 1989.

Алефельд Г., Херцбергер Ю. Введение в интервальные вычисления. М., 1987. 356 с.

Андрианов Ю.М., Субетто А.И. Квалиметрия в приборостроении и машиностроении. Л., 1990. 216 с.

Богданчук В.З., Егоров Б.М., Катулев А.Н. Агрегирование векторных критериев. Л., 1990. 127 с.

Вилкас Э. Теория полезности и принятие решений // Мат. методы в соц. науках. Вильнюс, 1971. С.13-60.

Гермейер Ю.Б. Введение в теорию исследования операций. М., 1971. 383 с.

Гидрометеорология и гидрохимия морей СССР. Том III. Балтийское море. Вып. 1. Гидрометеорологические условия. Под ред. Ф.С. Терзиева, В.А.Рожкова, А.И.Смирновой. СПб., 1992.

Гидрометеорология и гидрохимия морей. Том III. Балтийское море. Вып. 2. Гидрохимические условия и океанологические основы формирования биологической продуктивности. Под ред. Ф.С.Терзиева, В.А.Рожкова, Е.Я. Римша, И.С.Шпаер. СПб., 1994.

Гличев А.В., Рабинович Г.О., Примаков М.И. Прикладные вопросы квалиметрии. М., 1983. 136 с.

Доес Р. Устойчивая привлекательность неправильных линейных моделей принятия решений // Нормативные и дескриптивные модели принятия решений. М., 1981. С.305-309.

Дружинин Н.И., Шишкин А.И. Математическое моделирование и прогнозирование загрязнения поверхностных вод суши. Л., 1989.

Дюран Б., Оделл П. Кластерный анализ. /Пер. с англ. ; Под ред. . М., 1977.

Интегральная оценка экологического состояния и качества среды городских территорий. Под ред. А.К.Фролова, СПб, 1999, 253c. 9. Многокритериальные географо-экологические оценки состояния и устойчивости природных и урбанизированных систем. Под ред.В.В.Дмитриева и Н.В.Хованова. Деп. ВИНИТИ 01.09.2000 № деп.2342В00, 275 с.

Исаченко А.Г. Экологическая география Северо-Запада России СПб 1995.

Колесникова О.Н., Корников В.В., Рожков Н.Н. Стохастические процессы с равновероятными монотонными реализациями, моделирующие дефицит информации // Вестн. Ленингр. ун-та. 1987, №1. С.21-26. C. $227-243$

Ларичев О.И. Принятие решений как научное направление // Системн. исследов. Ежегодник-1982. М., 1982.

Меньшиков Г.Г. Практические начала интервальных вычислений. Л., 1991.92 с.

Новаковский Б.А., Прасолова А.И., Прасолов С.В. Геоинформационные технологии для создания и использования интегральных карт оценки состояния компонентов природной среды // ГИС для устойчивого развития территорий / Материалы Международной конференции. Апатиты, Россия 22-24 августа 2000 г. Апатиты 2000. Т.1.

Орлов А.И. Прикладная теория измерений // Прикл. многомерн. стат. Анализ. ь., 1978. С.68-138.

Пфанцагль И. Теория измерений. М,. 1976. 248 с.

Трухаев Р.И. Модели принятия решений в условиях неопределенности. М., 1981. 257 с.

Трухаев Р.И., Горшков И.С. Факторный анализ в организационных системах. М., 1985. 185 с.

Хованов К.Н., Хованов Н.В. Анализ и Синтез Показателей при Информационном Дефиците (АСПИД-3W). Свидетельство РосАПО об официальной регистрации программы для ЭВМ № 960087 от 22.03 .1996 г. Правообладатель: ЗАО «Академия».

Хованов Н.В. Анализ и синтез показателей при информационном дефиците. СПб., 1996. 196 с.

Хованов Н.В. АСПИД - система квалиметрических методов оценивания в условиях дефицита информации качества сложных технических объектов //Методология и практика оценки качества продукции. Л., 1988.

Хованов Н.В. Математические основы теории шкал измерения качества. Л., 1982. 185 с.

Хованов Н.В. Стохастические модели теории квалиметрических шкал. Л., 1986. 80 с.

Хованов Н.В. Универсальность линейной свертки отдельных показателей // Методол. и практика оценки качества продукции. Вып.3. Л., 1990. С.70-74.

Хоменюк В.В. Элементы теории многоцелевой оптимизации. М., 1983. 124 с.

Чиркова Т.В. Физиологические основы устойчивости растений СПб. 2002.

Dawes R., Carrigan B. Linear models in decision making // Psychol.Bull. 1974. Vol.81. P.95-106. P.282-293.

Dombi J/ Basic concepts for a theory of evaluation: the aggregative operator // Eur.J.Oper.Res. 1982. Vol.10, N3.

Hovanov N.V., Kornikov V.V., Tokin I.B. The Mathematical Methods System of Decision Making for developmental Strategy under Uncertainty // Global Environmental Change. Perspectives of remote Sensing and Geographic Information System. New Delhi - Calcutta 1995.

http://iaap.narod.ru/stkDiks.htm

http://www.gisa.ru/732.html

Wittmuss A. Scalarizing multiobjective optimization problems // Math.Res. !985. Vol.27. P.255-258.

\section{Практическая работа №3}

\section{Интегральная оценка качества природной среды на основе метода сводных показателей. Как построить интегральный показатель качества воды водоема.}

\author{
Рассмотрим основные этапы построения интегрального показателя на примере \\ оценки качества природных вод.
}


На первом этапе отбирается обоснованная система критериев состояния биоты и абиотической среды, с использованием которых возможно диагностирование экологического состояния природной системы. При этом нужно стремиться к тому, чтобы каждый из параметров был необходим, а все параметры вместе были достаточны для описания качества (состояния) рассматриваемой системы. При этом могут существовать характеристики, увеличение значений которых приводит к ухудшению качества (первый mun) и характеристики, увеличение значений которых приводит к улучшению значения качества или состояния экосистемы (второй тип).
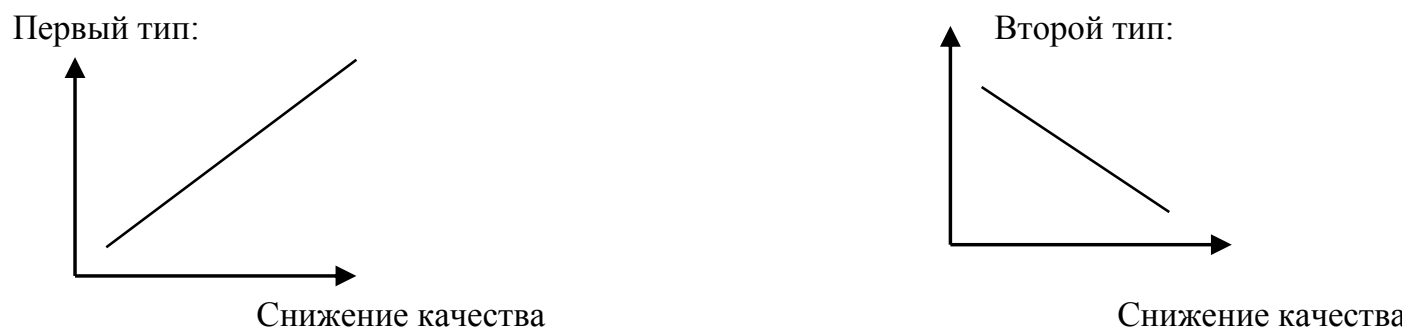

Кроме того, возможно существование характеристик, критические значения которых (например, значение $\mathrm{pH}=7,0$ ) разбивают шкалу изменений характеристики на два интервала с противоположными свойствами влияния переменной на состояние объекта.

Одновременно с введением признаков (критериев) оценивания вводятся классы состояния (качества, загрязнения и т.п.). В связи с этим мы обращаем внимание на существующие классификации качества и загрязнения природных вод. Всегда легче опираться на существующие классификации, чем вводить свои, но иногда просто необходимо бывает формировать авторские классификации для оценки состояния экосистем или различных их свойств.

В качестве критериев оценивания выберем следующие: насыщение воды кислородом (\%), индекс загрязнения воды (ИЗВ), индекс сапробности, биотический индекс Вудивисса (баллы). Введем классы качества (табл.1), опираясь на классификации, приведенные в работе А.А.Зенина и Н.В.Белоусовой $(1988$, с.77-78) и изменение ИЗВ по классам качества вод.

Таблица 1. Исходная классификация для оценки качества воды.

\begin{tabular}{|c|c|c|c|c|c|c|}
\hline Признаки & $\begin{array}{c}\text { Очень } \\
\text { чистые } \\
\chi-(\beta-o) \\
\chi \text { сапробность } \\
\text { I }\end{array}$ & $\begin{array}{c}\text { Чистые } \\
\alpha-O \\
\text { сапробность }\end{array}$ & $\begin{array}{c}\text { Умеренно } \\
\text { загрязненные, } \\
\beta-\mathrm{m} \\
\text { сапробность } \\
\text { III }\end{array}$ & $\begin{array}{c}\text { Загрязненные } \\
\alpha \text {-m } \\
\text { сапробность } \\
\text { IY }\end{array}$ & $\begin{array}{c}\text { Грязные } \\
\rho \\
\text { сапробность } \\
\text { Y }\end{array}$ & $\begin{array}{c}\text { Очень } \\
\text { грязные } \\
\text { гипер- } \\
\text { сапробность } \\
\text { YI }\end{array}$ \\
\hline $\begin{array}{l}\text { 1. Растворенный } \mathrm{O}_{2} \text {, } \\
\% \text { насыщения }\end{array}$ & 95 & 80 & 70 & 60 & 30 & 0 \\
\hline 2. Индекс загрязнения воды (ИЗВ) & $\leq 0,2$ & $0,2-1$ & $1-2$ & $2-4$ & 4-6 & $6-10$ \\
\hline $\begin{array}{l}\text { 3. Индекс сапробности по Пантле } \\
\text { и Букку в модификации } \\
\text { Сладечека }\end{array}$ & $<1$ & $1-1.5$ & $1.5-2.5$ & $2.5-3.5$ & $3.5-4.0$ & $>4$ \\
\hline $\begin{array}{l}\text { 4. Биотический индекс по } \\
\text { Вудивиссу в баллах }\end{array}$ & 10 & $9-7$ & $6-5$ & 4 & $3-2$ & $1-0$ \\
\hline
\end{tabular}

В данной классификации к первому mипу параметров относятся: содержание кислорода и биотический индекс Вудивисса (чем значение характеристики больше, тем качество лучше), ко второму muпy: ИЗВ и индекс сапробности (чем значение характеристики больше, тем качество хуже). На данном этапе всегда полезно проанализировать шкалы изменения параметров по классам состояния (качества). Применительно к нашей классификации отметим, что выбранные критерии характеризуют как состояние абиотической среды, так и состояние биоты; не все шкалы имеют левую и правую границы внутри классов; некоторые шкалы (шкала биотического индекса) не являются непрерывными.

Введем левую и правую границы для всех исходных характеристик качества воды, хотя заметим, что данная процедура не является строго обязательной. При этом необходимо помнить, что в качестве правой границы параметров, характеризующих состояние «чистых вод» (II класс) можно задавать значение ПДК, взятое из справочной 
литературы. В любом случае лучше убедиться в том, что правая граница «чистых» условий среды не превышает ПДК. В результате таблица 1 преобразуется в таблицу 2.

Таблица 2. Исходная классификация для оценки качества воды.

\begin{tabular}{|c|c|c|c|c|c|c|}
\hline Признаки & $\begin{array}{c}\text { Очень } \\
\text { чистые } \\
\chi-(\beta-o) \\
\text { Сапробность } \\
\text { I }\end{array}$ & $\begin{array}{c}\text { Чистые } \\
\alpha-O \\
\text { сапробность } \\
\\
\text { II }\end{array}$ & $\begin{array}{c}\text { Умеренно } \\
\text { загрязненные, } \\
\beta-\mathrm{m} \\
\text { сапробность } \\
\text { III } \\
\end{array}$ & $\begin{array}{c}\text { Загрязненные } \alpha \\
\text {-m } \\
\text { сапробность } \\
\text { IY }\end{array}$ & $\begin{array}{c}\text { Грязные } \\
\rho \\
\text { сапробность } \\
\\
\text { Y }\end{array}$ & $\begin{array}{c}\text { Очень } \\
\text { грязные } \\
\text { гипер- } \\
\text { сапробность } \\
\text { ҮI }\end{array}$ \\
\hline $\begin{array}{l}\text { 1.Растворенный } \mathrm{O}_{2}, \\
\text { \% насыщения }\end{array}$ & $100-95$ & $95-80$ & $80-70$ & $70-60$ & $60-30$ & $30-0$ \\
\hline $\begin{array}{l}\text { 2. Индекс загрязнения воды } \\
\text { (ИзВ) }\end{array}$ & $0-0,2$ & $0,2-1$ & $1-2$ & $2-4$ & $4-6$ & $6-10$ \\
\hline $\begin{array}{l}\text { 3. Индекс сапробности по } \\
\text { Пантле и Букку в } \\
\text { модификации Сладечека }\end{array}$ & $0-1$ & $1-1,5$ & $1,5-2,5$ & $2,5-3,5$ & $3,5-4,0$ & $4-4,5$ \\
\hline $\begin{array}{l}\text { 4. Биотический индекс по } \\
\text { Вудивиссу в баллах }\end{array}$ & $10-9$ & $9-7$ & $6-5$ & $4-3$ & $3-2$ & $1-0$ \\
\hline
\end{tabular}

На втором этапе с помощью нормирующих функций избавимся от размерности исходных характеристик так, чтобы наилучшим условиям по каждому критерию соответствовало значение равное 0 , а наихудшим, равное 1 (можно наоборот). Такое преобразование выполним следующим образом. Для критериев первого типа введем правило перевода в виде:

$$
q_{i}=q_{i}\left(x_{i}\right)=\left\{\begin{array}{lrc}
0, & n p u \quad x_{i} \leq \min _{i}, \\
\left(\frac{x_{i}-\min _{i}}{\max _{i}-\min _{i}}\right)^{\lambda}, n p u\left(\min _{i}<x_{i} \leq \max _{i}\right), \\
1, & n p u \quad x_{i}>\max _{i}
\end{array}\right.
$$

В (1): $q i$ - преобразованное значение из табл. $2 ; x_{i}$ - текущее значение из табл. $2 ; \mathrm{min}$ $i$ - минимальное (фоновое, допустимое и т.п.) значение параметра; $\max _{i}-$ максимальное значение параметра (лучше ориентироваться на региональные, но не на абсолютные максимумы параметров). Исследователь должен дополнительно выбрать показатель степени $\lambda$, определяющий характер и степень выпуклости нормирующей функции $q_{i}\left(x_{i}\right)$ : при $\lambda>1$ соответствующая нормирующая функция выпукла вниз, а при $\lambda<1$ вверх.

Для критериев второго типа введем правило перевода в виде:

$$
q_{i}=q_{i}\left(x_{i}\right)=\left\{\begin{array}{lcc}
1, & n p u & x_{i} \leq \min _{i}, \\
\left(\frac{\max _{i}-x_{i}}{\max _{i}-\min _{i}}\right)^{\lambda}, & n p u\left(\min _{i}<x_{i} \leq \max _{i}\right), \\
0, & n p u & x_{i}>\max _{i} .
\end{array}\right.
$$

Диапазон изменения $q_{i}$ всегда находится в пределах от 0 до 1. Таким образом, исходные параметры в различных шкалах измерения (абсолютные и средние величины в конкретных единицах измерения, относительные или бальные оценки и т.п.) приводятся к единой безразмерной шкале, после чего над их значениями можно производить математические действия с целью получения интегрального показателя состояния экосистемы (качества среды, устойчивости, благополучия и т.п.).

Зададим минимальные и максимальные значения параметров (табл.3). Для этого, как правило, используются минимальное ( $\min i)$ и максимальное ( $\max i)$ значения из каждой шкалы исходных характеристик.

Таблица 3. Задание минимальных и максимальных значений параметров для преобразований по (1) и (2).

\begin{tabular}{|l|c|c|}
\hline \multicolumn{1}{|c|}{ Признаки } & $\min _{i}$ & $\max _{i}$ \\
\hline 1. Растворенный О, \% насыщения & 0 & 100 \\
\hline 2. Индекс загрязнения воды (ИЗВ) & 0 & 10 \\
\hline
\end{tabular}




\begin{tabular}{|l|c|c|}
\hline $\begin{array}{l}\text { 3. Индекс сапробности по Пантле и Букку в } \\
\text { модификации Сладечека }\end{array}$ & 0 & 4,5 \\
\hline $\begin{array}{l}\text { 4. Биотический индекс по Вудивиссу в } \\
\text { баллах }\end{array}$ & 0 & 10 \\
\hline
\end{tabular}

В преобразованной форме табл.2 приобретает вид табл.4.

\begin{tabular}{|c|c|c|c|c|c|c|}
\hline Признаки & $\begin{array}{c}\text { Очень } \\
\text { чистые } \\
\chi^{-}(\beta-o) \\
\text { сапробность } \\
\text { I }\end{array}$ & $\begin{array}{c}\text { Чистые } \\
\alpha-O \\
\text { сапробность } \\
\text { II }\end{array}$ & $\begin{array}{c}\text { Умеренно } \\
\text { загрязненные, } \\
\beta-\mathrm{m} \\
\text { сапробность } \\
\text { III }\end{array}$ & $\begin{array}{c}\text { Загрязненные } \\
\alpha \text {-m } \\
\text { сапробность } \\
\text { IY }\end{array}$ & $\begin{array}{c}\text { Грязные } \\
\rho \\
\text { сапробность } \\
\text { Y }\end{array}$ & $\begin{array}{c}\text { Очень грязные } \\
\text { гипер- } \\
\text { сапробность } \\
\text { YI }\end{array}$ \\
\hline $\begin{array}{l}\text { 1. Растворенный } \mathrm{O}_{2} \text {, } \\
\% \text { насыщения }\end{array}$ & $0-0,05$ & $0,05-0,2$ & $0,2-0,3$ & $0,3-0,4$ & $0,4-0,7$ & $0,7-1$ \\
\hline $\begin{array}{l}\text { 2. Индекс загрязнения воды } \\
\text { (ИЗВ) }\end{array}$ & $0-0,02$ & $0,02-0,1$ & $0,1-0,2$ & $0,2-0,4$ & $0,4-0,6$ & $0,6-1$ \\
\hline $\begin{array}{l}\text { 3. Индекс сапробности по } \\
\text { Пантле и Букку в } \\
\text { модификации Сладечека }\end{array}$ & $0-0,22$ & $0,22-0,33$ & $0,33-0,55$ & $0,55-0,78$ & $0,78-0,89$ & $0,89-1$ \\
\hline $\begin{array}{l}\text { 4. Биотический индекс по } \\
\text { Вудивиссу в баллах }\end{array}$ & $0-0,1$ & $0,1-0,3$ & $0,4-0,5$ & $0,6-0,7$ & $0,7-0,8$ & $0,9-1$ \\
\hline
\end{tabular}

На третьем этапе выбирается вид интегрального показателя $Q(q, w)$. Комплексный показатель строится таким образом, что зависит не только от показателей $q_{i}$, но и от их значимости, определяемой весовыми коэффициентами $w_{i}$, сумма которых должна равняться $1\left(0 \leq w_{i} \leq 1\right)$.

В качестве выражения для интегрального показателя можно предложить линейную свертку показателей вида: $Q_{i}=\sum_{i=1}^{n} q_{i} w_{i}, i=1, \ldots$ n, где $n$ - число критериев оценивания.

На четвертом этапе вводятся оценки весовых коэффициентов wi. Как правило, уже само составление программы оценочных исследований является первичным "взвешиванием" параметров, компонентов и их свойств. Однако такое взвешивание оказывается недостаточным, так как влияние отобранных главных факторов также неравнозначно, что вызывает необходимость придавать при оценке различным параметрам (свойствам, компонентам) разные приоритеты, веса или коэффициенты значимости. Нередко при этом вес вводится без какого-либо четкого обоснования. Чаще всего применяются следующие способы учета "веса" отдельных критериев экологического состояния и качества природной среды: вес каждого из отобранных параметров принимается равным; вес наиболее важных параметров увеличивается или вес второстепенных показателей уменьшается в условное число раз; вес определяется с помощью мнений экспертов; вес каждого показателя определяется с помощью дополнительных расчетов. В самом простом случае, при равенстве весов исходных параметров, вес определяется простой формулой $p_{i}=1 / \mathrm{n}$. Для нашего случая $p_{i}=1 / 4$ или 0,25 .

В дальнейшем будет рассмотрен метод, позволяющий работать с учетом экспертной информации о весах $(I)$ :

$$
\begin{array}{ll}
\text { - } & \text { ординальная (порядковая) - OI: } O I=\left\{w_{r}>w_{s}, w_{u}=w_{v}, \ldots r, s, u, v \in\{1, \ldots, m\}\right\} \text {; } \\
\text { - } & \text { интервальная - II: } I I=\left\{0 \leq a_{i} \leq w_{i} \leq b_{i} \leq 1, \quad i \in(1, \ldots, m\}\right\} .
\end{array}
$$

В итоге мы сможем учитывать неполную, неточную, нечисловую информация (т.н. нннинформация):

$$
I=O I+I I \text {. }
$$

На пятом этапе для левой и правой границ каждого класса рассчитывается значение $\mathrm{I}=Q_{i}$. Рис.1 поясняет этот расчет. В результате выполнения пятого этапа мы получили шкалу интегрального показателя по классам качества при условии равновесного учета всех параметров оценивания. 


\begin{tabular}{|c|c|c|c|c|c|c|}
\hline Признаки & $\begin{array}{c}\text { Очень } \\
\text { чистые } \\
\chi-(\beta-o \\
\text { сапробность }\end{array}$ & $\begin{array}{c}\text { Чистые } \\
\alpha-O \\
\text { сапробност } \\
\text { ь } \\
\text { II }\end{array}$ & $\begin{array}{c}\text { Умеренно } \\
\text { загрязненные, } \\
\beta-\mathrm{m} \\
\text { сапробность } \\
\text { III }\end{array}$ & $\begin{array}{c}\text { Загрязненные } \\
\alpha \text {-m } \\
\text { сапробность } \\
\\
\text { IY }\end{array}$ & $\begin{array}{c}\text { Грязные } \\
\rho \\
\text { сапробность } \\
\\
\text { Y }\end{array}$ & $\begin{array}{c}\text { Очень } \\
\text { грязные } \\
\text { гипер- } \\
\text { сапробно } \\
\text { сть } \\
\text { YI }\end{array}$ \\
\hline $\begin{array}{l}\text { 1.Растворенный } \mathrm{O}_{2} \text {, } \\
\text { \% насыщения }\end{array}$ & 0,05 & $0,05-0,2$ & $0,20-0,30$ & $0,30-0,40$ & $0,40-0,70$ & $0,70-1$ \\
\hline $\begin{array}{l}\text { 2. Индекс } \\
\text { загрязнения воды } \\
\text { (ИЗВ) }\end{array}$ & 0,02 & $\begin{array}{c}0,02- \\
0,10\end{array}$ & $0,10-0,20$ & $0,20-0,40$ & $0,40-0,60$ & $0,60-1$ \\
\hline $\begin{array}{l}\text { 3. Индекс сапробности по } \\
\text { Пантле и Букку в } \\
\text { модификации Сладечека }\end{array}$ & 0,10 & $\begin{array}{c}0,22- \\
0,33\end{array}$ & $0,33-0,55$ & $0,55-0,78$ & $0,78-0,89$ & $0,89-1$ \\
\hline $\begin{array}{l}\text { 4. Биотический } \\
\text { индекс по } \\
\text { Вудивиссу в } \\
\text { баллах }\end{array}$ & & $\begin{array}{l}0,10- \\
\varphi, 3 \varphi\end{array}$ & 0,4-0,50 & $\begin{array}{c}0,60-0,70 \\
\mid\end{array}$ & $\begin{array}{c}0,70-0,80 \\
\mid\end{array}$ & $\downarrow$ \\
\hline
\end{tabular}

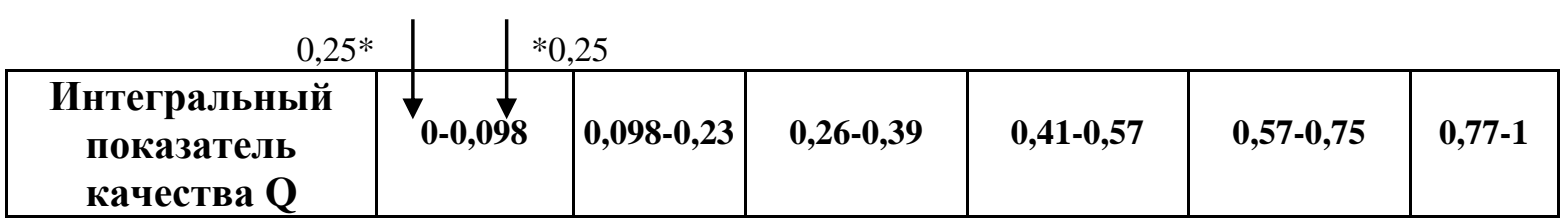

Рис.1. Построение интегрального показателя качества воды (пояснение в тексте).

На шестом этапе по собранным в полевых условиях данным и лабораторным определениям найдем значение интегрального показателя качества воды (см.табл.5).

Таблица 5. Исходные данные для оценки качества воды.

\begin{tabular}{|l|l|}
\hline 1. Растворенный $\mathrm{O}_{2}, \%$ насыщения & 75 \\
\hline $\begin{array}{l}\text { 2. Индекс загрязнения воды (ИЗВ) } \\
\text { 3. Индекс сапробности по Пантле и Букку в }\end{array}$ & 1,50 \\
\hline 4.дификации Сладечека & 6 \\
\hline
\end{tabular}

Как следует из таблицы, оценить качество воды однозначно при покомпонентной оценке не представляется возможным, так как по двум параметрам вода относится к III классу качества, по одному - ко II, и по одному - находится на границе II и III классов качества. Встречаются еще более сложные ситуации, когда разброс значений отдельных параметров укладывается в несколько классов состояния (качества). Это может быть связано как с несовершенством методической базы и оценочных шкал, так и с недостаточным опытом исполнителя.

По правилам построения исходной классификации рассчитаем значение интегрального показателя:

$$
\begin{array}{ll}
\text { 1. } & q_{1}=(100-75) / 100=0,25 \\
\text { 2. } & q_{2}=(0,90-0) / 10=0,09 \\
\text { 3. } & q_{3}=(1,50-0) / 4,5=0,33 \\
\text { 4. } & q_{4}=(10-6) / 10=0,40
\end{array}
$$

Интегральный показатель $\mathrm{I}=(0,25+0,09+0,33+0,40) * 0,25=\mathbf{0 , 2 7} ;$ таким образом, по совокупности критериев оценивания воду следует отнести к III классу (ближе к левой границе, практически на границе II-III классов), так как диапазон изменения интегрального показателя у этого класса 0,26-0,39 (см.рис.1). Таким же образом рассчитываются значения интегрального показателя по другим натурным данным. 
Задание по работе.

1. Разработать шкалы интегральных показателей для оценки качества воды оз.Суури для 2018 года на основе оценочных шкал и исходных данных (табл. 6).

Гидрофизические шкалы:

\begin{tabular}{|c|c|c|c|c|c|}
\hline $\begin{array}{c}\text { Классы } \\
\text { Параметры }\end{array}$ & 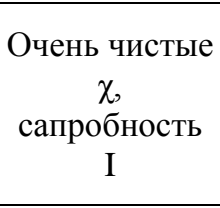 & $\begin{array}{c}\text { Чистые о, } \\
\text { сапробность } \\
\text { II }\end{array}$ & $\begin{array}{c}\text { Умеренно } \\
\text { загрязнённые } \\
\beta-m, \\
\text { сапробность } \\
\text { III } \\
\end{array}$ & $\begin{array}{c}\text { Загрязнённые } \\
\alpha-m, \\
\text { сапробность } \\
\text { IV }\end{array}$ & $\begin{array}{c}\text { Грязные } \rho, \\
\text { сапробность } \\
\text { V }\end{array}$ \\
\hline \multicolumn{6}{|l|}{$\begin{array}{c}\text { Прозрачность воды } \\
\text { по диску Секки, м }\end{array}$} \\
\hline \multicolumn{6}{|l|}{$\begin{array}{c}\text { Удельная } \\
\text { электропроводност } \\
\text { ь воды, мкСм/см }\end{array}$} \\
\hline $\begin{array}{c}\text { Интегральный } \\
\text { показатель } \\
\text { качества воды } \\
\text { (ИПК-1) }\end{array}$ & & & & & \\
\hline
\end{tabular}

Гидрохимические шкалы:

\begin{tabular}{|c|c|c|c|c|c|}
\hline $\begin{array}{c}\text { Классы } \\
\text { Параметры }\end{array}$ & $\begin{array}{c}\text { Очень чистые } \\
\text {, сапробность } \\
\text { I }\end{array}$ & $\begin{array}{c}\text { Чистые о, } \\
\text { сапробность } \\
\text { II }\end{array}$ & $\begin{array}{c}\text { Умеренно } \\
\text { загрязнённые } \beta- \\
\text { сапробность } \\
\text { III }\end{array}$ & $\begin{array}{c}\text { Загрязнённые } \alpha- \\
\text { сапробность } \\
\text { IV }\end{array}$ & $\begin{array}{c}\text { Грязные } \rho, \\
\text { сапробность } \\
\text { V }\end{array}$ \\
\hline БПК5, мгО/л & & & & & \\
\hline РО43-, мгР/л & & & & & \\
\hline NH4+, мгN/л & & & & & \\
\hline $\begin{array}{c}\text { О2, \% } \\
\text { насыщения }\end{array}$ & & & & & \\
\hline $\begin{array}{c}\text { Ин } \\
\text { показатель } \\
\text { качества воды } \\
\text { (ИПК-2) }\end{array}$ & & & & & \\
\hline
\end{tabular}

Гидробиологические шкалы:

\begin{tabular}{|c|c|c|c|c|c|}
\hline $\begin{array}{c}\text { Классы } \\
\text { Параметры }\end{array}$ & $\begin{array}{c}\text { Очень } \\
\text { чистые } \chi \\
\text { сапробность } \\
\text { I }\end{array}$ & $\begin{array}{c}\text { Чистые o, } \\
\text { сапробность } \\
\text { II }\end{array}$ & $\begin{array}{c}\text { Умеренно } \\
\text { загрязнённые } \\
\beta-m, \\
\text { сапробность } \\
\text { III }\end{array}$ & $\begin{array}{c}\text { Загрязнённые } \\
\alpha-m, \\
\text { сапробность } \\
\text { IV }\end{array}$ & $\begin{array}{c}\text { Грязные } \rho, \\
\text { сапробность } \\
\text { V }\end{array}$ \\
\hline $\begin{array}{c}\text { Биомасса } \\
\text { фитопланктона, } \\
\text { мг/л }\end{array}$ & & & & & \\
\hline $\begin{array}{c}\text { Хлорофилл «а», } \\
\text { мкг/л }\end{array}$ & & & & & \\
\hline $\begin{array}{c}\text { Первичная } \\
\text { продукция } \\
\text { фитопланктона } \\
\text { ГО2/м2-*сст }\end{array}$ & & & & & \\
\hline ВМWР & & & & & \\
\hline АSРТ & & & & & \\
\hline Сапробность & & & & & \\
\hline
\end{tabular}




\begin{tabular}{|c|l|l|l|l|l|}
\hline Индекс & & & & \\
Вудивисса & & & & & \\
\hline $\begin{array}{c}\text { Интегральный } \\
\text { показатель } \\
\text { качества воды } \\
\text { (ИПК3) }\end{array}$ & & & & \\
\hline
\end{tabular}

\begin{tabular}{|c|c|c|c|c|c|}
\hline $\begin{array}{c}\text { Классы } \\
\text { Параметры }\end{array}$ & $\begin{array}{c}\text { Очень } \\
\text { чистые } \chi, \\
\text { сапробность }\end{array}$ & $\begin{array}{c}\text { Чистые о, } \\
\text { сапробность }\end{array}$ & $\begin{array}{c}\text { Умеренно } \\
\text { загрязнённые } \\
\beta-m, \\
\text { сапробность }\end{array}$ & $\begin{array}{c}\text { Загрязнённые } \\
\alpha-m, \\
\text { сапробность }\end{array}$ & $\begin{array}{c}\text { Грязные } \rho, \\
\text { сапробность }\end{array}$ \\
\hline $\begin{array}{c}\text { Гидрофизические } \\
\text { (ИПК-1) }\end{array}$ & & & & & \\
\hline $\begin{array}{c}\text { Гидрохимические } \\
\text { (ИПК-2) }\end{array}$ & & & & & \\
\hline $\begin{array}{c}\text { Гидробиологические } \\
\text { (ИПК-3) }\end{array}$ & & & & \\
\hline $\begin{array}{c}\text { Интегральный } \\
\text { показатель } \\
\text { второго уровня } \\
\text { свертки }\end{array}$ & & & & \\
\hline
\end{tabular}

2. Выполнить интегральную оценку качества по наблюденным исходным данным в оз. Суури в 2018 г.

Показатели, определяемые в двух горизонтах: у поверхности и у дна (оз. Суури, 2018 г.)

\begin{tabular}{|c|c|c|c|c|}
\hline & \multicolumn{2}{|c|}{ Поверхость } & \multicolumn{2}{|c|}{ Дно } \\
\hline Параметр & $\begin{array}{c}\text { Исходные } \\
\text { значения }\end{array}$ & $\begin{array}{c}\text { Результат } \\
\text { нормирования }\end{array}$ & $\begin{array}{c}\text { Исходные } \\
\text { значения }\end{array}$ & $\begin{array}{c}\text { Результат } \\
\text { нормирования }\end{array}$ \\
\hline $\begin{array}{c}\text { Удельная } \\
\text { элекропроводность, } \\
\text { мкСм/см }\end{array}$ & 89,78 & 87,03 & \\
\hline Фосфаты, мг/л & 0,01 & & 0,013 & \\
\hline $\begin{array}{c}\text { Аммонийный азот, } \\
\text { мг/л }\end{array}$ & 0,24 & & 0,25 & \\
\hline $\mathrm{O}_{2,} \%$ насыщения & 54,89 & & 44,69 & \\
\hline $\mathrm{pH}$ & 7,18 & & 6,81 & \\
\hline БПК5, мгО/л & 2,35 & & 2,21 & \\
\hline
\end{tabular}

Показатели, определяемые в одном из горизонтов (оз. Суури, 2018 г.)

\begin{tabular}{|l|c|c|}
\hline \multicolumn{1}{|c|}{ Параметр } & $\begin{array}{c}\text { Исходные } \\
\text { значения }\end{array}$ & $\begin{array}{c}\text { Результат } \\
\text { нормирования }\end{array}$ \\
\hline Прозрачность воды, м & 1,5 & \\
\hline Биомасса фитопланктона, мг сыр. в/л & 0,8 & \\
\hline Хлорофилл а, мкг/л & 1,64 & \\
\hline $\begin{array}{l}\text { Первичная продукция } \\
\text { фитопланктона, ГО } / \mathrm{M}^{2} * \text { сут }\end{array}$ & 0,038 & \\
\hline ВМWР & 12,7 & \\
\hline АSPT & 2,54 & \\
\hline Сапробность & 1,84 & \\
\hline Индекс Вудивисса & 6 & \\
\hline
\end{tabular}




\section{Вопросы для проверки усвоения материала:}

1. Назовите недостатки классификации, рассмотренной в качестве примера в практической работе.

2. Принято ли оценивать качество воды в водоеме отдельно для поверностной и придонной воды.

3. Дайте определение «качества воды» с позиции антропоцентризма и биоцентризма.

4. Согласны ли Вы с известным определением: оценить экологическое состояние водоема, это значит оценить качество его воды. Да/нет, объясните.

\section{Литература}

Дмитриев В.В., Мякишева Н.В., Хованов Н.В. Многокритериальная оценка экологического состояния и устойчивости геосистем на основе метода сводных показателей. І. Качество природных вод.//Вестник СПбГУ, сер.7., вып.3 (N21), 1996. С.40-52.

Дмитриев В.В., Мякишева Н.В., Третьяков В.Ю., Хованов Н.В. Многокритериальная оценка экологического состояния и устойчивости геосистем на основе метода сводных показателей. II.Трофический статус водных экосистем.//Вестник СПбГУ, сер.7, вып.1 (N23), 1997. С.51-67.

Зенин А.А., Белоусова Н.В. Гидрохимический словарь. Л., Гидрометеоиздат, 1988, 240 с.

Дмитриев В.В., Мандрыка О.Н., Огуриов А.Н., Потапова Т.М. Состояние водных объектов Северо-Западного Приладожья и оценка их устойчивости к антропогенному эвтрофированию: Длительные изменения и современное состояние ландшафтов Приладожья: Сборник научн. трудов / Отв. ред. Г.А. Исаченко. СПб.,1995.

Дмитриев В.В., Васильев В.Ю., Горбовская А.Д и др. Диагностика состояния водоемов, наземной растительности и почвенного покрова геосистем Карельского Приладожья Ч.І, // Изв. РГО. 1996. Т.128. Вып.1, 2.

Дмитриев В.В., Фрумин Г.Т. Экологическое нормирование и устойчивость природных систем. - СПб., 2004. $294 \mathrm{c}$.

Сергеев Ю. Н., Денисенко А. В., Дмитриев В. В., Кулеш В. П. Модель распознавания образов как инструмент для оценки качества вод Невской губы ИЗВЕСТИЯ РУССКОГО ГЕОГРАФИЧЕСКОГО ОБЩЕСТВА 2018, № 5 ПРИЛОЖЕНИЕ, с. S3-S16 DOI: 10.1134/S0869607118050075 https://elibrary.ru/download/elibrary_36760697_16094338.pdf

Dmitriev, V. V., Terleev, V. V., Nikonorov, A. O., Ogurtsov, A. N., Osipov, A. G., Sergeyev, Y. N., Kulesh, V. P., Fedorova, I. V. (2020). Global Evaluation of the Status and Sustainability of Terrestrial Landscapes and Water Bodies. Landscape Modelling and Decision Support, 231-253. doi:10.1007/978-3-030-37421-1_12

Vasiliy Dmitriev, Svetlana Sedova, Anastasiia Plenkina, Viktoriia Khomiakova, Diana Avdeevich, Valeriia Ladanova, Andrei Ukis, Nikolai Paniutin E3S Web Conf. Volume 163, 2020 IV Vinogradov Conference "Hydrology: from Learning to Worldview" in Memory of Outstanding Russian Hydrologist Yury Vinogradov. 2020. St. Petersburg, Russia E3S Web of Conferences 163, 03002 (2020) DOI: https://doi.org/10.1051/e3sconf/202016303002

Sedova S.A., Dmitriev V.V. EVELOPMENT OF A METHODOLOGY FOR THE INTEGRATED ASSESSMENT OF THE ECOLOGICAL STATUS OF WATER BODIES ON THE EXAMPLE OF SMALL LAKES IN THE NORTHWESTERN LADOGA. European Journal of Natural History. - 2020. - № 1 - P. 37-44

Седова С.А., Дмитриев В.В., Четверова А.А. БАЗА ДАННЫХ ДЛЯ ВЫЯВЛЕНИЯ ЭКОЛОГИЧЕСКОГО СТАТУСА И ФАКТОРОВ МАССООБМЕНА В ВОДНОЙ ЭКОСИСТЕМЕ НА ПРИМЕРЕ ОЗЕРА "СУУРИ" (LАКЕSUURI-ECOSYSTEM). Свидетельство о регистрации базы данных RUS 2019621679 13.09.2019 https://elibrary.ru/download/elibrary_41182581_13663613.PDF

\section{Практическая работа №4}

Оценка эмерджентных свойств наземных и водных геосистем и ландшафтов. Балльные и балльно-индексные оценки состояния и устойчивости водных объектов, почв, наземных геосистем. 1. Балльно-индексная оценка устойчивости водоемов к изменению параметров естественного и антропогенного режимов. 2. Балльноиндексная оценка устойчивости водотоков к изменению параметров естественного и антропогенного режимов.

Устойчивость природных систем к воздействию и возможности ее оценивания. Как отмечал И.Н. Росновский (1993), все определения устойчивости природных систем сходятся в одном: устойчивость системы - это ее способность сохранять свои свойства и параметры режимов в условиях действующих внутренних и внешних возмущений. Такое определение совпадает с определением устойчивости в общей теории систем в кибернетике (Кафаров,1985; Ackoff, 1960; Bertalanfi, 1962). Оценка уязвимости или устойчивости к изменению свойств геосистемы не сводится только к учету одного какого-либо свойства (фактора). Она получается, как результат учета многих факторов, характеризующихся большим набором параметров оценивания, среди которых группы физико-географических факторов, климатических условий и характер 
антропогенного воздействия являются определяющими. На сегодняшний день выявлено многообразие взглядов и подходов к оценке состояния наземных и водных ландшафтов; отсутствие подходов, позволяющих на интегральной основе количественно оценивать неаддитивные (эмерджентные) свойства геосистем с учетом влияния факторов естественного и антропогенного режимов на их развитие. Разработаны немногочисленные подходы и методы, базирующиеся на индексах устойчивости, а также модели-классификации, подавляющее большинство которых построено на балльно-индексном подходе.

Кроме многообразия взглядов и подходов к оценке устойчивости; выявлено отсутствие подходов, позволяющих на интегральной основе количественно оценивать неаддитивные свойства геосистем с учетом влияния факторов естественного и антропогенного режимов. Интегральная оценка устойчивости и экологического благополучия геосистем на основе МСП и МРСП впервые разработана в наших исследованиях (Дмитриев, 2000; Alekseeva O.N. Dmitriev V.V., Gyzheva L.N., 2005).

Под устойчивостью геосистемы к изменению параметров режимов нами понимается её способность сохранять свои свойства и параметры режимов в условиях действующих на неё внешних и внутренних нагрузок. Тогда уязвимыми к изменению параметров режимов будут геосистемы, не способные сохранять указанные свойства на определенном временном интервале функционирования. Оценка уязвимости или устойчивости к изменению свойств геосистемы не сводится только к учету одного какоголибо свойства (фактора). Она получается как результат учета многих факторов, характеризующихся большим набором параметров оценивания, среди которых группы физико-географических факторов, климатических условий и характер антропогенного воздействия являются определяющими. Исследование этих факторов и их изменчивости расширяет кругозор исследователя, обусловливает необходимость формирования у него эколого-географического мышления. Модели и опыт интегральной оценки эмерджентных свойств (устойчивости, экологической напряженности, экологического благополучия и др.) рассматривается нами в серии публикаций последних лет (см. список литературы). Методы и модели апробированы для наземных и водных геосистем севера и северо-запада РФ.

Примеры авторских подходов к оценке устойчивости. В современной литературе существуют терминологические несоответствия многих понятий, связанных с устойчивостью. Часто авторы не оговаривают механизмы формирования устойчивости (1адаптационная - до некоторого предела свойства не меняются, и 2-регенерационная утраченные свойства быстро восстанавливаются), в оценочных исследованиях устойчивости смешиваются механизмы её формирования (присутствуют одновременно 1 и 2), подменяют термины (устойчивость - чувствительность, устойчивость изменчивость, устойчивость - самоочищение, устойчивость - сложность, устойчивость разнообразие). Встречаются попытки оценить устойчивость на покомпонентной основе. Медленно развивается индексология оценки устойчивости, встречаются работы, в которых под устойчивостью понимается вектор состояния системы, представленный в виде суммы или произведения параметров состояния, взятых со своими весами, реже абсолютизируется один из индексов и ему приписываются: универсальность, интегральность и т.П. свойства. Практически не развиваются исследования по изменению устойчивости при внешнем воздействии на систему. Важным также является, как разные авторы называют неустойчивую систему (уязвимая, изменчивая, чувствительная, ...). Рассмотрим несколько примеров:

1. В основе методологических построений уязвимости по В.Б. Погребову и А.Ю. Пузаченко (2003) оценка экологической уязвимости организмов, определяется как совокупность особенностей видов или групп растений и животных, которые зависят от их чувствительности к видам воздействия и способности восстанавливать исходное обилие и структуру популяций по окончании воздействия. При этом полагается, что экологическая уязвимость в целом определяется пребыванием групп организмов с различной уязвимостью и обилием. Схожая ситуация встречается в работах по газоустойчивости 
наземных растений к загрязнению воздуха. В данном подходе, на наш взгляд отсутствует важное дополнение, требующее обсуждения. Дело в том, что чувствительность и устойчивость (уязвимость) разные по природе понятия. Первая определяет способность системы реагировать на малые по величине воздействия, вторая - способность сохранять (или утрачивать) свои свойства и параметры режимов системы в результате воздействия.

Следуя данной логике необходимо показать, что наиболее чувствительные к воздействию ландшафты, являются и наиболее уязвимыми (наименее устойчивыми). Такое доказательство либо отсутствует в работах, либо принимается априорно, но чаще вообще не оговаривается. Например, авторами выявлены наиболее уязвимые районы моря к аварийным разливам нефти. Ими оказались мелководья, прилегающие к материку, островам и подводным поднятиям (банкам), приустьевые взморья, вершины губ и заливов.

2. В основе оценки уязвимости по М.А.Новикову (Эколого-рыбохозяйственный Атлас Баренцева моря, Изд. ПИНРО, 2003) под уязвимостью экосистемы понималась степень ее зависимости от внешних воздействий, которые могут привести к нарушению ее структуры и функционирования, т.е. к потере стабильности (пусть даже временной). Степень уязвимости различных акваторий по автору должна, определять возможные потери биомассы гидробионтов и продуктивности биоценозов в случае загрязнения или отчуждения тех или иных акваторий при промышленной эксплуатации шельфа (разработка полезных ископаемых и т.п.). Синтетическая оценка уязвимости в этом подходе рассчитывается авторами «путем интегрирования нормированных данных всех цифровых тематических карт района, с учетом "весовых" характеристик последних». В работе отсутствует понимание необходимости введения многопараметрической, интегральной классификации устойчивости, а полученный «путем интегрирования нормированных данных» вектор состояния системы, авторы отожествляют с устойчивостью (уязвимостью) ландшафтов к воздействию.

3. Выделяется ряд публикаций, в которых авторы пытались оценить степень устойчивости «параметров водных экосистем» (Л.А.Кудерский, 1996) по «абсолютной величине изменчивости параметра», по «относительной величине изменчивости параметра», по «относительному размаху изменчивости величины параметра», забывая о высокой эмерджентности экосистемы и её неаддитивного свойства (в названии статьи говорится об устойчивости водной экосистемы в целом, а не параметров устойчивости). Другие авторы (Шилин, 2006), предлагали вводить универсальный (по М.Б. Шилину интегральный) индекс, характеризующий состояние и устойчивость экосистемы, в качестве которого предлагается индекс Шеннона, на том основании, что наиболее сложные системы являются и наиболее устойчивыми. При этом устойчивость к определенному типу воздействия на экосистему сводится к оценке видового разнообразия в системе. Такой подход не учитывает совокупности большого числа физикогеографических, климатических, гидрологических, гео- и гидрохимических, продукционных и других характеристик и факторов, определяющих в итоге устойчивость различных наземных и водных ландшафтов к определенному типу воздействия или сочетание разных типов. Обзор т.н. индексов устойчивости приводится нами в учебном пособии B.В Дмитриева, Г.Т Фрумина «Экологическое нормирование и устойчивость природных систем», изд. Наука, СПб, 2004, с.252-253.

4. В работах по оценке устойчивости почвенного покрова к нефтяному загрязнению авторы (Глазовская, 1976, 1997) оценивали устойчивость ландшафтов по способности территорий к самоочищению от загрязнения, т.е. по сути, по биохимической деградации и разложении углеводородов под действием природных факторов. В настоящее время по полученным критериям разработана и применяется методология районирования крупных территорий по потенциальной способности земель, загрязненных углеводородами, к самоочищению. На примере России и её областей проведены картографический анализ и оценка почв, позволившие выделить почвенно-экологические ареалы с разной потенциальной способностью почв к самоочищению от углеводородов. В связи с 
активным освоением нефте- и газоносных районов арктической зоны России на первый план выходят исследования по устойчивости ландшафтов к нефтяному загрязнению. Основными факторами, определяющими устойчивость ландшафтов к загрязнению (геохимическая устойчивость), в том числе углеводородами нефти, согласно М.А. Глазовской (1976) являются: интенсивность метаболизма нефтепродуктов, возможность и интенсивность закрепления в ландшафтах углеводородов, вынос и рассеяние углеводородов.

5. В диссертации И.И. Кесорецких «Оценка уязвимости ландшафтов Калининградской области к антропогенным воздействиям (2015) предметом исследования названо «методическое обоснование интегрального показателя уязвимости ландшафтов к антропогенным воздействиям». По-видимому, предмет исследования - уязвимость (устойчивость) природных ландшафтов Калининградской области. Под экологической уязвимостью автор понимал «интегральный геоэкологический показатель состояния природной среды, отражающий возможность изменения ее компонентов в результате внешних воздействий, приводящих к нарушению ее структуры и функционирования» (с.7 автореферата). Вряд ли определение можно считать удачным. Во-первых, уязвимость (а не интегральный показатель) отражает утрату экосистемой или отсутствие у экосистемы способности сохранять свои свойства и параметры режимов в условиях внутренних и внешних воздействий на нее. Это интегративное свойство системы в целом, а интегральный показатель отражает модельное (авторское) представление этого свойства на определенный момент времени или за интервал времени. Во-вторых, сложная система, как и ее сложное (неаддитивное, эмерджентное) свойство не сводятся к изменениям «ее компонентов в результате внешних воздействий». Уязвимыми к изменению параметров режимов будут геосистемы, не способные сохранять свои свойства (параметры режимов) на определенном временном интервале функционирования. Оценка уязвимости или устойчивости к изменению свойств геосистемы не сводится только к учету одного какоголибо компонента (параметра, фактора). Она получается, как результат учета многих факторов, характеризующихся большим набором параметров оценивания, среди которых

Таблиша 1 - Матрица парамстров уязвимости ландшафтов к антропогенным воздействиям (Зотов, Кесорецких и др.. 2012)

\begin{tabular}{|c|c|c|c|c|c|c|c|c|c|c|}
\hline \multirow{3}{*}{ Параметр } & \multicolumn{10}{|c|}{ 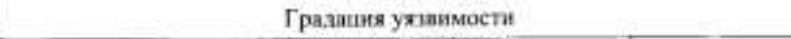 } \\
\hline & \multicolumn{2}{|c|}{ Bысоках } & \multicolumn{2}{|c|}{ Повышенная } & \multicolumn{2}{|c|}{ Умеренная } & \multicolumn{2}{|c|}{ Пlонивенмая } & \multicolumn{2}{|c|}{ Низкая } \\
\hline & or & Ino & or & too & ot & 20 & OT & 30 & or & no \\
\hline $\begin{array}{c}\text { Расстонние } \\
\text { 7o волотока } \\
\text { (M) } \\
\end{array}$ & 0 & 200 & 201 & 400 & 401 & 600 & 601 & 800 & 801 & 1000 \\
\hline $\begin{array}{c}\text { Уклон } \\
\text { земной } \\
\text { роверхности } \\
\text { () } \\
\end{array}$ & 20 & 17 & 16 & 13 & 12 & 9 & 8 & 5 & 4 & 0 \\
\hline $\begin{array}{c}\text { Густота } \\
\text { речноһ cetu } \\
\left(\mathrm{KM} / \mathrm{KN}^{2}\right)\end{array}$ & 1,4 & 1.25 & 1.24 & 1,11 & 1,10 & 0,96 & 0,95 & 0.80 & 0.79 & 0.60 \\
\hline $\begin{array}{l}\text { Hepecton:2й } \\
\text { статус }\end{array}$ & \multicolumn{2}{|c|}{ Ects } & \multicolumn{2}{|c|}{ Ects, } & \multicolumn{2}{|c|}{$\mathrm{Het}$} & \multicolumn{2}{|c|}{ Heт } & \multicolumn{2}{|c|}{ Нет } \\
\hline $\begin{array}{l}\text { Oxраняеманй } \\
\text { статуе }\end{array}$ & \multicolumn{2}{|c|}{ Ecth } & \multicolumn{2}{|c|}{ Eсть: } & \multicolumn{2}{|c|}{ Het } & \multicolumn{2}{|c|}{ Нет } & \multicolumn{2}{|c|}{ Het } \\
\hline $\begin{array}{c}\text { Уровень } \\
\text { трунтовых } \\
\text { по, (м) }\end{array}$ & 0,5 & 2.0 & 2.1 & 4.0 & 4.1 & 6.0 & 6.1 & 8.0 & 8.1 & 10,0 \\
\hline $\begin{array}{l}\text { Грануломет } \\
\text { ричсский } \\
\text { состав почв }\end{array}$ & \multicolumn{2}{|c|}{ Песчаныс } & \multicolumn{2}{|c|}{ Cynecrahte } & \multicolumn{2}{|c|}{ 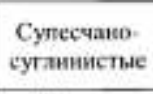 } & \multicolumn{2}{|c|}{ Суглиянстые } & \multicolumn{2}{|c|}{ Глинистые } \\
\hline Тив угодий & \multicolumn{2}{|c|}{ Бозотиме } & \multicolumn{2}{|c|}{ Jecmac } & \multicolumn{2}{|c|}{ Лесние } & \multicolumn{2}{|c|}{ Луговис (c/x) } & \multicolumn{2}{|c|}{ Лутовыс $(\mathrm{c} / \mathrm{x})$} \\
\hline
\end{tabular}

группы физико-географических факторов, климатических условий и характер антропогенного воздействия являются определяющими.

Несколько слов о типе устойчивости и выборе необходимых и достаточных параметров для оценки устойчивости ландшафта. У $\begin{array}{llll}\text { автора } & \text { их } & 8 & \text { (табл.1 }\end{array}$ автореферата, с.10).

Тип устойчивости (1-й тип - адаптационная, 2-й тип регенерационная) автором не обсуждается. С начала 1990-х гг. в перечни параметров для оценки устойчивости ландшафтов авторы включали

признаки, характеризующие отличительные особенности ландшафтов: радиационный баланс; радиационный индекс сухости; ветровой режим: а) количество дней со штилями в году; б) количество дней с сильными ветрами; интенсивность геоматических процессов (неотектоническая активность, сейсмичность, тип рельефа, свойства и особенности пород); устойчивость составных частей ландшафта (доминантных и детерминантных урочищ), контрастность урочищ в ландшафте; 
защищенность грунтовых вод и др. (см., например, Снакин В.В., Мельченко В.Е., Бутовский Р.О. и др. Оценка состояния и устойчивости геосистем. М. ВНИИ природа, 1992, 127 с., отсутствует в списке литературы в диссертации). Дополнительно к этим признакам в перечень параметров необходимо включать признаки, характеризующие внешнее воздействие на ландшафт, и влияющие на его устойчивость к воздействию. Другими словами, признаки также должны быть репрезентативны для целей экологического (экосистемного) нормирования.

Автор обосновал собственный набор критериев, по-видимому, с акцентом на регенерационную устойчивость (уязвимость). В пользу этого говорят определяющие механизмы сохранения устойчивости в представлении автора. Это «миграционные каналы транспортировки вещества в пределах ландшафта», «миграция поллютантов через поверхностные водотоки», «формирование стока (миграции химических загрязнителей) и эрозионных процессов», «пути миграции и накопления поллютантов», «особые условия использования» и т.п. Таким образом формируется своеобразный «каркас потоков вещества» в ландшафте, обеспечивающий способность ландшафта сохранять свои свойства и параметры режимов в условиях действующих внутренних и внешних возмущений, а, точнее, способность ландшафта возвращаться в исходное состояние после временного внешнего воздействия на него. Ключевым термином такого подхода мог стать «транзит вещества» через составные части ландшафта (геосистемы). Если геосистема способна осуществлять транзит, значит, она способна восстанавливать свои свойства и параметры режимов в условиях внешних воздействий и является устойчивой по 2-му типу. Но тогда, близость к речной сети и сама речная сеть, большие уклоны земной поверхности, близость к водотоку, высокая густота речной сети должны свидетельствовать о высоком транзите и т.о. низкой уязвимости (высокой устойчивости) по 2-му типу (регенерационная). На картах автореферата автора (рис.1 и 2) эти зоны, наоборот отражают повышенную уязвимость ландшафта. То же и в табл.1: максимальные значения уклона земной поверхности 20-17 уязвимость». То же для параметров 1 и 3 табл. 1.

Неясно, также, через какие признаки в оценке уязвимости (устойчивости) может быть явно учтено оказываемое воздействие (химическое, механическое). В этом случае система также может сохранить свой класс (устойчивости или уязвимости) или перейти в другой класс, если норма воздействия будет превышена.

\section{1. Балльно-индексная оценка устойчивости водоемов к изменению} параметров естественного и антропогенного режимов. Целью работы является оценка адаптационной устойчивости (уязвимости) водных объектов к изменению параметров режимов на основе балльно- индексного метода (Снакин и др.,1992, Дмитриев, 1995, Дмитриев 2000, 2004, 2007).

Параметры устойчивости (уязвимости) водных объектов объединены в экспертную балльно-индексную систему, которая учитывает региональные особенности водных объектов и дает возможность в пределах изменения заложенных в них параметров, провести сравнительную оценку уязвимости водных экосистем к воздействию. Если свойства водного объекта различаются по пространству и это дает основание говорить о физико-географическом, гидрологическом, гидрохимическом и гидробиологическом районировании в пределах определенной территории (акватории), то можно провести зонирование водосборной территории или акватории водоема по баллам уязвимости (устойчивости) и выделить наиболее уязвимые и устойчивые его районы.

Оценка устойчивости водоемов к изменению параметров естественного режима и к антропогенному эвтрофированию (или к изменению качества воды) проводится путем последовательного суммирования индексов для соответствующих признаков, разрядов и баллов по таблицам, получения суммарной балльной оценки и нахождению в итоге класса и подкласса устойчивости водоема (таблицы 1-4) (Дмитриев, 2000, Дмитриев, Фрумин, 
2004; Гальцова, Дмитриев, 2007; Дмитриев, Огурцов, 2013). Таким образом, необходимо последовательно просуммировать индексы (табл.1-3), затем разряды, в соответствии с примечаниями к каждой таблице. После этого по сумме разрядов по табл.4 найти баллы устойчивости (семейство устойчивости), прибавить к ней баллы трофности или качества вод (род устойчивости) и по полученной сумме баллов найти класс и подкласс водоема (комбинация семейств и родов). Рекомендуется оценивать отдельно устойчивость к изменению параметров естественного режима и антропогенному эвтрофированию и устойчивость к изменению параметров естественного режима и качества воды (загрязнению).

Таблица 1. Классификация водоемов по морфометрическим признакам

\begin{tabular}{|l|c|c|c|c|}
\hline Признаки (индекс) & 1 & 2 & 3 & 4 \\
\hline Площадь поверхн., км кв. & $>1000$ & $1000-101$ & $100-10$ & $<10$ \\
\hline Объем, км куб. & $>10$ & $10-1,1$ & $1-0,5$ & $<0,5$ \\
\hline Макс. глубина, м & $>50$ & $50-11$ & $11-5$ & $<5$ \\
\hline
\end{tabular}

Примечание. Водоем с суммой индексов от 3 до 4 относится к 1 разряду, от 5 до 7-к 6 разряду, от 8 до 11-к 11 разряду, от 11 до 12 -к 15 разр.

Таблица 2. Классификация водоемов по гидрологическому режиму

\begin{tabular}{|l|c|c|c|c|c|}
\hline Признаки (индекс) & 1 & 2 & 3 & 4 & 5 \\
\hline $\begin{array}{l}\text { Внутригодовая амплитуда } \\
\text { колебаний уровня, м }\end{array}$ & $<3$ & $3-4$ & $4-5$ & $5-6$ & $>6$ \\
\hline $\begin{array}{l}\text { Ср. температура воды в летн. } \\
\text { период }\end{array}$ & $>25$ & $25-20$ & $20-17$ & $17-15$ & $<15$ \\
\hline $\begin{array}{l}\text { Продолжительность } \\
\text { ледостава, мес. }\end{array}$ & $>5$ & $5-4$ & $4-3$ & $3-2$ & $<2$ \\
\hline
\end{tabular}

Примечание. Водоем с суммой индексов от 2 до 4 относится к 1 разряду, от 5 до 7-ко 2 разряду, от 8 до 11-к 3 разряду. За температуру воды принимают среднюю из суточных величин за летний период для типичного по климатическим условиям года.

Таблица 3. Классификация водоемов по условиям водообмена

\begin{tabular}{|l|c|c|c|}
\hline \multicolumn{1}{|c|}{ Признаки(индекс) } & 1 & 2 & 3 \\
\hline Наличие сезонной стратификации & да & - & нет \\
\hline $\begin{array}{l}\text { Вертикальное перемешивание (кол. раз } \\
\text { за год) }\end{array}$ & $<2$ & 2 & $>2$ \\
\hline Условия проточности & бессточный & сточный & проточный \\
\hline Характер регулирования & многолетнее & сезонное & $\begin{array}{c}\text { недельное, } \\
\text { суточное }\end{array}$ \\
\hline Водообмен в год & $<0.1$ & $0.1-5.0$ & $>5.0$ \\
\hline
\end{tabular}

Примечание. Водоем с суммой индексов равной 5 относится к 1 разряду, от 6 до 8-ко 2 разряду, от 9 до 14-к 3 разряду.

Таблица 4. Балльная оценка устойчивости водоемов к изменению физикогеографических, гидрологических параметров, трофности или качества воды

\begin{tabular}{|c|c|c|c|c|c|c|c|c|}
\hline \multicolumn{3}{|c|}{ Семейство уязвимости } & \multicolumn{2}{|c|}{$\begin{array}{c}\text { Род уязвимости по трофическому статусу или } \\
\text { по качеству воды }\end{array}$} & \multicolumn{4}{|c|}{$\begin{array}{c}\text { Основные комбинации семейств и родов } \\
\text { для отмеченных }(*) \text { баллов трофности } \\
\text { или качества }\end{array}$} \\
\hline $\begin{array}{l}\text { Обозна } \\
\text { чение }\end{array}$ & $\begin{array}{c}\text { Сумма } \\
\text { разря- } \\
\text { дов }\end{array}$ & Баллы & $\begin{array}{c}\text { Трофность } \\
\text { Качество воды }\end{array}$ & $\begin{array}{c}\text { Баллы } \\
\text { трофности. } \\
\text { Баллы } \\
\text { качества } \\
\text { воды }\end{array}$ & $\begin{array}{l}\text { Обозна- } \\
\text { чение }\end{array}$ & $\begin{array}{l}\text { Сумма } \\
\text { баллов }\end{array}$ & $\begin{array}{c}\text { Обоз- } \\
\text { наче- } \\
\text { ние }\end{array}$ & $\begin{array}{l}\text { Сумма } \\
\text { баллов }\end{array}$ \\
\hline IA & $3-5$ & 8 & $\begin{array}{l}\text { 1.Гиперэвтрофный и } \\
\text { эвтрофный *) }\end{array}$ & 1 & ІБ1 & 5 & ІІІБ1 & 16 \\
\hline ІБ & $6-9$ & 4 & 2.Эвтрофный -мезотрофный & 3 & ІБ2 & 9 & ІІІБ2 & 20 \\
\hline IIA & $10-11$ & 13 & 3. Мезотрофный *) & 5 & ІБЗ & 19 & IIIБ3 & \\
\hline ІІБ & $12-14$ & 10 & $\begin{array}{l}\text { 4.Мезотрофный - } \\
\text { олиготрофный }\end{array}$ & 8 & IA1 & 9 & IIIA1 & \\
\hline IIIA & $15-16$ & 18 & 5. Олиготрофный *) & 15 & IA2 & 13 & IIIA2 & 23 \\
\hline ІІІБ & $17-19$ & 15 & & & IA3 & 23 & IIIA3 & 30 \\
\hline IVA & $20-21$ & 22 & 1.Очень грязная и грязная *) & 1 & IIБ1 & 11 & IVБ1 & 19 \\
\hline IVБ & $22-23$ & 20 & 2. Загрязненная & 3 & ІІБ2 & 15 & IVБ2 & 25 \\
\hline & & & 3.Умеренно загрязненная *) & 5 & ІІБЗ & 25 & IVБ3 & 35 \\
\hline
\end{tabular}




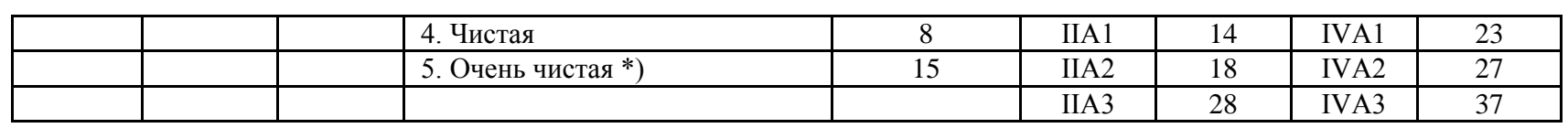

Для оценки трофического статуса воспользуемся таблицей 5. В таблице приведена сводка параметров оценивания трофности водоемов (см. также Дмитриев, Фрумин, 2004, с.258-259; практ.работа №2). Необходимо помнить, что основным критерием для оценки трофности служит первичная продукция в водоеме. Содержание хлорофилла, прозрачность воды, концентрация общего фосфора и азота и др. являются коррелятивными параметрами оценивания. Трофность или качество воды оценивается покомпонентно или на многокритериальной (интегральной) основе (Дмитриев и др., 1996, 1997, 2000) с указанием, по какому (каким) критериям они выполнялись. После этого снова входим в таблицу 4 (род уязвимости по трофическому статусу или по качеству воды) и по трофическому статусу или качеству воды выбираем соответствующие им баллы (от 1 до 15). Складываем их с баллами, полученными ранее (семейство устойчивости) и получаем итоговое число баллов (табл.7).

Таблица 5. Критерии распознавания трофности водных экосистем (Дмитриев и др., 1997).

\begin{tabular}{|c|c|c|c|c|c|}
\hline \multirow[t]{2}{*}{ Критерий } & \multicolumn{4}{|c|}{ Тип трофии } & \multirow[t]{2}{*}{ Источник } \\
\hline & Олиготр. & Мезотр. & Эвтроф. & Гипертр. & \\
\hline Валовая продукция фитопланктона & $10-30$ & $30-100$ & $100-300$ & $>300$ & Винберг, 1960 \\
\hline за год, г $\mathrm{C} / \mathrm{M}^{2}$ & $4-40$ & $40-150$ & $150-600$ & $>600$ & Романенко, 1985 \\
\hline Продукция фитопланктона, мгС/л сут. & $\begin{array}{c}0,005- \\
0,05\end{array}$ & $0,05-0,5$ & $0,5-5$ & $>5$ & Гутельмахер, 1986 \\
\hline \multicolumn{6}{|l|}{$\begin{array}{l}\text { Максимальная первичная продукция } \\
\text { за сутки }\end{array}$} \\
\hline$\Gamma \mathrm{O} / \mathrm{M}^{2}$ & $0,1-0,3$ & $0,3-0,7$ & $0,7-2,0$ & $>2,0$ & Винберг, 1960 \\
\hline$\Gamma \mathrm{C} / \mathrm{M}^{2}$ & $50-300$ & $250-1000$ & $600-8000$ & $>8000$ & Likens, 1975 \\
\hline \multirow{8}{*}{$\begin{array}{l}\text { Чистая первичная продукция, мгС/м² } \\
\text { сут. } \\
\text { Концентрация хлорофилла «а», } \mathrm{Cl} \\
\text { «а», мкг/л }\end{array}$} & & & & & \\
\hline & $0,1-1,0$ & $1-10$ & $10-100$ & $>100$ & Винберг, 1960 \\
\hline & $<4,3$ & $4,3-8,8$ & $>8,8$ & - & Dobsonetal, 1974 \\
\hline & $<2,5$ & $2-6$ & $>6$ & - & Rast Gek, 1978 \\
\hline & $<1,5$ & $1,5-10$ & $10-50$ & $>50$ & Трифонова, 1979 \\
\hline & $<3,0$ & $3-8$ & $8-20$ & $>20$ & Милиус,Кывасик, 1979 \\
\hline & $0,1-1,0$ & $1-10$ & $>10$ & - & Бульон, 1983 \\
\hline & $<4,0$ & $4-10$ & $10-100$ & $>100$ & Henderson-Selers, 1984 \\
\hline \multirow[b]{2}{*}{$\begin{array}{l}\text { Максимальная концентрация } \\
\text { хлорофилла «а», } \mathrm{Cl} \text { «а» }{ }_{\max }, \text { мкг/л }\end{array}$} & $6-16$ & $16-60$ & $>60$ & - & $\begin{array}{l}\text { Цветкова и др., } 1988 \\
\text { Хендерсон-Селерс, } 1990\end{array}$ \\
\hline & $<8,0$ & $8-25$ & $25-75$ & $>75$ & \\
\hline \multirow{2}{*}{$\begin{array}{l}\text { Средняя биомасса фитопланктона за } \\
\text { вегетационный период, } B_{f}, \text {, мг/л }\end{array}$} & $<1,0$ & $1-3$ & $3-10$ & $>10$ & Трифонова, 1979 \\
\hline & $<1,0$ & $1-3$ & $3-7$ & $>7$ & Милиус,Кывасик, 1979 \\
\hline \multirow{7}{*}{$\begin{array}{l}\text { Прозрачность воды по белому } \\
\text { диску, } \mathrm{H}_{\mathrm{sd}}, \text { м }\end{array}$} & $>4$ & $2-3$ & $<1$ & - & Gantrbland, 1931 \\
\hline & $11-6$ & $6-2$ & $<2$ & - & Thunmark, 1937 \\
\hline & $>5$ & $5-3$ & $<3$ & - & Aberg, Roch, 1942 \\
\hline & $>4$ & $4-1$ & $<1$ & - & Китаев, 1970 \\
\hline & $>6$ & $6-3$ & $<3$ & - & Henderson-Selers, 1984 \\
\hline & 9,9 & $4,2-2,4$ & $<1$ & - & Vollenweider, 1980 \\
\hline & $64-8$ & $8-2$ & $2-0,5$ & - & Carlson, 1977 \\
\hline $\begin{array}{l}\text { Отношение прозрачности } \mathrm{H}_{\mathrm{sd}} \text { к } \\
\text { глубине Н водоема }\end{array}$ & $1,01-2,0$ & $0,51-1,0$ & $0,25-0,5$ & - & Китаев, 1973 \\
\hline
\end{tabular}


Для оценки качества воды можно воспользоваться приведенными классификациями качества воды или наиболее простой из них, приведенной в таблице 6.

Таблица 6. Классификация загрязненности водных объектов по химическим параметрам (по Былинкиной, Драчеву, Ицковой; цит. по Зенин, Белоусова, 1988)

\begin{tabular}{|l|c|c|c|c|c|c|}
\multicolumn{1}{|c|}{$\begin{array}{c}\text { Класс качества } \\
\text { Параметры }\end{array}$} & $\begin{array}{c}\text { Очень } \\
\text { чистые } \\
\text { I }\end{array}$ & $\begin{array}{c}\text { Чистые } \\
\text { II }\end{array}$ & $\begin{array}{c}\text { Умеренно } \\
\text { загрязн. } \\
\text { III }\end{array}$ & $\begin{array}{c}\text { Загрязненн } \\
\text { ые } \\
\text { IY }\end{array}$ & $\begin{array}{c}\text { Грязные } \\
\text { Y }\end{array}$ & $\begin{array}{c}\text { Очень } \\
\text { грязные } \\
\text { YI }\end{array}$ \\
\hline Растворенный кислород, \% насыщ. & 95 & 80 & 70 & 60 & 30 & 0 \\
Абс. содержание мг/л. Лето. & 9 & 8 & $7-6$ & $5-4$ & $3-2$ & 0 \\
Зима. & $14-13$ & $12-11$ & $10-9$ & $5-4$ & $5-1$ & 0 \\
\hline БПК мгО/л & $0.5-1.0$ & $1.1-1.9$ & $2.0-2.9$ & $3.0-3.9$ & $4.0-10.0$ & $>10$ \\
\hline Окисляемость мгО/л & 1 & 2 & 3 & 4 & $5-15$ & $>15$ \\
\hline Аммонийный азот, мг/л & $<0.05$ & 0.1 & $0.2-0.3$ & $0.4-1.0$ & $1.1-3.0$ & $>3.0$ \\
\hline
\end{tabular}

Еще раз подчеркиваем, что при оценке устойчивости (уязвимости) водоема к эвтрофированию следует к полученной по табл. 4 сумме баллов (семейство уязвимости) прибавить баллы трофности (род уязвимости). Для этого необходимо предварительно оценить трофический статус водоема, а при оценке уязвимости водоема к загрязнению (изменению качества воды) к полученной по табл. 4 сумме баллов (семейство уязвимости) необходимо прибавить баллы качества воды (род уязвимости). Для этого необходимо предварительно оценить качество воды водоема. В правой части табл.4 приводятся только основные комбинации семейств и родов типов трофии или классов качества воды. В табл.7 приводятся результаты обобщения комбинаций и граничные значения баллов между классами уязвимости с учетом того, что первый класс характеризуется минимальной уязвимостью (максимальной устойчивостью), а последний класс максимальной уязвимостью (минимальной устойчивостью).

Еще раз заостряем внимание на том, что при получении выводов о степени уязвимости (устойчивости) водоема не следует отожествлять устойчивость с экологическим благополучием водной экосистемы. При высоком загрязнении или сильном эвтрофировании водоема он может оказаться достаточно устойчивым к антропогенному воздействию за счет незначительного количества баллов по роду уязвимости, но это не свидетельствует о его благополучии.

Обратите внимание, что класс водоема в табл.4 обозначен римской цифрой, он отражает физико-географические особенности водоема (см.табл.1). Подкласс водоема обозначен большими буквами «А» и «Б», он отражает оптимальность условий формирования водности и трофности (качества воды).

Таблица 7. Классы устойчивости водоемов

\begin{tabular}{|c|c|c|}
\hline Класс устойчивости & Баллы & Обозначения комбинаций \\
\hline I (макс.) & $\mathbf{5 - 1 1}$ & IБ1,ІБ2,IА1,ІІБ1 \\
\hline II & $\mathbf{1 3 - 1 6}$ & IА2,IIA1,IIБ2,IIIБ1, \\
\hline III & $\mathbf{1 8 - 2 3}$ & IБ3,IA3,IIIБ2,IIA2,IIIA1, IIIA2, \\
& & IVБ1, IVA1 \\
\hline IV & $\mathbf{2 5 - 2 8}$ & IIБ3,IIA3,IVБ2,IVA2 \\
\hline V (мин.) & $\mathbf{3 0 - 3 7}$ & IIББ3,IIIA3,IVБ3,IVA3 \\
\hline
\end{tabular}

Оптимальными условиями являются не экстремальные условия (см.табл.2 и 3), для которых сумма разрядов может быть наименьшей («А»), а наиболее благоприятные для формирования водности и трофности (качества воды) промежуточные условия («Б»). Водоемы с благоприятными условиями формирования будем считать менее уязвимыми (более устойчивыми) по сравнению с водоемами с неблагоприятными условиями, поэтому в табл. 4 им ставится в соответствие меньшее количество баллов. Чем меньшее количество баллов получено на данном этапе, тем более устойчива (менее уязвима) экосистема водоема. 


\section{2. Балльно-индексная оценка устойчивости водотоков к изменению параметров естественного и антропогенного режимов.}

Уязвимость (устойчивость) водных экосистем ицклического (озера, слабопроточные водоемы, пруды) и транзитного (реки, сильно проточные водоемы) типов обусловлена разными природными механизмами. Устойчивость первого типа можно назвать «адаптационной», устойчивость второго типа - «регенерационной». Если в первом случае важнейшим свойством природной системы является ее способность сохранять исходное состояние или плавно переходить в другое состояние, сохраняя при этом внутренние связи (инертность, пластичность), то во втором случае на первое место выходит способность системы многократно восстанавливать свои свойства, возвращаться в исходное состояние после временного внешнего воздействия (восстанавливаемость). К этому можно добавить, что биотические и абиотические составляющие экосистемы по механизмам устойчивости также различаются между собой. Устойчивость первых обусловлена способностью адаптации организмов к воздействию, как в результате внутренней резистентности биохимической организации, так и за счет способности к биохимическому разложению токсичных соединений и изменению удельных скоростей обменных процессов в экосистеме под влиянием воздействия. Устойчивость вторых достигается физико-механическими и химическими процессами переноса, разбавления, сорбции, миграции вещества.

Таблица 1. Классификация водотоков по физико-географическим признакам (ГОСТ 17.1.1.02-77)

\begin{tabular}{|l|c|c|c|}
\hline Признаки (индекс) & 1 & 2 & 3 \\
\hline Географическая зона & $\begin{array}{c}\text { недостаточного } \\
\text { увлажнения }\end{array}$ & $\begin{array}{c}\text { избыточного и } \\
\text { переменного увлажнения }\end{array}$ & --- \\
\hline Сезон года & зима & лето-осень & --- \\
\hline Период действия водотока & постоянный & --- & временный \\
\hline
\end{tabular}

Примечание. Водоток с суммой индексов от 3 до 4 относится к 1 разряду, от 5 до 7-к о 2 разряду. К зоне недостаточного увлажнения относится равнинная территория, расположенная южнее изолинии 0,5 л/с* км ${ }^{2}$ в соответствии с картой 30 -суточного стока $80 \%$-ной обеспеченности за летне-осенний период.

Таблица 2. Классификация водотоков по характеру маловодной фазы

\begin{tabular}{|l|c|c|c|}
\hline Признаки (индекс) & 1 & 2 & 3 \\
\hline Продолжительность низкого стока, мес. & $>2$ & --- & $<2$ \\
\hline Характер стока, категория & устойчивый & средний & прерывистый \\
\hline Продолжительность ледостава, мес. & $>5$ & $5-2$ & $<2$ \\
\hline Продолжительность отсутствия стока, мес. & $>1$ & --- & $<1$ \\
\hline
\end{tabular}

Примечание. Водоток с суммой индексов от 2 до 5 относится к 1 разряду, от 6 до 12 -к о 2 разряду.

Таблица 3. Классификация водотоков по гидрологическому режиму

\begin{tabular}{|l|c|c|c|}
\hline Признаки (индекс) & 1 & 2 & 3 \\
\hline Скорость течения, м/с & $>1$ & $0,2-1$ & $<0,2$ \\
\hline Колебания уровня, м & $>2$ & $2-1$ & $<1$ \\
\hline Температура воды, град.С & $>15$ & $15-10$ & $<10$ \\
\hline
\end{tabular}

Примечание. Водоток с суммой индексов от 3 до 4 относится к 1 разряду, от 5 до 7-к о 2 разряду, от 8 до 9 - к третьему разряду.

Таблица 4. Классификация водотоков по размеру и водности

\begin{tabular}{|l|c|c|c|c|}
\hline Признаки (индекс) & 1 & 2 & 3 & 4 \\
\hline Площадь водосбора, км & & 2 & $<00$ \\
\hline Расход воды, $\mathrm{m}^{3} / \mathrm{c}$ & $>50000$ & $50000-3000$ & $3000-2000$ & $<2$ \\
\hline
\end{tabular}

Примечание. Водотоки с суммой индексов 2 и 3 относятся к 1 разряду, 4 и 5-к 4 разряду, от 6 до 7 - к 6 разряду.

Таблица 5. Балльная оценка устойчивости водотоков к изменению физикогеографических, гидрологических параметров, качества воды

\begin{tabular}{|c|c|c|c|c|c|c|c|c|}
\hline \multicolumn{3}{|c|}{$\begin{array}{c}\text { Семейство устойчивости } \\
\text { (класс по ГОСТ 1.1.02-77) }\end{array}$} & \multicolumn{2}{|c|}{$\begin{array}{c}\text { Род устойчивости по } \\
\text { качеству воды }\end{array}$} & \multicolumn{4}{|c|}{ Комбинация семейств и родов } \\
\hline $\begin{array}{c}\text { Обозначе- } \\
\text { ние }\end{array}$ & $\begin{array}{c}\text { Сумма } \\
\text { разрядов }\end{array}$ & Баллы & Качество воды & Баллы & Обозначение & $\begin{array}{l}\text { Сумма } \\
\text { баллов }\end{array}$ & $\begin{array}{c}\text { Обозначе- } \\
\text { ние }\end{array}$ & $\begin{array}{l}\text { Сумма } \\
\text { баллов }\end{array}$ \\
\hline IA & $3-5$ & 14 & Грязн.(V-VI) & 1 & ІБ1 & 9 & IIІБ1 & 23 \\
\hline ІБ & $6-7$ & 8 & Загр.(III-IV) & 5 & ІБ2 & 13 & ІІІБ2 & 27 \\
\hline IIA & 8 & 20 & Чистый(I-II) & 15 & ІБЗ & 23 & ІІІБ3 & 37 \\
\hline IІБ & $9-10$ & 16 & & & IA1 & 15 & IIIA1 & 27 \\
\hline
\end{tabular}




\begin{tabular}{|c|c|c|c|c|c|c|}
\hline IIIA & 11 & 26 & IA2 & 19 & IIIA2 & 31 \\
\hline ІІІБ & $12-13$ & 22 & IA3 & 29 & IIIA3 & 41 \\
\hline & & & IIБ1 & 17 & & \\
\hline & & & ІІБ2 & 21 & & \\
\hline & & & ІІБ3 & 31 & & \\
\hline & & & IIA1 & 21 & & \\
\hline & & & IIA2 & 25 & & \\
\hline & & & IIA3 & 35 & & \\
\hline
\end{tabular}

Таблица 6. Классы устойчивости водотоков

\begin{tabular}{|c|c|c|}
\hline Класс устойчивости & Баллы & Обозначения комбинаций \\
\hline I (макс.) & $\mathbf{9 - 1 9}$ & IБ1,ІБ2,IА1,IIБ1, IIБ1 \\
\hline II & $\mathbf{2 1 - 2 9}$ & $\begin{array}{c}\text { IБ3,IА3,IIБ2, IIA1, IIA2, } \\
\text { IIIБ2,IIIБ1,IIIA1 }\end{array}$ \\
\hline III (мин) & $\mathbf{3 1 - 4 1}$ & IIБ3,IA3,IIIБ3,IIA3,IIIA2, IIIA3 \\
\hline
\end{tabular}

\section{Задание №1:}

1) оценить устойчивость (уязвимость) водоема Северо-Запада России к изменению параметров естественного режима и антропогенному эвтрофированию (или изменению качества воды). Для этого выбрать водоем, найти параметры режимов, необходимые для оценки устойчивости по балльно-индексной методике; определить класс устойчивости (уязвимости водоема).

2) ответить на вопрос, при каких изменениях параметров режимов водоемы повысят (понизят) свои классы устойчивости (уязвимости).

\section{Задание №2:}

1) оценить устойчивость (уязвимость) водотока (реки) Северо-Запада России к изменению параметров естественного режима и качества воды. Для этого выбрать реку, найти параметры режимов, необходимые для оценки устойчивости по балльно-индексной методике; определить класс устойчивости (степень уязвимости водотока).

2) ответить на вопрос, при каких изменениях параметров режимов река (водоток) повысит (понизит) свой класс устойчивости.

Задание №3. В каком направлении можно развить методы балльно-индексного оценивания устойчивости водоемов и водотоков.

\section{Литература}

Александрова Л.В., Васильев В.Ю., Дмитриев В.В., Мякишева Н.В., Огуриов А.Н., Третьяков Н.В., Хованов Н.В. Многокритериальные географо-экологические оценки состояния и устойчивости природных и урбанизированных систем. Под ред. В.В. Дмитриева и Н.В. Хованова. Деп. ВИНИТИ 01.09.2000, № деп.2342В00, 275 с.

Гальиова В.В., Дмитриев В.В. Практикум по водной экологии и мониторингу состояния водных систем, СПб., $2007,364 \mathrm{c}$.

Глазовская М.А. Ландшафтно-геохимические системы и их устойчивость к техногенезу // Биогеохимические циклы в биосфере.- М.,1976,-356 с.

Глазовская М.А. Методологические основы оценки эколого-геохимической устойчивости почв к техногенным воздействиям. М., изд. МГУ, 1997, 102 с.

Дмитриев В.В. Методика диагностики состояния и устойчивости водных экосистем // Эколого-географический анализ состояния природной среды: проблема устойчивости геоэкосистем. СПб., 1995. С.41-67.

Дмитриев В.В. Оценка экологического состояния водных объектов суши (часть II). Уязвимость водной экосистемы / Экология. Безопасность. Жизнь. Экологический опыт гражданских, общественных инициатив. Гатчина. 2000, c.284-296.

Дмитриев В.В. Эколого-географическая оценка состояния внутренних водоемов. Дисс. на соиск. учен. степ. докт. географ. наук, СПб:, 2000. 416 с.

Дмитриев В.В., Жиров А.И., Ласточкин А.Н. Прикладная экология. Учебник для студентов высш. учеб. заведений. М.: Издательский центр «Академия», 2008, 608 с.

Дмитриев В.В., Проценко Ю.А., Алексеева О.Н., Примак Е.А. Интегральная оценка качества воды и выявления водных экосистем с различной степенью антропогенной трансформации / Теория и практика эколого-географических исследований (Итоги научной работы Учебно-научного центра географии и геоэкологии в 2004 году) / Под ред. В.В.Дмитриева, А.И. Чистобаева, Т.А. Алиева, И.О. Шилова. СПб.: Изд.ТИН, 2005. с. 127-149.

Дмитриев В.В., Фрумин Г.Т. Экологическое нормирование и устойчивость природных систем. Учебное пособие, Изд. Наука, СПб, 2004, 294 с.

Дмитриев В.В., Огурцов А.Н. Подходы к оценке и ГИС-картографированию устойчивости и экологического благополучия геосистем. І. Интегральная оценка устойчивости наземных и водных геосистем. Вестник СПбГУ, серия 7 , вып.3, 2012, с.65-78. 
Дмитриев В.В., Огуриов А.Н. Подходы к интегральной оценке и ГИС-картографированию устойчивости и экологического благополучия геосистем. II. Методы интегральной оценки устойчивости наземных и водных геосистем. Вестник СПбГУ, сер.7 (геология, география), 2013, вып.3, с.88-103.

Дмитриев В.В., Огуриов А.Н. Подходы к интегральной оценке и ГИС -картографированию устойчивости и экологического благополучия геосистем. III. Интегральная оценка устойчивости почвы и наземных геосистем / Вестник СПбГУ. Сер. 7. 2014. Вып. 4, с.114-129.

Дмитриев В.В. Развитие методологии интегральной оценки экологического благополучия водного объекта. «Речной сток: пространственно-временная изменчивость и опасные гидрологические явления». Сборник трудов Третьей конференции Научно-образовательного центра. 13 ноября 2014 г. Москва, Россия. Отв. редактор д.г.н. Алексеевский Н.И., с.112-131.

Дмитриев В.В. Интегральная оценка экологического благополучия водного объекта: новый подход, результаты. Материалы международной научно-практической конференции «Обеспечение гидрометеорологической и экологической безопасности морской деятельности» (16-17 октября 2015 года, Астрахань, Российская Федерация). Астрахань, 2015, с.43-45

Кудерский Л.А. Естественные и техногенные водные экосистемы: проблема их устойчивости. Региональная экология, 1996, №3-4, с.31-36.

Оценка состояния и устойчивости экосистем. Под ред. В.А. Красилова, М., Изд. ВНИИ Природы, 1992, 127 с.

Погребов В.Б. и Пузаченко А.Ю. Экологическая уязвимость Баренцева, Белого, Балтийского, Черного и Каспийского морей к операциям по добыче и транспортировке нефти: сравнительный анализ, 2003.

Примак E.A., Дмитриев В.В. Оценка устойчивости водоемов Европейского Севера к изменению параметров естественного и антропогенного режимов // Водные ресурсы Европейского Севера: итоги и перспективы исследований. Материалы юбилейной конференции, посвященной 15-летию ИВПС, Петрозаводск, 2006, с.408-417.

Примак Е.А., Дмитриев В.В. Оценка уязвимости водоемов Европейского Севера к изменению параметров режимов // Экологические и гидрометеорологические проблемы больших городов и промышленных зон. Сборник трудов международной конференции. 25-27 октября 2006 г. - СПб.: изд. РГГМУ, 2007. с.115-123.

Примак Е.А., Дмитриев В.В. Разработка интегральных индексов для оценки устойчивости водоемов к изменению параметров естественного и антропогенного режимов / Географические и геоэкологические аспекты развития природы и общества. Сборник научных статей по материалам отчетных научно-практических конференций 2006-2007 гг. Под ред. Каледина Н.В., Дмитриева В.В., Алиева Т.А., СПб, Изд. Наука, 2008, с.234-241.

РД 52.24.620-200. РУКОВОДЯЩИЙ ДОКУМЕНТ. Методические указания. Охрана природы. Гидросфера. Организация и функционирование подсистемы мониторинга антропогенного эвтрофирования пресноводных экосистем. М., $2000,23 \mathrm{c}$ $2006,36 \mathrm{c}$

Шилин М.Б. Геоэкологический мониторинг прибрежных природно-технических систем. Автореф. докт. дис.,

Экологический энциклопедический словарь / Под ред. И.И. Дедю, 1990 г. , с.68.

Эколого-рыбохозяйственный Атлас Баренцева моря, Изд. ПИНРО, 2003.

Alexeeva O.N., Guzheva I.N., Dmitriev V.V. The development of approach to the water reservoir ecological prosperity assessment. 3rd Symposium «Quality and Management of Water Resources» Saint Petersburg, Russia, June 16-18, 2005. Book of proceedings. Scientific Editors V.V.Dmitriev, V.I.Sergeev Saint Petersburg, Изд. ГУП «Типография «Наука», 2005, с. 9-17.

Primak E. Elaboration of the integral index for the estimation of natural waters quality // Materials of $3^{\text {rd }}$ International Symposium «Quality and Management of Water Resources» St. Petersburg, Russia, June 16-18, 2005. Book of proceedings. St. Petersburg, 2005. p. 209-214.

Sedova S.A., Dmitriev V.V. EVELOPMENT OF A METHODOLOGY FOR THE INTEGRATED ASSESSMENT OF THE ECOLOGICAL STATUS OF WATER BODIES ON THE EXAMPLE OF SMALL LAKES IN THE NORTHWESTERN LADOGA. European Journal of Natural History. - 2020. - № 1 - P. 37-44

\section{Практическая работа № 5}

\section{Балльная оценка устойчивости почвы и элементарного ландшафта к изменению параметров естественного и антропогенного режимов. Интегральная оценка устойчивости почв.}

Почву будем рассматривать как компонент биогеоценоза в более широком смысле, чем общепринято, учитывая не только свойства основных почвенных горизонтов, но и грунтовых вод (если они принимают участие в биогеоценотических процессах), а также подстилающих пород. Такой подход соответствует понятию об эдафических условиях по В.Н.Сукачеву (1975).

Основной принцип выбора параметров состояния из большой совокупности почвенных характеристик - это не стремление характеризовать почву наиболее полно, а концентрация внимания на тех свойствах почвы, которые в наибольшей степени подвержены изменениям под воздействием антропогенных факторов, служат интегральным показателем этих изменений. Отобранная система параметров состояния должна наиболее полно и комплексно отражать произошедшие в почве изменения. 
В качестве одного из важных параметров состояния почвы предлагается использовать величину емкости катионного обмена (ЕКО) почвы. ЕКО почвы является ее неотъемлемым свойством (табл.1). Изменение величины ЕКО связаны с глубокими преобразованиями в почве. Уменьшение ЕКО свидетельствует о деградации почвы вследствие процессов водной и ветровой эрозии, дегумификации, снятия плодородного слоя и других нежелательных явлений, являющихся, как правиле, следствием антропогенных воздействий. Правильная эксплуатация почв нередко сопровождается также увеличением ЕКО в результате использования органических удобрений, разумных севооборотов, проведения противоэрозионных и рекультивационных мероприятий. Определение величины ЕКО рекомендуется проводить в соответствии с ГОСТ 174.4.01-84.

Гумусное состояние почв. С содержанием гумуса связаны важнейшие биохимические, физические, физико-химические и агрохимические свойства почв. Почвенный гумус является главным аккумулятором солнечной энергии на поверхности Земли и гарантом продуктивности, обеспечивающим экологическую устойчивость биосферы. Содержание его в почве - характерный генетический и классификационный признак для каждого из известных типов почв (табл.3). Повышение содержания гумуса способствует росту водопрочных агрегатов, общей морозности, наименьшей влагоёмкости, диапазона активной влаги. Гумус является источником многих питательных компонентов: большая часть азота, фосфора, серы находится в форме органических соединении. В почвах с большим содержанием гумуса разнообразнее видовой состав микроорганизмов и беспозвоночных животных и выше их численность. Ферментативная активность также нарастает с увеличением содержания гумуса. Гумус, особенно подвижная его часть, определяет интенсивность поступления $\mathrm{CO}_{2}$ в приземный слой воздуха, воздействуя тем самым на интенсивность фотосинтеза.

Гумусное состояние почв очень чувствительно к изменениям экологической обстановки. Зависимость его от характера растительного покрова, особенностей рельефа, увлажнения и пр. обусловливает существенное варьирование содержания гумуса даже в пределах элементарных почвенных ареалов. Антропогенные же факторы могут не только изменить интенсивность гумусообразования, но и кардинально менять его направленность. Примером может служить процесс дегумификации почв, широко распространенный сейчас не только в нашей стране, но и во всем мире.

Несмотря на то, что процесс дегумификации известен давно, его количественная оценка и планетарные масштабы вскрыты лишь в последние годы.

Когда уничтожается естественная растительность и целинные земли распахиваются, происходит резкое изменение всего биологического круговорота веществ и гидротермического режима в экосистеме, в том числе резко меняется биогеохимический цикл углерода. Первый результат такого воздействия на почву резкое снижение ее гумусированности. Последующая эволюция гумусового состояния почв определяется используемой технологией земледелия. С одной стороны, в условиях использования культурных ресурсосберегающих технологий, направленных на эффективное ведение хозяйства и рачительное воспроизводство почвенного плодородия, имеет место стабилизация гумусного состояния почвы или даже его улучшение по сравнению с исходной целиной. Формируются почвы огородные, садовые, плантационные, польдерные (поливные), выделяемые в настоящее время в особый класс антресолей в мировой систематике почв и известные в Западной Европе как культосоли, хортисоли, ригосоли (Schroeder, I984). Общая площадь таких созданных человеком почв в мире сравнительно небольшая, хотя они распространены малыми массивами практически во всех странах. 
Таблица 1. Параметры оценки устойчивости почв (1), ориентировочная оценка устойчивости различных типов почв по литературным данным (2), показатели гумусного состояния почв (3) (Оценка состояния и устойчивости экосистем. Под ред. В.А. Красилова, М., Изд. ВНИИ Природы, 1992, 127 с).

\begin{tabular}{|c|c|c|c|c|c|}
\hline $\begin{array}{l}\text { EKO, Mr- } \\
\text { skn/100r }\end{array}$ & $\begin{array}{c}\text { Moumocth } \\
\text { rysyconoro } \\
\text { ropusourra, } \\
\text { CM }\end{array}$ & $\begin{array}{c}\text { Boumuit } \\
\text { рским }\end{array}$ & 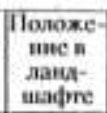 & 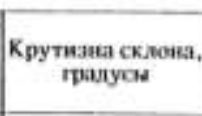 & Балм4 \\
\hline$>10$ & 4 & $\begin{array}{l}\text { мепро- } \\
\text { мавнові }\end{array}$ & $\begin{array}{l}\text { аккуму- } \\
\text { питианов }\end{array}$ & $\rightarrow \dot{x}$ & 1 \\
\hline $10-20$ & 3-9 & - & - & $\alpha-5,60^{16 t}$ & 2 \\
\hline $21-30$ & $10-25$ & 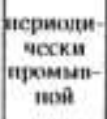 & $\int_{\text {moc }}$ & $5,61^{18 g t}-3,15^{26 t}$ & 3 \\
\hline $31-40$ & $26-80$ & - & - & $3,16^{\lg x t}-1,78^{\operatorname{left} t}$ & 4 \\
\hline$>40$ & $>80$ & 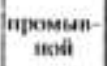 & 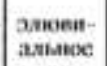 & $1.78^{16 / t}$ & 5 \\
\hline
\end{tabular}

1)

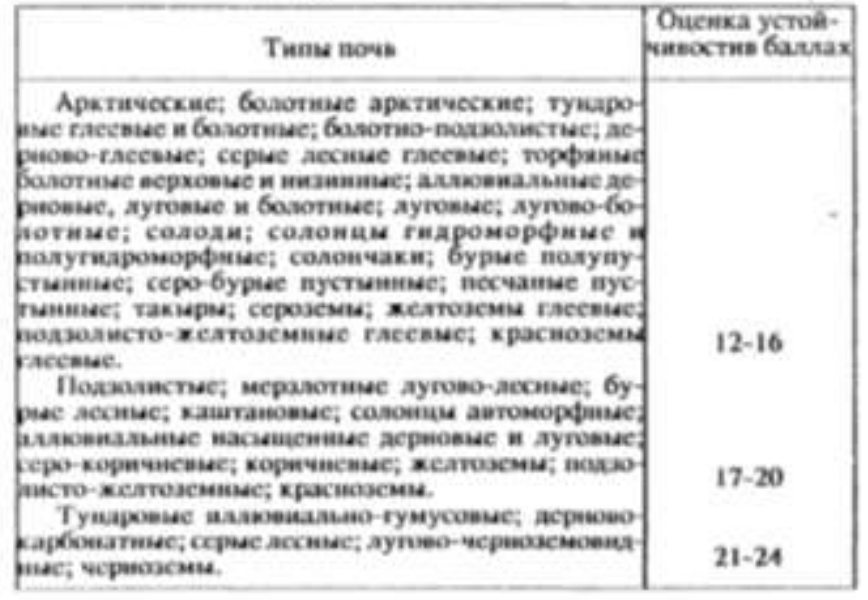

2)

\begin{tabular}{|c|c|c|}
\hline กочй. & 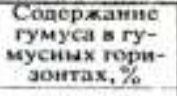 & $\begin{array}{l}\text { "Iroxamine" } \\
\text { nours, } \\
\mathrm{kr} / \mathrm{ras} \text {. 4ac }\end{array}$ \\
\hline 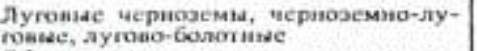 & 10 & 10 \\
\hline 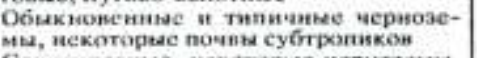 & $6-10$ & in \\
\hline 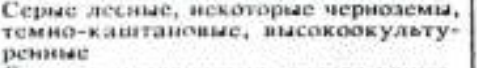 & $4-6$ & $7-10$ \\
\hline 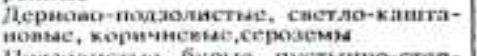 & $2-4$ & $5-7$ \\
\hline 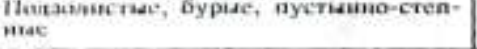 & 2 & $2-5$ \\
\hline
\end{tabular}

3)

С другой стороны, человеческая деятельность, особенно в последние десятилетия демографического взрыва и послевоенного постколониального развития, сопровождается почти повсеместной дегумификацей почв. Так, до того, как деятельность человека начала играть важную роль в эволюции почв, средняя мощность гумусового слоя составляла 0,5 м, средняя плотность его была $1,3 \mathrm{~T} / \mathrm{m}^{3}$, среднее содержание органического углерода в нем было $2,0 \%$; средний запас органического $C$ составлял 13000 т/км ${ }^{2}$; общий запас органического $C$ в гумусфере планеты был 1700 млрд т или $1,7 * 10^{18} \Gamma$ (Розанов, Розанов, 1990). Современное же состояние таково:

1) в пахотных почвах мира (15 млн. кв. км) средняя мощность гумусового слоя - 0,5 м; его средняя плотность - 1,2 т/м ${ }^{3}$; среднее содержание органического $C$ $1,5 \%$; средний запас органического углерода - 9000 т/км ${ }^{2}$; общий запас органического $C$ - 135 млрд. т или $1,35 * 10^{17}$ г;

2) в антропогенном "бедленде" мира (бывшие продуктивные земли, трансформированные человеком в пустыни, водохранилища, дороги, карьеры, застроенные земли и т.п.) - 20 млн. км², средняя мощность гумусового слоя 0,1 м; его средняя плотность 1,4 т/м ${ }^{3}$; среднее содержание органического $C-0,25 \%$; средний запас $C-350$ т /км ${ }^{2}$, общий запас органического углерода 7 млрд т, или $7 * 10^{15} \Gamma$.

За вторую половину XX века скорость дегумификации почвенного покрова планеты стала в 24,3 раза выше среднеисторической. Этому способствовали, как подтверждают многочисленные исследования, следующие антропогенные воздействия: богарное земледелие на маргинальных почвах, орошаемое земледелие и аридных, семиаридных и субгумидных условиях, несбалансированное применение химических удобрений; применение биоцидов в земледелии, пастбищное животноводство с 
превышением норм выпаса; вырубка лесов на равнинах; избыточное природопользование в тундрах, аридных территориях и др.

Метод определения содержания гумуса (органического углерода, \%) в почве по И.В.Тюрину хорошо отработан и рекомендован международной программой комплексного мониторинга.

Интегральная устойчивость почв. Рассмотрите модель-классификацию интегральной оценки почвенного покрова по статье Дмитриев B.B., Огурияов А.Н. Подходы к интегральной оценке и ГИС-картографированию устойчивости и экологического благополучия геосистем. III. Интегральная оценка устойчивости почвы и наземных геосистем / Вестник СПбГУ. Сер. 7. 2014. Вып. 4, с.114-129.

Таблица 2. Модель-классификация интегральной оценки почвенного покрова (Дмитриев, Огурцов, 2014).

\begin{tabular}{|c|c|c|c|c|c|c|c|c|}
\hline $\begin{array}{c}\text { Классы } \\
\text { и критерии оцен- } \\
\text { ки устоичивости } \\
\end{array}$ & $\begin{array}{l}1 \text { мани } \\
\text { устой- } \\
\text { чивость }\end{array}$ & $\begin{array}{c}\text { II } \\
\text { mиже } \\
\text { средней } \\
\end{array}$ & $\begin{array}{c}\text { III } \\
\text { средияи }\end{array}$ & $\begin{array}{c}\text { IV } \\
\text { mыше } \\
\text { средией }\end{array}$ & $\begin{array}{l}\text { V макс } \\
\text { устой- } \\
\text { чивость }\end{array}$ & $\min$ & $\max$ & $\begin{array}{l}\text { Tum } \\
\text { cansu }\end{array}$ \\
\hline $\begin{array}{l}\text { 1. EKO, } \\
M r-3 K B / 100 \mathrm{r}\end{array}$ & $\frac{80-60}{0-0,25}$ & $\frac{60-30}{0,25-0,625}$ & $\frac{30-20}{0.625-0.75}$ & $\frac{20-10}{0,75-0,875}$ & $\frac{10-0}{0,875-1,0}$ & 0 & 80 & Обрати. \\
\hline $\begin{array}{l}\text { 2. Мощность } \\
\text { гумусового гори- } \\
\text { soнта, } \mathrm{CM}\end{array}$ & $\frac{60-40}{0-0,333}$ & $\frac{40-20}{0,333-0,667}$ & $\frac{20-10}{0,667-0,833}$ & $\frac{10-3}{0,833-0,95}$ & $\frac{3-0}{0,95-1,0}$ & 0 & 60 & Обрати. \\
\hline $\begin{array}{l}\text { 3. Тип водного } \\
\text { режима, балиы }\end{array}$ & $\frac{1-2}{0-0,25}$ & $\frac{2-2,5}{0,25-0,375}$ & $\frac{2,5-3}{0,375-0,5}$ & $\frac{3-4}{0,5-0,75}$ & $\frac{4-5}{0,75-1,0}$ & 1 & 5 & Примал \\
\hline $\begin{array}{l}\text { 4. Положение } \\
\text { в ландшафте, } \\
\text { балды }\end{array}$ & $\frac{1-2}{0-0,25}$ & $\frac{2-3}{0,25-0,50}$ & $\frac{3-4}{0,50-0,75}$ & $\frac{4-4,5}{0,75-0,875}$ & $\frac{4,5-5}{0,875-1,0}$ & 1 & 5 & Прямая \\
\hline $\begin{array}{l}\text { 5. Крутиза скло- } \\
\text { на, градусы }\end{array}$ & $\frac{0-8}{0-0,20}$ & $\frac{8-16}{0,20-0,40}$ & $\frac{16-24}{0,40-0,60}$ & $\frac{24-32}{0,60-0,80}$ & $\frac{32-40}{0,80-1,0}$ & 0 & 40 & Прнман \\
\hline $\begin{array}{l}\text { 6. Иитенсип- } \\
\text { ность биогениого } \\
\text { круговорота }\end{array}$ & $\frac{0,5-0,29}{0-0,42}$ & $\frac{0,29-0,11}{0,42-0,78}$ & $\frac{0,11-0,07}{0,78-0,86}$ & $\frac{0,07-0,03}{0,86 \sim 0,94}$ & $\frac{0,03 \sim 0,0}{0,94-1,0}$ & 0,0 & 0,5 & OбратI. \\
\hline $\begin{array}{l}\text { Иитегратьный } \\
\text { показатеть } \\
\text { устойчивости } \\
\text { (Иту) }\end{array}$ & $\begin{array}{c}0-0,284 \\
\Delta=0,284\end{array}$ & $\begin{array}{c}0,284-0,558 \\
\Delta=0,274\end{array}$ & $\begin{array}{c}0,558-0,716 \\
\Delta=0,158\end{array}$ & $\begin{array}{c}0,716-0,865 \\
\Delta=0,149\end{array}$ & $\begin{array}{r}0,865-1,0 \\
\Delta=0,135\end{array}$ & - & - & - \\
\hline
\end{tabular}

Балльная оценка устойчивости фаций биогеоценоза. Ниже в таблице 2 приводится балльная оценка устойчивости фаций биогеоценоза по В.Е. Мельченко (Оценка состояния и устойчивости геосистем. М., ВНИИ Природа, 1992, с.79-82).

Таблица 3. Шкалы для балльной оценки устойчивости фации (Мельченко, 1992).

\begin{tabular}{|c|c|c|}
\hline Показатель устойчиности & $\begin{array}{c}\text { Зиачеиче показа- } \\
\text { теля }\end{array}$ & $\begin{array}{c}\text { Балли устой- } \\
\text { чнвости }\end{array}$ \\
\hline Биомасеа, w/ra & $\begin{array}{c}<125 \\
125-500 \\
500-1500 \\
1500-4000 \\
>4000\end{array}$ & $\begin{array}{l}1 \\
2 \\
3 \\
4 \\
5\end{array}$ \\
\hline 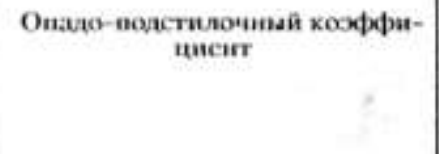 & $\begin{array}{l}>10 \\
10-3 \\
3-1 \\
1-0.5 \\
<0.5\end{array}$ & $\begin{array}{l}1 \\
2 \\
3 \\
4 \\
5\end{array}$ \\
\hline $\begin{array}{l}\text { Иитенсиниость геоматических } \\
\text { латсралыны ироцессон, см/ гол }\end{array}$ & $\begin{array}{l}<1 \\
1-5 \\
5-10 \\
10-20 \\
>20\end{array}$ & $\begin{array}{l}5 \\
4 \\
3 \\
2 \\
1\end{array}$ \\
\hline
\end{tabular}

Масштабы антропогенного воздействия вызывают как изменение состояния отдельных биотических компонентов, так и трансформацию экосистемы в целом. При этом нарушаются ее внутренняя структура и функционирование, обеспечивающие ей 
определенную устойчивость с помощью различных механизмов самоорганизации и самовоспроизводства.

С учетом изложенного при разработке показателей состояния наземных экосистем в качестве объекта исследования принята элементарная экосистема, близкая по характеру связей, функционирования и пространственного ограничения к биогеоценозу (фации). Поскольку наиболее чувствительной к антропогенным воздействиям является биотическая составляющая, при оценке состояния экосистем использованы в основном показатели, характеризующие биоту. Главную роль играет растительность, поскольку на растительные сообщества приходится 98-99\% массы всего органического вещества суши. Кроме того, растительность - наиболее физиономичный и динамичный компонент, обладающий высокими информативными и репрезентативными свойствами, изменчивость которых соответствует изменчивости всей экосистемы.

Для оценки состояния биоты экосистемы предлагается использовать структурнофункциональные характеристики, отражающие процессы создания, использований, разрушения и остаточного накопления в экосистемах биологической продукции различных категорий (первичной, вторичной, остаточной, мертвой) и некоторые этапы круговорота вещества, вовлеченных в биологические циклы.

Ниже приводится перечень параметров состояния, из которых пп. 1-5 являются основными исходными характеристиками, пп. 6-9 - производными, представляющими различные соотношения исходных величин.

1. Запас живой биомассы (фито-, зоо-, и микробиомассы) в г/м² или т /га абсолютно сухого веса. Под биомассой понимается общее количество живого органического вещества, накопленного к данному моменту (обычно в момент максимального развития). Биомасса характеризуется кроме абсолютных показателей, отнесенных к единице площади, соотношением биомассы различных групп организмов или их частей:

- для растений (автотрофов) - систематических, экологических групп, надземных и подземных частей, ассмилирующих и запасающих фракций;

- для гетеротрофов - систематических, экологических (трофических в том числе) групп; доля мигрирующей зоомассы;

- для микроорганизмов - соотношение запасов биомассы грибов, бактерий, актиномицетов.

2.Запас мертвого органического вещества, заключенного в сухостое, валеже, отмерших органах (сухие, но не отпавшие ветви на деревьях, кустах; ветошь у травянистых растений), а также накопившегося в лесной подстилке, торфяном горизонте почв, в степном войлоке. Мертвое органическое вещество включает также трупы животных, грибов и гумус почв, доля которого возрастает от таежных экосистем к пустынным с 41 \% до 99,5\%.

3. Интегральная характеристика структуры органического вещества экосистемы определяется как соотношение запаса гумуса, фитомассы, зоомассы и биомассы микроорганизмов. Представляется в виде формулы "органического вещества экосистемы" (Титлянова, 1983).

Показатели функционирования экосистем также должны учитываться при оценке их состояния. Под функционированием понимается смена состояний экосистем, определяемая изменениями в годичном цикле запасов веществ и интенсивностей потоков. Поскольку в основе функционирования биогеоценоза лежит биологический круговорот, основные его типы сводятся к следующей схеме:

- на восходящей ветви - создание первичной продукции при одновременном расходе ее на дыхание;

- на нисходящей ветви - потребление фитофагами, отмирание и деструкция (осуществляется животными сапрофагами и микроорганизмами, например, гумификация отмерших останков, минерализация гумуса микроорганизмами). 
4. Оиенка текущего функиионирования автотрофных и гетеротрофных компонентов может быть проведена по величинам первичной $u$ вторичной продуктивности, а также по их соотношению.

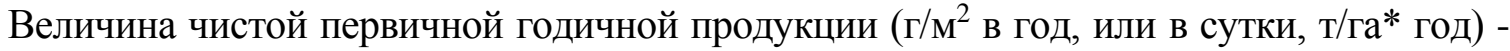
продукция автотрофных организмов, которая практически совпадает с продуктивностью фитоценоза. Она определяет энергетический потенциал экосистемы и характеризуется количеством органического вещества (фитомассы), образуемого за год в наземной и подземной сфере сообщества за вычетом части, затраченной на дыхание. Фактически это годичный прирост.

Величина вторичной продукции включает в себя продуцирование зоомассы и фитомассы гетеротрофных организмов и дает оценку "вклада" разных групп консументов и редуцентов и отчуждение фитомассы из годичного прироста и в деструкции и минерализации растительных остатков.

Отношение первичной продукции к вторичной отражает сбалансированность биологической продукции.

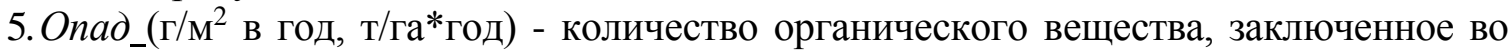
всех ежегодно отмирающих частях растений наземных и подземных сфер сообщества.

6.Истинный прирост (т/га в год) - количество органического вещества, остающееся в сообществе в результате годичного прироста, за вычетом опада.

7. Скорость воспроизводства органического вещества - отношение величинь первичной продукиии к запасу живой фитомассы (\%) - наибольшая в луговой степи, наименьшая - в лесу. Тундры и пустыни сближаются по этому показателю $(0,3$ и 0,2$)$ в связи с доминированием в них многолетних кустарников и кустарничков. Чем меньше показатель, тем больше задержка веществ и дальнейшая их консервация. Увеличение показателя свидетельствует о большом динамизме процесса.

8. Скорость общего оборота органического вещества - отношение величины запаса живого и мёртвого органического вещества (включая и не включая гумус) к продукиии (\%). Этот критерий позволяет выявить "подвижность" каждой единицы органического вещества при прохождении этапов трансформирования продукции. Например, она небольшая в полярном и бореальном поясах, и почти на порядок выше в луговой степи и пустыне.

9._Скорость деструктивных проиессов. Деструктивным процессам принадлежит исключительно важное место в биологическом круговороте наземных экосистем, т.к. преобладающая часть биологической продукции трансформируется в форме детрита под действием различных деструктивных агентов, минуя трофические цепи растительноядных организмов. Потребление животными продукции фитомассы составляет единицы процентов. До 88-99\% первичной продукции поступает в почвенную детритную подсистему.

В качестве показателя скорости деструкционных процессов используется отношение ежегодного поступления мертвой массы к её запасу: опадо-подстилочный коэффициент (\%).

В дополнение к основным и производным показателям рекомендуем показатели, связанные с изменением биогеохимического цикла, особенно в условиях техногонеза. Это показатели содержания химических элементов в органическом веществе:

а) годичное потребление (накопление) химических элементов, кг/(га*год);

б) годичный возврат химических элементов с опадом, кг/(га*год);

в) количество элементов, которое ежегодно удерживается в фитоценозе, определяется как разница между потреблением химических элементов и их возвратом, кг/га*год.

Показатели рассчитываются умножением веса отдельных структурных компонентов на содержание того или иного химического элемента.

Показатели скорости оборота химических элементов из-за недостаточно полного учета органического вещества ограничиваются одним звеном: высвобождением химических элементов из мертвых растительных остатков.

В заключении следует отметить, что состояние экосистем должно оцениваться не только с точки зрения их внутренней сбалансированности, но и сохранения их роли в глобальных 
процессах как источника органического вещества, изъятие которого приводит к изменению кислородного баланса атмосферы, интенсивного выветривания минеральной части почв и других процессов. В этой связи в качестве характеристики состояния используются показатели степени открытости экосистем, иными словами незамкнутость биологического круговорота (Базилевич, 1983).

Методы определения предлагаемых критериев подробно изложены и научных работах. Во многих из них приводятся количественные значения этих показателей по экосистемам, типичным для той или иной зоны, на которые можно ориентироваться при выборе показателей характеристики экосистем (Родин, Базилевич, 1965; Исаков, Казанская, Тишков, 1986).

Обобщенные методические разработки на современном уровне изучения биологического круговорота веществ, а также использование системного анализа для построения баланса органических и минеральных веществ в биогеоценозах различных природных зон представлены в работах (Базилевич и др., 1978; Программа и методика..., 1974).

Для оценки деградации следует исходить из фоновых данных. В этой связи можно рекомендовать предложенный А.М. Степановым (Степанов, Черненькова, 1987) коэффициент интегральной сохранности биогеоценозов. Коэффициент подсчитывается путем вычисления среднего арифметического всех имеющихся параметров компонентов биогеоценоза с предварительным нормированием каждого показателя. Метод апробирован в биогеоценозах, подвергшихся загрязнению воздушной среды.

В таблице 3 приводятся параметры балльной оценки устойчивости фаций биогеоценоза по В.Е. Мельченко (Оценка состояния и устойчивости геосистем. М., ВНИИ Природа, 1992, с.79-82). Как следует из таблицы, автор использовал для оценки устойчивости только 3 критерия из 9, рассмотренных выше.

\section{Задание по работе.}

Задание №1.

Используя балльную оценку устойчивости почвы к изменению параметров естественного и антропогенного режима рассчитайте сумму баллов для выбранного Вами типа почв. Сверьте Ваш результат с табл.1.2.

Задание №2. Выполните интегральную оценку устойчивости почвы на основе табл.2. Тип почвы выбрать самостоятельно.

Задание №3. Предложите оценочные шкалы и классификацию для балльной оценки устойчивости фации. Выполните оценку. Расскажите о полученном результате.

\section{Литература}

Александрова Л.В., Васильев В.Ю., Дмитриев В.В., Мякишева Н.В., Огуриов А.Н., Третьяков Н.В., Хованов Н.В. Многокритериальные географо-экологические оценки состояния и устойчивости природных и урбанизированных систем. Под ред. В.В. Дмитриева и Н.В. Хованова. Деп. ВИНИТИ 01.09.2000, № деп.2342В00, 275 с.

Глазовская М.A. Ландшафтно-геохимические системы и их устойчивость к техногенезу // Биогеохимические циклы в биосфере.- М.,1976,-356 с.

Глазовская М.А. Методологические основы оценки эколого-геохимической устойчивости почв к техногенным воздействиям. М., изд. МГУ, 1997, 102 с.

Дмитриев В.В. Методика диагностики состояния и устойчивости водных экосистем // Эколого-географический анализ состояния природной среды: проблема устойчивости геоэкосистем. СПб., 1995. С.41-67.

Дмитриев В.В. Оценка экологического состояния водных объектов суши (часть II). Уязвимость водной экосистемы / Экология. Безопасность. Жизнь. Экологический опыт гражданских, общественных инициатив. Гатчина. 2000, c.284-296.

Дмитриев В.В., Жиров А.И., Ласточкин А.Н. Прикладная экология. Учебник для студентов высш. учеб. заведений. М.: Издательский центр «Академия», 2008, 608 с.

Дмитриев В.В., Фрумин Г.Т. Экологическое нормирование и устойчивость природных систем. Учебное пособие, Изд. Наука, СПб, 2004, 294 с.

Дмитриев В.В., Огурияов А.Н. Подходы к оценке и ГИС-картографированию устойчивости и экологического благополучия геосистем. І. Интегральная оценка устойчивости наземных и водных геосистем. Вестник СПбГУ, серия 7 , вып.3, 2012, с.65-78.

Дмитриев В.В., Огуриов А.Н. Подходы к интегральной оценке и ГИС-картографированию устойчивости и экологического благополучия геосистем. II. Методы интегральной оценки устойчивости наземных и водных геосистем. 
Вестник СПбГУ, сер.7 (геология, география), 2013, вып.3, с.88-103.

Дмитриев В.В., Огуриов А.Н. Подходы к интегральной оценке и ГИС -картографированию устойчивости и экологического благополучия геосистем. III. Интегральная оценка устойчивости почвы и наземных геосистем / Вестник СПбГУ. Сер. 7. 2014. Вып. 4, с.114-129.

Оценка состояния и устойчивости экосистем. Под ред. В.А. Красилова, М., Изд. ВНИИ Природы, 1992, 127 с.

\section{Практическая работа № 6}

\section{Оценка эмерджентных свойств наземных геосистем. \\ Индикаторный подход в оценке устойчивости ландшафта. \\ Балльная и интегральная оценка устойчивости ландшафта по методу сводных показателей (композитных индексов).}

Оценка устойчивости ландшафта к изменению параметров режимов. Потенциальная устойчивость. Предмет исследования, оцениваемое свойство устойчивость наземного ландшафта. В настоящее время актуальнейшей задачей географических исследований является разработка подходов к оценке устойчивости ландшафтов при антропогенном освоении территории. В теоретических и прикладных географических исследованиях оценке устойчивости ландшафтов уделено особое внимание. Разработке ее методологии посвящена обширная литература (Мухина, 1973; Дьяконов, 1974; Куликов; 1976; Солнцева, 1982; Глазовская, 1983; Пузаченко, 1983; Солнцев, 1984; Арманд, 1989; Светлосанов, 1990; Мамай, 1993; Дмитриев, 2000, 2004, 2005, 2008, 2012, 2013, 2014, Осипов 2017 и др.). Однако методические разработки по оценке устойчивости ландшафтов к антропогенным нагрузкам немногочисленны и в своем большинстве связаны с оценкой отдельных факторов устойчивости.

Согласно основным положениям концепции динамики ландшафтов, основанной на понятиях местоположения и набора состояний разной длительности (Г.Исаченко, Резников, 1996), устойчивость рассматривается в динамическом аспекте, то есть применительно к каждой из возможных модификаций определенного типа (вида) геокомплексов. При ландшафтно-динамическом подходе к устойчивости, рекомендуется рассматривать три формы ее проявления: 1) потенциальную устойчивость - способность геокомплексов противостоять внешнему воздействию, сохранять свое состояние в течение заданного интервала времени неизменным; 2) восстанавливаемость - способность возвращаться в то состояние, которое наблюдалось до возмущающего воздействия; 3) вариантность поведения - возможность реализации различных динамических траекторий после или в период осуществления воздействия. Выделенные три формы проявления устойчивости близки к тому, что М.Д.Гродзинский (1987) называл соответственно инертностью, восстанавливаемостью и пластичностью.

Следуя данному подходу, устойчивость нельзя непосредственно измерить, невозможно найти какой-либо единый (универсальный) показатель устойчивости ландшафта. Рекомендуется по отдельности определять устойчивость ландшафта к каждому конкретному возмущающему фактору. Но и при таком раздельном подходе остается открытым вопрос о количественной мере (точнее - мерах) устойчивости. При классификации, а также оценке или ранжировании ландшафтов по признакам их устойчивости на первый план выдвигается тезис о невозможность использовать какиелибо прямые показатели, относящиеся именно к этому их свойству, что вынуждает авторов искать косвенные признаки и показатели. Следует отметить, что и в этом случает авторы, уходя от «прямых показателей», вводят собственную балльную систему оценки устойчивости, суммируют баллы и используют полученную сумму в качестве новой функциональной единицы систем, отражающей их устойчивость. Результаты такой оценки закладываются в основу методики составления карт устойчивости к площадным антропогенным воздействиям или потенциала устойчивости геосистем.

В других подходах (Снакин В. В., Мельченко В. Е., Бутовский Р. О. и др., 1992, Дмитриев, 2000) под устойчивостью геосистемы к изменению параметров режимов понимается её способность сохранять свои свойства и параметры режимов в условиях действующих на неё внешних и внутренних нагрузок. Тогда уязвимыми к изменению параметров режимов будут геосистемы, не способные сохранять указанные свойства на определенном временном интервале функционирования. Под инертностью системы 
понимается способность системы сохранять при внешнем воздействии исходное состояние в течение некоторого времени; под пластичностью - способность системы переходить из одного состояния равновесия в другое, сохраняя при этом внутренние связи и под восстанавливаемостью системы - способность системы возвращаться в исходное состояние после временного внешнего воздействия на нее. Первые два понятия трактуются авторами как адаптационная устойчивость, третье - как регенерационная. При этом термин потенциальная устойчивость либо не используется авторами, либо под потенциальной устойчивостью авторы понимают способность геосистемы сохранять свои свойства и параметры функционирования в условиях естественного изменения элементов режимов, характеризующих физико-географические, климатические, гидрологические условия. В данном подходе это первый шаг в оценке устойчивости, после которого следует оценка устойчивости к воздействию определенного типа. В итоге оценка устойчивости представляет собой многоуровневую и многокритериальную оценку способности систем сохранять свои свойства и параметры естественного и антропогенного режимов по совокупности параметров оценивания внутри определенного класса устойчивости.

Однако при оценке геосистем по многим показателям исследователь, как правило, сталкивается с проблемой их несравнимости в целом, когда по одним критериям проявление оцениваемого свойства геосистемы лучше другой, а по другим - хуже. Еще одним проявлением такой несравнимости является то, что по разным исходным характеристикам “наилучшими" и “наихудшими” являются разные геосистемы. Более того, одна и та же геосистема может быть “наилучшей” по одним характеристикам и "наихудшей” - по другим. Поэтому основным содержанием исследований остается выявление указанной неопределенности и решение данной проблемы в целом.

В тоже время индикаторный подход, активно развивающийся в последние годы, позволяет выделить ключевые индикаторы во многих гео- исследованиях для оценки простых (аддитивных) и сложных (неаддитивных) свойств.

Разработка индикаторов устойчивости позволит активно использовать их в дальнейшем в геоэкологических исследованиях.

Пример оценки устойчивости на основе индикаторного подхода. Оценка устойчивости на основе индекса биологической эффективности климата. Исследования потенциальной устойчивости природно-территориальных комплексов проводились для территории Тверской области (Огурцов, Дмитриев, 2017). В качестве индикатора устойчивости нами использовался индекс биологической эффективности климата (ТК) (Исаченко, 2001), представляющий собой интегральный критерий тепло- и влагообеспеченности, от которого зависит устойчивость ландшафта. В публикациях отмечено, что на региональном уровне высокие значения индекса характерны для наиболее устойчивых ландшафтов, а низкие - для неустойчивых (Абалаков, Лопаткин, 2014). В зависимости от величины индекса ТК предлагается 5-ступенчатая оценочная шкала (таблица 1).

Таблица 1. Оценочная шкала устойчивости по индексу ТК (Абалаков, Лопаткин 2014)

\begin{tabular}{|c|c|}
\hline Оценочная шкала устойчивости & Величина индекса $T K$ \\
\hline наиболее неустойчивые & $\leq 8$ \\
\hline неустойчивые & $8-12$ \\
\hline умеренно устойчивые & $12-16$ \\
\hline устойчивые & $16-20$ \\
\hline наиболее устойчивые & $\geq 20$ \\
\hline
\end{tabular}
1962):

Расчет индекса ТК проводился по формуле, предложенной Н.Н.Ивановым (Иванов,

$$
T K=0,01 \sum T_{>10} \times K_{u},
$$

где $\sum T_{>10} \times K_{u}-$ произведение суммы активных температур $>10^{\circ}$; и коэффициента увлажнения $K_{u}$, который определялся из отношения годового количества осадков к годовой испаряемости. Годовая испаряемость рассчитывалась по (Коломыц, 2010):

$$
E_{0}=1384-161,6 \times t_{\text {июля }}+6,245 \times t_{\text {июля }}^{2},
$$




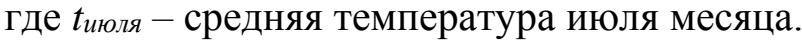

В качестве исходных данных для расчета индекса ТК и последующего построения интерполяционных карт по сеточной области размером 200x217 узлов служила информация по 23 метеостанциям с 2005 по 2015 г.г.

Обработка и анализ метеоданных проводились в программе Microsoft Excel. C помощью инструмента «сводная таблица» программы была проведена группировка метеоданных и расчет суммы активной температуры, годового количество осадков и годовой испаряемости. Ниже, на рисунке 1, приведен пример сводной таблицы расчета годовой суммы осадков по метеорологическому пункту Осташков и диаграмма среднегодового количества осадков и испаряемости по метеостанциям (рисунок 2).

Представленная в табличной форме метеоинформация в формате Excel была импортирована в ГИС Mapinfo и привязана к карте через процедуру «создание точечных объектов» по координатам метеостанций. В ходе этой процедуры был получен исходный массив данных для построения средствами ГИС по сеточной области интерполяционных моделей тематических поверхностей. После проведения интерполяционной процедуры были составлены картограммы компонентов индекса ТК (суммы активных температур и коэффициента увлажнения) (рисунок 1) и индекса биологической эффективности климата (рисунок 2).

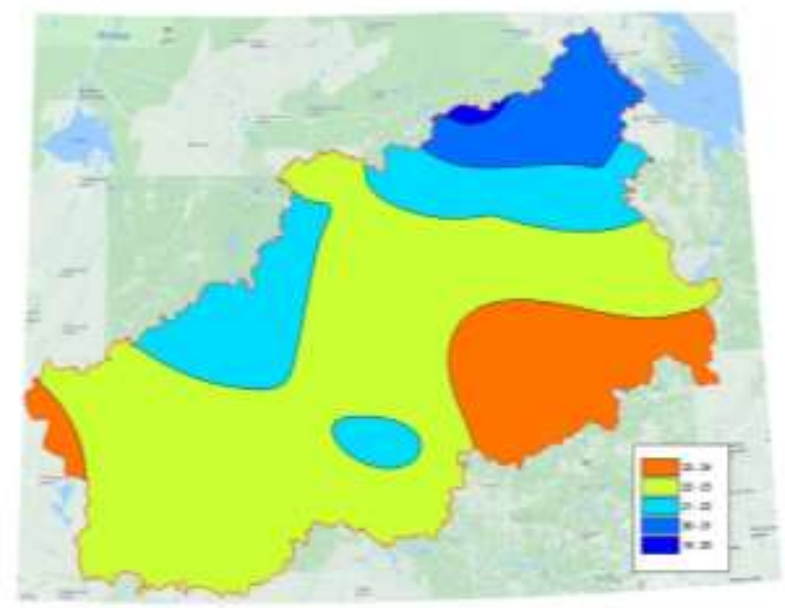

Рисунок 4 Картограмма индекса биологической эффективности

Анализ рисунка показывает, что за рассмотренный период повсеместно фиксируется превышение осадков над испаряемостью. Лишь для двух пунктов отмечается близость значений этих параметров, что нашло свое отражение в величинах коэффициента увлажнения, которые здесь больше 1 (рисунок 3б). Наибольшие значения коэффициента характерны для северо-восточной периферии области. В этом же северо-восточном направлении по мере увеличения коэффициента увлажнения отмечается уменьшение суммы активных температур. Наивысшие суммы активных температур (рисунок 3а) отмечаются в юго-восточной части области. Здесь формируется локальный тепловой максимум с величинами превышающими 2400. Повышенный тепловой фон имеет место и на западе Тверской области. Но здесь суммы активных температур несколько ниже, чем на юго-востоке области. В целом же по области средние величины коэффициента увлажнения и суммы активных температур составляют соответственно 1,5 и 2240.

Особенности изменений величин тепла и влаги отразилось на пространственном распределении индекса биологической эффективности климата (ТК) (рисунок 4). В юговосточной части и на западе области формируются зоны с величинами индекса ТК 23-24. В северо-восточном направлении величины ТК снижаются до 19-20. Значительная часть территории области (58\%) попадает в зону с индексами ТК 22-23.

Соотнесение картограммы индекса биологической эффективности климата с картой ландшафтов Тверской области (рисунок 5) и их анализ показывает, что ландшафты региона по величине индекса ТК изначально относятся к устойчивым и наиболее устойчивым природно-территориальным комплексам. В ландшафтной структуре Тверской области наибольшим распространением характеризуются природно-территориальные комплексы с индексом биологической эффективности климата более 20. Среди них 
наибольшей устойчивостью с индексом биологической эффективности климата 23-24 характеризуются ландшафтные районы в южной части Верхневолжской провинции. Такую же величину ТК имеют ландшафты в западной части Ловатского и ШлиноЦнинского ландшафтных районов.

Балльная оценка устойчивости ландшафта на основе модели-классификации В.E. Мельченко, 1992. В качестве основы для построения интегрального показателя устойчивости ландшафта к изменениям параметров естественного и антропогенного режимов используем балльную модель-классификацию оценки устойчивости ландшафта В.Е. Мельченко, 1992 (табл.4), приведенную в сборнике «Оценка состояния и устойчивости геосистем», М., ВНИИ природа, 1992, с.102-107.

Таблица 4 Модель-классификация оценки устойчивости ландшафта (по В.Е. Мельченко, 1992).

\begin{tabular}{|c|c|c|}
\hline Признак & Значение & Баллы устойчивости \\
\hline 1. Радиационный баланс, ккал/см² год & $\begin{array}{l}\text { от }-5 \text { до }+10 \\
\text { от } 11 \text { до } 20 \\
\text { от } 21 \text { до } 30 \\
\text { от } 31 \text { до } 50 \\
>50\end{array}$ & $\begin{array}{l}1 \\
2 \\
3 \\
4 \\
5\end{array}$ \\
\hline 2. Радиационный индекс сухости & $\begin{array}{c}<0,45 \\
0,45-1,5 \\
1,5-3,0 \\
>3,0\end{array}$ & $\begin{array}{l}3 \\
5 \\
3 \\
1\end{array}$ \\
\hline $\begin{array}{l}\text { 3. Ветровой режим } \\
\text { а) количество дней со штилями в году } \\
\text { б) количество дней с сильными ветрами }\end{array}$ & $\begin{array}{l}\text { Максимальное } \\
\text { Среднее } \\
\text { Минимальное } \\
\text { Максимальное } \\
\text { Среднее } \\
\text { Минимальное }\end{array}$ & $\begin{array}{l}1 \\
3 \\
5 \\
1 \\
3 \\
5\end{array}$ \\
\hline $\begin{array}{l}\text { 4. Интенсивность геоматических процессов (сумма } \\
\text { баллов от составных показателей: неотектоническая } \\
\text { активность, сейсмичность, тип рельефа, свойства пород) }\end{array}$ & $\begin{array}{c}17-20 \\
13-16 \\
9-12 \\
5-8 \\
4\end{array}$ & $\begin{array}{l}5 \\
4 \\
3 \\
2 \\
1\end{array}$ \\
\hline $\begin{array}{lcr}5 . & \text { Устойчивость } & \text { составных } \\
\text { (доминантных и детерминантных урочищ) } & \text { ландшафта }\end{array}$ & $\begin{array}{l}\text { Максимальная } \\
\text { Средняя } \\
\text { Минимальная }\end{array}$ & $\begin{array}{l}5 \\
3 \\
1\end{array}$ \\
\hline 6. Контрастность урочищ в ландшафте & $\begin{array}{l}\text { Максимальная } \\
\text { Средняя } \\
\text { Минимальная }\end{array}$ & $\begin{array}{l}5 \\
3 \\
1\end{array}$ \\
\hline 7. Защищенность грунтовых вод & $\begin{array}{c}\text { Защищены } \\
\text { Слабо защищены } \\
\text { Не защищены }\end{array}$ & $\begin{array}{l}5 \\
3 \\
1\end{array}$ \\
\hline
\end{tabular}

Устойчивость ландшафта рассматривается автором, как способность сохранять свою структуру и функционирование при внешних воздействиях. Ландшафт представляет собой природный территориальный комплекс (ПТК) сложного строения, состоящий из пространственного сочетания ПТК ранга урочищ, в свою очередь состоящих из фаций. Устойчивость ПТК каждого ранга рассматривается на фоне организующего (фации - на фоне урочищ, урочищ - на фоне ландшафта). Устойчивость собственно ПТК представлена как внутренняя (она определяется его свойствами), а устойчивость организующего ПТК - как внешняя по отношению к нему (условия его существования). Внешние условия существования ландшафта определяются климатическими факторами. Для устойчивости ландшафта особенно важны факторы, определяющие энергетику процессов в ландшафте: радиационный баланс, степень увлажнения, ветровой режим.

Радиационный баланс определяет энергетику основных биогенных и абиогенных процессов и ландшафте, а также, по мнению М.Л. Глазовской (1983), скорость и направление химических превращений техногенных продуктов.

Радиационный баланс - величина, зависящая от многих факторов, главные из которых: широта местности, влияющая на суммарную радиацию; характер подстилающей поверхности и увлажнение территорий, сказывающиеся на альбедо и эффективном излучении. В центральной Арктике, по расчетам Н.Г. Черниговского и М.С. Маршуновой, годовой радиационный баланс отрицательный и ранен - 2,6 ккал/с*год (цит. по Алисов, Полтараус, 1974). В зоне тундры он в среднем равен 15-20, в зоне тайги 
-25-30; и зоне лесостепей и степей -35-50 ккал/см*год (Алисов, Полтараус, 1974). Так как радиационный баланс определяет энергетику ландшафтообразующих процессов, то большим его значениям соответствует и максимальная устойчивость ландшафта (при прочих равных условиях).

Вклад этого показателя в устойчивость можно ориентировочно распределить следующим образом:

Радиационный баланс: до 10 ккал/год - 1 балл; от 11 до 20 - 2 балла; от 21 до 30 - 3 балла; от 31 до 50 - 4 балла; более 50 - 5 баллов.

Очень важно этот показатель учитывать в сочетании с показателем увлажнения. Степень увлажнения определяет условия существования биоты и интенсивность процессов, носителем которых является вода. Из показателей увлажнения, очень информативен радиационный индекс сухости $(\mathrm{K})$, предложенный М.И. Будыко, который представляет собой отношение между радиационным балансом территории и годовой суммой осадков, выраженное в калориях скрытой теплоты испарения: K=R/LQ, где R годовой радиационный баланс, L - скрытая теплота испарения, O- годовая сумма осадков (цит. по: Реймерс, 1990). Радиационный индекс сухости отражает возможность накопления влаги при данных радиационных условиях. При К=1,00 возможность испарения примерно соответствует количеству выпавшей влаги. Это значение К соответствует условиям максимальной устойчивости ПТК. При R/LQ менее 0,45 климат называется избыточно увлажненным: приход тепла к почве за счет радиационного баланса намного меньше, чем это нужно было бы для испарения выпавших осадков. При К от 0,45 до 1,00 климат называется влажным; при К от 1,00 до 3,00-недостаточно влажным, при К больше 3,00 - сухим (цит. по Хромов, 1968).

Значение индекса сухости, характеризующее недостаток увлажнения рассматривается как показатель наименьшей устойчивости (меньше, чем избыточном увлажнении). Учитывая сказанное, для индекса сухости, как показателя оптимального увлажнения в ландшафте, можно предложить следующую оценочную шкалу при оценке устойчивости ландшафта:

$$
\begin{array}{ll}
<0,45 & \text { - } 3 \text { балла; } \\
0,45-1,5 & \text { - } 5 \text { баллов; } \\
1,51-3,0 & \text { - } 3 \text { балла; } \\
>3,0 & \text { - I балл. }
\end{array}
$$

Показатель ветрового режима имеет двойственный характер, с одной стороны, количество дней со штилями в году на территории ландшафта характеризует степень рассеивания техногенных веществ в воздухе, а с другой, количество дней с сильными ветрами характеризует интенсивность процессов, разрушающих условия существования биоты. Вклад ветрового показателя в устойчивость фации нуждается в дальнейшей разработке, поэтому в табл.19 он оценен автором лишь на качественном уровне.

Предложенные климатические показатели для оценки устойчивости ПТК определяются из справочников (Климат СССР), а также поданным соответствующей близлежащей метеорологической станции.

Внутреннюю устойчивость ландшафта на фоне внешних (климатических) условий существования определяют следующие характеристики:

1) интенсивность геоматических процессов в ландшафте;

2) устойчивость доминантных и детерминантнык урочищ;

3) контрастность ПТК;

4) защищенность грунтовых вод.

Интенсивность геоматических процессов (ИГП) - это интенсивность как радиальных абиотических процессов, определяемых климатическими показателями, иногда называемыми зональными (количеством приходящей солнечной радиации и количество осадков), так и латеральных, обеспечивающих сопряжение между ПТК.

Интенсивность геоматических процессов проявляется как фактор устойчивости в двух ролях: в одной - как условие нестабильности фации, вступающее в диссонанс с биотой; с другой, как фактор латеральной сопряженности между ПТК и, соответственно, как фактор пространственного рассеивания эффекта антропогенного воздействия. 
Основными условиями развития латеральных геоматических процессов в ландшафте служат условия преобразования радиальных процессов: неотектоническая активность, сейсмичность, тип рельефа, свойства пород.

Геоматические процессы в обобщенном виде являются процессами перемещения вещества, интенсивность которых определяется как эндогенными, так и экзогенными факторами. В пространстве они имеют качественно различное проявление и виде следующих процессов: эрозионных, аллювиальных, делювиальных, оползневых, карстовых, суффозионных, заболачивания, осыпных, обвальных, термокарстовых, курумовых, пучения, наледеобразования, снежных лавин, селей, просадок, перевеивания, цунами, землетрясения, вулканизм и др.

Неотектоническая активность - основной показатель эндогенной энергетики процессов, который в сочетании с климатическими показателями определяет ИГП.

Устойчивость ландшафтов и зависимости от степени неотектонической активности предлагается оценить следующим образом:

1) относительные прогибания в областях устойчивых поднятий -3 балла;

2) устойчивые опускания - 4 балла;

3) преимущественно слабые новейшие поднятия - 5 баллов;

4) устойчивые интенсивные поднятия - 2 балла;

5) современный вулканизм - I балл. оценить:

В зависимости от сейсмичности, устойчивость ландшафта ориентировочно можно

сейсмичность < 3 баллов - 5 баллов;

3-5 балла -3 балла;

$>5$ баллов - I балл.

Тип рельефа "отражает возраст, стадию развития ландшафта, степень соответствия эндогенных и экзогенных процессов. По типам рельефа устойчивость ландшафта оценивается:

1) денудационный пенеплен - 5 баллов;

2) аккумулятивные равнины и низменности - 4 балла;

3) денудационные аккумулятивные - 3 балла;

4) структурно-денудационные плато и равнины - 3 балла;

5) денудационные плато - 3 балла;

6) внутригорные аккумулятивные и денудационные равнины - 2 балла;

7) горы -1 балл.

Характер структурных связей и состояние пород, в соответствии с классификацией И.П.Чуринова (1983), отражает подвижность твердого вещества, его пластичность и способность к выветриванию. Максимальной устойчивостью обладают породы магматические и метаморфические; минимальной - лессовые.

Свойства пород, могут проявляться не только на уровне ландшафта, но и урочища, т.к. в пределах ландшафта может наблюдаться сочетание различных пород.

Свойства пород как условие интенсивности геоматических процессов в ПТК, можно оценить по шкале устойчивости следующим образом:

1) магматические, метаморфические, вулканические-5 баллов;

2) терригенные, флишевые, моласовые - 4 балла;

3) растворимо-карбонатные, терригенно-карбонатные и соленосные - 3 балла;

4) глинистые с крупнообломочным материалом - 2 балла;

5) глинистые - 2 балла;

6) глинистые и песчаные с мелкообломочным материалом - 2 балла;

7) песчаные и мелкообломочные - 2 балла;

8) лессовые - 1 балл.

Вклад интенсивности геоматичсских процессов, как комплексного показатели в устойчивость ландшафта может быть оценен суммарной величиной рассмотренных четырех составляющих (неотектоническая активность, тип рельефа, сейсмичность, свойства пород). Максимальной устойчивостью будут обладать ландшафты с суммой баллов по составным показателям от 16 до 20 баллов, а минимальной - суммой баллов равной 4.

Важно отметить, что за счет антропогенного воздействий интенсивность геоматических процессов возрастает. 
Способность сохранять свою пространственную структуру оценивается не только по геоматическим процессам, хотя можно утверждать, что морфологическая структура ландшафта это результат действия этих процессов, но и в не меньшей мере по устойчивости её составных частей - ПТК подчиненного уровня: фаций и урочищ.

Устойчивость урочища определяется устойчивостью доминантных фаций и интенсивностью системообразующего геоматичского процесса или процессов (если их несколько).

В морфологической структуре ландшафта урочища играют различную роль, которая проявляется в сопряжении ПТК. Могут быть ПТК с активной ролью в ландшафте, определяющие его развитие. Эти ПТК можно назвать детерминантами. Эти ПТК обычно отличаются максимальным по площади эффектом рассеивания вещества и энергии. Они не обязательно сами отличаются интенсивными геоматическими процессами, а чаще - накопители вещества - носителя энергии в ландшафте (например, ледники и снежники, питающие реки). Иногда эти ПТК - барьеры на пути интенсивных потоков вещества (например, острова в реках, дюнный вал на пути ветров). По роли в ландшафте урочища можно разделить на активные, пассивные и детерминанты. Максимальной устойчивостью по роли в ландшафте, будут отличаться пассивные урочища (останцы, в денудационных ландшафтах), минимальной - ПТК Н-Н детерминанты. Поэтому при оценке устойчивости составных частей пространственной структуры ландшафта важна устойчивость не только доминантных (по площади) урочищ, но и детерминантных, играющих активную роль в ландшафте.

Представляет интерес, такой показатель устойчивости МСЛ, как контрастность сопряженных урочищ. Контрастность определяется по генезису урочищ (процессам, сформировавшим урочище, и свойствам вещества).

Контрастность сопряженных ПТК отражает возможность формирования природных и геохимических барьеров на пути миграции техногенных продуктов. Наиболее контрастные ПТК урочищ различного генезиса (например, эоловые песчаные дюны под сосняками сухотравными на слаборазвитых сухоторфянистых почвах и мелкохолмистые моренны с липняками широкотравными на суглинистых дерновоподзолистых почвах).

Защищенность грунтовых вод определяется по комплексу показателей: глубина грунтовых вод, поглотительная способность пород, трещиноватость, фильтрационные свойства пород (Гольдберг, 1984).

Грунтовые воды в ландшафте считаются защищенными при наличии мощного слабопроницаемого слоя пород и глубоком залегании грунтовых вод. грунтовые воды в ландшафте при наличии трещиноватых пород и карстовых ПТК не защищены, особенно, при достаточно близком залегании грунтовых вод. Этот показатель характеризует устойчивость как ландшафта в целом (по сочетанию условий защищенности), так и урочища. Этот показатель важен из-за необратимости процесса загрязнения грунтовых вод.

Показатели составных частей ландшафта и защищенности грунтовых вод из-за недостаточной изученности вопроса оценены на качественном уровне.

Указанные в табл.4 характеристики определяются ландшафтным картографическим методом, дистанционными методами (аэрофото и космическими), стационарными методами (особенно Гидрометеослужбы), по фондовым материалам геологических, геоморфологических и гидрогеологических исследований. В заключение автор отмечает, что при оценке устойчивости ландшафта необходимо определение всех показателей, т.к. они имеют смысл только в комплексе.

Отметим недостатки рассмотренных оценочных шкал и самой модели-классификации (табл.4). Прежде всего, табл. 4, строго говоря, не является классификацией устойчивости, поскольку в ней отсутствуют классы устойчивости. Не все шкалы являются непрерывными и имеют числовые значения оцениваемых параметров. Если оценочная шкала имеет числовое выражение, автор ставит ему в соответствие определенное количество баллов, заведомо огрубляя оценочную шкалу. В одних случаях шкалы рассчитаны на 5 классов устойчивости, в других - на 3 класса. В одних случаях связь между устойчивостью и выбранным признаком прямая, в других обратная, но всегда близкая к линейной и равномерной. В модели не предусмотрено включение источника воздействия на ландшафт и задание для него оценочной шкалы и оценки его влияния на устойчивость. 
Интегральная оценка потенциальной устойчивости ландшафтов. В опубликованных нами ранее работах рассмотрены особенности оценочных исследований эмерджентных свойств геосистем, к числу которых, прежде всего, относится «устойчивость» [1]. В целом, в современных публикациях оценка устойчивости геосистем характеризуется отсутствием: 1 - авторских определений устойчивости и ее типов (потенциальная устойчивость или устойчивость к изменению параметров естественного режима; устойчивость к воздействию одного типа; устойчивость к воздействию нескольких типов; совместный учет потенциальной устойчивости и устойчивости к воздействию и др.); 2 - обоснования для использования тех или иных методов ее оценки (балльная, балльно-индексная оценка; многокритериальная, интегральная оценка устойчивости и др.); 3 - обоснования возможности и целесообразности одновременного учета в разработанных подходах нескольких основных типов устойчивости (потенциальная, адаптационная, регенерационная) и их комбинаций или последовательных сочетаний; 4 - возможности аддитивного учета типов устойчивости, состояния геосистем и правомерности таких подходов. В последних публикациях обсуждаются сопутствующие акценты, например, в одном из обширных зарубежных обобщений, посвященных обзору имеющейся литературы (более 1500 исследований) по индексам, разработанным для оценки «территориальных детерминант» с точки зрения охраны окружающей среды, авторами выявлены 23 пространственно-распределенных композитных индекса, в основу которых заложена информация о 329 переменных [2]. Это разнообразие характеризует, с точки зрения авторов, отсутствие «общей основы» и «может привести к сильной субъективности и ограничению возможности сопоставления различных оценочных результатов» [2].

Целью исследования является разработка оценочной классификации потенциальной устойчивости геосистем и ее апробация на примере нескольких ключевых ландшафтов Российской Федерации. При разработке подхода к интегральной оценке потенциальной устойчивости исследуются: количество параметров оценивания (территориальных детерминант) и задание их весомости при расчете интегрального показателя устойчивости.

С нашей точки зрения, в «общую основу» и перечень этапов исследования, в числе прочих, необходимо всегда включать цель исследования (начальный этап) и проверку адекватности модельных представлений, отражающих исследуемое эмерджентное свойство (завершающий этап) или состояние (статус) самой системы.

Рассмотрим специфику объектов современных ландшафтно-экологических исследований. Для количественной оценки и моделирования ландшафтной структуры и ее влияния на виды и сообщества в зарубежных публикациях обсуждаются два фундаментальных подхода: т.н. «патч-ориентированные модели» (от англ. «patch», буквально - «заплатка») и «градиентные модели» [4]. Модели на основе патчей, рассматривают ландшафт как набор участков среды обитания, представляющих собой экологически однородные субъединицы ландшафта. В итоге структура ландшафта складывается из состава, конфигурации и взаимосвязей участков с различными размерами и качествами $[4,5]$. В отличие от этого, «градиентные модели» представляют собой ландшафтную структуру, основанную на непрерывных растровых или сеточных данных, без априорного выделения участков или субъединиц. Здесь ячейки сетки или пиксели являются наименьшими однородными и дискретными пространственными единицами, позволяющими осуществлять квазипрерывное изменение характеристик по всему ландшафту [4, 6, 7]. Используя первый подход, мы акцентируем необходимость доказательства адекватности результатов (верификации) оценочных исследований устойчивости, полученных на основе балльного, балльно-индексного подхода или моделей-классификаций, разработанных для интегральной оценки устойчивости, и невозможность прямого измерения интегративного свойства геосистем (устойчивость), 
характеризующего их способность сохранять свои свойства и параметры режимов при внешних воздействиях или внутренних трансформациях.

Сказанное выше, приводит к отказу многих авторов от использования терминов «модель» и «моделирование» в оценке эмерджентных свойств геосистем: устойчивость, уязвимость, благополучие, напряженность, экологический статус (или потенциал), «здоровье эко- или геосистемы» и др., поскольку в природе эти свойства в принципе нельзя измерить. В этом случае авторы употребляют термины «оценочная классификация», «обучающая классификация» и развивают методы косвенного подтверждения результатов оценки состояния системы, или ее сложного свойства на основе балльных оценок. Здесь, на наш взгляд, следует отметить, что непременным условием проверки адекватности модели «оригиналу» является выдвижение ряда гипотез, которые могут быть проверены по имеющимся натурным данным и результатам расчетов, или исходя из логики событий. Чем больше гипотез оправдывается или подтверждается, тем большее доверие заслуживает модель. Поэтому отсутствие разработки и доказательства таких гипотез является «слабым звеном» многих публикаций по данной проблеме. Авторы просто обходят стороной данный этап работы. При этом, как правило, не обсуждается системообразующий тип геосистемы, например, для водной геосистемы: 1 - циклический тип, 2 - транзитный, 3 - каскадный. Проверка нами ряда гипотез показала, что логично оценивать адаптационную устойчивость для водных эко- и геосистем 1 типа, регенерационную - для 2 или для 2 и 3 типов систем. В некоторых случаях можно обосновать последовательное изменение типов внутри года (ряда лет), если система меняет свой тип в результате естественных или антропогенных трансформаций.

В ландшафтных исследованиях, как правило, одновременно присутствуют все типы геосистем. Это позволяет сформировать патчи всех типов для оценки устойчивости ландшафта и использовать их одновременно. Присутствие того или другого типа патчей в ландшафте можно учитывать по занимаемой ими площади или через весовые множители, приписываемые тем или иным характеристикам. Развития этой идеи на практике пока не происходит, хотя в оценочных классификациях устойчивости у авторов, как правило, присутствуют одновременно параметры и шкалы первого и второго типов, часто одни и те же для разных типов геосистем $[3,8,11]$.

Следующая особенность оценочных исследований, отмеченная нами, состоит в медленном развитии индексологии устойчивости и других сложных свойств. В иностранных и последних российских публикациях речь идет, чаще всего, о т.н. «композитных индексах» [2]. Выявлено: отсутствие общей методологической структуры построения индексов, необходимость развития методов отбора переменных для конкретных целей, т.н. «рамочная основа» для индексов; необходимость повышения методологической транспарентности (открытости, доступности) для улучшения межтерриториального сопоставления результатов [2]. Редко авторами предлагаются «композитные индексы», для которых в процессе исследования были разработаны оценочные шкалы. Но даже, если такие шкалы существуют, то они часто заменяются авторами балльными шкалами, что снижает их ценность как основы «экологической квалиметрии» или «экологической аксиометрии». Возможно поэтому, хотя разработка составных индексов привлекает все большее внимание ученых и государственных органов, эта концепция, по-прежнему, не обладает способностью к транспонированию и устойчивостью, в том числе, из-за различных концепций и/или методологий [2]. В итоге, авторы приходят к выводу о том, что «не существует признанного стандарта или международного признанного правила для определения количества и типа переменных, которые должны быть включены в количественную оценку состояния окружающей среды» и что «до настоящего времени ни в одном исследовании не рассматривался вопрос о возможном включении данных в качестве носителя информации для использования в составных индексах состояния окружающей среды». [9]. 
Рассмотрим основные этапы построения классификаций или моделейклассификаций устойчивости $[1,3]$. Такие модели характеризуют способность сложной системы сохранять свои свойства (морфометрию и рельеф, климатические особенности, водный режим, его специфику и сезонные эффекты) и параметры режимов в результате естественных изменений и/или антропогенных воздействий и трансформаций. Вид представления знаний о свойствах и параметрах естественного и антропогенного режимов - классификация состояния и/или классификация устойчивости. Такая классификация формируется с учетом цели исследования, сформулированной на первом этапе работы.

После выявления типа устойчивости и его представления в моделиклассификации, механизмов формирования, отбора необходимых и достаточных критериев оценивания необходимо ввести классы и сформировать оценочные шкалы для всех критериев. Например, в [1] нами для оценки потенциальной устойчивости ландшафта в эколого-географическом зонировании территории были рекомендованы: 1радиационный баланс, ккал/см² год. Бо́льшим его значениям соответствует максимальная устойчивость ландшафта; 2-радиационный индекс сухости (К) - отношение между радиационным балансом территории и годовой суммой осадков, выраженное в калориях скрытой теплоты испарения. $\mathrm{K}=1,00$ соответствует условиям максимальной устойчивости ландшафта; 3-ветровой режим: а) количество дней со штилями в году (баллы). Чем больше дней со штилями, тем выше адаптационная устойчивость; 4ветровой режим: б) количество дней с сильными ветрами (баллы). Чем больше дней с сильными ветрами, тем ниже адаптационная устойчивость (и выше регенерационная устойчивость); 5 - интенсивность геоматических процессов (ИГП) характеризуется аддитивным учетом неотектонической активности, сейсмичности, типа рельефа, свойств пород. Максимальной величине ИГП соответствует максимальная устойчивость ландшафтов; 6 - устойчивость составных частей ландшафта (урочища разделены на активные, пассивные и детерминанты). Максимальная устойчивость закреплена за пассивными урочищами, минимальная за Н-H детерминантами; 7 - контрастность урочищ в ландшафте (чем выше контрастность, тем выше устойчивость или необходимо обосновать другие подходы); 8 - защищенность грунтовых вод. Грунтовые воды (ГВ) в ландшафте считаются защищенными (максимальная устойчивость) при наличии слабопроницаемого, мощного слоя пород и глубоком залегании ГВ. ГВ в ландшафте не защищены при наличии трещиноватых пород и карстовых ландшафтов (минимальная устойчивость), особенно, при достаточно близком залегании ГВ; 9 - индекс биологической эффективности климата (ТК) - интегральный критерий тепло- и влагообеспеченности, от которого зависит устойчивость ландшафта. Высокие значения индекса ТК характерны для устойчивых ландшафтов, а низкие - для неустойчивых. Первые 8 характеристик использовались нами в оценочной классификации устойчивости «ОКУ» в [3]. Перечисленные 9 критериев составляли основу оценочной классификации устойчивости «ОКУ1» в [1]. Отметим небольшую разницу в оценочных шкалах «ОКУ» в работах [1] и [3], обусловленную ошибками округления.

В настоящей версии оценочной классификации устойчивости «ОКУ2» учтем дополнительно еще два критерия. Это: 10 - индекс интенсивности биологического круговорота (ИБК) - величина отношения массы подстилки к той части опада, которая ее формирует. ИБК для заболоченных лесов $>50$, для кустарничковой тундры 20 - 50, для темнохвойных лесов, для 10 - 17, для широколиственных лесов $3-4$, саванны не более 0,2, влажные тропические леса не более 0,1 [10]. Учтем также: 11 - устойчивость почв к эрозионному смыву (эрозионный смыв в т/га в год). Под устойчивостью ландшафтов к смыву почв дождевыми осадками понимается их способность противостоять процессам смыва. Чем меньше смыв почвы, тем устойчивее ландшафт. Шкала эрозионного смыва (т/га в год): $8-6-$ минимальная устойчивость (I класс), 6 - 4 - устойчивость ниже средней (II класс), $4-2$ - средняя устойчивость (III класс), 2 - 1 - выше средней (IV класс), 1 -0 - максимальная устойчивость [11]. 
Внешний вид модели-классификации интегральной оценки устойчивости, построенной нами на основе выбранных 11 критериев, приведен в табл.1. Там же содержатся разработанные нами оценочные шкалы интегральных показателей устойчивости для «ОКУ1» и «ОКУ2» в предположении равенства весов (приоритетов) оценивания. Подсветкой в таблице выделены дополнительные параметры, учитываемые в «ОКУ $2 »$.

Таблица 1 - Модель-классификация оценки устойчивости ландшафта.

\begin{tabular}{|c|c|c|c|c|c|}
\hline Признак / класс устойчивости & $\begin{array}{l}\text { I } \\
\text { Минимальная } \\
\text { устойчивость }\end{array}$ & $\begin{array}{c}\text { II } \\
\text { Устойчивость } \\
\text { ниже средней }\end{array}$ & $\begin{array}{c}\text { III } \\
\text { Средняя } \\
\text { устойчивость }\end{array}$ & $\begin{array}{c}\text { IV } \\
\text { Устойчивость } \\
\text { выше } \\
\text { средней } \\
\end{array}$ & $\begin{array}{l}\mathrm{V} \\
\text { Максимальная } \\
\text { устойчивость. }\end{array}$ \\
\hline 1. Радиационный баланс, ккал/см² год & $\frac{-5-+10}{0-0,18}$ & $\frac{11-20}{0,18-0,29}$ & $\frac{20-30}{0,29-0,41}$ & $\frac{30-50}{0,41-0,65}$ & $\frac{50-80}{0,65-1,00}$ \\
\hline 2. Радиационный индекс сухости. & $\frac{5-4}{0-0,20}$ & \begin{tabular}{c|}
$4-3$ \\
$0,20-0,44$
\end{tabular} & \begin{tabular}{c|}
$3-2$ \\
$0,44-0,68$ \\
\end{tabular} & $\begin{array}{c}2-1 \\
0,68-0,88 \\
\end{array}$ & $\begin{array}{c}1-0,45 \\
0,88-1,00\end{array}$ \\
\hline $\begin{array}{l}\text { 3. Ветровой режим: а) количество дней со штилями в } \\
\text { году (баллы). }\end{array}$ & $\frac{0-1}{0-0,20}$ & $\frac{1-2}{0,20-0,40}$ & $\frac{2-3}{0,40-0,60}$ & $\frac{3-4}{0,60-0,80}$ & $\frac{4-5}{0,80-1,00}$ \\
\hline $\begin{array}{l}\text { 4. Ветровой режим: б) количество дней с сильными } \\
\text { ветрами (баллы). }\end{array}$ & $\frac{5-4}{0-0,20}$ & $\frac{4-3}{0,20-0,40}$ & $\frac{3-2}{0,40-0,60}$ & $\frac{2-1}{0,60-0,80}$ & $\frac{1-0}{0,80-1,00}$ \\
\hline 5. Интенсивность геоматических процессов, баллы & $\frac{0-4}{0-0,20}$ & $\frac{4-8}{0,20-0,40}$ & $\frac{8-12}{0,40-0,60}$ & $\frac{12-16}{0,60-0,80}$ & $\frac{16-20}{0,80-1,00}$ \\
\hline $\begin{array}{l}\text { 6. Устойчивость составных частей ландшафта, } \\
\text { баллы }\end{array}$ & $\frac{0-1}{0-0,20}$ & $\frac{1-2}{0,20-0,40}$ & $\frac{2-3}{0,40-0,60}$ & $\frac{3-4}{0,60-0,80}$ & $\frac{4-5}{0,80-1,00}$ \\
\hline 7. Контрастность урочищ в ландшафте, баллы. & $\frac{0-1}{0-0,20}$ & $\frac{1-2}{0,20-0,40}$ & $\frac{2-3}{0,40-0,60}$ & $\frac{3-4}{0,60-0,80}$ & $\begin{array}{c}4-5 \\
0,80-1,00\end{array}$ \\
\hline 8. Защищенность грунтовых вод, баллы. & $\frac{0-1}{0-0,20}$ & $\frac{1-2}{0,20-0,40}$ & $\frac{2-3}{0,40-0,60}$ & $\frac{3-4}{0,60-0,80}$ & $\frac{4-5}{0,80-1,00}$ \\
\hline $\begin{array}{l}\text { 9. Индекс биологической эффективности климата } \\
\text { (индекс ТК) }\end{array}$ & $\frac{0-4}{0-0,20}$ & $\frac{4-8}{0,20-0,40}$ & $\frac{8-12}{0,40-0,60}$ & $\frac{12-16}{0,60-0,80}$ & $\frac{16-20}{0,80-1,00}$ \\
\hline 10. Индекс интенсивности биологического круговорота & $\frac{0-0,1}{0-0,002}$ & $\frac{0,1-0,2}{0,002-0,004}$ & $\frac{3-4}{0,060-0,080}$ & $\frac{10-17}{0,200-0,340}$ & $\frac{20-50}{0,400-1}$ \\
\hline 11. Эрозионный смыв почв (т/гав год) & $\frac{8-6}{0-0,250}$ & $\frac{6-4}{0,250-0,500}$ & $\frac{4-2}{0,500-0,750}$ & $\frac{2-1}{0,750-0,875}$ & $\frac{1-0}{0,850-1}$ \\
\hline $\begin{array}{c}\text { Интегральный показатель устойчивости ландшафта } \\
\text { (ИПУЛ) для оценочной классификации «ОКУ1» } \\
\text { (9 параметров) }\end{array}$ & 0-0,198 & 0,198-0,392 & 0,392-0,588 & $\mathbf{0 , 5 8 8 - 0 , 7 9 3}$ & 0,793-1,00 \\
\hline $\begin{array}{c}\text { Интегральный показатель устойчивости ландшафта } \\
\text { (ИПУЛ) для оценочной классификации «ОКУ2» } \\
\text { (11 параметров) }\end{array}$ & $0-0,185$ & 0,185-0,367 & $0,372-0,556$ & $0,567-0,759$ & $0,762-1,00$ \\
\hline
\end{tabular}

Примечание. В числителе - значения параметра для левой и правой границ класса; в знаменателе - то же для нормированных значений показателей. Подсветкой выделены дополнительно учтенные критерии.

Для нормирования исходных параметров использовались функции «мини-макса», традиционно применяемые нами в построении интегральных показателей [12].

В расчетах использованы нормирующие функции 1 и 2, отражающие на данном этапе линейный характер изменения характеристик по классам устойчивости $(l=1,0)$. В $(1)$ и (2) $q_{i}$ - нормированное значение текущих показателей $x_{i}$. В качестве $\min _{i}$ и $\max _{i}$ использовались минимальное и максимальное значения характеристик в оценочных шкалах.

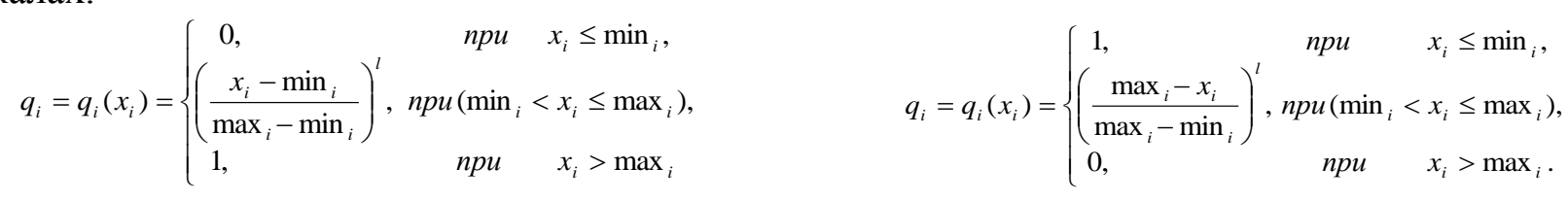

В последних строках табл.1 приведены рассчитанные значения интегрального показателя устойчивости (ИПУЛ) по классам для «ОКУ1» и «ОКУ2». Правила построения оценочных шкал интегральных показателей опубликованы нами в большом количестве работ [1, 3 и др.]. Для расчетов использовались: метод сводных показателей 
(МСП); метод рандомизированных сводных показателей (МРСП); АСПИД-методология [12]. Реализация этапов проводилась либо для нескольких уровней свертки информации, либо, как в табл.1, все параметры оценки сводились в единую исходную модельклассификацию. Наш опыт показывает, что для оценки экологического статуса (потенциала) геосистемы целесообразно ввести три группы параметров: 1 - группа, отражающая продукционный потенциал геосистемы (ландшафта); 2 - группа, отражающая качество и токсическое загрязнение сред (воздух, вода, почва); 3 - группа, отражающая потенциальную устойчивость геосистемы (ландшафта). В этом случае построение интегрального показателя экологического статуса (потенциала) геосистемы реализуется на основе 2-3-х уровневой свертки показателей. При этом необходимо решать вопрос о приоритетах оценивания, как внутри групп, так и между ними. Отметим, что в данной работе, как и в большинстве публикаций, рассмотрено «линейное агрегирование» принятых для оценки характеристик и отсутствует обоснование «умных приоритетов» (весов) для свертки показателей [13]. Последняя проблема рассматривается подробно в других наших работах [3, 14 и др.].

В качестве $d$-функции для построения интегрального показателя устойчивости нами использовалась линейная свертка нормированных значений вида

$$
Q=Q(q ; w)=Q\left(q_{1}, \ldots, q_{m} ; w_{1}, \ldots, w_{m}\right)=\sum_{i=1}^{m} q_{i} w_{i},
$$

представляющая собой сумму взвешенных значений показателей $q_{i}$ (результат нормирования $i-$ й характеристики), определяемую весовыми коэффициентами $w=\left(w_{1}, \ldots, w_{m}\right)$ отдельных критериев для интегральной оценки устойчивости. Введение условия $w_{1}+\ldots+w_{m}=1$, позволяет оценивать $w_{i}$ как относительную значимость нормированного показателя $q_{i}$.

В таблице 1 представлены исходные шкалы и нормированные значения параметров этих шкал по классам устойчивости и шкалы интегрального показателя устойчивости ландшафта (ИПУЛ) к изменению параметров естественного режима (потенциальная устойчивость) для «ОКУ1» и «ОКУ2». Данные модели-классификации построены в предположении равенства весов (приоритетов) между признаками $\left(w_{\mathrm{i}}=1 / 9\right.$ для «ОКУ1» и $w_{\mathrm{i}}=1 / 11$ для «ОКУ2»). Максимальной устойчивости поставлено в соответствие значение $q_{i}=1$, а минимальной $q_{i}=0$. При формировании шкал и нормировании показателей учтен вид связи выбранного параметра с исследуемым свойством ландшафта.

На первом этапе был рассмотрен ряд гипотетических ситуаций (сценариев) для условно заданных типов ландшафтов. Сценарии могут отражать минимально возможные для некоторой территории и максимально возможные значения характеристик или интервалы их изменения. По ним исследователь определяет, в каких пределах может изменяться интегральный показатель устойчивости для различных (характерных) типов ландшафтов или временных интервалов. Для этого можно использовать комбинации различных значений параметров, отражающих естественноисторическую фазу развития геосистем, а также средние, фоновые, экстремальные и т.п. значения параметров.

Рассмотрим примеры использования «ОКУ2» и сравним полученные результаты с результатами по «ОКУ1» для ландшафтов, перечень которых приведен в таблице 2. В таблице 3 заданы значения 11 территориальных детерминант для «ОКУ2» по ландшафтам.

Таблица 2 - Перечень некоторых ландшафтов, выбранных для оценки потенциальной устойчивости по «ОКУ2».

\begin{tabular}{|c|l|}
\hline$№$ п/п & \multicolumn{1}{c|}{ Название и особенности ландшафтов } \\
\hline 1 & Таежные ландшафты Новгородской области (Приильменская низменность). \\
\hline 2 & $\begin{array}{l}\text { Пологоволнистые междуречные равнины, покатые и пологие склоны долин, сложенные } \\
\text { песчаниками, мергелями, конгломератами, известняками уфимского яруса с } \\
\text { широколиственными лесами на серых и тёмно-серых лесных почвах Бирского, } \\
\text { Мишкинского и Благовещенского районов Республики Башкортостан. }\end{array}$ \\
\hline
\end{tabular}




\begin{tabular}{|l|l|}
\hline 3 & Ландшафты хвойно-широколиственных лесов Уфимского плато \\
\hline 4 & Равнинно-моренный ландшафт Лемболовской возвышенности Ленинградской области. \\
\hline 5 & Арктические ландшафты Земли Франца-Иосифа. \\
\hline
\end{tabular}

Таблица 3 - Примеры интегральной оценки устойчивости ландшафтов

\begin{tabular}{|c|c|c|c|c|c|}
\hline Признак / ландшафт & Ландшафт 1 & Ландшафт 2 & Ландшафт 3 & Ландшафт 4 & Ландшафт 5 \\
\hline $\begin{array}{l}\text { 1. Радиационный баланс, } \\
\text { ккал/см² год }\end{array}$ & $\frac{30}{0,412}$ & $\frac{37}{0,495}$ & $\frac{37}{0,495}$ & $\frac{25}{0,353}$ & $\frac{2}{0,082}$ \\
\hline $\begin{array}{l}\text { 2. Радиационный индекс } \\
\text { сухости. }\end{array}$ & $\begin{array}{l}0,05 \\
1\end{array}$ & $\frac{1-1,15}{0,825}$ & $\begin{array}{l}0,85-1 \\
0,895\end{array}$ & $\frac{0,5}{0,989}$ & $\frac{0,5}{0,989}$ \\
\hline $\begin{array}{l}\text { 3. Ветровой режим: а) } \\
\text { количество дней со } \\
\text { штилями в году (баллы). }\end{array}$ & $\begin{array}{l}5 \\
1\end{array}$ & $\frac{4}{0,80}$ & $\frac{4}{0,80}$ & $\frac{5}{1}$ & $\frac{3}{0,60}$ \\
\hline $\begin{array}{l}\text { 4. Ветровой режим: б) } \\
\text { количество дней с } \\
\text { сильными ветрами (баллы). }\end{array}$ & $\frac{3}{0,40}$ & $0, \frac{2}{60}$ & 0,80 & $0, \frac{1}{80}$ & $0, \frac{2}{6} 0$ \\
\hline $\begin{array}{l}\text { 5. Интенсивность } \\
\text { геоматических процессов, } \\
\text { баллы }\end{array}$ & $\frac{15}{0,75}$ & $\frac{9}{0,45}$ & $\frac{11}{0,55}$ & $0, \frac{7}{35}$ & 0,40 \\
\hline $\begin{array}{l}\text { 6. Устойчивость составных } \\
\text { частей ландшафта, баллы }\end{array}$ & $\frac{3}{0,60}$ & $0, \frac{1}{20}$ & $\begin{array}{l}\underline{4} \\
0,8\end{array}$ & $0, \frac{3}{6}$ & $0, \frac{1}{20}$ \\
\hline $\begin{array}{l}\text { 7. Контрастность урочищ в } \\
\text { ландшафте, баллы. }\end{array}$ & $\frac{3}{0,60}$ & $0, \frac{1}{20}$ & $\begin{array}{l}\underline{4} \\
0,8\end{array}$ & 0,60 & $0, \frac{1}{20}$ \\
\hline $\begin{array}{l}\text { 8. Защищенность } \\
\text { грунтовых вод, баллы. }\end{array}$ & $\frac{3}{0,60}$ & $\frac{3}{0,60}$ & $0, \frac{1}{20}$ & $0, \frac{3}{6}$ & $0, \frac{1}{20}$ \\
\hline $\begin{array}{l}\text { 9. Индекс биологической } \\
\text { эффективности климата } \\
\text { (индекс ТК) }\end{array}$ & $\frac{14}{0,70}$ & $\begin{array}{c}14 \\
0,70\end{array}$ & $\frac{15}{0,75}$ & $\frac{12}{0,60}$ & $\frac{1,5}{0,075}$ \\
\hline $\begin{array}{l}\text { 10. Индекс интенсивности } \\
\text { биологического } \\
\text { круговорота }\end{array}$ & $\frac{11}{0,22}$ & $\frac{3-4}{0,065}$ & $\frac{7-8}{0,15}$ & $\frac{13}{0,06}$ & $\frac{0,08}{0,002}$ \\
\hline $\begin{array}{l}\text { 11. Эрозионный смыв почв (т/га } \\
\text { в год) }\end{array}$ & $\frac{3}{0,375}$ & $\frac{7}{0,125}$ & $\frac{5}{0,375}$ & $\frac{3}{0,375}$ & $\frac{7}{0,125}$ \\
\hline $\begin{array}{c}\text { Интегральный показатель } \\
\text { устойчивости ландшафта } \\
\text { (ИПУЛ) для оценочной } \\
\text { классификации «ОКУ1» } \\
\text { (9 параметров) }\end{array}$ & $\begin{array}{c}0,673(\text { IVc) } \\
\text { границы } \\
\text { класса } \\
0,588-0,793\end{array}$ & $\begin{array}{c}\mathbf{0 , 5 4 1} \text { (IIIи) } \\
\text { границы } \\
\text { класса } \\
\mathbf{0 , 3 9 2 - 0 , 5 8 8}\end{array}$ & $\begin{array}{l}0,677(\text { IVc) } \\
\text { границы } \\
\text { класса } \\
\mathbf{0 , 5 8 8 - 0 , 7 9 3}\end{array}$ & $\begin{array}{c}\mathbf{0 , 6 5 5}(\text { IVл }) \\
\text { границы } \\
\text { класса } \\
0,588-0,793\end{array}$ & $\begin{array}{c}\text { 0,372 (III) } \\
\text { границы } \\
\text { класса } \\
0,198-0,392\end{array}$ \\
\hline $\begin{array}{c}\text { Интегральный показатель } \\
\text { устойчивости ландшафта } \\
\text { (ИПУЛ) для оценочной } \\
\text { классификации «ОКУ2» } \\
\text { (11 параметров) } \\
\end{array}$ & $\begin{array}{l}\mathbf{0 , 6 0 5} \text { (ІУл) } \\
\text { границы } \\
\text { класса } \\
\mathbf{0 , 5 6 7 - 0 , 7 5 9}\end{array}$ & $\begin{array}{c}0,460 \text { (IIIп) } \\
\text { границы } \\
\text { класса } \\
0,372-0,556\end{array}$ & $\begin{array}{l}0,601 \text { (IVл) } \\
\text { границы } \\
\text { класса } \\
0,567-0,759\end{array}$ & $\begin{array}{c}\mathbf{0 , 5 7 5} \text { (IVл) } \\
\text { границы } \\
\text { класса } \\
\mathbf{0 , 5 6 7 - 0 , 7 5 9}\end{array}$ & $\begin{array}{c}\text { 0,316 (III) } \\
\text { границы } \\
\text { класса } \\
0,185-0,367\end{array}$ \\
\hline
\end{tabular}

Примечание. В числителе - рекогносцировочное значение признака, в знаменателе - нормированное значение. В двух последних строках - результат свертки (ИПУ) с указанием близости к левой (л), правой (п) границам или к середине класса (c) и класс устойчивости с указанием границ класса. Подсветкой выделены дополнительно учтенные критерии.

Пример 1. Расчет интегрального показателя устойчивости ландшафта (ИПУЛ) выполнялся для таежных ландшафтов Новгородской области (Приильменская низменность). Полученное на основе «ОКУ2» значение ИПУЛ равно 0,605 , позволяет отнести данные ландшафты к IVл классу устойчивости (устойчивость выше средней) при ширине интервала класса 0,545-0,747 (табл.3). Расчеты показали, что изъятие (или добавление) 2-х параметров (10 и 11) незначительно сказалось на итоговом результате. В «ОКУ1» было получено ИПУЛ=0,673, что позволило отнести ландшафт к середине IV класса при ширине интервала оценочной шкалы ИПУЛ 0,588-0,793. Сравнивать между собой абсолютные значения ИПУЛ для «ОКУ1» и «ОКУ2» нельзя, поскольку значения левой и правой границ классов у них разные. Поэтому сравним значения ИПУЛ $/(\max 9-\min 9)$ и ИПУЛ $11 /\left(\max _{11}-\min _{11}\right)$. В качестве минимального и максимального значений использовались соответствующие граничные значения характеристик для IV класса в «ОКУ1» и «ОКУ2». В этом случае получаем, что разница в полученных результатах составила $4,2 \%$.

Пример 2. Расчет интегрального показателя устойчивости ландшафта (ИПУЛ) выполнялся для пологоволнистых междуречных равнин, покатых и пологих склонов долин, сложенных песчаниками, мергелями, конгломератами, известняками уфимского яруса с 
широколиственными лесами на серых и тёмно-серых лесных почвах Бирского, Мишкинского и Благовещенского районов Республики Башкортостан. Полученное на основе «ОКУ2» значение ИПУЛ равно 0,460, позволяет отнести данные ландшафты к ІІІп классу устойчивости при ширине интервала класса 0,372-0,556 (табл.3). Сравнение с значением ИПУЛ = 0,541 для «ОКУ1», ІІп при ширине интервала оценочной шкалы ИПУЛ 0,392-0,588 показало, что разница в полученных результатах составила 10,4\%. Как и в первом примере получаем, что ИПУЛ, и ИПУЛ 11 попадают в один класс, но ИПУЛ, дает несколько более высокую устойчивость ландшафта внутри классов (на величину указанных \%).

Пример 3. Расчет интегрального показателя устойчивости ландшафта (ИПУЛ) выполнялся для ландшафтов хвойно-широколиственных лесов Уфимского плато. Для «ОКУ1» получено: 0,677 (IVc), границы класса 0,588-0,793. Для «ОКУ2» получено: 0,601 (IVл), границы класса 0,567-0,759. По расчету на основе «ОКУ2» выявлен сдвиг в сторону снижения устойчивости примерно на 5,5\% по сравнению с «ОКУ1».

Пример 4. Расчет интегрального показателя устойчивости ландшафта (ИПУЛ) выполнялся для равнинно-моренных ландшафтов Лемболовской возвышенности Ленинградской области. Для «ОКУ1» получено: 0,655 (IVл), границы класса 0,588-0,793. Для «ОКУ2» получено: 0,575 (IVл), границы класса 0,567-0,759. По расчету на основе «ОКУ2» выявлен сдвиг в сторону снижения устойчивости примерно на 6,7\% по сравнению с «ОКУ1».

Пример 5. Расчет интегрального показателя устойчивости ландшафта (ИПУЛ) выполнялся для арктических ландшафтов Земли Франца-Иосифа. Для «ОКУ1» получено: 0,372 (ІІп), устойчивость ниже средней, границы класса 0,198-0,392. Для «ОКУ2» получено: 0,316 (ІІп), границы класса 0,185-0,367. По расчету на основе «ОКУ2» выявлен сдвиг в сторону снижения устойчивости примерно на 10,5\% по сравнению с «ОКУ1».

В целом, во всех случаях, при количестве исходных территориальных детерминант близких к 10, выявлено, что ИПУЛ на основе «ОКУ2» давал, в зависимости от ландшафта, сдвиг в сторону меньшей устойчивости для II-IV классов в пределах 4,2-10,4\%. На примере арктических ландшафтов Земли Франца-Иосифа показано, что их потенциальная устойчивость низкая (II класс, ниже средней). Ранее выполненное нами исследование [1] показало также, что добавление в «ОКУ» или изъятие из нее одного параметра (индекс ТК) при равновесомом их учете практически не сказалось на итоговом результате. Например, изъятие из «ОКУ1» индекса ТК дало характерное значение ИПУЛ, равное 0,531 (ІІІп), что определило разницу с рассмотренным в «ОКУ1» результатом в пределах 5\% при ширине интервала оценочной шкалы ИПУЛ, построенной для 8 параметров, для III класса 0,391-0,586. Выявлено также, что, придание в 2 раза большего веса одному параметру по сравнению с другими (на примере ТК) по расчетам на основе «ОКУ1», дало значение ИПУЛ, равное 0,630, что свидетельствовало о приближении ИПУЛ вплотную к граничному значению между III и IV классами $(0,654$ - правая граница III класса для оценочной шкалы с учетом неравновесомости задания приоритетов).

Следующими шагами в работе с моделями-классификациями устойчивости будет сбор и уточнение исходных данных для патч-ориентированных моделей интегральной оценки устойчивости ландшафтов в среде ГИС с учетом неравновесомого задания приоритетов (весов) для территориальных детерминант на основе ASPID-методологии учета неполной, неточной и нечисловой информации в оценочных исследованиях.

\section{Задание по работе.}

1. На основе модели-классификации табл.1 оцените устойчивость наземного ландшафта для выбранного Вами ключевого (или гипотетического) района (районов). Рассчитайте интегральный показатель устойчивости ландшафта (ИПУЛ) по 11 исходным шкалам при равновесомых (или неравновесомых) значениях приоритетов оценивания. При использовании неравновесомых значений параметров необходимо получить новую шкалу ИПУ. 


\section{Литература (основная)}

1. Дмитриев В.В., Огурцов А.Н., Морозова А.С., Пилюгина А.А., Свердлова О.А., Сиротина П.М., Федорова М.Е., Черепанов С.В., Шакуров В.А. Интегральная оценка устойчивости ландшафтов: модели, результаты, перспективы // Международный журнал прикладных и фундаментальных исследований. 2017. № 9 С. 110-114.

Dmitriev V.V., Ogurtsov A.N., Morozova A.S., Pilyugina A.A., Sverdlova O.A., Sirotina P.M., Fedorova M.E., Cherepanov S.V., Shakurov V.A. Integral assessment of landscape stability: models, results, prospects // International Journal of Applied and Fundamental Research. 2017. № 9. P. 110-114 (in Russian).

2. Delphine Brousmichea, Florent Occellia, Michaël Geninb, Damien Cunya, Annabelle Derama, Caroline Lanier Spatialized composite indices to evaluate environmental health inequalities: Meeting the challenge of selecting relevant variables. Ecological Indicators. 111 (2020) 106023. DOI: 10.1016/j.ecolind.2019.106023.

3. Дмитриев В.В., Огурцов А.Н. Подходы к оценке и ГИС-картографированию устойчивости и экологического благополучия геосистем. ІІІ. Интегральная оценка устойчивости почвы и наземных геосистем // Вестник СПбГУ. 2014. Серия 7. Геология. География. № 4. С. 114-130.

Dmitriev V.V., Ogurtsov A.N. Approaches to the assessment and GIS mapping of the sustainability and environmental well-being of geosystems. III. Integral assessment of soil stability and terrestrial geosystems // Vestnik SPbGU. 2014. Seriya 7. Geologiya. Geografiya. № 4. P. 114-130 (in Russian).

4. Lausch A, Blaschke T, Haase D, Herzog F, Syrbe R-U, Tischendorf L, et al. Understanding and quantifying landscape structure - A review on relevant process characteristics, data models and landscape metrics Ecological Modelling. Vol. 295. 10 January 2015. P. 31-41. DOI: 10.1016/j.ecolmodel.2014.08.018.

5. Turner MG. Landscape ecology: the effect of pattern on process. Annu Rev Ecol Syst. 1989. Vol. 20. P. 171-197.

6. McGarigal K, Tagil S, Cushman SA. Surface metric: an alternative to patch metrics for the quantification of landscape structure. Landsc Ecol. 2009. Vol. 24. P. 433-450.

7. Erős, T., Lowe, W. H. The Landscape Ecology of Rivers: from Patch-Based to Spatial Network Analyses. Curr Landscape Ecol Rep 4. 2019. P.103-112. DOI: 10.1007/s40823-019-00044-6.

8. Снакин В.В., Алябина И.О., Кречетов П.П. Экологическая оценка устойчивости почв к антропогенному воздействию // Известия РАН. Серия географическая. 1995. № 5. С. 50-57.

Snakin V.V., Alyabin I.O., Krechetov P.P. Ecological assessment of soil resistance to anthropogenic effects // Izvestiya RAN. Seriya geograficheskaya. 1995. № 5. P. 50-57 (in Russian).

9. He, Y.X., Jiao, Z., Yang, J. Comprehensive evaluation of global clean energy development index based on the improved entropy method. Ecol. Indic. 2018. Vol. 88. 305-321. DOI: 10.1016/j.ecolind.2017.12.013.

10. Степановских А.С. Общая экология. Учебник для вузов. М.: ЮНИТИ-ДАНА, 2000. 420 с.

Stepanovsky A.S. General ecology. Textbook for high schools. M.: UNITY-DANA, 2000. 420 p. (in Russian).

11. Осипов А. Г. Интегральная оценка устойчивости ландшафтов при создании сельскохозяйственных угодий природно-аграрных систем // Вестник СПбГУ. Серия 7. Геология. География. 2016. № 3. C. 150-162. DOI: 10.21638/11701/spbu07.2016.312.

Osipov A.G. Integral assessment of landscape stability when creating agricultural land of natural-agrarian systems // Vestnik SPbGU. Seriya 7. Geologiya. Geografiya.. 2016. № 3. P. 150-162 (in Russian).

12. Hovanov N., Hovanov K., Yudaeva M. Multicriteria estimation of probabilities on basis of expert nonnumeric, nonexact and non-complete knowledge. European Journal of Operational Research. 2009. 195(3). P. 857-863.

13. Шмелева И.А., Шмелев С.Э. Глобальные города: многокритериальная оценка устойчивого развития // Биосфера. 2019. Т. 11. № 1. С. 1-18. DOI: 10.24855/biosfera.v11i1.470

Shmeleva I.A., Shmelev S.E. Global cities: a multi-criteria assessment of sustainable development // Biosphere. 2019. V. 11. № 1. P. 1-18 (in Russian).

14. Огурцов А.Н., Дмитриев В.В. Интегральная оценка и геоинформационный анализ социальных детерминант здоровья населения Крайнего севера Европейской части Российской Федерации // ИнтерКарто. ИнтерГИС. 2019. Т. 25. №1. C. 23-34. DOI: 10.35595/2414-9179-2019-1-25-23-34.

Ogurtsov A.N., Dmitriev V.V. Integrated Assessment and Geoinformational Analysis of Social Determinants of Population Health of the Extreme North of the European Part of the Russian Federation // InterCarto. InterGIS 2019. V. 25. № 1. P. 23-34 (in Russian).

\section{Дополнительная литература}

Александрова Л.В., Васильев В.Ю., Дмитриев В.В., Мякишева Н.В., Огурчов А.Н., Третьяков Н.В., Хованов Н.В. Многокритериальные географо-экологические оценки состояния и устойчивости природных и урбанизированных систем. Под ред. В.В. Дмитриева и Н.В. Хованова. Деп. ВИНИТИ 01.09.2000, № деп.2342В00, 275 с.

Арманд А.Д. Механизмы устойчивости геосистем // Факторы и механизмы устойчивости геосистем. М., 1989, c.33-46.

Воробейчик Е.Л., Садыков О.Ф., Фарафонтов М.Г. Экологическое нормирование техногенных загрязнений наземных экосистем. Екатеринбург, 1994.

Глазовская М. А. Методологические основы оценки эколого-геохимической устойчивости почв к техногенным воздействиям. М.: Изд-во МГУ, 1997. 102 с.

Глазовская М.А. Ландшафтно-геохимические системы и их устойчивость к техногенезу // Биогеохимические циклы в биосфере.- М.,1976,-356 с.

Глазовская М.А. Методологические основы оценки эколого-геохимической устойчивости почв к техногенным воздействиям. М., изд. МГУ, 1997, 102 с.

Дедю И.И. Экологический энциклопедический словарь. Кишинев, 1990, 406 с.

Дмитриев В.В. «Определение интегрального показателя состояния природного объекта как сложной системы», научно-теоретический журнал «Общество. Среда. Развитие». №4 (12), 2009, с.146-165. 
Дмитриев В.В. Интегральные оценки состояния сложных систем в природе и обществе (статья). Междисциплинарный научный и прикладной журнал «Биосфера», 2010, т.2, №3.

Дмитриев B.B. Методика диагностики состояния и устойчивости водных экосистем // Эколого-географический анализ состояния природной среды: проблема устойчивости геоэкосистем. СПб., 1995. С.41-67.

Дмитриев B.B. Прикладная экология в системе высшего географического и гидрометеорологического образования/ Вопросы прикладной экологии. Сборник научных трудов РГГМУ, СПб, изд. РГГМУ, 2002, с.90-96.

Дмитриев B.B. Устойчивость природных объектов к изменению параметров естественного и антропогенного режимов/ в кн. Дмитриев В.В., Фрумин Г.Т. Экологическое нормирование и устойчивость природных систем, СПб., 2004, c.241-278.

Дмитриев В.В. Экологическое нормирование состояния и антропогенных воздействий на природные экосистемы. Вестник С-Петерб. ун-та. Серия 7, 1994, вып 2. С.60-70.

Дмитриев В.В., Жиров А.И., Ласточкин А.Н. Прикладная экология. Учебник для студентов высш. учеб. заведений. М.: Издательский центр «Академия», 2008, 608 с.

Дмитриев B.В., Огуриов А.Н. Подходы к интегральной оценке и ГИС-картографированию устойчивости и экологического благополучия геосистем. І. Интегральная оценка устойчивости наземных и водных геосистем. Вестник СПбГУ, сер.7 (геология, география), 2012, вып.3, с.65-78.

Дмитриев B.В., Огуриов А.Н. Подходы к интегральной оценке и ГИС-картографированию устойчивости и экологического благополучия геосистем. II. Методы интегральной оценки устойчивости наземных и водных геосистем. Вестник СПбГУ, сер.7 (геология, география), 2013, вып.3, с.88-103.

Дмитриев В.В., Огуриов А.Н. Подходы к интегральной оценке и ГИС-картографированию устойчивости и экологического благополучия геосистем. III. Интегральная оценка устойчивости почвы и наземных геосистем. Вестник СПбГУ. Сер. 7. 2014. Вып. 4, с.114-129.

Дмитриев В.В., Огуриов А.Н. Геоинформационный анализ индекса биологической эффективности климата как критерия оценки потенциальной устойчивости ландшафта. Международная конференция ИнтерКарто-ИнтерГИС - 23 «Геоинформационное обеспечение устойчивого развития территорий Азиатско-Тихоокеанского региона в условиях глобальных климатических изменений». Материалы Международной конференции «ИнтерКарто/ИнтерГИС». 2017;1(23):191-204. DOI:10.24057/2414-9179-2017-1-23-191-204.

Дмитриев В.В., Панов В.Е., Пряхина Г.В. Методические указания по учебно-производственной практике «Экологическое состояние водных объектов»: Учебно-методическое пособие. - СПб. : ВВМ, 2010. — 104 с.

Дмитриев В.В., Фрумин Г.Т. Экологическое нормирование и устойчивость природных систем., СПб., 2004, 294

c.

Исаченко А.Г. Ландшафтоведение и физико-географическое районирование. М., 1991, 366 с. СПб.,1999,112 с.

Исаченко Г.А. Методы полевых ландшафтных исследований и ландшафтно-экологическое картографирование.

Одум Ю. Основы экологии / Пер. с 3-го англ. изд. под ред. Н.П. Наумова. М., 1975, 740 с.

Оценка состояния и устойчивости экосистем. Под ред. В.А. Красилова, М., Изд. ВНИИ Природы, 1992, 127 с.

Примак Е.A., Дмитриев В.В. Разработка интегральных индексов для оценки устойчивости водоемов к изменению параметров естественного и антропогенного режимов / Географические и геоэкологические аспекты развития природы и общества. Сборник научных статей по материалам отчетных научно-практических конференций 2006-2007 гг. Под ред. Каледина Н.В., Дмитриева В.В., Алиева Т.А., СПб, Изд. Наука, 2008, с.234-241.

Проблемы эколого-географической оценки состояния природной среды / Под ред. П.П. Арапова и Ю.П. Селиверстова. СПб., 1994.

Пузаченко Ю.Г. Проблемы устойчивости и нормирования // Структурно-функциональная организация и устойчивость биологических систем. Днепропетровск, 1990, с.122-147.

Реймерс Н.Ф. Природопользование: Словарь-справочник. М., 1990, 638 с.

Росновский И.Н. Устойчивость почвы: техногенно-механические аспекты. Новосибирск, 1993, 170 с.

Светлосанов B.A. Устойчивость и стабильность природных экосистем // Итоги науки и техники. Серия «Теоретические и общие вопросы географии». М., 1990, с.56-74.

Свирежев Ю.М., Логофет Д.О. Устойчивость биологических сообществ, М., 1978, 190 с.

Словарь терминов и понятий, связанных с охраной живой природы / Н.Ф.Реймерс, А.В.Яблоков / М., 1982, 144

c.

Снакин В.В., Мельченко В.Е., Бутовский Р.О. и др. Оценка состояния и устойчивости геосистем. М. ВНИИ природа, 1992, $127 \mathrm{c}$. $2006,36 \mathrm{c}$

Шилин М.Б. Геоэкологический мониторинг прибрежных природно-технических систем. Автореф. докт. дисс.,

Alexeeva O.N., Guzheva I.N., Dmitriev V.V. The development of approach to the water reservoir ecological prosperity assessment. 3rd Symposium «Quality and Management of Water Resources» Saint Petersburg, Russia, June 16-18, 2005. Book of proceedings. Scientific Editors V.V.Dmitriev, V.I.Sergeev Saint Petersburg, Изд. ГУП «Типография «Наука», 2005, с. 9-17.

\section{Практическая работа №7 \\ Моделирование и оценка эмерджентных свойств наземных и водных геосистем и ландшафтов. Интегральная оценка экологического благополучия водоема.}

Экологическое благополучие водных объектов. В научной литературе уже более 30 лет обсуждаются подходы к оценке экологического благополучия (ЭБ) сложных систем в природе и обществе. Вводятся термины «здоровье экосистемы», «биологическая целостность», «экологическая целостность», «экологическое качество среды», 
«экологический паспорт территории (реки, объекта и др.)», «экологическое благополучие/неблагополучие территории (акватории)» и т.д. В РФ существует ГОСТопределение экологического благополучия. Вряд ли его можно признать удачным. По ГОСТ 17.1.1.01-77 экологическое благополучие водного объекта - нормальное воспроизведение основных звеньев экологической системы водного объекта. К основным звеньям отнесены пелагические и придонные ракообразные и рыбы.

В работах, приведенных в списке литературы, нами обсуждалось, что в современных зарубежных исследованиях ключевыми понятиями являются биологическая оценка (Biological Assessment) и биологическая целостность (Biological Integrity). Биологическая целостность на западе часто рассматривается как ключ к определению здоровья экосистемы, а «здоровье экосистемы», Haskell et al. (1991); Meyer (1997); Chessman (2002) (цит. по Семенченко, Разлуцкий, 2010) в основном связывают с ее устойчивостью, и если устойчивость нарушена, то такая экосистема, по мнению исследователей, теряет свой исходный (здоровый) статус ${ }^{1)}$.

В противовес этому нами было рекомендовано применение аксиологического подхода и показано, что устойчивость является лишь одним из параметров оценки экологического благополучия и что устойчивая экосистема может являться сильно антропогенно-трансформированной системой и в этом случае не может считаться благополучной. Обобщение и анализ подходов к выделению нормальной (понимаемой как хорошая, оптимальная) экосистемы позволили определить «хорошую» экосистему как экосистему с максимальной и разнообразной продукцией (удовлетворяющей экономические и эстетические потребности человека), существующую неограниченно долго в изменяющейся среде (Воробейчик, Садыков, Фарафонтов, 1994).

Необходимым условием для построения моделей экологического благополучия является введение признаков и классов ЭБ. Признаки «хороших» (для человека и/или для гидробионтов) водных систем и их изменение по классам благополучия составляют основу классификации экологического благополучия водного объекта. Наш опыт показывает, что при ее создании необходимо использовать совмещение антропоцентрического и биоцентрического подходов, учитывать принципы нормирования Н.C. Строганова: приоритетность в использовании водоемов, достаточность самоочищения, обеспеченность условий жизни для промысловых объектов, пригодность воды для питьевых целей. Признаками благополучной водной экосистемы нами предлагалось считать: 1) максимальное видовое разнообразие биоты; 2) высокое качество воды; 3) высокую устойчивость к изменению параметров режимов; 4) низкую скорость загрязнения, закисления, эвтрофикации; 5) высокую скорость самоочищения.

В работе (Дмитриев, Пряхина, Огурцов и др., 2018) введены понятия «экологический статус» (ЭС) водоема (водного объекта) и экологическое благополучие водного объекта (ЭБ) с позиций био-(эко)центризма и антропоцентризма. В био(эко)центристском определении акцентируется использование водного объекта для жизни организмов-гидробионтов или для сохранения экосистемы в целом, в антропоцентристском подходе - способность системы выполнять социальноэкономические функции без нарушения функций жизнеобеспечения (средо- и ресурсовоспроизводства). При рассмотрении ЭС нами учитывались: трофический

1) Европейская Рамочная Водная Директива (Directive of the European Parliament and of the Council establishing a framework for Community action in the field of water policy) была принята в 2000 г. Этот документ регламентирует подходы к политике охраны, использования и управления водными ресурсами с целью к 2015 г. гармонизировать и унифицировать подходы стран ЕС к управлению водными ресурсами и их охране. Основная цель Директивы достижение экологического благополучия или высокого экологического статуса (в переводных изданиях пишут «хорошего экологического статуса») для всех водных систем. Основой экологического статуса водного объекта в этих изданиях объявляется «экологическое качество воды» и даже «хорочее экологическое качество воды» (см. Семенченко В.П., Разлуикий В.И. «Экологическое качество поверхностных вод», Минск, «Беларуская навука», 2010,329 с). Под термином «экологическое качество воды» понимают «структуру и функционирование сообществ водных организмов, которое отражает состояние водных масс». По нашему мнению, надо было написать «экологическое состояние водного объекта» или «химический и биологический состав воды и её физические свойства, обусловливающие использование водного объекта как среды жизни организмами - гидробионтами». 
статус водоема или способность продуцировать органическое вещество первичными продуцентами, качество воды с позиций био-(эко)центризма, устойчивость системы. Таким образом, допускалось, что одно эмерджентное свойство может определять другое или влиять на него. В последнее время, в основном в переводной литературе или у неспециалистов участилось определение ЭС на основе термина «экологическое качество воды». Встречается даже термин «хорошее экологическое качество» (буквальный перевод с английского). Остается сожалеть, что в такой форме в РФ акцентируется биоцентризм (экоцентризм) в оценке качества воды и состоянии экосистемы. Акцент на методы биологического контроля качества воды, принятый в Европе использующийся в данных исследованиях, активно развивается в последние годы и в РФ, их одновременное использование с методами гидрохимического анализа качества дает более надежные результаты. В нашем представлении ЭС отличается от ЭБ природного объекта. Для термина ЭБ на основе аксиологического подхода нами предлагались различные определения.

Например, под экологически благополучной природной системой понималась система, способная продуцировать органическое вещество, выполнять социальноэкономические функции без нарушения функций жизнеобеспечения (средо- и ресурсовоспроизводства), являющаяся разнообразной по составу биоты, чистой (по химическому составу воды и гидробиологическим критериям качества воды), устойчивой к изменению параметров естественного и антропогенного режимов, способной к самоочищению, обладающей способностью сохранять названные свойства и функции достаточно долго в изменяющихся условиях среды и жизни организмов. В данном определении сделана попытка объединить био- и антропоцентризм в подходе к исследованию ЭБ. Понятно, что разная аксиология ЭБ будет обусловливать разную аксиометрию и порождать разные модели-классификации для интегральной оценки ЭБ (Дмитриев, Пряхина, Огурцов и др., 2018).

Обобщение и анализ перечисленных признаков требуют учета перспектив использования водной экосистемы человеком. Это обусловливает внесение необходимых для свертки информации приоритетов между исходными критериями. Полученный результат оценки в этом случае может иметь не только региональную и временную привязки, но и зависеть от вида ее использования. Таким образом, одна и та же экосистема, в зависимости от планирования ее использования человеком для своих нужд может быть названа благополучной в большей или меньшей степени.

Данная практическая работа представляет собой пример оценки эмерджентного свойства водоема - его экологического благополучия (ЭБ) на примере малого озера в карельском Приладожье за 2012 г. Результатом данной работы будет сравнение показателей экологического благополучия за период исследования, с ответом на вопрос, сохранило: ли озеро свой класс ЭБ, или же перешло в другой класс.

Таблица 1. Исходные данные для оценки благополучия оз. Суури по материалам натурных наблюдений 2012 г.

\begin{tabular}{|l|c|}
\hline \multicolumn{1}{|c|}{ Признак } & 2012 г. \\
\hline $\begin{array}{l}\text { 1. Валовая первичная продукция в } \\
\text { подповерхностном слое воды, мг С/л сут. }\end{array}$ & 0,28 \\
\hline 2. Средняя прозрачность воды по белому диску, м & 1,65 \\
\hline $\begin{array}{l}\text { 3. Отношение прозрачности к глубине при } \\
\text { средней глубине 2,2 м, среднее }\end{array}$ & 0,48 \\
\hline 4. рН воды в летнее время на поверхности, среднее & 6,62 \\
\hline $\begin{array}{l}\text { 5. Удельная электропроводность, мкСм/см на поверхности, } \\
\text { среднее }\end{array}$ & 63 \\
\hline
\end{tabular}




\begin{tabular}{|l|c|} 
6. Средняя концентрация азота $\mathrm{NH}_{4}$, мг $\mathrm{N} / л$ & 0,798 \\
на поверхности, среднее & 98 \\
\hline $\begin{array}{l}\text { 7. Процентное насыщение воды кислородом на } \\
\text { поверхности, среднее, \% }\end{array}$ & 28,5 \\
\hline 8. Индекс ВМWР по зообентосу, средний & 0,004 \\
\hline 9. Фосфор РО4, мгР/л на поверхности, среднее & 2,38 \\
\hline $\begin{array}{l}\text { 10. Индекс Шеннона (по правой границе предела } \\
\text { изменчивости) }\end{array}$ & 26 \\
\hline 11. Устойчивость в баллах по У1 & 30 \\
\hline $\begin{array}{l}\text { 12. Устойчивость в баллах по У2, для поверхностного слоя } \\
\text { воды }\end{array}$ & 7,1 \\
\hline 13. Время осветления воды зоопланктоном, сут. & 1,65 \\
\hline 14. D/Р отношение & \\
\hline
\end{tabular}

Интегральный показатель трофности (ИПТ) оценим по 4-м критериям: валовая первичная продукция (w1), прозрачность воды (w2), отношение прозрачности к глубине (w3) и рН воды в летнее время (w4). При задании весов при построении ИПТ введем приоритеты оценивания так, чтобы: $\mathrm{w}_{1}>\mathrm{w}_{2}>\mathrm{w}_{3}=\mathrm{w}_{4}$. Для расчетов используем $\mathrm{w}_{1}=0,49 ; \mathrm{w}_{2}$ $=0,29 ; \mathrm{w}_{3}=\mathrm{w}_{4}=0,11$.

Таблица 2. Расчет интегрального показателя трофности водной экосистемы по моделиклассификации.

\begin{tabular}{|l|c|c|c|}
\hline \multicolumn{1}{|c|}{ Критерий } & 2012 & $\begin{array}{c}\text { Результат } \\
\text { нормирования }\end{array}$ & $\begin{array}{c}\text { Результат } \\
\text { нормирования } \\
\text { с учетом веса }\end{array}$ \\
\hline 1. Валовая первичная мг С/л сут. & 0,28 & & \\
\hline 2. Средняя прозрачность воды по белому диску, м & 1,65 & & \\
\hline 3. Отношение прозрачности к глубине & 0,48 & & \\
\hline 4. рН воды в летнее время & 6,62 & & \\
\hline \multicolumn{2}{|c|}{ ИПТ } & \multicolumn{3}{|l|}{} \\
\hline
\end{tabular}

Далее необходимо определить, что трофический статус водной экосистемы по величине интегрального показателя трофности (ИПТ) попадает в ... класс ЭБ водоема.

Интегральный показатель качества воды (ИПКВ) оценим по 6 критериям: прозрачность воды (w1), Удельная электропроводность воды (мк См/см) (w2), азот $\mathrm{NH}_{4}$, (мг N/ת) (w3), Процентное насыщение воды кислородом, \% (w4), гидробиологический индекс BMWP (w5) и фосфор $\mathrm{PO}_{4}$ (мг P/л) (w6). При задании приоритетов (весов) при построении ИПКВ введем приоритеты $\mathrm{w}_{1}=\mathrm{w}_{6}<\mathrm{w}_{2}=\mathrm{w}_{3}=\mathrm{w}_{4}=\mathrm{w}_{5}$. Для расчетов используем $\mathrm{w}_{1}=\mathrm{w}_{6}=0,112 ; \mathrm{w}_{2}=\mathrm{w}_{3}=\mathrm{w}_{4}=\mathrm{w}_{5}=0,194$.

Таблица 3. Расчет интегральный показателя качества воды по модели-классификации.

\begin{tabular}{|l|c|c|c|}
\hline \multicolumn{1}{|c|}{ Критерий } & 2012 & $\begin{array}{c}\text { Результат } \\
\text { нормирования }\end{array}$ & $\begin{array}{c}\text { Результат } \\
\text { нормирования } \\
\text { с учетом веса }\end{array}$ \\
\hline $\begin{array}{l}\text { 1. Средняя прозрачность воды по белому диску, } \\
\text { м }\end{array}$ & 1,65 & & \\
\hline 2. Удельная электропроводность, мкСм/см & 63 & & \\
\hline 3. Средняя концентрация азота $\mathrm{NH}_{4}, \mathrm{MгN} / л$ & 0,798 & & \\
\hline 4. Процентное насыщение воды кислородом, \% & 98 & & \\
\hline 5. ВМWР & 28,5 & & \\
\hline 6. Фосфор $\mathrm{PO}_{4}, \mathrm{MгР/л}$ & 0,004 & & \\
\hline
\end{tabular}


Далее необходимо определить, что интегральный показателя качества воды равен ... и попадает в ... класс ЭБ водоема.

Оценку остальных параметров мы можем произвести непосредственно из данных измерений. Классификация их соответствует параметрам и рекомендациям по формированию оценочных шкал для интегральной оценки ЭБ водоёма. Для D/Pотношения можно использовать равномерную линейную шкалу (от 1-го, до 5-го класса ЭБ): 0-0,2; 0,2-0,4; 0,4-0,6; 0,6; 0,6-0,8; 0,8-1,0.

Таблища 4. Показатели устойчивости, закисления, самоочищения для оценочной классификации ЭБ.

\begin{tabular}{|l|c|l|}
\hline Признак & 2012 г. & $\begin{array}{l}\text { Результат } \\
\text { нормирования }\end{array}$ \\
\hline $\begin{array}{l}\text { 1. Индекс Шеннона (по правой границе предела } \\
\text { изменчивости) }\end{array}$ & 2,38 & \\
\hline 2. Устойчивость в баллах по У1 & 26 & \\
\hline 3. рН воды в летнее время на поверхности, среднее & 6,62 & \\
\hline 4. Время осветления воды зоопланктоном, сут. & 7,1 & \\
\hline 5. D/Р отношение & 1,65 & \\
\hline
\end{tabular}

Для второго уровня свёртки показателям придавались разные веса. Были отобраны средние веса по 10 комбинациям задания приоритетов, представленных ниже.

Таблица 6. Результаты вычисления среднего значения для весов второго уровня свертки

\begin{tabular}{|l|r|r|r|r|r|r|r|r|r|r|c|}
\hline № & 1 & 2 & 3 & 4 & 5 & 6 & 7 & 8 & 9 & 10 & CPEДНЕE \\
\hline w2=w3 & 0,200 & 0,250 & 0,300 & 0,350 & 0,250 & 0,400 & 0,300 & 0,200 & 0,250 & 0,300 & $\mathbf{0 , 2 8 0}$ \\
\hline w6=w7 & 0,150 & 0,200 & 0,100 & 0,100 & 0,150 & 0,050 & 0,150 & 0,175 & 0,125 & 0,125 & $\mathbf{0 , 1 3 3}$ \\
\hline w1=w4=w5 & 0,100 & 0,033 & 0,066 & 0,033 & 0,066 & 0,033 & 0,033 & 0,083 & 0,083 & 0,050 & $\mathbf{0 , 0 5 8}$ \\
\hline
\end{tabular}

При том, что $\mathrm{w}_{2}=\mathrm{w}_{3}>\mathrm{w}_{6}=\mathrm{w}_{7}>\mathrm{w}_{1}=\mathrm{w}_{4}=\mathrm{w}_{5}$, было найдено: $\mathrm{w}_{2}=\mathrm{w}_{3}=\mathbf{0 , 2 8} ; \mathrm{w}_{6}=\mathrm{w}_{7}=\mathbf{0 , 1 3 3}$; $\mathrm{w}_{1}=\mathrm{w}_{4}=\mathrm{w}_{5}=\mathbf{0 , 0 5 8}$

Границы третьего класса ИПЭБ, взятые из предварительно построенной шкале ИП ЭБ с учетом данных весов, выглядят следующим образом: 0,353 - $\mathbf{0 , 5 2 6 .}$

Таблица 7. Оценка экологического благополучия оз. Суури по материалам натурных наблюдений 2012г. (второй уровень свертки показателей)

\begin{tabular}{|l|r|r|}
\hline \multicolumn{1}{|c|}{ Показатели/год } & 2012 & \\
\hline $\begin{array}{l}\text { Интегральный показатель } \\
\text { экологического } \\
\text { благополучия (ИПЭБ) }\end{array}$ & \\
\hline
\end{tabular}

В итоге, получено значение ИПЭБ для озера Суури. Выявлено, что озеро попадает в ... класс экологического благополучия, ближе к границе с... классом.

\section{Задания по работе:}

1. Выполните оценку ЭБ для оз.Суури для 2012 года.

2. Задайте значения параметров в другие годы. Рассчитайте для них ЭБ.

3. Предложите свою модель-классификацию ЭБ и сделайте по ней оценку ЭБ для 1-2 лет. Сравните полученные результаты. 


\section{Литература}

Александрова Л.В., Васильев В.Ю., Дмитриев В.В. и др. Многокритериальные географо-экологические оценки состояния и устойчивости природных и урбанизированных систем. Под ред. В. В. Дмитриева и Н. В. Хованова. Деп. ВИНИТИ № 2342В00, 2000, 275 с.

Алексеев Д.К., Гальцова В.В., Дмитриев В.В. Экологический мониторинг: современное состояние, подходы и методы. Часть I. Экологический мониторинг атмосферного воздуха и поверхностных вод суши. Учебное пособие. Изд. РГГМУ, СПб, 2011, 302 с.

Гальцова В.В., Дмитриев В.В. Практикум по водной экологии и мониторингу состояния водных систем: учеб. пос. - СПб.: Наука, 2007. - 364 с.

Дмитриев В.В. Оценка воздействия на водный объект на основе АСПИД-моделей экологического благополучия (статья в сборнике научных трудов международного Форума). Сборник материалов XVIII Международного экологического Форума «День Балтийского моря» 22-23 марта 2017 г. Изд. «ООО Свое издательство», г. Санкт-Петербург, 2017, с.336-350. https://elibrary.ru/item.asp?id=29997289; https://elibrary.ru/item.asp?id=30798701

Дмитриев В.В., Амаро Медина Д.Р., Огурцов А.Н., Добрынина А.С. Оценка экологического статуса системы «река-водосбор»: подходы, методика, результаты. Экология речных бассейнов: Труды 9-й Междунар. науч.- практ. конф. / Под общ. ред. проф. Т.А. Трифоновой; Владим. гос. ун-т. им. А.Г. и Н.Г. Столетовых, Владимир, 2018. С. 46-52. https://elibrary.ru/item.asp?id=35609968

Дмитриев В.В., Зуева Н.В., Лубенцова А.С., Валатин Д.И., Васякина А.В., Непомнящая А.В., Никонов И.А., Осташов А.А., Подшивалова Д.О., Прокопеня А.Д., Соколова Д.П., Черненко Ю.И. Экологическое состояние водных объектов карельского Приладожья: традиционный взгляд и современные акценты. Ученые записки РГГМУ, вып. 47, 2017 , с. $126-144$.

Дмитриев В.В., Зуева Н.В., Огурцов А.Н., Примак Е.А., Федорова И.В. Интегральные оценки в индексологии состояния водных экосистем и их эмерджентных свойств. Современные проблемы водохранилищ и их водосборов. Труды Международной научно-практической конференции (29 мая - 1 июня 2017 г., г. Пермь). Том 2. Качество воды. Геоэкология. Пермь, 2017, c.201-207. https://elibrary.ru/item.asp?id=30533776

Дмитриев В.В., Огурцов А.Н. Устойчивость сложных систем в природе и обществе: методология, оценка, результаты. Ученые записки РГГМУ, 2017, №48, c.72-84. https://elibrary.ru/item.asp?id=30744920

Дмитриев В.В., Огурцов А.Н., Васильев В.Ю. Интегральная оценка экологического состояния водных объектов, трофности и качества воды, экологической напряженности рек, озер и морских акваторий. Географические и экологические аспекты гидрологии. Труды научной сессии, посвященной 90летию кафедры гидрологии суши факультета географии и геоэкологии СПбГУ - С. Петербург, 26-27 марта 2008 г. / Под научной редакцией В.С. Вуглинского - СПб, Арт-Экспресс, 2010. - с.143-153.

Дмитриев В.В., Огурцов А.Н., Васильев В.Ю., Примак Е.А., Лобачева Ю.В., Скрыгина В.К. Оценка эмерджентных свойств сложных систем в природе и обществе на основе моделей интегрального оценивания / Сборник трудов VI международной конференции «Экологические и гидрометеорологические проблемы больших городов и промышленных зон, ЭКОГИДРОМЕТ - 2012». 2-4 июля 2012. Под редакцией: Л.Н.Карлина, В.Н. Воробьева, В.А. Шелутко, В.В.Дмитриева. - СПб.: изд. РГГМУ, 2013. - с.18-27.

Дмитриев В.В., Огурцов А.Н., Морозова А.С., Пилюгина А.А., Свердлова О.А., Сиротина П.М., Федорова М.Е., Черепанов С.В., Шакуров В.А. ИНТЕГРАЛЬНАЯ ОЦЕНКА УСТОЙЧИВОСТИ ЛАНДШАФТОВ: МОДЕЛИ, РЕЗУЛЬТАТЫ, ПЕРСПЕКТИВЫ. Международный журнал прикладных и фундаментальных исследований. - 2017. - № 9. - C. 110-114; URL: https://applied-research.ru/ru/article/view?id=11837 (дата обращения: 26.09.2017). ИД Академия Естествознания. г.Пенза. https://elibrary.ru/item.asp?id=30056223

Дмитриев В.В., Панов В.Е., Пряхина Г.В. Методические указания по учебно-производственной практике «Экологическое состояние водных объектов»: Учебно-метод. пособие. - СПб.: ВВМ, 2010. - 116 с.

Дмитриев В.В., Пряхина Г.В., Огурцов А.Н., Примак Е.А., Амаро Медина Д.Р. Оценка эмерджентных свойств водных объектов: трофический статус, устойчивость, экологическое благополучие. В сборнике: Третьи Виноградовские чтения. Грани гидрологии. Сборник докладов международной научной конференции памяти выдающегося русского гидролога Юрия Борисовича Виноградова. Санкт-Петербург, 28-30 марта 2018 г. Под редакцией О.М. Макарьевой. Издательство «Наукоемкие технологии», Санкт-Петербург, 2018. С. 347-354. https://elibrary.ru/item.asp?id=35342482

Дмитриев В.В., Федорова И.В., Бирюкова А.С. Подходы к интегральной оценке и ГИС - картографированию устойчивости и экологического благополучия геосистем Часть IV. Интегральная оценка экологического благополучия наземных и водных геосистем. Вестник СПбГУ. Сер. 7. 2016. Вып. 2. С.37-53.

Добрынина А.С., Дмитриев В.В. Разработка и апробация моделей интегральной оценки экологического благополучия речных систем. Современные проблемы водохранилищ и их водосборов. Труды Международной научнопрактической конференции (29 мая - 1 июня 2017 г., г. Пермь). Том 2. Качество воды. Геоэкология. Пермь, 2017, с.208213. https://elibrary.ru/item.asp?id=30533777

Лубенцова А. С., Верещагина Е. А., Дмитриев В. В. Оценка состояния водных экосистем, испытывающих влияние предприятий атомной энергетики, на примере Калининской АЭС. Экология водоемов - охладителей энергетических станций: сб. материалов Всерос. науч.-практ. конф. с международным участием / Забайкал. гос. ун-т; [отв. ред. Г. Ц. Цыбекмитова]. - Чита: ЗабГУ, 2017. c.185-193. https://elibrary.ru/item.asp?id=30666075 2010,329 c.

Семенченко В.П., Разлуцкий В.И. «Экологическое качество поверхностных вод», Минск, «Беларуская навука»,

Dmitriev V.V., Fedorova I.V., Birykova A.S. Approaches to assessment and GIS mapping of sustainability and environmental well-being of geosystems. Part IV. Integrated assessment of ecological wellbeing of terrestrial and aquatic ecosystems. Vestnik of Saint-Petersburg University. Series 7. Geology. Geography, 2016, issue 2, pp. 37-53. doi: $10.21638 / 11701 / \mathrm{spbu07.2016.204}$ 


\section{СОДЕРЖАНИЕ}

\begin{tabular}{|c|c|}
\hline Введение....... & $3-4$ \\
\hline Краткое содержание разделов пособия......................... & $5-7$ \\
\hline $\begin{array}{l}\text { Раздел 1. Введение в курс «Интегральная оценка наземных и водных } \\
\text { геосистем» и родственных курсов, содержащих основы теории, методологии и } \\
\text { методы интегрального оценивания состояния и устойчивости сложных } \\
\text { природных объектов и их свойств (организационно-методический раздел)...... }\end{array}$ & $8-19$ \\
\hline $\begin{array}{l}\text { Раздел } 2 . \quad \text { Теоретико-методологические } \\
\text { экосностем, геосистем, ландшафтов и их эмерджентных свойств........... }\end{array}$ & $19-111$ \\
\hline 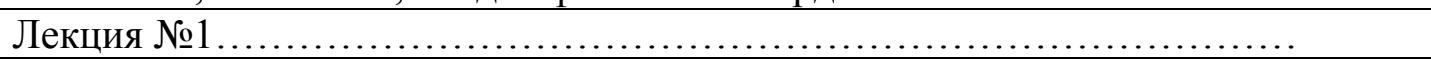 & $19-36$ \\
\hline 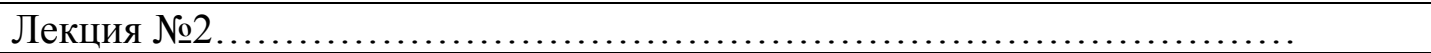 & $36-52$ \\
\hline Лекция №3................................................................... & $52-71$ \\
\hline Лекция №4............................................................ & $71-82$ \\
\hline 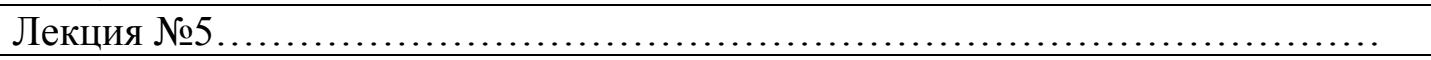 & $82-93$ \\
\hline 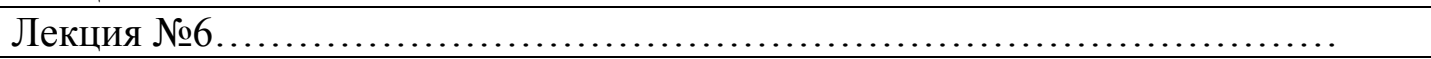 & 93-111 \\
\hline $\begin{array}{l}\text { Раздел 3. Методические основы интегральной оценки экосистем, геосистем, } \\
\text { ландшафтов и их эмерджентных свойств..................................... }\end{array}$ & $111-125$ \\
\hline 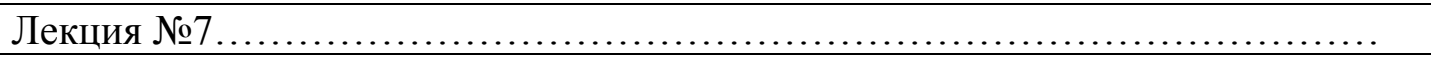 & $111-125$ \\
\hline 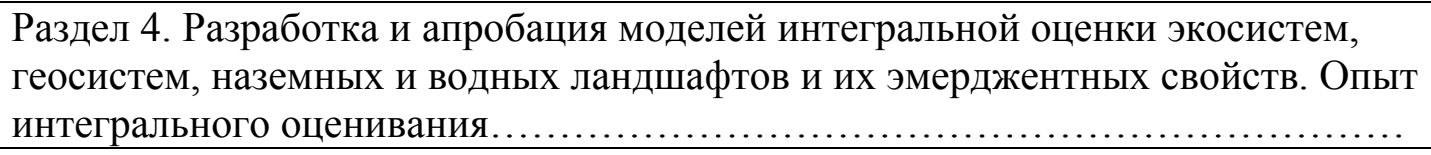 & $125-138$ \\
\hline Лекция №8.............................. & $125-138$ \\
\hline 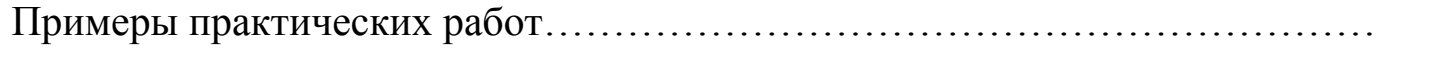 & $138-198$ \\
\hline Практическая работа №1 .................................................. & $138-146$ \\
\hline Практическая работа №2 ............................................... & $146-154$ \\
\hline 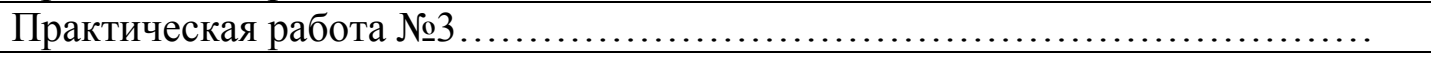 & $154-161$ \\
\hline Практическая работа №4 ................................................ & $161-171$ \\
\hline 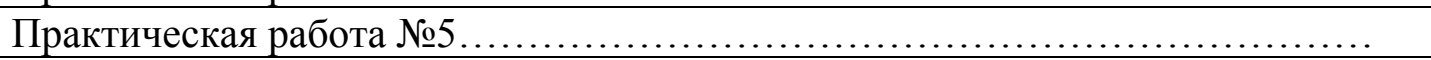 & $171-178$ \\
\hline Практическая работа №6................................................. & $178-193$ \\
\hline Практическая работа №7 .............................................. & 193-198 \\
\hline Содержание...................... & 199 \\
\hline
\end{tabular}




\author{
Автор-составитель: \\ ДМИТРИЕВ ВАСИЛИЙ ВАСИЛЬЕВИЧ \\ профессор кафедры гидрологии суши \\ Института наук о Земле СПбГУ, \\ доктор географических наук, профессор
}

\title{
ОЦЕНКА СОСТОЯНИЯ И УСТОЙЧИВОСТИ НАЗЕМНЫХ И ВОДНЫХ ГЕОСИСТЕМ
}

Подписано в печать 06.05.2020. Формат 60×84/16. Печать цифровая. Усл. печ. л. 12,5. Тираж 100. Заказ 48.

\author{
Выпущено ООО «Медиапапир» \\ с готового оригинал-макета, предоставленного автором. \\ 194021, Санкт-Петербург, Политехническая ул., д. 24, лит. В, пом. 11-Н № 25, 26. \\ Тел.: (812) 987-75-26 \\ mediapapir@gmail.comwww.mediapapir.com www.mediapapir.ru
}

